UNIVERSIDADE DE SÃO PAULO

ESCOLA DE ENGENHARIA DE SÃO CARLOS

\title{
ESTUDO DE MECANISMOS DE DEFORMAÇÃO LENTA DA GIPSITA BANDADA DA CHAPADA DO ARARIPE EM ENSAIOS DE FLUÊNCIA MONITORADOS POR EMISSÃO ACÚSTICA
}

\author{
HUMBERTO IVÁN PEHOVAZ ALVAREZ
}

Tese apresentada à Escola de Engenharia de São Carlos da Universidade de São Paulo para obtenção do Título de Doutor em Geotecnia.

Área de concentração:

Orientador: Prof. Dr. Tarcísio Barreto Celestino

Co-orientador: Prof. Dr. Antonio Airton Bortolucci 
A minha mãe, María Alvarez de Pehovaz, meu exemplo de vida, integridade, luta e fortaleza.

A meu irmão, Richard Paúl Pehovaz Alvarez, meu amigo, companheiro e confidente. 


\section{Agradecimentos}

A Deus, pela oportunidade de vida, pelas pessoas que colocou em meu caminho e por tudo o que ele faz na minha vida.

Ao Prof. Dr. Tarcísio Barreto Celestino, pela oportunidade, orientação, ajuda e amizade, agradeço-lhe por ter acreditado em mim.

Ao Prof. Dr. Antônio Airton Bortolucci, pela compreensão, motivação, incentivo e ajuda nas vezes que precisei dele, muito obrigado por tudo.

À Coordenação de Aperfeiçoamento de Pessoal de Nível Superior-CAPES, pela bolsa concedida.

À Fundação de Amparo à Pesquisa do Estado de São Paulo - FAPESP, pelo financiamento da pesquisa.

À Universidade Regional do Cariri - URCA em nome do Historiador Armando Lopes Rafael e do Prof. Francisco de Assis Cunha.

Aos geólogos Francisco Idalécio de Freitas e Carlos Hindeburgo Nunes Holanda pela ajuda nos contatos com as mineradoras de gipsita da Chapada do Araripe.

Ao CPCA - Centro de Pesquisas Paleontológicas da Chapada do Araripe (DNPM-10o DS/CE - Departamento Nacional de Produção Mineral) em nome do Geólogo José Arthur Ferreira Gomes de Andrade pela ajuda na obtenção das amostras de gipsita bandada da Chapada do Araripe.

À mineradora Rancharia pela disponibilidade das amostras de gipsita bandada.

Ao Departamento de Geotecnia da Escola de Engenharia de São Carlos - USP pela oportunidade de realização do curso de Pós Graduação.

Aos Professores do Departamento de Geotecnia pelos conhecimentos transmitidos, saudável convivência, apoio e amizade.

Ao Prof. Dr. Nelson Aoki pela motivação, frutíferas discussões e, sobretudo sua amizade, da qual me sinto muito orgulhoso e grato.

Ao Prof. Fabio Taioli por suas sugestões no desenvolvimento da pesquisa e no exame de qualificação.

Ao Prof. Antenor Zanardo da Universidade Estadual Paulista - UNESP de Rio Claro pela revisão das descrições petrográficas e das seções delgadas.

A Pedro Feres Filho e Marco Aurélio Luzio da Physical Acoustic of South America PASA pelo interesse na pesquisa realizada e solucionar alguns problemas logísticos apresentados ao longo da pesquisa. 
A Jorge Nicolau dos Santos do Laboratório de termodinâmica e fluidos do Departamento de Engenharia Mecânica da EESC-USP pela revisão e sugestões realizadas ao equipamento de emissão acústica.

Aos técnicos do Departamento de Geotecnia, sem exceção, pela ajuda sempre efetiva na preparação e execução dos ensaios. Especialmente para meu grande amigo Benedito Osvaldo de Souza pela sua honestidade, paciência, profissionalismo e dedicação para o melhor desenvolvimento da pesquisa.

Ao Dr. Herivelto Moreira dos Santos, responsável pelo setor de informática, pela amizade e auxilio na parte computacional.

Aos funcionários do Departamento de Geotecnia: Maristela Z. Batissaco, Neiva Cardoso, Álvaro Nery.

As funcionárias da biblioteca, Marielza Ortega Roma por sua paciência, amizade e apoio na procura de referencias bibliográficas, em especial a Elena Luzia Palloni Gonçalves na formatação das referencias bibliográficas.

Ao Dr. Antonio Samaniego Alcântara pela amizade e apoio que permitiram concluir estes estudos.

Aos meus amigos Mauricio Giambastiani, Jeselay Reis e Heraldo Pitanga pela amizade, apoio nos momentos difíceis desta pesquisa e pelas frutíferas discussões técnicas nesses anos.

Aos colegas do Departamento de Geotecnia, sem exceção, muito obrigado pelos belos momentos vividos, por abrir seus corações e por todo o carinho desinteressado. Especialmente a meus queridos amigos Miguel, Eliana, Jocy, Marcilene, Jefferson, Rogério, Leo, Jorge, Carmen, Marina, Juliana, Osvaldo, Vagner por me escutarem e me darem forças nos momentos mais difíceis desta pesquisa.

A meus amigos peruanos Gonzalo Ordoñez e Gladys Omura, muito obrigado por seu apoio e confiança, fico eternamente agradecido.

A minha amiga colombiana Mélida del Pilar, muito obrigado pela paciência, amizade e dedicação de seu tempo para me ajudar na formatação da tese.

A Clarice, amiga, parceira e confidente, uma pessoa especial que chegou à minha vida, por sua companhia, seu apoio nos momentos difíceis e por alegrar minha vida.

Meus agradecimentos finais, mas não menos importantes, vão para as pessoas que mais amo nesta vida: minha família, sem eles eu nada seria. Em especial minha mãe, por seu esforço, sacrifício e dedicação, tanto assim que esteve comigo neste último ano para me apoiar e me dar forças; a meu irmão pela paciência e apoio em todos os momentos desta pesquisa.

A todos que, direta ou indiretamente, contribuíram para a realização deste trabalho. 


\section{SUMARIO}

RESUMO X xi

ABSTRACT

LISTA DE FIGURAS xiii

LISTA DE TABELAS Xxvii

LISTA DE SIGLAS XXXi

LISTA DE SIMBOLOS XXXiii

\section{CAPITULO I}

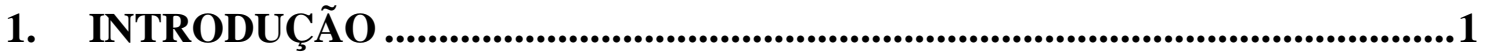

1.1. Considerações preliminares e exposição do problema ...................................1

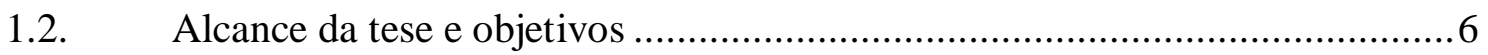

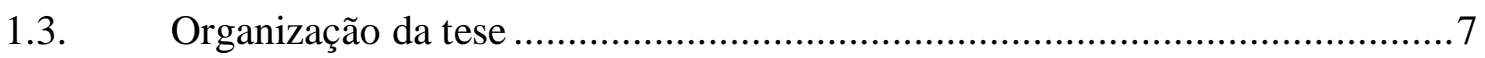

\section{CAPITULO II}

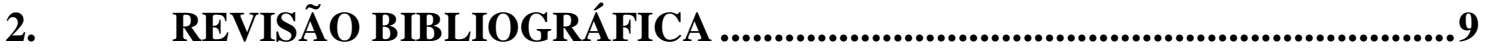

2.1. Microfissuramento e dano associado ........................................................... 9

2.2. $\quad$ A técnica da emissão acústica ............................................................ 11

2.2.1. Fontes de emissão acústica..................................................................... 11

2.2.2. Parâmetros da emissão acústica............................................................... 12

2.3. Estudo do microfissuramento por técnicas de emissão acústica ....................14

2.4. Dano ligado ao microfissuramento e à emissão acústica...............................16

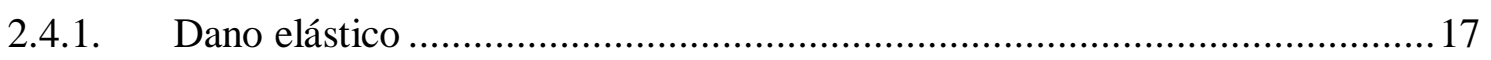

2.4.2. Estimativa da danificação por emissão acústica........................................... 20

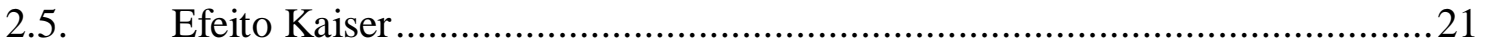

2.6. Freqüência característica da emissão acústica e o processo de fissuramento.23

2.7. Estudos anteriores dos mecanismos de deformação dos gipsitos...................26 


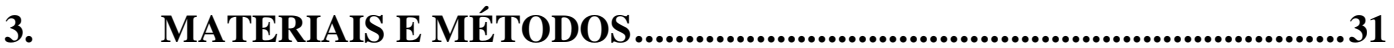

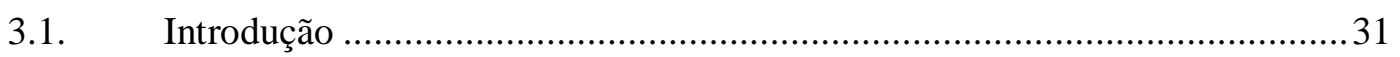

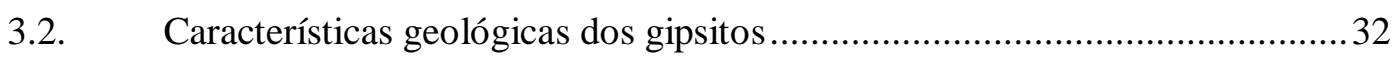

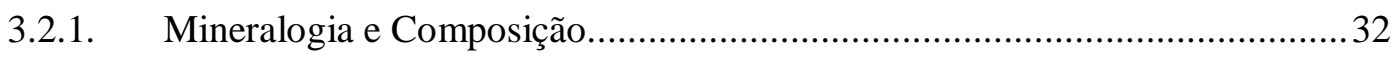

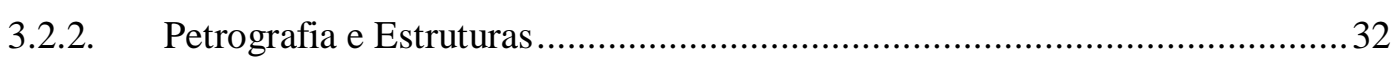

3.3. Gipsitos da Formação Santana (Cretáceo inferior), Chapada do Araripe

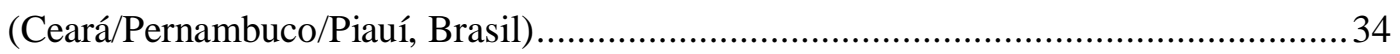

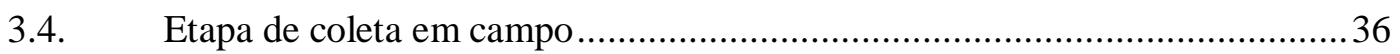

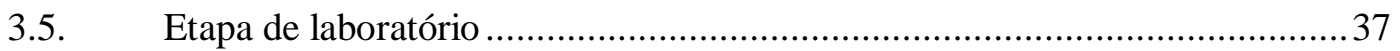

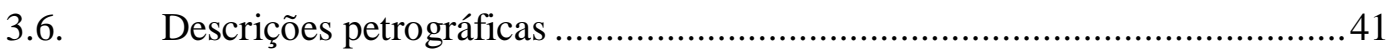

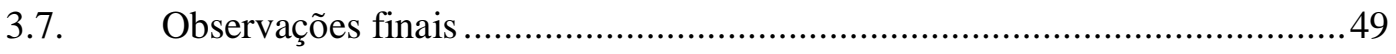

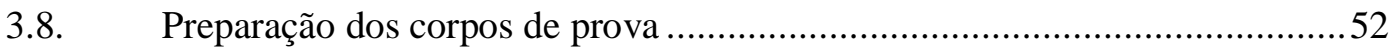

3.9. Instrumentação dos corpos de prova e calibração do equipamento de

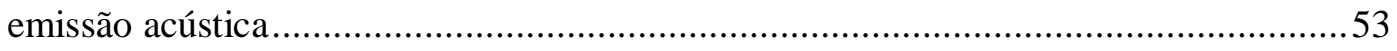

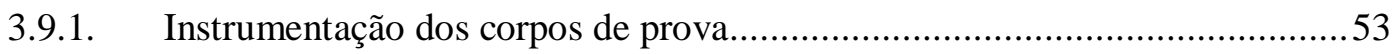

3.9.2. Calibração do equipamento de emissão acústica...........................................56

3.10. Sistema de carregamento e instrumentação dos ensaios de deformação

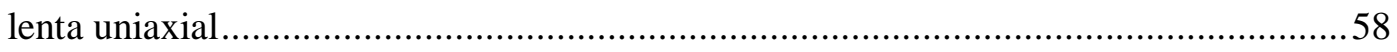

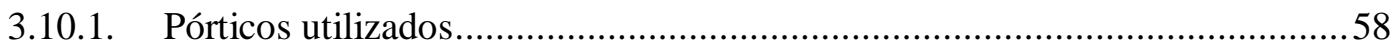

3.10.2. Sistema de aplicação, controle e regulagem da carga....................................59

3.11. Sistemas de aquisição e armazenamento dos dados ....................................... 63

3.11.1. Problemas de ruídos encontrados ................................................................64

3.11.2. Solução dos problemas de ruídos encontrados..............................................65

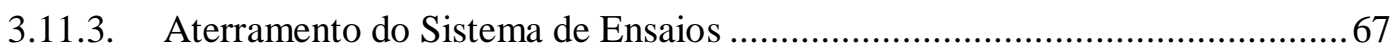

3.11.4. Alteração na Unidade Mecânica Hidráulica................................................. 70

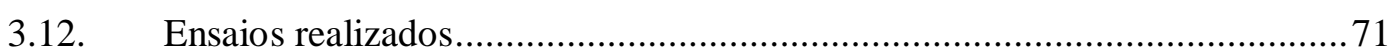

3.12.1. Ensaios de compressão uniaxial com uso da técnica de emissão acústica.......71

3.12.2. Ensaios de compressão uniaxial com ciclos variáveis de carregamento

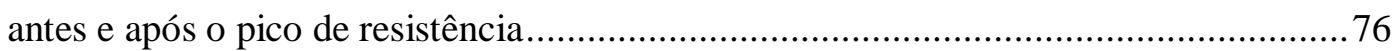

3.12.3. Ensaios de fluência de curta duração ............................................................ 81

3.12.4. Ensaios de fluência de longa duração .......................................................... 88

3.12.5. Ensaios especiais de fluência de curta duração com ciclos de acréscimos de carregamento anteriores e posteriores ao descarregamento 103 
3.12.6. Ensaio especial de compressão uniaxial com ciclos variáveis de carregamento antes e após o pico de resistência (Complemento do Tipo CVIII) .........106

\section{CAPITULO IV}

4. RESULTADOS E DISCUSSÃO

4.1. Ensaios de compressão uniaxial com uso da técnica de emissão acústica ......117

4.2. Ensaios de compressão uniaxial com ciclos variáveis de carregamento antes do pico de resistência com técnica de emissão acústica

4.3. Ensaios de compressão uniaxial com ciclos variáveis de carregamento antes e após o pico de resistência.

4.4. Ensaios de fluência de curta e longa duração

4.5. Comportamento Acústico do Gipsito Bandado após os Ensaios de Fluência

4.6. Ensaios de fluência de longa duração com dois ciclos de carregamento e descarregamento sucessivos e posterior ciclo crescente de carga

4.7. Ensaios especiais de fluência de curta duração com ciclos de acréscimos

de carregamento anteriores e posteriores ao descarregamento

4.8. Ensaio especial de compressão uniaxial com ciclos variáveis de carregamento antes e após o pico de resistência (Complementação do tipo CVIII) .... 188

\section{CAPITULO V}

5. CONCLUSÕES E SUGESTÕES PARA PESQUISAS FUTURAS 203

5.1. Conclusões 204

5.2. Sugestões para pesquisas futuras 207

REFERÊNCIAS BIBLIOGRÁFICAS 


\section{Resumo}

PEHOVAZ-ALVAREZ, H. I. Estudo de mecanismos de deformação lenta da Gipsita Bandada da Chapada do Araripe em ensaios de fluência monitorados por emissão acústica. 2009. 338 f. Tese (Doutorado) - Escola de Engenharia de São Carlos, Universidade de São Paulo, São Carlos, 2009.

Estudos experimentais realizados por alguns autores abordaram os mecanismos de deformação nas gipsitas, tais como o fluxo plástico e a dissolução por pressão. Ainda assim, é pequeno o conhecimento do comportamento mecânico das rochas de gipso. Nesta tese foram estudados os mecanismos de deformação lenta em gipsitas bandadas da Formação Santana da Chapada de Araripe com uso da técnica de emissão acústica. Adotou-se este procedimento como técnica indireta de deteç̧ão do processo de microfissuramento, para evitar mudanças que ocorrem na microestrutura durante seu descarregamento e preparação de amostras para sua observação por técnicas diretas. Realizaram-se ensaios de fluência de curto e longo prazo numa prensa hidráulica servocontrolada MTS 815 e em conjunto modulares (torres individuais) em um laboratório de fluência especialmente equipado. Encontrou-se que o mecanismo do microfissuramento está fortemente influenciado por processos de cicatrização durante ensaios de fluência de longo prazo. Devido ao processo de cicatrização da microfissura, a fluência terciaria nunca foi alcançada, mesmo em corpos de prova carregados com até $95 \%$ da resistência à compressão uniaxial. Nesta tese outros resultados importantes foram alcançados como: identificar que o fenômeno de microfissuramento para a rocha em questão é detectado por fenômenos de emissão acústica de freqüências intermediárias (de 100 a $400 \mathrm{kHz}$ ) e constatar que o efeito Kaiser se manifesta neste tipo de rochas de modo inequívoco para solicitações rápidas, enquanto após ensaios de fluência de longa duração, não mais se manifesta, por causa da cicatrização. Ou seja, corpos de prova submetidos mais uma vez à compressão uniaxial após o descarregamento, voltam a apresentar eventos de emissão acústica e, conseqüentemente, a geração de novas microfissuras. Este fato somente pode ser explicado por um processo de cicatrização da microfissura durante a fluência de longo prazo. Esta cicatrização, devido a fenômenos físico-químicos, apresentou outros indícios como um aumento no módulo de elasticidade após ensaios de fluência, quando comparado aos valores antes do ensaio, e mesmo um endurecimento (aumento da resistência à compressão uniaxial) também após a fluência. Esclareceu-se também de modo inequívoco que o descarregamento provoca o progresso do microfissuramento. Além dos sinais característicos do microfissuramento, constatou-se que o módulo de elasticidade, medido nos mesmos níveis de tensão, é mais alto antes que depois do descarregamento. O decréscimo de rigidez é indício do processo de dano por microfissuramento.

Palavras-chave: Microfissuramento. Mecanismos de deformação lenta. Fluência. Gipsita bandada. Formação Santana. Emissão acústica. Efeito Kaiser. 


\section{Abstract}

PEHOVAZ-ALVAREZ, H. I. Study of slow deformation mechanisms of the banded gypsum rock of the Chapada do Araripe in creep tests monitored by acoustic emission. 2009. 338 f. Thesis (Doctoral) - Escola de Engenharia de São Carlos, Universidade de São Paulo, São Carlos, 2009.

Experimental studies by several authors have shown some of the key deformation mechanisms in gypsum, such as plastic flow and pressure dissolution. Even so, there is still sparse knowledge about the mechanical behavior of natural gypsum rocks. Creep mechanisms of the banded gypsum rock of Santana Formation from the Chapada do Araripe (Santana Formation) in creep tests were studied with acoustic emission technique correlating the stress levels related to microcracking to the energy release associated with these mechanisms. This procedure was adopted as an indirect technique of detection of the microcracking process, to prevent changes that occur in the microstructure during unloading and in sample preparation for its observations with direct techniques. Short- and long-term creep tests were carried out in an MTS 815 servo-controlled testing system and in modular sets (single towers) in a specially equipped creep laboratory. It was found that the microcrack mechanism is strongly influenced by healing processes during long-term creep. Due to the microcrack healing process, tertiary creep was never reached, even in specimens loaded with up to $95 \%$ of the uniaxial compressive strength. In this thesis other important results were reached as: to identify that the microcracking phenomenon for the rock in question is detected by acoustic emission phenomena of intermediate frequencies (from 100 to $400 \mathrm{kHz}$ ) and to evidence that the Kaiser effect unequivocally manifests in this type of rock when subjected to quick loads, while after long-term creep tests, it is no longer evidenced on account of healing. In other words, the specimens subjected once again to uniaxial compression after unloading, again show acoustic emission events and therefore the generation of new microcracks. This fact can only be explained by a microcrack healing process during long-term creep. This healing, due to physical-chemical phenomena, presented other indications as an increase in the modulus of elasticity after creep tests, when compared to the values before the test, and even a hardening (increase of the uniaxial compressive strength) also after the creep. It was also clarified in unequivocal way that the unloading provokes microcracking progress. In addition to the microcracking characteristic indications, it was found that the modulus of elasticity, when measured at the same stress levels, is higher before unloading than after the unloading. The stiffness decrease is indication of the microcracking damage process.

Keywords: Microcracking. Creep mechanisms. Creep. Banded gypsum rock. Santana Formation. Acoustic emission. Kaiser effect. 


\section{LISTA DE FIGURAS}

Figura 2.1 Diagrama tensão versus deformação mostrando os estágios de

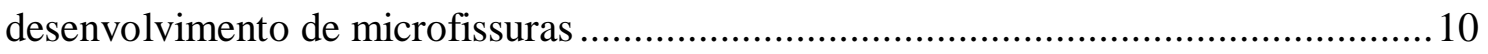

Figura 2.2 Variação da energia dissipada $(U d)$ em ensaio cíclico em Calcário Irati......10

Figura 2.3 Parâmetros importantes da emissão acústica .......................................... 14

Figura 2.4 Comportamento da emissão acústica em relação aos estágios do processo de

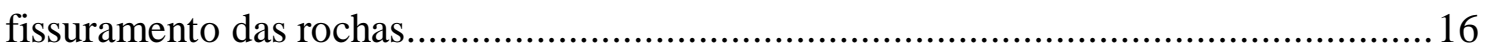

Figura 2.5 Seção efetiva de um sólido danificado ...................................................17

Figura 3.1 Microfotografias do gipso. (a-b) Cristais de gipso preenchendo uma cavidade em dolomito mostrando a típica cor de interferência cinza de primeira

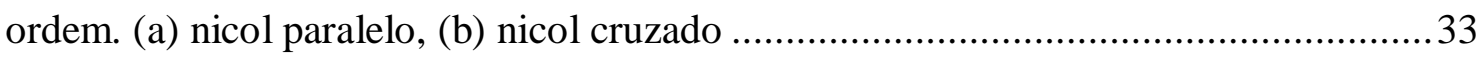

Figura 3.2 Mapa de localização e esquema estratigráfico - Chapada de Araripe ............35

Figura 3.3 Exemplo da forma de ocorrência dos afloramentos do gipsito bandado ........36

Figura 3.4 Exemplos de amostras coletadas em campo: observe-se detalhe de

ondulações (dobramentos suaves) e de cristais com estrutura fibro-radiada .37

Figura 3.5 Amostra GBA3 apresentando corte realizado na amostra em duas

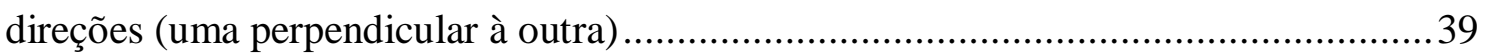

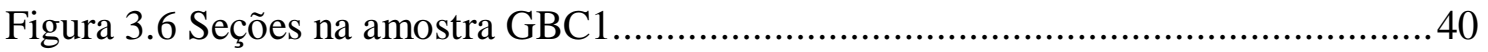

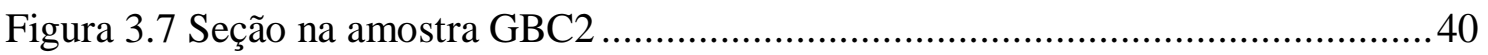

Figura 3.8 Amostra 8 que na tentativa de gerar uma nova seção desagregou-se ...........41

Figura 3.9 Aspectos gerais da rocha, com destaque para o bandamento e orientação dos cristais observados e fotografiados em lupa com nicóis cruzados

Figura 3.10 Banda de granulação mais fina formada por cristais de gipso alongados e orientados e equidimensionais sem inclusões de anidrita. Nicóis cruzados. Amostra GBA3. 
Figura 3.11 Banda de granulação mais grossa, com cristais de gipso ricos em minúsculas inclusões de anidrita. Nicóis cruzados. Amostra GBC1

Figura 3.12 Detalhe do cristal de barita ou celestita com inclusões de anidrita na amostra GBC2-C. Nicóis cruzados

Figura 3.13 Contato brusco entre as bandas finas e grossas e detalhe da banda de granulação mais grossa com cristal de barita ou celestita. Nicóis cruzados. Amostra GBA3

Figura 3.14 Imagem de banda de granulação mais fina entre bandas de granulação mais grossa, com cristais de gipso ricos em inclusões de anidrita. Nicóis cruzados. Amostra GBC1

Figura 3.15 Detalhe da banda de granulação mais grossa mostrando cristais de gipso com inclusões de anidrita. Nicóis cruzados.

Figura 3.16 Relação entre as duas bandas, a primeira de granulação grossa, alongada intercalada por granulação mais fina ambas formadas por cristais de gipso alongados e orientados e equidimensionais. Nicóis cruzados. Amostra GBC2-A.

Figura 3.17 Modelo esquemático da formação das bandas composicionais 49

Figura 3.18 Corpos de prova colocados em um dessecador. .52

Figura 3.19 Extensômetros elétricos de resistência em roseta dupla colado no corpo de prova .54

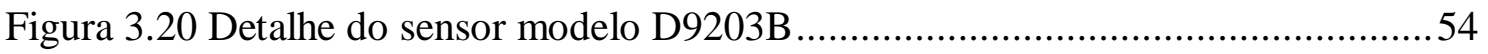

Figura 3.21 Detalhe do pré-amplificador .55

Figura 3.22 Detalhe do sensor com o acoplante no corpo de prova .55

Figura 3.23 Configuração do teste para estudar a sensibilidade mediante a quebra do grafite de dureza $2 \mathrm{H}$

Figura 3.24 Pórtico de reação tipo coluna utilizado para ensaios de deformação lenta uniaxial. 59

Figura 3.25 Conjunto modular (torre individual) utilizado para ensaios de deformação lenta uniaxial 
Figura 3.26 a) Bomba hidráulica ligada aos dois painéis de controle instalada fora do laboratório de fluência para evitar interferências nas medições com o equipamento de emissão acústica. b) Painel de controle mostrando os manômetros utilizados para sua construção

Figura 3.27 Painel de controle dentro da qual se encontra o pressostato.....

Figura 3.28 Painéis reguladores de carga

Figura 3.29 Detalhe do acumulador de pressão colocado para manter a pressão constante no macaco plano tórico .

Figura 3.30 Detalhe dos cabos isolados com fita crepe

Figura 3.31 Detalhe dos sensores colocados fora dos corpos de prova

Figura 3.32 Detalhe dos fios de cobre utilizados para manter a mesma voltagem nas torres individuais.

Figura 3.33 Vala escavada para implantação do fio e barras metálicas de cobre para aterramento

Figura 3.34 Interligação com cabo de cobre.

Figura 3.35 Detalhe da cabeça da haste de cobre interligada com o cabo de cobre

Figura 3.36 Derivação do fio terra

Figura 3.37 Detalhe do conector, da rosca e da mesa ............................................... 70

Figura 3.38 Unidade Hidráulica Elétrica e Manual .................................................... 70

Figura 3.39 Curva completa tensão versus deformações axial, radial e volumétrica do corpo de prova GBEA3 do ensaio de compressão uniaxial com uso da técnica de emissão acústica

Figura 3.40 Detalhe da instrumentação do corpo de prova GBEA3. Note-se o sensor piezoelétrico e um dos extensômetros elétricos em roseta dupla colado no corpo de prova

Figura 3.41 Curva tensão versus deformações axial, radial e volumétrica do corpo de prova GBEA18 do ensaio de compressão uniaxial com uso da técnica de emissão acústica 
Figura 3.42 Detalhe da instrumentação do corpo de prova GBEA17. Notem-se os quatro sensores piezoelétricos e um dos extensômetros elétricos em roseta dupla colado no corpo de prova

Figura 3.43 Curva tensão versus deformações axial, radial e volumétrica do corpo de prova GBEA11 do ensaio de compressão uniaxial com ciclos variáveis de carregamento antes e após o pico de resistência

Figura 3.44 Detalhe da instrumentação do corpo de prova GBEA11. Notem-se os seis sensores piezoelétricos fixados por bandas elásticas e um dos extensômetros elétricos em roseta dupla colado no corpo de prova

Figura 3.45 Curva tensão versus deformações axial, radial e volumétrica do corpo de prova GBEA5 do ensaio de compressão uniaxial com ciclos variáveis de carregamento antes e após o pico de resistência

Figura 3.46 Detalhe da instrumentação do corpo de prova GBEA5. Notem-se os dois sensores piezoelétricos fixados por bandas elásticas e um dos extensômetros elétricos em roseta dupla colado no corpo de prova .79

Figura 3.47 Curva tensão versus deformações axial, radial e volumétrica do corpo de prova GBpec4da do ensaio de compressão uniaxial com ciclos variáveis de carregamento antes e após o pico de resistência.....

Figura 3.48 Detalhe da instrumentação do corpo de prova GBpec4da. Notem-se os quatro sensores piezoelétricos fixados por bandas elásticas e um dos extensômetros elétricos em roseta dupla colado no corpo de prova

Figura 3.49 Curvas típicas do ensaio de fluência de curta duração realizado na prensa hidráulica servocontrolada no corpo de prova GBEA6. (a) Tensão versus tempo. (b) Deformações axial, radial e volumétrica versus tempo

Figura 3.50 Detalhe da instrumentação do corpo de prova GBEA6

Figura 3.51 Curvas típicas do ensaio de fluência de curta duração realizado na prensa hidráulica servocontrolada no corpo de prova GBflu4MTS. (a) Tensão versus tempo. (b) Deformações axial, radial e volumétrica versus tempo..... 
Figura 3.52 Detalhe da instrumentação do corpo de prova GBflu4MTS. Note-se um dos extensômetros elétricos em roseta dupla colado ao corpo de prova. Observe-se que não foram colocados sensores piezoelétricos

Figura 3.53 Curvas típicas do ensaio de fluência de curta duração realizado na prensa hidráulica servocontrolada no corpo de prova GBflu6MTS. (a) Tensão versus tempo. (b) Deformações axial, radial e volumétrica versus tempo....

Figura 3.54 Detalhe da instrumentação do corpo de prova GBflu6MTS. Note-se os quatro sensores piezoelétricos fixados por bandas elásticas e um dos extensômetros elétricos em roseta dupla colado ao corpo de prova

Figura 3.55 Configuração dos ensaios de fluência de longa duração nos módulos individuais e painel de controle das cargas aplicadas aos corpos de prova 90

Figura 3.56 Curvas típicas do corpo de prova GBEAF4 do ensaio de fluência de longa duração com ciclos variáveis de carregamento e descarregamento. (a) Tensão versus tempo. (b) Deformações axial, radial e volumétrica versus tempo

Figura 3.57 Detalhe da instrumentação dos corpos de prova nas torres individuais nos ensaios de fluência de longa duração. Notar os relógios comparadores utilizados e o sensor piezoelétrico fixado por uma banda elástica .93

Figura 3.58 Configuração do ensaio de fluência de longa duração no pórtico de reação tipo coluna e painel de controle de carga aplicada ao corpo de prova GBEAF3

Figura 3.59 Curva tensão versus tempo do corpo de prova GBEAF3 do ensaio de fluência de longa duração submetido a ciclos variáveis de carregamento e descarregamento

Figura 3.60 Detalhe da instrumentação do corpo de prova GBEAF3 no pórtico de reação tipo coluna

Figura 3.61 Detalhe da instrumentação do corpo de prova GBfluencia10 nas torres individuais nos ensaios de fluência de longa duração

Figura 3.62 Configuração dos ensaios de fluência de longa duração nos módulos individuais. Note-se o corpo de prova GBfluencia7 rompido 
Figura 3.63 Configuração do ensaio de fluência de longa duração do corpo de prova GBfluencia8 no pórtico de reação tipo coluna

Figura 3.64 Detalhe da instrumentação do corpo de prova GBfluencia8 no pórtico de reação tipo coluna....

Figura 3.65 Curva tensão versus tempo do ensaio de fluência de longa duração (274 horas) no corpo de prova GBfluencia13.

Figura 3.66 Curva deformações axial, radial e volumétrica versus tempo do ensaio de fluência de longa duração (274 horas) no corpo de prova GBfluencia13 100

Figura 3.67 Configuração dos ensaios de fluência de longa duração nos módulos individuais dos corpos de prova GBfluencia11, GBfluencia12, GBfluencia13 e GBfluencia14

Figura 3.68 Detalhe da instrumentação do corpo de prova GBfluencia13.

Figura 3.69 Tensão versus deformações axial, radial e volumétrica no ensaio de compressão uniaxial no corpo de prova GBfluencia13 posterior ao ensaio de fluência de longa duração

Figura 3.70 Tensão versus deformações axial, radial e volumétrica no ensaio especial de fluência de curta duração com ciclos de acréscimos de carregamento anteriores e posteriores ao descarregamento no corpo de prova GBEA24

Figura 3.71 Curva tensão versus tempo correspondente ao ensaio especial de fluência de curta duração com ciclos de acréscimos de carregamento anteriores e posteriores ao descarregamento no corpo de prova GBEA24

Figura 3.72 Tensão versus deformações axial, radial e volumétrica no ensaio de carregamento e descarregamento antes e após o pico de resistência no corpo de prova GBpec4da (Segundo ensaio no mesmo corpo de prova). Note-se que o corpo de prova foi ensaiado até a região pós-pico 106

Figura 3.73 Tensão versus deformações axial, radial e volumétrica no ensaio de compressão uniaxial do corpo de prova GBpec4da após ter sido submetido a dois ensaios de carregamento e descarregamento antes e após o pico de resistência (Terceiro ensaio no mesmo corpo de prova) 
Figura 4.1 Tensão e contagem versus tempo dos eventos de emissão acústica do ensaio de compressão uniaxial no corpo de prova GBEA2 (controle de deslocamento do prato e carregamento perpendicular às camadas)

Figura 4.2 Tensão e energia absoluta versus tempo dos eventos de emissão acústica do ensaio de compressão uniaxial no corpo de prova GBEA2 (controle de deslocamento do prato e carregamento perpendicular às camadas)

Figura 4.3 Tensão e contagem versus tempo dos eventos de emissão acústica no sensor 4 (freqüências intermediárias de 100 a 400 kHz) do ensaio de compressão uniaxial no corpo de prova GBEA18 (controle de força e carregamento perpendicular às camadas)

Figura 4.4 Tensão e energia absoluta versus tempo dos eventos de emissão acústica no sensor 4 (freqüências intermediárias de 100 a $400 \mathrm{kHz}$ ) do ensaio de compressão uniaxial no corpo de prova GBEA18 (controle de força e carregamento perpendicular às camadas).

Figura 4.5 Tensão e energia absoluta acumulada versus tempo dos eventos de emissão acústica do ensaio de compressão uniaxial no corpo de prova GBEA2 (controle de deslocamento do prato e carregamento perpendicular às camadas)

Figura 4.6 Tensão e energia absoluta acumulada versus tempo dos eventos de emissão acústica no sensor 4 (freqüências intermediárias de 100 a $400 \mathrm{kHz}$ ) do ensaio de compressão uniaxial no corpo de prova GBEA18 (controle de força e carregamento perpendicular às camadas)

Figura 4.7 Energia absoluta acumulada dos eventos de emissão acústica como função da tensão aplicada durante o carregamento do corpo de prova GBEA2 (carregamento perpendicular às camadas)

Figura 4.8 Geometria do corpo de prova utilizado por Ganne, Vervoort e Wevers ......120

Figura 4.9 Ensaio de compressão simples no corpo de prova GBEA17 - (a): escala normal; (b): ampliação do eixo de contagem acumulada. O sensor 3 detecta freqüências baixas (de 20 a $100 \mathrm{kHz}$ ) e o sensor 4 detecta freqüências intermediárias (de 100 a $400 \mathrm{kHz}$ ).... 
Figura 4.11 Ensaio de compressão simples no corpo de prova GBEA19 - (a): escala normal; (b): ampliação do eixo de contagem acumulada. O sensor 3 detecta freqüências baixas (de 20 a $100 \mathrm{kHz}$ ) e o sensor 4 detecta freqüências intermediárias (de 100 a $400 \mathrm{kHz}$ ).

Figura 4.12 Ensaio de compressão simples no corpo de prova GBEA20 - (a): escala normal; (b): ampliação do eixo de contagem acumulada. O sensor 3 detecta freqüências baixas (de 20 a $100 \mathrm{kHz}$ ) e o sensor 4 detecta freqüências intermediárias (de 100 a 400 kHz)

Figura 4.13 Curva tensão versus deformações axial, radial e volumétrica do corpo de prova GBEA10 submetido a 5 ciclos de carregamento e descarregamento (carregamento perpendicular às camadas)

Figura 4.14 Energia absoluta acumulada dos eventos de emissão acústica como função da tensão aplicada durante o carregamento e descarregamento do corpo de prova GBEA5 antes do pico de resistência (carregamento paralelo às camadas)

Figura 4.15 Tensão e energia absoluta versus tempo do corpo de prova GBEA5 submetido a ciclos variáveis de carregamento antes do pico de resistência (carregamento paralelo às camadas)

Figura 4.16 Tensão e energia absoluta acumulada versus tempo do corpo de prova GBEA5 submetido a ciclos variáveis de carregamento antes do pico de resistência (carregamento paralelo às camadas)

Figura 4.17 Tensão e energia absoluta acumulada versus tempo dos sensores 1, 2 e 3 no corpo de prova GBEA12 submetido a ciclos variáveis de carregamento antes e após o pico de resistência (carregamento perpendicular às camadas).

Figura 4.18 Tensão e energia absoluta acumulada versus tempo dos sensores 4, 5 e 6 no corpo de prova GBEA12 submetido a ciclos variáveis de carregamento antes e após o pico de resistência (carregamento perpendicular às camadas).

Figura 4.19 Tensão e contagem cada 30 segundos versus tempo dos eventos de emissão acústica no sensor 4 (freqüências intermediárias de 100 a 400 kHz) do ensaio de fluência de curta duração (a) No corpo de prova GBflu8MTS (49 horas) e (b) No corpo de prova GBflu9MTS (64 horas). 
Figura 4.20 Tensão e contagem cada 30 segundos versus tempo dos eventos de emissão acústica no sensor 2 (freqüências intermediárias de 100 a $400 \mathrm{kHz}$ ) do ensaio de fluência de longa duração (274 horas) (a) No corpo de prova GBfluencia11 e (b) No corpo de prova GBfluencia13.

Figura 4.21 Deformação axial e contagem acumulada versus tempo dos eventos de emissão acústica no sensor 4 (freqüências intermediárias de 100 a 400 kHz) do ensaio de fluência de curta duração. (a) No corpo de prova GBflu8MTS (49 horas) e (b) No corpo de prova GBflu9MTS (64 horas).

Figura 4.22 Deformação axial e contagem acumulada versus tempo dos eventos de emissão acústica no sensor 2 (freqüências intermediárias de 100 a 400 kHz) do ensaio de fluência de longa duração (274 horas). (a) No corpo de prova GBfluencia11 e (b) No corpo de prova GBfluencia13.

Figura 4.23 Deformação axial versus contagem acumulada dos eventos de emissão acústica no sensor 4 (freqüências intermediárias de 100 a $400 \mathrm{kHz}$ ) do ensaio de fluência de curta duração. (a) No corpo de prova GBflu8MTS (49 horas) e (b) No corpo de prova GBflu9MTS (64 horas). Observe-se a relação linear que existe entre a deformação axial e a contagem acumulada.

Figura 4.24 Deformação axial versus contagem acumulada dos eventos de emissão acústica no sensor 4 (freqüências intermediárias de 100 a $400 \mathrm{kHz}$ ) do ensaio de fluência de longa duração (274 horas). (a) No corpo de prova GBfluencia11 e (b) No corpo de prova GBfluencia13. Observe-se a relação linear que existe entre a deformação axial e a contagem acumulada

Figura 4.25 Relação I1/(I1+H1) e deformação axial vs tempo em janelas de 30 segundos, onde: I1 numero de contagens no sensor 3 (freqüências baixas de 20 a $100 \mathrm{kHz}$ ) e H1 numero de contagens no sensor 4 (freqüências intermediárias de 100 a $400 \mathrm{kHz}$ ) do ensaio de fluência de curta duração. (a) No corpo de prova GBflu8MTS (49 horas) (b) No corpo de prova GBflu9MTS (64 horas) 
Figura 4.26 Relação I1/(I1+H1) e deformação axial versus tempo em janelas de 30 segundos, onde: I1 numero de contagens no sensor 1 (freqüências baixas de 20 a $100 \mathrm{kHz}$ ) e H1 numero de contagens no sensor 2 (freqüências intermediárias de 100 a $400 \mathrm{kHz}$ ) do ensaio de fluência de longa duração (274 horas). (a) No corpo de prova GBfluencia11 e (b) No corpo de prova GBfluencia13

Figura 4.27 Emissão acústica indicativa de microfissuramento no sensor 4 (freqüências intermediárias de 100 a $400 \mathrm{kHz}$ ) em ensaios de fluência de curta duração. (a) No corpo de prova GBflu10MTS (40 horas). (b) No corpo de prova GBflu12MTS (23 horas).

Figura 4.28 Emissão acústica indicativa de microfissuramento no sensor 2 (freqüências intermediárias de 100 a $400 \mathrm{kHz}$ ) em ensaios de fluência de longa duração (274 horas). (a) No corpo de prova GBfluencia12. (b) No corpo de prova GBfluencia14

Figura 4.29 Tensão e contagem acumulada versus tempo para recarregamento no sensor 4 (freqüências intermediárias de 100 a 400 kHz) - (a) Ensaio GBfluencia6. (b) Ensaio GBfluencia8 (corpos de prova submetidos anteriormente à fluência de longa duração de 55 dias) 155

Figura 4.30 Tensão e contagem acumulada versus tempo para recarregamento no sensor 4 (freqüências intermediárias de 100 a 400 kHz) - (a) Ensaio GBfluencia9. (b) Ensaio GBfluencia10 (corpos de prova submetidos anteriormente à fluência de longa duração de 45 dias)

Figura 4.31 Módulo de elasticidade versus número de ciclo de carregamento ou descarregamento dos corpos de prova GBEAF1 e GBEAF2 (carregamento paralelo às camadas) nos ensaios de fluência de longa duração (150 dias) 162

Figura 4.32 Módulo de elasticidade versus número de ciclo de carregamento ou descarregamento dos corpos de prova GBEAF1 e GBEAF3 (carregamento paralelo às camadas) nos ensaios de fluência de longa duração (150 dias)

Figura 4.33 Módulo de elasticidade versus número de ciclo de carregamento ou descarregamento dos corpos de prova GBEAF4 e GBEAF5 (carregamento perpendicular às camadas) nos ensaios de fluência de longa duração (150 dias) 
Figura 4.34 Evolução dos módulos de elasticidade nos carregamentos dos corpos de prova versus tensão aplicada nos ensaios de fluência de longa duração (150 dias)

Figura 4.35 Tensão e contagem versus tempo dos eventos de emissão acústica do ensaio de fluência de longa duração no corpo de prova GBEAF4. (a) Segundo carregamento e (b) Terceiro carregamento

Figura 4.36 Deformação axial e contagem acumulada versus tempo dos eventos de emissão acústica do ensaio de fluência de longa duração no corpo de prova GBEAF4. (a) Segundo carregamento e (b) Terceiro carregamento

Figura 4.37 Deformação axial versus contagem acumulada dos eventos de emissão acústica do ensaio de fluência de longa duração no corpo de prova GBEAF4. (a) Segundo carregamento e (b) Terceiro carregamento

Figura 4.38 Módulos de elasticidade (estático e na fase cíclica) versus tempo no corpo de prova GBEA14 (carregamento perpendicular às camadas), com ciclos de acréscimos de carregamento anteriores e posteriores ao descarregamento de freqüência 0,25 Hz (1,14 MPa/s)

Figura 4.39 Módulos de elasticidade (estático e na fase cíclica) versus tempo no corpo de prova GBEA25 (carregamento paralelo às camadas), com ciclos de acréscimos de carregamento anteriores e posteriores ao descarregamento de freqüência $0,025 \mathrm{~Hz}(6,82 \mathrm{MPa} / \mathrm{min})$

Figura 4.40 Módulos de elasticidade (estático e na fase cíclica) versus tempo no corpo de prova GBEA24 (carregamento $45^{\circ}$ com camadas), com ciclos de acréscimos de carregamento anteriores e posteriores ao descarregamento de freqüência $0,004 \mathrm{~Hz}(1,14 \mathrm{MPa} / \mathrm{min})$

Figura 4.41 Tensão e contagem versus tempo dos eventos de emissão acústica no sensor 2 (freqüências intermediárias de 100 a $400 \mathrm{kHz}$ ) do corpo de prova GBEA25 (carregamento paralelo às camadas)

Figura 4.42 Tensão e contagem versus tempo dos eventos acústicos no primeiro ciclo de acréscimo de carregamento anterior ao descarregamento correspondente ao corpo de prova GBEA25 com freqüência de 0,025 Hz (6,82 MPa/min). 
Figura 4.43 Tensão e contagem versus tempo dos eventos acústicos no segundo ciclo de acréscimo de carregamento anterior ao descarregamento correspondente ao corpo de prova GBEA25 com freqüência de 0,025 Hz (6,82 MPa/min).

Figura 4.44 Tensão e contagem versus tempo dos eventos acústicos no terceiro ciclo de acréscimo de carregamento anterior ao descarregamento correspondente ao corpo de prova GBEA25 com freqüência de 0,025 Hz (6,82 MPa/min).....

Figura 4.45 Tensão e contagem versus tempo dos eventos de emissão acústica no sensor 2 (freqüências intermediárias de 100 a $400 \mathrm{kHz}$ ) do corpo de prova GBEA24 (carregamento $45^{\circ}$ com camadas)..... 176

Figura 4.46 Tensão e contagem versus tempo dos eventos acústicos no primeiro ciclo de acréscimo de carregamento anterior ao descarregamento correspondente ao corpo de prova GBEA24 com freqüência de 0,004 Hz (1,14 MPa/min).....

Figura 4.47 Tensão e contagem versus tempo dos eventos acústicos no segundo ciclo de acréscimo de carregamento anterior ao descarregamento correspondente ao corpo de prova GBEA24 com freqüência de 0,004 Hz (1,14 MPa/min)....

Figura 4.48 Tensão e contagem versus tempo dos eventos de emissão acústica no sensor 2 (freqüências intermediárias de 100 a $400 \mathrm{kHz}$ ) do corpo de prova GBEA14 (perpendicular às camadas) 178

Figura 4.49 Tensão e contagem versus tempo dos eventos acústicos no primeiro ciclo de acréscimo de carregamento anterior ao descarregamento correspondente ao corpo de prova GBEA14 com freqüência de 0,25 Hz (1,14 MPa/s).

Figura 4.50 Tensão e contagem versus tempo dos eventos acústicos no segundo ciclo de acréscimo de carregamento anterior ao descarregamento correspondente ao corpo de prova GBEA14 com freqüência de 0,25 Hz (1,14 MPa/s).

Figura 4.51 Módulo de elasticidade e relação entre a deformação radial e deformação axial versus tempo do ensaio de carregamento e descarregamento antes e após o pico de resistência no corpo de prova GBpec4da (Primeiro ensaio) ..... 181 Figura 4.52 Módulo de elasticidade e relação entre a deformação radial e a deformação axial versus tempo do ensaio de carregamento e descarregamento antes e após o pico de resistência no corpo de prova GBpec4da (Segundo ensaio) ......181 
Figura 4.53 Tensão e contagem versus tempo dos eventos de emissão acústica no sensor 1 (freqüências intermediárias de 100 a 400 kHz) do ensaio de carregamento e descarregamento antes e após o pico de resistência no corpo de prova GBpec4da (Primeiro ensaio)

Figura 4.54 Tensão e contagem versus tempo dos eventos de emissão acústica no sensor 1 (freqüências intermediárias de 100 a 400 kHz) do ensaio de carregamento e descarregamento antes e após o pico de resistência no corpo de prova GBpec4da (Segundo ensaio)

Figura 4.55 Detalhe do gráfico Tensão e contagem versus tempo para recarregamento no ensaio do corpo de prova GBpec4da (corpo de prova submetido anteriormente a dois ensaios de carregamento e descarregamento antes e após o pico de resistência) 


\section{LiSTA DE TABELAS}

Tabela 3.1 Características mineralógicas e petrográficas do gipso .33

Tabela 3.2 Composição modal...... 44

Tabela 3.3 Propriedades físico-mecânicas da rocha estudada .51

Tabela 3.4 Ensaios de compressão uniaxial com uso da técnica de emissão acústica

Tabela 3.5 Ensaios de compressão uniaxial com ciclos variáveis de carregamento antes e após o pico de resistência.

Tabela 3.6 Ensaios de fluência de curta duração realizados na prensa hidráulica servocontrolada

Tabela 3.7 Ensaios de fluência de longa duração com temperatura controlada

Tabela 3.8 Níveis de tensão médios alcançados e duração dos ciclos de carregamento e descarregamento correspondentes aos ensaios de fluência de longa duração realizados nas quatro torres individuais

Tabela 3.9 Níveis de tensão médios alcançados e duração dos ciclos de carregamento e descarregamento correspondentes ao ensaio de fluência de longa duração realizado no pórtico de reação tipo coluna

Tabela 3.10 Níveis de tensão médios alcançados e percentagem da resistência pico alcançados no carregamento das quatro torres individuais

Tabela 3.11 Níveis de tensão médios alcançados e percentagem da resistência pico alcançados no carregamento nas quatro torres individuais

Tabela 3.12 Ensaios especiais de fluência de curta duração com ciclos de acréscimos de carregamento anteriores e posteriores ao descarregamento

Tabela 4.1 Resultados do ensaio de compressão uniaxial com controle de deslocamento do prato de $0,03 \mathrm{~mm} / \mathrm{min}$ 
Tabela 4.2 Resultados do ensaio de compressão uniaxial com controle de força de $4,50 \mathrm{kN} / \mathrm{min}$

Tabela 4.3 Níveis de tensão no início do registro de eventos de emissão acústica (fae), na ocorrência e no crescimento das fissuras intergranulares (ie) e resistência pico $\left(\sigma_{\mathrm{c}}\right)$ dos corpos de prova com controle de deslocamento do prato. Entre parêntesis, a percentagem em relação à resistência pico $\left(\sigma_{c}\right)$

Tabela 4.4 Nível de tensão no início do fissuramento $\left(\sigma_{\mathrm{ci}}\right)$, tensão de dano por fissuramento $\left(\sigma_{\mathrm{cd}}\right)$ e a resistência pico $\left(\sigma_{\mathrm{c}}\right)$ dos corpos de prova com controle do deslocamento do prato.

Tabela 4.5 Níveis de tensão no início do registro de eventos de emissão acústica (fae), na ocorrência e no crescimento das fissuras intergranulares (ie) e resistência pico $\left(\sigma_{c}\right)$ dos corpos de prova com controle de força. Entre parêntesis, a percentagem em relação à resistência pico $\left(\sigma_{c}\right)$

Tabela 4.6 Nível de tensão no início do fissuramento $\left(\sigma_{\mathrm{ci}}\right)$, tensão de dano por fissuramento $\left(\sigma_{\mathrm{cd}}\right)$ e a resistência pico $\left(\sigma_{\mathrm{c}}\right)$ dos corpos de prova com controle de força

Tabela 4.7 Níveis de tensão alcançados nos ciclos de carregamento e descarregamento para os corpos de prova GBEA5 e GBEA10

Tabela 4.8 Níveis de tensão no inicio do registro de emissão acústica (fae), na ocorrência e no crescimento das fissuras intergranulares (ie) e resistência pico dos corpos de prova GBEA5 e GBEA10

Tabela 4.9 Níveis de tensão alcançados nos ciclos de carregamento e descarregamento para os corpos de prova estudados, indicando a condição de carregamento e se foi realizado antes ou após o pico de resistência

Tabela 4.10 Níveis de tensão no inicio do registro de eventos de emissão acústica (fae), na ocorrência e no crescimento das fissuras intergranulares (ie) e resistência pico dos corpos de prova

Tabela 4.11 Resultados dos ensaios de fluência de curta duração 140

Tabela 4.12 Resultados dos ensaios de fluência de longa duração 140 
Tabela 4.14 Resultados das médias da resistência à compressão uniaxial $\left(\bar{\sigma}_{c}\right)$, resistência pico depois do ensaio de fluência de curta duração $\left(\bar{\sigma}_{c s}\right)$ e resistência pico depois do ensaio de fluência de longa duração $\left(\bar{\sigma}_{c l}\right)$

Tabela 4.15 Características dos ensaios de fluência de longa duração com carregamento na direção paralela às camadas e medições de emissão acústica com um sensor.

Tabela 4.16 Características dos ensaios de fluência de longa duração com carregamento na direção perpendicular às camadas e medições de emissão acústica com um sensor.

Tabela 4.17 Resultados de módulos de elasticidade na fase cíclica nos ciclos de carregamento anteriores e posteriores ao descarregamento completo no corpo de prova GBEA14 (perpendicular às camadas)

Tabela 4.18 Resultados de módulos de elasticidade na fase cíclica nos ciclos de carregamento anteriores e posteriores ao descarregamento completo no corpo de prova GBEA25 (paralelo às camadas)

Tabela 4.19 Resultados de módulos de elasticidade na fase cíclica nos ciclos de carregamento anteriores e posteriores ao descarregamento completo no corpo de prova GBEA24 (45 com camadas) 


\section{Lista DE SIGLAS}

$\begin{array}{ll}\text { ABNT } & \text { Associação Brasileira de Normas Técnicas } \\ \text { ASTM } & \text { American Society for Testing and Materials } \\ \text { CE } & \text { Ceará } \\ \text { DNPM } & \text { Departamento Nacional de Produção Mineral } \\ \text { EESC } & \text { Escola de Engenharia de São Carlos } \\ \text { GB } & \text { Gipsito Bandado } \\ \text { IPT } & \text { Instituto de Pesquisas Tecnológicas } \\ \text { ISRM } & \text { International Society for Rock Mechanics } \\ \text { NBR } & \text { Norma Brasileira } \\ \text { NUMA } & \text { Núcleo de Manufatura Avançada } \\ \text { PE } & \text { Pernambuco } \\ \text { PI } & \text { Piauí } \\ \text { UNESP } & \text { Universidade Estadual Paulista } \\ \text { USP } & \text { Universidade de São Paulo }\end{array}$




\section{LiSTA DE SÍMBOLOS}

Deformação do material danificado

$\varepsilon_{a x} \quad$ Deformação axial

$\underline{\sigma} \quad$ Tensor de tensão efetiva

$\underline{\sigma} \quad$ Tensão efetiva

$\sigma_{c} \quad$ Resistência à compressão uniaxial

$\bar{\sigma}_{c} \quad$ Média da resistência à compressão uniaxial

$\sigma_{c i} \quad$ Tensão associada ao início do fissuramento

$\sigma_{c d} \quad$ Tensão de dano por fissuramento

$\bar{\sigma}_{c s} \quad$ Média da resistência de pico depois do ensaio de fluência de curta duração

$\bar{\sigma}_{c l} \quad$ Média da resistência de pico depois do ensaio de fluência de longa duração

$\chi \quad$ Densidade de fissuras

A, $B \quad$ Constantes da correlação na fluência secundaria

$A_{\text {EA }} \quad$ Amplitude de uma onda de emissão acústica, em Volt

$\bar{c} \quad$ Comprimento médio das fissuras

D Dano

$\widetilde{E} \quad$ Módulo de elasticidade efetiva

E $\quad$ Módulo de elasticidade

$E_{\text {est }} \quad$ Módulo de elasticidade estática

$E_{\text {cicl }} \quad$ Módulo de elasticidade na fase cíclica nos ciclos de carregamento anteriores e posteriores ao descarregamento completo. 


\begin{tabular}{|c|c|}
\hline$E_{c l}^{\prime}$ & Módulo de elasticidade depois do ensaio de fluência de longa duração \\
\hline fae & Tensão do início do registro de eventos de emissão acústica \\
\hline$H_{1}$ & Sensor de freqüências intermediárias (100-400kHz) \\
\hline$I_{1}$ & Sensor de freqüências baixas $(20-100 \mathrm{kHz})$ \\
\hline ie & $\begin{array}{l}\text { Tensão correspondente à ocorrência e crescimento das fissuras } \\
\text { intergranulares }\end{array}$ \\
\hline$k$ & Constante dependente do equipamento e do material \\
\hline$l$ & Comprimento da fissura \\
\hline $\bar{n}$ & Normal da superfície considerada \\
\hline$N$ & Número de fissuras contidas no sólido \\
\hline$N_{\text {acum }}$ & Número acumulado de contagens \\
\hline$\vec{T}_{e}(\vec{n})$ & Tensão efetiva atuando na face de normal $\vec{n}$ \\
\hline$\vec{T}_{t}(\vec{n})$ & Tensão total atuando na face de normal $\vec{n}$ \\
\hline$S$ & Seção considerada \\
\hline$S_{D}$ & Seção danificada \\
\hline$S_{\text {eff }}$ & Seção efetiva \\
\hline$v$ & Coeficiente de Poisson \\
\hline$v_{c l}^{\prime}$ & Coeficiente de Poisson depois do ensaio de fluência de longa duração \\
\hline$V$ & Volume do sólido \\
\hline
\end{tabular}




\section{INTRODUÇÃO}

\subsection{Considerações preliminares e exposição do problema}

Muitas obras subterrâneas são construídas em maciços rochosos frágeis submetidos a elevadas tensões. Sob estas condições, pode desenvolver-se uma zona danificada ou perturbada ao redor do túnel ou da caverna. Esta zona pode diminuir a estabilidade das estruturas rochosas e alterar as propriedades do maciço rochoso. A formação da zona potencialmente instável é afetada por vários fatores, tais como a redistribuição de tensões e os métodos de escavação. A evolução da zona perturbada pode levar à ruptura localizada (CHANG; LEE, 2004). Conseqüentemente, é necessário conhecer e avaliar os mecanismos de ruptura e de dano da rocha sob diferentes níveis de tensão. Em geral, as propriedades elásticas, de fluência, dilatância, dano, propagação de fissuras, ruptura e permeabilidade são de interesse para este propósito.

As propriedades acima mencionadas são freqüentemente dependentes umas das outras e não poderiam ser tratadas independentemente. Por exemplo, a fluência e a 
dilatância, ou a dilatância e a permeabilidade, tendo-se que levar em conta que muitas delas são dependentes do tempo.

Para o desenvolvimento de leis e modelos confiáveis, devem ser realizados ensaios de laboratório com técnicas experimentais apropriadas para a avaliação das propriedades dependentes do tempo e estudos dos mecanismos físicos envolvidos.

Giambastiani (2005), utilizou diversas técnicas diretas e indiretas para analisar os possíveis mecanismos físicos de fluência em rochas evaporíticas sulfáticas, em condições de carregamento uniaxial e temperatura ambiente. Evidências indiretas, como a ruptura frágil dos corpos de prova em ensaios de fluência e velocidades ultrassônicas menores de corpos de prova submetidos a carregamentos com tensões constantes poderiam apoiar a idéia de que a deformação lenta é devida a micromecanismos de deformação rúpteis como o início e propagação de microfissuras. No entanto, os ensaios de fluência sob compressão uniaxial constante não apresentaram claramente o início da fluência secundária. A duração dos ciclos de carregamento foi de aproximadamente 25 dias e de 7 dias para descarregamento.

Com relação aos mecanismos físicos de fluência, Giambastiani (2005) não chegou a conclusões definitivas devido à falta de coerência nos resultados, mas especulou que no processo de fluência acontecem diferentes mecanismos segundo o nível de tensão aplicada: a baixas tensões, aconteceriam mecanismos físico-químicos como difusão e dissolução por pressão; a níveis intermediários, deslocamentos intra e inter cristalinos e a altas tensões, próximas da tensão de dilatância e de ruptura, atuariam mecanismos de microfissuramento.

Várias técnicas têm sido desenvolvidas para detectar e estudar o crescimento de fissuras de materiais frágeis. A mais comum destas envolve o uso de extensômetros para medir ligeiras mudanças na deformação da amostra que podem ser correlacionadas 
com o fechamento, a abertura e a coalescência das fissuras (BIENIAWSKI, 1967; MARTIN, 1993). Outras técnicas envolvem o uso de materiais fotoelásticos (HOEK; BIENIAWSKY, 1965), padrões de difração óptica (WAWERSIK; FAIRHURST, 1970), lâminas delgadas (GANNE; VERVOORT; WEVERS, 2007); microscópio eletrônico de varredura (VAN DE STEEN; VERVOOT; SAHIN, 2002), interferometria a laser (CHENGYONG et al. 1990), ensaios ultra-sônicos (VEVERKA; RUDAJEV; LOKAJIČEK, 2004), resistividade elétrica (VAN DE STEEN et al. 1998), tomografia computadorizada de raios-X (SANTOS; VARGAS; BARROSO, 2004) e emissão acústica (EBERHARDT; STEAD; STIMPSON, 1999; RUDAJEV; VILHELM; LOKAJIČEV， 2000; DIEDERICHS; KAISER; EBERHARDT, 2004; GANNE; VERVOORT; WEVERS, 2007).

Destas técnicas, a observação microscópica direta do desenvolvimento do microfissuramento durante a deformação provou ser uma ferramenta muito útil para entender os micromecanismos envolvidos (GANNE; VERVOORT; WEVERS, 2007).

Entretanto, exceto sob circunstâncias muito restritas, é difícil observar o desenvolvimento das microfissuras enquanto a amostra está sendo deformada. Para usar o microscópio eletrônico de varredura (MEV) ou mesmo um microscópio óptico simples, é quase sempre necessário parar o ensaio e descarregar a amostra para fazer a observação. As mudanças que ocorrem na microestrutura durante o descarregamento e a preparação para sua observação não são conhecidas. Assim, há muita incerteza sobre o que está sendo observado, se é realmente a mesma microestrutura que estava presente quando a amostra estava sob a carga. Adicionalmente, os métodos observacionais somente levam em conta o que está acontecendo em uma superfície plana, de modo que obter uma imagem tridimensional do processo de microfissuramento é difícil. 
Uma das mais úteis técnicas indiretas de monitoramento do fissuramento é o registro de emissões acústicas (EA), que se fundamenta na detecção de ondas de natureza mecânica emitidas durante a solicitação dos materiais. As pequenas alterações que ocorrem nos materiais, quando estes iniciam os processos de fratura, geram, em maior ou menor grau, uma quantidade de ondas de natureza acústica originadas pela liberação de energia que está associada a estes mecanismos.

Tais emissões são detectadas por transdutores acústicos colados à amostra. São depois processadas eletronicamente dependendo da informação requerida. O método mais comum consiste simplesmente em registrar o número acumulado das emissões acústicas. Analisando o número de emissões acústicas como uma função das tensões ou das deformações, a influência do microfissuramento na deformação pode ser determinada.

Giambastiani (2005), baseado na hipótese de que a evolução do dano por início e propagação de microfissuras pode ser revelada por métodos de emissão acústica, realizou ensaios de fluência de algumas horas de duração (22,2 horas com dois estágios de carregamento constante: $12 \mathrm{MPa}$ e $22,5 \mathrm{MPa}$ ) em gipsito nodular acoplado a um equipamento de emissão acústica. Para isto, utilizou um equipamento construído no Laboratório NUMA da EESC-USP que foi desenvolvido para monitorar o desgaste de ferramentas nos processos de usinagem de metais. Seu funcionamento baseia-se no monitoramento contínuo da amplitude do sinal acústico gerado durante esses processos. Desta forma, a verificação do desgaste da ferramenta baseia-se na amplitude média dos eventos de emissão acústica, ou seja, quando tal amplitude média ultrapassar um determinado limiar, isto indica o momento de substituição da ferramenta, uma vez que sua eficiência está comprometida. Deve-se observar, no entanto, que nenhum estudo 
paramétrico foi efetuado e que o sinal foi analisado de forma contínua no domínio do tempo.

Neste trabalho, foram exploradas as potencialidades da técnica de emissão acústica para identificar os mecanismos físicos de deformação durante a fluência, correlacionando os níveis de tensões associados ao desenvolvimento das microfissuras com a liberação de energia associada a estes mecanismos.

Importantes pesquisas experimentais têm sido realizadas para quantificar os danos induzidos por tensão em ensaios de compressão uniaxial. Os resultados dos ensaios demonstraram que os danos e as características da deformação do material danificado poderiam quantificar as tensões e deformações requeridas para passar de um estágio do desenvolvimento das microfissuras a outro.

O objetivo principal deste trabalho é verificar se o microfissuramento é o mecanismo físico fundamental da fluência em condição de temperatura ambiente e carregamento uniaxial em gipsitos.

Foram realizadas quatro séries de ensaios, compreendendo:

- Ensaios de compressão uniaxial com uso da técnica de emissão acústica (13 ensaios)

- Ensaios de compressão uniaxial com ciclos variáveis de carregamento antes e após o pico de resistência (9 ensaios)

- Ensaios de fluência de curta duração sob tensão constante realizados na prensa hidráulica servocontrolada (12 ensaios)

- Ensaios de fluência de longa duração sob tensão constante no laboratório de fluência construído para tal finalidade (14 ensaios)

- Ensaios especiais de fluência de curta duração com ciclos de acréscimos de carregamento anteriores e posteriores ao descarregamento ( 3 ensaios) 
- 3 ensaios em um mesmo corpo de prova (dois ensaios em compressão uniaxial com ciclos variáveis de carregamento antes e após o pico de resistência e finalmente compressão uniaxial)

\subsection{Alcance da tese e objetivos}

O trabalho que resultou na apresentação da presente tese insere-se em uma linha de pesquisa que tem sido desenvolvido em caráter pioneiro, junto ao Departamento de Geotecnia da Escola de Engenharia de São Carlos da Universidade de São Paulo. O mesmo consiste no estudo das propriedades dependentes do tempo de rochas evaporíticas sulfáticas, que são responsáveis pelas deformações lentas observadas em algumas obras subterrâneas.

Foi desenvolvida uma investigação experimental com amostras de gipsito bandado provenientes da Formação Santana, Cretáceo inferior, da Chapada do Araripe (Ceará/Pernambuco/Piauí, Brasil), por já existir um conhecimento incipiente da mesma rocha estudada anteriormente por Giambastiani (2005).

Foram estabelecidos os seguintes objetivos específicos:

- Estudar a anisotropia da rocha e associá-la com a resposta dos eventos de emissão acústica.

- $\quad$ Estabelecer o intervalo de freqüências do sensor que detecta os eventos de emissão acústica no fenômeno de microfissuramento.

- $\quad$ Estabelecer alguma correlação entre os eventos de emissão acústica e as deformações no corpo de prova durante a fluência

- Verificar a ocorrência do efeito Kaiser

- Verificar se o descarregamento provoca progresso no microfissuramento. 


\subsection{Organização da tese}

A tese foi dividida em seis capítulos e cinco apêndices. No capítulo 2 apresentase uma revisão bibliográfica do assunto tratado com ênfase no microfissuramento e o dano associado, assim como o estudo destes fenômenos por técnicas de emissão acústica.

No capítulo 3, são descritas as análises petrográficas realizadas na rocha estudada, a determinação das características físico-mecânicas da mesma, assim como a preparação e instrumentação dos corpos de prova, os equipamentos utilizados e o procedimento de execução e gráficos típicos dos ensaios realizados nesta tese.

Os resultados experimentais e uma discussão e análise dos resultados obtidos são apresentadas no Capítulo 4, salientando-se algumas considerações dos eventos de emissão acústica. O efeito Kaiser e os padrões de emissão acústica demonstraram que o microfissuramento é o mecanismo fundamental da fluência neste tipo de rocha. Observou-se que fenômenos de difusão e dissolução por pressão inibem ou cicatrizam este microfissuramento. Evidências geológicas e resultados experimentais são colocados em discussão para enriquecer a análise.

No Capítulo 5, são apresentadas algumas conclusões baseadas nos resultados experimentais obtidos, nas observações realizadas durante a execução dos ensaios e nos resultados obtidos da literatura especializada, assim como sugestões para pesquisas futuras. 


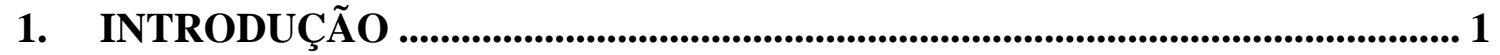

1.1. Considerações preliminares e exposição do problema ..................................... 1

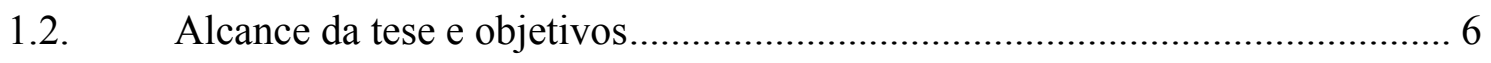

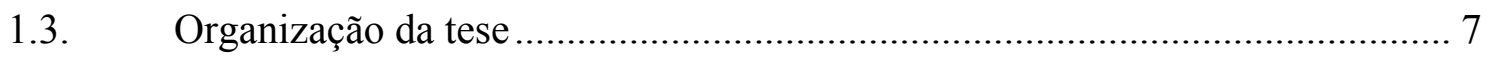




\section{REVISÃO BIBLIOGRÁFICA}

\subsection{Microfissuramento e dano associado}

Martin (1993), distingue três níveis de tensão num ensaio de compressão, conforme a Figura 2.1, associados ao desenvolvimento de microfissuras, a saber: a) $\boldsymbol{\sigma}_{\mathbf{c i}}$ : tensão associada ao início do microfissuramento; b) $\boldsymbol{\sigma}_{\mathbf{c d}}$ : tensão de dano por fissuramento ou início da dilatância e c) $\boldsymbol{\sigma}_{\mathbf{f}}$ : resistência pico. Martin e Chandler (1994), estudaram o dano induzido por microfissuramento através de ensaios cíclicos de cargadescarga em compressão uniaxial e triaxial, com o objetivo de estudar o comportamento após o pico de resistência.

Por sua vez, Nóbrega (1994), estudou o comportamento mecânico de um calcário dolomítico e de argamassa (relação água:cimento:areia de 1:2:0,38) submetidos a carregamento cíclico em compressão uniaxial e correlacionou o dano no material ao trabalho despendido ao longo do ensaio (Figura 2.2). 


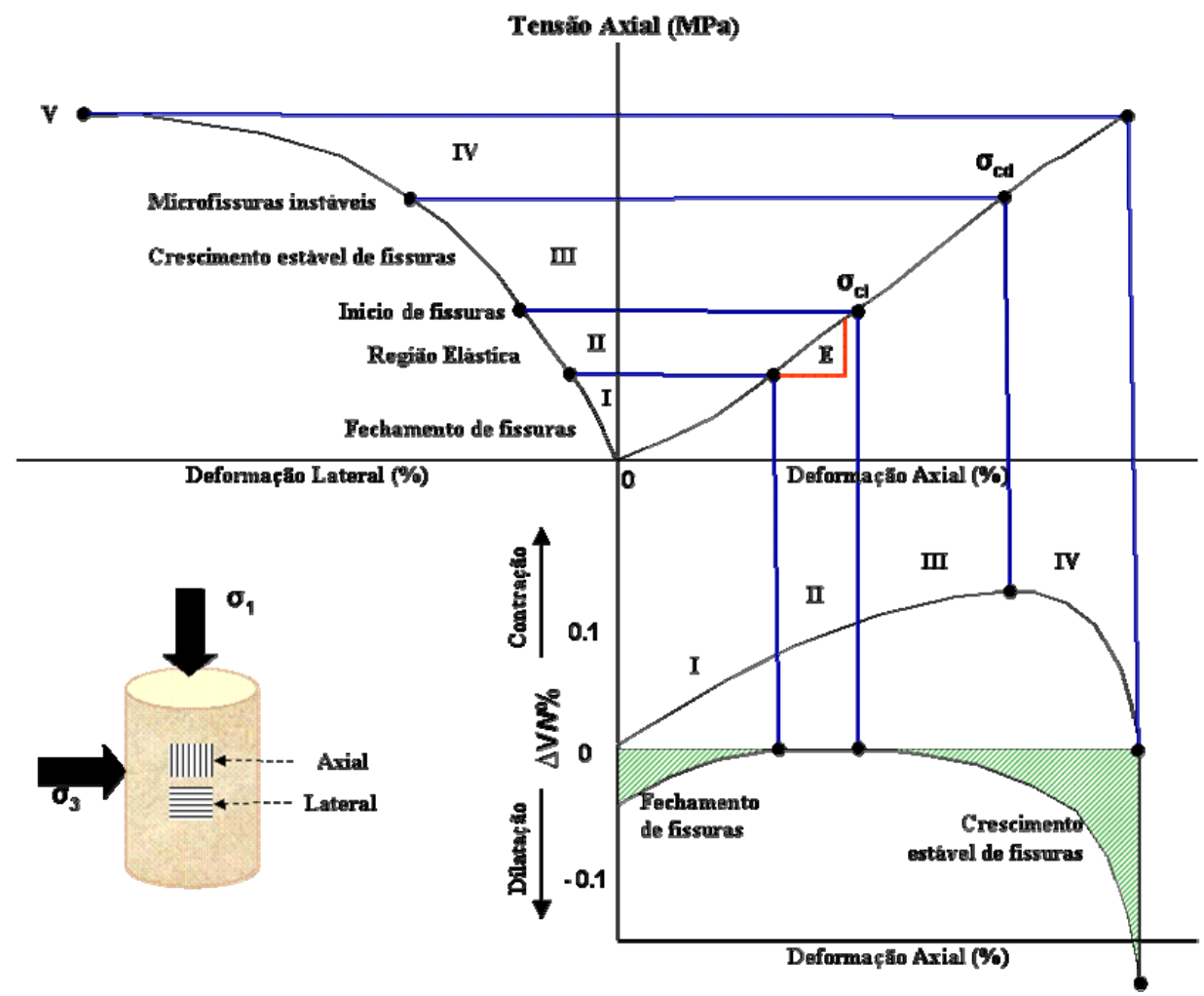

Figura 2.1 Diagrama tensão versus deformação mostrando os estágios de desenvolvimento de microfissuras

Fonte: Adaptado de Martin; Chandler (1994); Eberhardt et al. (1999)

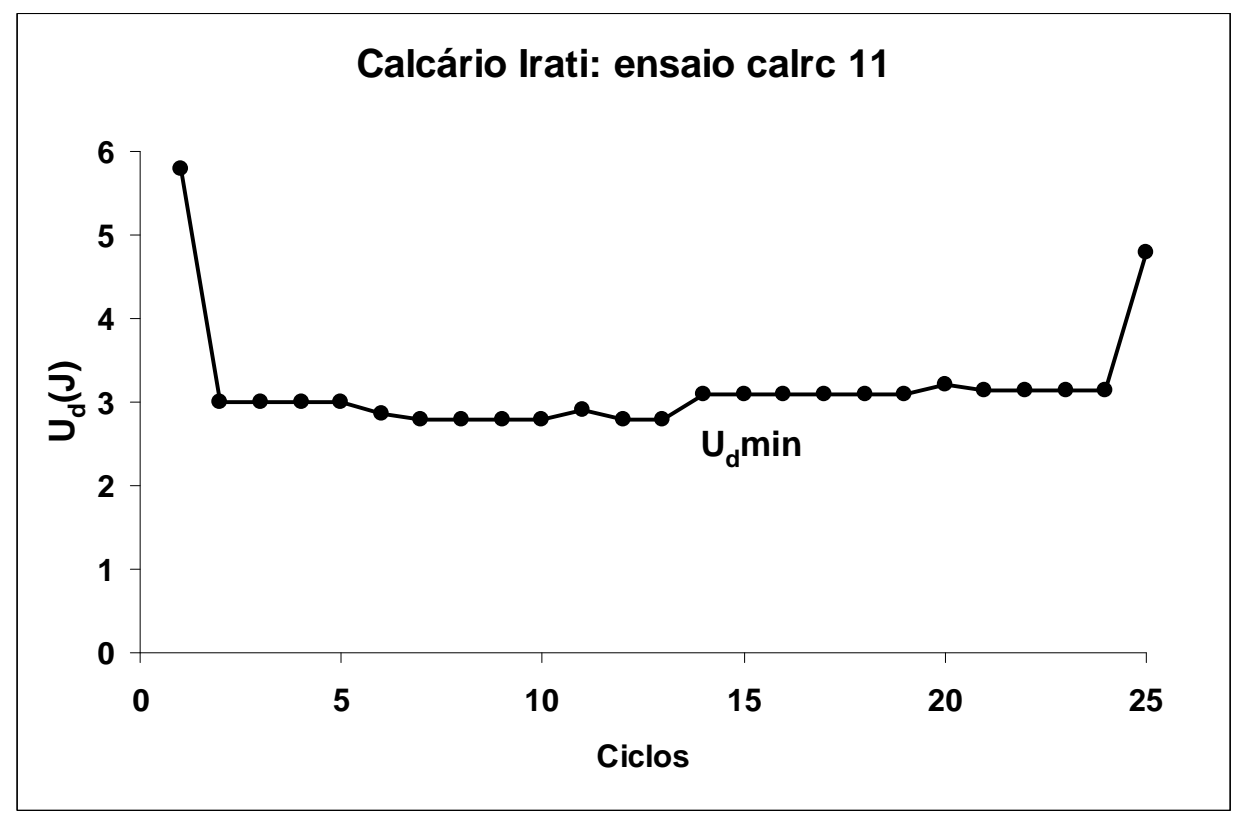

Figura 2.2 Variação da energia dissipada (Ud) em ensaio cíclico em Calcário Irati Fonte: Nóbrega (1994) 
A causa da ruptura por fadiga em ensaios cíclicos com picos de carregamento inferiores à resistência à compressão simples é um fenômeno complexo e tem sido discutida por vários autores. Nóbrega e Celestino (1995), defendem a idéia de que, como os comprimentos de fissuras induzidas crescem durante um ciclo, crescem também os fatores de intensidade de tensão, que localmente atingem o valor limite do material. No estudo do mecanismo básico da fluência de rochas (crescimento de fissuras versus deslocamentos intracristalinos), os resultados apresentados por Celestino, Bortolucci e Nóbrega (1995), levam à conclusão de que o crescimento de fissuras é uma componente real e importante, mesmo em rochas resistentes (granitos de grão médio). Eles estudaram o crescimento controlado de fissura isolada no ensaio de compressão diametral, e apontaram a importância da fluência associada àquele mecanismo. Fatores de intensidade de tensão nestes ensaios de compressão diametral foram obtidos como descrito por Celestino et al. (2001).

\subsection{A técnica da emissão acústica}

A emissão acústica é uma técnica utilizada em um grande número de aplicações geotécnicas. É definida como "a classe dos fenômenos por meio do qual ondas elásticas transientes são geradas pela rápida liberação de energia a partir de uma fonte localizada ou fontes dentro de um material, ou as ondas elásticas transientes assim geradas" de acordo com as normas ANSI/ASTM (ASTM, 1972).

\subsubsection{Fontes de emissão acústica}

A freqüência característica fundamental de um sinal de emissão acústica observada depende das características da fonte, e da distância entre a fonte e o transdutor. Acredita-se que muitos fatores estão envolvidos na geração de sinais 
acústicos. Estes fatores estão relacionados à microestrutura da não homogeneidade local e ao dano.

Quando um corpo de prova rochoso é carregado, as microestruturas com resistência débil romperão primeiro devido à concentração de tensões locais. A tensão será liberada localmente e ondas elásticas (emissões acústicas) serão geradas.

Hardy (1968) resumiu as fontes de emissão acústica como:

a) Nível Micro: Deslizamento

b) Nível Meso: Atrito no contorno do grão; fechamento das microfissuras; início e propagação das microfissuras através e entre os grãos minerais, nucleamento das microfissuras e coalescência.

c) Nível Mega: Fraturamento e ruptura de grandes áreas do material ou movimento relativo entre as unidades estruturais.

A qualidade da freqüência fundamental de um sinal de emissão acústica observada depende da escala da fonte. Nos ensaios em laboratório, os sinais de emissão acústica gerados a partir de corpos de prova rochosos têm freqüências no intervalo de $150 \mathrm{kHz}-1 \mathrm{MHz}$ enquanto que freqüências abaixo de $1 \mathrm{~Hz}$ podem ser observadas em ensaios de campo a grande escala.

\subsubsection{Parâmetros da emissão acústica}

Em geral, os sinais de emissão acústica são randômicos ocorrendo transientes cujas características dependem das propriedades mecânicas do corpo de prova utilizado no laboratório ou na estrutura em ensaios de campo, e a partir do grau e tipo de instabilidade envolvida.

Embora tais sinais tenham até recentemente sido descritos principalmente em termos de fatores como taxa de eventos e localização da fonte, eles contêm uma 
informação adicional considerável fazendo isto possível para caracterizá-los em termos de outros parâmetros úteis. Tais parâmetros poderiam ser determinados para dados individuais ou dados multi-canais. No último caso mais que um transdutor é usado e os dados a partir de cada transdutor são adquiridos e processados em um canal de dados separado.

No domínio do tempo tais dados são comumente descritos em termos dos seguintes parâmetros:

1. Contagem $(\mathrm{N})$ : O número de vezes que o sinal de emissão acústica corta o limiar de detecção.

2. Amplitude (A): O valor pico (máximo) de cada evento registrado.

3. Duração (D): O tempo do sinal de emissão acústica que excede o limiar de detecção.

4. Energia de emissão acústica (intensidade do sinal): A intensidade do valor absoluto do sinal de emissão acústica detectado.

5. Taxa do evento (NR): O número de eventos $(\Delta \mathrm{N})$ observados por unidade de tempo de monitoração $(\Delta \mathrm{t})$.

6. "Hit" de emissão acústica: O processo de detecção e medição de sinal de emissão acústica em um canal.

7. Energia acumulada ( $\sum E$ ): A somada energia emitida por todos os eventos observados durante um período de tempo específico.

12. Taxa de energia (ER): A soma da energia emitida por todos os eventos observados por unidade de tempo $(\Delta \mathrm{t})$.

13. Período (T): O tempo entre picos sucessivos do evento.

14. Freqüência Fundamental Media (f): O recíproco do período médio calculado sobre " $n$ " ciclos do evento. 
15. Duração do evento $\left(\tau_{\mathrm{D}}\right)$ : $\mathrm{O}$ tempo total de ocorrência para um evento individual.

Na Figura 2.3, apresentam-se os parâmetros mais importantes da emissão acústica usados neste trabalho.

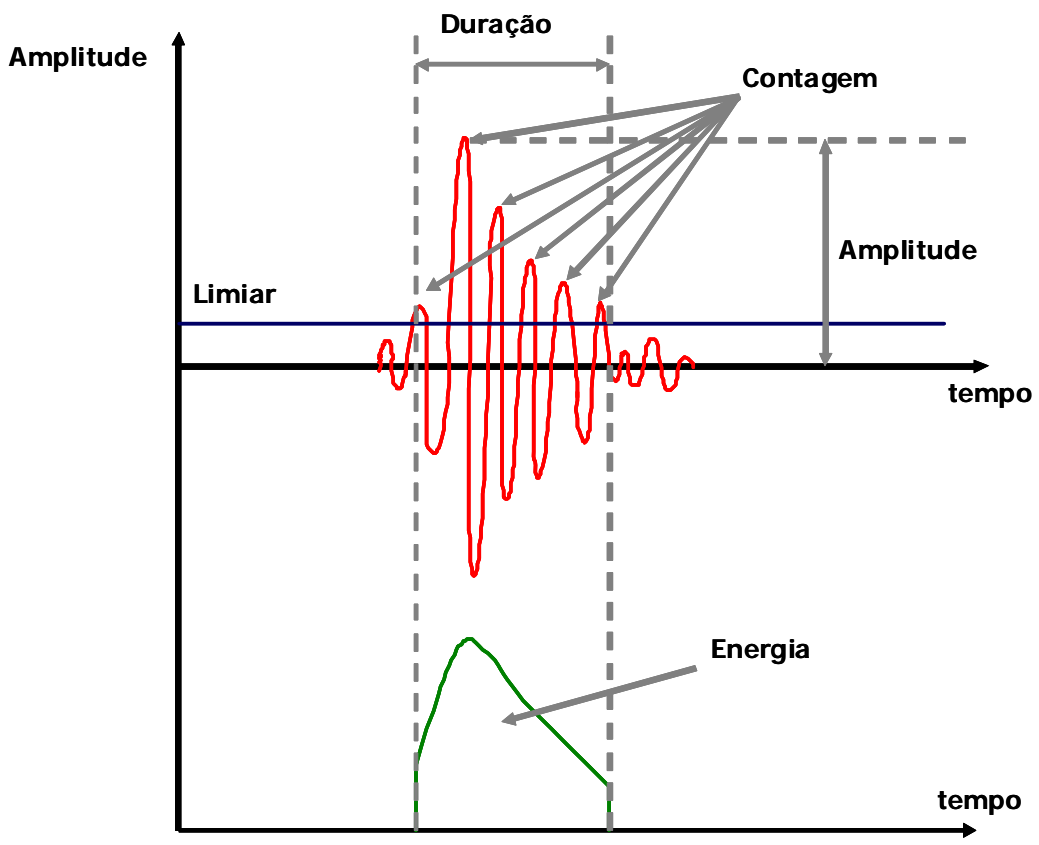

Figura 2.3 Parâmetros importantes da emissão acústica

\subsection{Estudo do microfissuramento por técnicas de emissão acústica}

Scholz (1968), Holcomb e Martin (1985) e Pestman e Van Munster (1996), estudaram o início da formação das microfissuras em amostras de granito, arenito e mármore através de técnicas de emissão acústica. Em 1991, Lockner estudou o agrupamento e o crescimento de fissuras por cisalhamento em rochas frágeis (granitos) e posteriormente desenvolveu um modelo conceitual que descreve o agrupamento das fissuras baseado em uma interação das mesmas (LOCKNER et al., 1992). 
Hardy (1981), estudou as propriedades visco-elásticas de rochas intactas e os comportamentos fundamentais de rochas salinas, incluindo dissolução, ponto de plastificação e características do fenômeno de fluência. Além disso, estudos na relação entre a emissão acústica e as mudanças microscópicas na microestrutura da rocha devidas à pressão hidráulica foram também realizadas (CARLSON et al., 1998).

As técnicas de emissão acústica se desenvolveram rapidamente nos anos oitenta e noventa. O método foi utilizado para monitorar o dano durante a deformação de rochas e para prever a ocorrência da instabilidade.

Labuz, Shah e Dowding (1987), estudaram as fontes de emissão acústica próximas da extremidade da fissura em um ensaio de flexão em vigas de granito, tentando fornecer algumas evidências da existência de uma zona de processo de fissura.

A técnica de guias de onda para otimizar aplicações no campo foi sugerida por Hardy e Taioli (1988). Glaser e Nelson (1992), ensaiaram corpos de prova (granitos e dolomitos) com entalhe chevron carregados em condições controladas e isolaram as emissões acústicas características associadas com o Modo I e o Modo II de fissura.

Mansurov (1994), discutiu a possibilidade de usar o monitoramento de emissão acústica para prever as cargas críticas da rocha. Enfocou seus estudos nos estágios característicos do processo de ruptura, tomando em conta o estado após o pico de resistência.

Na Figura 2.4, apresenta-se o comportamento da emissão acústica em relação aos estágios do processo de fissuramento sugeridos por Bieniawski (1967) e Thill (1972).

Rudajev, Vilhelm e Lokajičev (2000), estudaram a distribuição estatística dos sinais de emissão acústica e a relação dos parâmetros ao processo de fissuramento. Mostraram que a variação e os valores dos coeficientes de autocorrelação incorporam 
uma informação significativa do estado de tensões e dos estágios de desintegração da rocha.

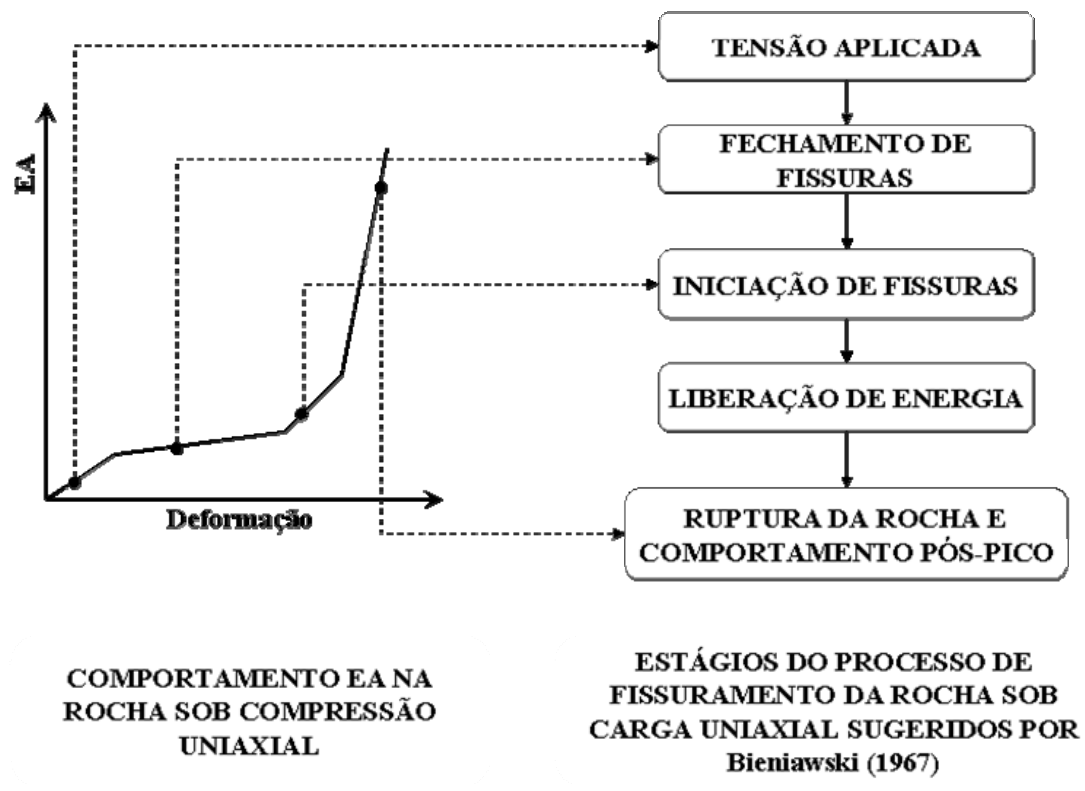

Figura 2.4 Comportamento da emissão acústica em relação aos estágios do processo de fissuramento das rochas

Fonte: Adaptado de Bieniawski (1967)

Carvalho e Labuz (2002), realizaram ensaios de compressão biaxial em arenitos com monitoramento dos eventos de emissão acústica com a finalidade de estudar a localização de fissuras sob condições controladas.

Diferentes pesquisadores definiram os níveis de tensão dos diferentes estágios no processo de ruptura de materiais frágeis, combinando curvas tensão-deformação com os diagramas de emissão acústica obtidos em ensaios de compressão uniaxial (EBERHARDT et al.,1999; DIEDERICHS; KAISER; EBERHARDT, 2004) e em ensaios particulares onde o dano foi induzido por tensões de compressão simples como por tensões de tração direta em uma direção em corpos de prova com geometrias particulares (GANNE; VERVOORT; WEVERS, 2007). 


\subsection{Dano ligado ao microfissuramento e à emissão acústica}

Será apresentada inicialmente a revisão da teoria do dano elástico aplicado a um sólido que contém uma população de fissuras. Em seguida, será visto como a emissão acústica poderá estimar a danificação de uma rocha.

\subsubsection{Dano elástico}

A presença de vazios num material, no caso de microfissuras, tem por efeito modificar suas características mecânicas em escala macroscópica. O dano elástico é definido como a relação entre as propriedades elásticas do material não danificado e as do material danificado (AMITRANO, 1999).

Amitrano (1999), apresenta uma formulação considerando um sólido contendo vazios e submetido a esforços externos. Através de uma seção qualquer do sólido, a área que transmite o esforço é a área total menos a área de vazios (Figura 2.5).

Eventualmente no limite, obtém-se a tensão efetiva em função da superfície total e da superfície danificada.

$\vec{T}_{e}(\vec{n})=\lim _{s \rightarrow 0} \frac{\vec{F}}{S_{\text {eff }}}=\lim _{s \rightarrow 0} \frac{\vec{F}}{S-S_{D}}$

Em que, $\vec{T}_{e}(\vec{n})$ : tensão efetiva atuando na face de normal $\vec{n}$.

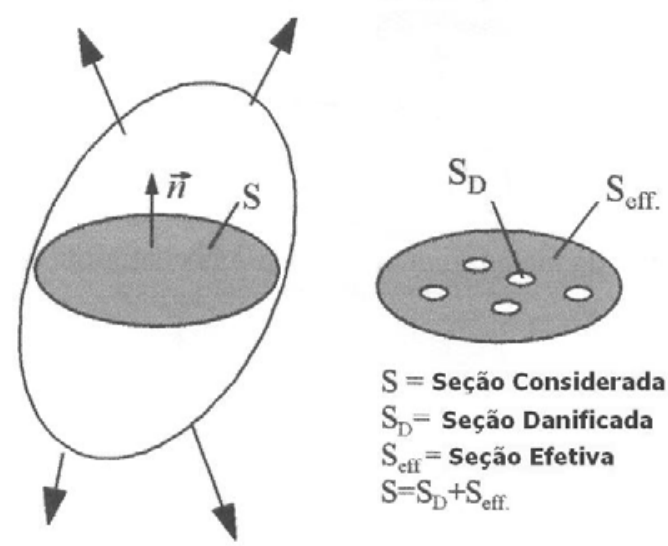

Figura 2.5 Seção efetiva de um sólido danificado Fonte: Amitrano (1999) 
Define-se então o dano, $D$, como a relação entre $S_{D}$ e $S$.

$D=\frac{S_{D}}{S}$

Em que:

$\mathrm{D}=0$ para um material intacto

$\mathrm{D}=1$ para um material inteiramente danificado

Pode-se relacionar a tensão efetiva em função da tensão total e da superfície efetiva ou o dano D:

$$
\vec{T}_{e}(\vec{n})=\lim _{s \rightarrow 0} \frac{\vec{F}}{S\left(1-\frac{S_{D}}{S}\right)}=\frac{\vec{T}_{t}(\vec{n})}{\left(1-\frac{S_{D}}{S}\right)}=\frac{\vec{T}_{t}(\vec{n})}{(1-D)}
$$

Em que, $\vec{T}_{t}(\vec{n})$ : tensão total atuando na face de normal $\vec{n}$.

Para um dano não isotrópico seria necessário recorrer a uma expressão tensorial de dano para relacionar com o estado de tensão efetiva.

No caso de um dano isotrópico (seção independente da orientação), generalizase o resultado para obter o estado de tensão efetiva em função de um dano escalar, $D$ :

$$
\underline{\tilde{\sigma}}=\frac{\underline{\sigma}}{1-D}
$$

Em que :

$\underline{\sigma}$ : Tensor de tensão total

$\underline{\widetilde{\sigma}}$ : Tensor de tensão efetiva.

Pode-se então relacionar o dano às propriedades elásticas fazendo a hipótese da equivalência em deformação. Ou seja, considera-se que a deformação do material danificado é igual à deformação do material intacto submetido à tensão efetiva.

Material não danificado:

$\underline{\varepsilon}=F(\underline{\sigma}, t)$ 
Material danificado:

$\underline{\varepsilon}=F(\underline{\tilde{\sigma}}, t)=F\left(\frac{\underline{\sigma}}{1-D}, t\right)$

É necessário, além disso, uma lei de evolução de $D$ (em função da tensão, da deformação, do tempo, etc.) para descrever completamente o comportamento do material durante a danificação.

A partir do conceito de dano elástico, pode-se estabelecer analiticamente uma relação entre o módulo de elasticidade efetiva de um sólido e a densidade de fissuras (para uma revisão dos modelos existentes, ver KEMENY; COOK, 1986). Apresenta-se aqui o modelo de Walsh (1965), que é estabelecido para uma população de fissuras distribuídas aleatoriamente no sólido.

$\frac{\widetilde{E}}{E}=\frac{1}{1+\pi \cdot \chi\left(1-v^{2}\right)}$

Em que,

$E$ : módulo de elasticidade

$\tilde{E}$ : módulo de elasticidade efetiva

$v$ : coeficiente de Poisson

$\chi:$ densidade de fissuras

$\chi=\frac{N \cdot \bar{c}^{2}}{S}$ em 2 dimensões

$\chi=\frac{N \cdot \bar{c}^{3}}{V}$ em 3 dimensões

Em que, 
$N$ : número de fissuras contidas no sólido

$\bar{c}:$ comprimento médio das fissuras

$S:$ seção considerada

$V$ : volume do sólido

Note-se que estes autores consideram que seus resultados são principalmente utilizáveis para uma solicitação onde as fissuras permanecem abertas. No caso de uma solicitação em compressão, é necessário, por conseguinte, fazer a hipótese suplementar de que as fissuras permaneçam abertas.

Além desta abordagem analítica, existem modelos numéricos que permitem considerar o módulo de elasticidade efetivo de um sólido que contém uma população de fissuras. Notadamente, o modelo proposto por Scavia (1995), permite este tipo de cálculo (RE; SCAVIA, 1998).

As relações estabelecidas entre o módulo de elasticidade efetivo de um sólido e a população de fissuras mostram a interdependência de emissão acústica e dano.

\subsubsection{Estimativa da danificação por emissão acústica}

Cox e Meredith (1993), apoiando-se em resultados apresentados por Kemeny e Cook (1986), utilizaram a emissão acústica para estimar o dano de um corpo de prova de rocha durante a solicitação mecânica em ensaios de laboratório.

Os autores consideraram que a emissão acústica é produzida pela propagação de fissuras. Eles fazem a seguinte hipótese sobre a relação entre a amplitude da onda emitida e a dimensão da físsura:

$$
A_{E A}=k \cdot l^{3}
$$

Em que, 
$A_{E A}:$ amplitude de uma onda de emissão acústica, em Volt

$l$ : comprimento da fissura

$k$ : constante dependente do equipamento e do material

A amplitude das emissões acústicas permite assim considerar a densidade de fissuras criadas durante a solicitação:

$\chi=c . \sum A_{E A}$

Em que,

$\chi:$ densidade de fissuras

$A_{E A}$ : amplitude de uma onda de emissão acústica, em Volt

$c$ : constante ligada ao equipamento e ao material

$\chi$ sendo sem dimensão, a unidade de $c$ é $\mathrm{V}^{-1}$

Estes autores consideram que $c$ continua inalterado durante a solicitação. Além disso, consideram implicitamente que as fissuras continuam abertas durante a solicitação embora se tratando de ensaios de compressão uniaxial.

O fato que permite considerar a densidade de fissuras supõe que todas as fissuras criadas durante a solicitação produzem uma emissão acústica passível de registro. Ora, devido às limitações instrumentais, o registro é apenas parcial. A fim de superar esta limitação, os autores consideram a soma das amplitudes de emissão acústica a partir da distribuição estatística das amplitudes de emissão acústica. Fazem isto para intervir nos limiares de detecção e saturação do sistema bem como na taxa de atividade acústica.

\subsection{Efeito Kaiser}

Efeito Kaiser é a característica da imediata irreversibilidade de um resultado de emissão acústica de uma tensão aplicada. Se o efeito está presente, não existe emissão 
acústica detectável até que o nível de tensão previamente aplicado seja excedido (ASSOCIAÇÃO BRASILEIRA DE NORMAS TÉCNICAS - ABNT, 2004).

O efeito Kaiser foi observado em vários tipos de rochas: arenitos (COX; MEREDITH; STUART, 1991; PESTMAN; VAN MUNSTER, 1996), calcários (LAVROV, 2001; LAVROV et al. 2002a), argilitos (LAVROV et al. 2002b) e rochas salinas (LAVROV et al. 2002b; FILIMONOV et al. 2002).

Lavrov (2003) relatou que o efeito Kaiser foi observado também em outros tipos de rochas como: granito, granodiorito, quartzito, andesito, basalto, mármore, xisto, gnaisse, turfa, dolomito, folhelho e carvão.

Lavrov (2000) indicou que o início da emissão acústica durante o recarregamento coincide com o início da deformação plástica devido ao fato de que a emissão acústica e o efeito Kaiser são governados pelos mesmos mecanismos como a plasticidade e o endurecimento por deformação.

Em rochas frágeis, o efeito Kaiser é observado até o início da dilatância, isto é, até um nível de tensão de 70 a $80 \%$ da resistência a compressão simples (LI; NORDLUND, 1993). O efeito Kaiser aparece freqüentemente até um nível de tensão não exatamente igual, mas ligeiramente mais baixo do que a tensão maior do carregamento prévio. Esta tendência aumenta enquanto a tensão se aproxima da resistência pico nas rochas frágeis. Em rochas dúcteis, o efeito Kaiser é igualmente observado nos carregamentos cíclicos realizados antes e após o pico de resistência (FILIMONOV et al. 2002).

Para obter ocorrência de efeito Kaiser bem pronunciado, a tensão de precarregamento deve estar entre 30 e $80 \%$ da resistência pico. Este intervalo é certamente dependente da rocha. O limite inferior deste intervalo (de 20 a $30 \%$ da resistência pico) é devido ao fato de que, abaixo deste limite, são detectadas pequenas 
emissões acústicas, mesmo sem precarregamento, e este "silêncio" pode ser mal interpretado como efeito Kaiser (LAVROV, 2003).

\subsection{Freqüência característica da emissão acústica e o processo de fissuramento}

Nenhum estudo detalhado foi realizado com relação à mudança no conteúdo espectral de faixa de freqüências de emissões acústicas na rocha sob uma carga constante com o tempo, embora tal estudo tenha grande potencial para revelar os processos de microfissuramento que conduzem à ruptura da rocha (OHNAKA, 1983; OHNAKA; MOGI, 1982).

Ohnaka e Mogi (1981, 1982), não trataram os espectros de freqüência de emissões acústicas individuais, mas monitoraram a mudança relativa no conteúdo de freqüência de emissões acústicas ao longo de ensaios de fluência em termos estatísticos. Realizaram uma comparação estatística da taxa da contagem dos eventos da emissão monitorados através de uma janela de freqüências baixas com a detecção simultânea através de uma janela de uma freqüências mais elevadas. Nestas experiências, as emissões acústicas geradas durante a compressão uniaxial incremental de rochas frágeis foram contadas após filtragem passa banda. Durante todo o processo a partir da aplicação da carga até a ruptura, a taxa de contagem monitorada através de uma janela passa baixa foi comparada estatisticamente com aquela monitorada através de uma janela passa alta. Encontrou-se que a taxa de emissão monitorada através de uma janela passa baixa aumenta mais rapidamente do que aquela monitorada através de uma janela passa alta quando a rocha se aproxima da ruptura.

Ohnaka e Mogi (1981, 1982), ensaiaram dois tipos de rochas: andesito de Shinkomatsu e granito de Mannari. Foi confirmado nestas experiências que a freqüência espectral observada da atividade de emissão acústica não depende dos locais do transdutor. Três faixas estreitas de freqüência diferentes foram selecionadas: uma 
janela L de freqüência baixa (com picos de sensibilidade ao redor de $30 \mathrm{kHz}$ ), uma janela de freqüência média I $(250-400 \mathrm{kHz})$, e uma janela de freqüência alta $\mathrm{H}(\sim 1$ MHz). Os canais de monitoração foram operados com um ganho de $86 \mathrm{~dB}$ e um limiar de $0.5 \mathrm{~V}(25 \mu \mathrm{V}$ referidos à entrada).

Ohnaka (1983), apresentou dados em características de freqüência de emissões acústicas em rochas sob cargas constantes e na seqüência do tempo da atividade de emissão acústica durante a fluência até a ruptura, e discutiu os processos do microfissuramento que conduzem à ruptura em termos da taxa de emissão acústica e das suas características de freqüência.

De acordo com os resultados obtidos por Ohnaka (1983), os processos completos a partir da aplicação de uma carga constante até a ruptura podem ser divididos em termos da atividade de emissão acústica em três fases: uma fase primária onde a atividade de emissão acústica cai com o tempo, uma fase secundária onde os níveis de atividade da emissão atingem um patamar mínimo e uma fase terciária onde a atividade da emissão acelera rapidamente com o tempo até a ruptura.

Ohnaka (1983), relatou que existem trabalhos anteriores (MOGI, 1962 ${ }^{1}$; HARDY et $\mathrm{al}^{2}$., 1969 apud OHNAKA, 1983) onde se indica que a deformação de fluência é diretamente proporcional à atividade de emissão acústica nas rochas sob uma tensão constante aplicada, sugerindo que a deformação de fluência é devida ao microfissuramento dentro da rocha.

Foi observado que as taxas de emissão n (l) e n (h) monitoradas através de uma janela de freqüência baixa e de uma janela de uma freqüência mais elevada, respectivamente, caem com o tempo quase na mesma proporção na fase primária; isto é,

\footnotetext{
${ }^{1}$ MOGI, K. (1962). Study of elastic shocks caused by the fractere of heterogeneous materials and its relations to earth qluake phenoMENA. Bulletin Earthquake Research Institute University of Tokyo, v.40, p.125-173.

2 HARDY, H.R. et al. (1969). Creep and microseismic activity in geological materials. In: SYMPOSIUM ON ROCK MECHANICS, 11., Berkeley. Proceedings... New York: AIME. p.377-413.
} 
$\mathrm{n}(\mathrm{l}) /[\mathrm{n}(\mathrm{l})+\mathrm{n}(\mathrm{h})]$ é quase constante em termos estatísticos durante toda esta fase. Isto sugere que a distribuição de tamanho das fissuras produzidas permanece quase constante em termos estatísticos durante toda esta fase, desde que o índice da freqüência das ondas acústicas emitidas por fissuramento possa ser influenciado pelo tamanho da fissura (OHNAKA; MOGI, 1982). Ainda na fase secundária, n (l)/[n (l) + n (h)] permaneceu estatisticamente quase constante. Mas, a fase terciária foi caracterizada por uma aceleração mais rápida da taxa de emissão de freqüência mais baixa n(l); em outras palavras, $\mathrm{n}(\mathrm{l}) /[\mathrm{n}(\mathrm{l})+\mathrm{n}(\mathrm{h})]$ aumentou com o tempo.

Há duas possíveis explicações para a dependência da freqüência espectral observada na fase terciária: (1) geração de fissuras maiores (ou coalescência das fissuras em tamanhos maiores), e (2) a atenuação relativa dos componentes da onda de freqüências mais elevadas (OHNAKA; MOGI, 1981, 1982).

O cisalhamento ou abertura de fissuras maiores formadas pelo enlace de microfissuras podem gerar ondas elásticas que contêm componentes de freqüência mais baixa (OHNAKA; MOGI, 1982). Isto contribuirá para explicar o aumento de $\mathrm{n}(\mathrm{l}) /[\mathrm{n}(\mathrm{l})+\mathrm{n}(\mathrm{h})]$ na fase terciária.

A formação de fissuras abertas causa regiões dilatantes dentro de um corpo de rocha deformado. O desenvolvimento de tais regiões dilatantes tem o efeito de atenuar as ondas emitidas. Em um estágio onde a dilatância é pronunciada e amplamente desenvolvida, as componentes de onda de freqüência mais altas são mais atenuadas (OHNAKA; MOGI, 1982). Holcomb (1978) e Nishizawa, Ito e Ishido ${ }^{3}$ (1980, apud OHNAKA, 1983) mostraram que enquanto a rocha se aproxima da ruptura, a atenuação aumenta mais fortemente em freqüências mais elevadas.

\footnotetext{
${ }^{3}$ NISHIZAWA, O.; ITO, H.; ISHIDO, T. (1980). Elastic wave spectra and cracks in rock (II). Programme and Abstracts, Seis. Soc. Japan n. 2, p. 133
} 
Scholz (1968) e Cruden (1970), supuseram que cada evento de microfissuramento contribui com um incremento constante de deformação da fluência, e desenvolveram teorias similares para a fluência transiente na base da probabilidade da fissura de pequenas regiões individuais dentro da rocha. Para verificar a hipótese que cada uma das fissuras contribui com um incremento constante de deformação de fluência, é importante examinar uma correlação entre o número cumulativo de eventos da emissão e a deformação volumétrica inelástica, já que o fissuramento é inelástico e tridimensional (KRANZ; SCHOLZ, 1977).

Quando a tensão aplicada alcança rapidamente um nível constante que seja uma porcentagem elevada da resistência à ruptura, um grande número de novas fissuras será formado durante o carregamento. Nem todas estas fissuras se comportam depois disso independentemente. Isto significa que a interação pode ter um efeito considerável nas fissuras não somente nas fases secundária e terciária, mas na fase primária. Além disto, para as rochas que contêm um número maior de fissuras e poros pré-existentes, o fissuramento por interação de fissuras pode ocorrer mais dominantemente em número nas fases iniciais (OHNAKA, 1983).

\subsection{Estudos anteriores dos mecanismos de deformação dos gipsitos}

Estudos experimentais realizados por vários autores mostraram alguns dos principais mecanismos de deformação, tais como o fluxo plástico e a dissolução por pressão da gipsita pura sintética ou em agregados policristalinos de gipsita (GRATIER, 1993; De MEER; SPIERS, 1993).

O fluxo plástico está presente no comportamento instantâneo e de longo prazo, enquanto a dissolução por pressão está envolvida somente no comportamento de longo prazo de gipsitas umedecidas. Atribui-se que a fluência devida à dissolução por pressão 
controle a compactação das massas de gipsitas na crosta terrestre o que tem sido exaustivamente estudado (CRACKER; SCHILLER, 1962; RUTTER, 1983; DE MEER; SPIERS, 1995; DE MEER; SPIERS; PEACH, 1997). Algumas analogias foram feitas com os mesmos fenômenos em depósitos de rochas salinas. Entretanto, a fluência em gipsitas umedecidas parece ter a taxa limitada por precipitação o que contrasta com a fluência pela dissolução por pressão controlada por difusão nas rochas salinas (DE MEER; SPIERS, 1995; JESCHKE; VOSBECK; DREYBRODT, 2001).

Mesmo que o comportamento mecânico da gipsita pura sintética seja bem conhecido devido a seu uso como rocha artificial homogênea, é pequeno o conhecimento do comportamento mecânico do gipsito natural. Na maioria dos casos, os estudos mencionados dos mecanismos de deformação foram realizados em gipsita pura sintética. Nos casos raros onde o gipsito natural foi usado para testes, a gipsita foi moída, peneirada e lavada antes de dar forma às amostras dos testes (DE MEER; SPIERS, 1995).

Outros estudos mostraram o papel do meio ambiente no comportamento mecânico dos gipsitos (COQUARD; BOISTELLE, 1994; FINOT et al., 2001; SIPPLE et al., 2001). A maioria destes estudos foi realizada em amostras saturadas com água destilada ou outras soluções aquosas polares ou não polares. Alguns estudos microscópicos de cristais de gipso têm mostrado a natureza complexa do comportamento do gipsito sob condições não saturadas (FINOT et al., 2000, 2001).

Segundo alguns autores, o comportamento de um material policristalino durante a fluência primaria e secundária poderia ser vista como uma competição entre o endurecimento e o processo de recuperação do estado mecânico intramolecular depois de produzida a deformação da estrutura cristalina (AUBERTIN; GILL, 1993; ESTREIN, 1998; BLUM, 2001; YAHYA; AUBERTIN; JULIEN, 2000). 
Auvray et al. ${ }^{4}$ (2004, apud GIAMBASTIANI, 2005), exploraram o efeito de umidade relativa no comportamento dependente do tempo dos gipsitos de uma mina subterrânea na localidade de Grozon (França). Realizaram ensaios de fluência uniaxial a $10 \mathrm{MPa}$ de tensão constante, com três umidades relativas diferentes (30, 60 e 90 \%) a partir de amostras extraídas em diferentes épocas da escavação (1920, 1970 e 2000). Observaram que o aumento da taxa de deformação estava relacionado com o aumento da umidade relativa e com a idade das amostras.

Hoxha, Giraud e Homand (2005), propuseram um modelo do comportamento de longo prazo de um gipsito natural, que leva em conta uma variação de deformação volumétrica durante a fluência, uma influência significativa da umidade relativa na taxa de deformação de fluência e fluência inversa durante o descarregamento.

Hoxha, Homand e Auvray (2006), estudaram os mecanismos de deformação do gipsito natural de uma mina subterrânea na localidade de Grozon (França) em ensaios instantâneos e de longo prazo. Aparte dos mecanismos plásticos clássicos, estes autores identificaram um mecanismo parecido com o dano ajudado pela variação na umidade relativa. Este mecanismo é provavelmente devido à migração de moléculas de água de seus locais na estrutura cristalina do gipso $\left(\mathrm{CaSO}_{4} \cdot 2 \mathrm{H}_{2} \mathrm{O}\right)$ enquanto está sob tensão. Assim, mais que a tensão efetiva, um mecanismo complexo estaria reduzindo a energia de ativação da fluência, ajudada pela umidade relativa e a tensão. Este mecanismo é considerado como o mecanismo principal que controla o comportamento de longo prazo do gipsito natural enquanto que o comportamento instantâneo do gipsito é principalmente controlado pelos mecanismos de deformação plástica e não é muito sensível às mudanças na umidade relativa.

\footnotetext{
${ }^{4}$ AUVRAY, C.H. et al. (2004). Influence du temps et de l'hygrometrie sur le comportement du gypse. Revue Française de Geotechnique, n.106-107, p. 41-51.
} 
Diferentes autores têm indicado que a influência da umidade relativa no comportamento mecânico dos gipsitos poderia ser resultado de mecanismos múltiplos. Badens et al. (1999), supuseram que a variação do módulo de Young dos gipsitos como função da umidade relativa é devida ao engrossamento da camada de água nas bordas dos grãos, facilitando assim seus deslizamentos.

Segundo Hoxha, Homand e Auvray (2006), outros autores explicaram a influência da umidade relativa sobre o comportamento dos gipsitos por um mecanismo de dissolução-precipitação onde uma dissolução parcial do gipsito próximo aos pontos de contato dos cristais explica a diminuição nas propriedades mecânicas do gipsito com o aumento da umidade relativa.

Auvray, Homand e Hoxha (2008), estudaram o comportamento dependente do tempo do gipsito natural por meio de microscópio eletrônico de varredura (MEV) nas paredes de pilares e zonas mais antigas de uma mina subterrânea na localidade de Grozon (França). Estes estudos revelaram os graus de instabilidade que variam dependendo do período da mineração e que as variações da umidade relativa influenciaram nos valores da convergência medidas in situ revelando desenvolvimentos sazonais que são função destas variações da umidade relativa.

Estes autores apresentaram um conjunto de hipóteses que permitiram explicar dentro das variações da taxa de fluência como esta se relaciona à umidade relativa. Segundo Finot et al. (1997, 2001), uma umidade relativa entre 10 e 30\% causa uma migração de moléculas de água para as periferias dos cristais. De fato, uma das duas moléculas de água do gipsito tem uma energia de enlace mais fraca que a outra, que é considerada como um ânion (HEIJNEN; HARTMAN, 1991; MANDAL; MANDAL, 2002). A conseqüência desta migração é o desenvolvimento de vazios cristalográficos (lattice vacancy) de possível deslizamento (WILLIAMS, 1988; SIPPLE et al., 2001). 
Estes vazios cristalográficos são suscetíveis a uma neoprecipitação nanoscópica de anidrita. Conseqüentemente, este processo favorece uma "reparação própria" do dano. Quando a umidade relativa for próxima a 100\%, uma migração das moléculas de água ocorre no sentido oposto. O resultado desta circulação é uma dissolução que pode conduzir microfissuras na superfície $\left(\begin{array}{lll}0 & 1 & 0\end{array}\right)$ e nas bordas. Todas estas observações foram feitas na superfície de um cristal de gipso natural graças a um microscópio de força atômica (SIPPLE et al., 2001). 


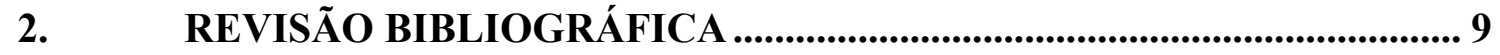

2.1. Microfissuramento e dano associado........................................................... 9

2.2. A técnica da emissão acústica ............................................................. 11

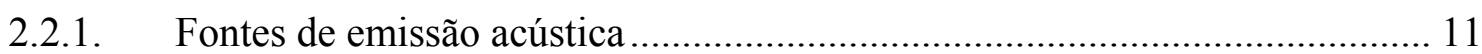

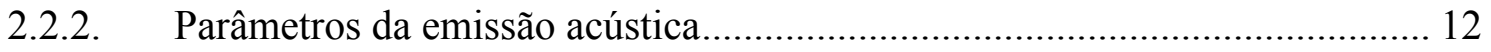

2.3. Estudo do microfissuramento por técnicas de emissão acústica .................... 14

2.4. Dano ligado ao microfissuramento e à emissão acústica ............................... 17

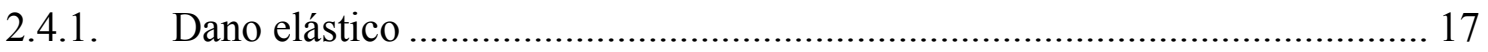

2.4.2. Estimativa da danificação por emissão acústica........................................... 20

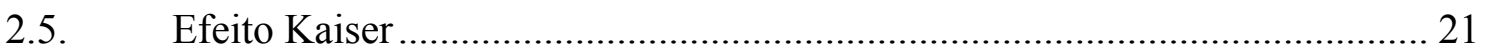

2.6. Freqüência característica da emissão acústica e o processo de fissuramento. 23

2.7. Estudos anteriores dos mecanismos de deformação dos gipsitos................... 26

Figura 2.1 Diagrama tensão versus deformação mostrando os estágios de

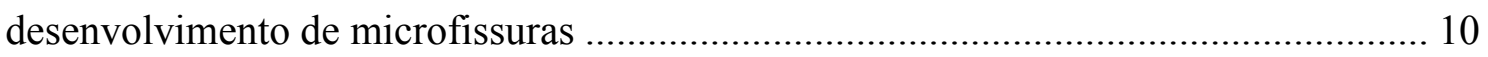

Figura 2.2 Variação da energia dissipada $(U d)$ em ensaio cíclico em Calcário Irati ..... 10

Figura 2.3 Parâmetros importantes da emissão acústica ........................................... 14

Figura 2.4 Comportamento da emissão acústica em relação aos estágios do processo de

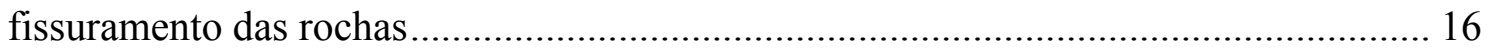

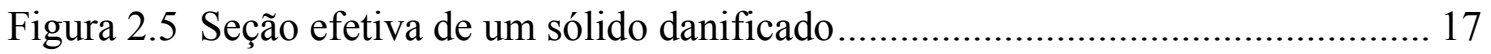




\section{MATERIAIS E MÉTODOS}

\subsection{Introdução}

A natureza mineralógica de uma seqüência evaporítica é o resultado tanto da combinação dos eventos ocorridos no momento de formação da seqüência (condições ambientais da evaporação, concentração da salmoura, duração dos ciclos de evaporação e recarga da bacia, etc.) como dos eventos desenvolvidos durante a evolução da seqüência na história geológica (diagênese, metamorfismo, deformação tectônica, circulação de fluidos, etc.).

As rochas evaporíticas podem ser de origem marinha, terrestre ou mista. A diferença fundamental entre estes ambientes é a composição mineralógica dos depósitos. Nas águas continentais dominam os sais de $\mathrm{Na}_{2} \mathrm{CO}_{3}$ e $\mathrm{Na}_{2} \mathrm{SO}_{4}$ sobre os sais de $\mathrm{CaCO}_{3}, \mathrm{CaSO}_{4}$ e cloretos predominantes nas salmouras marinhas.

O gipsito é o sulfato primário que se deposita na bacia evaporítica e o anidrito é o produto de desidratação do gipsito por processos diagenéticos. 


\subsection{Características geológicas dos gipsitos}

\subsubsection{Mineralogia e Composição}

Dos minerais evaporíticos de composição sulfatada, os mais importantes são o gipso e a anidrita. A Tabela 3.1 apresenta as características cristalográficas e petrográficas do gipso, resumidas por Giambastiani (2005) dos livros de Dana (1971) e de Kerr (1959).

\subsubsection{Petrografia e Estruturas}

Para Carozzi (1953) o gipso constitui massas homogêneas de cor branca, sendo rosa ou marrom quando contém impurezas de argilas e/ou óxidos de ferro em escala macroscópica.

A Figura 3.1 mostra algumas características mineralógicas e texturais do gipso em lâminas delgadas (ADAMS; MACKENZIE; GUILFORD, 1984).

Segundo Pettijohn (1980), o gipso varia desde cristalino grosso até granular fino, sendo esta última a textura mais comum. Pode apresentar planos de acamamento evidente ou existir como um corpo compacto carente de acamamento e de fissuras.

No microscópio, o gipso pode ter textura pseudoporfírica ou pseudoofítica; a primeira se caracteriza por cristais grandes, prismáticos, engastados em uma pasta finamente cristalina do mesmo material. A textura pseudoofítica se caracteriza por cristais laminares grandes que envolvem cristais euedrais pequenos, bem formados. Os cristais maiores, variedade selenita, provavelmente são de origem posterior à da matriz. Estes cristais parecem ser mais de caráter porfiroblástico que fenocristais. 

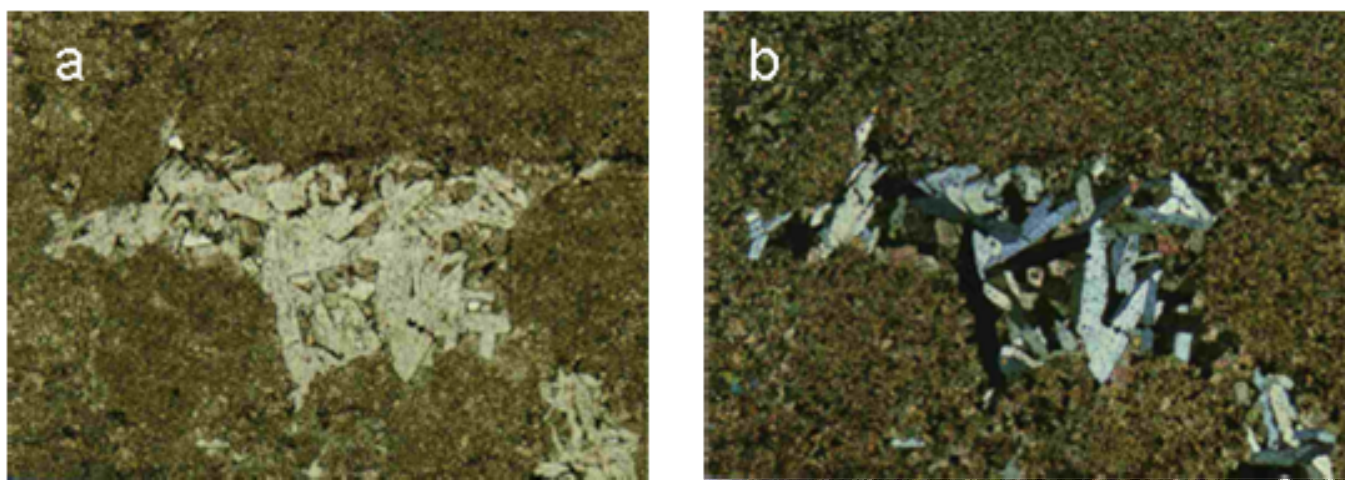

Figura 3.1 Microfotografias do gipso. (a-b) Cristais de gipso preenchendo uma cavidade em dolomito mostrando a típica cor de interferência cinza de primeira ordem. (a) nicol paralelo, (b) nicol cruzado

Fonte: Adams, Mackenzie e Guilford (1984)

Tabela 3.1 Características mineralógicas e petrográficas do gipso

\begin{tabular}{|c|c|}
\hline Propriedades & Gipso \\
\hline Composição Química & $\begin{array}{c}\mathbf{S O}_{4} \text { Ca.2H } \\
\text { O } \\
\left(\mathrm{CaO} 32,6 \%, \mathrm{SO}_{3} 46,5 \%, \mathrm{H}_{2} \mathrm{O} 20,9 \%\right) \\
\text { Monoclínico }\end{array}$ \\
\hline Cristalografia & $\begin{array}{c}2 / \mathrm{m} \\
\text { Cristais de hábito simples; tabulares segundo }\{010\} \text {; formas de } \\
\text { diamante com eixos }\{120\} \text { e }\{-111\} \\
\{010\} \text { perfeito }\end{array}$ \\
\hline Clivagem & $\begin{array}{c}\{100\} \text { superfície conchoidal } \\
\{011\} \text { fratura fibrosa }\end{array}$ \\
\hline Dureza & 2 \\
\hline Densidade específica & 2,32 \\
\hline Brilho & $\begin{array}{l}\text { Usualmente vítreo; também perolado e sedoso, } \\
\text { incolor, branco, cinza; transparente a translúcido }\end{array}$ \\
\hline Cor & $\begin{array}{c}\text { Alabastro é uma variedade de grão fino e massivo. } \\
\text { Selenita é uma variedade que produz folhas de clivagem incolores e } \\
\text { delgadas } \\
\text { Positiva }\end{array}$ \\
\hline Birrefringência & $\begin{array}{c}\mathrm{a}=1,520 ; \mathrm{b}=1,523 ; \mathrm{c}=1,530 \\
\text { Ángulo } 2 \mathrm{~V}=58^{\circ}\end{array}$ \\
\hline $\begin{array}{l}\text { Características } \\
\text { Diagnósticas }\end{array}$ & $\begin{array}{l}\text { Distingue-se por sua baixa dureza e por suas três direções de } \\
\text { clivagem desiguais. Solúvel em } \mathrm{HCl} \text { diluído e quente; em solução } \\
\text { com } \mathrm{BaCl}_{2} \text { dá um precipitado branco de sulfato de bário. Em um } \\
\text { tubo fechado torna-se branco e libera água. Sua solubilidade em } \\
\text { ácido e a presença de muita água distinguem-no da anidrita } \\
\text { Cor: Incolor em lâmina delgada }\end{array}$ \\
\hline $\begin{array}{l}\text { Características } \\
\text { Petrográficas }\end{array}$ & $\begin{array}{l}\text { Hábito: Agregados anedrais e subedrais. Freqüentemente em grãos } \\
\text { pouco uniformes. Às vezes com estrutura fibrosa. } \\
\text { Relevo: baixo, } n \text { ligeramente }<\text { bálsamo. } \\
\text { Birrefringência: bastante fraca. Maior cor de interferência é branca } \\
\text { ou amarela. } \\
\text { Extinção: paralela à melhor clivagem em seção normal }\{010\} .\end{array}$ \\
\hline
\end{tabular}

Fonte: Adaptado de Giambastiani (2005) 
O arranjo dos minerais em camadas, nódulos, massas uniformes etc., observáveis em escala do afloramento, recebe o nome de macroestrutura. $\mathrm{O}$ arranjo observável no microscópio ótico recebe o nome de microestrutura ou fábrica (ORTI CABO; ROSELL ORTIZ, 1981). Geralmente as duas estruturas são interdependentes.

Murray (1964) simplifica as macroestruturas dos depósitos de gipso como sendo de dois tipos básicos: estruturas laminares e estruturas nodulares. Os evaporitos laminares mostram contínuas laminações de espessuras milimétricas. Por outro lado, as estruturas nodulares podem ser desde nódulos isolados em uma matriz calcária até camadas de nódulos muito próximas, separadas entre si por delgadas camadas de calcários ou material clástico.

\subsection{Gipsitos da Formação Santana (Cretáceo inferior), Chapada do Araripe (Ceará/Pernambuco/Piauí, Brasil)}

Foram usadas amostras do gipsito bandado provenientes da Formação Santana, Cretáceo inferior, da Chapada de Araripe-CE/PE/PI, Brasil, por já existir um conhecimento incipiente da mesma estudada anteriormente por Giambastiani (2005).

A Bacia do Araripe é a bacia interior mais extensa do nordeste brasileiro que se localiza na divisa dos estados do Ceará, Pernambuco e Piauí no Brasil (Figura 3.2). É constituída por quatro sequencias estratigráficas distintas, limitadas por discordâncias (ASSINE, 1992). A Formação Santana se encontra na sequencia Aptiana-Albiana (Cretáceo Inferior) que corresponde a um ciclo transgressivo-regressivo com ingresão marinha de curta duração responsável pelas extensas camadas de gipsito. A Formação Santana está caracterizada na parte inferior por uma seção pelítica-carbonática própria de ambientes lacustres de baixa energia, com influxo terrígeno. Por sobre os calcários 
laminados, acham-se presentes evaporitos associados a folhelhos verdes e/ou pretos.

Formam camadas lenticulares de $30 \mathrm{~m}$ de espessura máxima e apresenta-se na forma de

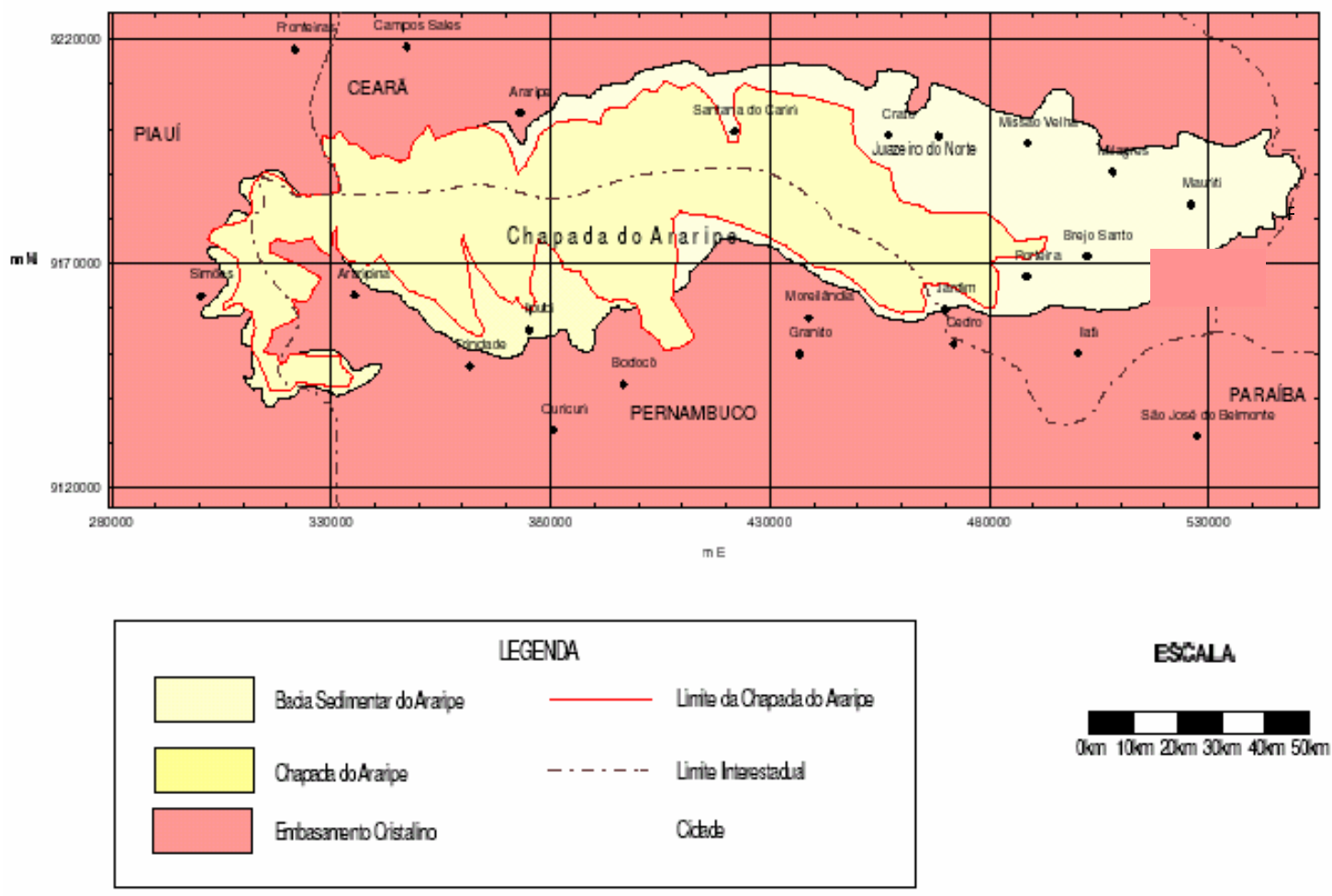

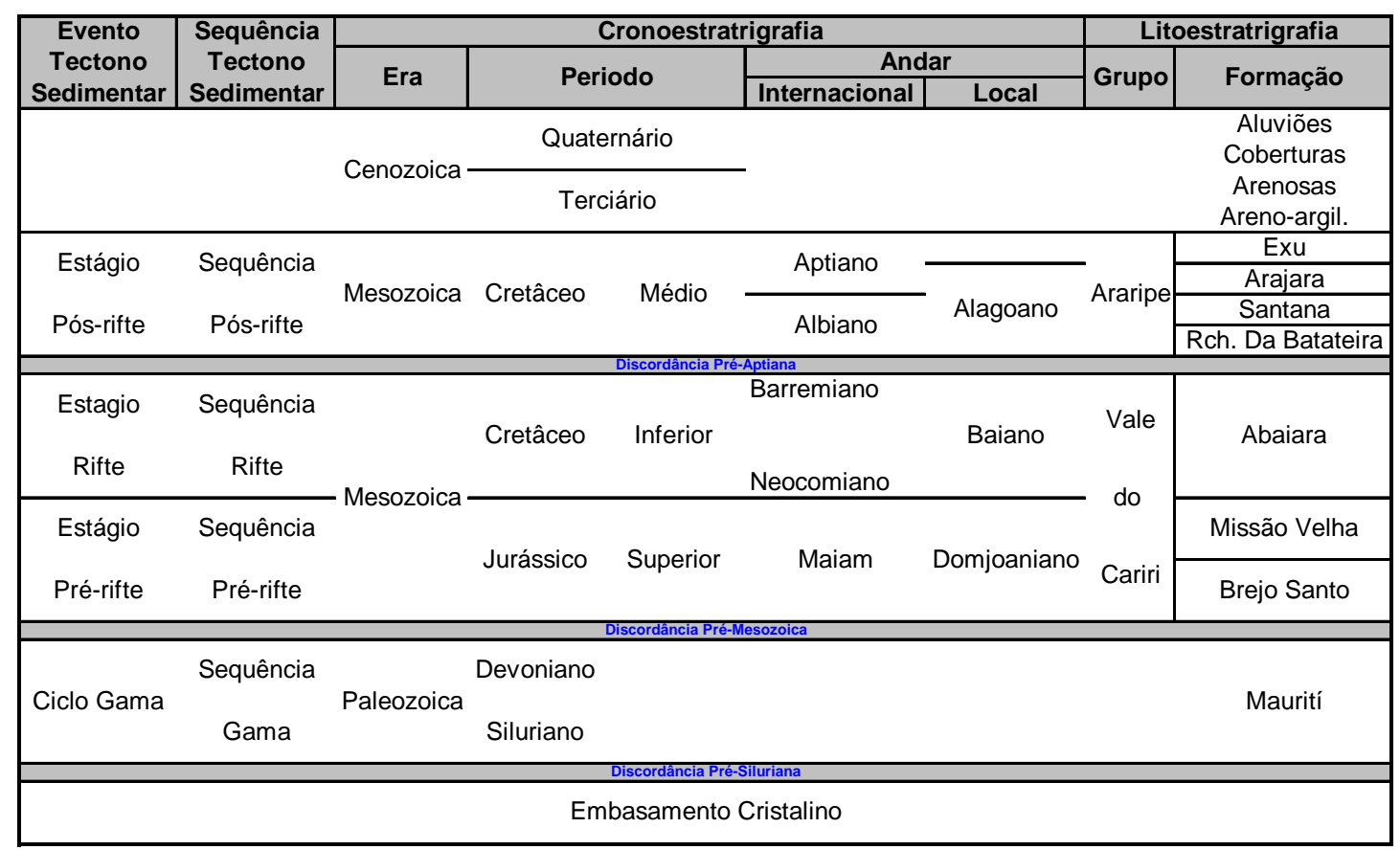

Figura 3.2 Mapa de localização e esquema estratigráfico - Chapada de Araripe Fonte: Giambastiani (2005) 
sulfato de cálcio. Podem-se distinguir duas fácies principais: a) gipsito laminado primário com cristais colunares dispostos em paliçadas (palisades) e gipsito secundário representados pelas variedades alabastro, porfiroblástico (rosetas de gipso incolor) e nodular (ASSINE, 1992). Variedades fibrosas são produtos de recristalização a partir de soluções ricas em sulfato de cálcio mobilizadas nos processos de diagênese.

\subsection{Etapa de coleta em campo}

A primeira etapa do trabalho foi realizada em campo (Figura 3.3) com o objetivo principal de coletar as amostras do gipsito bandado da Formação Santana para realização tanto dos ensaios como para a confecção de seções delgadas com objetivo de analisá-las petrograficamente.
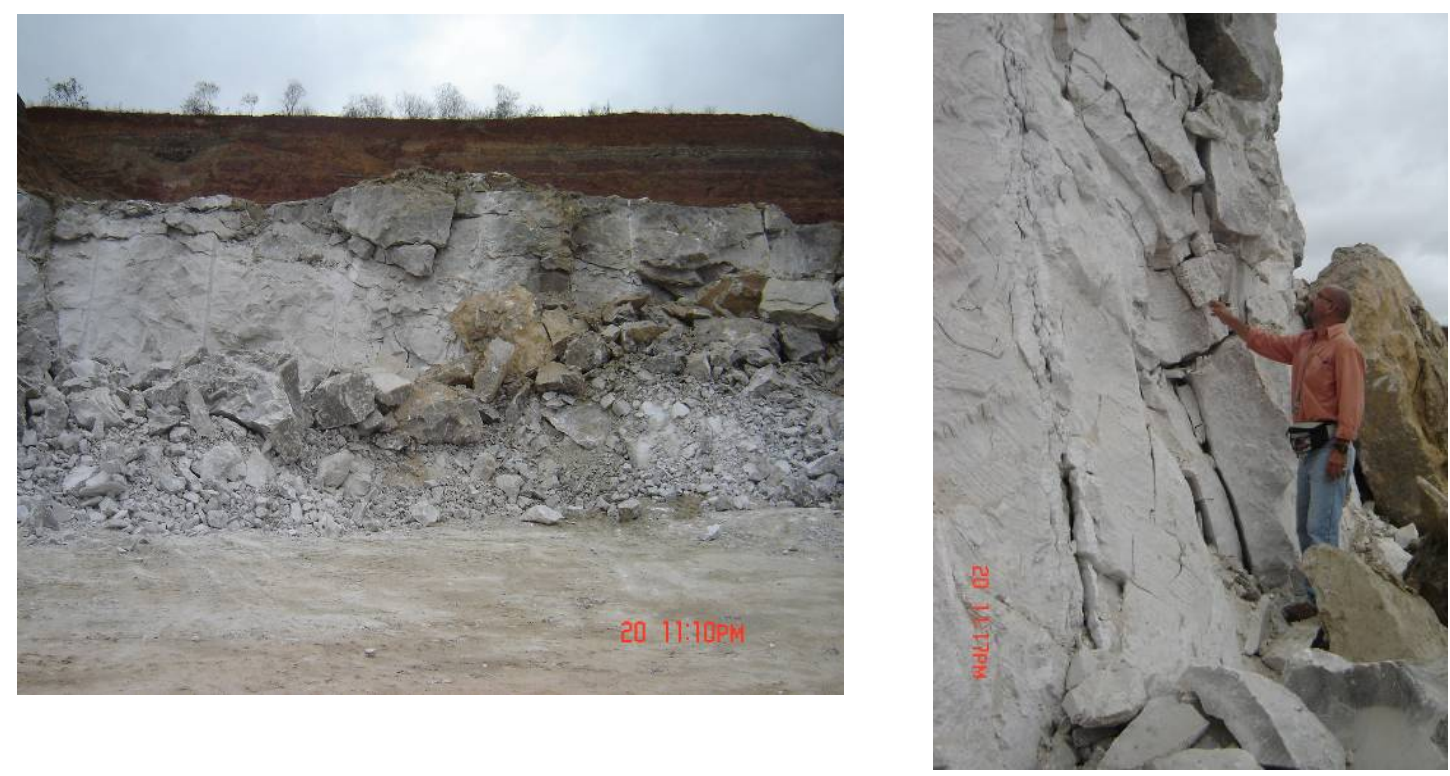

Figura 3.3 Exemplo da forma de ocorrência dos afloramentos do gipsito bandado

As amostras foram coletadas de afloramentos de aproximadamente $3 \mathrm{~m}$ de espessura na forma de blocos de aproximadamente $40 \times 40 \times 30 \mathrm{~cm}$ da mina de gipsito 
da Mineração Rancharia, localizada no Município de Araripina no Estado de Pernambuco (Figura 3.4).
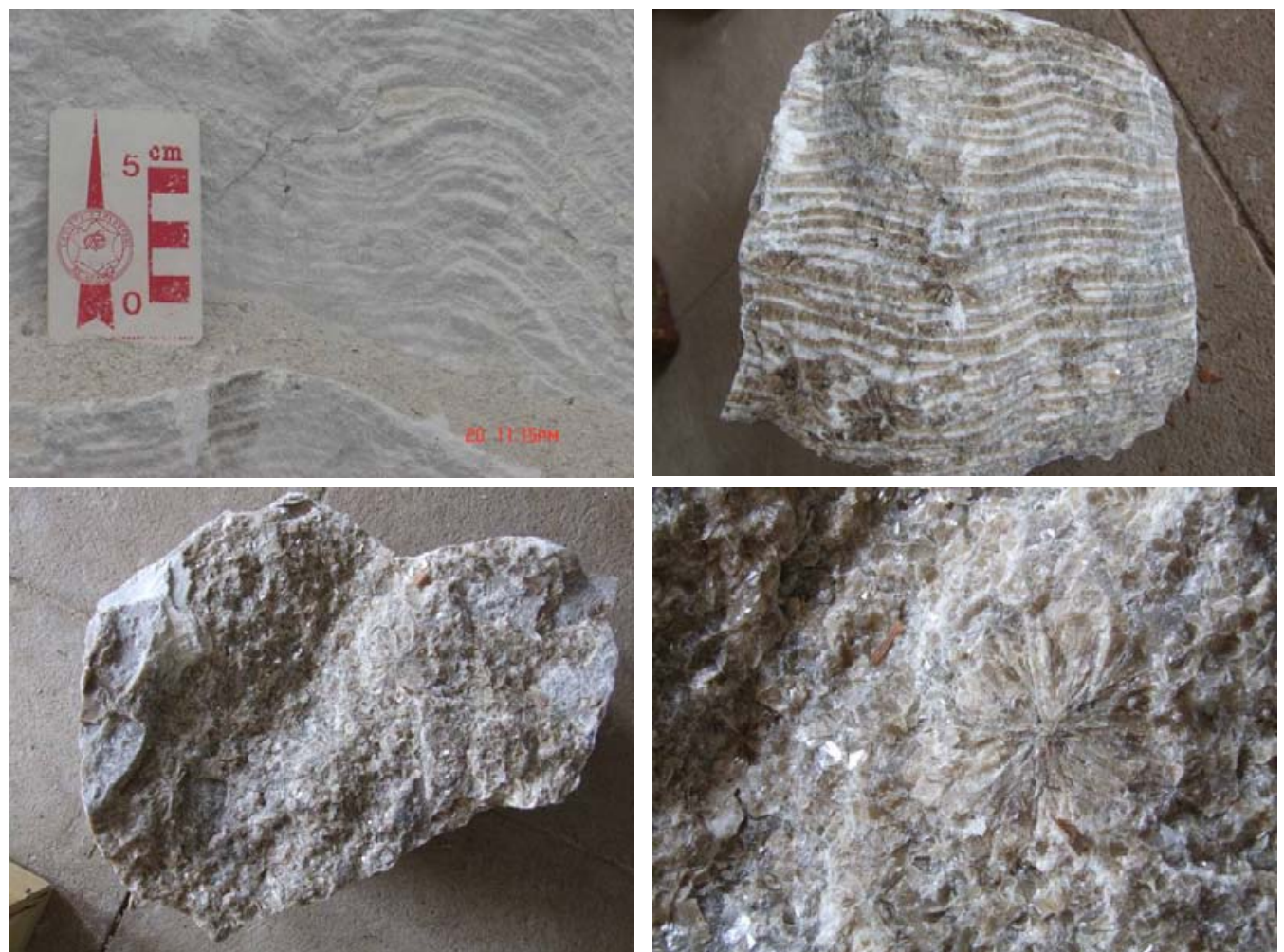

Figura 3.4 Exemplos de amostras coletadas em campo: observe-se detalhe de ondulações (dobramentos suaves) e de cristais com estrutura fibro-radiada

\subsection{Etapa de laboratório}

Primeiramente, as amostras foram encaminhadas para o laboratório de laminação do Departamento de Petrologia e Metalogenia da UNESP - Rio Claro para preparação das lâminas delgadas, onde foram serradas, cortadas em tabletes, depois submetidas ao desgaste até alcançar em proporções ideais para serem coladas nas lamínulas. Das amostras encaminhadas foram confeccionadas 7 lâminas delgadas, denominadas respectivamente de GBA3-A, GBA3-B, GBC1-A, GBC1-B, GBC2-A, GBC2-B e GBC2-C, que representassem da melhor maneira as diferentes direções em relação ao acamamento ou ao eixo da dobra, permitindo uma análise detalhada dos cristais e estruturas presentes. 
As fotos foram obtidas em lupa petrográfica de marca LEICA (estereomicroscópio), com polaróides cruzados, de todas as seções laminadas. A vertical das fotos obtidas com a lupa corresponde a aproximadamente $13 \mathrm{~mm}$ e as fotomicrografias em microscópio com polaróides cruzados ou paralelos de acordo com a necessidade. As objetivas foram de 10x, 25x e 50x dependendo do detalhe desejado.

A amostra com apenas duas bandas, uma branca de estrutura fibrosa e outra marrom (cinza quando observada ao microscópio), granular não pode ser confeccionada pelo fato de se fragmentar por inteiro, durante o processo de corte na serra e polimento. Deste material apenas pode ser obtida uma lâmina delgada, com impregnação utilizando bomba de vácuo e resina especial, equipamento que o laboratório de laminação do Departamento de Petrologia e Metalogenia da Universidade Estadual Paulista (UNESP) - Rio Claro não dispõe. As amostras foram cortadas em direções distintas de acordo com o que se pretendia visualizar. Para confecção de todas as lâminas, foram escolhidas preferencialmente as posições perpendicular e oblíqua às camadas, o que permite a observação com maior nitidez das diferenças texturais e composicionais.

A Figura 3.5 apresenta a amostra GBA3 da qual foram confeccionadas as lâminas GBA3-A e GBA3-B constituindo duas seções indicadas na figura: A na direção concordante com o eixo da dobra e B na direção perpendicular ao acamamento (uma perpendicular à outra). Observa-se o detalhe dos bandamentos dobrados, composicionais de gipsito um de cor branca e outro de cor marrom devido à própria estruturação e direção de crescimento dos cristais. 


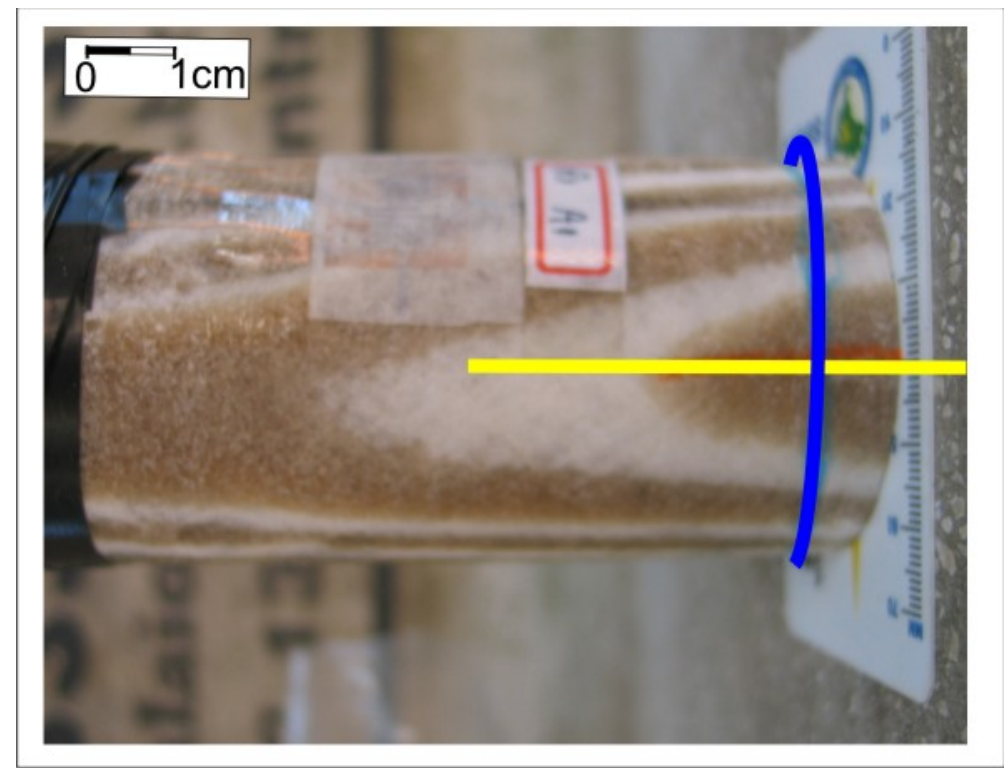

Direção de confecção das amostras para lâmina

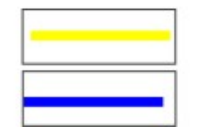

Direção concordante com eixo da dobra

Direção concordante com o acamamento

Figura 3.5 Amostra GBA3 apresentando corte realizado na amostra em duas direções (uma perpendicular à outra)

As Figuras 3.6 e 3.7 apresentam as direções de confecção das amostras GBC1 e GBC2 para as lâminas analisadas. Da amostra GBC1 foram confeccionadas as lâminas GBC1-A e GBC1-B constituindo duas seções: A na direção oblíqua e B na direção perpendicular ao acamamento. Já da amostra GBC2 foram confeccionadas as lâminas GBC2-A, GBC2-B e GBC2-C constituindo neste caso três seções: A na direção perpendicular, B na direção concordante e C na direção oblíqua ao acamamento. 


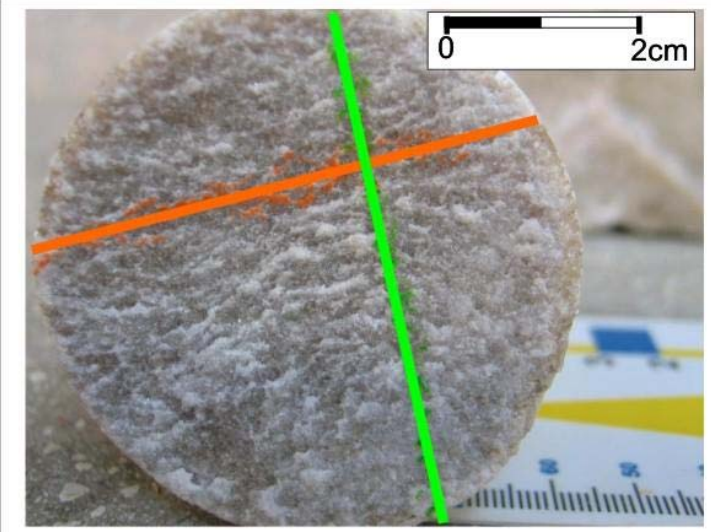

Direção de confecção das amostras para lâmina

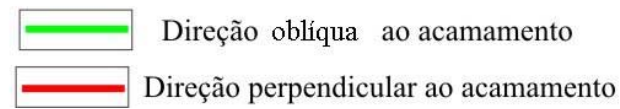

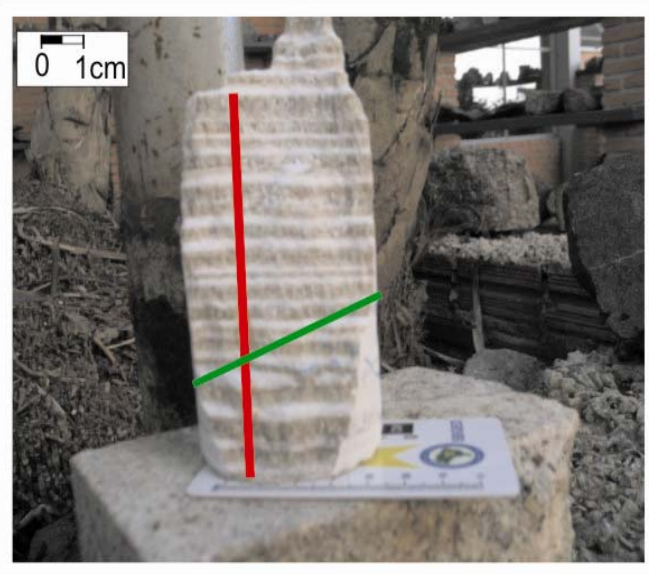

Direção de confecção das amostras para lâmina Direção oblíqua ao acamamento Direção perpendicular ao acamamento

Figura 3.6 Seções na amostra GBC1

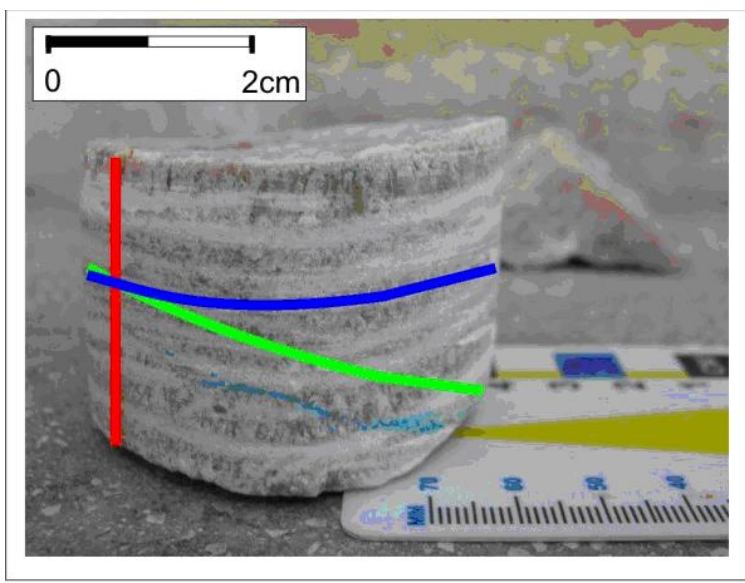

Direção de confecção das amostras para lâmina

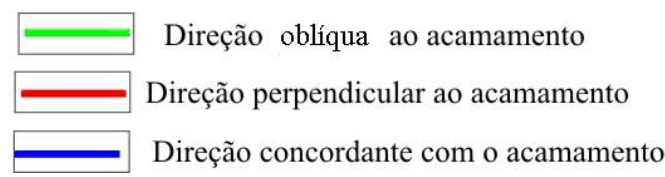

Figura 3.7 Seção na amostra GBC2

A Figura 3.8 apresenta um detalhe da amostra 8 que na tentativa de gerar uma nova seção se desagregou. Este detalhe deixa claro que se trata de um gipsito praticamente puro com texturas diferentes. A primeira constituída por fibras de dimensões centimétricas dispostas perpendicularmente ao bandamento e tonalidade 
branca, enquanto a outra apresenta aspecto granular e dimensões milimétricas a submilimétricas de tonalidade marrom.

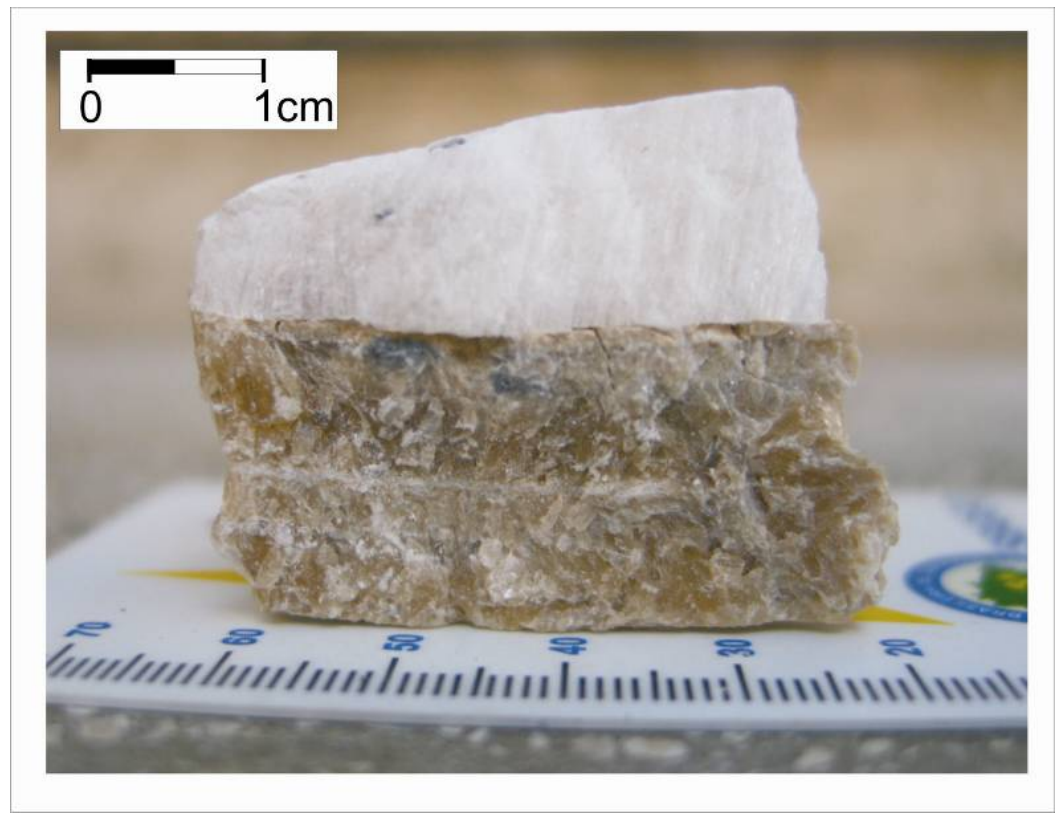

Figura 3.8 Amostra 8 que na tentativa de gerar uma nova seção desagregou-se

\subsection{Descrições petrográficas}

As descrições petrográficas e as analises das lâminas delgadas foram realizadas na UNESP de Rio Claro sob supervisão do Prof. Antenor Zanardo ${ }^{1}$.

A partir da análise petrográfica do material, verificou-se que é constituído por cristais de gipso submilimétricos a milimétricos, com textura granular orientada, na porção marrom (cinza quando observada em microscópio) e gipsito fibroso, com as fibras orientadas perpendicularmente ao bandamento com os cristais atingindo comprimento centimétrico e espessura submilimétrica a milimétrica (menor que $2 \mathrm{~mm}$ ), na porção branca.

\footnotetext{
${ }^{1}$ Antenor Zanardo é professor Doutor da UNESP de Rio Claro.
} 
Todas as lâminas delgadas apresentam composição mineralógica idêntica e pequena variação textural. A estrutura é bandada, com o bandamento definido pela variação granulométrica e subordinadamente pelo grau de orientação dimensional. As bandas maiores possuem granulação média variando de 2,5 a $6 \mathrm{~mm}$, enquanto que as bandas de granulação mais fina exibem espessuras normalmente menores que 3 mm. Essas bandas dispõem-se de forma paralela, possuem limites bruscos, porém os cristais exibem certo "interdigitamento", aparentemente não representando planos de fraqueza estrutural do material. As bandas de granulação mais finas e de menores espessuras, às vezes, são descontínuas aparecendo isoladas no interior de bandas de granulação mais grossa.

Os cristais normalmente são bem alongados, alcançando comprimento superior a 8 (oito) vezes a largura, e orientados perpendicularmente ao bandamento, sendo que esta orientação, com certa freqüência, nas bandas de granulação mais fina apresentam orientação oblíqua, sugerindo rotação durante a formação, por movimento relativo entre as duas bandas limítrofes de granulação mais grossa, em função de deslocamento flexural ou cisalhamento.

A orientação cristalográfica mostra ser bem menor que a dimensional, o eixo cristalográfico "c" raramente está na orientação dimensional ou disposto perpendicularmente às bandas.

As bandas de granulação mais fina tendem a ser formadas por cristais mais equidimensionais, gerando menor orientação dimensional, sendo que maiores cristais chegam a atingir 4 (quatro) mm de comprimento e a largura em média é menor que 0,5 $\mathrm{mm}$, porém pode atingir mais de $2 \mathrm{~mm}$, no caso de alguns cristais maiores, relativamente equidimensionais (Figura 3.9). 
Todas as microfotografias mostradas na Figura 3.9 destacam o contacto brusco entre as bandas. Pode-se observar uma banda de granulação mais grossa constituída por cristais de gipso orientados e outra banda fina também composta por cristais alongados, orientados e equidimensionais.
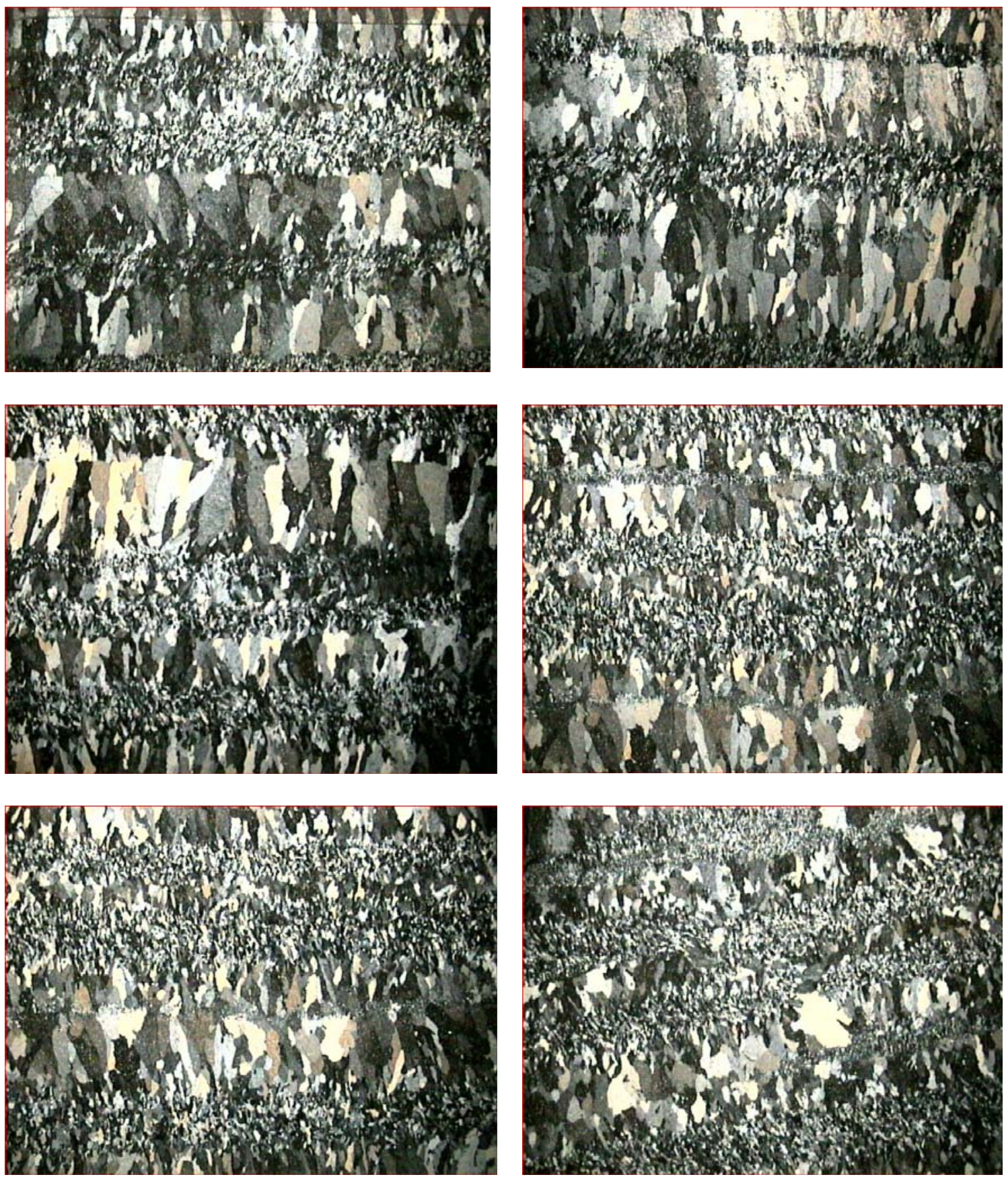

Figura 3.9 Aspectos gerais da rocha, com destaque para o bandamento e orientação dos cristais observados e fotografiados em lupa com nicóis cruzados 
A composição modal quase não varia de lâmina para lâmina, como apresentado na Tabela 3.2 .

Tabela 3.2 Composição modal

\begin{tabular}{cccc}
\hline Minerais principais & Porcentagem $(\%)$ & Minerais secundários & Porcentagem $(\%)$ \\
\hline Gipso & \pm 97 & Material carbonoso & traços \\
Anidrita & \pm 2 & Óxidos/hidróxidos & traços \\
Barita/Celestita & $<1$ & Titanita & traços \\
Carbonato (calcita) & traços & Argilominerais & traços \\
\hline
\end{tabular}

Não foram encontrados grãos detríticos, a não ser traços de argilominerais, sendo o material de origem química com traços de material orgânico, representado pelo material carbonoso, que aparece como película no plano de clivagem do gipsito e intersticialmente.

O gipsito forma cristais tabulares a equidimensionais de dimensões bem variadas, atingindo cerca de $4 \mathrm{~mm}$ na dimensão maior. Os cristais maiores apresentam textura poiquiloblástica por conterem uma nuvem de minúsculos cristais de anidrita e mais raramente carbonato, barita ou celestita e outros minerais de ocorrência esporádica, sendo os menores, dispostos na banda de granulação menor, isentos ou praticamente isentos de inclusões (Figuras 3.10, 3.11 e 3.12).
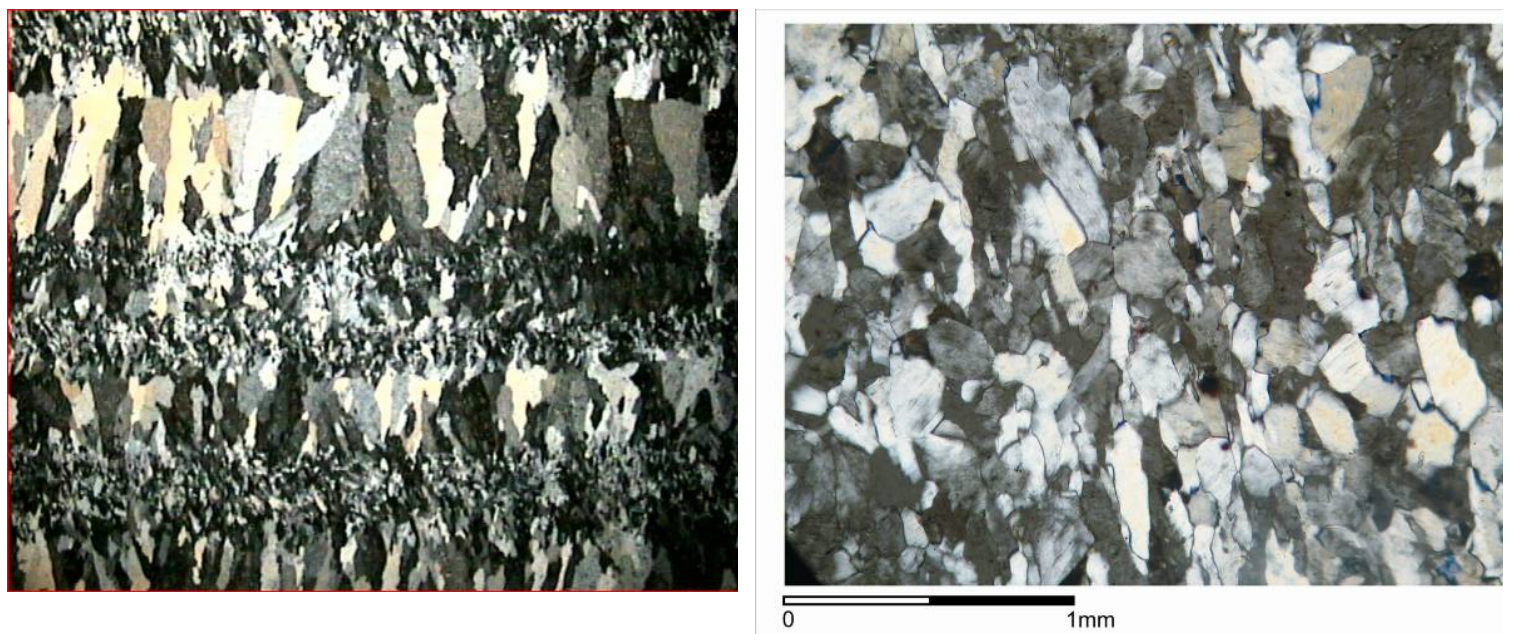

Figura 3.10 Banda de granulação mais fina formada por cristais de gipso alongados e orientados e equidimensionais sem inclusões de anidrita. Nicóis cruzados. Amostra GBA3 
A Figura 3.11 apresenta o detalhe da banda de granulação mais grossa mostrando cristais de gipso orientados e ricos em inclusões de anidrita. No canto inferior direito aparece o contato da banda de granulação mais grossa com a banda de granulação mais fina. A cor azulada que aparece no contacto entre as duas gipsitas trata-se de efeito de luz causado provavelmente pela espessura mais grossa.
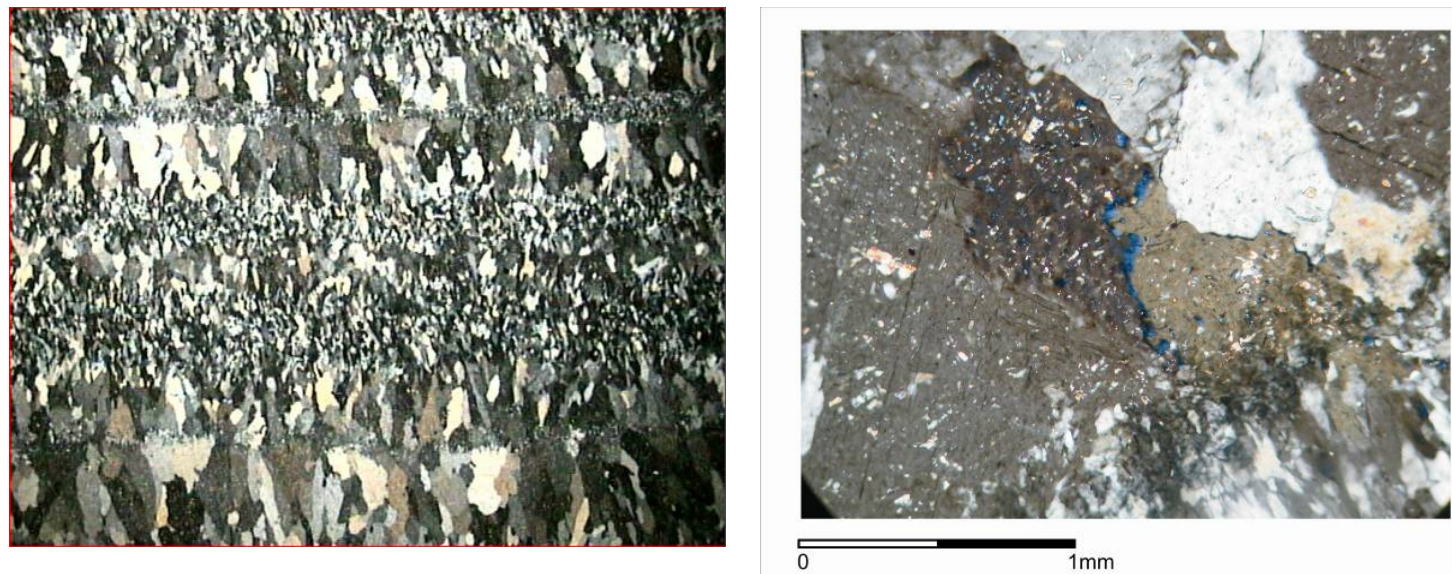

Figura 3.11 Banda de granulação mais grossa, com cristais de gipso ricos em minúsculas inclusões de anidrita. Nicóis cruzados. Amostra GBC1

A Figura 3.12 apresenta o detalhe do cristal de barita ou celestita com inclusões de anidrita. Este cristal apresenta bordas simplectítica ou intercrescimento vermiforme com gipsita conforme mostra a segunda figura, em domínio de granulação mais fina.
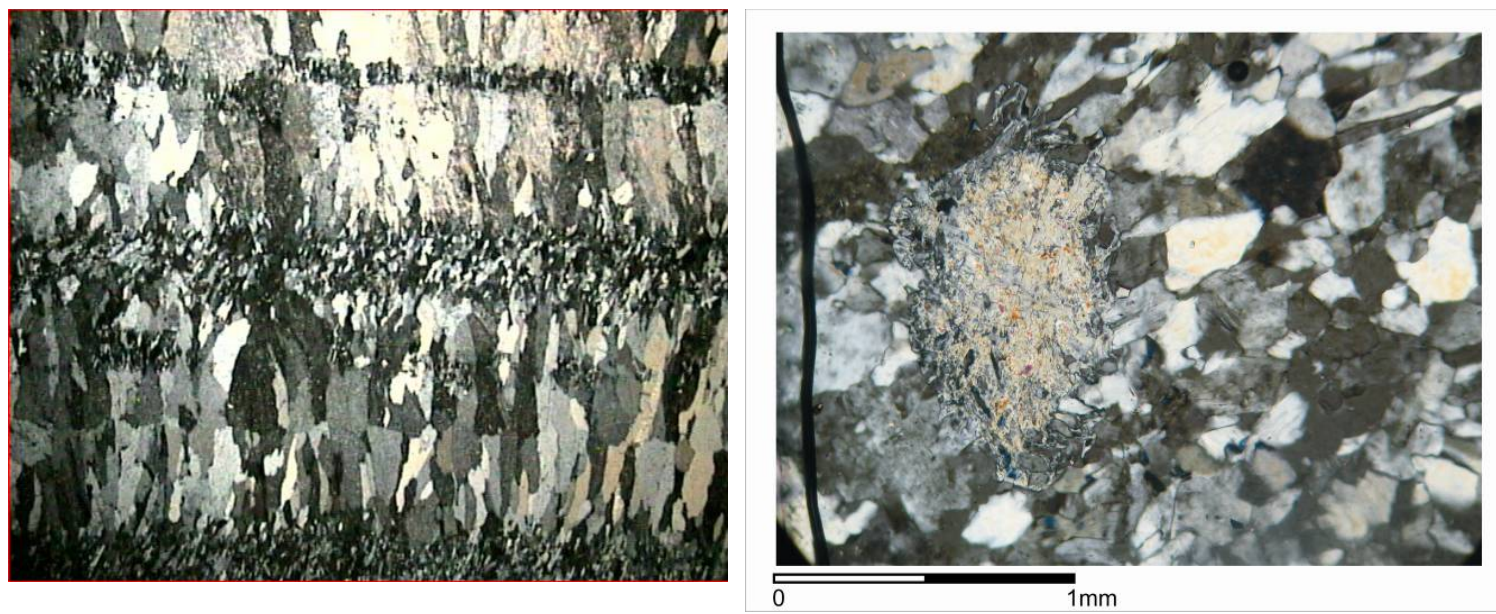

Figura 3.12 Detalhe do cristal de barita ou celestita com inclusões de anidrita na amostra GBC2-C. Nicóis cruzados 
$\mathrm{Na}$ primeira fotomicrografia da Figura 3.13 se observa o detalhe do contato brusco (abrupto) entre as bandas finas e grossas. A segunda mostra o detalhe da banda de granulação mais grossa, com cristal subedral de barita ou celestita, e o detalhe do contato da banda de granulação mais grossa com a banda de granulação mais fina no canto superior esquerdo.
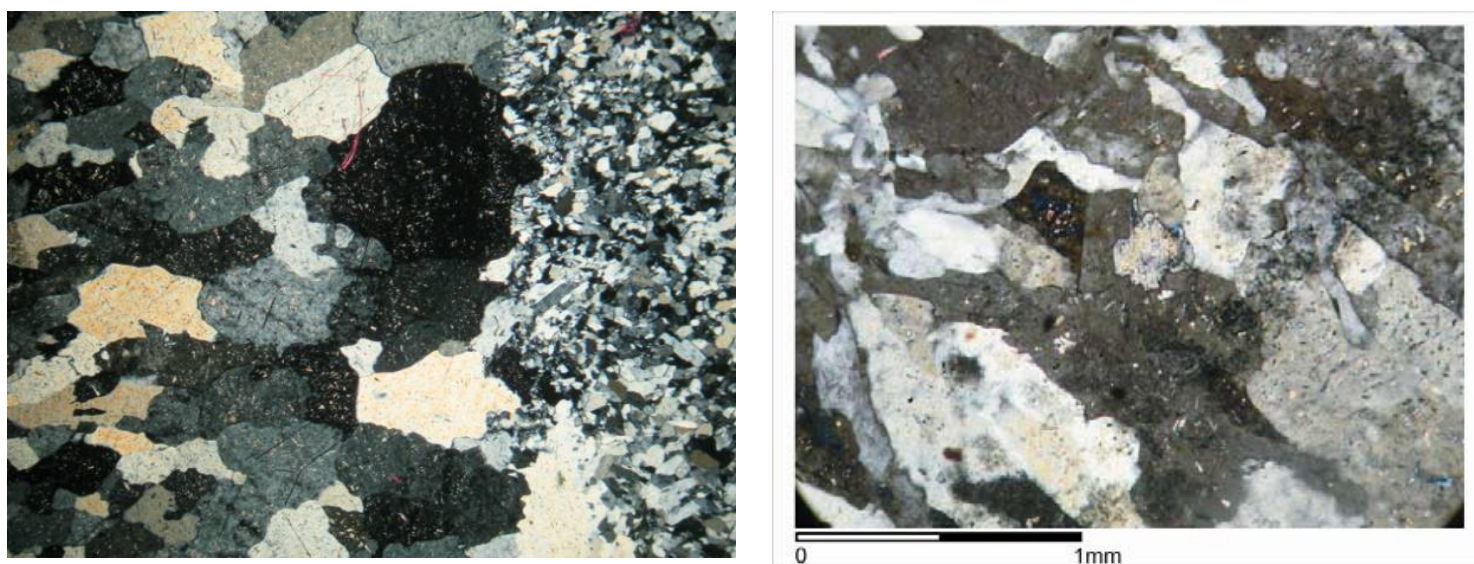

Figura 3.13 Contato brusco entre as bandas finas e grossas e detalhe da banda de granulação mais grossa com cristal de barita ou celestita. Nicóis cruzados. Amostra GBA3

A anidrita aparece como minúsculos cristais, normalmente menores que $30 \mu \mathrm{m}$, no interior de cristais de gipso, nas bandas de maior granulação média. São anedrais, equidimensionais a tabulares e não apresentam orientação perceptível (Figuras 3.14 e $3.15)$.

O carbonato aparenta ser calcita e ocorre como inclusões no gipsito ou como pequenos cristais intersticiais anedrais e submilimétricos. O óxido é representado por hematita e ocorre como minúsculas pontuações dispersas e raras e o hidróxido aparenta ser de ferro, formando películas intersticiais

Não foi possível observar deformação causada pelo ensaio mecânico. Apenas na seção GBC1-A observou-se uma delgada banda de concentração de extinção ondulante, que corresponde a uma deformação tardia pós-cristalização da gipsita. 

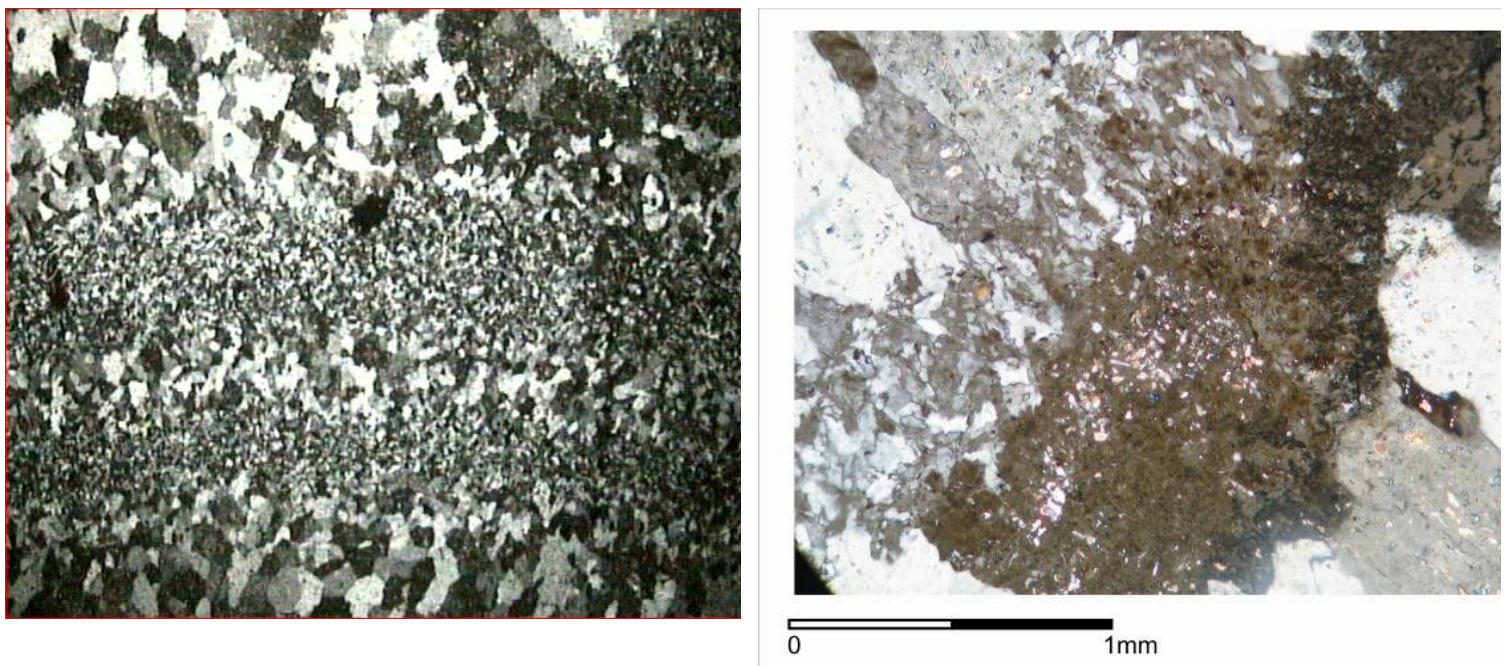

Figura 3.14 Imagem de banda de granulação mais fina entre bandas de granulação mais grossa, com cristais de gipso ricos em inclusões de anidrita. Nicóis cruzados. Amostra GBC1
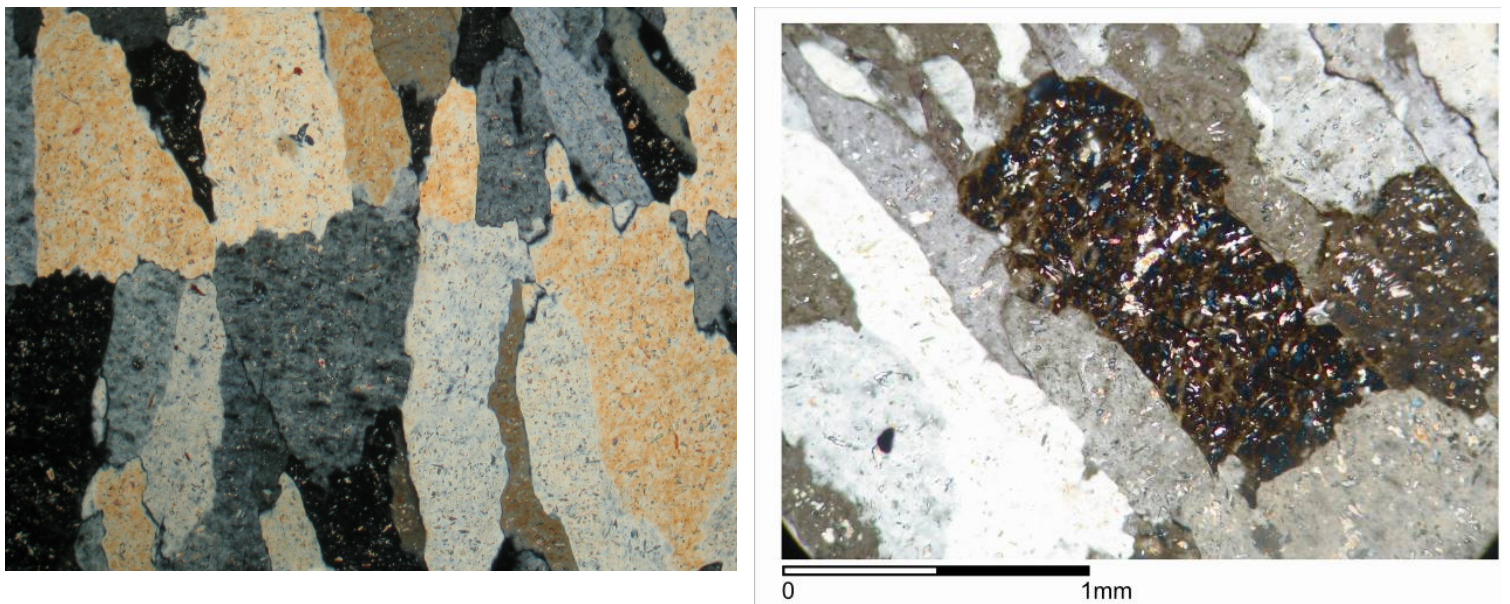

Figura 3.15 Detalhe da banda de granulação mais grossa mostrando cristais de gipso com inclusões de anidrita. Nicóis cruzados

A lâmina GBC1-A exibe uma orientação pouco menor que GBC1-B e os aspectos mineralógicos e estruturais são bastante similares. A lâmina GBC2-A exibe aspectos mineralógicos e texturais idênticos à GBC1-A. A lâmina GBC2-B exibe melhor orientação dimensional dos cristais de gipso que GBC2-A, sendo que GBC2-C é a que exibe menor orientação dimensional dos cristais de gipso, em especial, nas bandas de granulação mais fina. 
A qualidade da lâmina GBA3-A não é muito boa; ocorreu desgaste excessivo e o grau de orientação fica mais bem observado entre as lâminas GBC2-C e GBC2-A que apresentam carbonato intersticial. A lâmina GBA3-B apresenta melhor orientação dimensional que a GBA3-A e as bandas de granulação mais fina, normalmente com espessuras menores que $3 \mathrm{~mm}$, exibem orientação menor e cristais mais equidimensionais.

Quanto ao aspecto deformacional ligado aos ensaios de resistência à compressão simples, na seção delgada não aparece nenhuma evidência. Pode ser que as microfissuras produzidas no corpo de prova até a ruptura, já tenham sido removidas na confecção da lâmina delgada.

De acordo com a análise macroscópica realizada na amostra 8 da qual não se pode obter a lâmina, trata-se de gipsita praticamente pura com textura diferente, constituída por fibras de dimensões centimétricas dispostas perpendicularmente ao bandamento e outra com aspecto granular e dimensões milimétricas a submilimétricas. Portanto, apresenta um aspecto similar ao apresentando na Figura 3.16, porém com fibras muito mais longas.
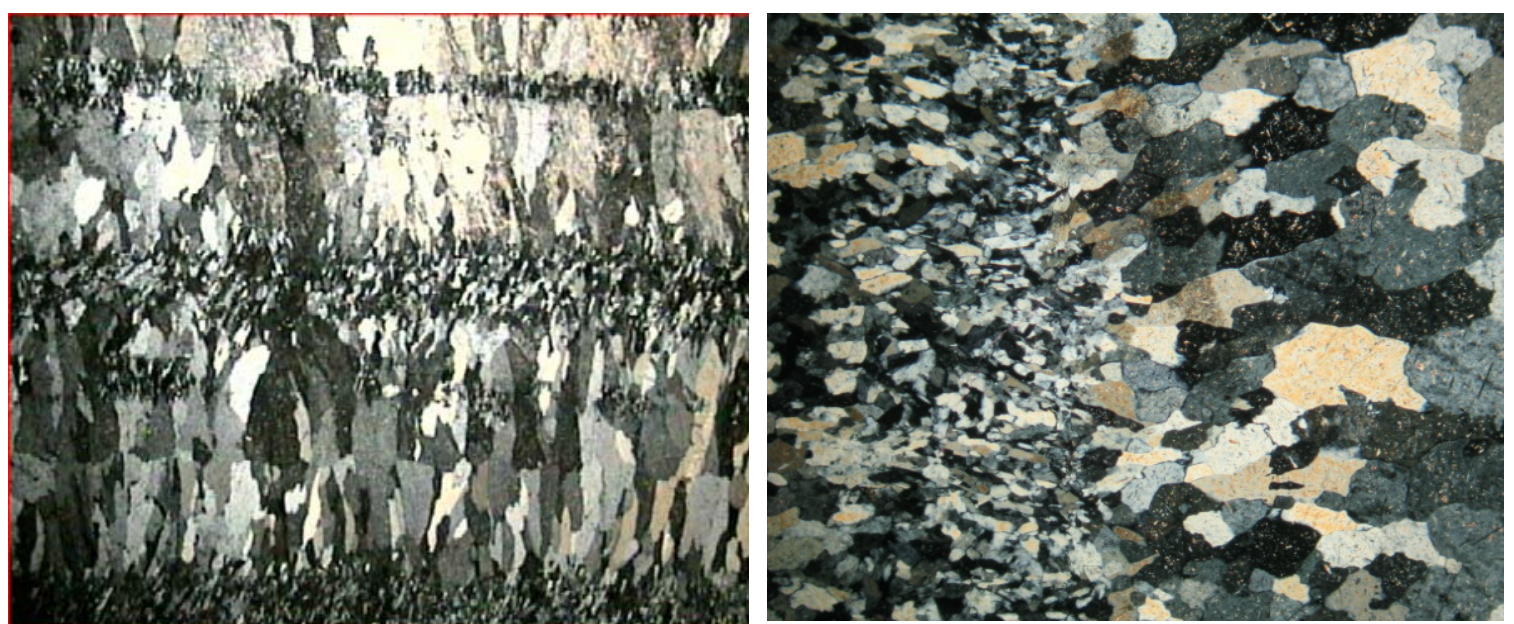

Figura 3.16 Relação entre as duas bandas, a primeira de granulação grossa, alongada intercalada por granulação mais fina ambas formadas por cristais de gipso alongados e orientados e equidimensionais. Nicóis cruzados. Amostra GBC2-A 


\subsection{Observações finais}

Observou-se que a composição mineralógica em toda a rocha é idêntica, apresentando pequena variação textural. Como se trata de uma rocha bandada, este bandamento é bem definido pela variação granulométrica e subordinadamente pelo grau de orientação dimensional. A figura esquemática (Figura 3.17) mostra a provável formação deste bandamento.

Provavelmente ocorreu um esforço deformacional horizontal que causou a compressão da rocha forçando os minerais a crescerem na posição vertical. Como já foi dito anteriormente estas bandas caracterizam-se pela granulação média maior, normalmente variando de 2,5 a 6 mm, enquanto que as de granulação mais fina exibem espessuras normalmente menores que $3 \mathrm{~mm}$ sendo paralelas.

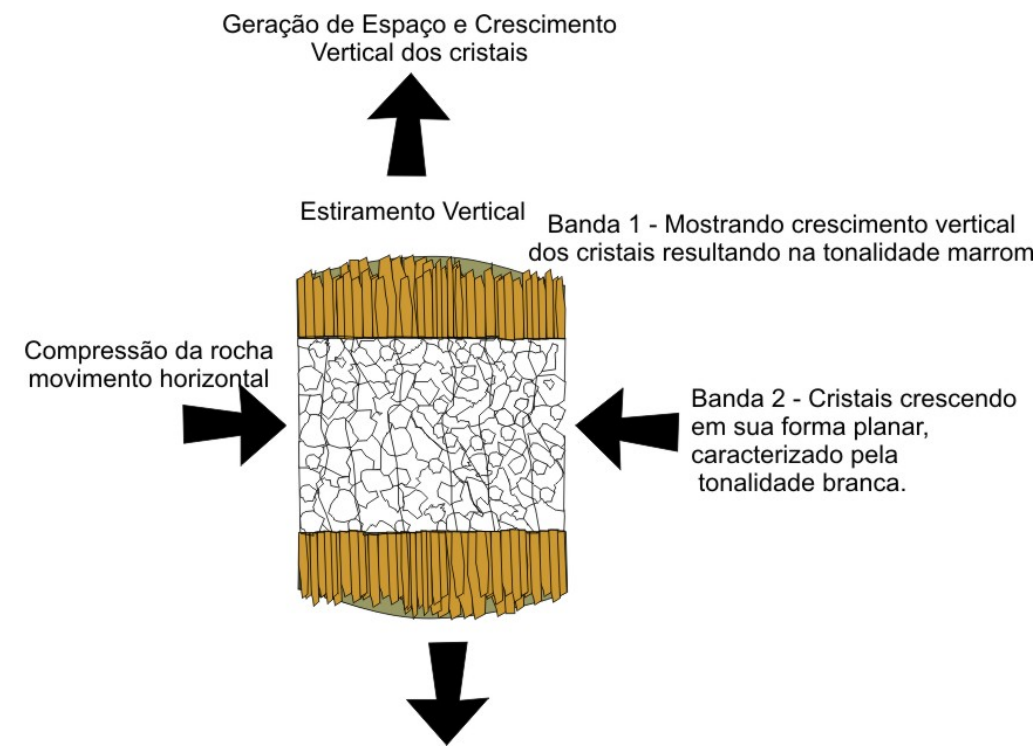

Figura 3.17 Modelo esquemático da formação das bandas composicionais

Possuem limites bruscos, porém os cristais exibem certo "interdigitamento", aparentemente não representando planos de fraqueza estrutural do material. As bandas 
de granulação mais fina e de menores espessuras são, às vezes descontínuas aparecendo isoladas no interior de bandas de granulação mais grossa. Basicamente são constituídas por gipso em praticamente sua totalidade seguida por anidrita, barita/celestita e traços de carbonato, óxidos/hidróxidos, titanita e argilominerais.

Os aspectos texturais sugerem que o material original era anidrita (material este originado por deposição ou gerado no auge da diagênese, quando foi colocado em maior profundidade sob atuação da subsidência da bacia). Com a transformação da anidrita para gipsita ocorre expressivo aumento de volume resultante em esforço atectônico que deve ter provocado a separação dos estratos abrindo espaços para o crescimento dos cristais de gipso perpendicularmente ao bandamento, ou planos de descolamento, conforme mostra a Figura 3.17. Esse processo deve ter ocorrido com o soerguimento (subida) da bacia (epirogênese positiva), que possibilitou a exumação e/ou exposição do depósito evaporítico.

Esta caracterização da orientação dos cristais, presença de inclusões de outros minerais e a explicação da provável formação do bandamento neste tipo de rocha é fundamental para explicar os resultados obtidos na determinação das propriedades físico-mecânicas (Tabela 3.3) e os resultados a serem discutidos no Capítulo 4 de Resultados e Discussão.

Comparando os resultados obtidos da resistência uniaxial com carregamento nas direções perpendicular e paralela às camadas é evidente uma anisotropia da rocha. A resistência à compressão uniaxial é maior nos corpos de prova submetidos a carregamento na direção paralela às camadas que nos corpos de prova submetidos a carregamento na direção perpendicular às camadas (contrário do esperado) devido ao crescimento dos cristais do bandeamento de granulação mais grossa nessa direção. 
Tabela 3.3 Propriedades físico-mecânicas da rocha estudada

\begin{tabular}{|c|c|c|}
\hline \multirow{2}{*}{$\begin{array}{l}\text { Propriedades físico- } \\
\text { mecânicas }\end{array}$} & \multicolumn{2}{|c|}{ Gipsito bandado } \\
\hline & Perpendicular às camadas & Paralelo às camadas \\
\hline Número de ensaios & 5 & 5 \\
\hline$\sigma_{\mathrm{c}}(\mathrm{MPa})^{*, 1}$ & $23,0 \pm 2,6$ & $24,0 \pm 2,4$ \\
\hline $\mathrm{E}(\mathrm{GPa})^{*, 1}$ & $28,6 \pm 1,5$ & $35,7 \pm 8,0$ \\
\hline$v^{*, 1}$ & $0,3 \pm 0,05$ & $0,3 \pm 0,10$ \\
\hline$\sigma_{\mathrm{c}}(\mathrm{MPa})^{*, 2}$ & $20,9 \pm 0,9$ & $24,1 \pm 0,7$ \\
\hline $\mathrm{E}(\mathrm{GPa}){ }^{*, 2}$ & $22,3 \pm 2,6$ & $21,4 \pm 6,2$ \\
\hline$v^{*, 2}$ & $0,3 \pm 0,11$ & $0,3 \pm 0,06$ \\
\hline$\sigma_{\mathrm{ci}}(\mathrm{MPa})$ & $1,6 \pm 0,8$ & $2,3 \pm 1,1$ \\
\hline$\sigma_{\mathrm{cd}}(\mathrm{MPa})$ & $81,6 \pm 6,7$ & $76,7 \pm 5,2$ \\
\hline$\sigma_{\mathrm{t}}(\mathrm{MPa}) * *$ & $1,8 \pm 0,2$ & $2,7 \pm 0,3$ \\
\hline $\begin{array}{l}\text { Velocidade sônica } * * * \\
\qquad(\mathrm{~km} / \mathrm{s})\end{array}$ & $5,02 \pm 0,19$ & $4,79 \pm 0,09$ \\
\hline Porosidade aparente $(\%){ }^{\&}$ & \multicolumn{2}{|c|}{$2,68 \pm 0,43$} \\
\hline Absorção (\%) ${ }^{\&}$ & \multicolumn{2}{|c|}{$1,18 \pm 0,97$} \\
\hline $\begin{array}{l}\text { Massa específica aparente } \\
\text { seca }(\mathrm{g} / \mathrm{cm} 3)^{\&}\end{array}$ & \multicolumn{2}{|c|}{$2,28 \pm 0,015$} \\
\hline
\end{tabular}

Nota: $\sigma_{c}$ : Resistência à compressão uniaxial; $\sigma_{t}$ : Resistência à tração indireta; E: Módulo de Elasticidade; v: Coeficiente de Poisson. ${ }^{*}$ INTERNATIONAL SOCIETY OF ROCK MECHANICS - ISRM (1979a); ${ }^{* *}$ ISRM (1978a); ${ }^{* * *}$ ISRM (1978b); ${ }^{*}$ ISRM (1979b); 1: Taxa de carregamento com acréscimo de força constante $=4.5 \mathrm{kN} / \mathrm{min}$ (tempo médio do ensaio até a ruptura $=14 \mathrm{~min}$ ). 2 : Taxa de carregamento com deslocamento do prato constante $=0.06 \mathrm{~mm} / \mathrm{min}$ (tempo médio do ensaio até a ruptura $=10 \mathrm{~min}$ ). $\sigma_{\mathrm{ci}}$ : tensão associada ao início do fissuramento. $\sigma_{\mathrm{cd}}$ : tensão do dano por fissuramento. $\sigma_{\mathrm{ci}}$ e $\sigma_{\mathrm{cd}}$ segundo método proposto por Martin (1993).

Diante destes resultados preliminares, decidiu-se realizar os ensaios nas duas direções principais: a) ensaios com carregamento perpendicular às camadas e b) ensaios com carregamento paralelo às camadas. Salienta-se que pelas ondulações (dobramentos suaves) existentes nas amostras coletadas em campo, alguns corpos de prova não poderiam ser carregados perpendicular ou paralelamente às camadas; nestes casos não foram consideradas estas amostras para não influenciar nos resultados finais. 


\subsection{Preparação dos corpos de prova}

Foram extraídos testemunhos cilíndricos a partir dos blocos do gipsito bandado nas duas direções principais (paralela ao eixo das camadas e perpendicular ao mesmo) com a finalidade de estudar o comportamento nessas duas direções.

Para a preparação dos corpos de prova, foram atendidas as tolerâncias sugeridas pela norma ASTM D4543-01 reaprovada em 2001. Utilizou-se para o corte um disco de 400 mm de diâmetro e para a retificação das bases uma retifica mecânica com rebolo diamantado, sendo estas etapas efetuadas sob umedecimento, com utilização de água. A seguir, os corpos de prova foram colocados em um dessecador para manter uma umidade constante como mostrado na Figura 3.18.

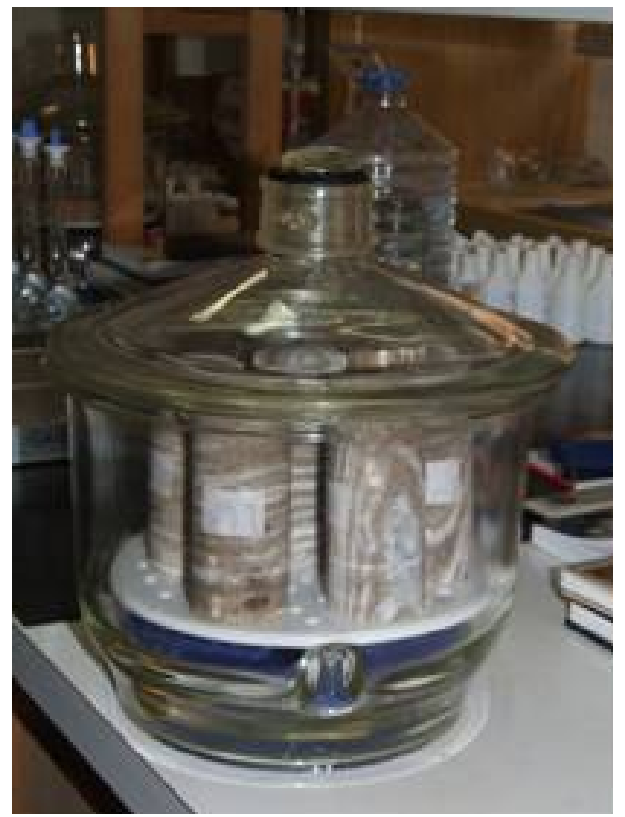

Figura 3.18 Corpos de prova colocados em um dessecador

As amostras utilizadas nos ensaios de compressão uniaxial foram extraídas com broca diamantada de diâmetro interno de $54.5 \mathrm{~mm}$ que normalmente utiliza água como fluido de resfriamento. Foram retificadas para garantir o acabamento superficial: 
paralelismo entre as faces e perpendicularidade com o eixo longitudinal, obtendo-se corpos de prova de 52,0 até 53,5 mm de diâmetro e de 119,7 até $123,5 \mathrm{~mm}$ de comprimento.

Para alguns dos ensaios de compressão uniaxial, com ciclos variáveis de carregamento antes e após o pico de resistência, foi utilizada uma broca diamantada de diâmetro interno de 73,6 mm, obtendo-se corpos de prova de 72,8 até $73 \mathrm{~mm}$ de diâmetro e de 132,3 até 135,4 mm de comprimento.

O diâmetro médio do corpo de prova foi calculado a partir de seis medidas realizadas com paquímetro $(0,02 \mathrm{~mm}$ de precisão) ao longo do corpo de prova em posições equidistantes. A altura média do corpo de prova foi obtida de seis medidas em posições distantes $60^{\circ}$ entre si. A massa específica aparente seca foi obtida usando os procedimentos sugeridos pela ISRM (1979b) usando uma balança com 0,1 g de precisão.

\subsection{Instrumentação dos corpos de prova e calibração do equipamento de emissão acústica}

\subsubsection{Instrumentação dos corpos de prova}

Todos os corpos de prova foram instrumentados com dois extensômetros elétricos de resistência em roseta dupla colados na parte central, diametralmente opostos, para duas medidas de deformações axiais e duas circunferencias seguindo procedimentos da ISRM (Figura 3.19) 


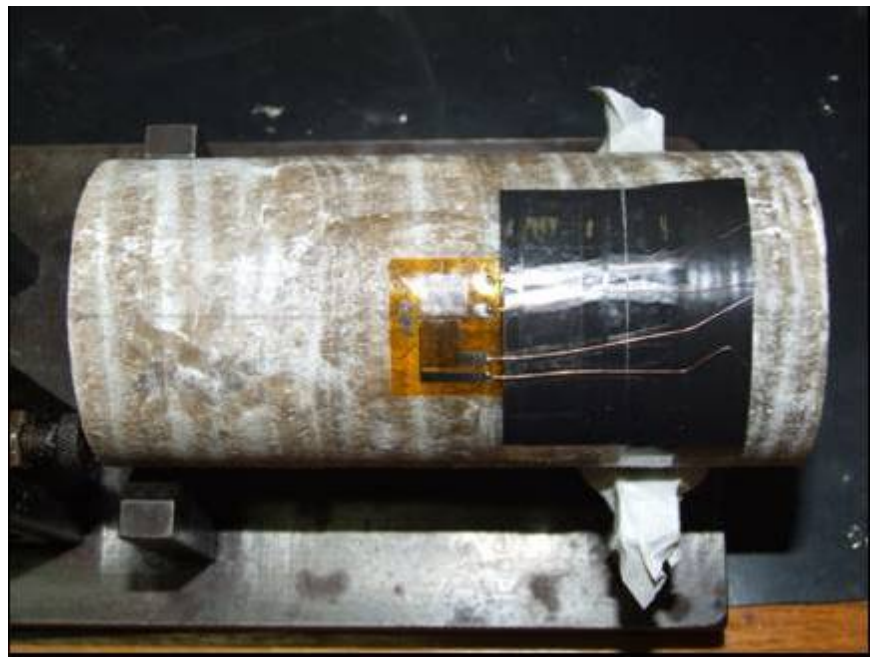

Figura 3.19 Extensômetros elétricos de resistência em roseta dupla colado no corpo de prova

Para o registro das emissões acústicas foram acoplados sensores de $175 \mathrm{kHz}$ de freqüência característica (PAC modelo D9203B, Figura 3.20), conectado cada um deles a um pré-amplificador com ganho regulável de 20,40 e 60 dB (Figura 3.21) com um cabo coaxial de transmissão sensor - pré-amplificador (modelo DSC4A).

Dentre as características dos amplificadores, o ganho de amplificação é a mais importante. Neste trabalho foi utilizado ganho de $40 \mathrm{~dB}$ baseado em experiências anteriores de outros pesquisadores (COX; MEREDITH, 1993; ZIETLOW; LABUZ, 1994; EBERHARDT et al., 1997; EBERHARDT; STEAD; STIMPSON, 1999).

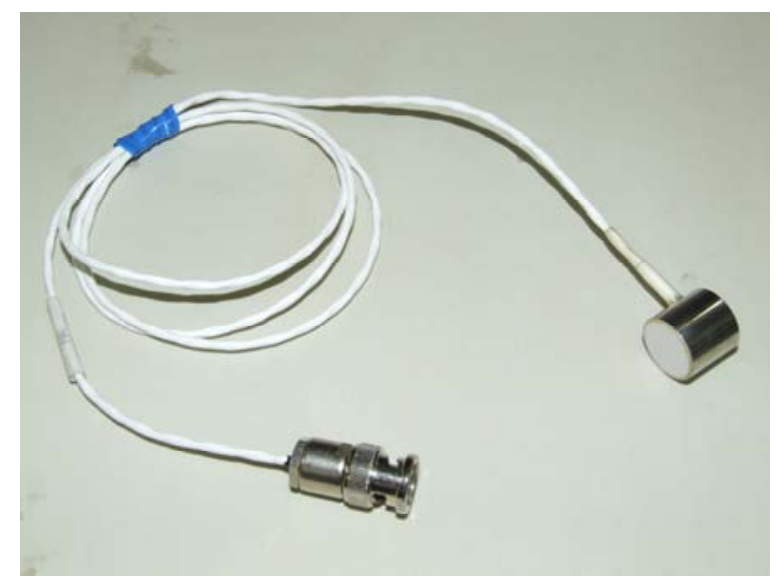

Figura 3.20 Detalhe do sensor modelo D9203B 


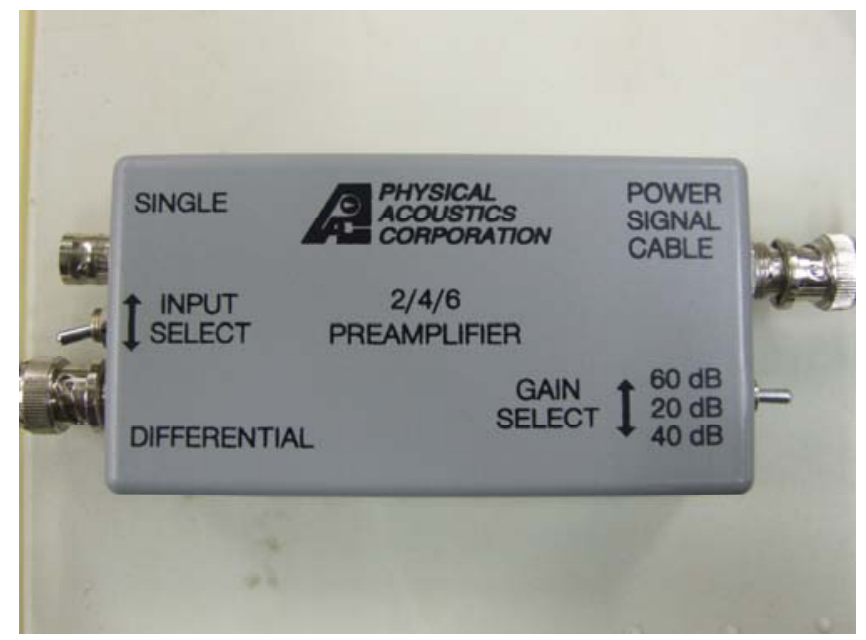

Figura 3.21 Detalhe do pré-amplificador

O acoplamento e montagem do sensor têm como objetivo tornar a sensibilidade de todos os canais consistente, alta e estável.

O acoplamento é essencial para preencher o espaço entre o sensor e a estrutura, garantindo uma transmissão mais eficiente da onda de energia.

A montagem é essencial para manter seguro o sensor na posição durante o ensaio. Isto foi realizado colocando-se vaselina como acoplante na superfície do corpo de prova e fixando-se o sensor por meio de bandas elásticas como mostrado na Figura 3.22 .

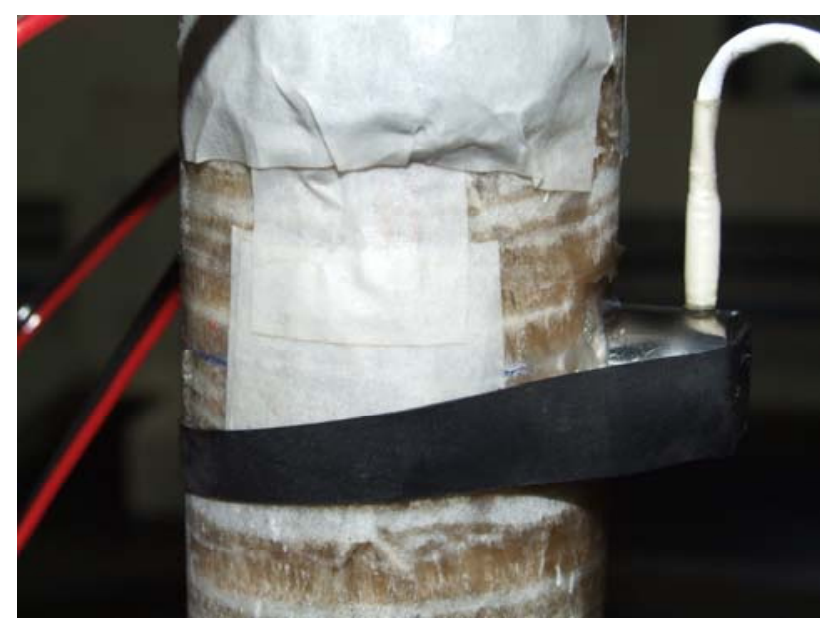

Figura 3.22 Detalhe do sensor com o acoplante no corpo de prova 


\subsubsection{Calibração do equipamento de emissão acústica}

$\mathrm{Na}$ preparação para os ensaios, foram tomadas precauções contra o ruído, observar a freqüência de operação, estabelecer corretamente o ganho, limite de voltagem, sensibilidade, determinar qual será a estratégia de localização de fontes, determinar os parâmetros de tempo [tempo de definição de pico (PDT), tempo de definição do hit (HDT) e tempo de trava do hit (HLT)], selecionar corretamente os gráficos de dados e definir a técnica de discriminação (filtragem) a ser utilizada.

O PDT é o tempo constante de um retrigger em uma coleta do circuito que determina o tempo de definição do pico. O HDT é o tempo constante do retrigger de uma coleta do circuito que determina o fim do hit. O HLT é um tempo de trava, iniciando no fim do hit, durante o qual o sistema não responde ao corte do limite de voltagem. O HDT é o mais importante destes.

A escolha da freqüência de operação (assumindo sensor ressonante) é negociada entre a rejeição de ruído e a faixa de detecção.

A calibração do equipamento de emissão acústica, que permitiu definir o limiar de referência de avaliação dos ensaios realizados, foi realizada colocando vários sensores livres em contato com o meio onde se realizou cada tipo de ensaio, determinando para cada laboratório um limiar diferente (limiar de referência de $50 \mathrm{~dB}$ no laboratório de mecânica das rochas e 45 dB no laboratório de ensaios de fluência da EESC-USP).

A atenuação é a perda da amplitude do sinal com o aumento da distância da fonte. A atenuação é importante porque controla a detectabilidade de fontes distantes; portanto, é um fator-chave na determinação do espaçamento de sensores para ensaio de 
emissão acústica. Os fatores principais que causam atenuação são: espalhamento das ondas pela geometria ou por perda em meio adjacente e absorção da onda (amortecimento, atrito interno).

Para teste dos sensores (sensibilidade), provocou-se, sobre o corpo de prova instrumentado, um fenômeno de emissão acústica pela quebra com grafite de uma lapiseira (dureza 2H), simulando uma trinca pequena (Figura 3.23).

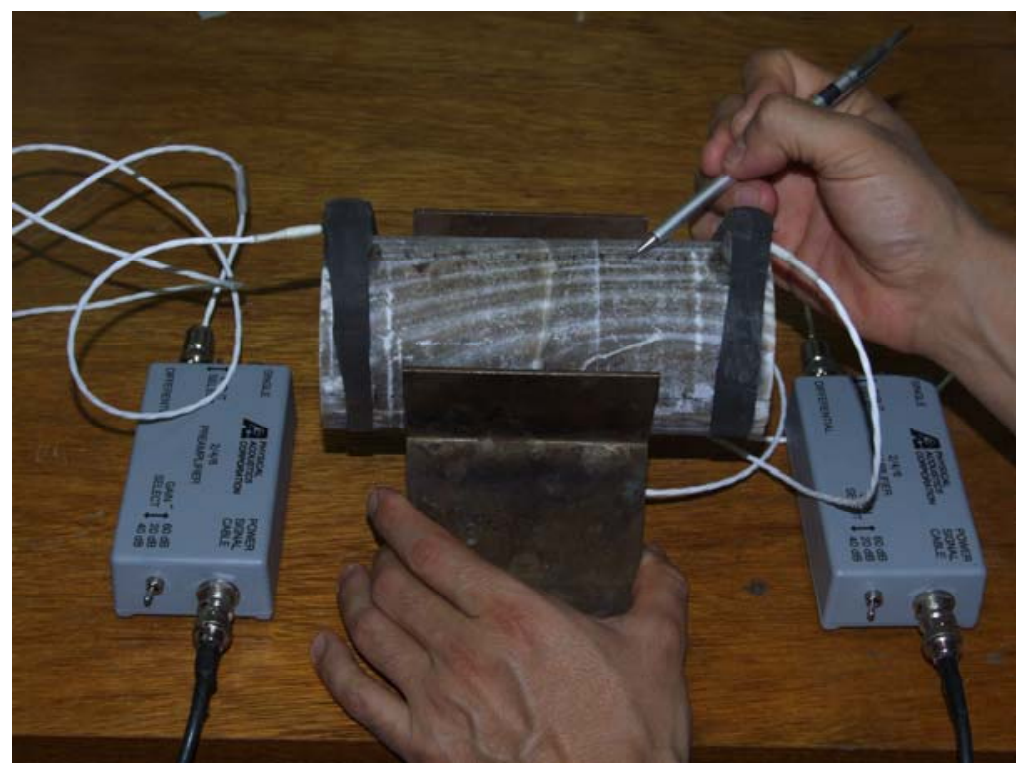

Figura 3.23 Configuração do teste para estudar a sensibilidade mediante a quebra do grafite de dureza $2 \mathbf{H}$

Os problemas devidos a montagem/acoplamento deficiente podem ser a causa da inconsistência de resposta dos canais, como medido pela quebra de grafite. Falhas de cabo são normalmente descobertas quando o sinal correspondente a quebra de grafite não chega através do componente em teste ou quando existe um ruído excessivo em um canal. Estas falhas são melhor diagnosticadas com um multímetro. Deve-se verificar a continuidade do condutor central; continuidade do fio terra e circuito aberto entre condutor central e terra. Falhas intermitentes geralmente podem ser identificadas por agitação dos conectores com o multímetro conectado. 


\subsection{Sistema de carregamento e instrumentação dos ensaios de deformação lenta uniaxial}

Os ensaios de deformação lenta uniaxial sob tensão constante foram realizados de acordo com o método proposto pela norma ASTM D 4405-93 (Standard Test Method for Creep of Cylindrical Soft Rock Core Specimens in Uniaxial Compression).

O sistema de ensaios de fluência foi montado em um laboratório especialmente equipado para manter constantes a temperatura e a umidade. O controle da temperatura foi feito através de um sistema de refrigeração e aquecimento automático e o controle da umidade por um desumidificador.

\subsubsection{Pórticos utilizados}

O equipamento utilizado é uma adaptação daquele desenvolvido pelo Instituto de Pesquisas Tecnológicas do Estado de São Paulo (IPT) para a campanha de ensaios de fluência em rochas evaporíticas da mineração Taquari - Vassouras (GIAMBASTIANI, 2005). Do equipamento original foram aproveitados o pórtico de aço tipo coluna, as bases metálicas e os macacos planos tóricos.

A Figura 3.24 mostra um pórtico de reação tipo coluna formados por 6 separadores de aço, de geometria triangular unidos por três barras rosqueadas de 1" localizadas nos vértices das placas. As extremidades do pórtico foram encostadas no piso e teto da sala de ensaios de forma a conferir maior estabilidade ao sistema. No pórtico foi colocado um corpo de prova para estudar a estabilidade do sistema e isolar o corpo de prova de possíveis deformações produzidas pela manipulação dos pórticos. 


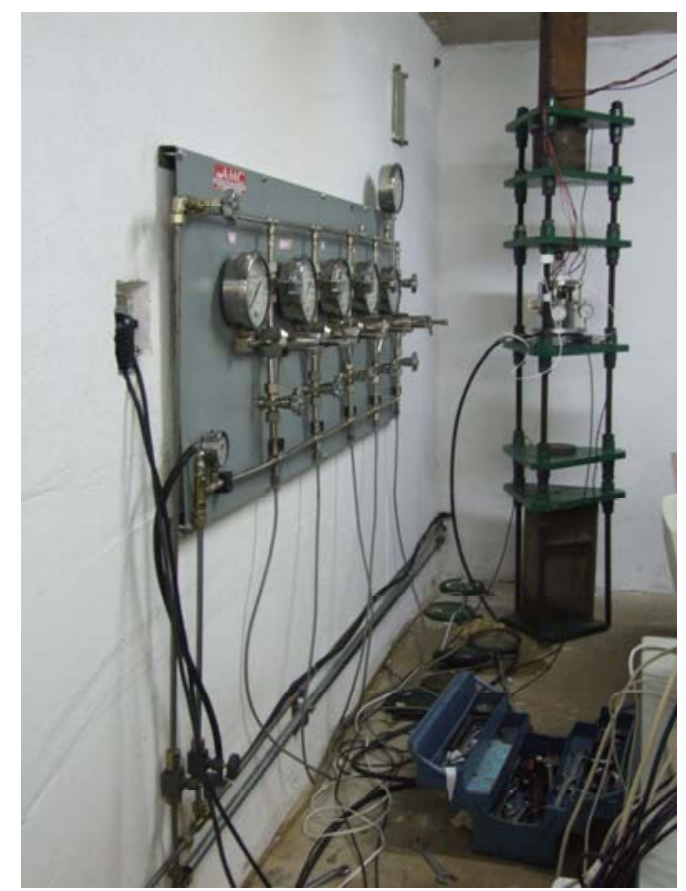

Figura 3.24 Pórtico de reação tipo coluna utilizado para ensaios de deformação lenta uniaxial

Cada conjunto modular (torre individual) consta de um macaco plano tórico, com bases metálicas de dureza 90 HRB que transmitem a carga aplicada para o corpo de prova. O dispositivo utiliza esferas metálicas para melhor transmissão da carga axial, possuindo ainda, suportes metálicos para posicionar os relógios comparadores (para medição dos deslocamentos axial e radial). Uma célula de carga, à base de extensômetros elétricos, mede a carga real aplicada no corpo de prova (Figura 3.25).

\subsubsection{Sistema de aplicação, controle e regulagem da carga}

O sistema de aplicação, controle e regulagem da carga foi modificado de um sistema pneumático para um sistema hidráulico com os objetivos de diminuir a possibilidade de vazamentos das válvulas e de aumentar a segurança com a manipulação da pressão aplicada aos macacos planos tóricos. 


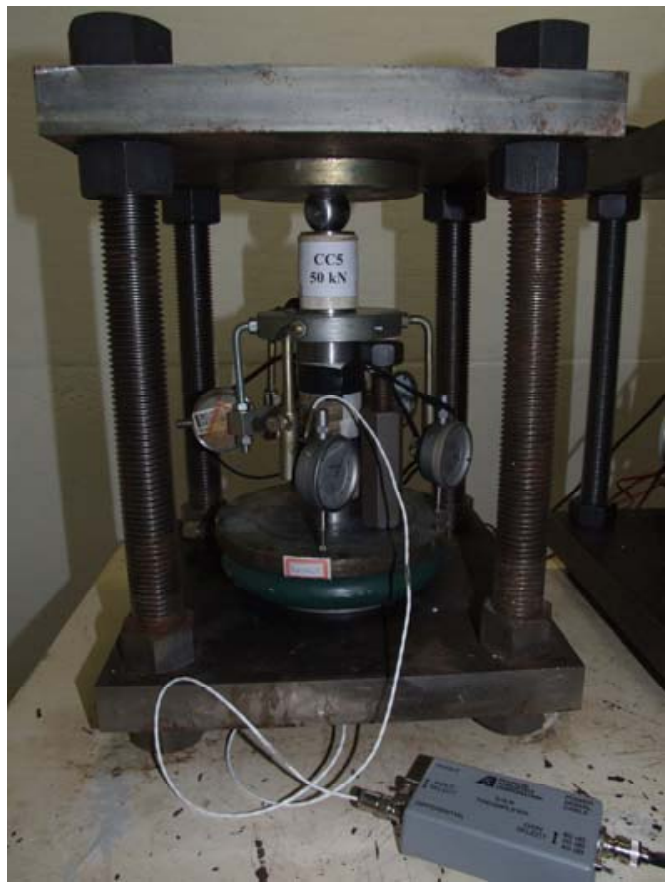

Figura 3.25 Conjunto modular (torre individual) utilizado para ensaios de deformação lenta uniaxial

O atual sistema consta de uma bomba hidráulica (Figura 3.26a), marca Hidrodinâmica, com as seguintes características técnicas: a) Bomba de engrenagem, b) Pressão Máxima de trabalho 250 bar. A bomba é ligada a dois painéis de controle constituídos por válvulas de registro, reguladores, manômetros e tubulações para altas pressões.

O óleo é conduzido para o macaco plano tórico através do dispositivo de regulagem feita no painel e por mangueiras de pressão especialmente acondicionadas para esta finalidade. A leitura de fundo de escala dos manômetros é de 96,6 bars e a sensibilidade do regulador permite realizar ajustes precisos da carga aplicada ao corpo de prova.

O sistema de carregamento consta de um painel de controle (Figura 3.26b) responsável pelo acionamento do motor da bomba hidráulica que está ligada a um retorno e a uma bomba de óleo. 

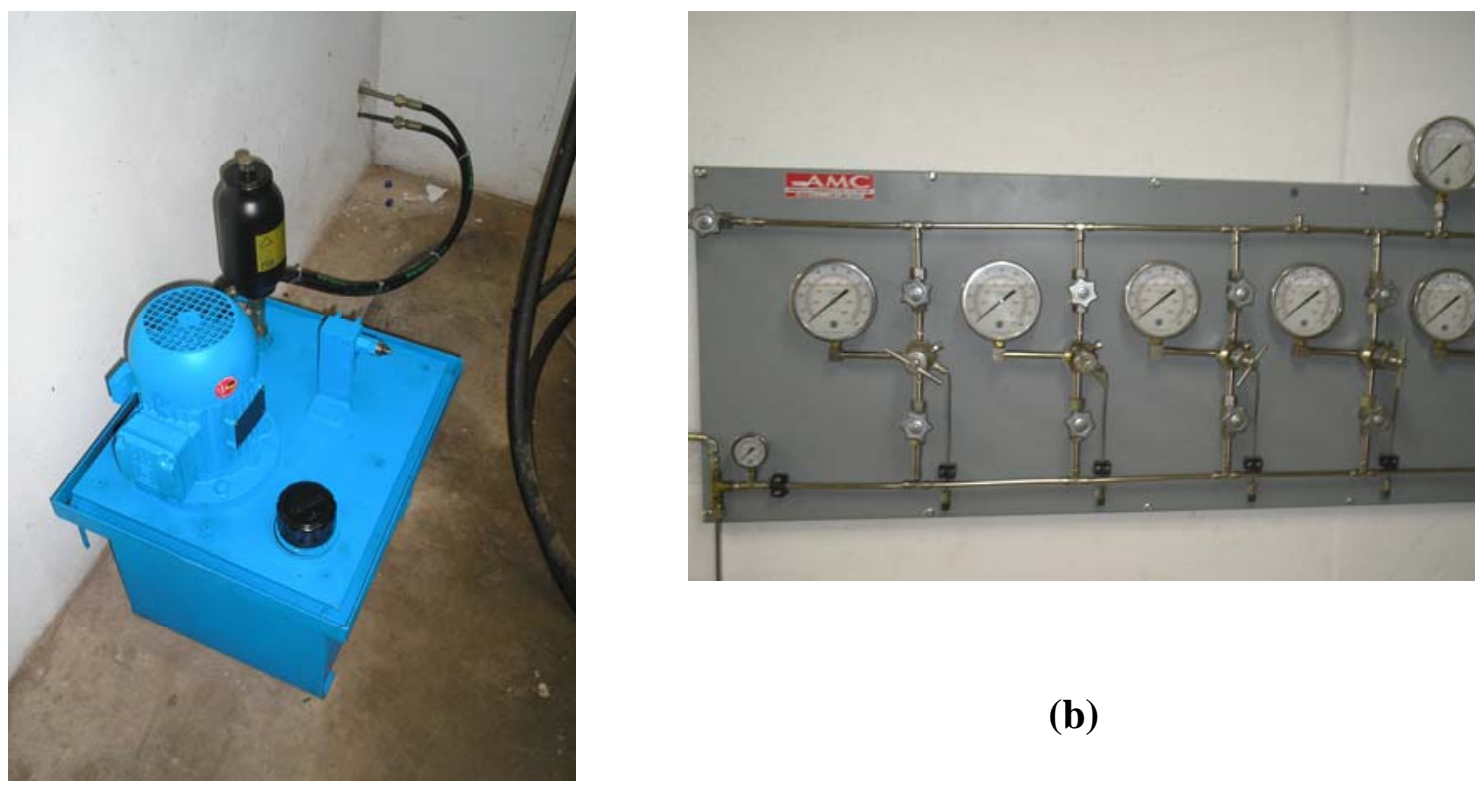

(b)

(a)

Figura 3.26 a) Bomba hidráulica ligada aos dois painéis de controle instalada fora do laboratório de fluência para evitar interferências nas medições com o equipamento de emissão acústica. b) Painel de controle mostrando os manômetros utilizados para sua construção

Para que a unidade hidráulica sempre envie pressão adequada ao sistema, existe um painel de controle com um pressostato (Figura 3.27), que tem como função básica evitar no sistema níveis de sobrepressão ou subpressão. Estes níveis de pressão são monitorados entre dois limites estabelecidos que desligam e ligam a unidade hidráulica.

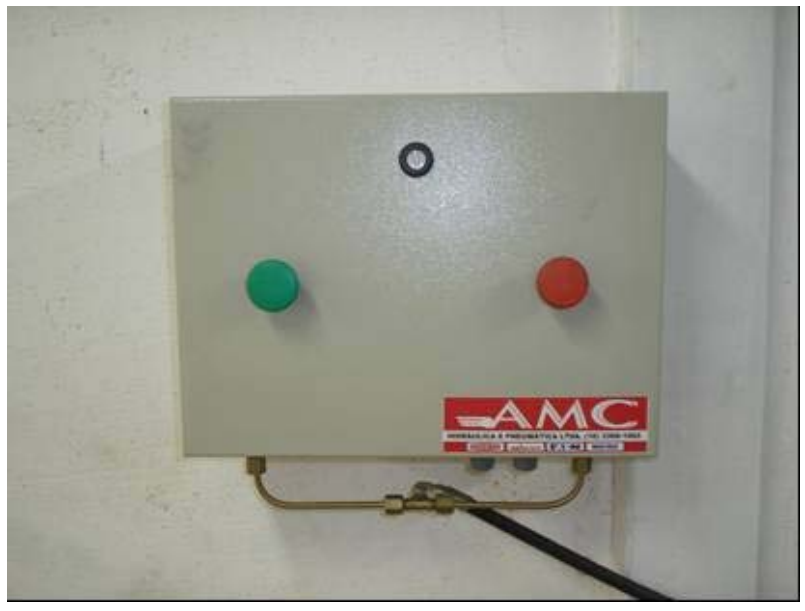

Figura 3.27 Painel de controle dentro da qual se encontra o pressostato 
Como o sistema do pressostato estava emitindo ruido aos sensores piezelétricos que registram os eventos de emissão acústica, ele foi desativado e o painel de controle está sendo acionado manualmente para evitar a interferência que o sistema proporcionava.

O controle da pressão aplicada nos macacos planos tóricos é realizado através de manômetros de precisão. Os painéis reguladores de carga (Figura 3.28) constam de cinco manômetros marca Salcas, caixa de aço inoxidável, diâmetro do mostrador de $152.4 \mathrm{~mm}$, rosca reta $1 / 2$ ” BSP, escala $100 \mathrm{kgf} / \mathrm{cm}^{2}$ e subdivisão $0.5 \mathrm{kgf} / \mathrm{cm}^{2}$, precisão \pm $0.5 \%$. Os manômetros foram aferidos tomando como padrão um manômetro da Wykeham Farrance com escala $0-140 \mathrm{kgf} / \mathrm{cm}^{2}$.

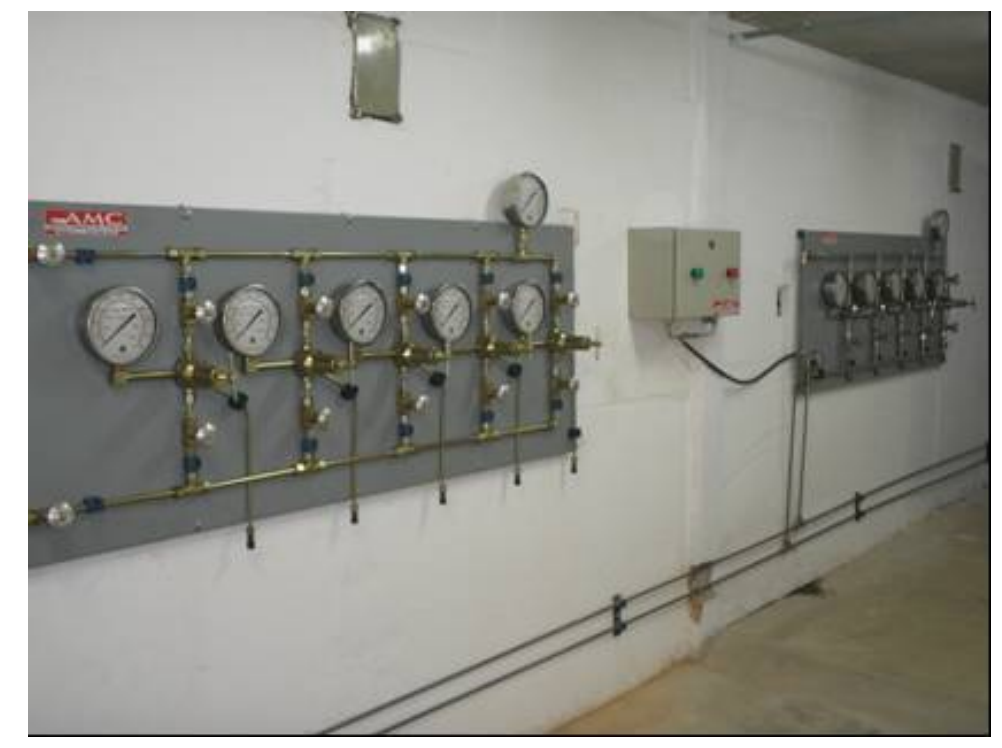

Figura 3.28 Painéis reguladores de carga

No painel de ensaios foram instalados acumuladores de pressão que suprem com mais rapidez o óleo necessário para corrigir variações bruscas de pressão, corrigindo rapidamente a pressão enviada ao macaco plano tórico (Figura 3.29). 


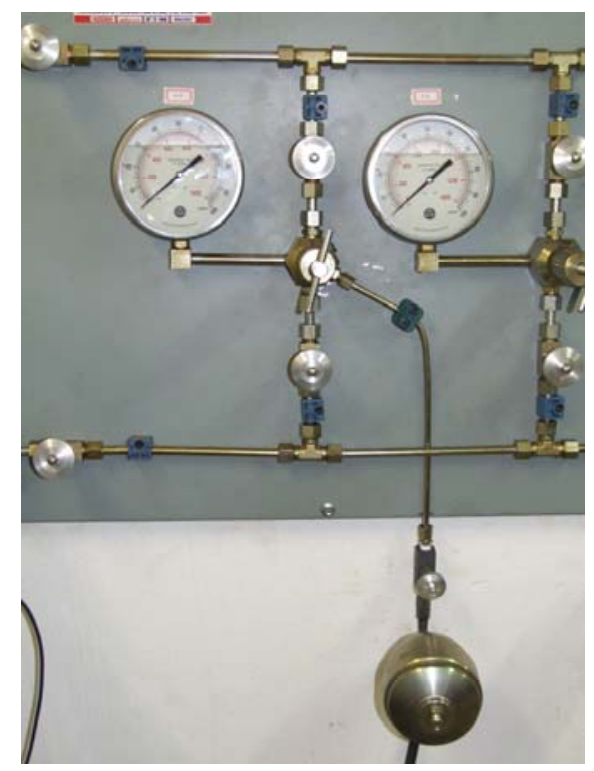

Figura 3.29 Detalhe do acumulador de pressão colocado para manter a pressão constante no macaco plano tórico

\subsection{Sistemas de aquisição e armazenamento dos dados}

Os corpos de prova foram instrumentados com extensômetros elétricos para medida de deformação e os dados gerados por essa instrumentação foram capturados e armazenados por um sistema automático de aquisição. Esse sistema também é composto por condicionadores de sinais e por um microcomputador com programa de armazenamento de dados.

Foi utilizado o Sistema 5000, Modelo 5100-Scanner da Vishay Measurements Groups que tem como princípio de funcionamento o conversor anológico/digital (A/D) de 16 bits e com tempo total da conversão de sinais de $40 \mu$ s por leitura.

A freqüência de leitura variou de 1 leitura por segundo até 5 leituras por segundo dependendo do tipo de ensaio realizado.

As conexões dos extensômetros elétricos são feitas nos cartões de aquisição na parte traseira do Sistema 5000. Os cartões de aquisição podem ser para leitura em extensômetro de montagem de ponte completa, meia ponte e um quarto de ponte, 
possuindo uma fonte de alimentação de tensão constante para a excitação das pontes de 0, 0,5, 1, 2, 5 e 10 VDC (Volts em Corrente Contínua). Ainda os cartões possuem 5 canais de leitura que podem receber sinais de corrente continua (DC) ou alternada (AC), além de sinais de extensômetros de alto nivel.

Para o registro das emissões acústicas foi acoplado em cada corpo de prova sensores de $175 \mathrm{kHz}$ de freqüência característica (modelo D9203B), conectados a um pré-amplificador com ganho regulável de 20,40 e $60 \mathrm{~dB}$ e com um cabo coaxial de transmissão sensor - pré-amplificador (modelo DSC4A).

Foi utilizada uma placa Modelo SAMOS PCI-8 com 8 canais, 16 bits, $400 \mathrm{kHz}$, com módulo de forma de onda para aquisição de dados de emissão acústica. Os dados são armazenados, analisados e processados mediante o software Aewin for SAMOS. Para a filtragem dos dados foi utilizado o pacote de software AEwin Post.

\subsubsection{Problemas de ruídos encontrados}

Nos ensaios com detecção da emissão acústica é de suma importância identificar ruídos extra-ensaios que podem ser captados pelo sistema.

\subsubsection{Crosstalk}

A diafonia (crosstalk) ocorre quando um sinal transmitido através de um cabo interfere ou até mesmo corrompe o sinal que está sendo transmitido através do cabo adjacente. Fisicamente falando, isto ocorre porque quando um dado está sendo transmitido através de um cabo, é gerado um campo eletromagnético ao seu redor. Se o outro cabo estiver posicionado dentro deste campo eletromagnético, funcionará como 
uma antena, capturando o sinal e, assim, modificando o sinal que estava sendo transmitido através dele.

Os fatores que contribuem para o aumento da diafonia são:
a) freqüência
b) características físicas dos cabos
c) processos de instalação e manutenção
d) aterramento ineficiente

Outros fatores que podem contribuir são:
a) força de tração na instalação (altera enrolamento)
b) raio de curvatura apertada
c) esmagamento dos cabos ou agressão mecânica
d) conectores

\subsubsection{Popcorn Noise}

O "popcorn noise" é um ruído randômico e transiente que eventualmente ocorre, normalmente devido a instabilidades dos próprios componentes eletrônicos utilizados nos sistemas de amplificação e filtragem. Por ocorrer de forma imprevisível, é de difícil discriminação e filtragem. O ruído recebe esse nome, pois assim como o "estouro" do milho de pipoca, é imprevisível.

\subsubsection{Solução dos problemas de ruídos encontrados}

Para solucionar os problemas de ruído encontrados no registro de eventos de emissão acústica, foram realizadas as seguintes ações: 
a) Isolamento dos cabos com fita crepe (Figura 3.30).

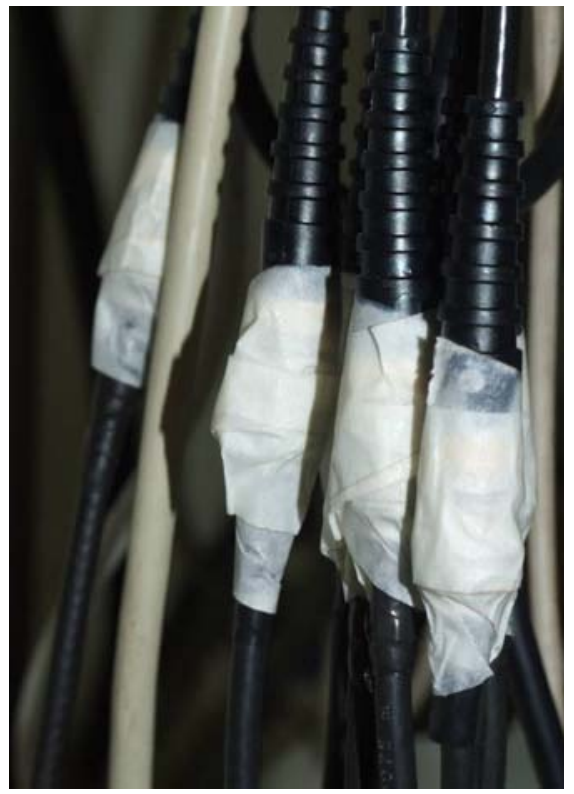

Figura 3.30 Detalhe dos cabos isolados com fita crepe

b) Colocação de sensores nas torres individuais para verificar a ocorrência de ruídos mecânicos e eletromagnéticos (Figura 3.31).

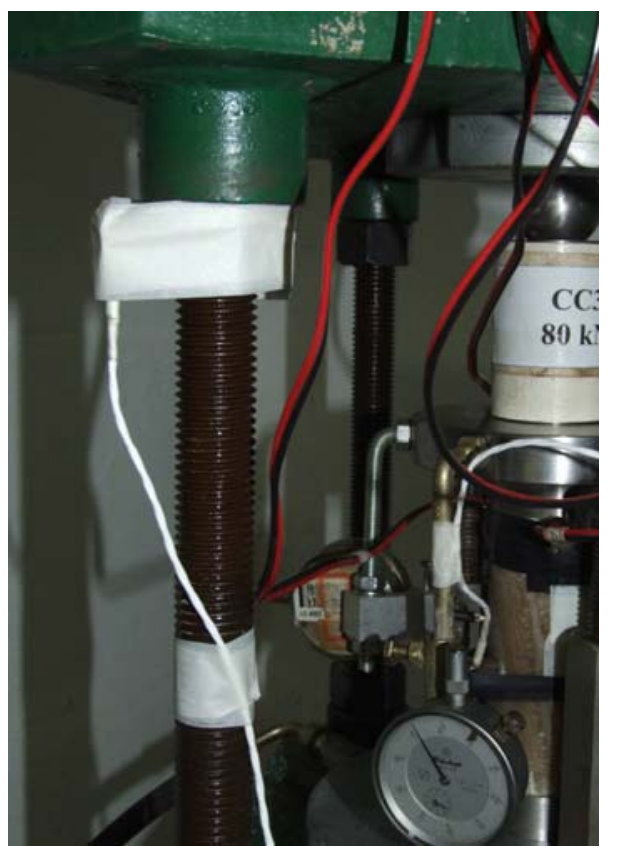

Figura 3.31 Detalhe dos sensores colocados fora dos corpos de prova 
c) Interconexão elétrica das torres para mantê-las no mesmo potencial (Figura $3.32)$.

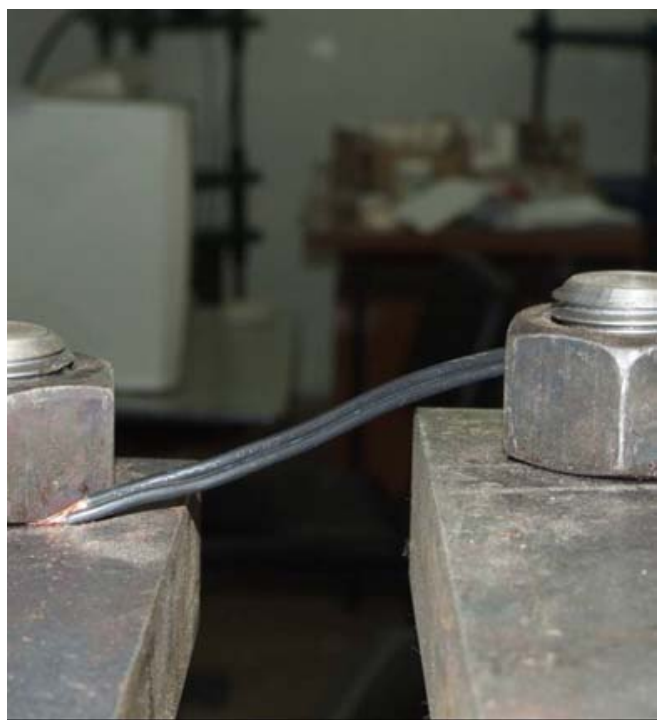

Figura 3.32 Detalhe dos fios de cobre utilizados para manter a mesma voltagem nas torres individuais

Com as medidas adotadas para eliminar tais ruídos, houve eliminação quase completa dos ruídos, no entanto ainda eram verificadas algumas interferências. Em continuidade às medidas, foi feito um aterramento específico para o sistema de ensaios.

\subsubsection{Aterramento do Sistema de Ensaios}

O aterramento é muito importante nos ensaios de fluência pelo fato de se operar com equipamentos eletrônicos sensíveis que estão interligados entre si. Qualquer diferença de potencial entre os vários dispositivos eletrônicos gera correntes elétricas que podem introduzir ruídos no sistema. $\mathrm{O}$ aterramento proporciona o mesmo potencial elétrico na carcaça de todos os dispositivos.

O aterramento feito foi construído a 10 metros de distância do laboratório. Foram cravadas no solo quatro hastes de cobre de 1,5 $\mathrm{m}$ de comprimento interligadas por um cabo de cobre nu. Este cabo de cobre, com cerca de 10 metros de comprimento, 
interliga as hastes ao laboratório. Para tanto foi feita uma vala com 10 metros de extensão e cerca de $20 \mathrm{~cm}$ de largura e $30 \mathrm{~cm}$ de profundidade (Figuras 3.33 e 3.34 ).

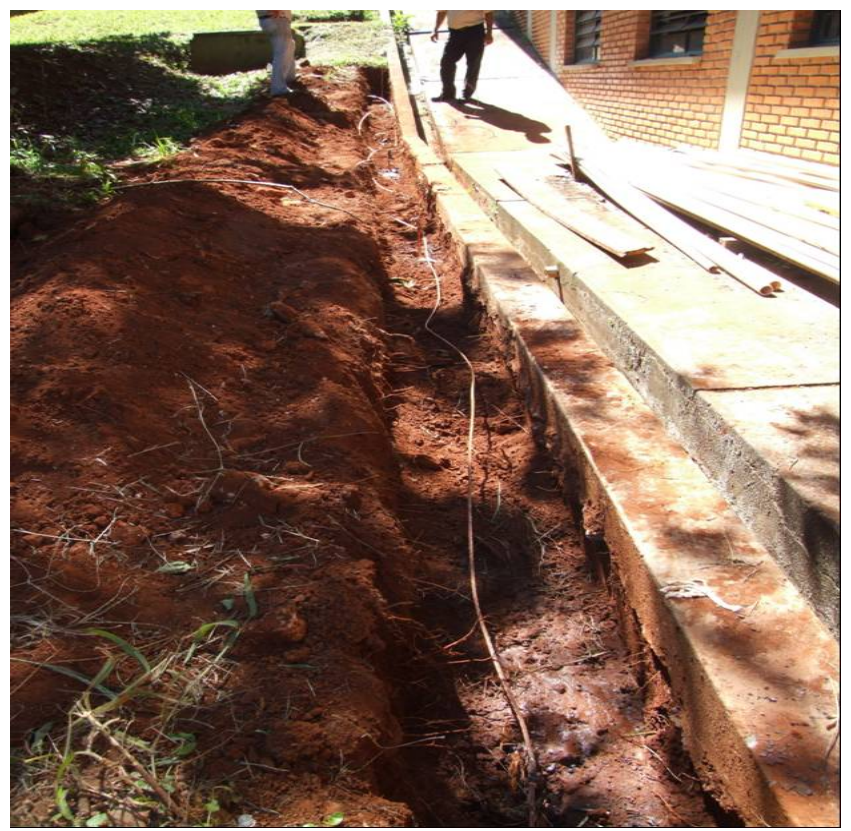

Figura 3.33 Vala escavada para implantação do fio e barras metálicas de cobre para aterramento

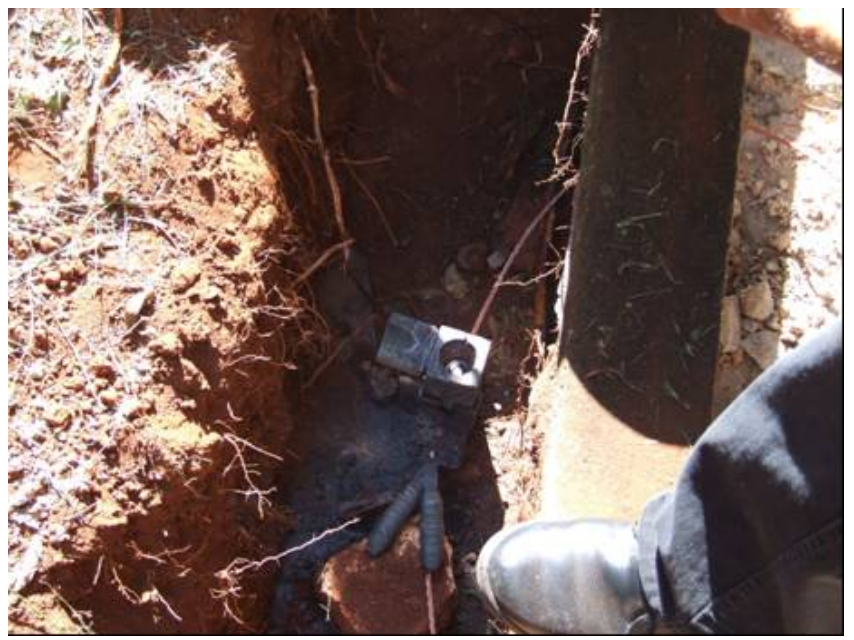

Figura 3.34 Interligação com cabo de cobre

As barras cravadas e o cabo de cobre foram soldados entre si, de forma que, mesmo enterrados, asseguram um perfeito contato entre o cabo e as barras (Figura $3.35)$ 


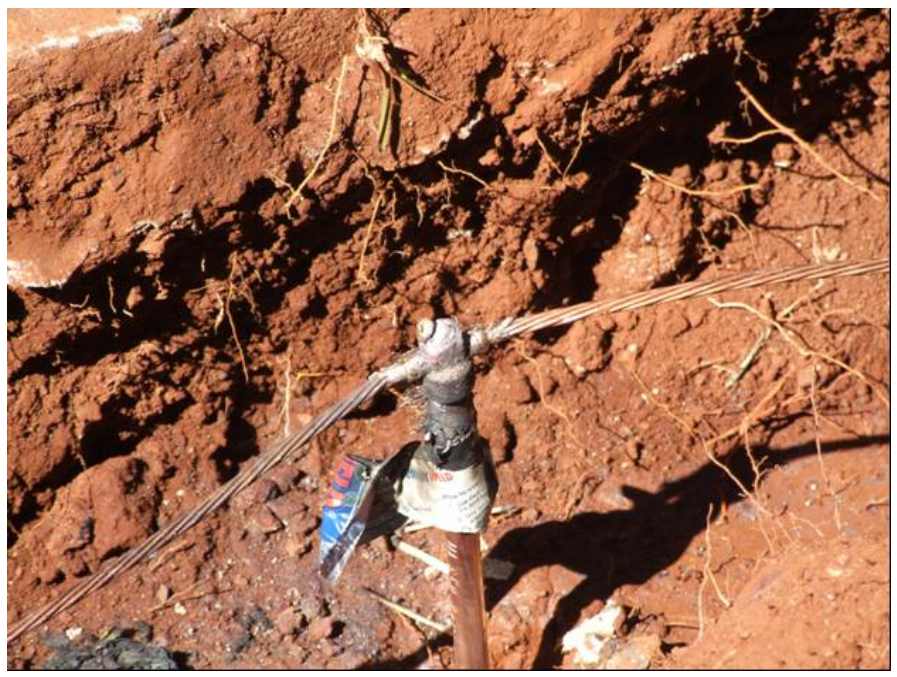

Figura 3.35 Detalhe da cabeça da haste de cobre interligada com o cabo de cobre

Feita a soldagem, o cabo foi levado até o laboratório de ensaios de fluência, e através de uma derivação foi ramificado para as torres individuais e para o pórtico de reação tipo coluna (Figura 3.36).

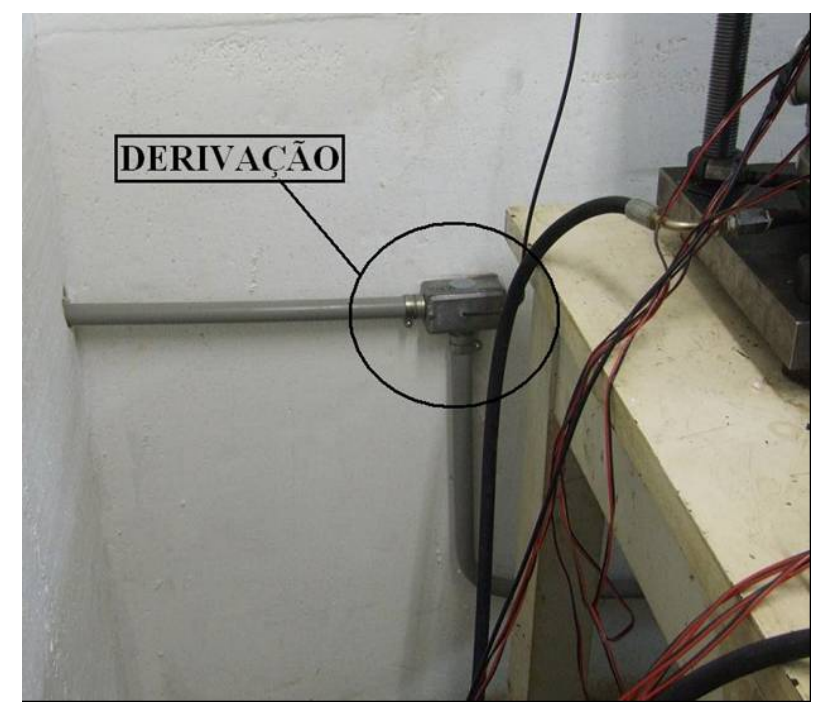

Figura 3.36 Derivação do fio terra

Da derivação saiu um conector que está diretamente ligado ao cabo do aterramento, sendo que esse conector é acoplado ao pórtico entre a mesa e a rosca que o prende (Figura 3.37). 


\subsubsection{Alteração na Unidade Mecânica Hidráulica}

Outra possível fonte de ruído estudada foi o acionamento do motor da unidade hidráulica que mantém a pressão do óleo constante no sistema de carga. Optou-se por instalar, paralelamente ao sistema elétrico da unidade, uma unidade manual de aplicação de pressão (uma bomba hidráulica manual). Desta forma, manteve-se a pressurização inicial feita através do sistema elétrico, mas durante o ensaio, todo o ajuste de pressão é feito manualmente, sem acionamento do motor elétrico (Figura 3.38).

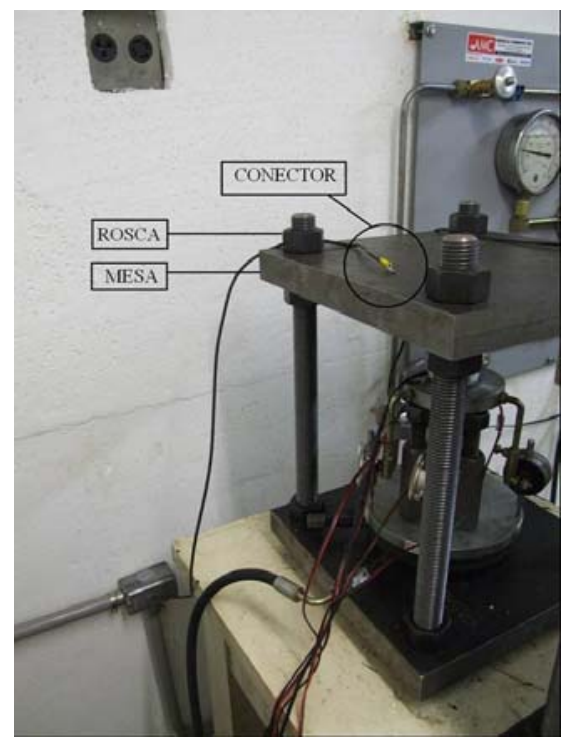

Figura 3.37 Detalhe do conector, da rosca e da mesa

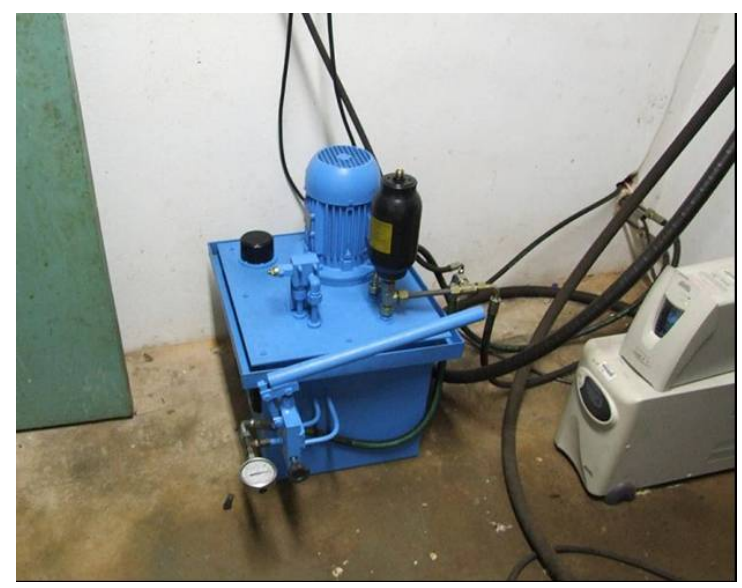

Figura 3.38 Unidade Hidráulica Elétrica e Manual 


\subsection{Ensaios realizados}

Descrevem-se neste item os ensaios realizados com as informações gerais sobre equipamento utilizado, tipo de controle de carregamento, orientação do carregamento com relação às camadas, instrumentação, etc. São apenas apresentados resultados típicos. Os resultados completos e sua análise serão apresentados no Capítulo 4.

Foram realizados os seguintes ensaios:

- Ensaios de compressão uniaxial com uso da técnica de emissão acústica (CSI e CSII)

- Ensaios de compressão uniaxial com ciclos variáveis de carregamento antes e após o pico de resistência (CVI, CVII e CVIII)

- Ensaios de fluência de curta duração (FCI, FCII e FCIII)

- Ensaios de fluência de longa duração (FLI, FLII e FLIII)

- Ensaios especiais de fluência de curta duração com ciclos de acréscimos de carregamento anteriores e posteriores ao descarregamento (GBEA14, GBEA24 e GBEA25)

- 3 ensaios no corpo de prova GBpec4da (dois ensaios em compressão uniaxial com ciclos variáveis de carregamento antes e após o pico de resistência e finalmente compressão uniaxial)

\subsubsection{Ensaios de compressão uniaxial com uso da técnica de emissão acústica}

Foram realizados 13 ensaios de compressão uniaxial com uso da técnica de emissão acústica com as características apresentadas na Tabela 3.4. Estes ensaios serão detalhados nos sub-itens seguintes. 
Tabela 3.4 Ensaios de compressão uniaxial com uso da técnica de emissão acústica

\begin{tabular}{|c|c|c|c|c|c|c|}
\hline $\begin{array}{c}\text { Ensaio } \\
\text { Tipo }\end{array}$ & $\begin{array}{l}\text { Número } \\
\text { de } \\
\text { ensaios }\end{array}$ & $\begin{array}{l}\text { Orientação } \\
\text { Camadas }\end{array}$ & Carregamento & Controle & Equipamento & $\begin{array}{l}\text { Emissão } \\
\text { Acústica }\end{array}$ \\
\hline CSI-A & 2 & Perpendicular & $\begin{array}{l}\text { Compressão } \\
\text { Simples }\end{array}$ & $\begin{array}{l}\text { Deslocamento } \\
0,03 \mathrm{~mm} / \mathrm{min}^{*}\end{array}$ & MTS & $\begin{array}{c}1 \\
\text { sensor }\end{array}$ \\
\hline CSI-B & 2 & Paralelo & $\begin{array}{l}\text { Compressão } \\
\text { Simples }\end{array}$ & $\begin{array}{l}\text { Deslocamento } \\
0,03 \mathrm{~mm} / \mathrm{min}^{*}\end{array}$ & MTS & $\begin{array}{c}1 \\
\text { sensor }\end{array}$ \\
\hline CSII-A & 5 & Perpendicular & $\begin{array}{l}\text { Compressão } \\
\text { Simples }\end{array}$ & $\begin{array}{c}\text { Força } \\
4,5 \mathrm{kN} / \mathrm{min}^{* *}\end{array}$ & MTS & $\begin{array}{c}4 \\
\text { sensores }\end{array}$ \\
\hline CSII-B & 4 & Paralelo & $\begin{array}{l}\text { Compressão } \\
\text { Simples }\end{array}$ & $\begin{array}{c}\text { Força } \\
4,5 \mathrm{kN} / \mathrm{min}^{* *}\end{array}$ & MTS & $\begin{array}{c}4 \\
\text { sensores }\end{array}$ \\
\hline
\end{tabular}

\subsubsection{Ensaios Tipo CSI}

Foram realizados quatro ensaios de compressão uniaxial até a ruptura, dois com carregamento perpendicular às camadas e dois com carregamento paralelo às camadas, cuja curva completa típica obtida se mostra na Figura 3.39.

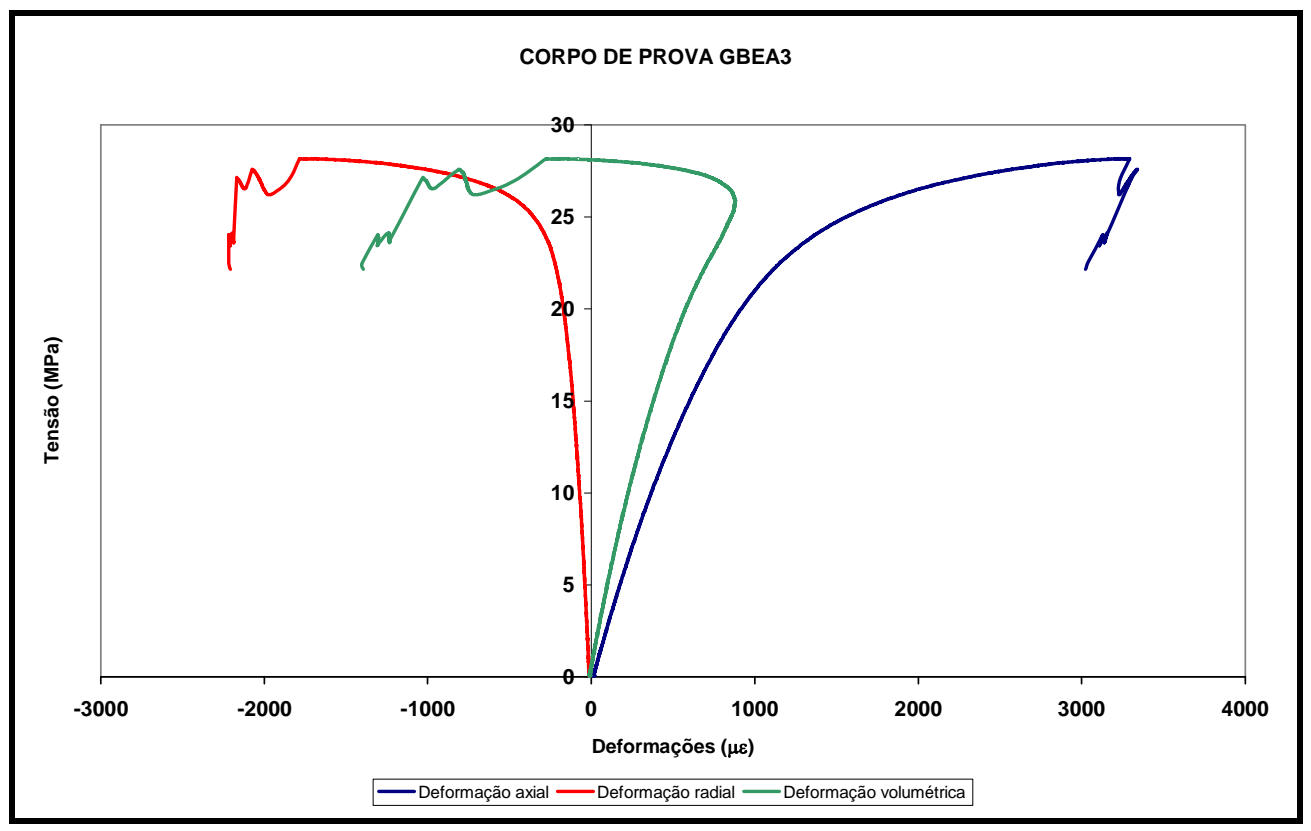

Figura 3.39 Curva completa tensão versus deformações axial, radial e volumétrica do corpo de prova GBEA3 do ensaio de compressão uniaxial com uso da técnica de emissão acústica 
Retirados do dessecador, cada corpo de prova foi instrumentado com um sensor piezoelétrico de $175 \mathrm{kHz}$ de freqüência característica (modelo D9203B) para registrar os eventos de emissão acústica, concomitantemente com deformações (Figura 3.40).

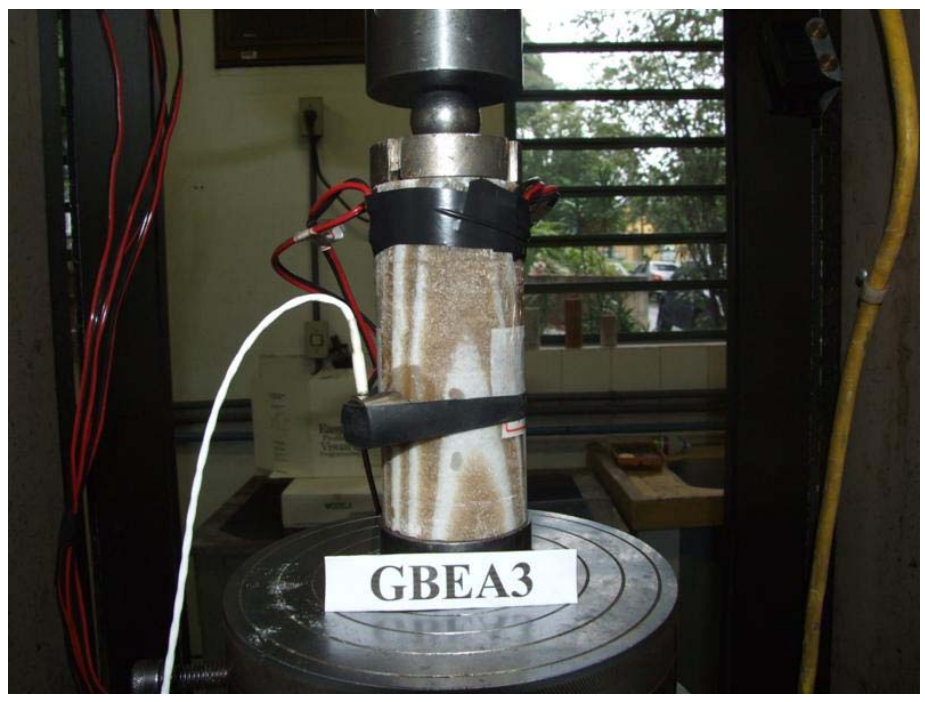

Figura 3.40 Detalhe da instrumentação do corpo de prova GBEA3. Note-se o sensor piezoelétrico e um dos extensômetros elétricos em roseta dupla colado no corpo de prova

O sistema de monitoração consiste em um filtro passa banda de $125 \mathrm{kHz}$ a 1 MHz e um pré-amplificador com ganho total de 40 ou $60 \mathrm{~dB}$. Os dados de emissão acústica foram gravados simultâneamente com dados de deformação, com um sistema de monitoração de eventos de emissão acústica, usando um limiar de $50 \mathrm{~dB}$ que foi definido em testes preliminares.

Após a detecção, os sinais foram amplificados com um ganho de $40 \mathrm{~dB}$. O sistema de aquisição de dados de emissão acústica é o SAMOS PCI-8. Cada sinal de emissão acústica foi descrito em termos de suas amplitude, contagens, energia, tempo de ascensão e duração.

A análise dos dados de laboratório foi focalizada na possível identificação dos níveis de tensão no inicio do registro de eventos de emissão acústica (fae) e na ocorrência e crescimento das fissuras intergranulares (ie) realizada com base em 
correlações entre os dados dos extensômetros elétricos de resistência (medição das deformações) e a resposta da emissão acústica, relacionando a energia total acumulada dos eventos de emissão acústica como função da tensão aplicada.

\subsubsection{Ensaios Tipo CSII}

Foram realizados nove ensaios de compressão uniaxial até a ruptura, cinco com carregamento perpendicular às camadas e quatro com carregamento paralelo às camadas, cujo resultado típico obtido se mostra na Figura 3.41.

Para execução dos ensaios, foi utilizada a prensa hidráulica servocontrolada MTS com controle de força a uma taxa de carregamento constante de 4,5 kN/min.

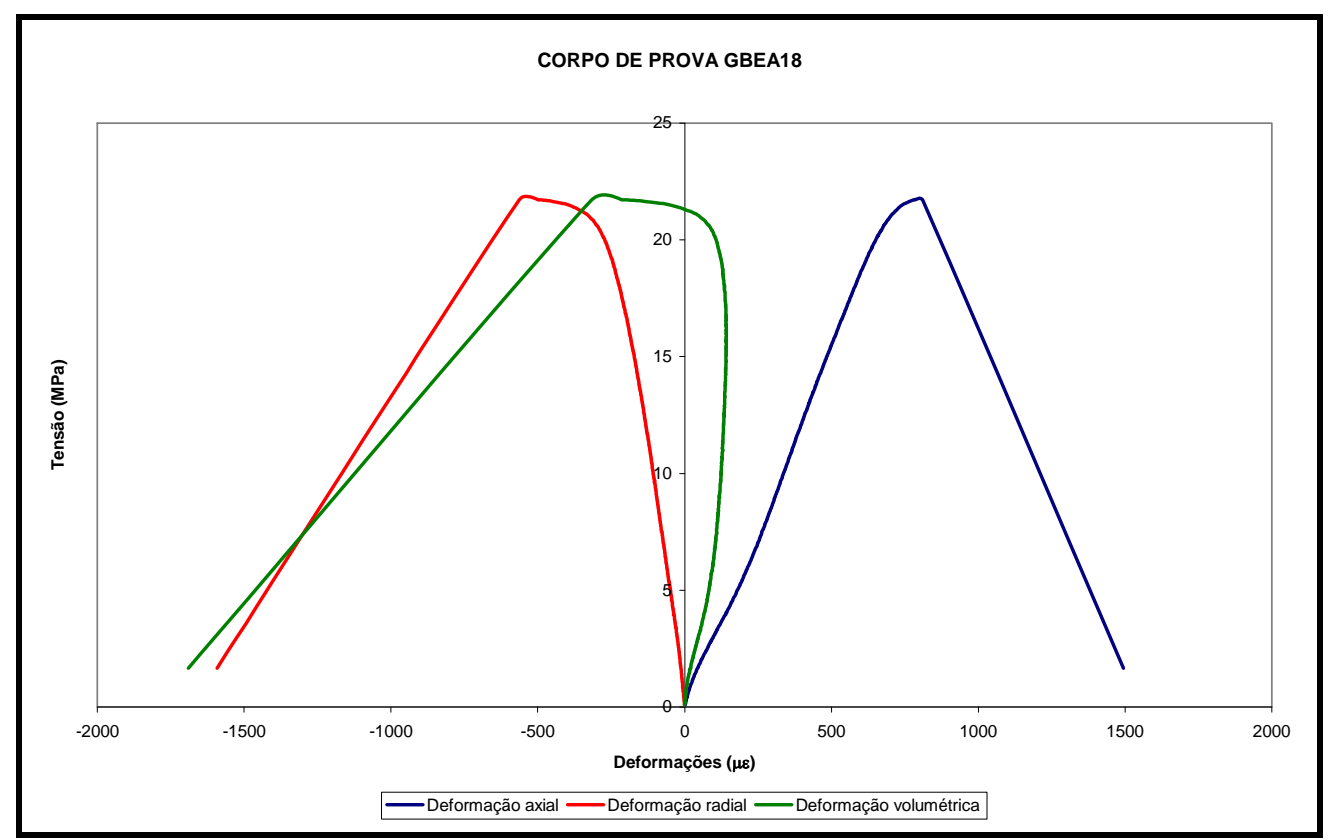

Figura 3.41 Curva tensão versus deformações axial, radial e volumétrica do corpo de prova GBEA18 do ensaio de compressão uniaxial com uso da técnica de emissão acústica

Retirados do dessecador, cada corpo de prova foi instrumentado com quatro sensores piezoelétricos de $175 \mathrm{kHz}$ de freqüência característica (modelo D9203B) para registrar os eventos de emissão acústica, concomitantemente com deformações (Figura $3.42)$. 


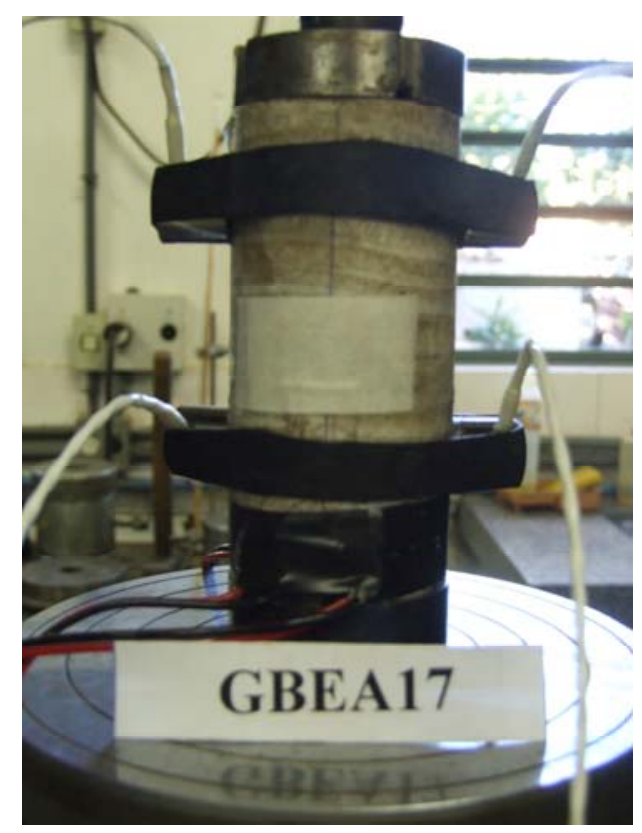

Figura 3.42 Detalhe da instrumentação do corpo de prova GBEA17. Notem-se os quatro sensores piezoelétricos e um dos extensômetros elétricos em roseta dupla colado no corpo de prova

Apesar de se utilizarem sensores idênticos, foram selecionadas duas faixas estreitas de freqüência diferentes por meio de filtros analógicos disponíveis no sistema de aquisição de dados:

a) Freqüências baixas (de 20 a 100 kHz) e

b) Freqüências intermediárias (de 100 a 400 kHz).

Salienta-se que foi escolhido esse limite superior $(400 \mathrm{kHz})$ por motivos operacionais devido ao fato de que o intervalo de freqüência de aquisição de dados da placa SAMOS PCI-8 é de $1 \mathrm{kHz}$ a $400 \mathrm{kHz}$.

Para discutir os processos do microfissuramento que conduzem à ruptura, foram analisadas a taxa de eventos de emissão acústica e as características de freqüência das emissões acústicas. 


\subsubsection{Ensaios de compressão uniaxial com ciclos variáveis de carregamento antes e após o pico de resistência}

Foram realizados 8 ensaios de compressão uniaxial com ciclos variáveis de carregamento antes e após o pico de resistência com as características apresentadas na Tabela 3.5. Estes ensaios serão detalhados nos sub-itens seguintes.

Tabela 3.5 Ensaios de compressão uniaxial com ciclos variáveis de carregamento antes e após o pico de resistência

\begin{tabular}{|c|c|c|c|c|c|c|}
\hline $\begin{array}{c}\text { Ensaio } \\
\text { Tipo }\end{array}$ & $\begin{array}{l}\text { Número } \\
\text { de ensaios }\end{array}$ & $\begin{array}{l}\text { Orientação } \\
\text { Camadas }\end{array}$ & Carregamento & Controle & Equipamento & $\begin{array}{l}\text { Emissão } \\
\text { Acústica }\end{array}$ \\
\hline CVI-A & 2 & Perpendicular & $\begin{array}{l}\text { Compressão } \\
\text { Simples }\end{array}$ & $\begin{array}{l}\text { Carreg } 5 \mathrm{kN} / \mathrm{min} \\
\text { Desc } 15 \mathrm{kN} / \mathrm{min}\end{array}$ & MTS & $\begin{array}{c}6 \\
\text { sensores }\end{array}$ \\
\hline CVI-B & 2 & Paralelo & $\begin{array}{l}\text { Compressão } \\
\text { Simples }\end{array}$ & $\begin{array}{l}\text { Carreg } 5 \mathrm{kN} / \mathrm{min} \\
\text { Desc } 15 \mathrm{kN} / \mathrm{min}\end{array}$ & MTS & $\begin{array}{c}6 \\
\text { sensores }\end{array}$ \\
\hline CVII-A & 2 & Perpendicular & $\begin{array}{l}\text { Compressão } \\
\text { Simples }\end{array}$ & $\begin{array}{l}\text { Carreg e descarreg } \\
0,03 \mathrm{~mm} / \mathrm{min}\end{array}$ & MTS & $\begin{array}{c}2 \\
\text { sensor }\end{array}$ \\
\hline CVII-B & 1 & Paralelo & $\begin{array}{l}\text { Compressão } \\
\text { Simples }\end{array}$ & $\begin{array}{l}\text { Carreg e descarreg } \\
0,03 \mathrm{~mm} / \mathrm{min}\end{array}$ & MTS & $\begin{array}{c}2 \\
\text { sensor }\end{array}$ \\
\hline CVIII & 2 & Perpendicular & $\begin{array}{l}\text { Compressão } \\
\text { Simples }\end{array}$ & $\begin{array}{c}\text { Carreg e descarreg } \\
0,03 \mathrm{~mm} / \mathrm{min}\end{array}$ & MTS & $\begin{array}{c}4 \\
\text { sensores }\end{array}$ \\
\hline
\end{tabular}

\subsubsection{Ensaios Tipo CVI}

Para execução dos ensaios, foi utilizada a prensa hidráulica servocontrolada MTS com controle de força a uma taxa de carregamento constante de $5 \mathrm{kN} / \mathrm{min}$ e descarregamento de $15 \mathrm{kN} / \mathrm{min}$. Os objetivos iniciais deste tipo de ensaio foram de verificar se as microfissuras se propagam no descarregamento, mediante análise da resposta da emissão acústica nesta fase.

Foram realizados quatro ensaios deste tipo, dois com carregamento na direção perpendicular às camadas e dois com carregamento na direção paralela às camadas, cujos resultados típicos se mostram na Figura 3.43. 


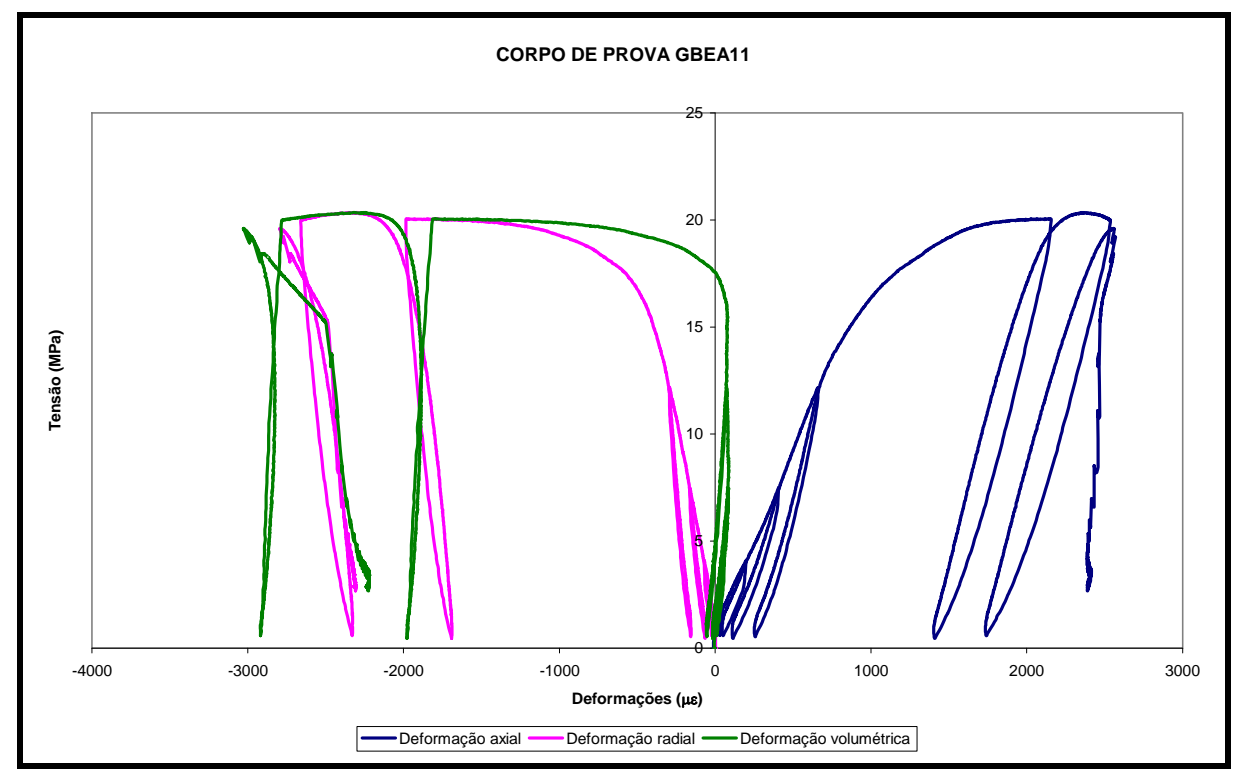

Figura 3.43 Curva tensão versus deformações axial, radial e volumétrica do corpo de prova GBEA11 do ensaio de compressão uniaxial com ciclos variáveis de carregamento antes e após o pico de resistência

Para esta finalidade, o corpo de prova foi instrumentado com dois extensômetros elétricos em roseta dupla colados na sua parte central e com seis sensores piezoelétricos de $175 \mathrm{kHz}$ de freqüência característica, como mostrado na Figura 3.44.

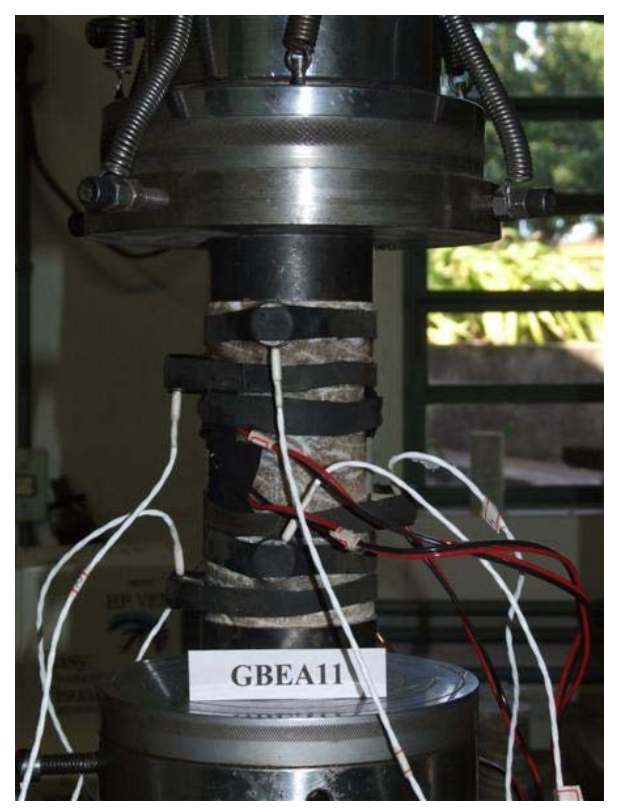

Figura 3.44 Detalhe da instrumentação do corpo de prova GBEA11. Notem-se os seis sensores piezoelétricos fixados por bandas elásticas e um dos extensômetros elétricos em roseta dupla colado no corpo de prova 
A análise dos dados de laboratório foi focalizada no estudo do comportamento face às solicitacões de carregamento e descarregamento a diferentes níveis de tensão no trecho inicial, no trecho elástico, no trecho antes do pico de resistência e no trecho depois do pico de resistência, na verificação da propagação das fissuras e da ocorrência do efeito Kaiser neste tipo de rochas.

\subsubsection{Ensaios Tipo CVII}

Para execução dos ensaios, foi utilizada a prensa hidráulica servocontrolada MTS com controle de deslocamento do prato com uma taxa constante de $0,03 \mathrm{~mm} / \mathrm{min}$ tanto no carregamento quanto no descarregamento.

Foram realizados três ensaios deste tipo, dois com carregamento na direção perpendicular às camadas e um com carregamento na direção paralela às camadas, cujos resultados típicos se mostram na Figura 3.45.

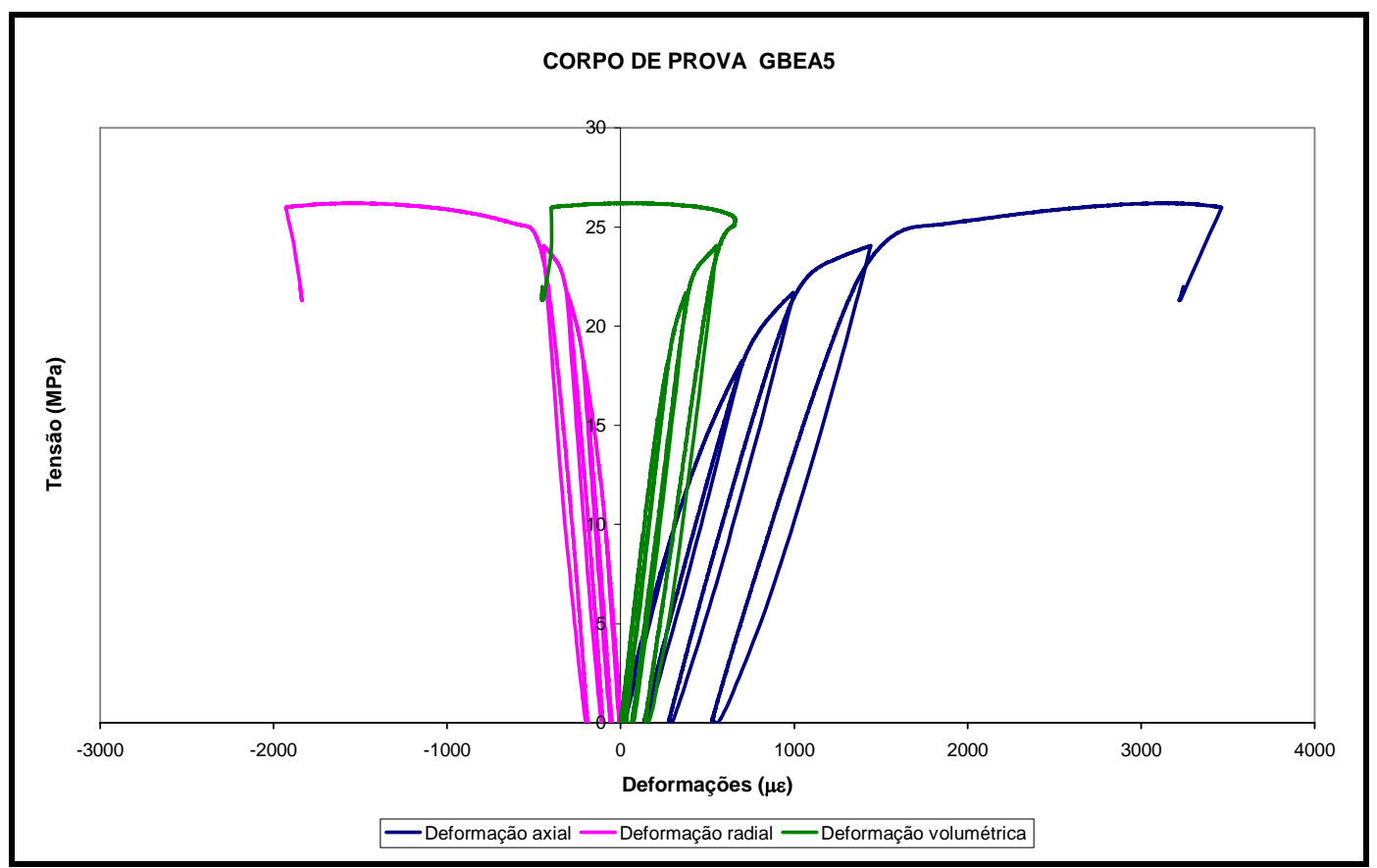

Figura 3.45 Curva tensão versus deformações axial, radial e volumétrica do corpo de prova GBEA5 do ensaio de compressão uniaxial com ciclos variáveis de carregamento antes e após o pico de resistência 
Cada corpo de prova foi instrumentado com dois extensômetros elétricos em roseta dupla colados na sua parte central e com dois sensores piezoelétricos de $175 \mathrm{kHz}$ de freqüência característica, como mostrado na Figura 3.46.

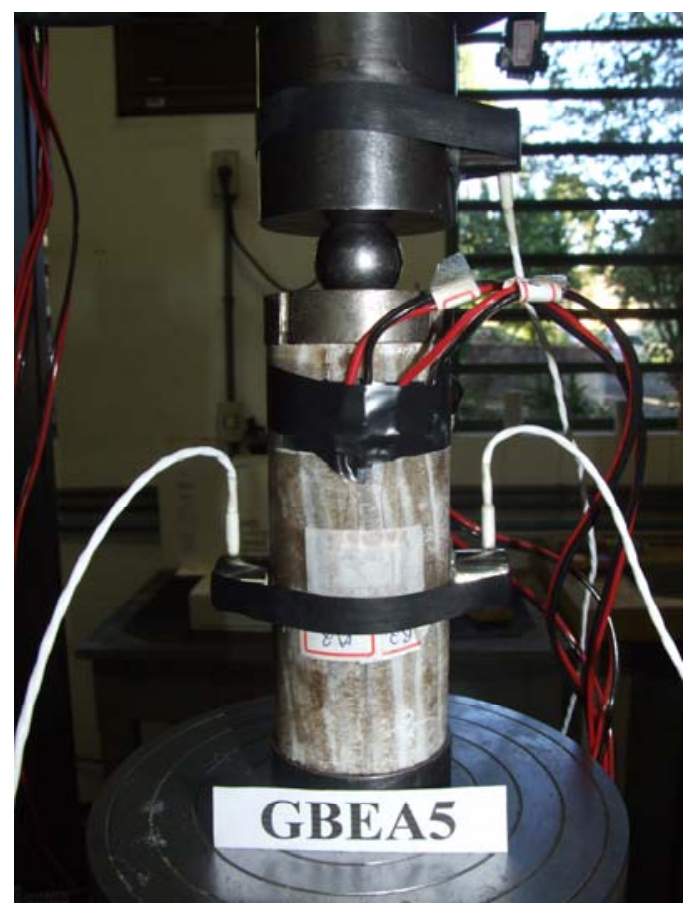

Figura 3.46 Detalhe da instrumentação do corpo de prova GBEA5. Notem-se os dois sensores piezoelétricos fixados por bandas elásticas e um dos extensômetros elétricos em roseta dupla colado no corpo de prova

\subsubsection{Ensaios Tipo CVIII}

Para execução dos ensaios, foi utilizada a prensa hidráulica servocontrolada MTS com controle de deslocamento do prato com uma taxa constante de $0,03 \mathrm{~mm} / \mathrm{min}$ tanto no carregamento quanto no descarregamento.

Foram realizados dois ensaios deste tipo com carregamento na direção perpendicular às camadas, cuja curva típica obtida se mostra na Figura 3.47. 


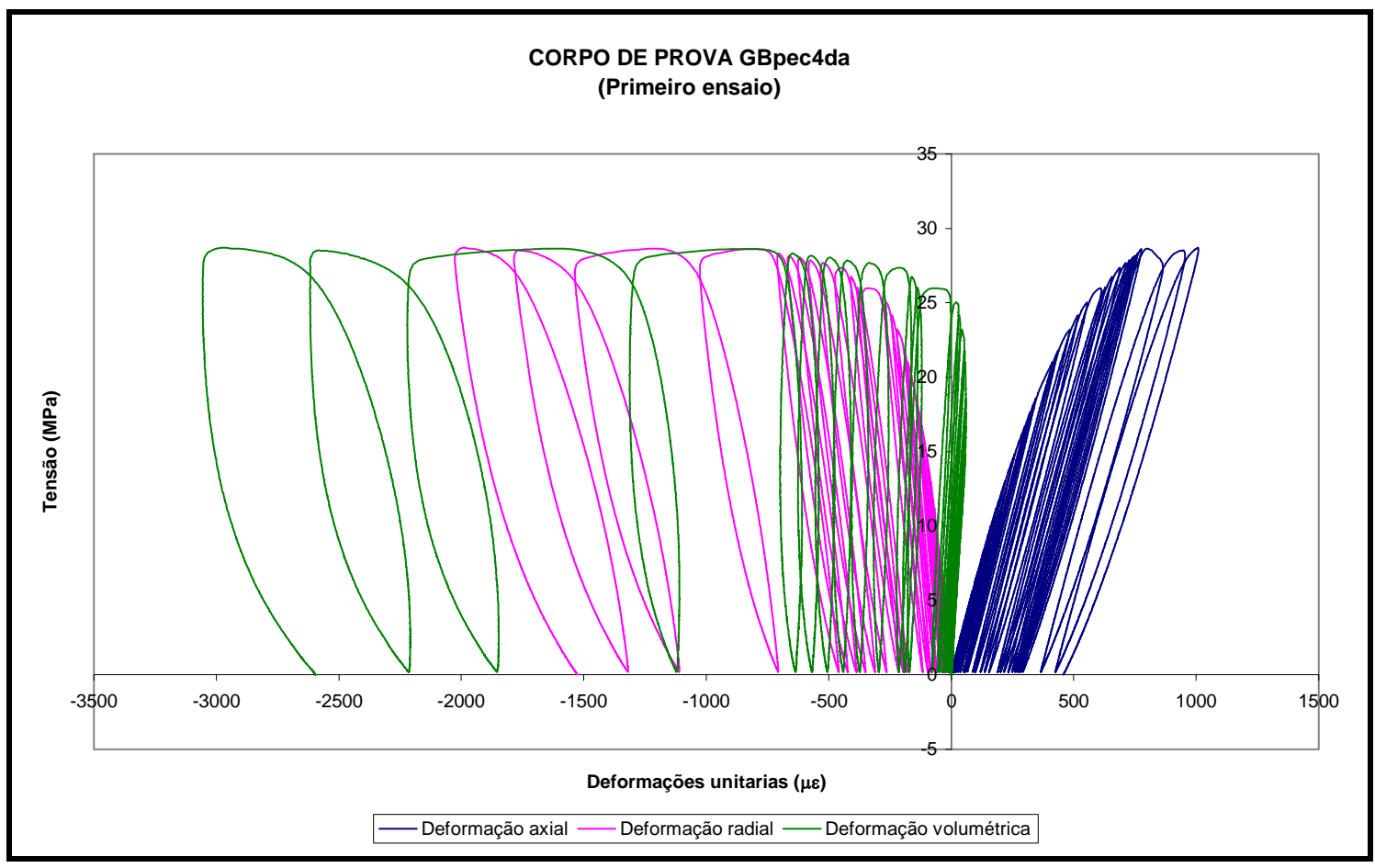

Figura 3.47 Curva tensão versus deformações axial, radial e volumétrica do corpo de prova GBpec4da do ensaio de compressão uniaxial com ciclos variáveis de carregamento antes e após o pico de resistência

Similarmente aos Ensaios Tipo CSII de compressão uniaxial, apesar de se utilizarem sensores idênticos, foram selecionadas duas faixas estreitas de freqüência diferentes por meio de filtros analógicos disponíveis no sistema de aquisição de dados:

a) Freqüências baixas (de 20 a $100 \mathrm{kHz}$ ) e

b) Freqüências intermediárias (de 100 a 400 kHz).

Cada corpo de prova foi instrumentado com dois extensômetros elétricos em roseta dupla colados na sua parte central e com dois sensores piezoelétricos de $175 \mathrm{kHz}$ de freqüência característica, como mostrado na Figura 3.48. 


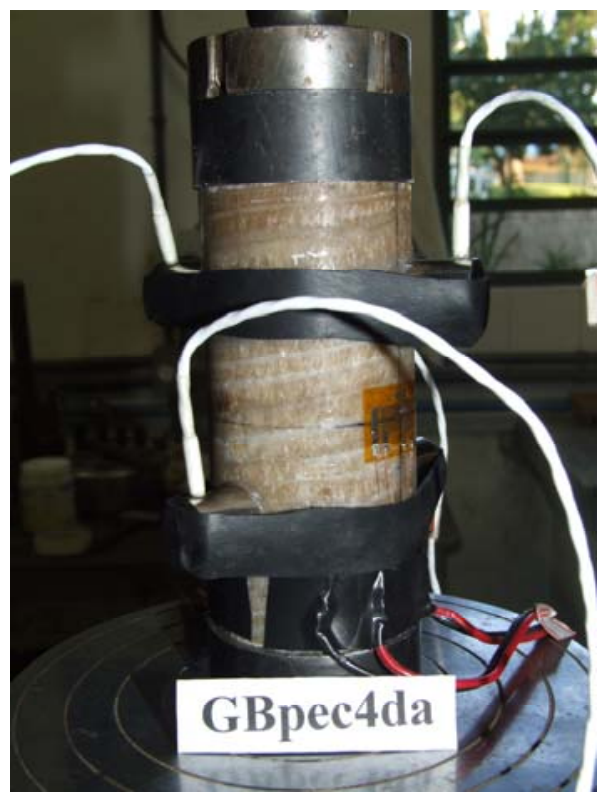

Figura 3.48 Detalhe da instrumentação do corpo de prova GBpec4da. Notem-se os quatro sensores piezoelétricos fixados por bandas elásticas e um dos extensômetros elétricos em roseta dupla colado no corpo de prova

Os objetivos iniciais deste tipo de ensaio foram: obter a curva completa do ensaio antes e após o pico de resistência e verificar se as microfissuras se propagam no descarregamento mediante a análise da resposta da emissão acústica nesta fase.

\subsubsection{Ensaios de fluência de curta duração}

Foram realizados 12 ensaios de fluência de curta duração na prensa hidráulica servocontrolada com as características apresentadas na Tabela 3.6. Detalhes de cada tipo de ensaio são apresentados nos sub-itens seguintes.

Tabela 3.6 Ensaios de fluência de curta duração realizados na prensa hidráulica servocontrolada

\begin{tabular}{cccccc}
\hline $\begin{array}{c}\text { Ensaio } \\
\text { Tipo }\end{array}$ & $\begin{array}{c}\text { Número } \\
\text { de ensaios }\end{array}$ & $\begin{array}{c}\text { Orientação } \\
\text { Camadas }\end{array}$ & $\begin{array}{c}\text { Velocidade do } \\
\text { carregamento }\end{array}$ & Equipamento & $\begin{array}{c}\text { Emissão } \\
\text { Acústica }\end{array}$ \\
\hline FCI-A & 1 & Perpendicular & $4,5 \mathrm{kN} / \mathrm{min}$ & MTS & 1 sensor \\
FCI-B & 1 & Paralelo & $7,0 \mathrm{kN} / \mathrm{min}$ & MTS & 1 sensor \\
FCII & 3 & Perpendicular & $4,5 \mathrm{kN} / \mathrm{min}$ & MTS & sem EA \\
FCIII-A & 3 & Perpendicular & $4,5 \mathrm{kN} / \mathrm{min}$ & MTS & 4 sensores \\
FCIII-B & 4 & Paralelo & $4,5 \mathrm{kN} / \mathrm{min}$ & MTS & 4 sensores \\
\hline
\end{tabular}




\subsubsection{Ensaios Tipo FCI}

Inicialmente foram realizados dois ensaios de fluência de curta duração com a finalidade de verificar os níveis de tensões a serem aplicados nos ensaios de fluência de longa duração a serem realizados no laboratório de fluência especialmente condicionado, assim como verificar o comportamento do sistema de aquisição de eventos de emissão acústica em ensaios de maior duração.

Como exemplo típico, apresenta-se na Figura 3.49 o resultado de um ensaio sob dois níveis de tensão $(9,29$ e 18,66 $\mathrm{MPa}$, correspondentes a 34 e $68 \%$ da resistência pico, respectivamente) no corpo de prova GBEA6 com duração respectivamente de 5 dias e depois de 6 dias. 


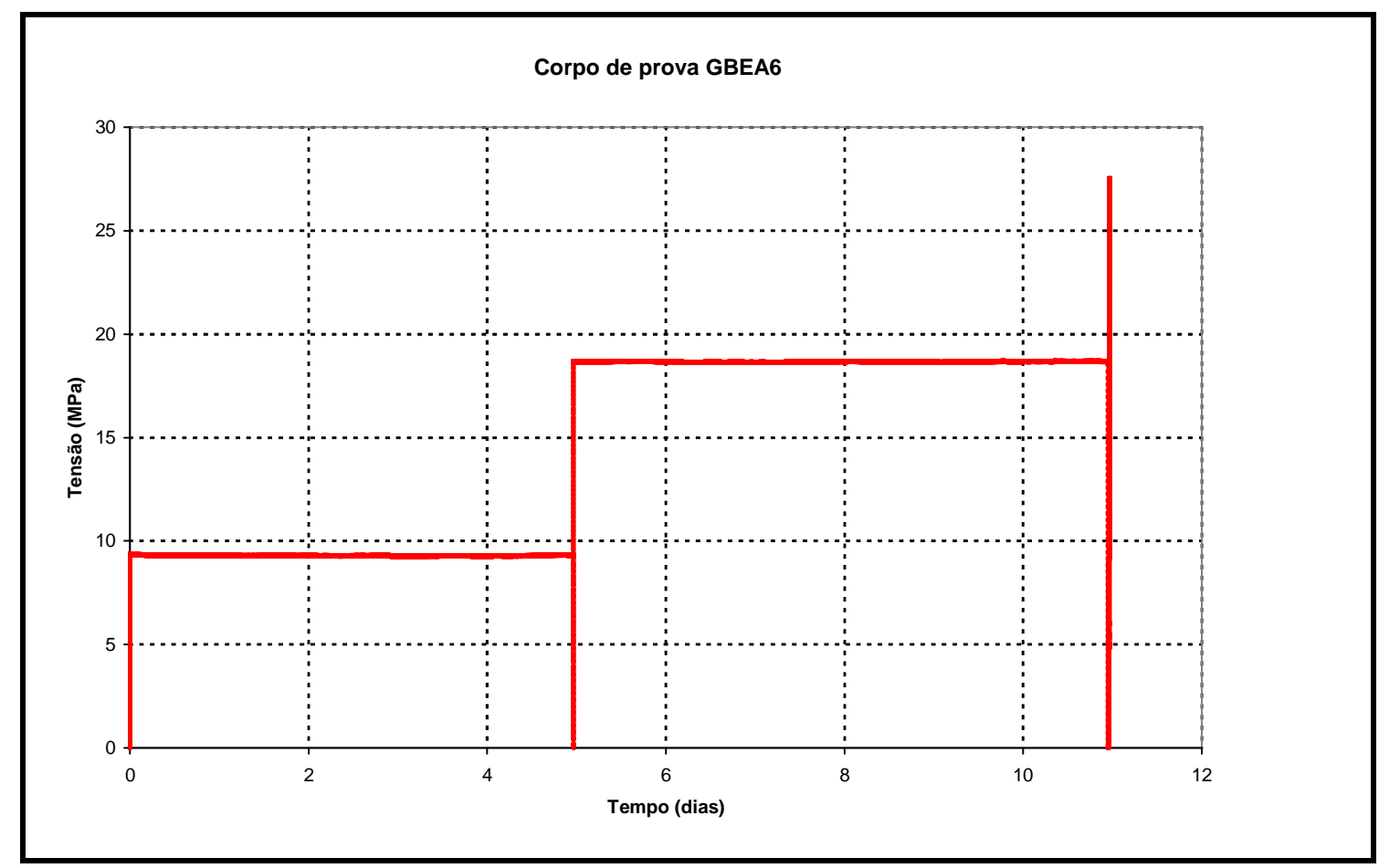

(a)

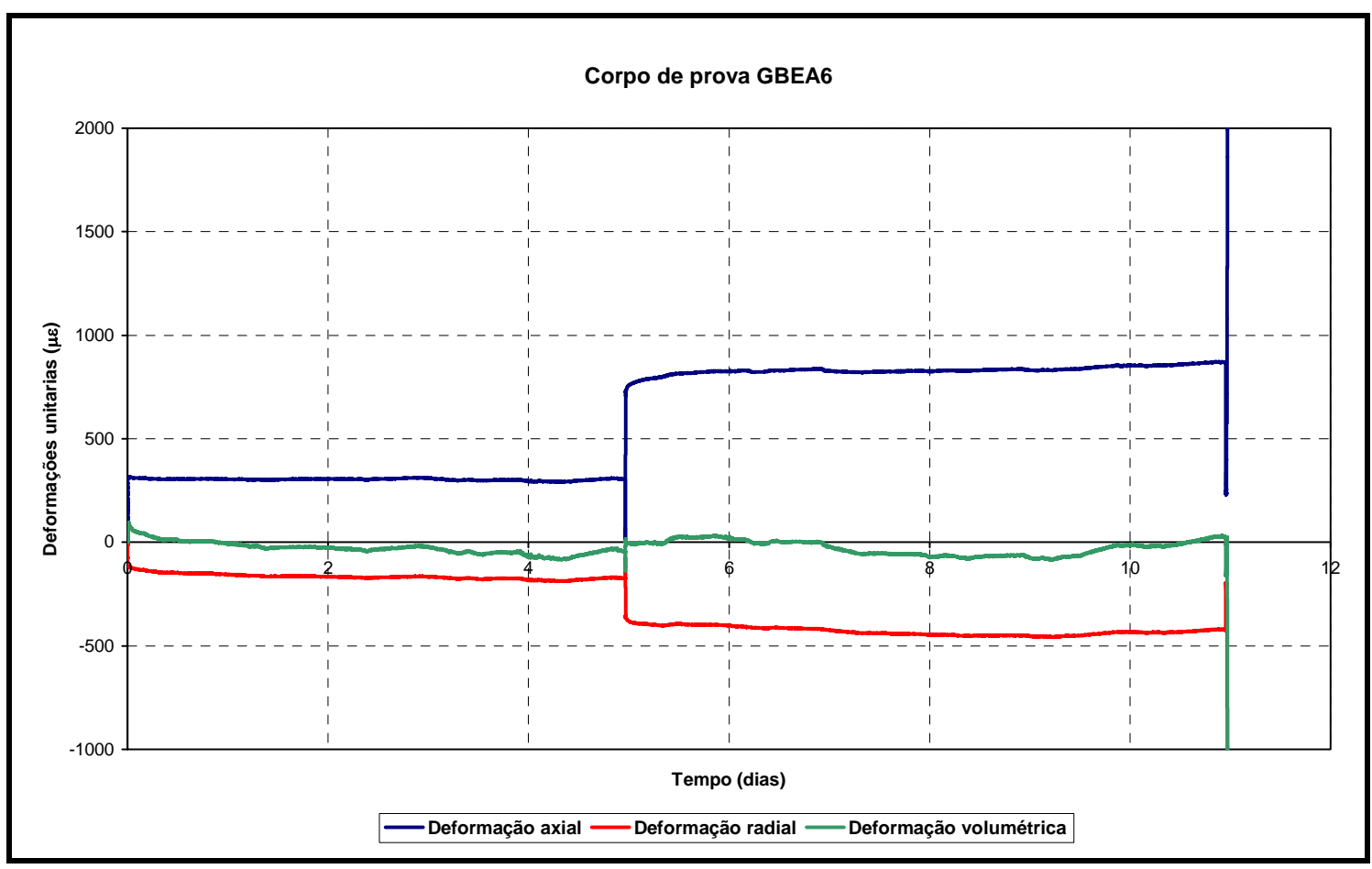

(b)

Figura 3.49 Curvas típicas do ensaio de fluência de curta duração realizado na prensa hidráulica servocontrolada no corpo de prova GBEA6. (a) Tensão versus tempo. (b) Deformações axial, radial e volumétrica versus tempo 
Para execução deste ensaio, foi utilizada uma taxa de carregamento constante de $7 \mathrm{kN} / \mathrm{min}$ e uma taxa de descarregamento de $20 \mathrm{kN} / \mathrm{min}$. O corpo de prova foi instrumentado como nos ensaios de compressão uniaxial com uso da técnica de emissão acústica, como mostrado na Figura 3.50.

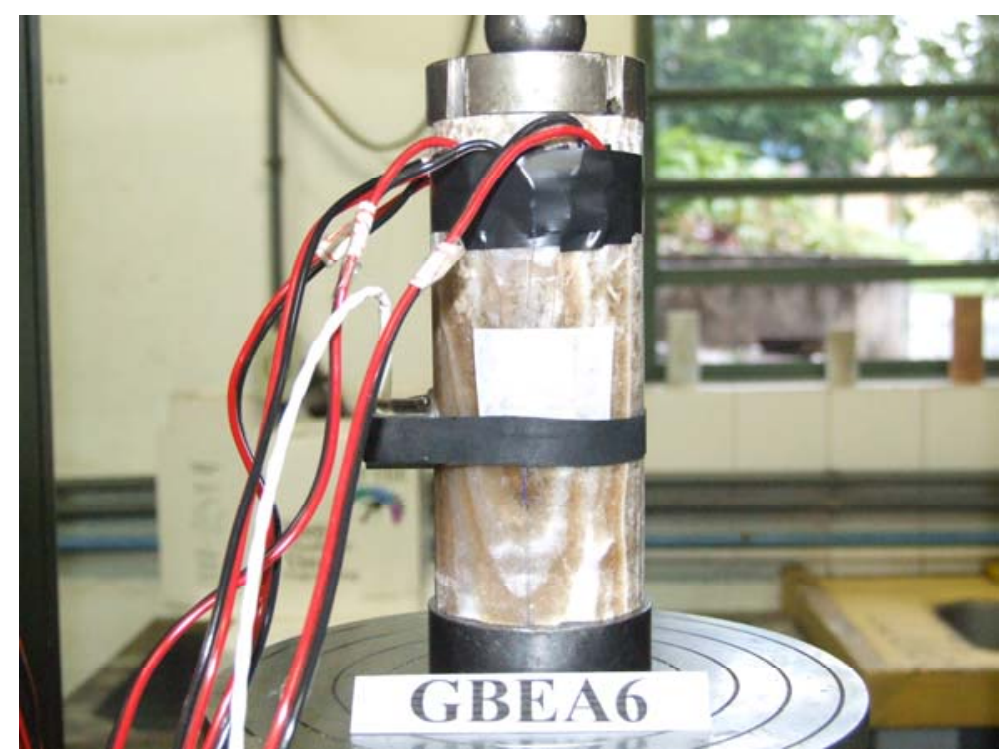

Figura 3.50 Detalhe da instrumentação do corpo de prova GBEA6

\subsubsection{Ensaios Tipo FCII}

Foram realizados três ensaios de fluência de curta duração com carregamento a distintos níveis de tensão na direção perpendicular às camadas $(20,39$, 22,67 e 24,48 $\mathrm{MPa}$, correspondentes a 81,91 e $97 \%$ da resistência pico, respectivamente) sob carga constante com duração de entre 3 e 5 dias.

Uma curva típica se mostra na Figura 3.51. 


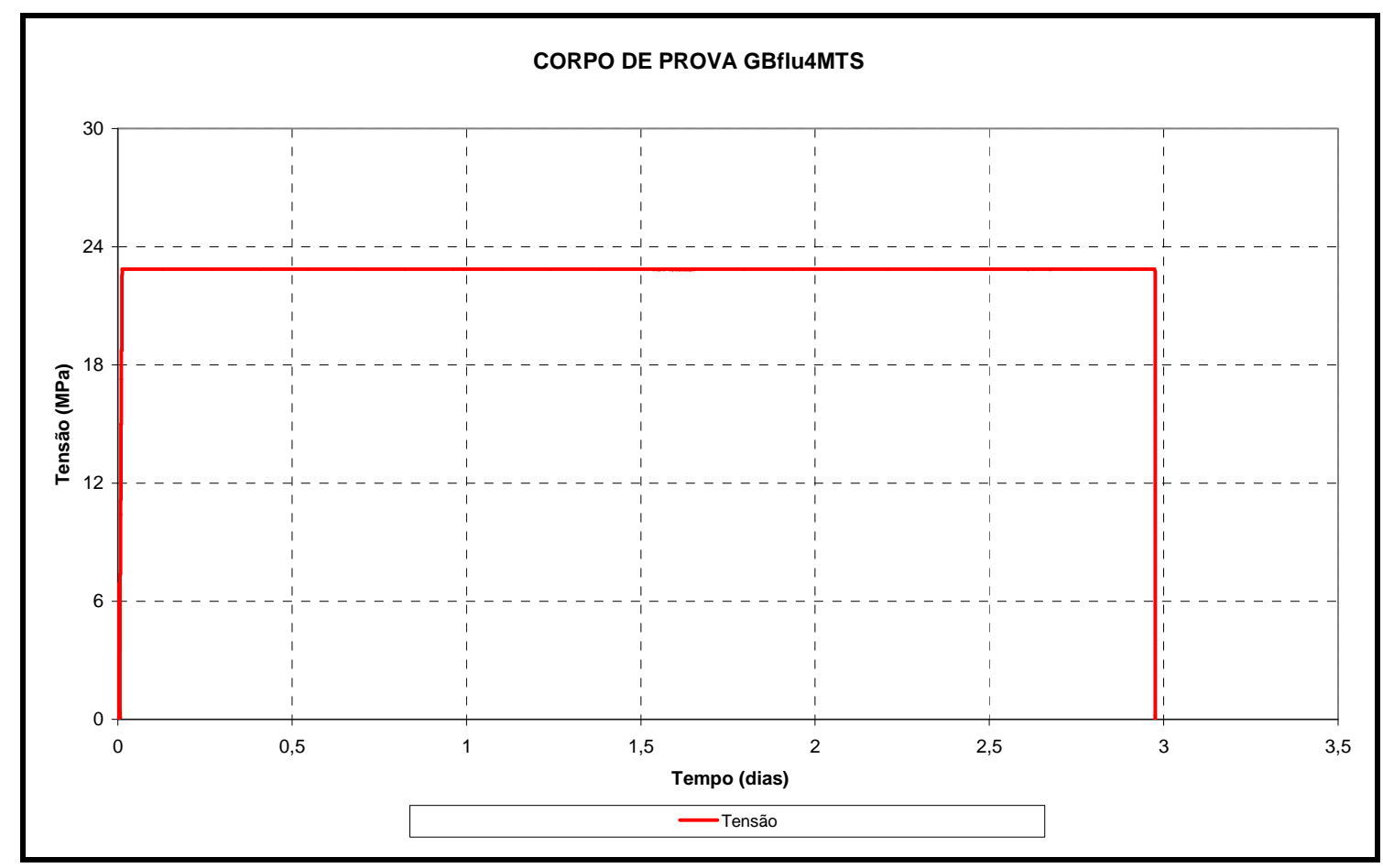

(a)

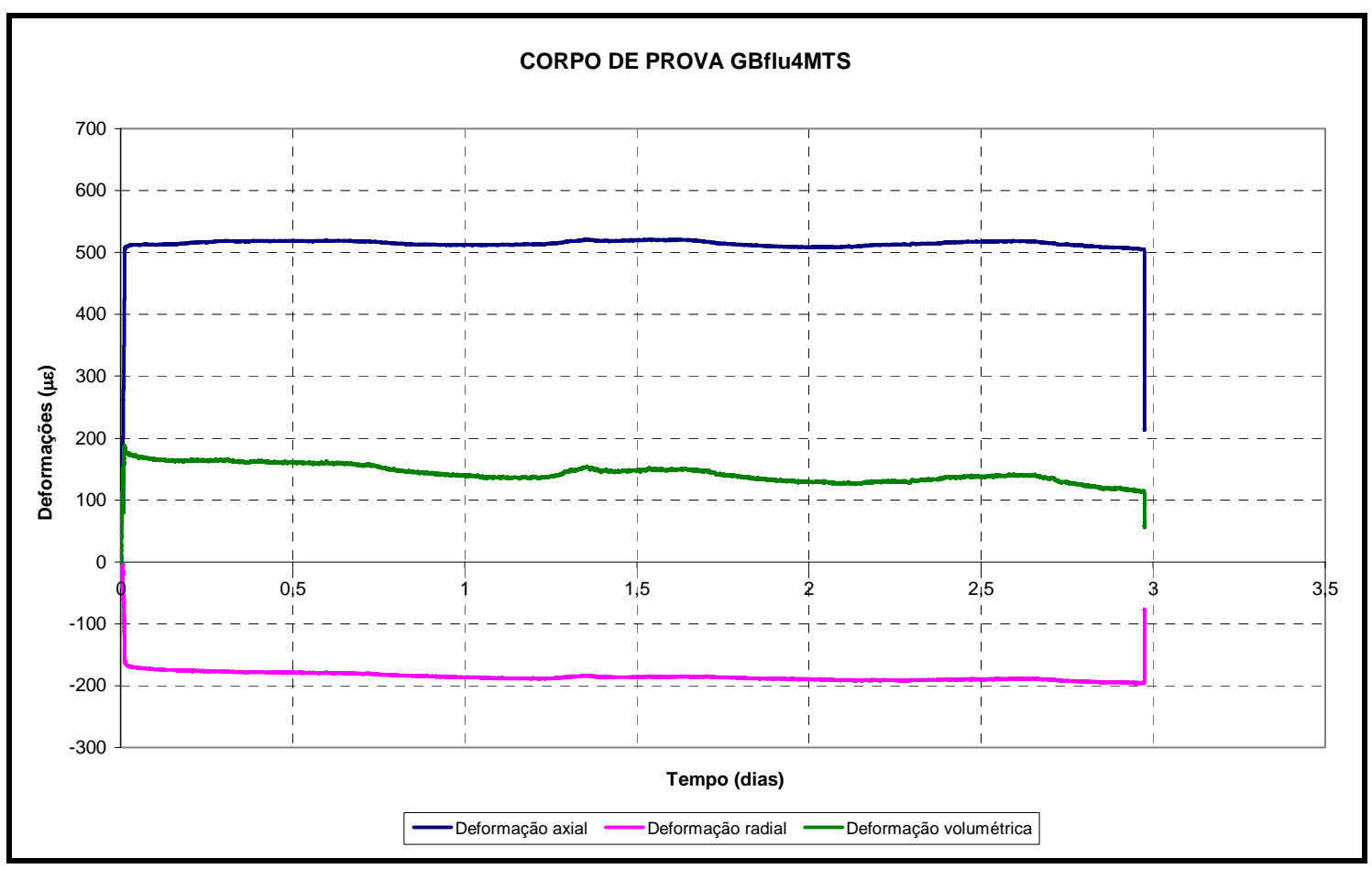

(b)

Figura 3.51 Curvas típicas do ensaio de fluência de curta duração realizado na prensa hidráulica servocontrolada no corpo de prova GBflu4MTS. (a) Tensão versus tempo. (b) Deformações axial, radial e volumétrica versus tempo 
Cada corpo de prova foi instrumentado com dois extensômetros elétricos em roseta dupla colados na sua parte central como mostrado na Figura 3.52.

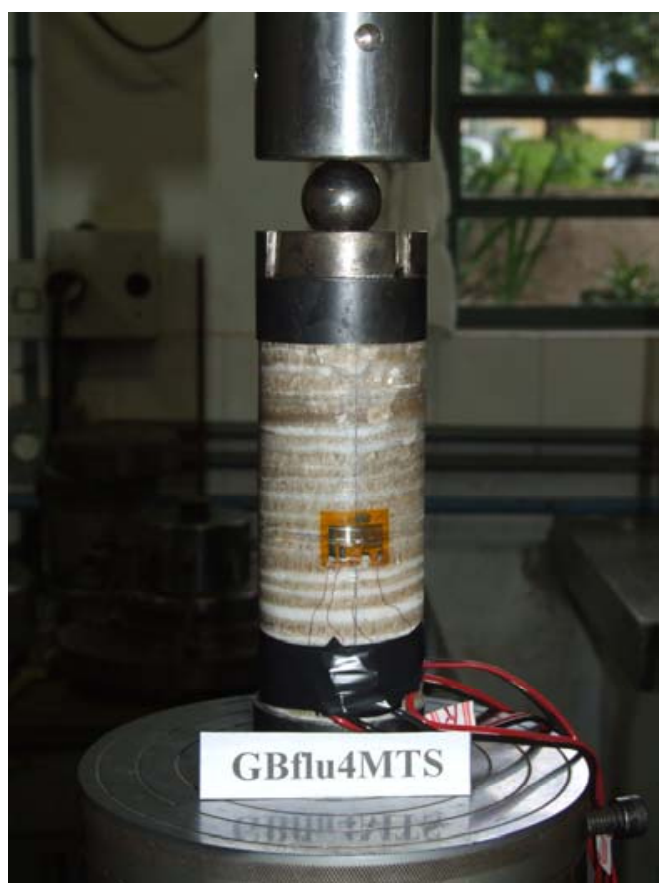

Figura 3.52 Detalhe da instrumentação do corpo de prova GBflu4MTS. Note-se um dos extensômetros elétricos em roseta dupla colado ao corpo de prova. Observe-se que não foram colocados sensores piezoelétricos

\subsubsection{Ensaios Tipo FCIII}

Foram realizados sete ensaios de curta duração do tipo FCIII: três com carregamento perpendicular às camadas e quatro com carregamento paralelo às camadas. Os níveis de tensão alcançados no carregamento perpendicular às camadas foram entre 19,7 e 20,9 $\mathrm{MPa}$, correspondentes a 73 e $89 \%$ da resistência pico, respectivamente. Os níveis de tensão alcançados no carregamento paralelo às camadas foram entre 22,4 e 26,3 $\mathrm{MPa}$, correspondentes a 80 e $84 \%$ da resistência pico, respectivamente, sob carga constante com duração de entre 1 e 3 dias.

Uma curva típica se mostra na Figura 3.53. 


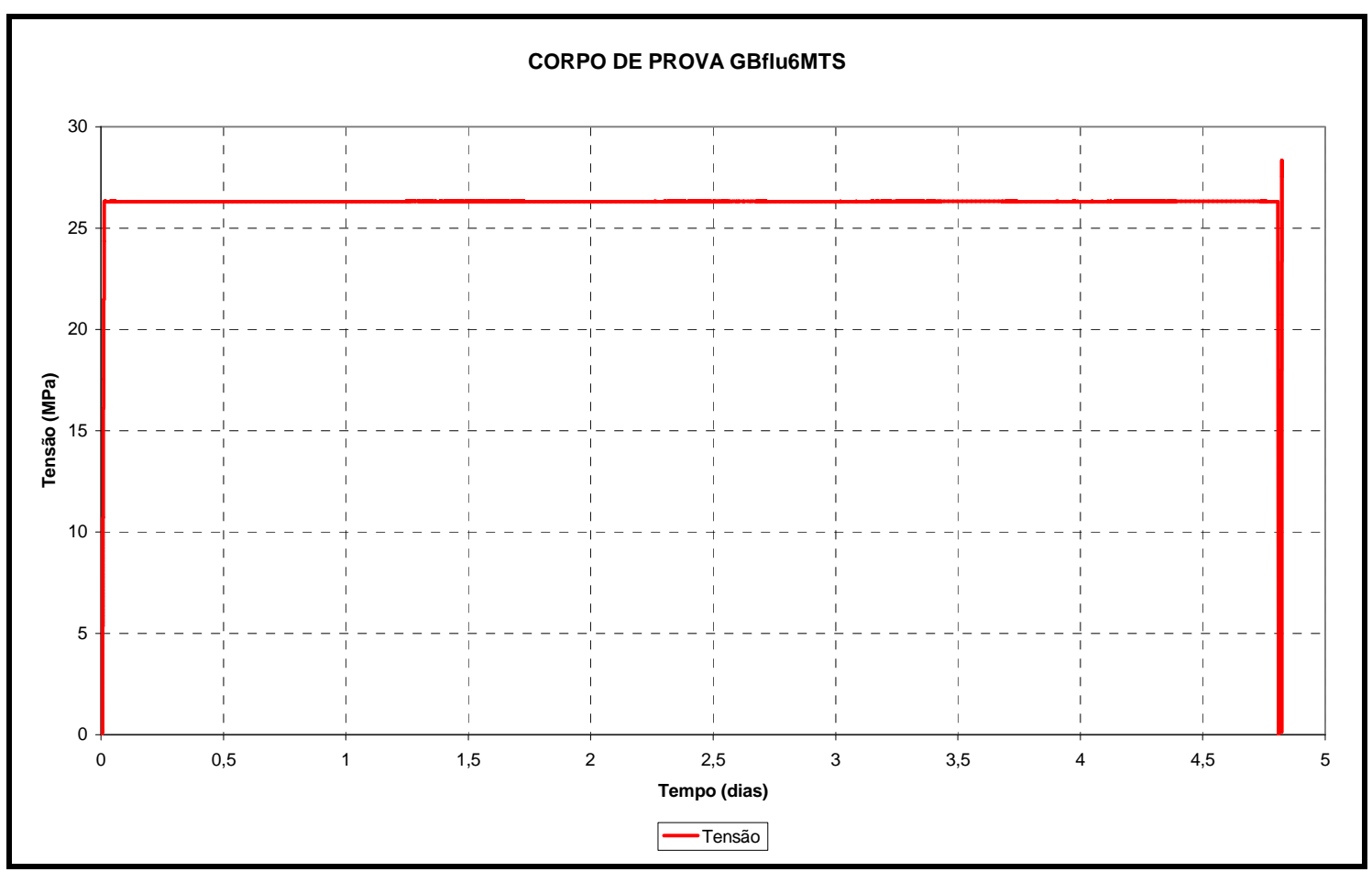

(a)

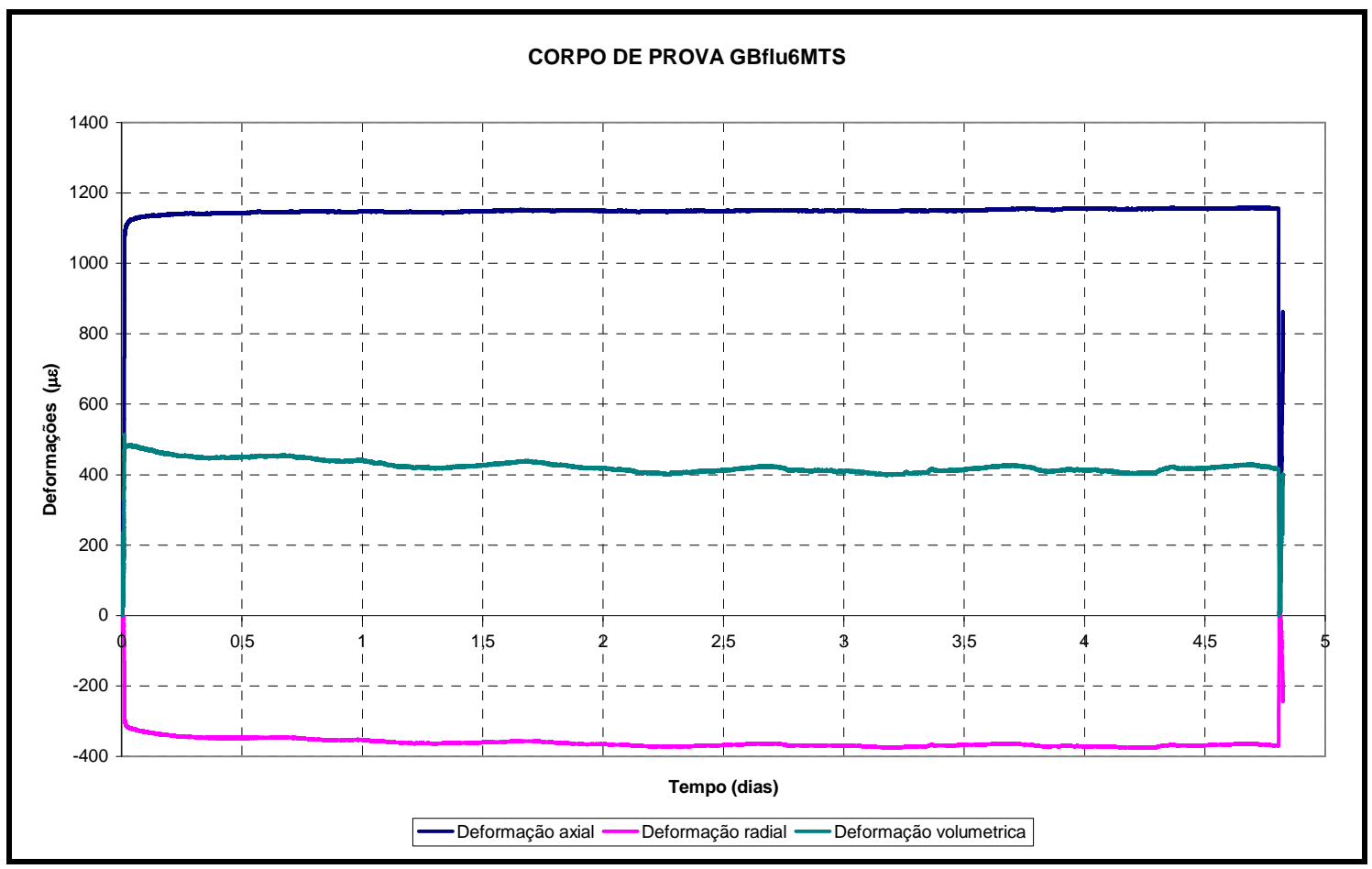

(b)

Figura 3.53 Curvas típicas do ensaio de fluência de curta duração realizado na prensa hidráulica servocontrolada no corpo de prova GBflu6MTS. (a) Tensão versus tempo. (b) Deformações axial, radial e volumétrica versus tempo 
O corpo de prova foi instrumentado com dois extensômetros elétricos em roseta dupla colados na sua parte central e com quatro sensores piezoelétricos de $175 \mathrm{kHz}$ de freqüência característica, como mostrado na Figura 3.54.

Foram selecionadas duas faixas estreitas de freqüência diferentes por meio de filtros analógicos disponíveis no sistema de aquisição de dados:

a) Freqüências baixas (de 20 a $100 \mathrm{kHz}$ ) e

b) Freqüências intermediárias (de 100 a 400 kHz).

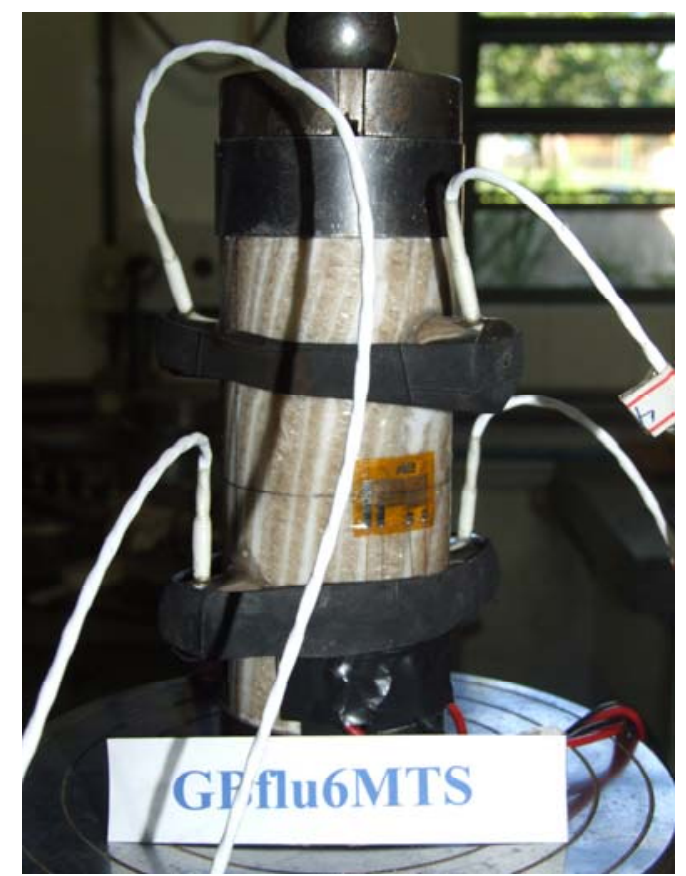

Figura 3.54 Detalhe da instrumentação do corpo de prova GBflu6MTS. Note-se os quatro sensores piezoelétricos fixados por bandas elásticas e um dos extensômetros elétricos em roseta dupla colado ao corpo de prova

\subsubsection{Ensaios de fluência de longa duração}

Foram realizados 14 ensaios de fluência de longa duração no laboratório de fluência, sob condicões de tensão constante e temperatura controlada, com as caracteristicas apresentadas na Tabela 3.7. Em todos, o controle de carregamento foi feito com o sistema hidráulico já descrito anteriormente. O carregamento foi aplicado 
com macacos planos tóricos. Detalhes de cada ensaio são apresentados nos sub-itens seguintes.

Tabela 3.7 Ensaios de fluência de longa duração com temperatura controlada

\begin{tabular}{cccc}
\hline $\begin{array}{c}\text { Ensaio } \\
\text { Tipo }\end{array}$ & $\begin{array}{c}\text { Número de } \\
\text { ensaios }\end{array}$ & Orientação/Camadas & $\begin{array}{c}\text { Emissão } \\
\text { Acústica }\end{array}$ \\
\hline FLI-A & 3 & Perpendicular & 1 sensor \\
FLI-B & 2 & Paralelo & 1 sensor \\
FLII-A & 2 & Perpendicular & sem EA \\
FLII-B & 3 & Paralelo & sem EA \\
FLIII-A & 2 & Perpendicular & 2 sensores \\
FLIII-B & 2 & Paralelo & 2 sensores \\
\hline
\end{tabular}

\subsubsection{Ensaios Tipo FLI}

Para execução dos ensaios, foram utilizadas as quatro torres individuais (corpos de prova GBEAF1, GBEAF2, GBEAF4 e GBEAF5) e um pórtico de reação tipo coluna (corpo de prova GBEAF3). A configuração dos ensaios de fluência de longa duração nos módulos individuais que estão conectados a um painel de controle é mostrada na Figura 3.55.

Os corpos de prova ensaiados nas torres individuais foram submetidos a dois ciclos de carregamento e descarregamento sucessivos, um ciclo de carregamento até um determinado nível de tensão e um ciclo de carregamento e descarregamento final como mostrado na Figura 3.56 e na Tabela 3.8 onde se indicam os níveis de tensão médios alcançados e a duração dos ciclos de carregamento e descarregamento correspondentes. 


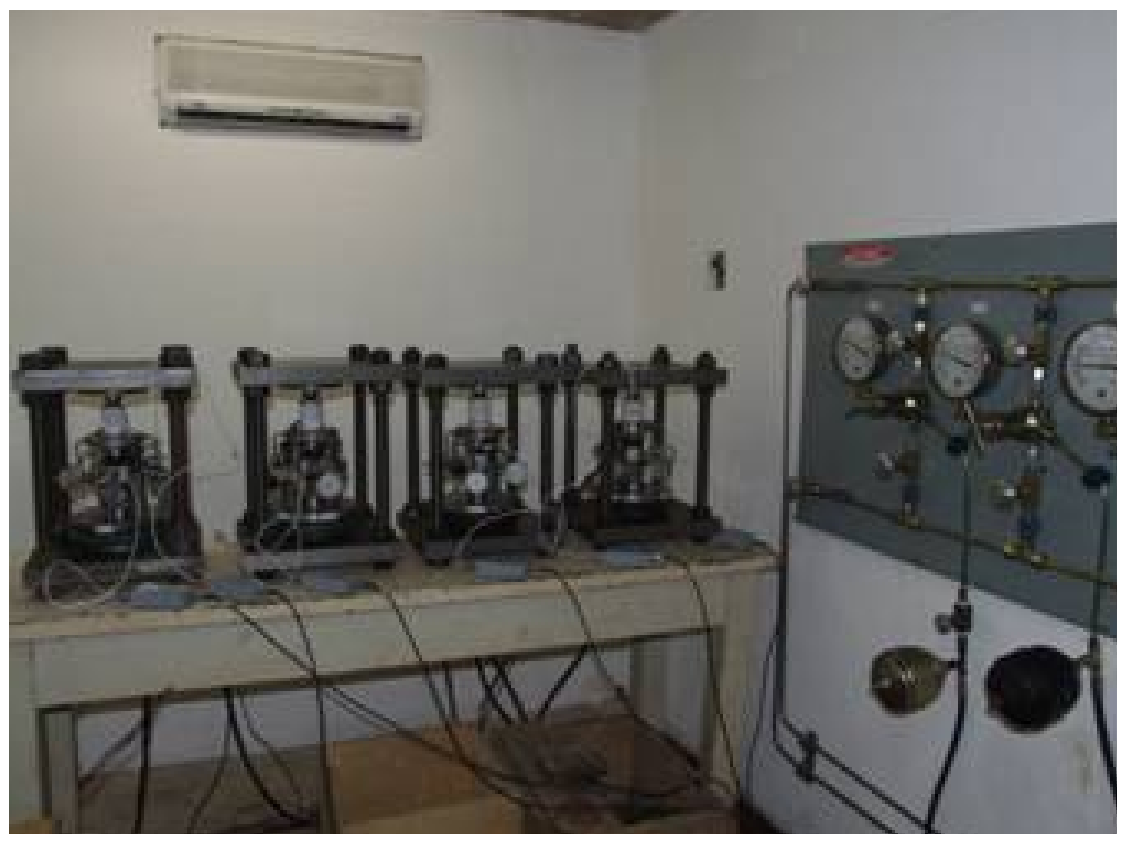

Figura 3.55 Configuração dos ensaios de fluência de longa duração nos módulos individuais e painel de controle das cargas aplicadas aos corpos de prova

Os primeiros dois ciclos de carregamento e descarregamento de cada corpo de prova estudado tiveram como objetivos iniciais:

- verificar o comportamento, tanto do sistema de aplicação de carga, como do painel de controle e do registro dos eventos de emissão acústica, auxiliando nas modificações do sistema de aplicação da carga e do painel de controle para manter constantes as cargas aplicadas nos corpos de prova;

- identificar e solucionar os problemas de ruídos existentes durante os ensaios de fluência;

- analisar a variação do módulo de deformabilidade para as diferentes trajetórias de tensão utilizadas nos ensaios de fluência de longa duração a fim de se obter evidências sobre os possíveis mecanismos de deformação responsáveis pela fluência observada na rocha estudada. 


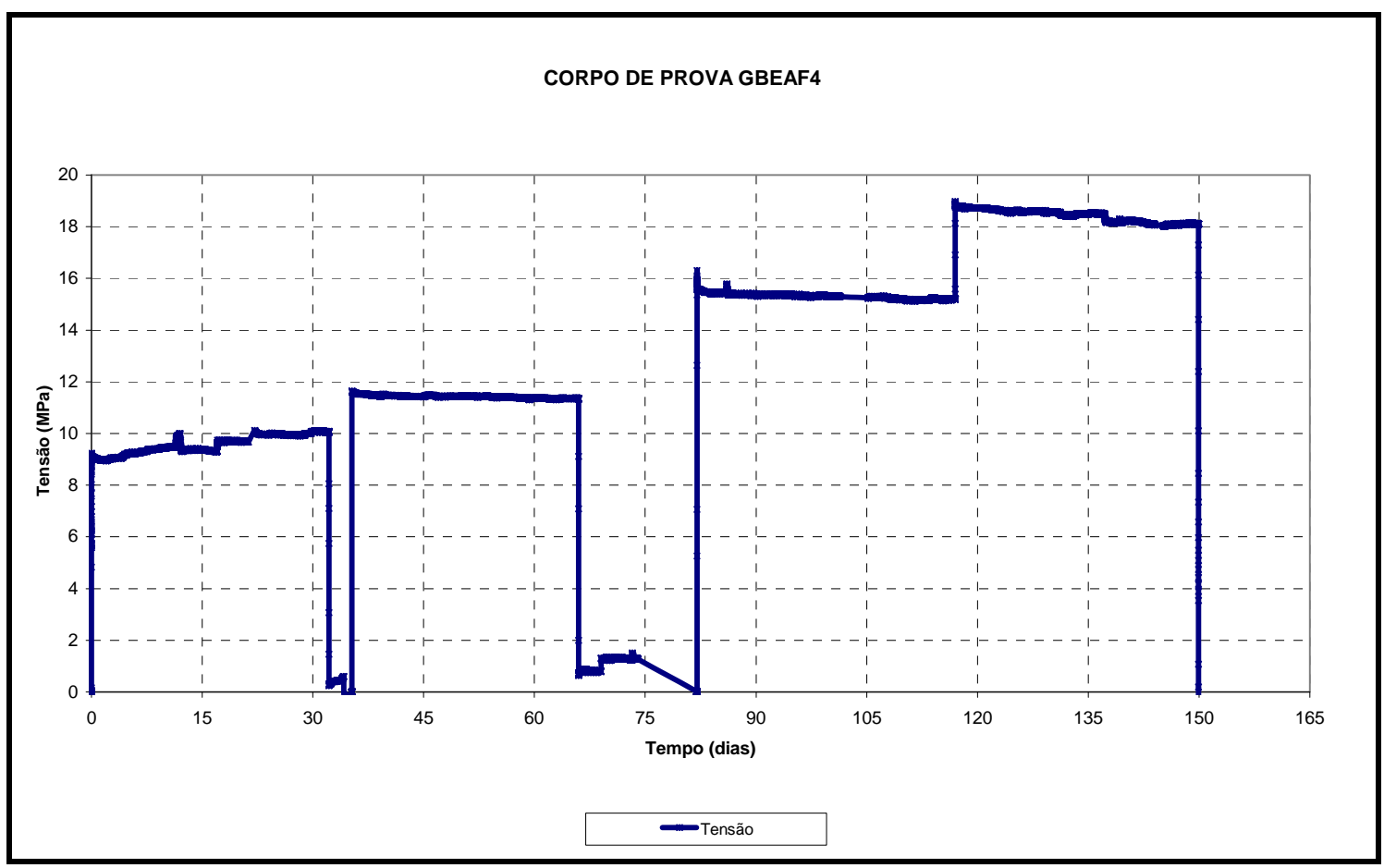

(a)

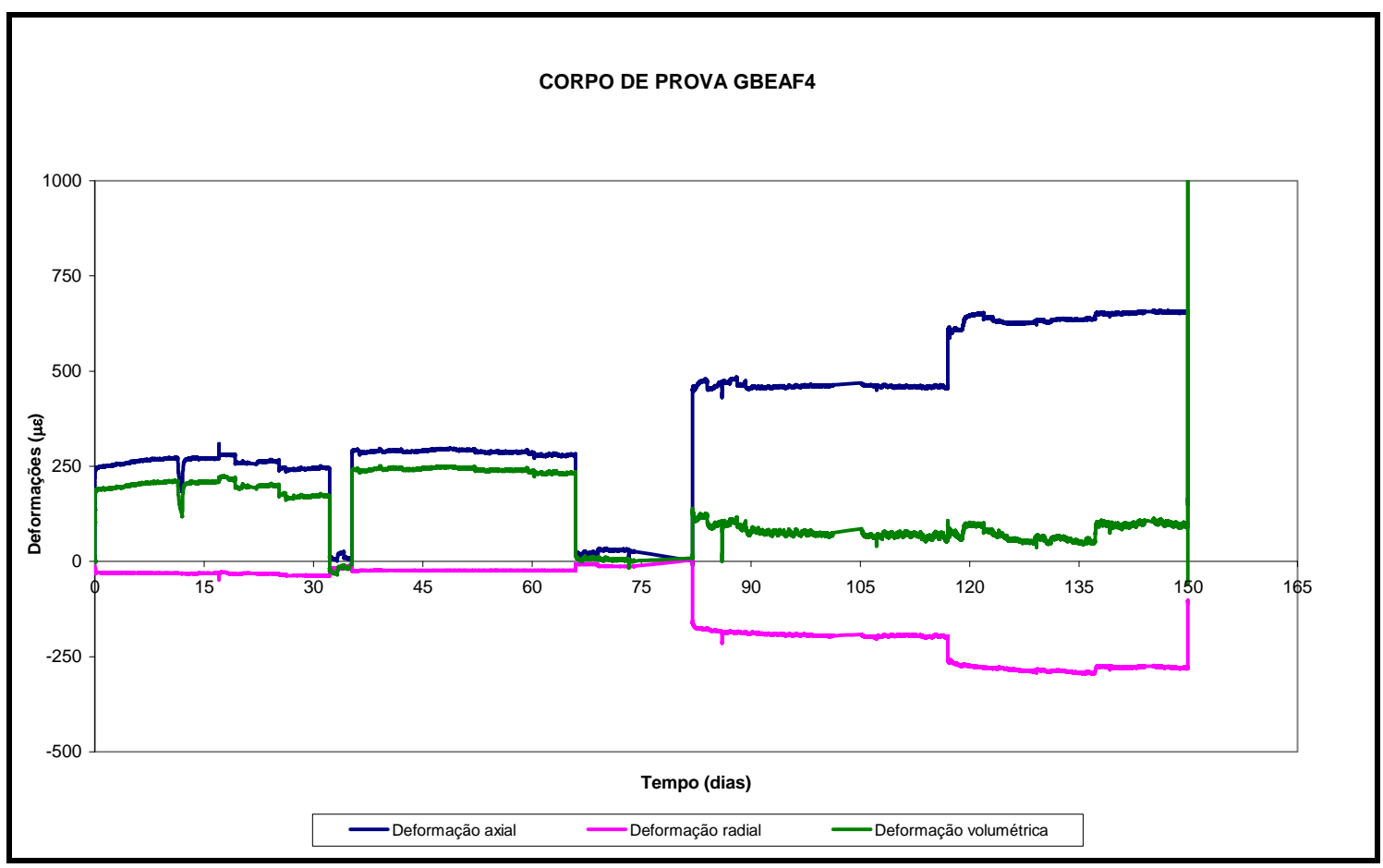

(b)

Figura 3.56 Curvas típicas do corpo de prova GBEAF4 do ensaio de fluência de longa duração com ciclos variáveis de carregamento e descarregamento. (a) Tensão versus tempo. (b) Deformações axial, radial e volumétrica versus tempo 
Tabela 3.8 Níveis de tensão médios alcançados e duração dos ciclos de carregamento e descarregamento correspondentes aos ensaios de fluência de longa duração realizados nas quatro torres individuais

\begin{tabular}{c|cc|cc|cc|cc}
\hline Corpo de prova & \multicolumn{2}{c}{ GBEAF1 } & \multicolumn{2}{c}{ GBEAF2 } & \multicolumn{2}{c}{ GBEAF4 } & \multicolumn{2}{c}{ GBEAF5 } \\
\hline Condição & $\begin{array}{c}\text { Tensão } \\
\text { (MPa) }\end{array}$ & $\begin{array}{c}\text { Duração } \\
\text { (dias) }\end{array}$ & $\begin{array}{c}\text { Tensão } \\
(\mathrm{MPa})\end{array}$ & $\begin{array}{c}\text { Duração } \\
\text { (dias) }\end{array}$ & $\begin{array}{c}\text { Tensão } \\
(\mathrm{MPa})\end{array}$ & $\begin{array}{c}\text { Duração } \\
\text { (dias) }\end{array}$ & $\begin{array}{c}\text { Tensão } \\
\text { (MPa) }\end{array}$ & $\begin{array}{c}\text { Duração } \\
\text { (dias) }\end{array}$ \\
$\begin{array}{c}\text { Primeiro } \\
\text { Carregamento }\end{array}$ & 9 & 32 & 10,1 & 32 & 9,7 & 32 & $\begin{array}{c}\text { Muito } \\
\text { Variável }\end{array}$ & 32 \\
$\begin{array}{c}\text { Descarregamento } \\
\text { Segundo }\end{array}$ & - & 3 & - & 3 & - & 3 & - & 3 \\
$\begin{array}{c}\text { Carregamento } \\
\text { Descarregamento }\end{array}$ & 11 & 30 & 12,1 & 30 & 11,4 & 30 & 11,8 & 30 \\
$\begin{array}{c}\text { Terceiro } \\
\text { Carregamento } \\
\text { Quarto }\end{array}$ & 14,2 & 34 & 15,0 & 34 & 15,3 & 34 & 17,7 & 34 \\
Carregamento & 18,1 & 33 & 18,2 & 33 & 18,3 & 33 & 18,5 & 33 \\
\hline
\end{tabular}

A Figura 3.57 mostra o detalhe de um corpo de prova instrumentado com relógios comparadores (para leituras periódicas a fim de evitar perdas eletrônicas), dois extensômetros elétricos em roseta dupla (para registrar os deslocamentos e deformações dos corpos de prova) e um sensor piezoelétrico de $175 \mathrm{kHz}$ de freqüência característica (para registrar os eventos de emissão acústica). A medição de cargas foi feita através de células de carga à base de extensômetros elétricos. 


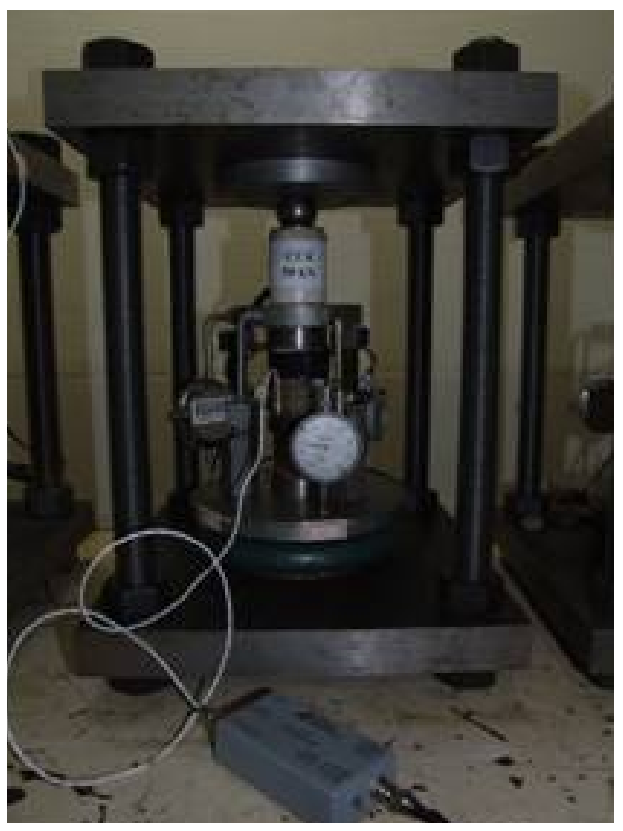

Figura 3.57 Detalhe da instrumentação dos corpos de prova nas torres individuais nos ensaios de fluência de longa duração. Notar os relógios comparadores utilizados e o sensor piezoelétrico fixado por uma banda elástica

A configuração do ensaio de fluência de longa duração realizado no pórtico de reação tipo coluna e que está conectado a um painel de controle é mostrada na Figura 3.58 .

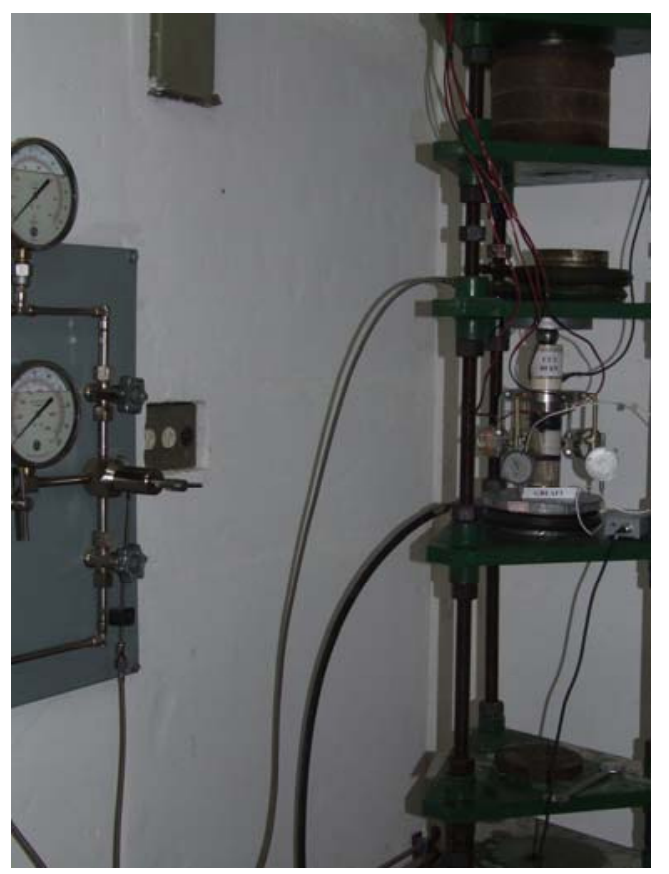

Figura 3.58 Configuração do ensaio de fluência de longa duração no pórtico de reação tipo coluna e painel de controle de carga aplicada ao corpo de prova GBEAF3 
O corpo de prova ensaiado no pórtico de reação tipo coluna foi submetido a ciclos de carregamento e descarregamento diferentes daqueles a que foram submetidos os corpos de prova ensaiados nas torres individuais, como mostrado na Figura 3.59 e na Tabela 3.9 onde se indicam os níveis de tensão médios alcançados e a duração dos ciclos de carregamento e descarregamento correspondentes.

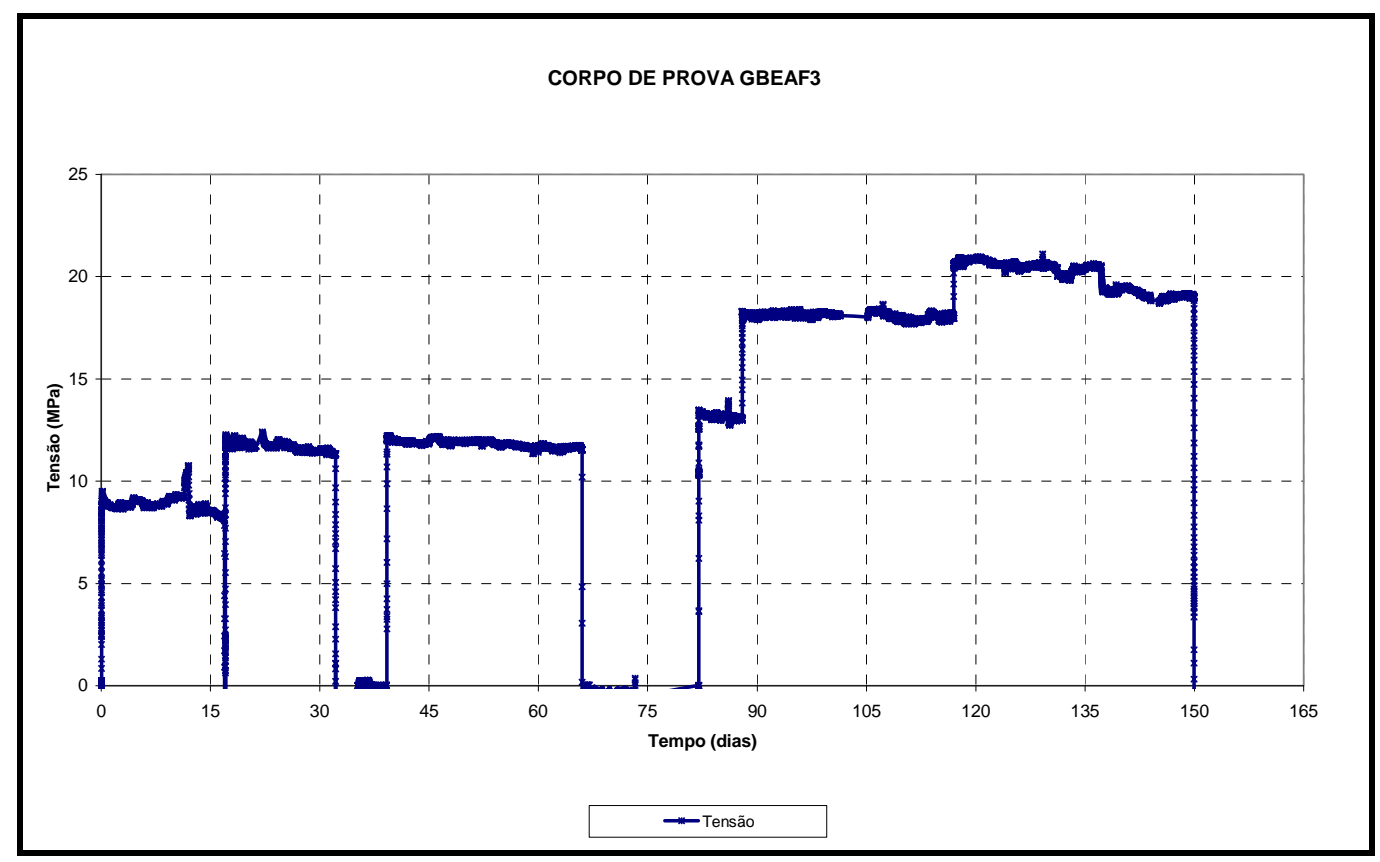

Figura 3.59 Curva tensão versus tempo do corpo de prova GBEAF3 do ensaio de fluência de longa duração submetido a ciclos variáveis de carregamento e descarregamento

Neste corpo de prova, testou-se o sistema de aplicação de cargas e o painel de controle para manter constantes as cargas aplicadas, assim como identificar e solucionar os problemas de ruídos mecânicos existentes durante o carregamento do sistema.

A Figura 3.60 mostra o detalhe do corpo de prova GBEAF3 instrumentado com relógios comparadores, dois extensômetros elétricos em roseta dupla e um sensor piezoelétrico de $175 \mathrm{kHz}$ de freqüência característica. 
Tabela 3.9 Níveis de tensão médios alcançados e duração dos ciclos de carregamento e descarregamento correspondentes ao ensaio de fluência de longa duração realizado no pórtico de reação tipo coluna

\begin{tabular}{ccc|ccc}
\hline Corpo de prova & \multicolumn{2}{c|}{ GBEAF3 } & Corpo de prova & \multicolumn{2}{c}{ GBEAF3 } \\
\hline Condição & $\begin{array}{c}\text { Tensão } \\
(\mathrm{MPa})\end{array}$ & $\begin{array}{c}\text { Duração } \\
(\text { dias })\end{array}$ & Condição & $\begin{array}{c}\text { Tensão } \\
(\mathrm{MPa})\end{array}$ & $\begin{array}{c}\text { Duração } \\
\text { (dias) }\end{array}$ \\
\hline $1^{\circ}$ Carregamento & 8,6 & 17 & Descarregamento & - & 16 \\
Descarregamento & - & 0 & $4^{\circ}$ Carregamento & 13,1 & 5 \\
$2^{\circ}$ Carregamento & 11,6 & 15 & $5^{\circ}$ Carregamento & 18,1 & 30 \\
Descarregamento & & 7 & $6^{\circ}$ Carregamento & 19,5 & 33 \\
$3^{\circ}$ Carregamento & 11,7 & 27 & - & - & - \\
\hline
\end{tabular}

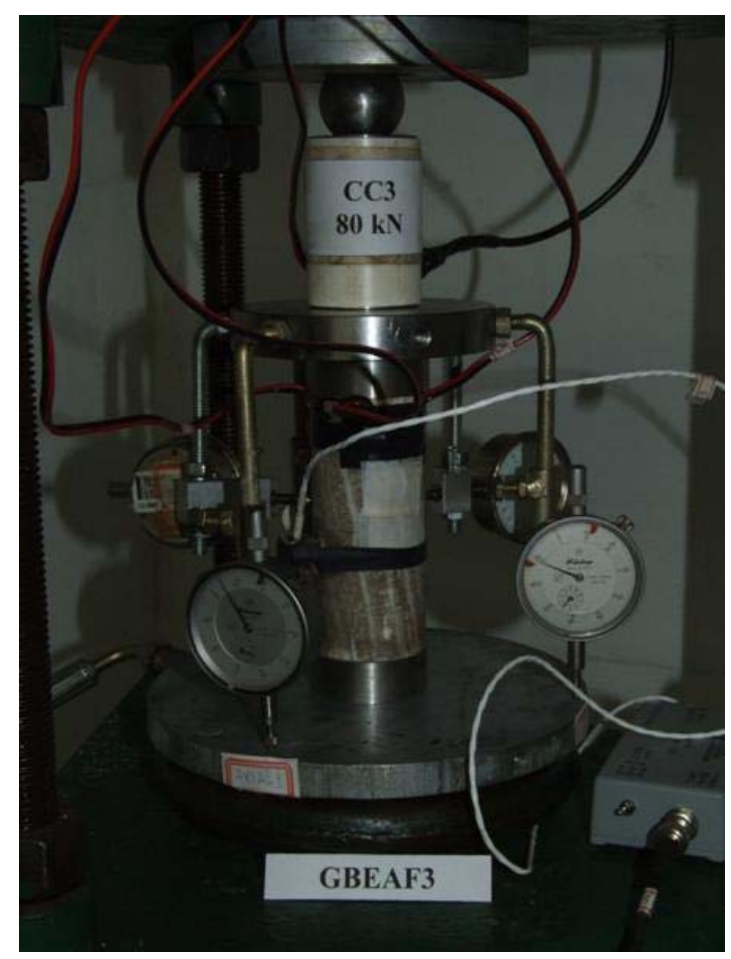

Figura 3.60 Detalhe da instrumentação do corpo de prova GBEAF3 no pórtico de reação tipo coluna

\subsubsection{Ensaios Tipo FLII}

Para execução dos ensaios, foram utilizadas as quatro torres individuais (corpos de prova GBfluencia6 (CC1), GBfluencia7 (CC2), GBfluencia9 (CC4) e Gbfluencia10(CC5)) e um pórtico de reação tipo coluna (corpo de prova GBfluencia8 (CC3)). 
Os corpos de prova GBfluencia6 e GBfluencia7 foram ensaiados com carregamento paralelo às camadas e os corpos de prova GBfluencia8, GBfluencia9 e Gbfluencia10 com carregamento perpendicular às camadas.

Neste tipo de ensaios, somente se aplicou um carregamento e descarregamento para calcular o módulo de elasticidade dos corpos de prova, para posteriormente carregar o corpo de prova até um determinado nível de tensão que foi mantida ao longo de todo o ensaio.

$\mathrm{Na}$ Tabela 3.10 se indicam os níveis de tensão médios alcançados no carregamento nas quatro torres individuais com suas respectivas percentagens da resistência pico.

Tabela 3.10 Níveis de tensão médios alcançados e percentagem da resistência pico alcançados no carregamento das quatro torres individuais

\begin{tabular}{|c|c|c|c|}
\hline \multirow[b]{2}{*}{$\begin{array}{l}\text { Corpo de } \\
\text { Prova }\end{array}$} & \multirow[b]{2}{*}{ Carregamento } & \multicolumn{2}{|c|}{ Condição do carregamento } \\
\hline & & $\begin{array}{l}\text { Tensão } \\
\text { (MPa) }\end{array}$ & $\begin{array}{c}\text { Percentagem da } \\
\text { resistência pico } \\
(\%)\end{array}$ \\
\hline GBfluencia6 & Paralelo às camadas & 24,35 & 86 \\
\hline GBfluencia8 & $\begin{array}{l}\text { Perpendicular às } \\
\text { camadas }\end{array}$ & 24,16 & 95 \\
\hline GBfluencia9 & $\begin{array}{l}\text { Perpendicular às } \\
\text { camadas }\end{array}$ & 22,43 & 77 \\
\hline GBfluencia10 & $\begin{array}{l}\text { Perpendicular às } \\
\text { camadas }\end{array}$ & 21,44 & 85 \\
\hline
\end{tabular}

A Figura 3.61 mostra o detalhe de um corpo de prova instrumentado com relógios comparadores e dois extensômetros elétricos em roseta dupla (para registrar os deslocamentos e deformações dos corpos de prova). A medição de cargas foi feita através de células de carga à base de extensômetros elétricos. 


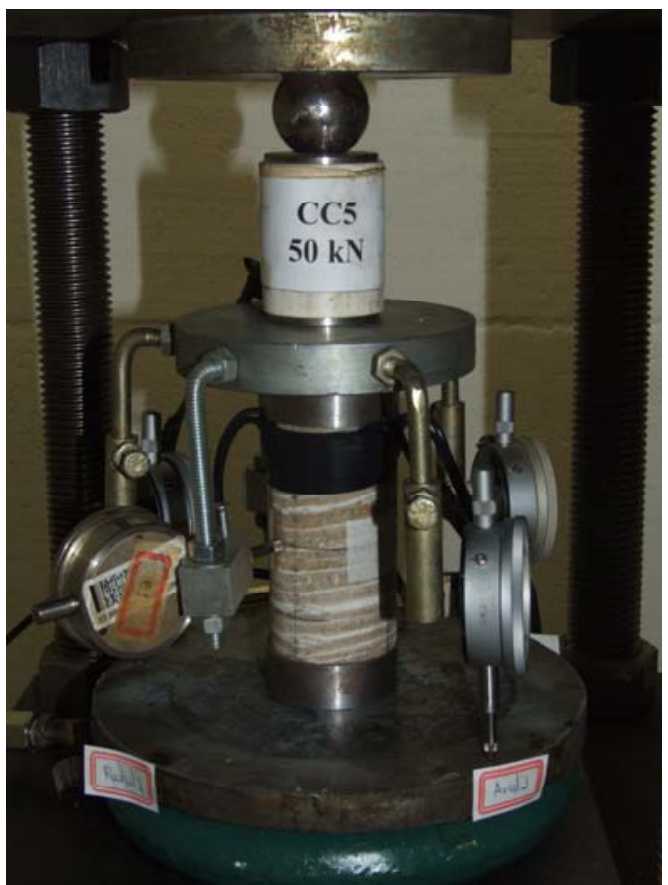

Figura 3.61 Detalhe da instrumentação do corpo de prova GBfluencia10 nas torres individuais nos ensaios de fluência de longa duração

Salienta-se que estes ensaios foram realizados sem registro de eventos de emissão acústica e que se perdeu um dos ensaios antes mencionados (GBfluencia7) depois de 10 dias, tentando recuperar pequenas perdas da carga aplicada neste corpo de prova (Figura 3.62).

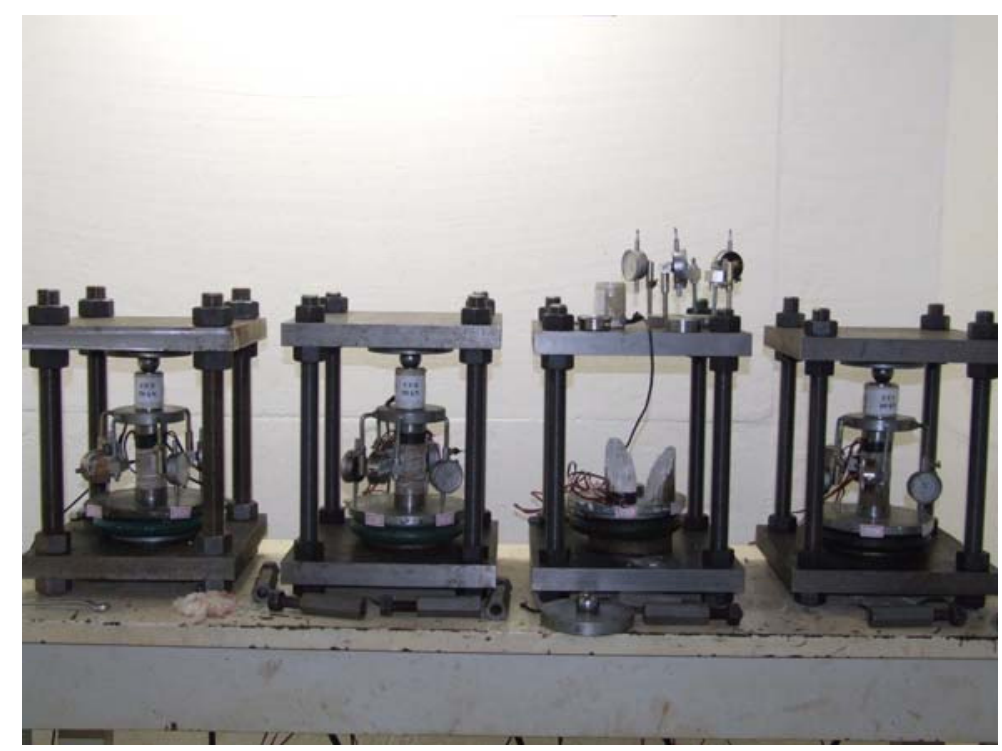

Figura 3.62 Configuração dos ensaios de fluência de longa duração nos módulos individuais. Notese o corpo de prova GBfluencia7 rompido 
A configuração do ensaio de fluência de longa duração do corpo de prova GBfluencia8 realizado no pórtico de reação tipo coluna é mostrada na Figura 3.63.

No corpo de prova GBfluencia8 o carregamento foi perpendicular às camadas com uma tensão de 24,2 MPa que equivale a 95\% da resistência pico.

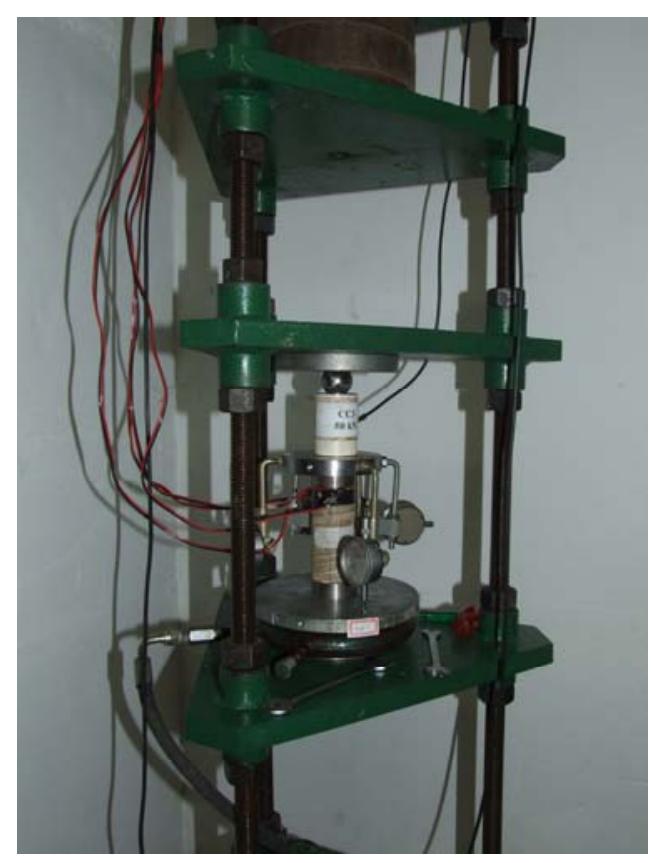

Figura 3.63 Configuração do ensaio de fluência de longa duração do corpo de prova GBfluencia8 no pórtico de reação tipo coluna

A Figura 3.64 mostra o detalhe do corpo de prova GBfluencia8 (CC3) instrumentado com relógios comparadores e dois extensômetros elétricos em roseta dupla. A medição de cargas foi feita através de células de carga à base de extensômetros elétricos. 


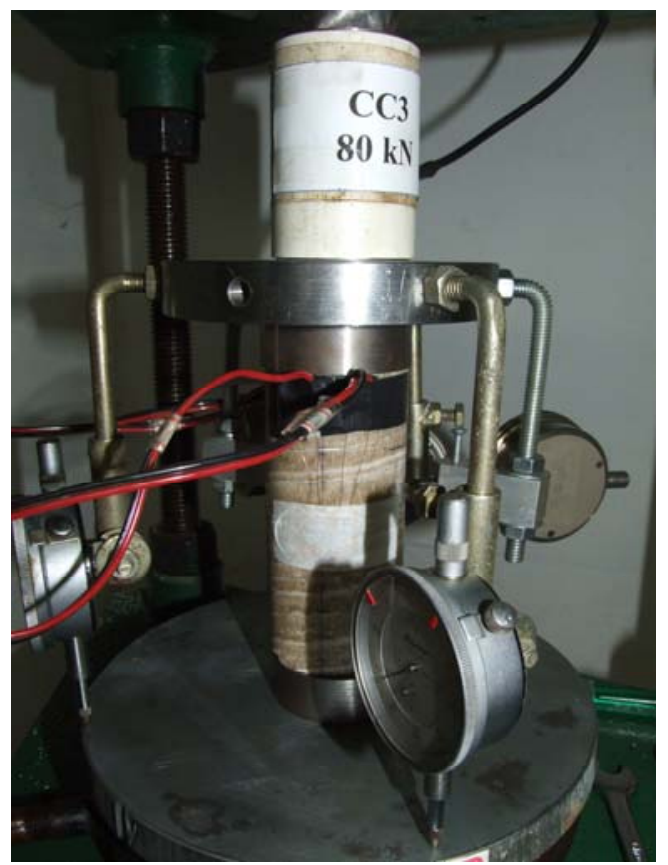

Figura 3.64 Detalhe da instrumentação do corpo de prova GBfluencia8 no pórtico de reação tipo coluna

\subsubsection{Ensaios Tipo FLIII}

Para execução dos ensaios, foram utilizadas quatro torres individuais (corpos de prova GBfluencia11, GBfluencia12, GBfluencia13 e GBfluencia14). Resultados típicos são apresentados nas Figuras 3.65 e 3.66. Os corpos de prova GBfluencia11 e GBfluencia12 foram ensaiados com carregamento perpendicular às camadas e os corpos de prova GBfluencia13 e GBfluencia14 com carregamento paralelo às camadas. 


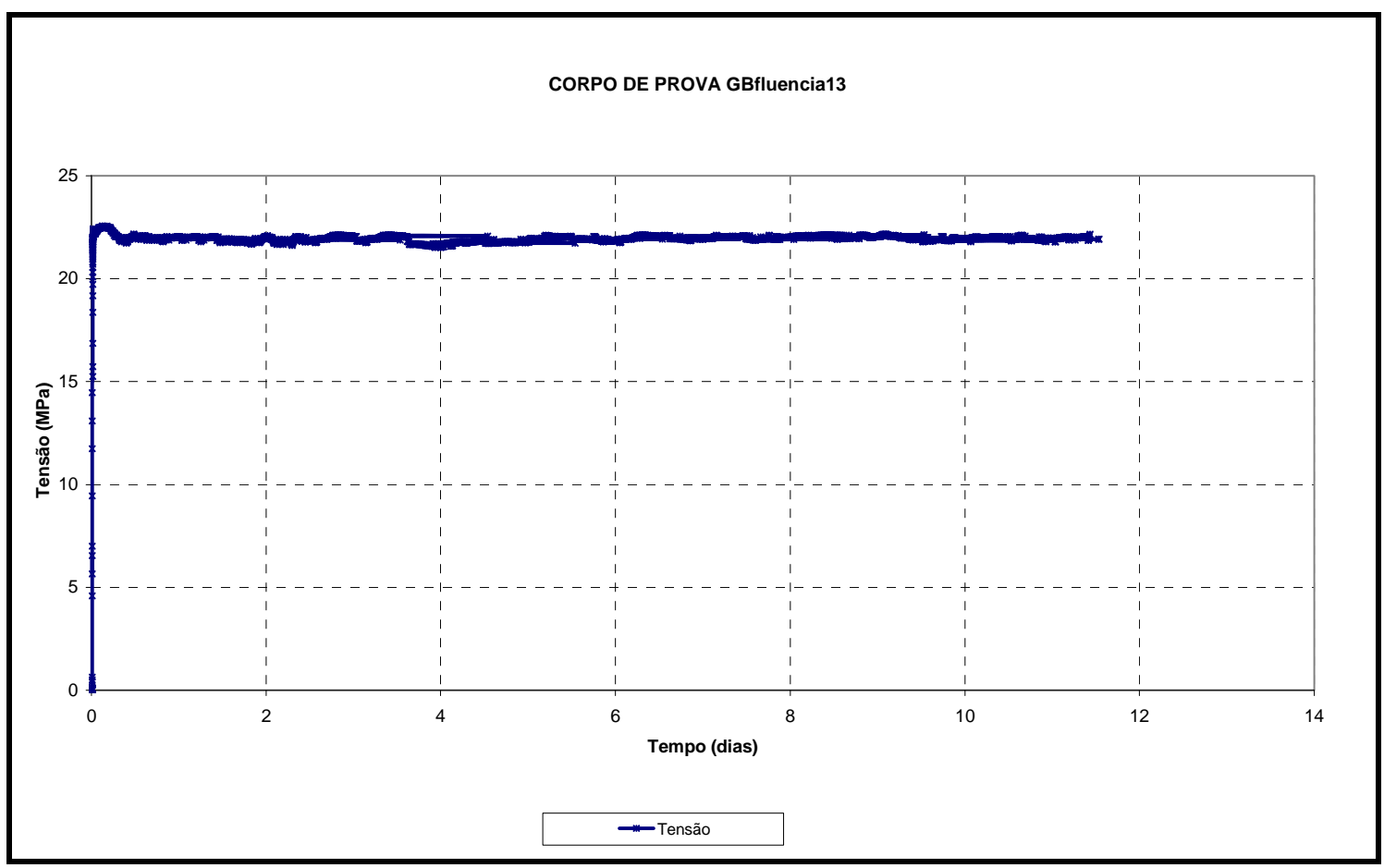

Figura 3.65 Curva tensão versus tempo do ensaio de fluência de longa duração (274 horas) no corpo de prova GBfluencia13

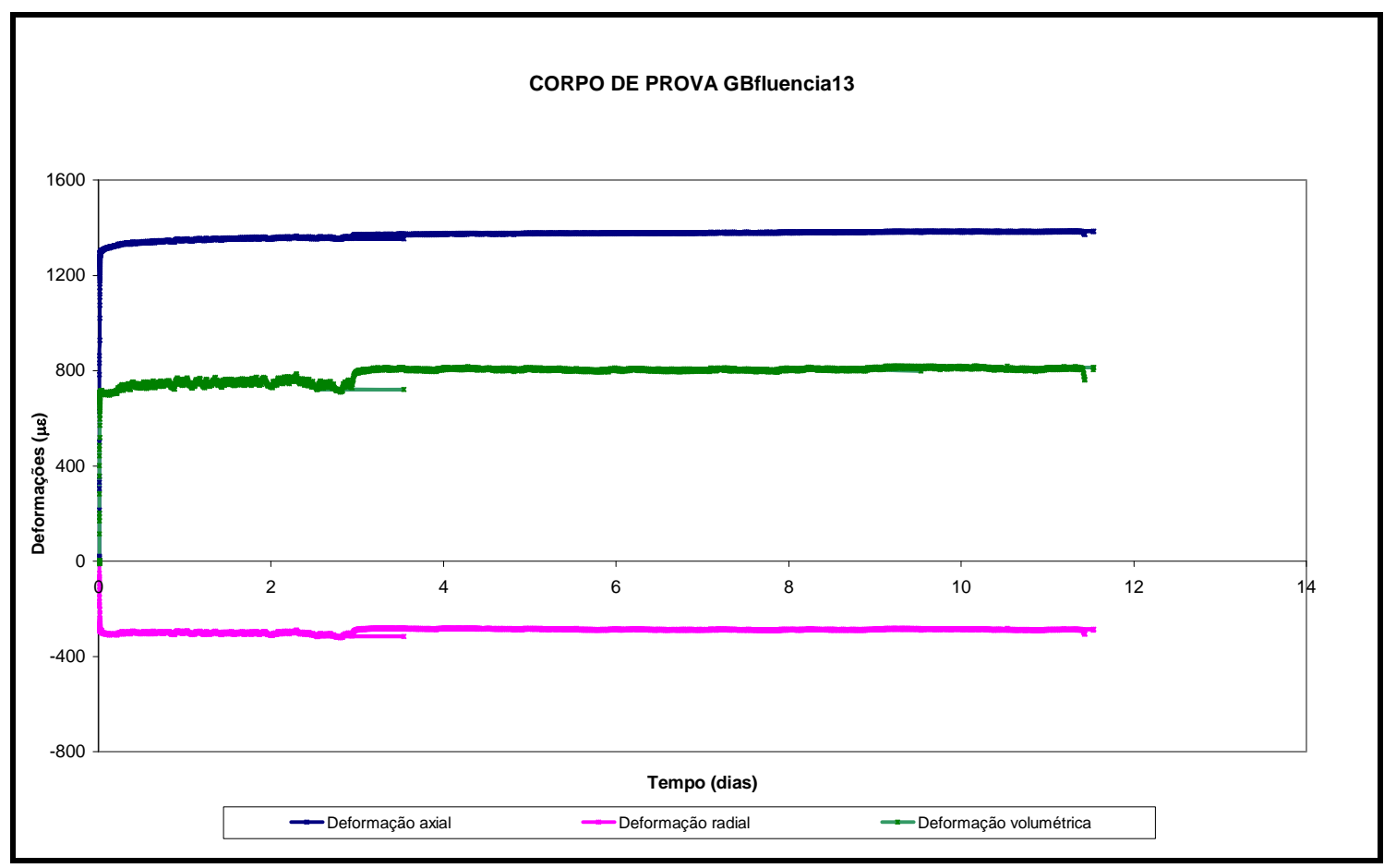

Figura 3.66 Curva deformações axial, radial e volumétrica versus tempo do ensaio de fluência de longa duração (274 horas) no corpo de prova GBfluencia13 
Na Tabela 3.11 se indicam os níveis de tensão médios no carregamento nas quatro torres individuais, as percentagens da resistência pico obtidas ao realizar ensaios de compressão uniaxial em cada corpo de prova depois do ensaio de fluência de longa duração e a variação da tensão ao longo do ensaio.

Tabela 3.11 Níveis de tensão médios alcançados e percentagem da resistência pico alcançados no carregamento nas quatro torres individuais

\begin{tabular}{lcccc}
\hline & & \multicolumn{3}{c}{ Condição do carregamento } \\
\cline { 3 - 5 } Corpo de Prova & Carregamento & $\begin{array}{c}\text { Tensão } \\
(\mathrm{MPa})\end{array}$ & $\begin{array}{c}\text { Variação da tensão } \\
\text { ao longo do ensaio }\end{array}$ & $\begin{array}{c}\text { Percentagem da } \\
\text { resistência pico } \\
(\%)\end{array}$ \\
\hline GBfluencia11 & $\begin{array}{c}\text { Perpendicular às } \\
\text { camadas }\end{array}$ & 21,30 & $2,1 \%$ & 74 \\
GBfluencia12 & $\begin{array}{c}\text { Perpendicular às } \\
\text { camadas }\end{array}$ & 20,38 & $2,4 \%$ & 97 \\
GBfluencia13 & Paralelo às camadas & 21,97 & $4,8 \%$ & 71 \\
GBfluencia14 & Paralelo às camadas & 23,38 & $3,7 \%$ & 87 \\
\hline
\end{tabular}

A Figura 3.67 mostra a configuração geral dos ensaios de fluência de longa duração nos módulos individuais.

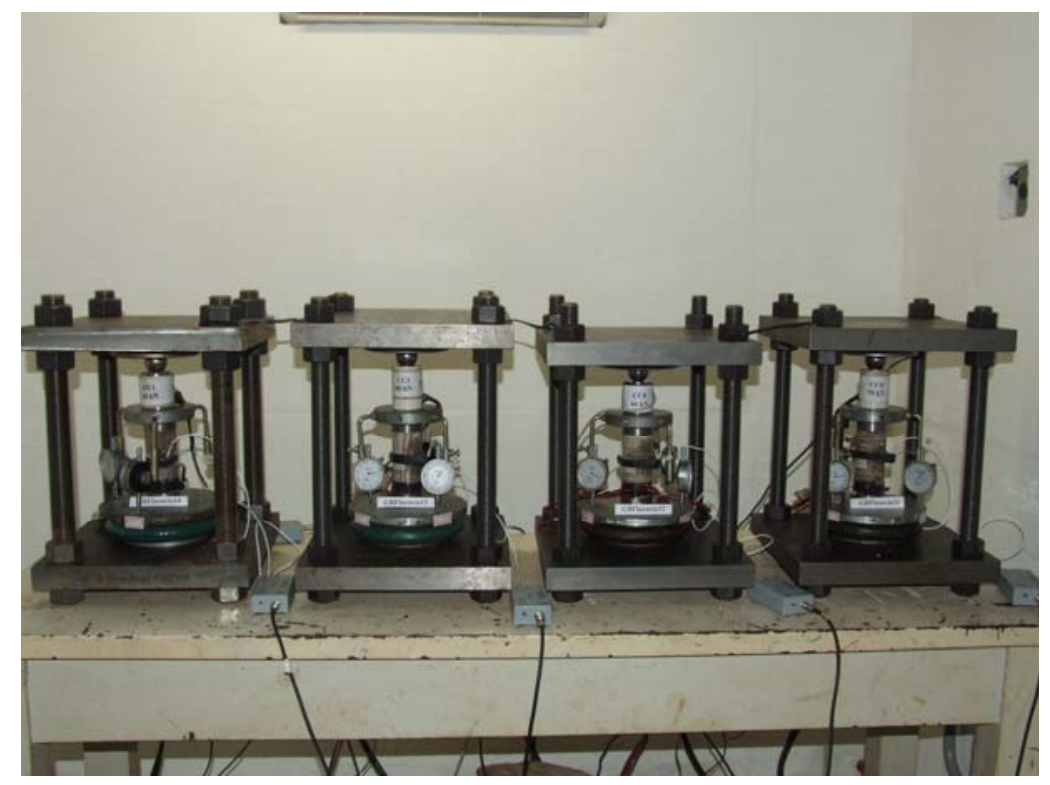

Figura 3.67 Configuração dos ensaios de fluência de longa duração nos módulos individuais dos corpos de prova GBfluencia11, GBfluencia12, GBfluencia13 e GBfluencia14 
A Figura 3.68 mostra o detalhe de um corpo de prova instrumentado com três relógios comparadores e dois extensômetros elétricos em roseta dupla (para registrar os deslocamentos axiais e deformações dos corpos de prova) e dois sensores piezoelétricos de $175 \mathrm{kHz}$ de freqüência característica (para registrar os eventos de emissão acústica). A medição de cargas foi feita através de células de carga à base de extensômetros elétricos.

Foram selecionadas duas faixas estreitas de freqüência diferentes por meio de filtros disponíveis no sistema de aquisição de dados:

a) Freqüências baixas (de 20 a $100 \mathrm{kHz}$ ) e

b) Freqüências intermediárias (de 100 a 400 kHz).

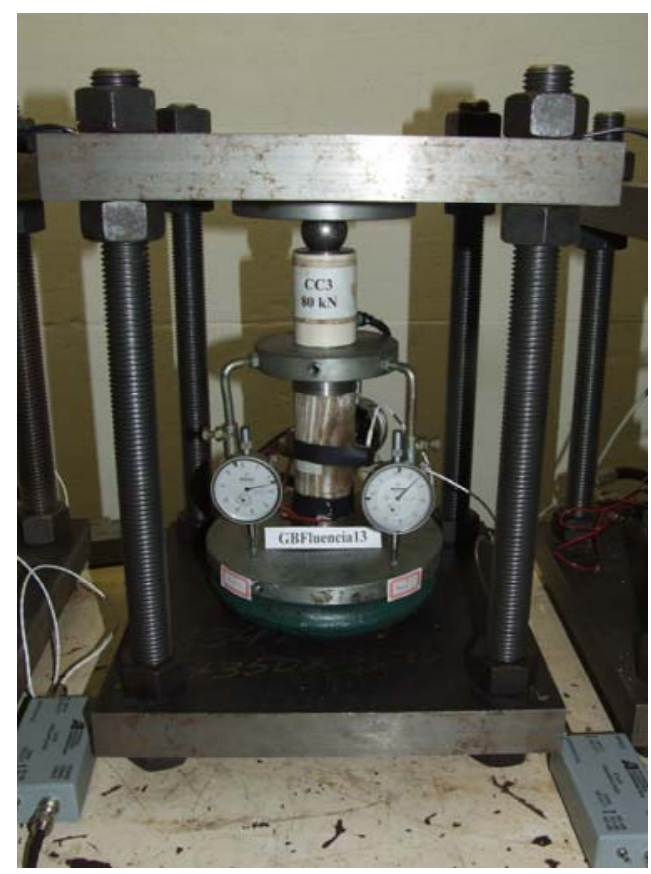

Figura 3.68 Detalhe da instrumentação do corpo de prova GBfluencia13

Após 15 dias de ensaio, os corpos de prova foram descarregados instantaneamente e submetidos a um ensaio de compressão uniaxial.

A representação típica dos resultados é mostrada na Figura 3.69. 


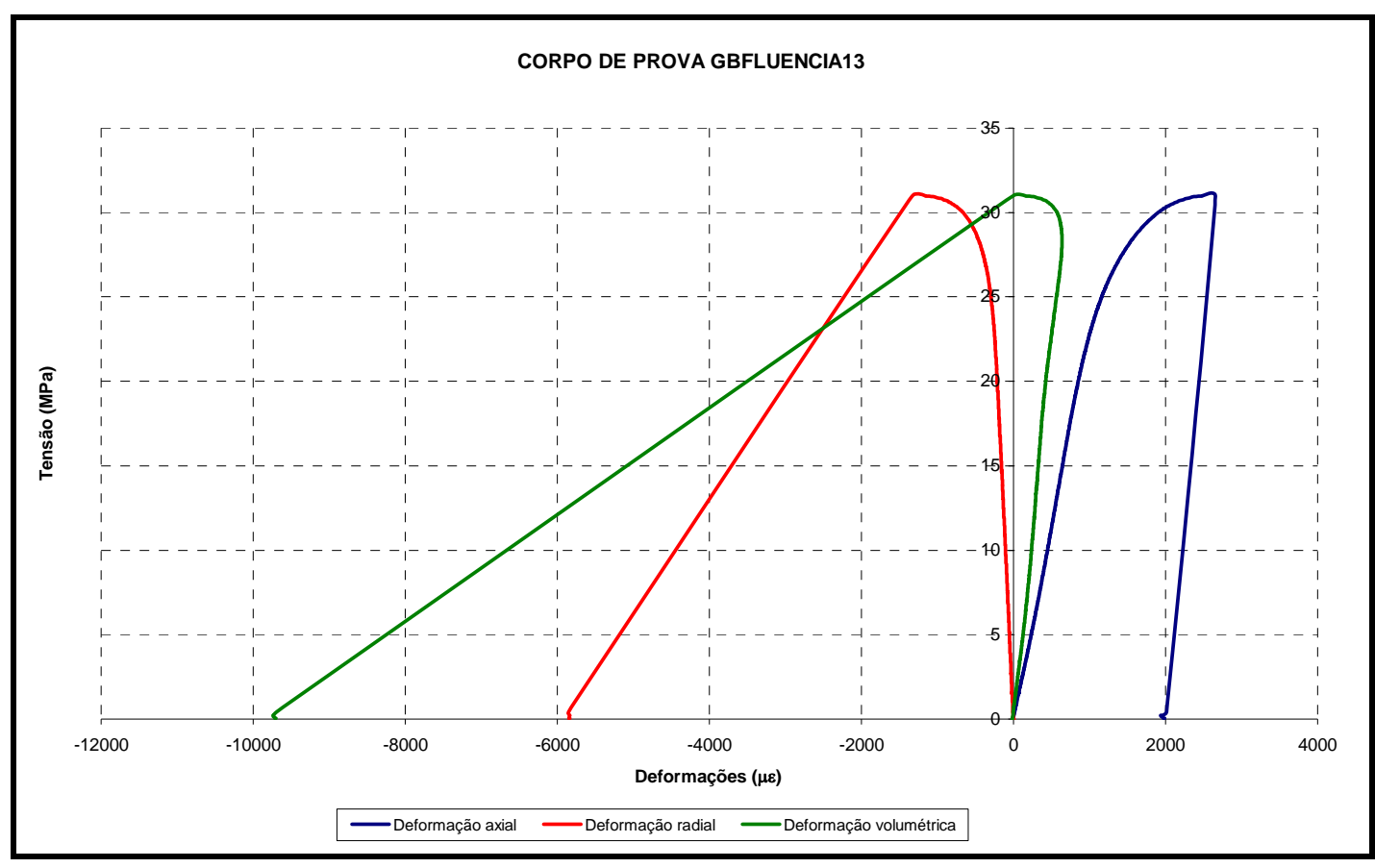

Figura 3.69 Tensão versus deformações axial, radial e volumétrica no ensaio de compressão uniaxial no corpo de prova GBfluencia13 posterior ao ensaio de fluência de longa duração

\subsubsection{Ensaios especiais de fluência de curta duração com ciclos de acréscimos de carregamento anteriores e posteriores ao descarregamento}

Foram realizados 3 ensaios de fluência de curta duração (3-6 horas) na prensa hidráulica servocontrolada com ciclos de acréscimos de carregamento anteriores e posteriores aos descarregamentos com a finalidade de comprovar se o descarregamento provoca propagação das microfissuras. Compararam-se para isto os módulos de elasticidade dos ciclos anteriores e posteriores ao descarregamento.

As características dos três ensaios são apresentadas na Tabela 3.12.

Uma curva típica obtida neste tipo de ensaio se mostra na Figura 3.70. Os três corpos de prova foram submetidos a uma taxa de carregamento e descarregamento constante de 4,5 e $18 \mathrm{kN} / \mathrm{min}$ respectivamente. As freqüências dos ciclos de carregamento anteriores e posteriores aos descarregamentos foram as mesmas. 
Tabela 3.12 Ensaios especiais de fluência de curta duração com ciclos de acréscimos de carregamento anteriores e posteriores ao descarregamento

\begin{tabular}{|c|c|c|c|}
\hline Corpo de prova & GBEA14 & GBEA25 & GBEA24 \\
\hline Condição de carregamento & $\begin{array}{l}\text { Perpendicular às } \\
\text { camadas }\end{array}$ & $\begin{array}{l}\text { Paralelo às } \\
\text { camadas }\end{array}$ & $45^{\circ}$ com camadas \\
\hline $\begin{array}{l}\text { Freqüência dos ciclos de } \\
\text { acréscimos de carregamento }(\mathrm{Hz})\end{array}$ & 0,25 & 0,025 & 0,004 \\
\hline $\begin{array}{l}\text { Velocidade de carregamento nos } \\
\text { ciclos de acréscimos de } \\
\text { carregamento }\end{array}$ & $1,14 \mathrm{MPa} / \mathrm{s}$ & $6,82 \mathrm{MPa} / \mathrm{min}$ & $1,14 \mathrm{MPa} / \mathrm{min}$ \\
\hline $\begin{array}{l}\text { Nível de tensão de fluência } \\
\text { aplicado (MPa) }\end{array}$ & $\begin{array}{c}18,15 \\
(74,4 \%)\end{array}$ & $\begin{array}{c}20,50 \\
(73,7 \%)\end{array}$ & $\begin{array}{c}18,16 \\
(60,5 \%)\end{array}$ \\
\hline $\begin{array}{l}\text { Tensão máxima do acréscimo de } \\
\text { carregamento }(\mathrm{MPa})\end{array}$ & $\begin{array}{c}20,40 \\
(83,6 \%)\end{array}$ & $\begin{array}{c}22,78 \\
(81,9 \%)\end{array}$ & $\begin{array}{c}20,42 \\
(68,1 \%)\end{array}$ \\
\hline Tensão de ruptura (MPa) & 24,40 & 27,80 & 30,00 \\
\hline $\begin{array}{c}\mathrm{N}^{\circ} \text { ciclos antes do primeiro } \\
\text { descarregamento }\end{array}$ & 11 & 6 & 5 \\
\hline $\begin{array}{c}\mathrm{N}^{\circ} \text { ciclos antes do segundo } \\
\text { descarregamento }\end{array}$ & 7 & 6 & 5 \\
\hline $\begin{array}{c}\mathrm{N}^{\circ} \text { ciclos antes do terceiro } \\
\text { descarregamento }\end{array}$ & - & 7 & - \\
\hline
\end{tabular}

Os corpos de prova foram submetidos a um ensaio de fluência de curta duração (de 3-6 horas) até os níveis de tensão de fluência indicados na Tabela 3.12. Em seguida, procedeu-se à aplicação de ciclos de acréscimos ( $8 \%$ da tensão de ruptura) de carregamentos como mostrado na Figura 3.71. Prosseguindo, descarregou-se e recarregou-se completamente o corpo de prova, aplicando-se novo carregamento cíclico. Seguiu-se novo descarregamento completo e recarregamento até a ruptura.

Cada corpo de prova foi instrumentado com dois extensômetros elétricos em roseta dupla colados na sua parte central e com dois sensores piezoelétricos de $175 \mathrm{kHz}$ de freqüência característica.

Foram selecionadas duas faixas estreitas de freqüências diferentes por meio de filtros analógicos disponíveis no sistema de aquisição de dados:

a) Freqüências baixas (de 20 a 100 kHz) e

b) Freqüências intermediárias (de 100 a 400 kHz). 


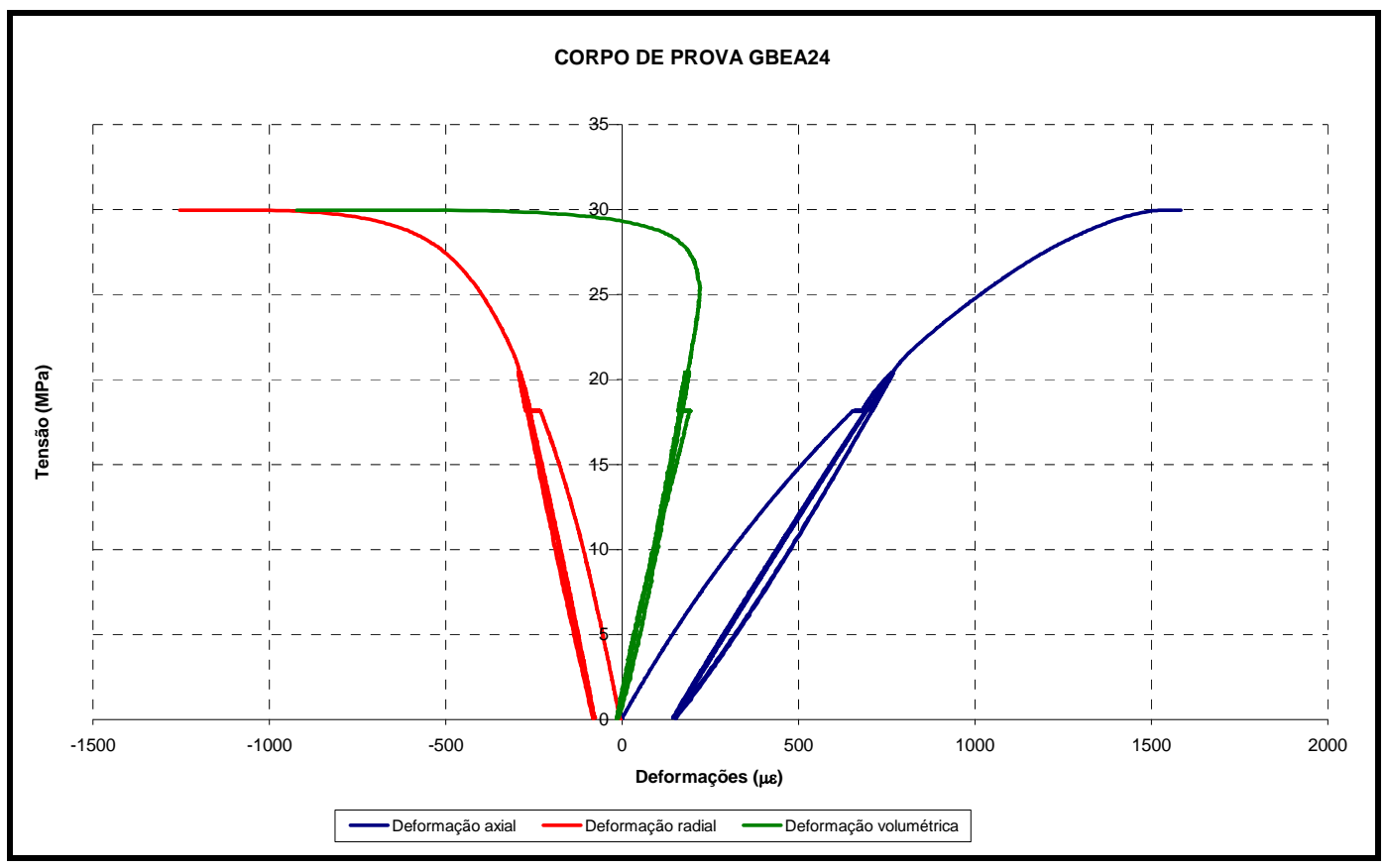

Figura 3.70 Tensão versus deformações axial, radial e volumétrica no ensaio especial de fluência de curta duração com ciclos de acréscimos de carregamento anteriores e posteriores ao descarregamento no corpo de prova GBEA24

Uma curva tensão versus tempo típica destes ensaios é mostrada na Figura 3.71.

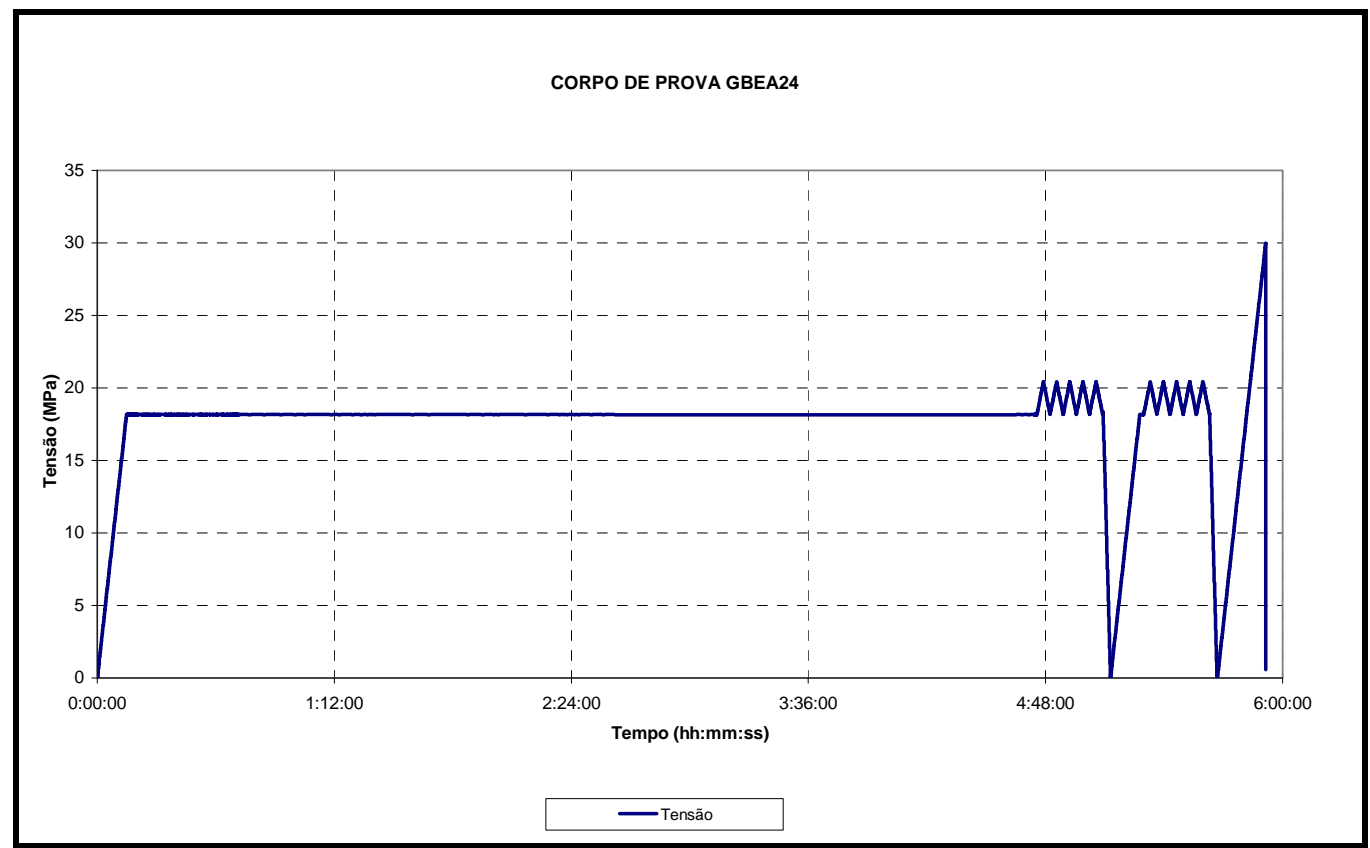

Figura 3.71 Curva tensão versus tempo correspondente ao ensaio especial de fluência de curta duração com ciclos de acréscimos de carregamento anteriores e posteriores ao descarregamento no corpo de prova GBEA24 
3.12.6. Ensaio especial de compressão uniaxial com ciclos variáveis de carregamento antes e após o pico de resistência (Complemento do Tipo CVIII)

Este tipo de ensaio repete os procedimentos do ensaio tipo CVIII descrito no item 3.12.2.3, porém prosseguindo com carregamento cíclico após o pico, conforme Figura 3.72. Após descarregamento total e decorridas 3 horas, o corpo de prova foi submetido a ensaio de compressão uniaxial com controle de força, como mostra a Figura 3.73.

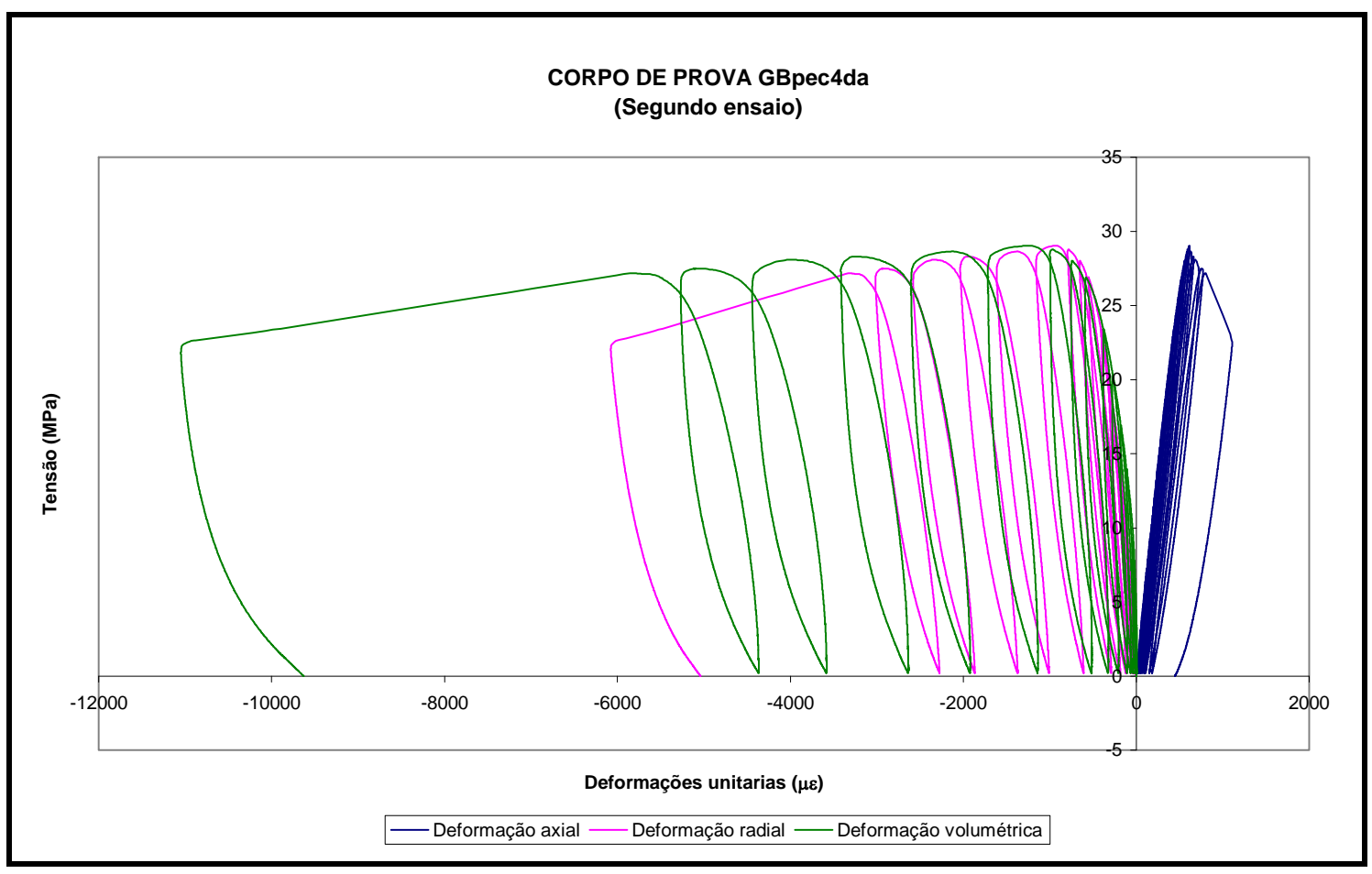

Figura 3.72 Tensão versus deformações axial, radial e volumétrica no ensaio de carregamento e descarregamento antes e após o pico de resistência no corpo de prova GBpec4da (Segundo ensaio no mesmo corpo de prova). Note-se que o corpo de prova foi ensaiado até a região pós-pico 


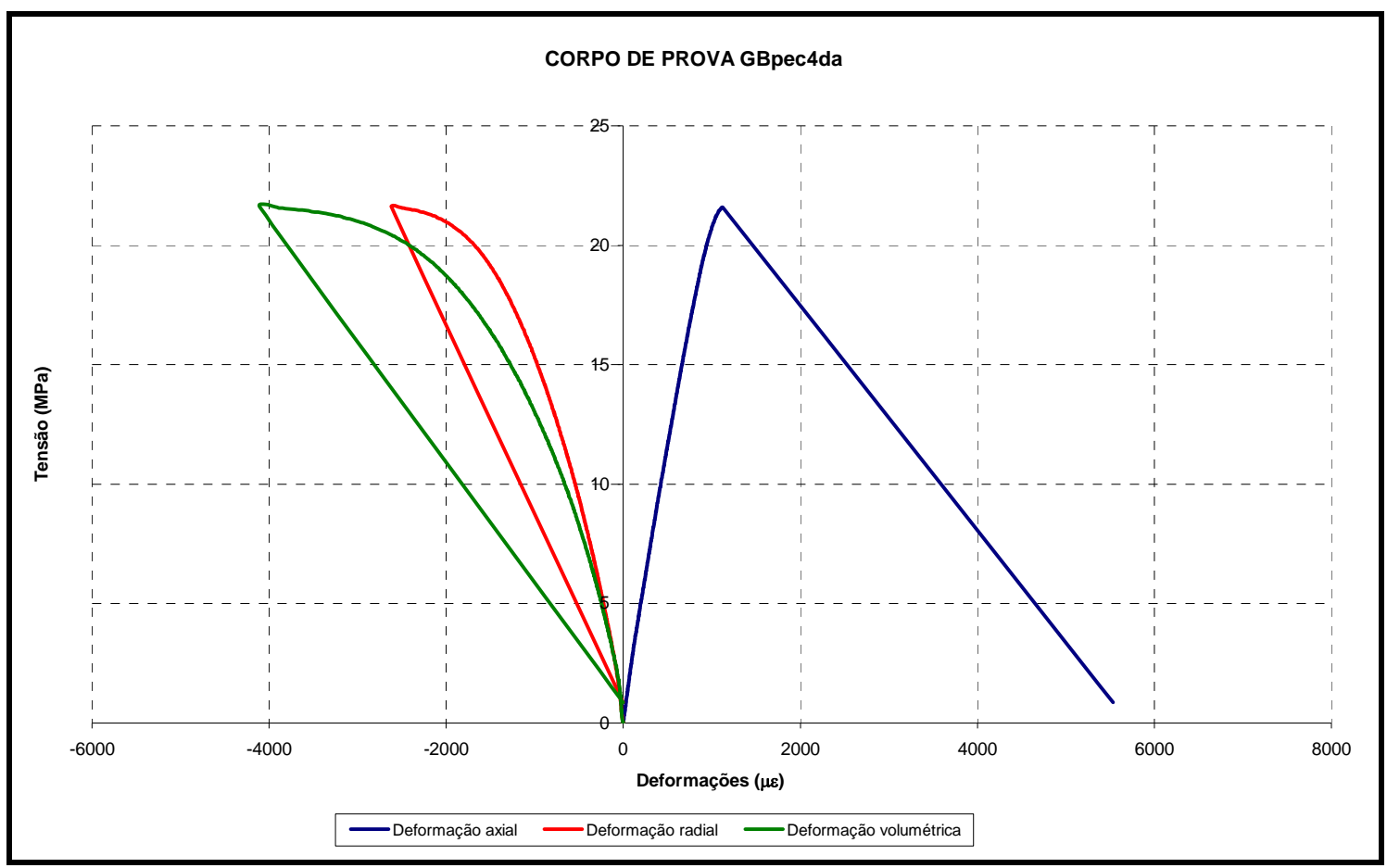

Figura 3.73 Tensão versus deformações axial, radial e volumétrica no ensaio de compressão uniaxial do corpo de prova GBpec4da após ter sido submetido a dois ensaios de carregamento e descarregamento antes e após o pico de resistência (Terceiro ensaio no mesmo corpo de prova) 


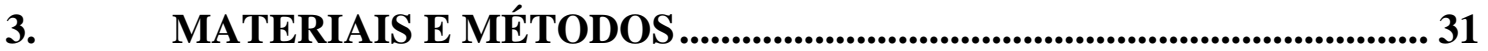

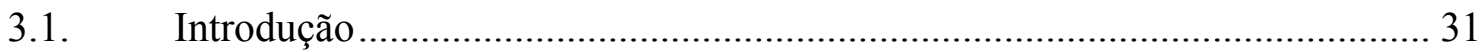

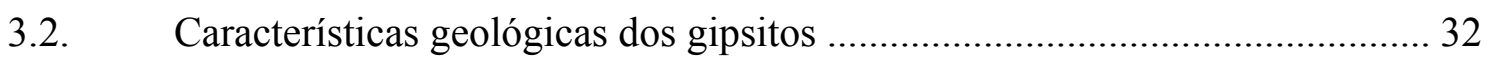

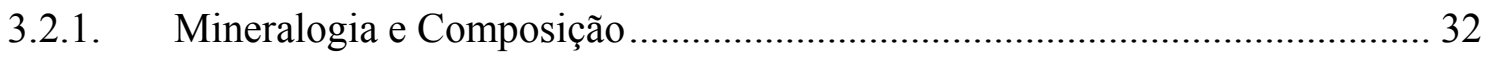

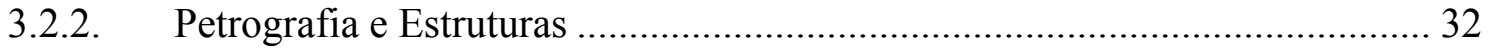

3.3. Gipsitos da Formação Santana (Cretáceo inferior), Chapada do Araripe

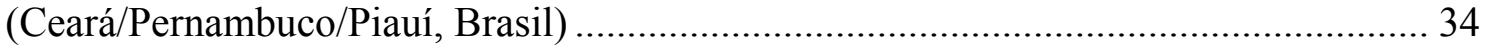

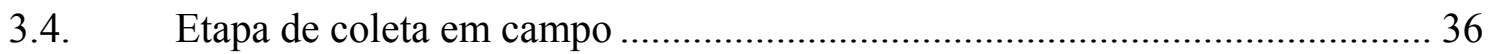

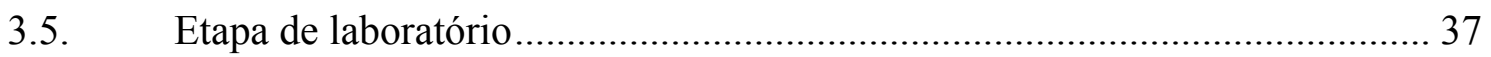

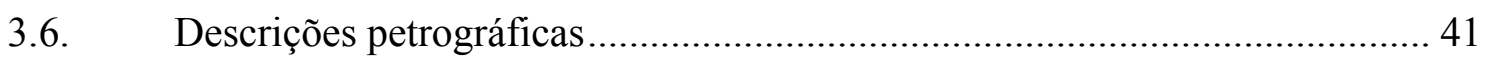

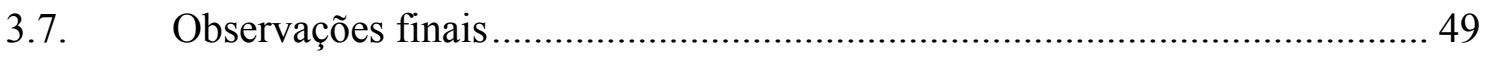

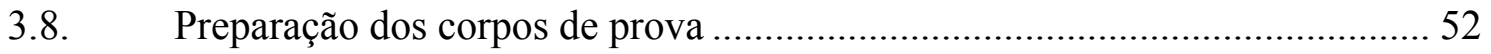

3.9. Instrumentação dos corpos de prova e calibração do equipamento de

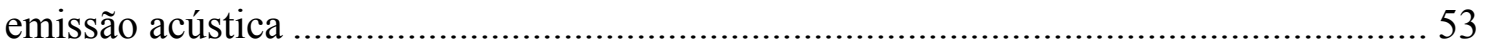

3.9.1. Instrumentação dos corpos de prova ................................................................ 53

3.9.2. Calibração do equipamento de emissão acústica............................................ 56

3.10. Sistema de carregamento e instrumentação dos ensaios de deformação

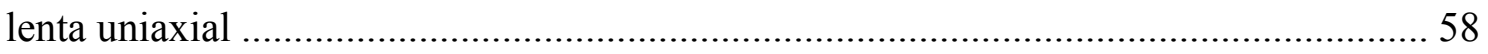

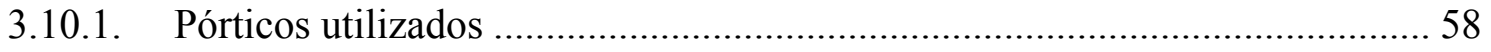

3.10.2. Sistema de aplicação, controle e regulagem da carga .................................... 59

3.11. Sistemas de aquisição e armazenamento dos dados ...................................... 63

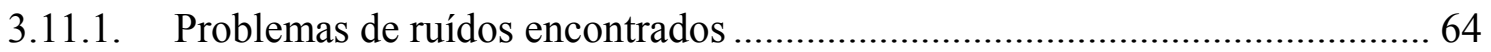

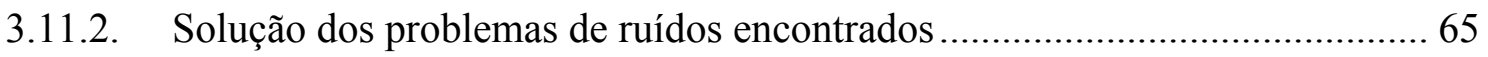

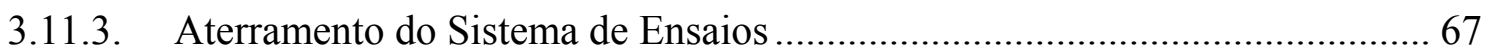

3.11.4. Alteração na Unidade Mecânica Hidráulica.................................................. 70

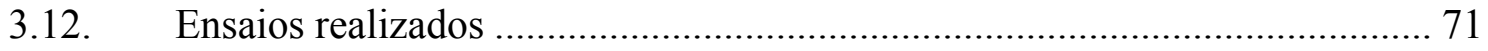

3.12.1. Ensaios de compressão uniaxial com uso da técnica de emissão acústica ..... 71

3.12.2. Ensaios de compressão uniaxial com ciclos variáveis de carregamento

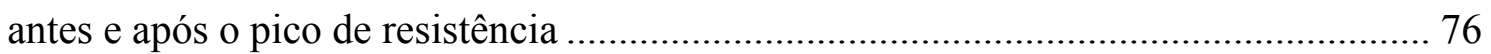

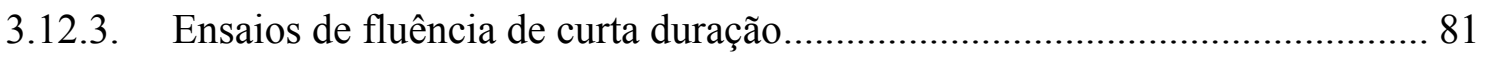

3.12.4. Ensaios de fluência de longa duração......................................................... 88 
3.12.5. Ensaios especiais de fluência de curta duração com ciclos de acréscimos de carregamento anteriores e posteriores ao descarregamento.

3.12.6. Ensaio especial de compressão uniaxial com ciclos variáveis de carregamento antes e após o pico de resistência (Complemento do Tipo CVIII)

Figura 3.1 Microfotografias do gipso. (a-b) Cristais de gipso preenchendo uma cavidade em dolomito mostrando a típica cor de interferência cinza de primeira ordem. (a) nicol paralelo, (b) nicol cruzado

Figura 3.2 Mapa de localização e esquema estratigráfico - Chapada de Araripe 35

Figura 3.3 Exemplo da forma de ocorrência dos afloramentos do gipsito bandado ...... 36

Figura 3.4 Exemplos de amostras coletadas em campo: observe-se detalhe de ondulações (dobramentos suaves) e de cristais com estrutura fibro-radiada.

Figura 3.5 Amostra GBA3 apresentando corte realizado na amostra em duas direções (uma perpendicular à outra)

Figura 3.6 Seções na amostra GBC1

Figura 3.7 Seção na amostra GBC2

Figura 3.8 Amostra 8 que na tentativa de gerar uma nova seção desagregou-se

Figura 3.9 Aspectos gerais da rocha, com destaque para o bandamento e orientação dos cristais observados e fotografiados em lupa com nicóis cruzados

Figura 3.10 Banda de granulação mais fina formada por cristais de gipso alongados e orientados e equidimensionais sem inclusões de anidrita. Nicóis cruzados. Amostra GBA3

Figura 3.11 Banda de granulação mais grossa, com cristais de gipso ricos em minúsculas inclusões de anidrita. Nicóis cruzados. Amostra GBC1

Figura 3.12 Detalhe do cristal de barita ou celestita com inclusões de anidrita na amostra GBC2-C. Nicóis cruzados

Figura 3.13 Contato brusco entre as bandas finas e grossas e detalhe da banda de granulação mais grossa com cristal de barita ou celestita. Nicóis cruzados. 
Figura 3.14 Imagem de banda de granulação mais fina entre bandas de granulação mais grossa, com cristais de gipso ricos em inclusões de anidrita. Nicóis cruzados. Amostra GBC1

Figura 3.15 Detalhe da banda de granulação mais grossa mostrando cristais de gipso com inclusões de anidrita. Nicóis cruzados

Figura 3.16 Relação entre as duas bandas, a primeira de granulação grossa, alongada intercalada por granulação mais fina ambas formadas por cristais de gipso alongados e orientados e equidimensionais. Nicóis cruzados. Amostra GBC2-A

Figura 3.17 Modelo esquemático da formação das bandas composicionais 49

Figura 3.18 Corpos de prova colocados em um dessecador.

Figura 3.19 Extensômetros elétricos de resistência em roseta dupla colado no corpo de prova

Figura 3.20 Detalhe do sensor modelo D9203B

Figura 3.21 Detalhe do pré-amplificador 55

Figura 3.22 Detalhe do sensor com o acoplante no corpo de prova

Figura 3.23 Configuração do teste para estudar a sensibilidade mediante a quebra do grafite de dureza $2 \mathrm{H}$

Figura 3.24 Pórtico de reação tipo coluna utilizado para ensaios de deformação lenta uniaxial

Figura 3.25 Conjunto modular (torre individual) utilizado para ensaios de deformação lenta uniaxial.

Figura 3.26 a) Bomba hidráulica ligada aos dois painéis de controle instalada fora do laboratório de fluência para evitar interferências nas medições com o equipamento de emissão acústica. b) Painel de controle mostrando os manômetros utilizados para sua construção

Figura 3.27 Painel de controle dentro da qual se encontra o pressostato

Figura 3.28 Painéis reguladores de carga 
Figura 3.29 Detalhe do acumulador de pressão colocado para manter a pressão constante no macaco plano tórico

Figura 3.30 Detalhe dos cabos isolados com fita crepe. 66

Figura 3.31 Detalhe dos sensores colocados fora dos corpos de prova. 66

Figura 3.32 Detalhe dos fios de cobre utilizados para manter a mesma voltagem nas torres individuais

Figura 3.33 Vala escavada para implantação do fio e barras metálicas de cobre para aterramento

Figura 3.34 Interligação com cabo de cobre. 68

Figura 3.35 Detalhe da cabeça da haste de cobre interligada com o cabo de cobre. 69

Figura 3.36 Derivação do fio terra.

Figura 3.37 Detalhe do conector, da rosca e da mesa 70

Figura 3.38 Unidade Hidráulica Elétrica e Manual. 70

Figura 3.39 Curva completa tensão versus deformações axial, radial e volumétrica do corpo de prova GBEA3 do ensaio de compressão uniaxial com uso da técnica de emissão acústica.

Figura 3.40 Detalhe da instrumentação do corpo de prova GBEA3. Note-se o sensor piezoelétrico e um dos extensômetros elétricos em roseta dupla colado no corpo de prova

Figura 3.41 Curva tensão versus deformações axial, radial e volumétrica do corpo de prova GBEA18 do ensaio de compressão uniaxial com uso da técnica de emissão acústica

Figura 3.42 Detalhe da instrumentação do corpo de prova GBEA17. Notem-se os quatro sensores piezoelétricos e um dos extensômetros elétricos em roseta dupla colado no corpo de prova

Figura 3.43 Curva tensão versus deformações axial, radial e volumétrica do corpo de prova GBEA11 do ensaio de compressão uniaxial com ciclos variáveis de carregamento antes e após o pico de resistência. 
Figura 3.44 Detalhe da instrumentação do corpo de prova GBEA11. Notem-se os seis sensores piezoelétricos fixados por bandas elásticas e um dos extensômetros elétricos em roseta dupla colado no corpo de prova

Figura 3.45 Curva tensão versus deformações axial, radial e volumétrica do corpo de prova GBEA5 do ensaio de compressão uniaxial com ciclos variáveis de carregamento antes e após o pico de resistência.

Figura 3.46 Detalhe da instrumentação do corpo de prova GBEA5. Notem-se os dois sensores piezoelétricos fixados por bandas elásticas e um dos extensômetros elétricos em roseta dupla colado no corpo de prova.....

Figura 3.47 Curva tensão versus deformações axial, radial e volumétrica do corpo de prova GBpec4da do ensaio de compressão uniaxial com ciclos variáveis de carregamento antes e após o pico de resistência.

Figura 3.48 Detalhe da instrumentação do corpo de prova GBpec4da. Notem-se os quatro sensores piezoelétricos fixados por bandas elásticas e um dos extensômetros elétricos em roseta dupla colado no corpo de prova......

Figura 3.49 Curvas típicas do ensaio de fluência de curta duração realizado na prensa hidráulica servocontrolada no corpo de prova GBEA6. (a) Tensão versus tempo. (b) Deformações axial, radial e volumétrica versus tempo 83

Figura 3.50 Detalhe da instrumentação do corpo de prova GBEA6 84

Figura 3.51 Curvas típicas do ensaio de fluência de curta duração realizado na prensa hidráulica servocontrolada no corpo de prova GBflu4MTS. (a) Tensão versus tempo. (b) Deformações axial, radial e volumétrica versus tempo.

Figura 3.52 Detalhe da instrumentação do corpo de prova GBflu4MTS. Note-se um dos extensômetros elétricos em roseta dupla colado ao corpo de prova. Observe-se que não foram colocados sensores piezoelétricos 86

Figura 3.53 Curvas típicas do ensaio de fluência de curta duração realizado na prensa hidráulica servocontrolada no corpo de prova GBflu6MTS. (a) Tensão versus tempo. (b) Deformações axial, radial e volumétrica versus tempo 
Figura 3.54 Detalhe da instrumentação do corpo de prova GBflu6MTS. Note-se os quatro sensores piezoelétricos fixados por bandas elásticas e um dos extensômetros elétricos em roseta dupla colado ao corpo de prova

Figura 3.55 Configuração dos ensaios de fluência de longa duração nos módulos individuais e painel de controle das cargas aplicadas aos corpos de prova.

Figura 3.56 Curvas típicas do corpo de prova GBEAF4 do ensaio de fluência de longa duração com ciclos variáveis de carregamento e descarregamento. (a) Tensão versus tempo. (b) Deformações axial, radial e volumétrica versus tempo ...... 91

Figura 3.57 Detalhe da instrumentação dos corpos de prova nas torres individuais nos ensaios de fluência de longa duração. Notar os relógios comparadores utilizados e o sensor piezoelétrico fixado por uma banda elástica 93

Figura 3.58 Configuração do ensaio de fluência de longa duração no pórtico de reação tipo coluna e painel de controle de carga aplicada ao corpo de prova GBEAF3

Figura 3.59 Curva tensão versus tempo do corpo de prova GBEAF3 do ensaio de fluência de longa duração submetido a ciclos variáveis de carregamento e descarregamento

Figura 3.60 Detalhe da instrumentação do corpo de prova GBEAF3 no pórtico de reação tipo coluna.

Figura 3.61 Detalhe da instrumentação do corpo de prova GBfluencia10 nas torres individuais nos ensaios de fluência de longa duração

Figura 3.62 Configuração dos ensaios de fluência de longa duração nos módulos individuais. Note-se o corpo de prova GBfluencia7 rompido

Figura 3.63 Configuração do ensaio de fluência de longa duração do corpo de prova GBfluencia8 no pórtico de reação tipo coluna

Figura 3.64 Detalhe da instrumentação do corpo de prova GBfluencia8 no pórtico de reação tipo coluna

Figura 3.65 Curva tensão versus tempo do ensaio de fluência de longa duração (274 horas) no corpo de prova GBfluencia13 
Figura 3.66 Curva deformações axial, radial e volumétrica versus tempo do ensaio de fluência de longa duração (274 horas) no corpo de prova GBfluencia13

Figura 3.67 Configuração dos ensaios de fluência de longa duração nos módulos individuais dos corpos de prova GBfluencia11, GBfluencia12, GBfluencia13 e GBfluencia14

Figura 3.68 Detalhe da instrumentação do corpo de prova GBfluencia13.

Figura 3.69 Tensão versus deformações axial, radial e volumétrica no ensaio de compressão uniaxial no corpo de prova GBfluencia13 posterior ao ensaio de fluência de longa duração

Figura 3.70 Tensão versus deformações axial, radial e volumétrica no ensaio especial de fluência de curta duração com ciclos de acréscimos de carregamento anteriores e posteriores ao descarregamento no corpo de prova GBEA24

Figura 3.71 Curva tensão versus tempo correspondente ao ensaio especial de fluência de curta duração com ciclos de acréscimos de carregamento anteriores e posteriores ao descarregamento no corpo de prova GBEA24.....

Figura 3.72 Tensão versus deformações axial, radial e volumétrica no ensaio de carregamento e descarregamento antes e após o pico de resistência no corpo de prova GBpec4da (Segundo ensaio no mesmo corpo de prova). Note-se que o corpo de prova foi ensaiado até a região pós-pico

Figura 3.73 Tensão versus deformações axial, radial e volumétrica no ensaio de compressão uniaxial do corpo de prova GBpec4da após ter sido submetido a dois ensaios de carregamento e descarregamento antes e após o pico de resistência (Terceiro ensaio no mesmo corpo de prova)

Tabela 3.1 Características mineralógicas e petrográficas do gipso

Tabela 3.2 Composição modal

Tabela 3.3 Propriedades físico-mecânicas da rocha estudada

Tabela 3.4 Ensaios de compressão uniaxial com uso da técnica de emissão acústica 
Tabela 3.5 Ensaios de compressão uniaxial com ciclos variáveis de carregamento antes e após o pico de resistência

Tabela 3.6 Ensaios de fluência de curta duração realizados na prensa hidráulica servocontrolada

Tabela 3.7 Ensaios de fluência de longa duração com temperatura controlada

Tabela 3.8 Níveis de tensão médios alcançados e duração dos ciclos de carregamento e descarregamento correspondentes aos ensaios de fluência de longa duração realizados nas quatro torres individuais

Tabela 3.9 Níveis de tensão médios alcançados e duração dos ciclos de carregamento e descarregamento correspondentes ao ensaio de fluência de longa duração realizado no pórtico de reação tipo coluna

Tabela 3.10 Níveis de tensão médios alcançados e percentagem da resistência pico alcançados no carregamento das quatro torres individuais

Tabela 3.11 Níveis de tensão médios alcançados e percentagem da resistência pico alcançados no carregamento nas quatro torres individuais

Tabela 3.12 Ensaios especiais de fluência de curta duração com ciclos de acréscimos de carregamento anteriores e posteriores ao descarregamento 


\section{RESULTADOS E DISCUSSÃO}

Neste capítulo apresentam-se a discussão e a análise dos resultados obtidos nos diferentes ensaios realizados na presente tese. São analisados os resultados obtidos por cada tipo de ensaio, indicando algumas particularidades ou detalhes especiais que são considerados para explicar os fenômenos observados.

\subsection{Ensaios de compressão uniaxial com uso da técnica de emissão acústica}

A resistência à compressão uniaxial $\left(\sigma_{c}\right)$ foi determinada seguindo a Norma ASTM D2938-95 "Standard Test Method for Unconfined Compressive Strength of Intact Rock Core Specimens" reaprovada em 2002; o módulo de elasticidade $(E)$ segundo a ISRM (1979b) e o coeficiente de Poisson conforme método sugerido pela ISRM (1999). Os detalhes das características dos equipamentos utilizados e da instrumentação dos corpos de prova foram descritos, conforme item 3.9.1.

Analisando os resultados obtidos de ensaios de compressão uniaxial com controle de deslocamento do prato e controle de força nas direções perpendicular e 
paralela às camadas observa-se uma anisotropia da rocha estudada (Tabelas 4.1 e 4.2).

A resistência à compressão uniaxial é maior nos corpos de prova submetidos a carregamento na direção paralela às camadas que nos corpos de prova submetido a carregamento na direção perpendicular às camadas (contrariamente ao esperado) devido à orientação preferencial do crescimento dos cristais na direção perpendicular às camadas como descrito no item 3.7. Isto é devido provavelmente a esforços deformacionais atectônicos horizontais que causaram uma compressão da rocha na direção perpendicular ao crescimento dos cristais.

Tabela 4.1 Resultados do ensaio de compressão uniaxial com controle de deslocamento do prato de $0,03 \mathrm{~mm} / \mathrm{min}$

\begin{tabular}{|c|c|c|c|c|c|}
\hline \multicolumn{6}{|c|}{ Direção perpendicular às camadas-1 sensor } \\
\hline $\begin{array}{l}\text { Corpo de } \\
\text { prova }\end{array}$ & $\begin{array}{c}\sigma_{\mathrm{c}} \\
(\mathrm{MPa})\end{array}$ & $\begin{array}{c}\text { Módulo de } \\
\text { Elasticidade } \\
\text { (GPa) } \\
\end{array}$ & $\begin{array}{l}\text { Coeficiente } \\
\text { de Poisson }\end{array}$ & $\begin{array}{c}\text { Velocidade } \\
\text { sônica }(\mathbf{k m} / \mathbf{s})\end{array}$ & $\begin{array}{c}\text { Massa específica } \\
\text { aparente seca } \\
\left(\mathrm{g} / \mathrm{cm}^{3}\right) \\
\end{array}$ \\
\hline GBEA1 & 25,18 & 25,98 & 0,24 & n.d. & 2,30 \\
\hline GBEA2 & 22,47 & 43,41 & 0,34 & n.d. & 2,29 \\
\hline \multicolumn{6}{|c|}{ Direção paralela às camadas-1 sensor } \\
\hline $\begin{array}{l}\text { Corpo de } \\
\text { prova }\end{array}$ & $\begin{array}{c}\sigma_{\mathrm{c}} \\
(\mathbf{M P a})\end{array}$ & $\begin{array}{c}\text { Módulo de } \\
\text { Elasticidade } \\
\text { (GPa) }\end{array}$ & $\begin{array}{l}\text { Coeficiente } \\
\text { de Poisson }\end{array}$ & $\begin{array}{c}\text { Velocidade } \\
\text { sônica }(\mathbf{k m} / \mathbf{s})\end{array}$ & $\begin{array}{c}\text { Massa específica } \\
\text { aparente seca } \\
\left(\mathrm{g} / \mathrm{cm}^{\mathbf{3}}\right)\end{array}$ \\
\hline GBEA3 & 28,17 & 46,22 & 0,24 & n.d. & 2,29 \\
\hline GBEA4 & 27,38 & 18,22 & 0,17 & n.d. & 2,30 \\
\hline
\end{tabular}

Tabela 4.2 Resultados do ensaio de compressão uniaxial com controle de força de 4,50 $\mathrm{kN} / \mathrm{min}$

\begin{tabular}{|c|c|c|c|c|c|}
\hline \multicolumn{6}{|c|}{ Direção perpendicular às camadas-4 sensores } \\
\hline $\begin{array}{l}\text { Corpo de } \\
\text { prova }\end{array}$ & $\sigma_{\mathrm{c}}(\mathrm{MPa})$ & $\begin{array}{c}\text { Módulo de } \\
\text { Elasticidade } \\
\text { (GPa) }\end{array}$ & $\begin{array}{l}\text { Coeficiente } \\
\text { de Poisson }\end{array}$ & $\begin{array}{c}\text { Velocidade } \\
\text { sônica } \\
(\mathbf{k m} / \mathbf{s}) \\
\end{array}$ & $\begin{array}{c}\text { Massa específica } \\
\text { aparente seca }\left(\mathrm{g} / \mathrm{cm}^{3}\right)\end{array}$ \\
\hline GBEA17 & 22,90 & 39,04 & 0,33 & 4,59 & 2,30 \\
\hline GBEA18 & 21,73 & 32,18 & 0,37 & 4,40 & 2,30 \\
\hline GBEA22 & 27,49 & 51,68 & 0,29 & 4,74 & 2,30 \\
\hline GBflu7MTS & 21,55 & 55,24 & 0,29 & 4,44 & 2,29 \\
\hline GBpec3da & 21,22 & 47,50 & 0,29 & 4,58 & 2,29 \\
\hline \multicolumn{6}{|c|}{ Direção paralela às camadas-4 sensores } \\
\hline $\begin{array}{l}\text { Corpo de } \\
\text { prova }\end{array}$ & $\sigma_{\mathrm{c}}(\mathrm{MPa})$ & $\begin{array}{c}\text { Módulo de } \\
\text { Elasticidade } \\
\text { (GPa) } \\
\end{array}$ & $\begin{array}{l}\text { Coeficiente } \\
\text { de Poisson }\end{array}$ & $\begin{array}{c}\text { Velocidade } \\
\text { sônica } \\
(\mathbf{k m} / \mathbf{s}) \\
\end{array}$ & $\begin{array}{c}\text { Massa específica } \\
\text { aparente seca }\left(\mathrm{g} / \mathrm{cm}^{3}\right)\end{array}$ \\
\hline GBEA19 & 24,53 & 53,35 & 0,31 & 4,18 & 2,30 \\
\hline GBEA20 & 21,26 & 35,10 & 0,15 & 4,28 & 2,31 \\
\hline GBEA21 & 27,02 & 38,29 & 0,40 & 4,52 & 2,32 \\
\hline GBEA23 & 23,06 & 16,12 & 0,26 & 4,17 & 2,29 \\
\hline
\end{tabular}


Quanto aos registros dos eventos de emissão acústica nos ensaios de compressão uniaxial com controle do deslocamento do prato e com controle de força se pode concluir que:

- A máxima contagem e a máxima energia absoluta dos eventos de emissão acústica não coincidem nos ensaios com controle do deslocamento. A máxima contagem ocorre após o pico de resistência, enquanto a máxima energia absoluta ocorre antes do pico de resistência. Isto pode ser observado, por exemplo, nas Figuras 4.1 e 4.2, que apresentam o histórico de carregamento e contagem e o histórico de carregamento e energia absoluta, respectivamente, de eventos de emissão acústica no corpo de prova GBEA2 (carregamento perpendicular às camadas).

- $\quad$ Nos ensaios com controle de força, a máxima contagem e a máxima energia absoluta dos eventos de emissão acústica coincidem com o pico de resistência do corpo de prova GBEA18 (carregamento perpendicular às camadas), como mostrado nas Figuras 4.3 e 4.4.

Nas Figuras 4.5 e 4.6 são apresentados gráficos típicos de tensão e energia absoluta acumulada versus tempo dos eventos de emissão acústica nos corpos de prova GBEA2 e GBEA18, respectivamente. 


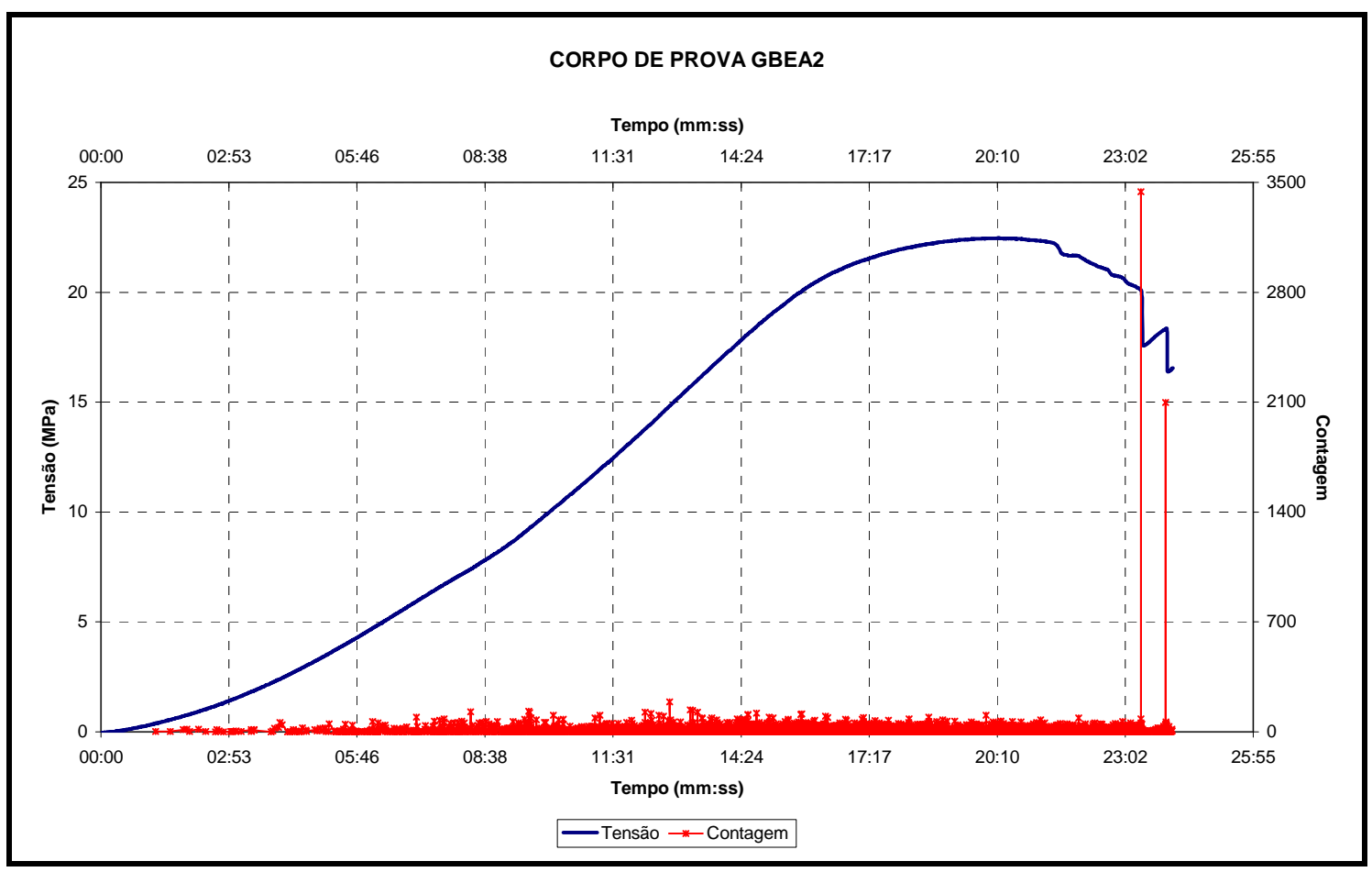

Figura 4.1 Tensão e contagem versus tempo dos eventos de emissão acústica do ensaio de compressão uniaxial no corpo de prova GBEA2 (controle de deslocamento do prato e carregamento perpendicular às camadas)

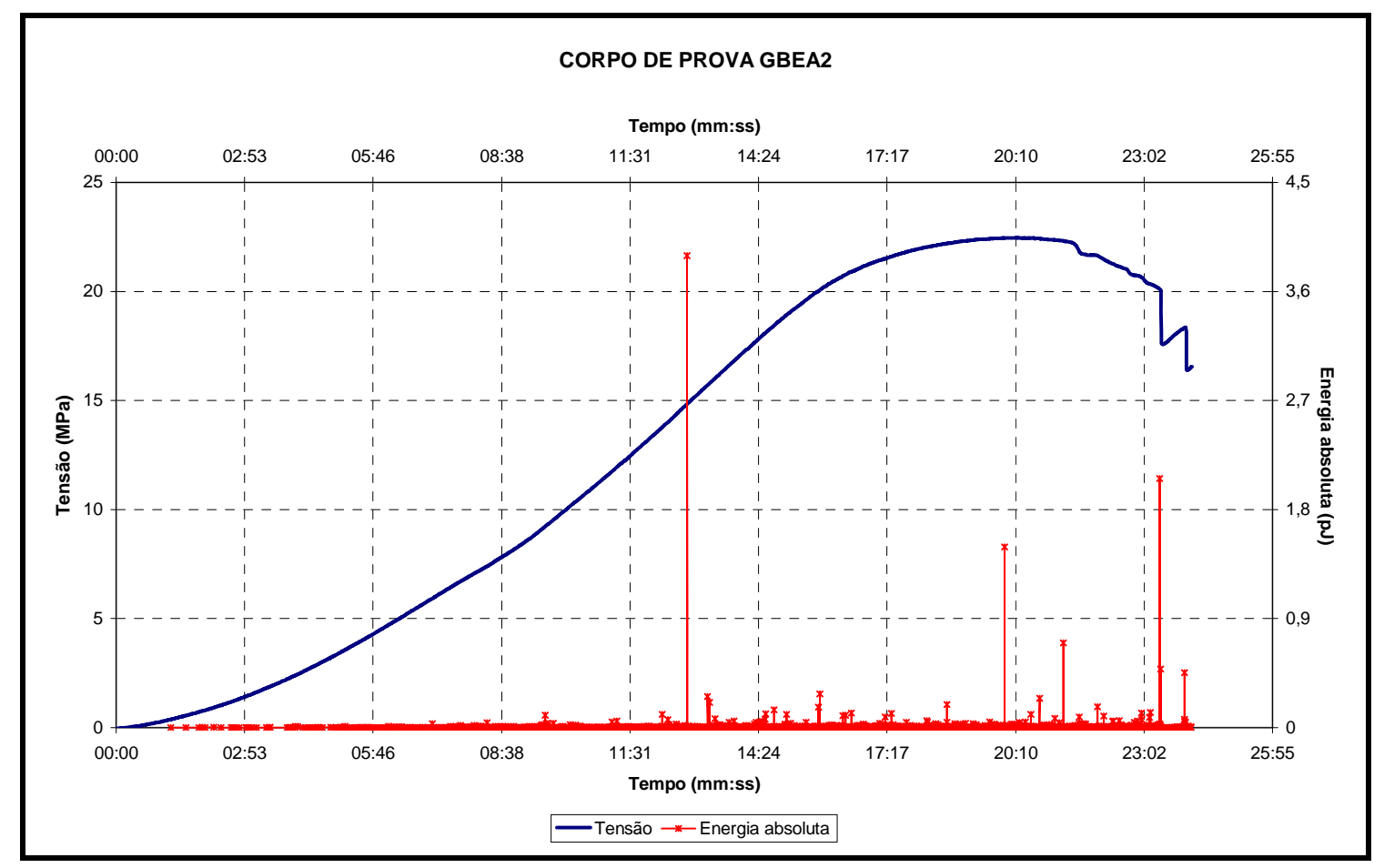

Figura 4.2 Tensão e energia absoluta versus tempo dos eventos de emissão acústica do ensaio de compressão uniaxial no corpo de prova GBEA2 (controle de deslocamento do prato e carregamento perpendicular às camadas) 


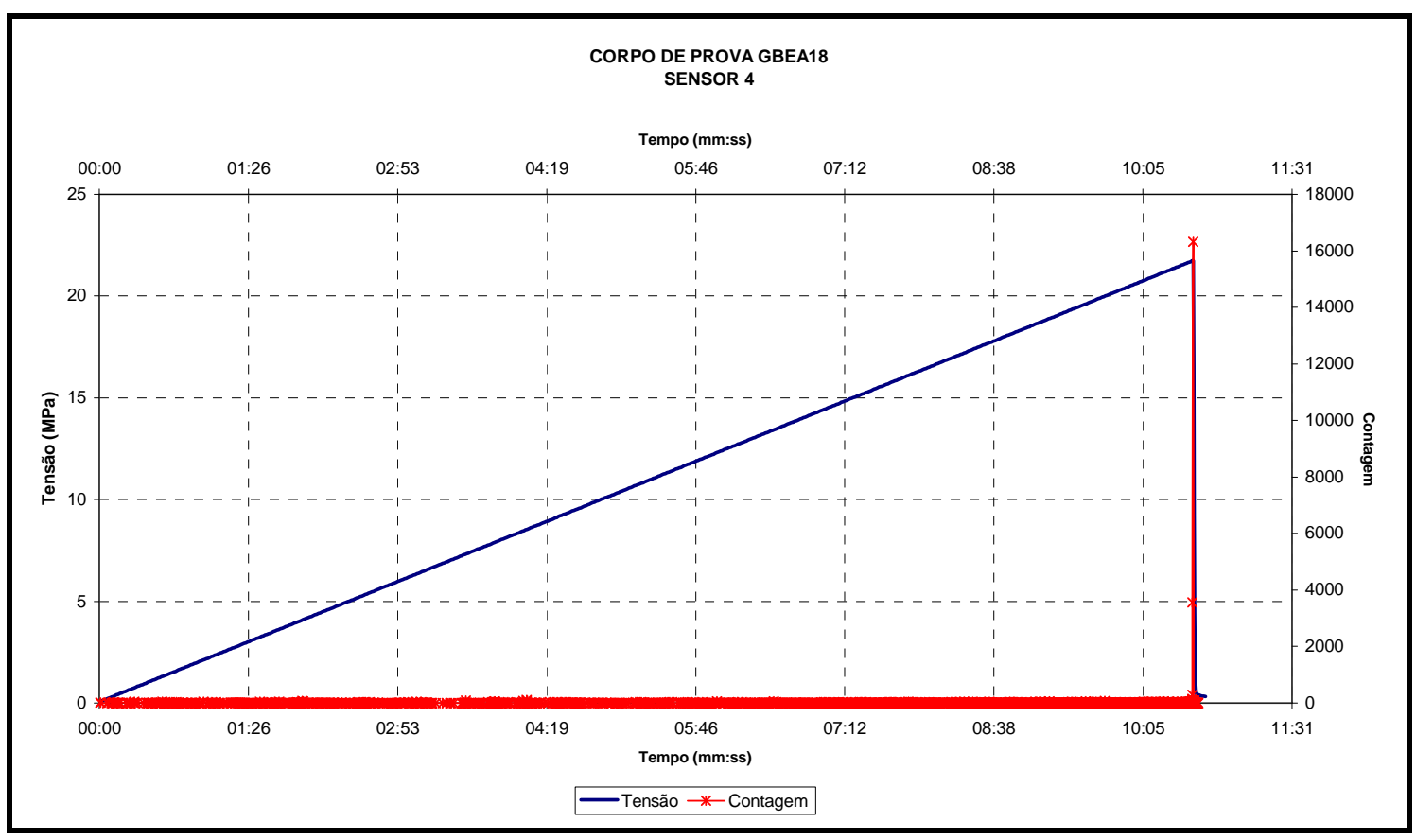

Figura 4.3 Tensão e contagem versus tempo dos eventos de emissão acústica no sensor 4 (freqüências intermediárias de 100 a $400 \mathrm{kHz}$ ) do ensaio de compressão uniaxial no corpo de prova GBEA18 (controle de força e carregamento perpendicular às camadas)

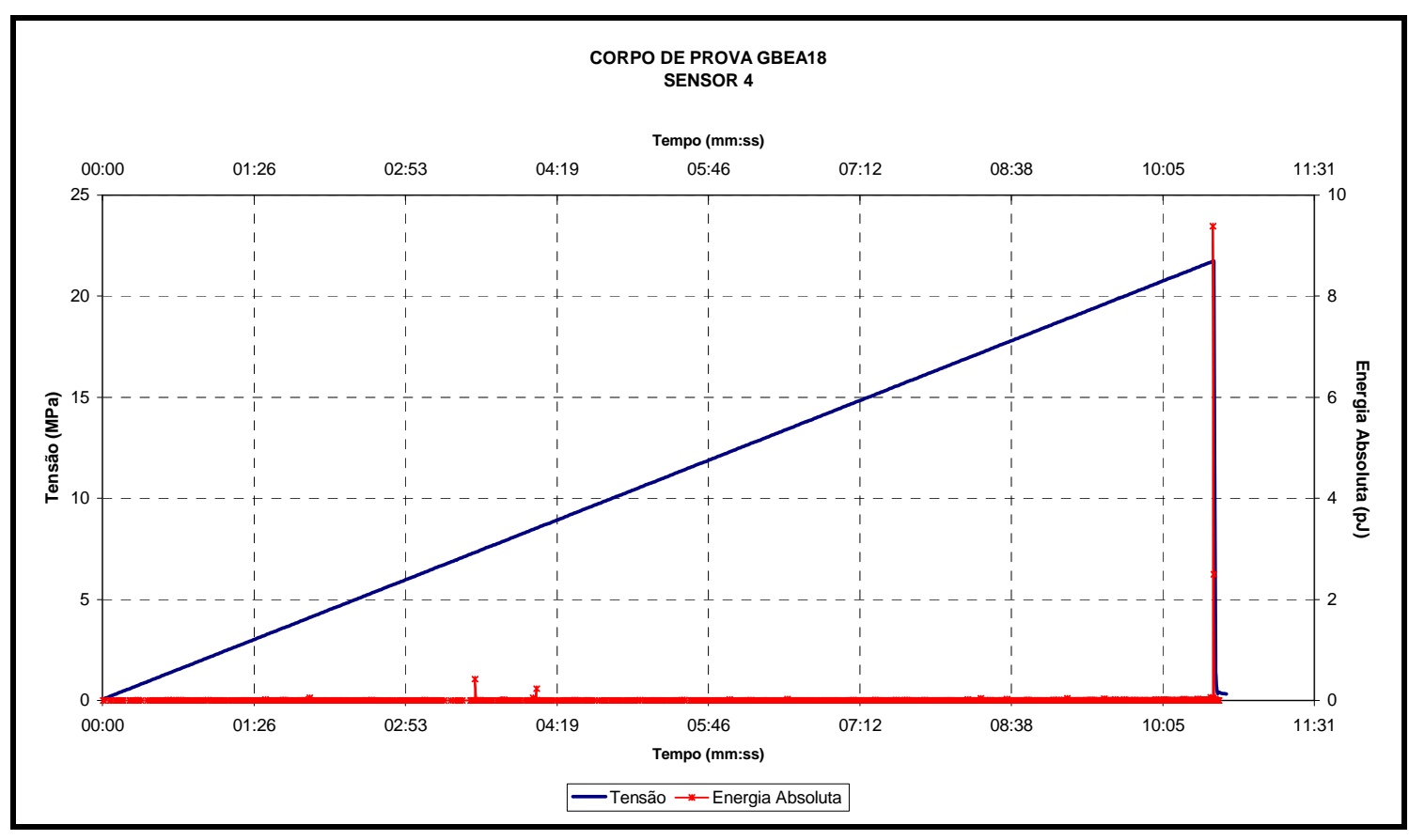

Figura 4.4 Tensão e energia absoluta versus tempo dos eventos de emissão acústica no sensor 4 (freqüências intermediárias de 100 a $400 \mathrm{kHz}$ ) do ensaio de compressão uniaxial no corpo de prova GBEA18 (controle de força e carregamento perpendicular às camadas) 


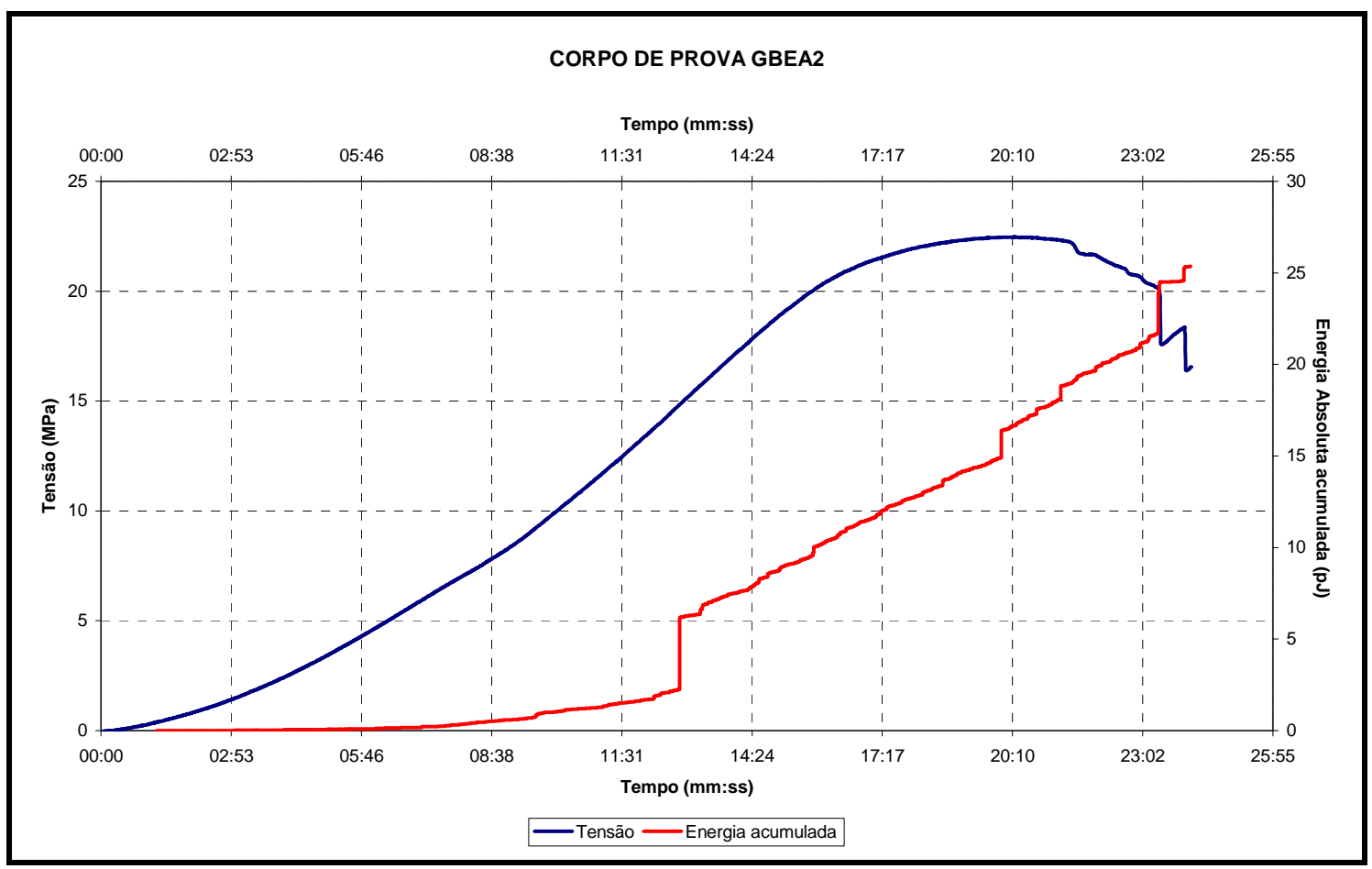

Figura 4.5 Tensão e energia absoluta acumulada versus tempo dos eventos de emissão acústica do ensaio de compressão uniaxial no corpo de prova GBEA2 (controle de deslocamento do prato e carregamento perpendicular às camadas)

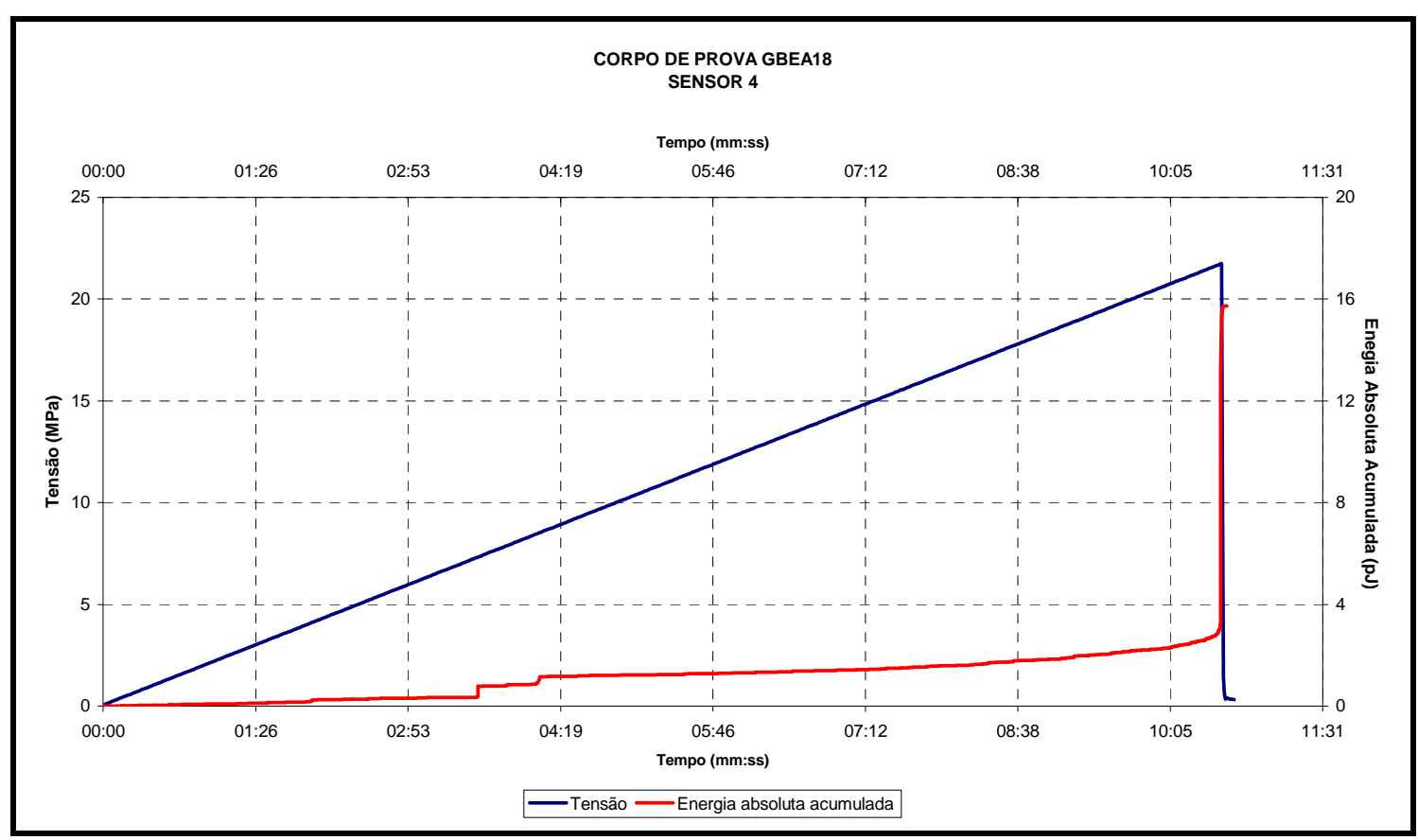

Figura 4.6 Tensão e energia absoluta acumulada versus tempo dos eventos de emissão acústica no sensor 4 (freqüências intermediárias de 100 a $400 \mathrm{kHz}$ ) do ensaio de compressão uniaxial no corpo de prova GBEA18 (controle de força e carregamento perpendicular às camadas) 
No Apêndice 1, são apresentados gráficos típicos de histórico de carregamentos, deformações, contagem, contagem acumulada, energia absoluta e energia absoluta acumulada de corpos de prova submetidos a compressão uniaxial com uso da técnica de emissão acústica com os dois tipos de controle (deslocamento do prato ou força) e nas duas orientações do carregamento com relação as camadas (paralelo ou perpendicular).

Ainda que estas amostras não sejam adequadas para definir o nível de tensão associado ao início do fissuramento $\left(\boldsymbol{\sigma}_{\mathbf{c i}}\right)$ e à tensão de dano por fissuramento $\left(\boldsymbol{\sigma}_{\mathbf{c d}}\right)$, devido ao fissuramento intrínseco das amostras pelo método de obtenção dos blocos no campo, pela preparação dos corpos de prova, entre outros fatores. Analisou-se a evolução da energia absoluta acumulada dos eventos de emissão acústica como função da tensão aplicada com a finalidade de correlacionar estes eventos com o processo de microfissuramento e identificar o padrão de emissão acústica como indício deste processo.

Como exemplo, na Figura 4.7, observa-se o incremento das inclinações da energia absoluta acumulada dos eventos de emissão acústica como função da tensão aplicada no corpo de prova GBEA2 onde o carregamento é perpendicular às camadas. São determinados os níveis de tensões "fae" no trecho OA (no ponto A se produz o primeiro registro de emissão acústica) e "ie" no trecho CD (no ponto C se produz um segundo incremento bem definido da inclinação da reta produzindo o crescimento das fissuras intergranulares). 


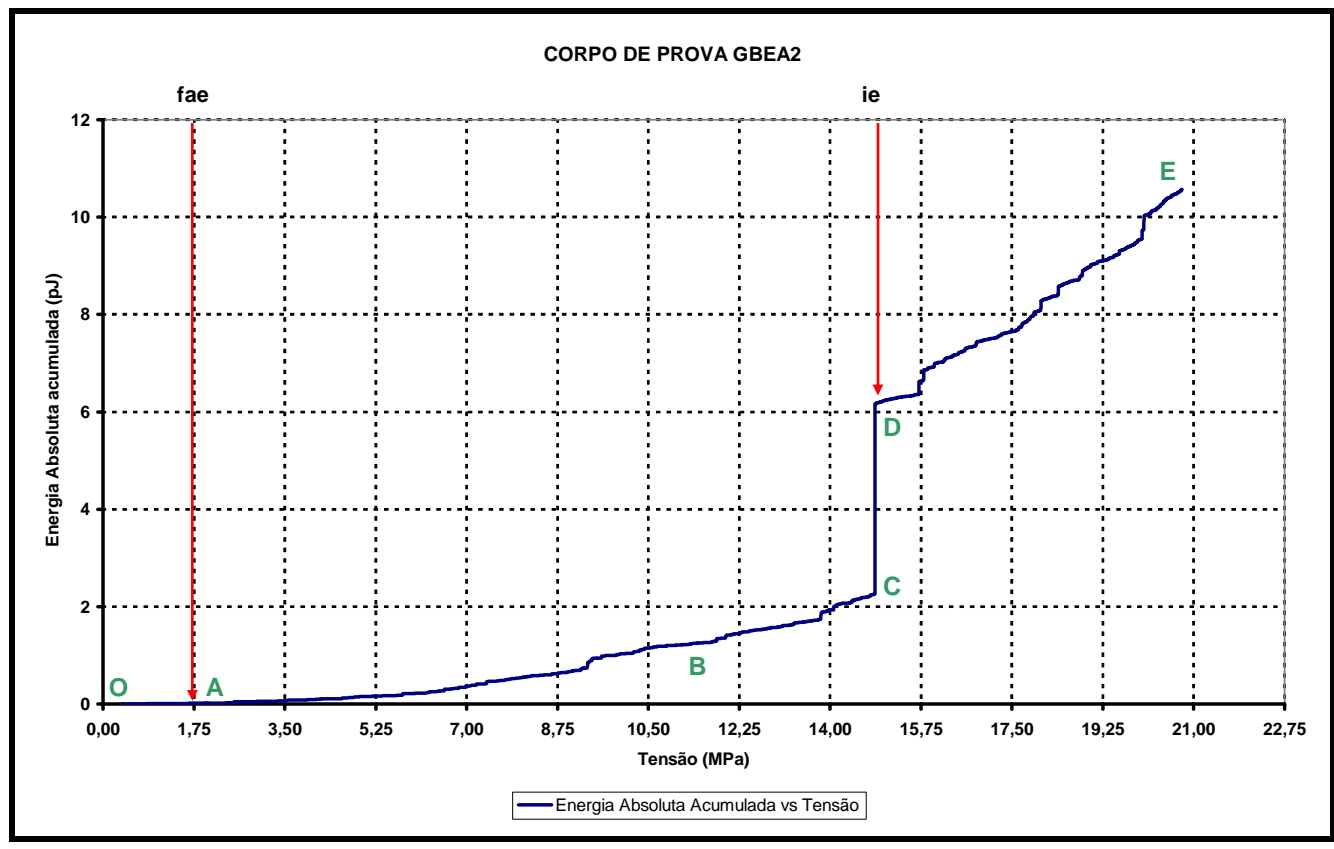

Figura 4.7 Energia absoluta acumulada dos eventos de emissão acústica como função da tensão aplicada durante o carregamento do corpo de prova GBEA2 (carregamento perpendicular às camadas)

Baseando-se na evolução do registro da energia absoluta acumulada dos eventos de emissão acústica, distinguem-se quatro fases:

a) Inicialmente, não é registrada nenhuma emissão acústica, determinando o nível de tensão fae (primeiro registro de emissão acústica);

b) Depois do primeiro registro de emissão acústica (fae), a energia absoluta acumulada dos eventos de emissão acústica cresce linearmente com a tensão aplicada;

c) Em seguida, tem-se uma fase onde se observa um primeiro incremento da inclinação da reta no gráfico energia absoluta acumulada versus tensão, sendo difícil definir claramente o nível de tensão associado. Esta fase é chamada por Ganne, Vervoort e Wevers (2007), como de formação e crescimento de fissuras sistemáticas;

d) Finalmente, ocorre outra fase onde se observa um segundo incremento claramente definido da inclinação da reta, onde se produz um salto no gráfico 
energia absoluta acumulada versus tensão. Esta fase é chamada por Ganne,

Vervoort e Wevers (2007), como de interação e coalescência de fissuras.

As transições entre duas fases sucessivas são consideradas como os níveis de tensões onde se produz a iniciação sistemática das fissuras (fae) e a ocorrência e o crescimento das fissuras intergranulares (ie).

A Tabela 4.3 apresenta os resultados obtidos dos ensaios de compressão uniaxial com controle de deslocamento do prato a partir dos registros da energia absoluta acumulada dos eventos de emissão acústica, indicando a tensão do início do registro de eventos de emissão acústica (fae) e a tensão onde se produz a ocorrência e o crescimento das fissuras intergranulares (ie), como definem Ganne, Vervoort e Wevers (2007).

O valor do nível de tensão correspondente ao início do registro de eventos de emissão acústica (fae) varia de 1,6 a 2,3\% de $\sigma_{\mathrm{c}}$ e o nível de tensão onde se produz a ocorrência e o crescimento das fissuras intergranulares (ie) varia de 69 a $78 \%$ de $\sigma_{c}$.

Os resultados dos níveis de tensões associados ao início do fissuramento $\left(\boldsymbol{\sigma}_{\mathbf{c i}}\right)$ e à tensão de dano por fissuramento $\left(\boldsymbol{\sigma}_{\mathbf{c d}}\right)$ se apresentam na Tabela 4.4. Estes níveis de tensões foram determinados segundo o método sugerido por Martin (1993) que usa a deformação volumétrica calculada para identificar o início da fissura.

Tabela 4.3 Níveis de tensão no início do registro de eventos de emissão acústica (fae), na ocorrência e no crescimento das fissuras intergranulares (ie) e resistência pico $\left(\sigma_{c}\right)$ dos corpos de prova com controle de deslocamento do prato. Entre parêntesis, a percentagem em relação à resistência pico $\left(\sigma_{c}\right)$

\begin{tabular}{ccccc}
\hline $\begin{array}{c}\text { Corpo de } \\
\text { prova }\end{array}$ & $\begin{array}{c}\text { Condição de } \\
\text { carregamento }\end{array}$ & fae (MPa) & $\begin{array}{c}\text { ie } \\
\text { (MPa) }\end{array}$ & $\begin{array}{c}\text { Resistência } \\
\text { pico- } \boldsymbol{\sigma}_{\mathbf{c}} \\
(\mathbf{M P a})\end{array}$ \\
\hline GBEA1 & Perpendicular às camadas & 0,46 & 19,21 & 25,18 \\
GBEA2 & Perpendicular às camadas & $(1,8 \%)$ & $(76,3 \%)$ & $(100 \%)$ \\
& & $(1,6 \%)$ & $(70 \%)$ & $(100 \%)$ \\
GBEA3 & Paralelo às camadas & 0,63 & 22,00 & 28,17 \\
& & $(2,2 \%)$ & $(78,1 \%)$ & $(100 \%)$ \\
GBEA4 & Paralelo às camadas & 0,57 & 19,00 & 27,38 \\
& & $(2,1 \%)$ & $(69,4 \%)$ & $(100 \%)$ \\
\hline
\end{tabular}


Martin (1993) definiu o início do fissuramento $\left(\boldsymbol{\sigma}_{\mathbf{c i}}\right)$ como a tensão na qual a dilatância (incremento de volume de fissuras) começa no gráfico deformação axial versus deformação volumétrica calculadas. A tensão de dano por fissuramento $\left(\boldsymbol{\sigma}_{\mathbf{c d}}\right)$, onde acontece o crescimento instável de fissuras ocorre no ponto de reversão na curva de deformação volumétrica medida (MARTIN, 1993; EBERHARDT et al., 1998).

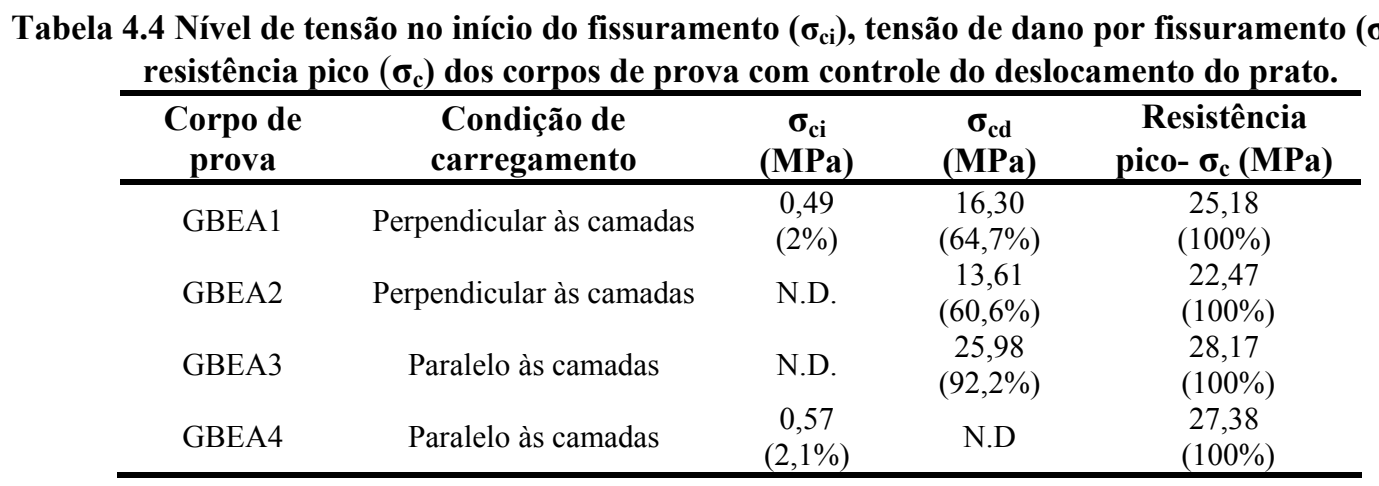

Salienta-se que estes resultados foram obtidos nos ensaios de compressão uniaxial com uso da técnica de emissão acústica, sendo usados extensômetros elétricos em roseta dupla para a determinação das deformações específicas. Devido à existência de resultados muito dispersos e alguns deles não determinados claramente, procedeu-se à comparação com os resultados obtidos nos ensaios de caracterização para determinar as propriedades físico-mecânicas (Tabela 3.3).

Comprovou-se que o valor do nível de tensão associado ao início do fissuramento $\left(\boldsymbol{\sigma}_{\mathbf{c i}}\right)$ varia de 1,6 a $2,3 \%$ de $\sigma_{\mathrm{c}}$ e a tensão de dano por fissuramento $\left(\boldsymbol{\sigma}_{\mathbf{c d}}\right)$ varia de 76 a $82 \%$ de $\sigma_{c}$. Neste caso, a instrumentação das deformações axiais foi realizada com extensômetros localizados e as deformações radiais com um extensômetro circunferencial.

A Tabela 4.5 apresenta os resultados de fae e ie nos ensaios de compressão uniaxial com controle de força. 
Tabela 4.5 Níveis de tensão no início do registro de eventos de emissão acústica (fae), na ocorrência e no crescimento das fissuras intergranulares (ie) e resistência pico $\left(\sigma_{c}\right)$ dos corpos de prova com controle de força. Entre parêntesis, a percentagem em relação à resistência pico $\left(\sigma_{c}\right)$

\begin{tabular}{ccccc}
\hline $\begin{array}{c}\text { Corpo de } \\
\text { prova }\end{array}$ & Condição de carregamento & $\begin{array}{c}\text { fae } \\
(\mathbf{M P a})\end{array}$ & $\begin{array}{c}\text { ie } \\
(\mathbf{M P a})\end{array}$ & $\begin{array}{c}\text { Resistência pico- } \\
\boldsymbol{\sigma}_{\mathbf{c}} \text { (MPa) }\end{array}$ \\
\hline \multirow{2}{*}{ GBEA17 } & Perpendicular às camadas & 6,78 & 13,10 & 22,90 \\
& & $(29,61 \%)$ & $(57,21 \%)$ & $(100 \%)$ \\
GBEA18 & Perpendicular às camadas & 0,10 & 13,40 & 21,73 \\
& & $(0,46 \%)$ & $(61,67 \%)$ & $(100 \%)$ \\
GBEA22 & Perpendicular às camadas & 0,35 & 12,30 & 27,49 \\
& & $(1,27 \%)$ & $(44,74 \%)$ & $(100 \%)$ \\
GBflu7MTS & Perpendicular às camadas & 0,27 & 13,00 & 21,55 \\
& & $(1,25 \%)$ & $(60,32 \%)$ & $(100 \%)$ \\
GBpec3da & Perpendicular às camadas & 2,30 & 13,40 & 21,22 \\
& & $(10,84 \%)$ & $(63,15 \%)$ & $(100 \%)$ \\
GBEA19 & Paralelo às camadas & 0,14 & 14,10 & 24,53 \\
& & $(0,57 \%)$ & $(57,48 \%)$ & $(100 \%)$ \\
GBEA20 & Paralelo às camadas & 0,13 & 9,24 & 21,26 \\
& & $(0,61 \%)$ & $(43,46 \%)$ & $(100 \%)$ \\
GBEA21 & Paralelo às camadas & 0,20 & 11,95 & 27,02 \\
& & $(0,74 \%)$ & $(44,23 \%)$ & $(100 \%)$ \\
GBEA23 & Paralelo às camadas & 0,13 & 17,16 & 23,06 \\
& & $(0,56 \%)$ & $(74,41 \%)$ & $(100 \%)$ \\
\hline
\end{tabular}

$\mathrm{Na}$ Tabela 4.6 se apresentam o nível de tensão associado ao início do fissuramento $\left(\boldsymbol{\sigma}_{\mathbf{c i}}\right)$ e a tensão de dano por fissuramento $\left(\boldsymbol{\sigma}_{\mathbf{c d}}\right)$, determinadas segundo o método sugerido por Martin (1993).

Tabela 4.6 Nível de tensão no início do fissuramento $\left(\sigma_{\mathrm{c} i}\right)$, tensão de dano por fissuramento $\left(\sigma_{\mathrm{cd}}\right)$ e a resistência pico $\left(\sigma_{c}\right)$ dos corpos de prova com controle de força

\begin{tabular}{|c|c|c|c|c|}
\hline $\begin{array}{c}\text { Corpo de } \\
\text { prova }\end{array}$ & Condição de carregamento & $\sigma_{\mathrm{ci}}(\mathrm{MPa})$ & $\sigma_{\mathrm{cd}}(\mathrm{MPa})$ & $\begin{array}{c}\text { Resistência pico- } \sigma_{\mathrm{c}} \\
(\mathrm{MPa})\end{array}$ \\
\hline GBEA17 & Perpendicular às camadas & N.D. & N.D. & $\begin{array}{c}22,90 \\
(100 \%)\end{array}$ \\
\hline GBEA18 & Perpendicular às camadas & $\begin{array}{c}17.06 \\
(78.51 \%)\end{array}$ & $\begin{array}{c}17.34 \\
(79.80 \%)\end{array}$ & $\begin{array}{c}21,73 \\
(100 \%)\end{array}$ \\
\hline GBEA22 & Perpendicular às camadas & $\begin{array}{c}9.08 \\
(27,49 \%)\end{array}$ & N.D. & $\begin{array}{l}27,49 \\
(100 \%)\end{array}$ \\
\hline GBflu7MTS & Perpendicular às camadas & N.D. & N.D & $\begin{array}{l}21,55 \\
(100 \%)\end{array}$ \\
\hline GBpec3da & Perpendicular às camadas & $\begin{array}{c}1.49 \\
(7.02 \%)\end{array}$ & $\begin{array}{c}19,65 \\
(92,60 \%)\end{array}$ & $\begin{array}{c}21,22 \\
(100 \%)\end{array}$ \\
\hline GBEA19 & Paralelo às camadas & $\begin{array}{c}23,21 \\
(94,62 \%)\end{array}$ & $\begin{array}{c}23,51 \\
(95,84 \%)\end{array}$ & $\begin{array}{c}24,53 \\
(100 \%)\end{array}$ \\
\hline GBEA20 & Paralelo às camadas & N.D & N.D. & $\begin{array}{l}21,26 \\
(100 \%)\end{array}$ \\
\hline GBEA21 & Paralelo às camadas & N.D & N.D & $\begin{array}{l}27,02 \\
(100 \%)\end{array}$ \\
\hline GBEA23 & Paralelo às camadas & $\begin{array}{c}12,56 \\
(54,47 \%)\end{array}$ & $\begin{array}{c}19,34 \\
(83,87 \%)\end{array}$ & $\begin{array}{c}23,06 \\
(100 \%)\end{array}$ \\
\hline
\end{tabular}


Comparando os resultados obtidos nos ensaios de compressão uniaxial com controle de deslocamento do prato e com controle de força com outros relatados na literatura por Martin (1997), Eberhardt, Stead e Stimpson (1999) e Diederichs, Kaiser e Eberhardt (2004) no granito Lac du Bonnet, que indicam valores de 30 a $40 \%$ de $\sigma_{c}$ para $\boldsymbol{\sigma}_{\mathbf{c}}$, e de 70 a $75 \%$ de $\sigma_{\mathrm{c}}$ para $\boldsymbol{\sigma}_{\mathbf{c d}}$, e por Ganne, Vervoort e Wevers (2007) no calcário crinoidal belga, que indicam valores de 52 a $62 \%$ de $\sigma_{\mathrm{c}}$ para $\sigma_{\mathbf{c i}}$ e de 86 a $90 \%$ de $\sigma_{\mathrm{c}}$ para $\boldsymbol{\sigma}_{\mathrm{cd}}$, podemos indicar o seguinte:

a) Geometria e tipo de rocha diferente

Quanto à geometria, realizaram-se ensaios de compressão uniaxial com corpos de prova cilíndricos como Martin e Chandler (1994), Eberhardt, Stead e Stimpson (1999) e Diederichs, Kaiser e Eberhardt (2004).

Ganne, Vervoort e Wevers (2007) realizaram ensaios com outra geometria, com corpos de prova retangulares de $31 \mathrm{~mm}$ de espessura, $60 \mathrm{~mm}$ de largura e $140 \mathrm{~mm}$ de comprimento com um furo semicircular de $58 \mathrm{~mm}$ de diâmetro em uma das faces do corpo de prova (Figura 4.8).

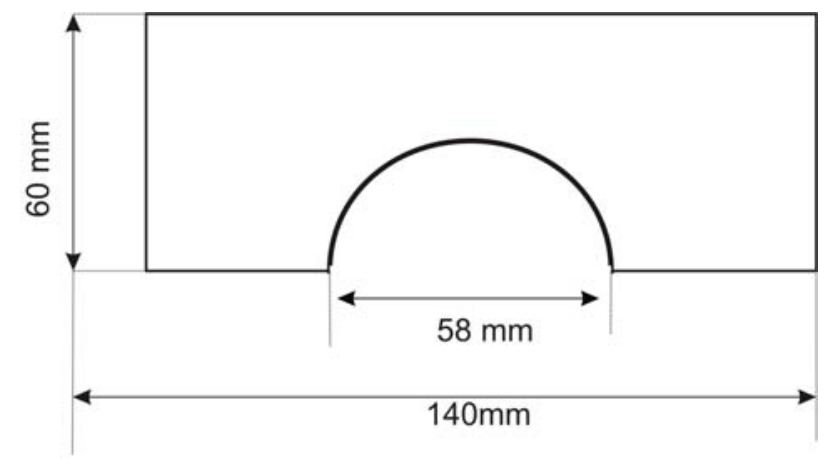

Figura 4.8 Geometria do corpo de prova utilizado por Ganne, Vervoort e Wevers Fonte: Ganne, Vervoort e Wevers (2007) 
Quanto ao tipo de rocha, Martin e Chandler (1994), Eberhardt, Stead e Stimpson (1999) e Diederichs, Kaiser e Eberhardt (2004) estudaram o granito Lac du Bonnet; Ganne, Vervoort e Wevers (2007) estudaram o calcário crinoidal belga. Nesta tese, foi estudado o gipsito bandado da Formação Santana.

\section{b) Determinação dos níveis de tensão}

A determinação dos níveis de tensão associados ao início do físsuramento $\left(\boldsymbol{\sigma}_{\mathbf{c i}}\right)$ e ao dano por fissuramento $\left(\boldsymbol{\sigma}_{\mathbf{c d}}\right)$ foi baseada no método sugerido por Martin (1993) da mesma maneira que Eberhardt, Stead e Stimpson (1999) e Ganne, Vervoort e Wevers (2007).

Quanto à determinação dos níveis de tensão do início do registro de eventos de emissão acústica (fae) e a tensão correspondente à ocorrência e o crescimento instável das fissuras (ie), Diederichs, Kaiser e Eberhardt (2004) usaram o gráfico bi-logaritmico do número de eventos de emissão acústica acumulado versus tensão aplicada. Ganne, Vervoort e Wevers (2007) usaram o gráfico em escala natural da energia absoluta acumulada dos eventos de emissão acústica versus carga aplicada. Nos ensaios apresentados nesta tese, usou-se o gráfico em escala natural da energia absoluta acumulada dos eventos de emissão acústica e a tensão aplicada. Utilizou-se a energia absoluta acumulada dos eventos de emissão acústica registrada devido ao fato de ser fisicamente mais significativa. 
c) Identificação do padrão de emissão acústica como indício do processo de $\underline{\text { microfissuramento }}$

Neste tipo de ensaio, já são conhecidos o momento e a intensidade das ocorrências do fenômeno de microfissuramento. A correlação entre microfissuramento e padrão de emissão acústica (intensidade e freqüência dos sinais) é conhecida para algumas rochas (OHNAKA, 1983; BARR; HUNT, 1999; MANTHEI, 2005; ZHANG et al., 1990), mas não ainda para o gipsito bandado da Formação Santana.

São apresentados a seguir os resultados de 4 ensaios nos corpos de prova GBEA17 e GBEA18 (carregamento perpendicular à estratificação) e GBEA19 e GBEA20 (carregamento paralelo à estratificação). Espera-se de antemão que o microfissuramento se inicie mais cedo com carregamento paralelo à estratificação.

Os ensaios foram realizados com controle de força, com uma taxa de carregamento de 2,03 $\mathrm{MPa} / \mathrm{min}$.

Os corpos de prova foram instrumentados com 4 sensores piezoelétricos de 175 $\mathrm{kHz}$ de freqüência característica selecionando duas faixas estreitas de freqüência diferente por meio de filtros analógicos disponíveis no sistema de aquisição de dados: freqüências baixas I1 (de 20 a 100 kHz) e freqüências intermediárias H1 (de 100 a 400 $\mathrm{kHz})$.

A Figura 4.9a apresenta os resultados do ensaio no corpo de prova GBEA17. São apresentados ao longo do tempo os valores de: tensão imposta (função linear) e respostas de emissão acústica dos dois sensores em termos de contagem acumulada no número de eventos. O corpo de prova rompeu sob uma tensão de 22,90 MPa.

Sabe-se que o início do microfissuramento se dá quando é atingida a tensão $\sigma_{\mathrm{ci}}$ que costuma usualmente ter ordem de grandeza de 30\% da resistência à compressão 
simples (MARTIN; CHANDLER, 1994). Para o gipsito bandado em questão, valores mais baixos foram encontrados, como já apresentado na Tabela 3.3. De fato, os primeiros sinais de emissão acústica aparecem no sensor de freqüências intermediárias (de 100 a $400 \mathrm{kHz}$ ) depois de cerca de 3,2 minutos do início do carregamento, quando a tensão aplicada era cerca de $27 \%$ da resistência à compressão simples atingida. No mesmo sensor, o número acumulado de eventos cresce acentuadamente entre 80 e $90 \%$ da resistência à compressão simples, um valor coerente com $\sigma_{c d}$, a tensão que marca o início do microfissuramento instável. Logo antes da ruptura, o número de evento se acentua substancialmente. Desta figura, parece que a resposta do sensor de freqüências intermediárias (de 100 a $400 \mathrm{kHz}$ ) detecta eventos de microfissuramento.

O sensor de freqüências baixas (de 20 a $100 \mathrm{kHz}$ ) mostra um início de atividade mais tardio, e na escala desta figura não chega a apresentar qualquer mudança de tendência apreciável ao longo do ensaio. Ampliando-se a escala de contagem acumulada, como mostrado na Figura 4.9b (valor máximo de escala de 1200 eventos, enquanto na Figura 4.9a aquele valor é de 160000), observa-se que a resposta do sensor de freqüências baixas somente se inicia após cerca de 7 minutos de ensaio, quando a tensão aplicada já era cerca de $64 \%$ da resistência a compressão simples. Este valor é muito elevado para ser atribuído à tensão de início de microfissuramento $\sigma_{\text {ci }}$. Muito próximo à ruptura, a contagem de eventos de freqüências baixas também sobe, porém em número muito menor (cerca de 800) que o detectado pelo sensor de freqüências intermediárias (mais de 120000). Ohnaka (1983) pondera que logo antes da ruptura, a coalescência de microfissuras leva à formação de superfícies de cisalhamento, fenômeno responsável por acréscimo de eventos de freqüências baixa. 
Todos os argumentos, portanto, são consistentes no sentido de demonstrar que na rocha em questão o microfissuramento gera eventos de emissão acústica detectados pelo sensor de freqüências intermediárias H1 (de 100 a 400 kHz).

Para o outro corpo de prova com carregamento perpendicular à estratificação (GBEA18, Figura 4.10) praticamente todos os fenômenos se repetem, a menos que a detecção de eventos de emissão acústica de freqüência intermediária se inicia mais cedo, embora em número mais reduzido. Esta diferença pode ser explicada pela existência prévia de microfissuramento natural ou induzido pelo processo de preparação do corpo de prova. A consistência dos outros argumentos leva ainda a confirmar a associação entre microfissuramento e eventos de emissão acústica no intervalo de freqüência de 100 a $400 \mathrm{kHz}$.

Como esperado, o microfissuramento se inicia mais cedo em corpos de prova com carregamento paralelo à estratificação, como apresentado nas Figuras 4.11 e 4.12. Todas as outras características observadas para o corpo de prova GBAE17 (Figura 4.9) são ainda observadas.

Em suma, pode-se concluir que o microfissuramento gera eventos de emissão acústica detectados pelo sensor de freqüências intermediárias de 100 a $400 \mathrm{kHz}$. 


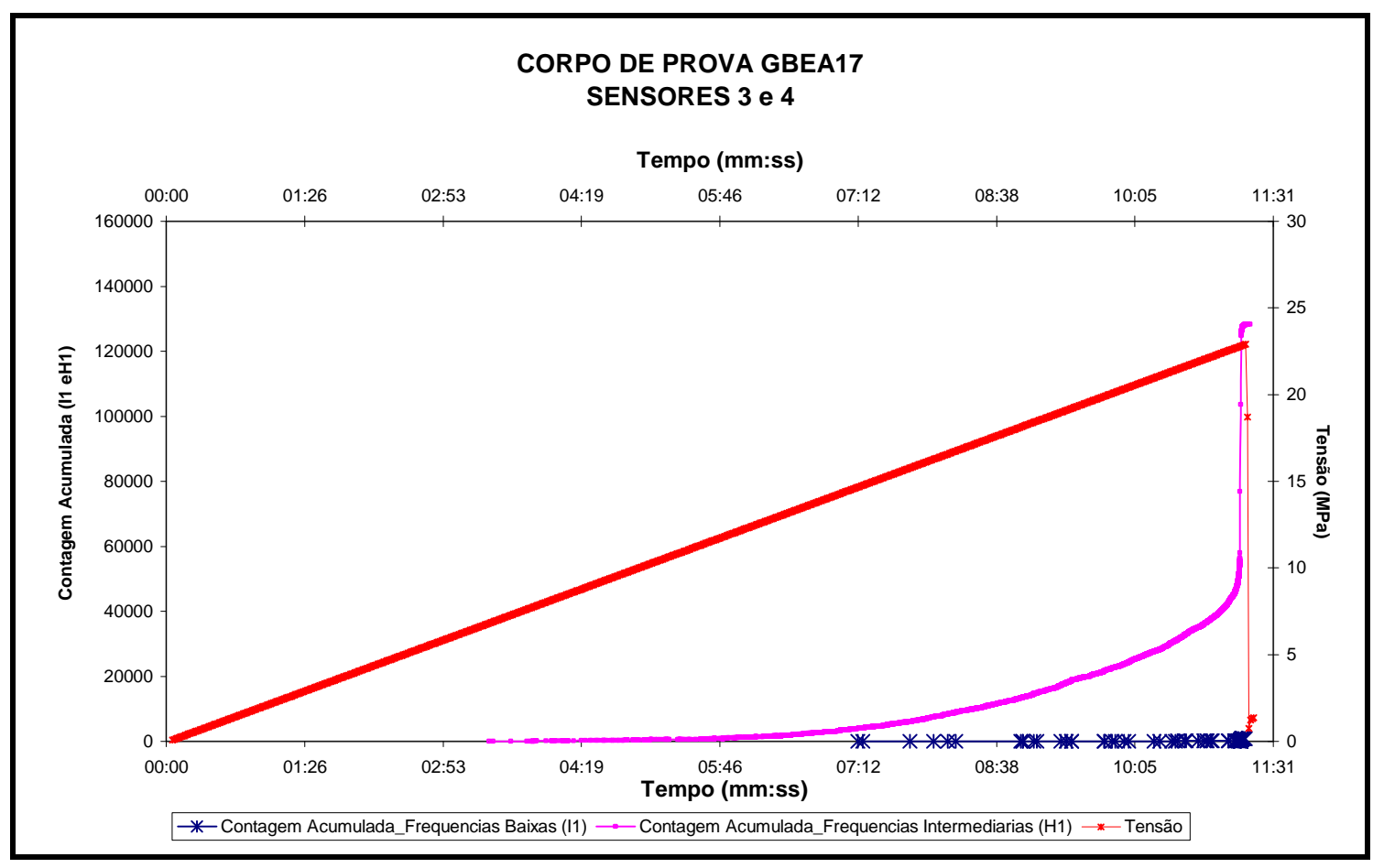

(a)

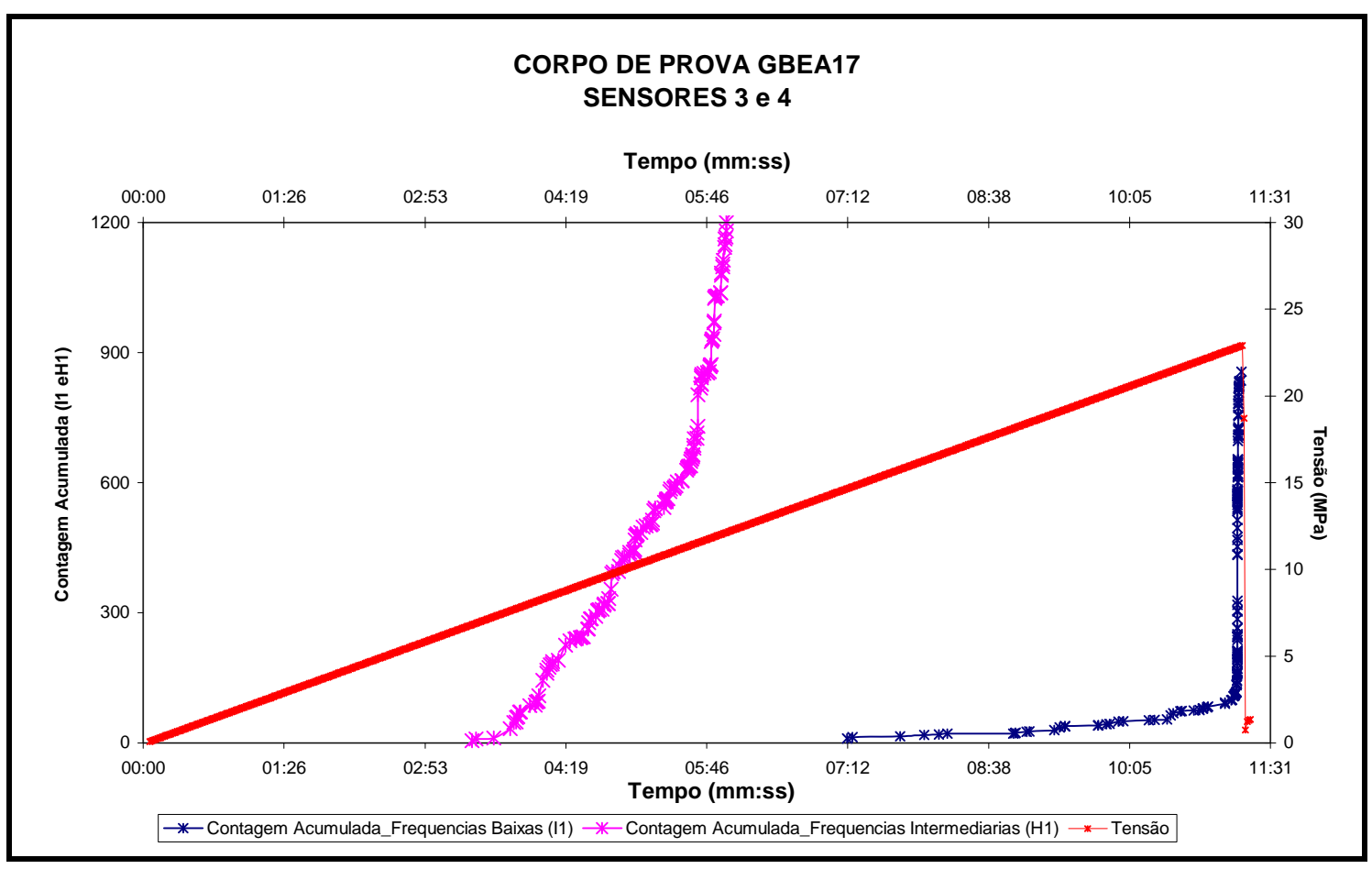

(b)

Figura 4.9 Ensaio de compressão simples no corpo de prova GBEA17 - (a): escala normal; (b): ampliação do eixo de contagem acumulada. $O$ sensor 3 detecta freqüências baixas (de 20 a $100 \mathrm{kHz}$ ) e o sensor 4 detecta freqüências intermediárias (de 100 a $400 \mathrm{kHz})$ 


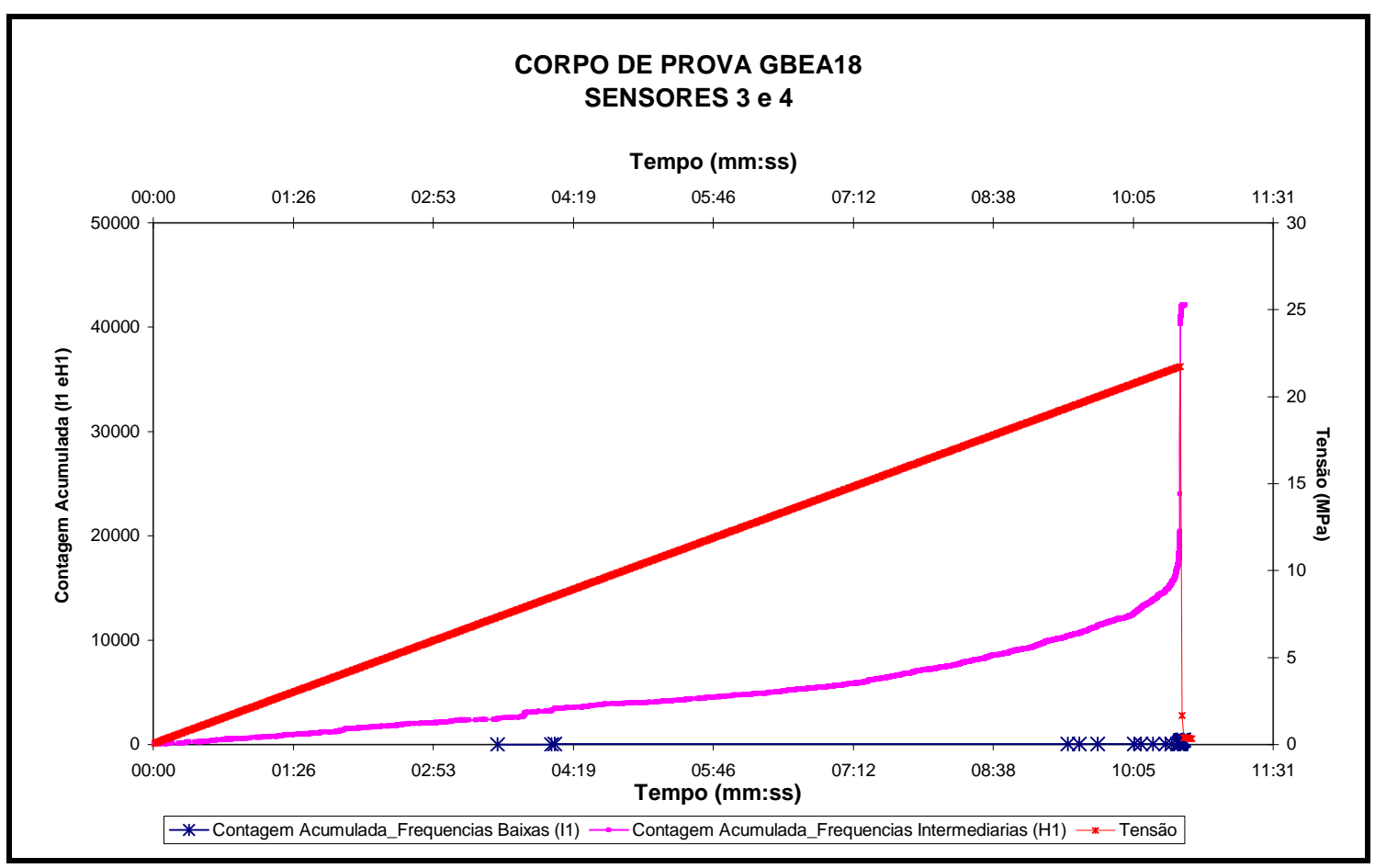

(a)

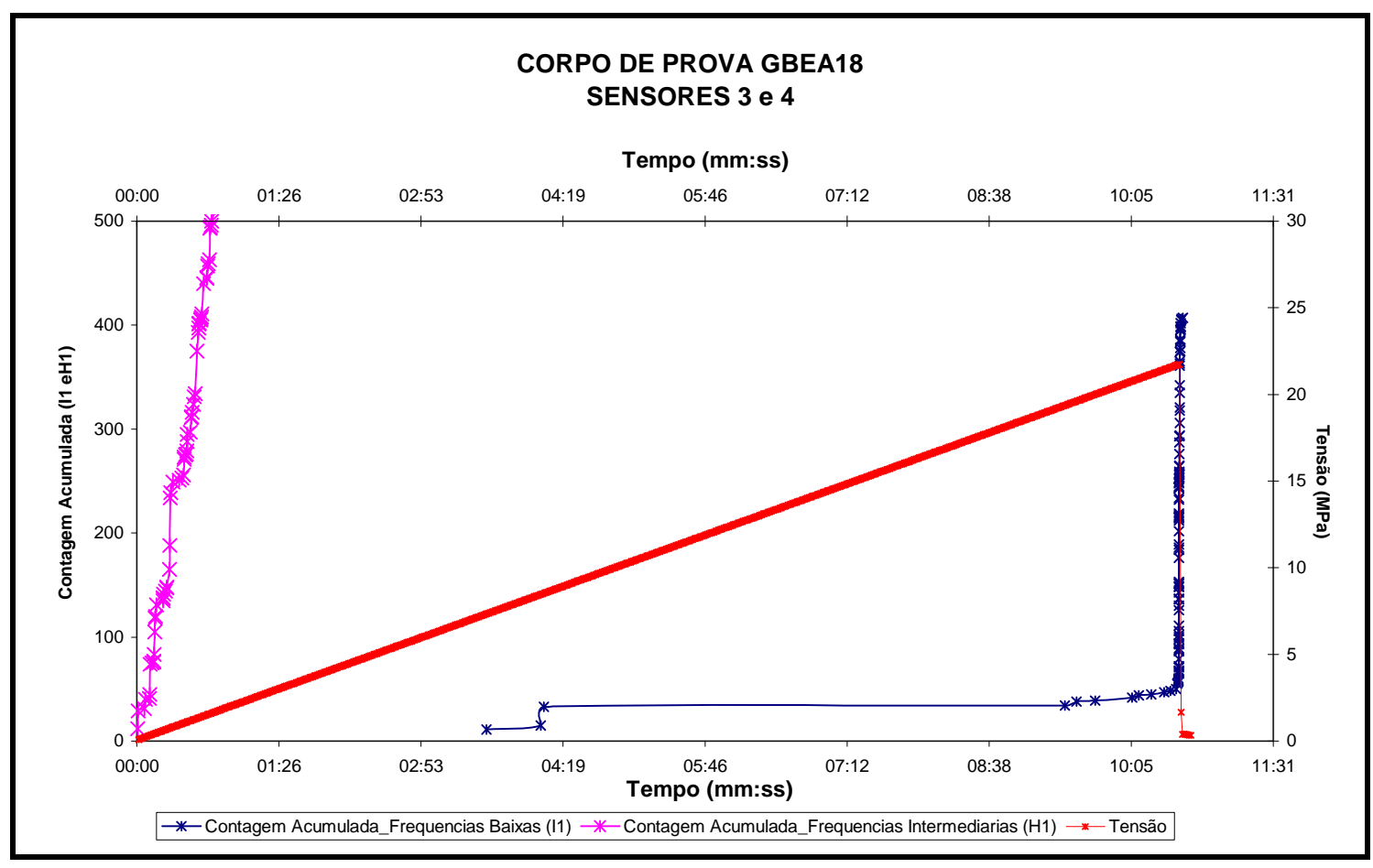

(b)

Figura 4.10 Ensaio de compressão simples no corpo de prova GBEA18 - (a): escala normal; (b): ampliação do eixo de contagem acumulada. O sensor 3 detecta freqüências baixas (de 20 a $100 \mathrm{kHz}$ ) e o sensor 4 detecta freqüências intermediárias (de 100 a $400 \mathrm{kHz})$ 


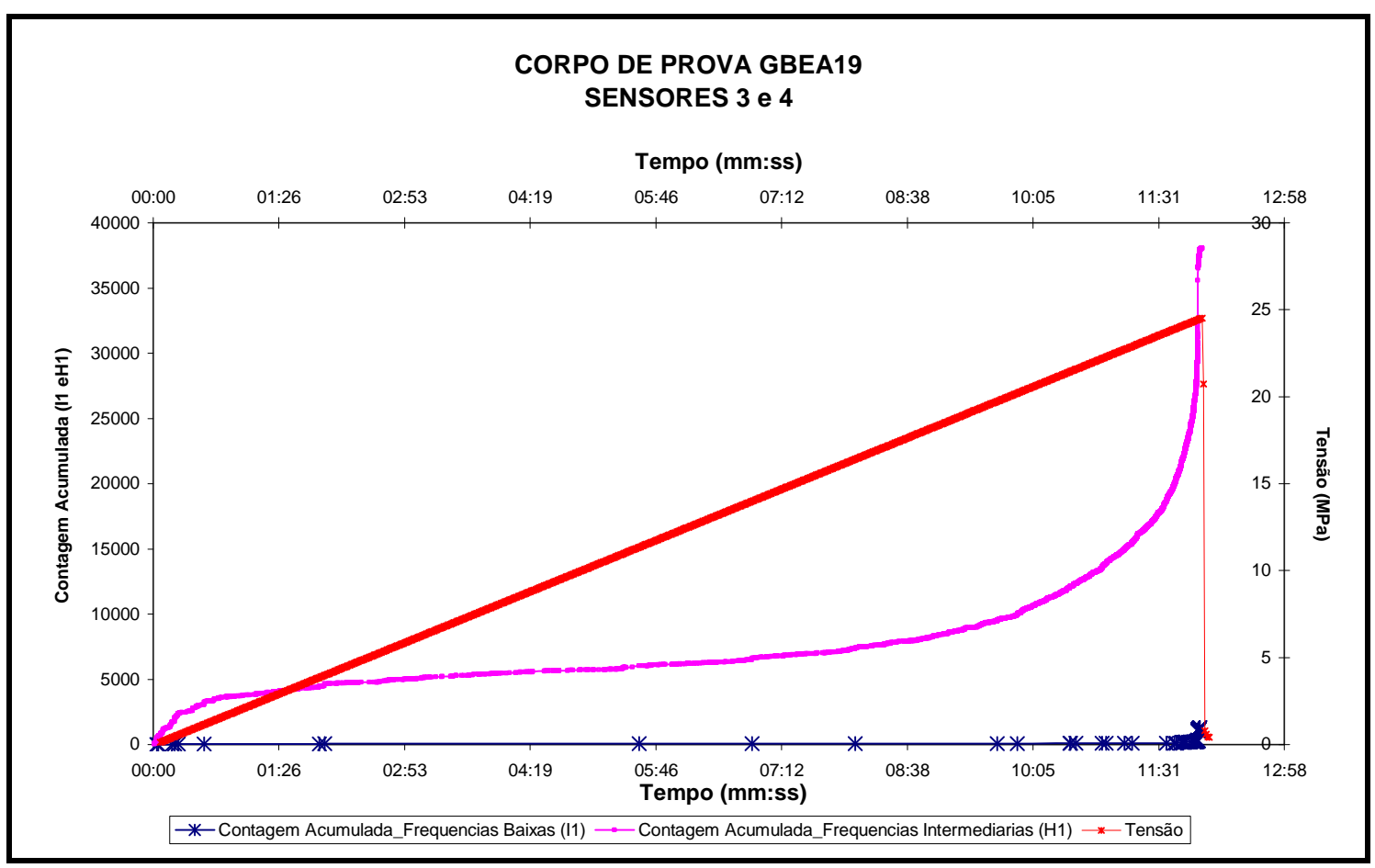

(a)

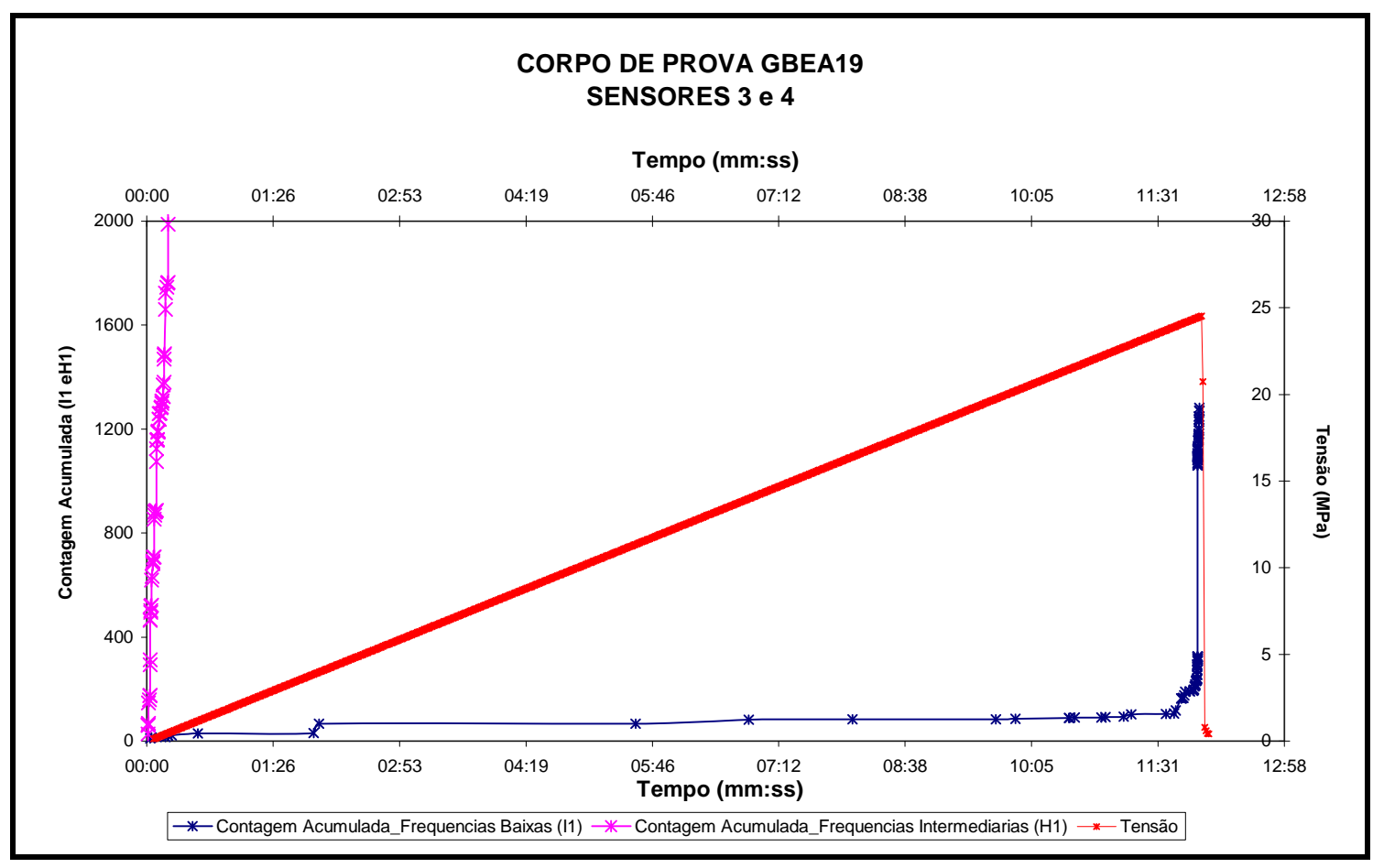

(b)

Figura 4.11 Ensaio de compressão simples no corpo de prova GBEA19 - (a): escala normal; (b): ampliação do eixo de contagem acumulada. $O$ sensor 3 detecta freqüências baixas (de 20 a $100 \mathrm{kHz}$ ) e o sensor 4 detecta freqüências intermediárias (de 100 a $400 \mathrm{kHz})$ 


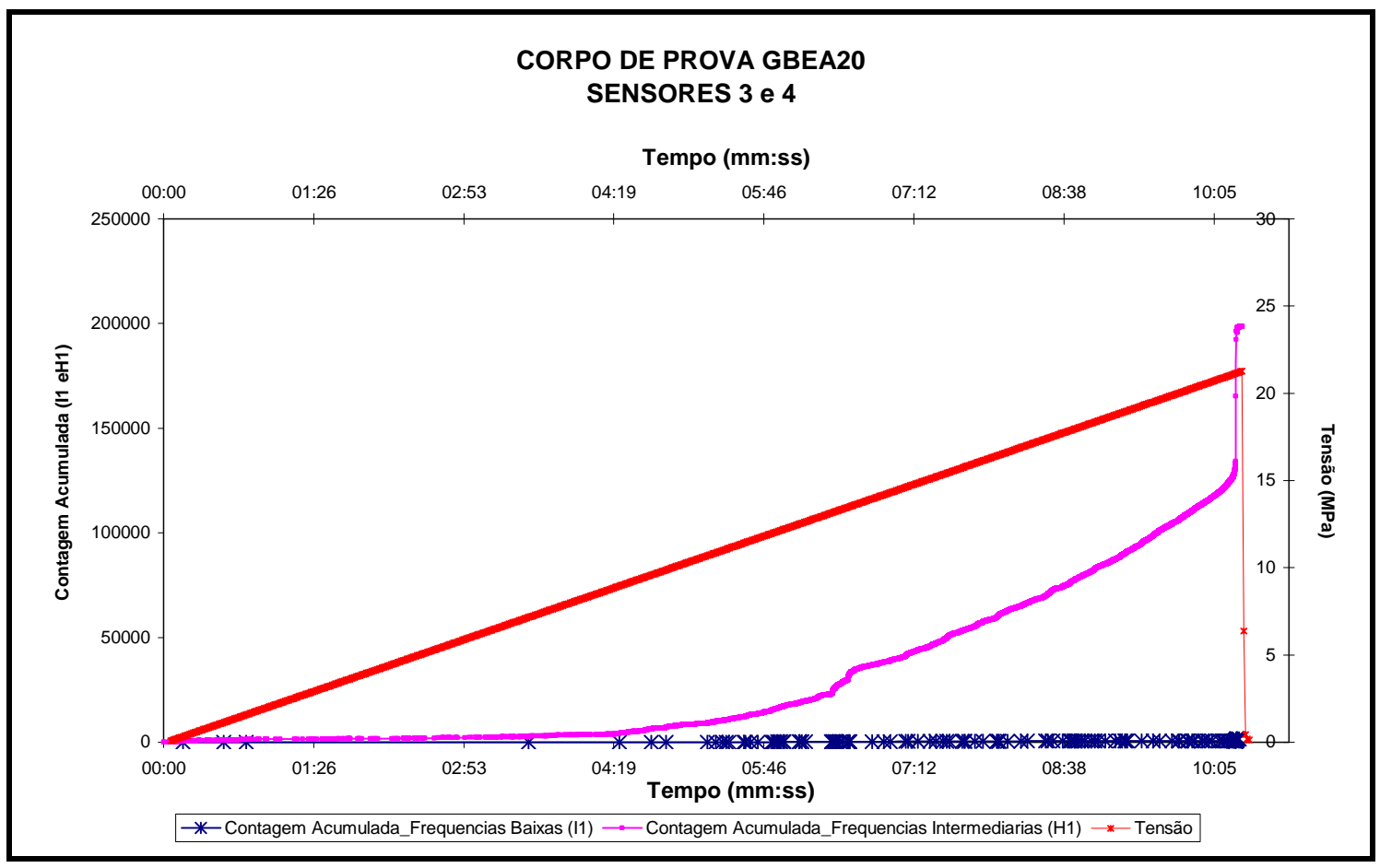

(a)

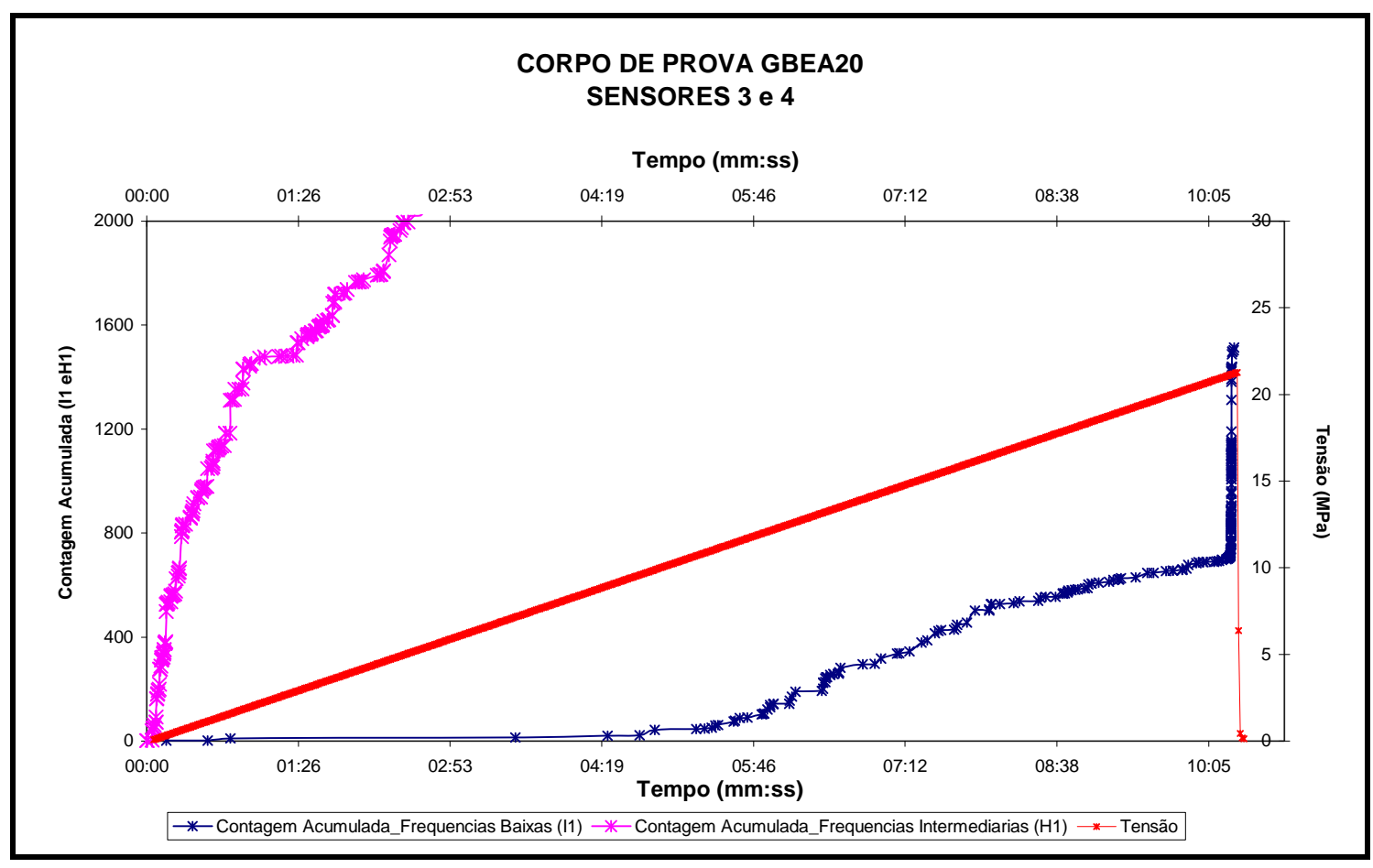

(b)

Figura 4.12 Ensaio de compressão simples no corpo de prova GBEA20 - (a): escala normal; (b): ampliação do eixo de contagem acumulada. $O$ sensor 3 detecta freqüências baixas (de 20 a $100 \mathrm{kHz}$ ) e o sensor 4 detecta freqüências intermediárias (de 100 a $400 \mathrm{kHz})$ 


\subsection{Ensaios de compressão uniaxial com ciclos variáveis de carregamento antes do pico de resistência com técnica de emissão acústica}

Estes ensaios seguiram os procedimentos indicados nos itens 3.12.2.1 (Ensaios tipo CVI) e 3.12.2.2 (Ensaios tipo CVII).

O corpo de prova GBEA10 (Tipo CVI) foi ensaiado com carregamento perpendicular às camadas com controle de força a uma taxa de carregamento constante de $5 \mathrm{kN} / \mathrm{min}$ e taxa de descarregamento constante de $15 \mathrm{kN} / \mathrm{min}$ (Figura 4.13).

O ensaio no corpo de prova GBEA5 (Tipo CVII) foi realizado com carregamento paralelo às camadas com controle de deslocamento do prato a uma taxa de $0.03 \mathrm{~mm} / \mathrm{min}$ no carregamento e taxa de $4 \mathrm{~mm} / \mathrm{min}$ no descarregamento (Figura $3.45)$.

Os objetivos destes ensaios foram comprovar se seria possível encontrar os mesmos níveis de tensão correspondentes ao início do registro de eventos de emissão acústica (fae) e o nível de tensão correspondente à ocorrência e ao crescimento das fissuras intergranulares (ie), realizando ciclos de carregamento e descarregamento a determinados níveis de tensão, em particular no trecho elástico e no trecho antes do pico de resistência, assim como verificar a ocorrência do efeito Kaiser. 


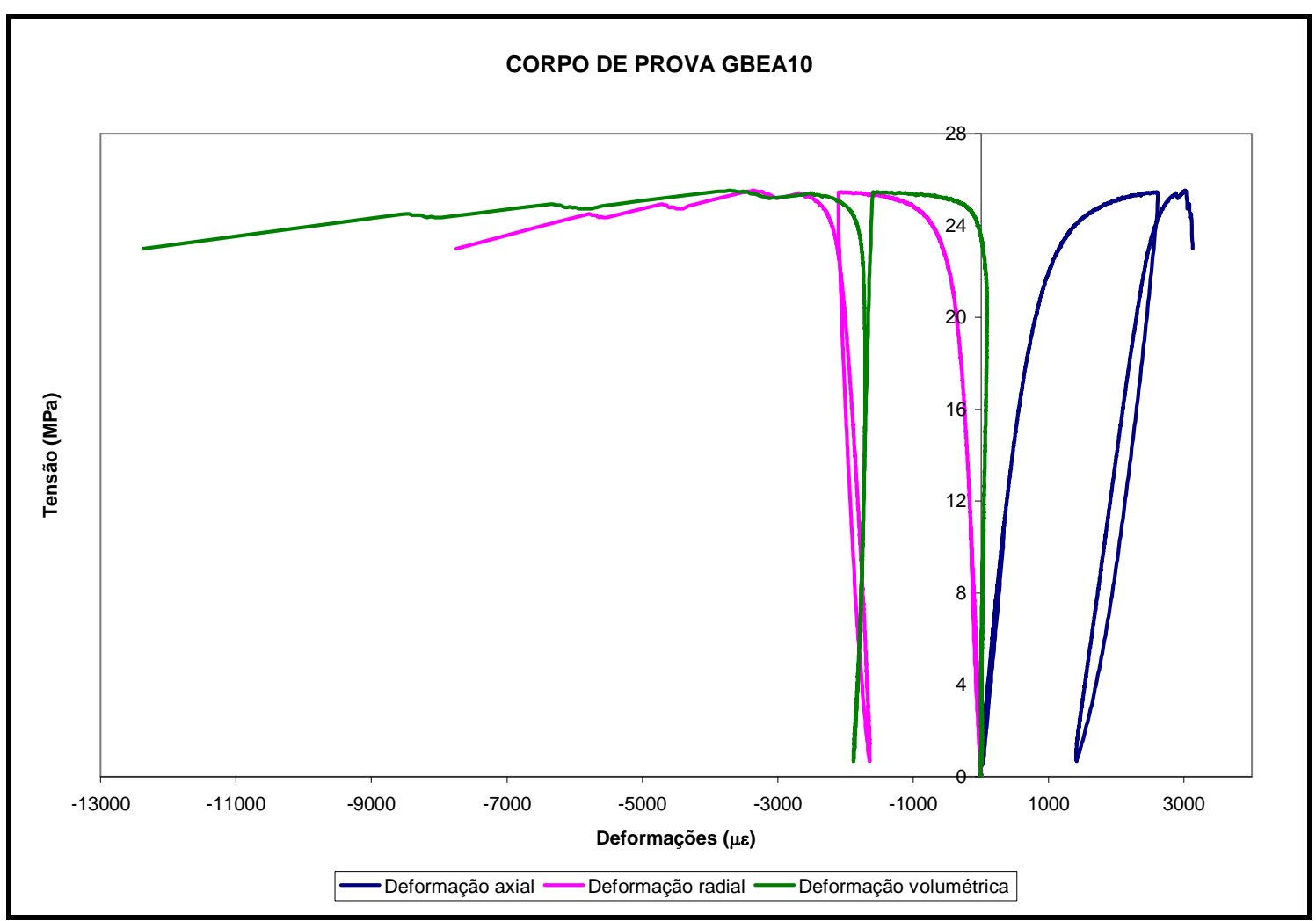

Figura 4.13 Curva tensão versus deformações axial, radial e volumétrica do corpo de prova GBEA10 submetido a 5 ciclos de carregamento e descarregamento (carregamento perpendicular às camadas)

A Tabela 4.7 apresenta os níveis de tensões alcançados nos ciclos de carregamento e descarregamento. Salienta-se que, em todos os casos, o descarregamento foi até o nível de tensão 0 .

Tabela 4.7 Níveis de tensão alcançados nos ciclos de carregamento e descarregamento para os corpos de prova GBEA5 e GBEA10

\begin{tabular}{ccccc}
\hline $\begin{array}{c}\text { Corpo de } \\
\text { Prova }\end{array}$ & $\begin{array}{c}\text { Condição de } \\
\text { carregamento }\end{array}$ & Ciclos & $\begin{array}{c}\text { Máxima tensão } \\
\text { aplicada no } \\
\text { carregamento (MPa) }\end{array}$ & $\begin{array}{c}\text { \% em relação à } \\
\text { resistência pico }\end{array}$ \\
\hline GBEA5 & Paralelo às camadas & Primeiro & 9,55 & 36,5 \\
& & Segundo & 18,26 & 69,7 \\
& Terceiro & 21,70 & 82,8 \\
& Quarto & 24,06 & 91,8 \\
\hline GBEA10 & Perpendicular às camadas & Primeiro & 1,49 & 5,8 \\
& & Segundo & 3,80 & 14,9 \\
& & Terceiro & 7,52 & 29,5 \\
& & Quarto & 10,97 & 43,0 \\
& & Quinto & 25,44 & 99,8 \\
\hline
\end{tabular}


A Tabela 4.8 apresenta os resultados obtidos a partir dos registros da energia absoluta acumulada dos eventos de emissão acústica, indicando o início do registro de eventos de emissão acústica (fae) e a ocorrência e o crescimento das físsuras intergranulares (ie).

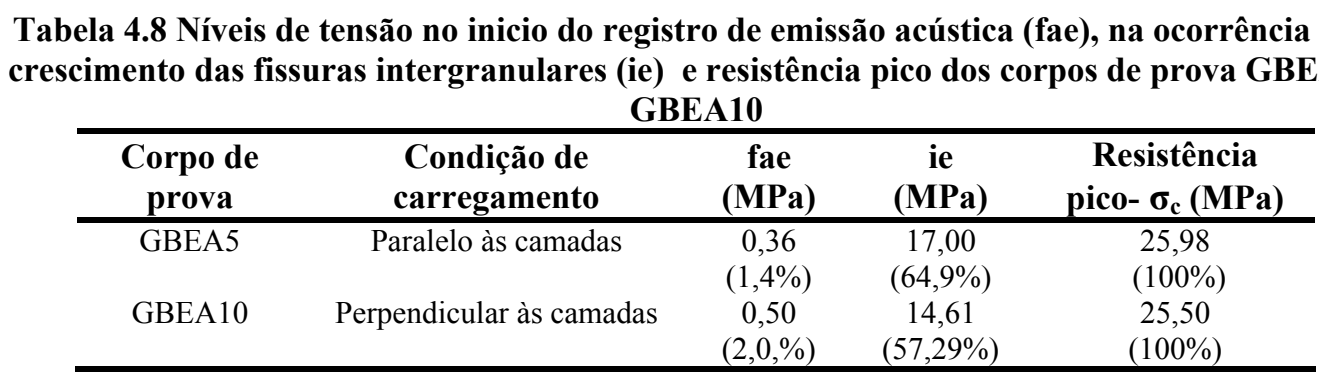

O valor do nível de tensão correspondente ao início do registro de emissão acústica (fae) e o nível de tensão correspondente à ocorrência e ao crescimento das fissuras intergranulares (ie) são 1,4 e 2,0\% de $\sigma_{\mathrm{c}}$ e 65 e $57 \%$ de $\sigma_{\mathrm{c}}$, respectivamente. Estes valores são próximos aos encontrados nos ensaios de compressão uniaxial com controle de deslocamento do prato (Tabela 4.3) e com controle de força (Tabela 4.5) e que variam de 1,6 a $2,2 \%$ de $\sigma_{\mathrm{c}}$ (controle do deslocamento do prato) e de 0,4 a $1,3 \%$ de $\sigma_{\mathrm{c}}$ (controle de força) para o nível de tensão correspondente ao início do registro de emissão acústica (fae) e de 69 a $78 \%$ de $\sigma_{c}$ (controle do deslocamento do prato) e de 43 a $75 \%$ de $\sigma_{c}$ (controle de força) para o nível de tensão correspondente à ocorrência e ao crescimento das fissuras intergranulares (ie).

Na Figura 4.14 se apresenta um gráfico típico de energia absoluta acumulada dos eventos de emissão acústica como função da tensão aplicada durante o carregamento e descarregamento do corpo de prova GBEA5 antes do pico de resistência.

Estes resultados parecem indicar a possibilidade de determinar o nível de tensão onde ocorre o crescimento das fissuras intergranulares em ensaios de compressão uniaxial submetidos a ciclos variáveis de carregamento antes do pico de resistência. 


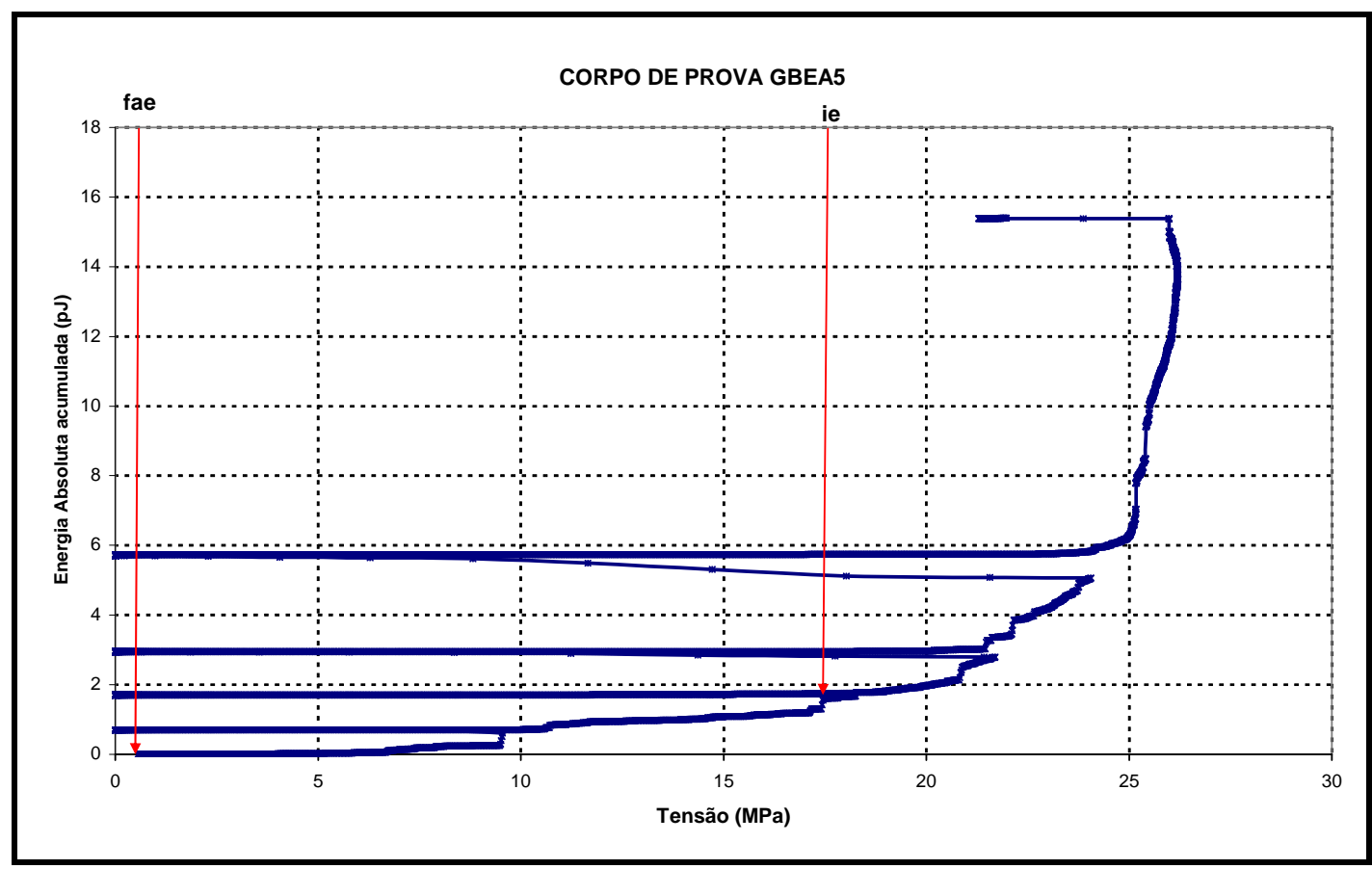

Figura 4.14 Energia absoluta acumulada dos eventos de emissão acústica como função da tensão aplicada durante o carregamento e descarregamento do corpo de prova GBEA5 antes do pico de resistência (carregamento paralelo às camadas)

Analisando os resultados e gráficos de emissão acústica e de tensão ao longo do tempo, observa-se a ocorrência do efeito Kaiser neste tipo de rocha (Figuras 4.15 e 4.16).

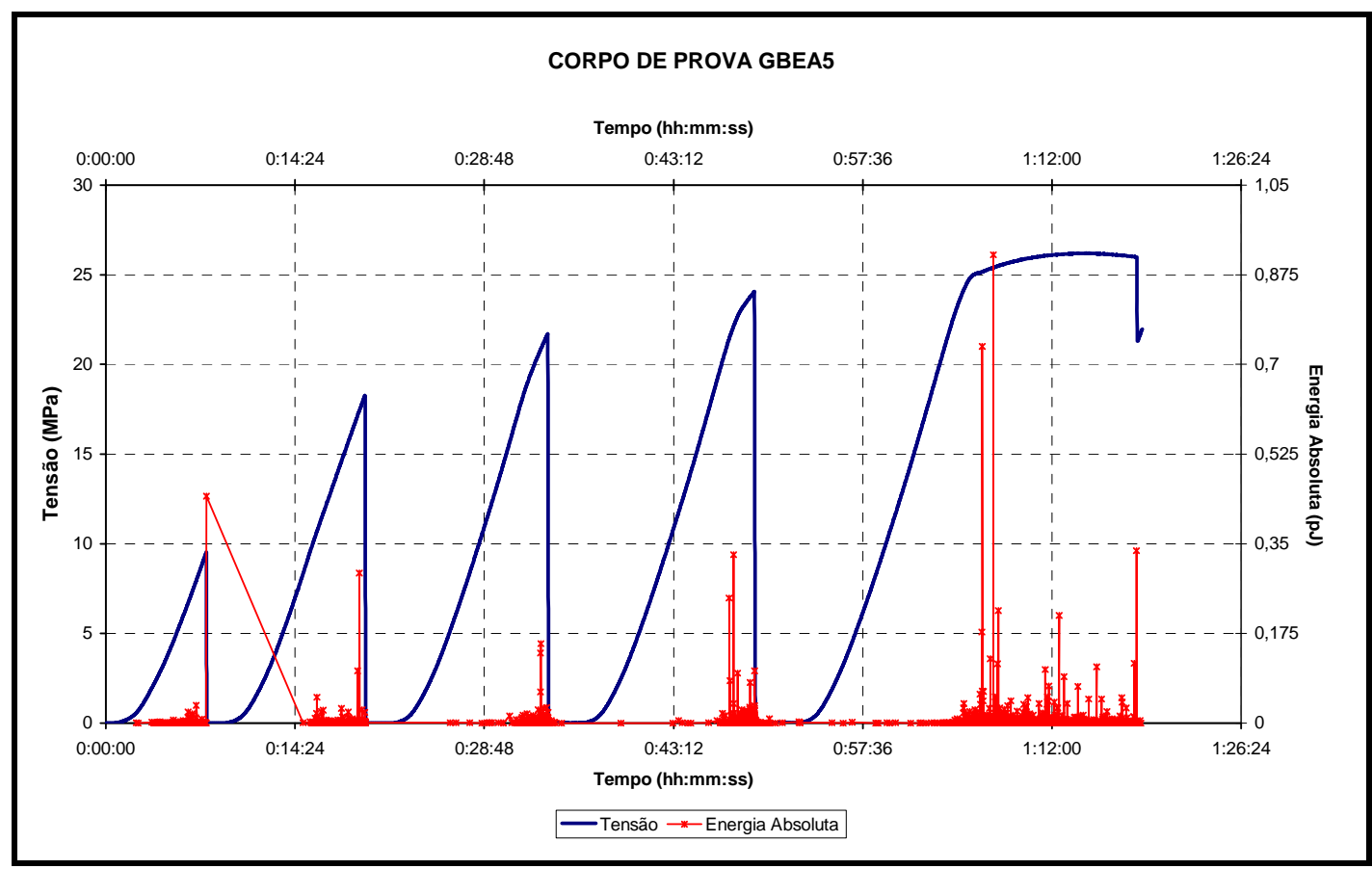

Figura 4.15 Tensão e energia absoluta versus tempo do corpo de prova GBEA5 submetido a ciclos variáveis de carregamento antes do pico de resistência (carregamento paralelo às camadas) 


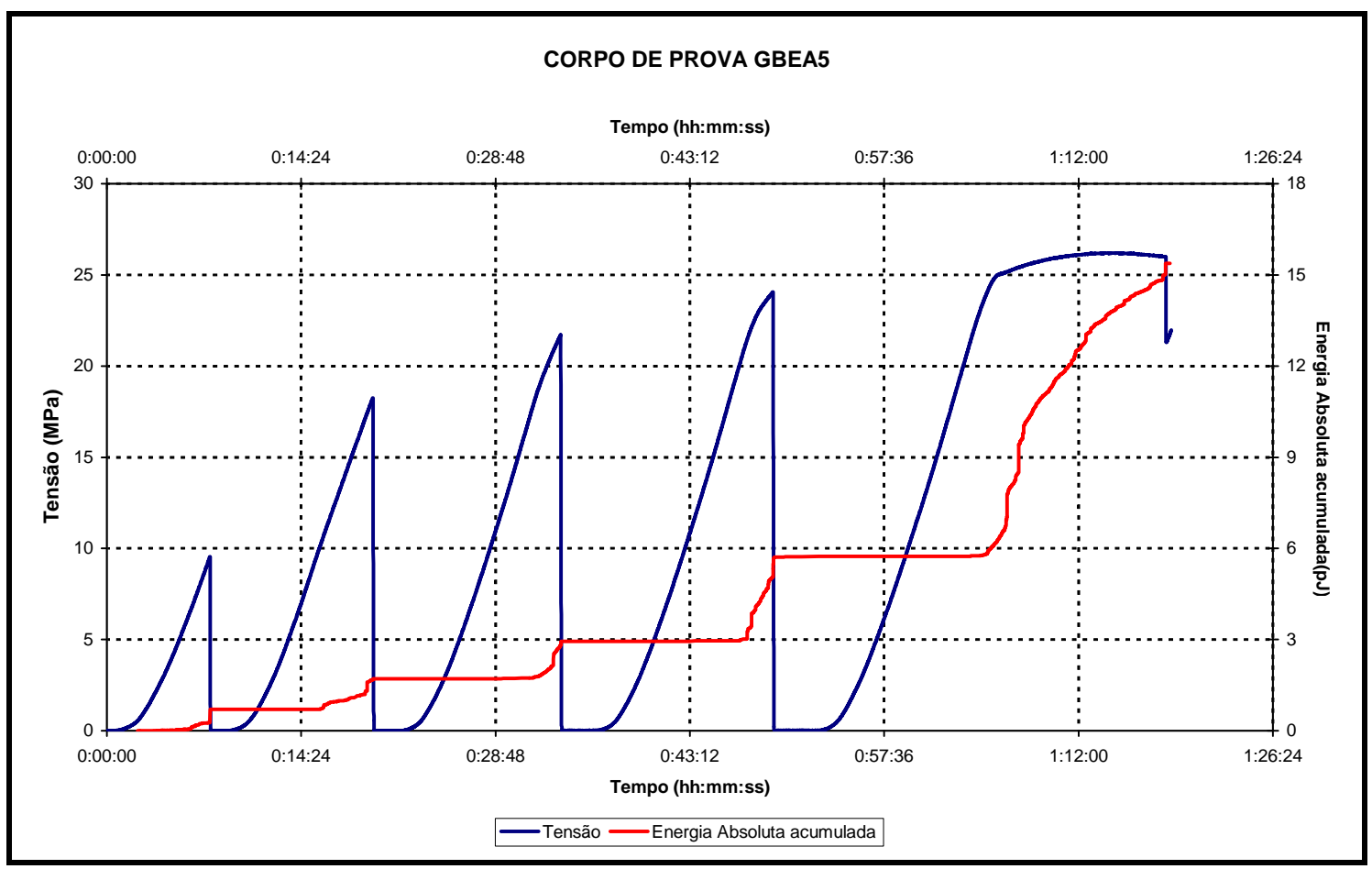

Figura 4.16 Tensão e energia absoluta acumulada versus tempo do corpo de prova GBEA5 submetido a ciclos variáveis de carregamento antes do pico de resistência (carregamento paralelo às camadas)

Os resultados obtidos concordam com a constatação de que, para se obter um efeito Kaiser bem pronunciado, a tensão de pré-carregamento deve estar entre 30 e $80 \%$ da resistência pico, a qual neste caso variou entre 6 e 70\% da resistência pico. Pode-se observar que o efeito Kaiser é bem pronunciado antes e após do início da dilatância.

\subsection{Ensaios de compressão uniaxial com ciclos variáveis de carregamento antes e após o pico de resistência}

Estes ensaios seguiram os procedimentos indicados nos itens 3.12.2.1 (Ensaios tipo CVI) e 3.12.2.2 (Ensaios tipo CVII). Foram ensaiados quatro corpos de prova com carregamento perpendicular às camadas (GBEA8, GBEA9, GBEA15 e GBEA16) e dois com carregamento paralelo às camadas (GBEA11 e GBEA12). 
Os ensaios realizados foram do tipo CVI para os corpos de prova GBEA8, GBEA15 e GBEA16 e do tipo CVII para os corpos de prova GBEA9, GBEA11 e GBEA12.

Os objetivos destes ensaios foram: a) Comprovar se seria possível encontrar os mesmos níveis de tensão correspondentes ao início do registro de eventos de emissão acústica (fae) e o nível de tensão correspondente à ocorrência e ao crescimento das fissuras intergranulares (ie), realizando ciclos de carregamento e descarregamento sob determinados níveis de tensão, em particular no trecho elástico, no trecho antes do pico de resistência e no trecho após o pico de resistência e b) Verificar a ocorrência do efeito Kaiser.

Apresentam-se na Tabela 4.9 os níveis de tensões alcançados nos ciclos variáveis de carregamento antes e após o pico de resistência nos corpos de prova estudados.

Verifica-se, da Tabela 4.9, que a máxima tensão aplicada em cada carregamento variou entre 6 e $90 \%$ da resistência pico, permitindo observar um efeito Kaiser bem pronunciado.

Como exemplo, nas Figuras 4.17 e 4.18, é possível observar que o efeito Kaiser é bem pronunciado antes e após o início da dilatância e completamente bem pronunciado na região após o pico na parte descendente da curva tensão-deformação, assim como comentam Filimonov et al. (2002) para rochas salinas. 
Tabela 4.9 Níveis de tensão alcançados nos ciclos de carregamento e descarregamento para os corpos de prova estudados, indicando a condição de carregamento e se foi realizado antes ou após o pico de resistência

\begin{tabular}{|c|c|c|c|c|c|}
\hline $\begin{array}{l}\text { Corpo } \\
\text { de } \\
\text { prova }\end{array}$ & $\begin{array}{c}\text { Direção de } \\
\text { carregamento }\end{array}$ & Ciclos & $\begin{array}{l}\text { Antes ou após o } \\
\text { pico de resistência }\end{array}$ & $\begin{array}{l}\text { Máxima tensão } \\
\text { aplicada no } \\
\text { carregamento } \\
\text { (MPa) }\end{array}$ & $\begin{array}{c}\text { \% em relação } \\
\text { à resistência } \\
\text { pico }\end{array}$ \\
\hline \multirow[t]{3}{*}{ GBEA8 } & Perpendicular às camadas & Primeiro & Antes & 11,03 & 46,27 \\
\hline & & Segundo & Após & 23,28 & 97,65 \\
\hline & & Terceiro & Após & 22,15 & 92,91 \\
\hline \multirow[t]{5}{*}{ GBEA9 } & Perpendicular às camadas & Primeiro & Antes & 1,42 & 5,56 \\
\hline & & Segundo & Antes & 3,48 & 13,63 \\
\hline & & Terceiro & Antes & 25,29 & 99,06 \\
\hline & & Quarto & Na ruptura & 25,53 & 100,00 \\
\hline & & Quinto & Após & 23,19 & 90,83 \\
\hline \multirow[t]{6}{*}{ GBEA11 } & Paralelo às camadas & Primeiro & Antes & 1,54 & 7,57 \\
\hline & & Segundo & Antes & 4,08 & 20,05 \\
\hline & & Terceiro & Antes & 7,50 & 36,86 \\
\hline & & Quarto & Antes & 12,19 & 59,90 \\
\hline & & Quinto & Antes & 20,04 & 98,48 \\
\hline & & Sexto & Após & 19,96 & 98,08 \\
\hline \multirow[t]{6}{*}{ GBEA12 } & Paralelo às camadas & Primeiro & Antes & 1,81 & 11,09 \\
\hline & & Segundo & Antes & 3,98 & 24,40 \\
\hline & & Terceiro & Antes & 7,36 & 45,16 \\
\hline & & Quarto & Antes & 9,89 & 60,70 \\
\hline & & Quinto & Após & 16,23 & 99,57 \\
\hline & & Sexto & Após & 15,77 & 96,73 \\
\hline \multirow[t]{7}{*}{ GBEA15 } & Perpendicular às camadas & Primeiro & Antes & 3,37 & 13,48 \\
\hline & & Segundo & Antes & 6,91 & 27,64 \\
\hline & & Terceiro & Antes & 10,80 & 43,20 \\
\hline & & Quarto & Antes & 14,49 & 57,96 \\
\hline & & Quinto & Antes & 18,04 & 72,16 \\
\hline & & Sexto & Antes & 21,70 & 86,80 \\
\hline & & Sétimo & Após & 19,91 & 79,64 \\
\hline \multirow[t]{9}{*}{ GBEA16 } & Perpendicular às camadas & Primeiro & Antes & 4,00 & 13,98 \\
\hline & & Segundo & Antes & 7,60 & 26,56 \\
\hline & & Terceiro & Antes & 11,32 & 39,57 \\
\hline & & Quarto & Antes & 15,02 & 52,50 \\
\hline & & Quinto & Antes & 18,81 & 65,75 \\
\hline & & Sexto & Antes & 22,33 & 78,05 \\
\hline & & Sétimo & Antes & 25,75 & 90,00 \\
\hline & & Oitavo & Após & 26,50 & 92,62 \\
\hline & & Nono & Após & 25,18 & 88,01 \\
\hline
\end{tabular}




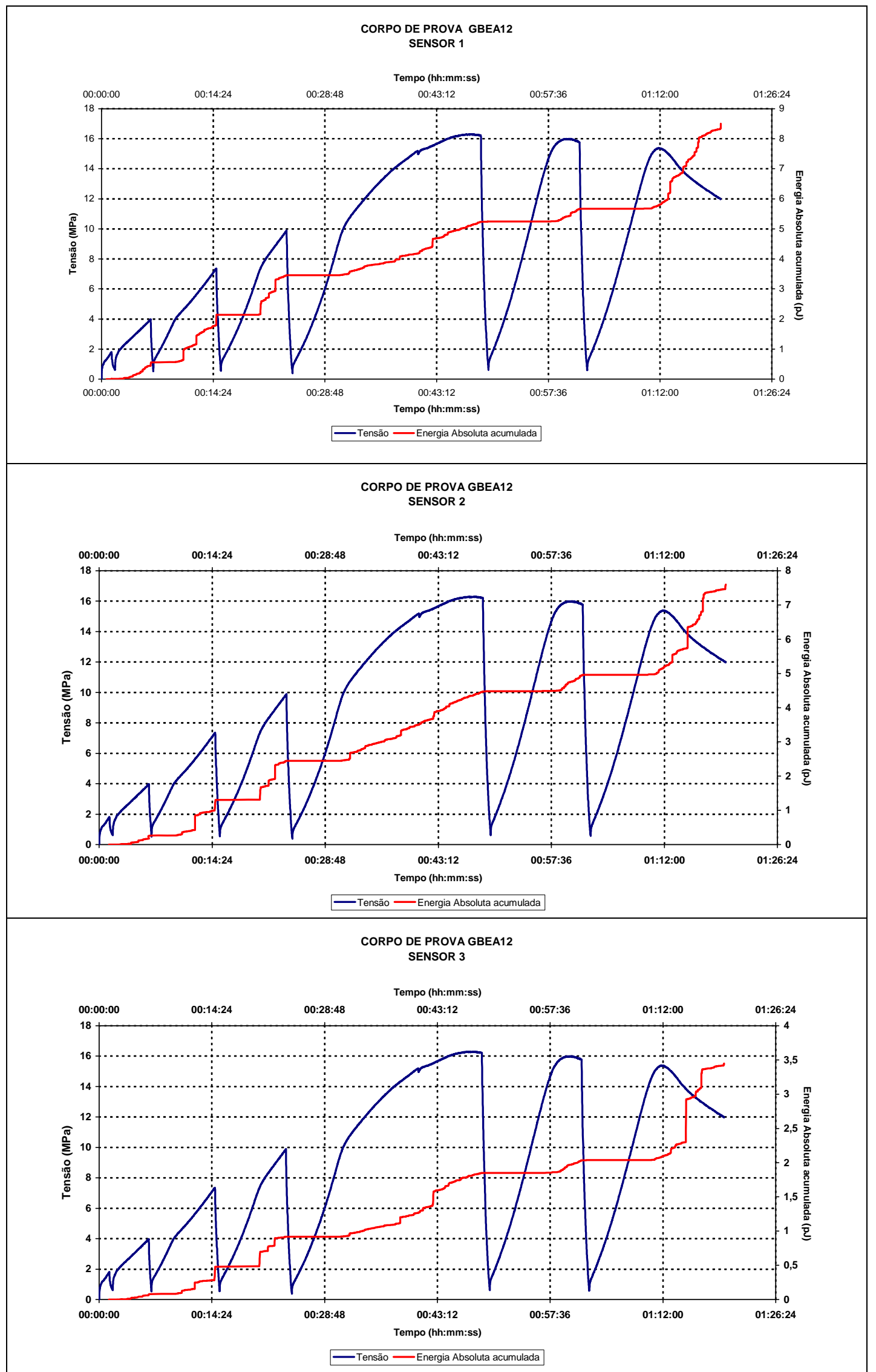

Figura 4.17 Tensão e energia absoluta acumulada versus tempo dos sensores 1, 2 e 3 no corpo de prova GBEA12 submetido a ciclos variáveis de carregamento antes e após o pico de resistência (carregamento perpendicular às camadas) 


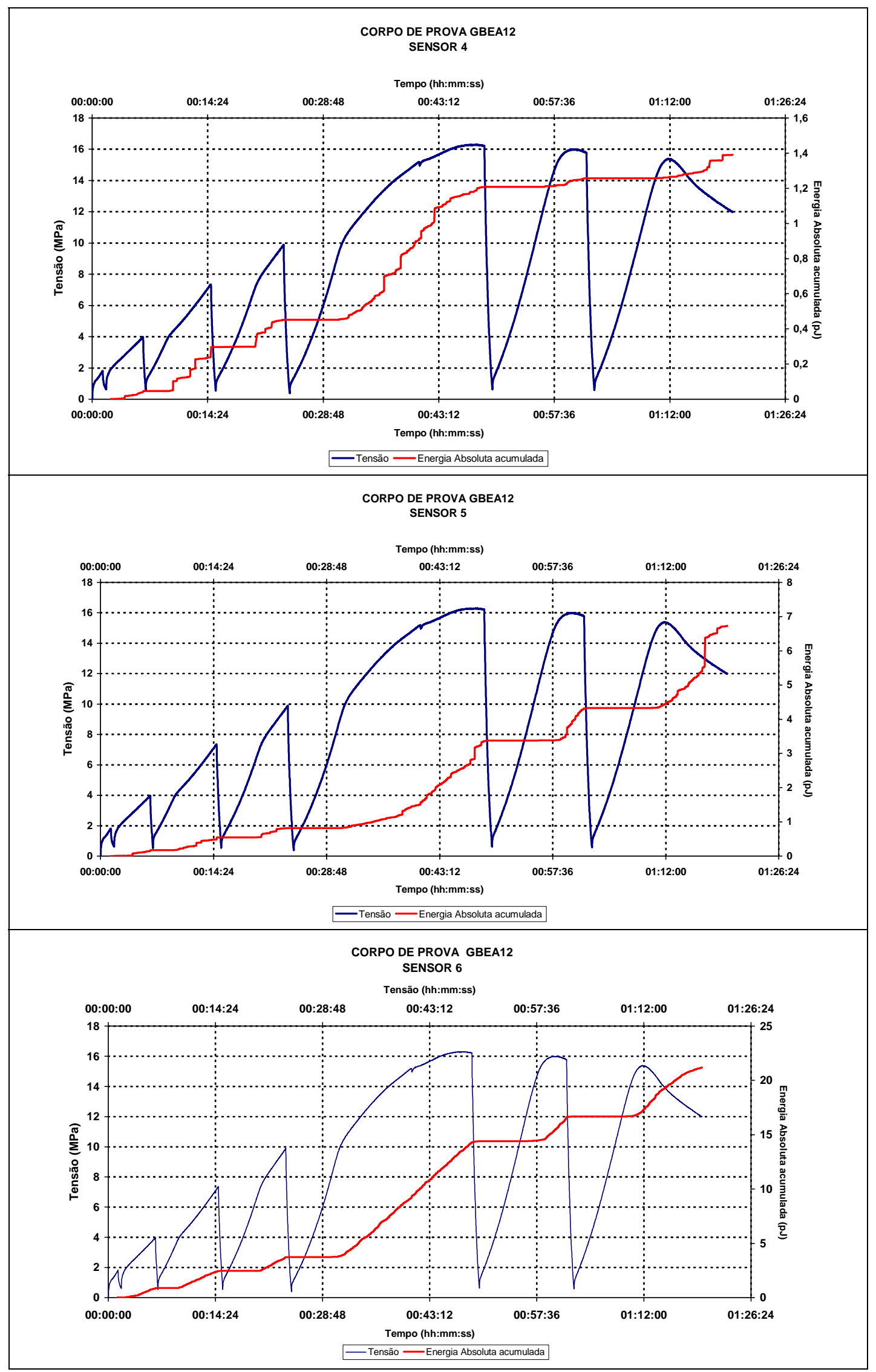

Figura 4.18 Tensão e energia absoluta acumulada versus tempo dos sensores 4,5 e 6 no corpo de prova GBEA12 submetido a ciclos variáveis de carregamento antes e após o pico de resistência (carregamento perpendicular às camadas) 
A Tabela 4.10 apresenta os resultados obtidos a partir dos registros da energia absoluta acumulada dos eventos de emissão acústica como função da tensão aplicada dos corpos de prova estudados, indicando o início do registro de eventos de emissão acústica (fae) e a ocorrência e o crescimento das fissuras intergranulares (ie).

Tabela 4.10 Níveis de tensão no inicio do registro de eventos de emissão acústica (fae), na ocorrência e no crescimento das fissuras intergranulares (ie) e resistência pico dos corpos de prova

\begin{tabular}{ccccc}
\hline $\begin{array}{c}\text { Corpo de } \\
\text { prova }\end{array}$ & $\begin{array}{c}\text { Condição de } \\
\text { carregamento }\end{array}$ & $\begin{array}{c}\text { fae } \\
(\mathbf{M P a})\end{array}$ & $\begin{array}{c}\text { ie } \\
(\mathbf{M P a})\end{array}$ & $\begin{array}{c}\text { Resistência } \\
\text { pico- } \mathbf{\sigma}_{\mathbf{c}} \\
(\mathbf{M P a})\end{array}$ \\
\hline GBEA8 & Perpendicular às camadas & 0,60 & 13,70 & 23,84 \\
& & $(2,52 \%)$ & $(57,47 \%)$ & $(100 \%)$ \\
GBEA9 & Perpendicular às camadas & 1,05 & 22,96 & 25,53 \\
& & $(4,11 \%)$ & $(89,93 \%)$ & $(100 \%)$ \\
GBEA11 & Paralelo às camadas & 2,24 & 7,54 & 20,35 \\
& & $(11,01 \%)$ & $(37,06 \%)$ & $(100 \%)$ \\
GBEA12 & Paralelo às camadas & 0,62 & 10,73 & 16,30 \\
& & $(3,80 \%)$ & $(65,83 \%)$ & $(100 \%)$ \\
GBEA15 & Perpendicular às camadas & 0,21 & 15,68 & 25,00 \\
& & $(0,84 \%)$ & $(62,72 \%)$ & $(100 \%)$ \\
GBEA16 & Perpendicular às camadas & 0,70 & 15,92 & 28,61 \\
& & $(2,45 \%)$ & $(55,64 \%)$ & $(100 \%)$ \\
\hline
\end{tabular}

O valor do nível de tensão correspondente ao início do registro de eventos de emissão acústica (fae) varia de 0,8 a $11 \%$ de $\sigma_{\mathrm{c}}$ e o nível de tensão correspondente à ocorrência e o crescimento das fissuras intergranulares (ie) varia de 55 a $90 \%$ de $\sigma_{c}$.

A diferença obtida com os valores encontrados nos ensaios de compressão uniaxial com controle de deslocamento do prato (Tabela 4.3) e com controle de força (Tabela 4.5) é devida ao fato que os corpos de prova GBEA9, GBEA11 e GBEA12 são visivelmente fissurados, o que permitiria concluir que no caso de rochas dúcteis como os gipsitos bandados o início do registro de eventos de emissão acústica (fae) se dá quando inicia o microfissuramento. O que acontece inicialmente é o fechamento das microfissuras ou rearranjo das partículas até um nível de tensão onde começa o início da propagação das microfissuras.

Considerando os outros corpos de prova (GBEA8, GBEA15 e GBEA16) para a determinação dos níveis de tensão no inicío do registro de eventos de emissão acústica 
(fae) e na ocorrência e crescimento das fissuras intergranulares (ie), podemos observar que o valor do nível de tensão correspondente ao início do registro de eventos de emissão acústica (fae) varía de 0,8 a 2,5\% de $\sigma_{\mathrm{c}}$ e o nível de tensão correspondente à ocorrência e crescimento das fissuras intergranulares (ie) varia de 55 a $65 \%$ de $\sigma_{\mathrm{c}}$. Estes valores são próximos aos encontrados nos ensaios de compressão uniaxial com controle de deslocamento do prato (Tabela 4.3) e com controle de força (Tabela 4.5) e que variam de 1,6 a $2,2 \%$ de $\sigma_{\mathrm{c}}$ (controle do deslocamento do prato) e de 0,4 a $1,3 \%$ de $\sigma_{\mathrm{c}}$ (controle de força) para o nível de tensão correspondente ao início do registro de emissão acústica (fae) e de 69 a 78\% de $\sigma_{\mathrm{c}}$ (controle do deslocamento do prato) e de 43 a $75 \%$ de $\sigma_{\mathrm{c}}$ (controle de força) para o nível de tensão correspondente à ocorrência e crescimento das fissuras intergranulares (ie).

No Apêndice 2, são apresentados gráficos típicos de histórico de carregamentos, deformações, contagem, contagem acumulada, energia absoluta e energia absoluta acumulada de corpos de prova submetidos a compressão uniaxial com ciclos variáveis de carregamento antes e após o pico de resistência nas duas orientações do carregamento com relação às camadas (paralela e perpendicular) e dois tipos de controle (deslocamento do prato e força).

\subsection{Ensaios de fluência de curta e longa duração}

Estes ensaios seguiram os procedimentos indicados nos itens 3.12.3.3 (Ensaios tipo FCIII), 3.12.4.2 (Ensaios tipo FLII) e 3.12.4.3 (Ensaios tipo FLIII). Os resultados obtidos para os ensaios de fluência de curta e longa duração nas direções perpendicular e paralela às camadas são apresentados nas Tabelas 4.11 e 4.12 . 
Todos os ensaios de fluência de curta duração apresentados na Tabela 4.11 foram do tipo FCIII.

Os ensaios de fluência de longa duração apresentados na Tabela 4.12 foram do tipo FLII para os corpos de prova GBfluencia6, GBfluencia8, GBfluencia9 e GBfluencia10 e do tipo FLIII para os corpos de prova GBfluencia11, GBfluencia12, GBfluencia13 e GBfluencia14.

Tabela 4.11 Resultados dos ensaios de fluência de curta duração

\begin{tabular}{ccccccc}
\hline $\begin{array}{c}\text { Corpo de } \\
\text { prova }\end{array}$ & $\begin{array}{c}\text { Orientação das } \\
\text { camadas }\end{array}$ & $\begin{array}{c}\text { Emissão } \\
\text { Acústica }\end{array}$ & $\begin{array}{c}\text { Duração do } \\
\text { ensaio } \\
\text { (horas) }\end{array}$ & $\begin{array}{c}\text { Tensão } \\
\text { aplicada } \\
\text { (MPa) }\end{array}$ & $\begin{array}{c}\text { \% em relação } \\
\text { a tensão de } \\
\text { ruptura }\end{array}$ & $\begin{array}{c}\text { Tensão } \\
\text { ruptura } \\
\left(\mathbf{\sigma}_{\mathbf{c}}^{*}\right) \\
(\mathbf{M P a})\end{array}$ \\
\hline GBflu8MTS & Paralela & 4 sensores & 49 & 22,41 & 80,50 & 27,84 \\
GBflu9MTS & Perpendicular & 4 sensores & 64 & 19,96 & 76,98 & 25,93 \\
GBflu10MTS & Perpendicular & 4 sensores & 40 & 20,87 & 89,11 & 23,42 \\
GBflu11MTS & Paralela & 4 sensores & 22 & 22,78 & 79,82 & 28,54 \\
GBflu12MTS & Paralela & 4 sensores & 23 & 23,87 & 83,78 & 28,49 \\
GBflu13MTS & Perpendicular & 4 sensores & 65 & 19,66 & 73,00 & 26,93 \\
\hline
\end{tabular}

Tabela 4.12 Resultados dos ensaios de fluência de longa duração

\begin{tabular}{|c|c|c|c|c|c|c|}
\hline $\begin{array}{l}\text { Corpo de } \\
\text { prova }\end{array}$ & $\begin{array}{c}\text { Orientação das } \\
\text { camadas }\end{array}$ & $\begin{array}{l}\text { Emissão } \\
\text { Acústica }\end{array}$ & $\begin{array}{c}\text { Duração } \\
\text { do ensaio } \\
\text { (horas) }\end{array}$ & $\begin{array}{c}\text { Tensão } \\
\text { aplicada } \\
\text { (MPa) }\end{array}$ & $\begin{array}{c}\% \text { em } \\
\text { relação a } \\
\text { tensão de } \\
\text { ruptura }\end{array}$ & $\begin{array}{c}\text { Tensão } \\
\text { ruptura } \\
\left(\sigma_{\mathrm{c}}^{*}\right)(\mathrm{MPa})\end{array}$ \\
\hline GBfluencia6 & Paralela & sem EA & 1320 & 24,35 & 85,52 & 28,81 \\
\hline GBfluencia8 & Perpendicular & sem EA & 1320 & 24,16 & 95,38 & 25,33 \\
\hline GBfluencia9 & Perpendicular & sem EA & 1080 & 22,43 & 76,53 & 29,31 \\
\hline GBfluencia10 & Perpendicular & sem EA & 1080 & 21,44 & 85,42 & 25,10 \\
\hline GBfluencia11 & Perpendicular & 2 sensores & 274 & 21,30 & 74,00 & 28,78 \\
\hline GBfluencia12 & Perpendicular & 2 sensores & 274 & 20,38 & 97,19 & 20,97 \\
\hline GBfluencia13 & Paralela & 2 sensores & 274 & 21,97 & 70,94 & 30,97 \\
\hline GBfluencia14 & Paralela & 2 sensores & 274 & 23,38 & 87,34 & 26,77 \\
\hline
\end{tabular}

Quando a tensão axial aplicada é elevada rapidamente para um nível de tensão determinado, a atividade de emissão acústica aumenta muito rapidamente, e uma vez que a tensão é mantida constante, a taxa de eventos de emissão acústica cai com o tempo. Um exemplo típico deste fato é mostrado nas Figuras 4.19 e 4.20, onde o número acumulado de contagens, $N_{\text {acum }}$, dos eventos de emissão acústica detectados 
através dos sensores de freqüência intermediárias são apresentados ao longo do tempo. Observe-se a partir destas figuras que a taxa de eventos de emissão acústica cai com o tempo.

Nas Figuras 4.21 e 4.22, o número acumulado de contagens dos eventos de emissão acústica e a deformação axial são traçados ao longo do tempo.

O aspecto muito semelhante das tendências de deformação axial versus tempo, e contagem acumulada versus tempo sugere a existência de uma correlação entre as duas variáveis. A existência de tal correlação é um indício muito forte da questão central desta pesquisa, qual seja a de que a deformação lenta se deva ao processo de microfissuramento, denunciado pela emissão acústica.

Este fato foi explorado investigando diretamente a correlação entre a deformação axial e a contagem acumulada de eventos de emissão acústica (Figuras 4.23 e 4.24). Observa-se uma relação linear entre a deformação axial e a contagem acumulada no trecho predominante de fluência secundária. 


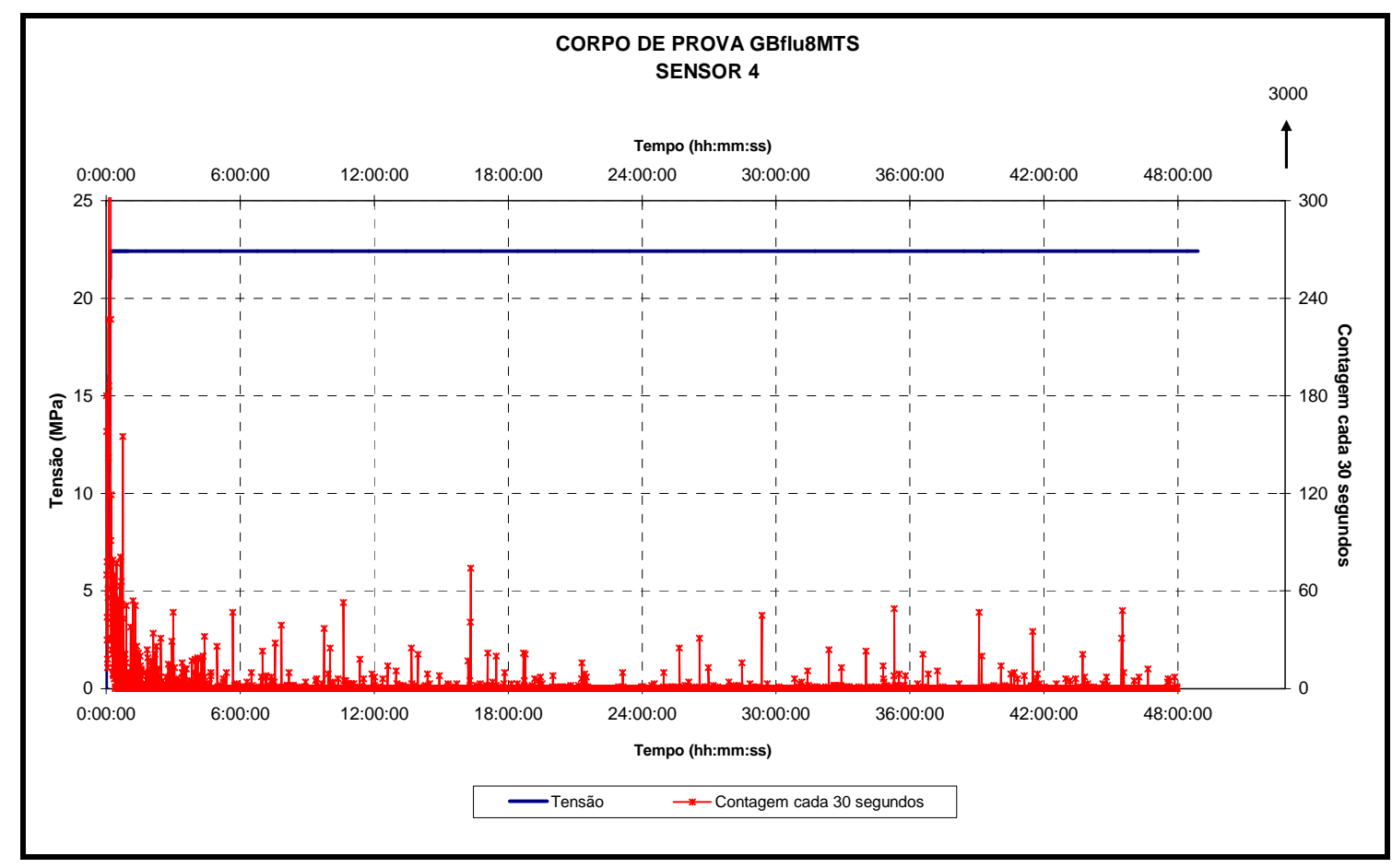

(a)

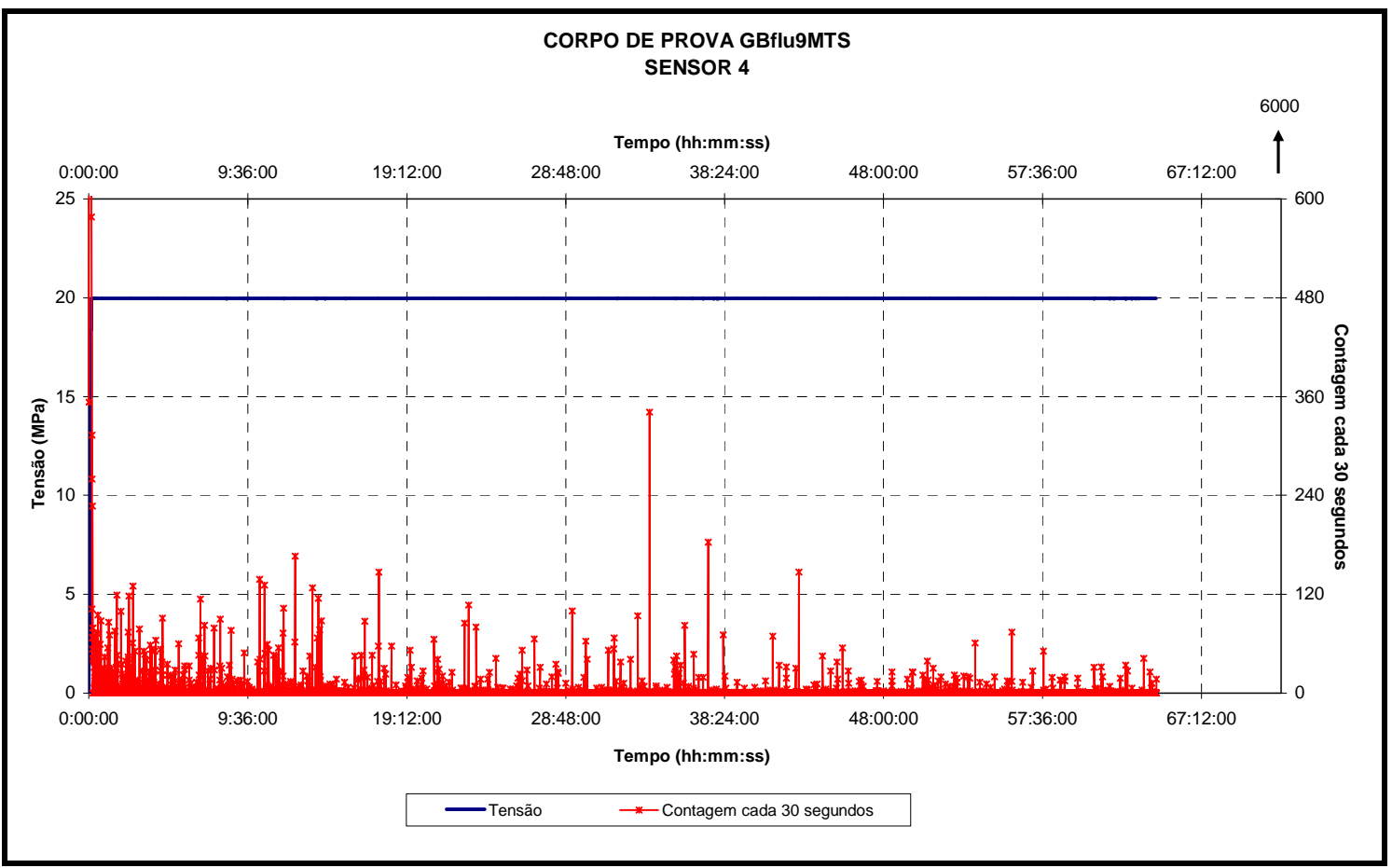

(b)

Figura 4.19 Tensão e contagem cada 30 segundos versus tempo dos eventos de emissão acústica no sensor 4 (freqüiências intermediárias de 100 a $400 \mathrm{kHz}$ ) do ensaio de fluência de curta duração (a) No corpo de prova GBflu8MTS (49 horas) e (b) No corpo de prova GBflu9MTS (64 horas) 


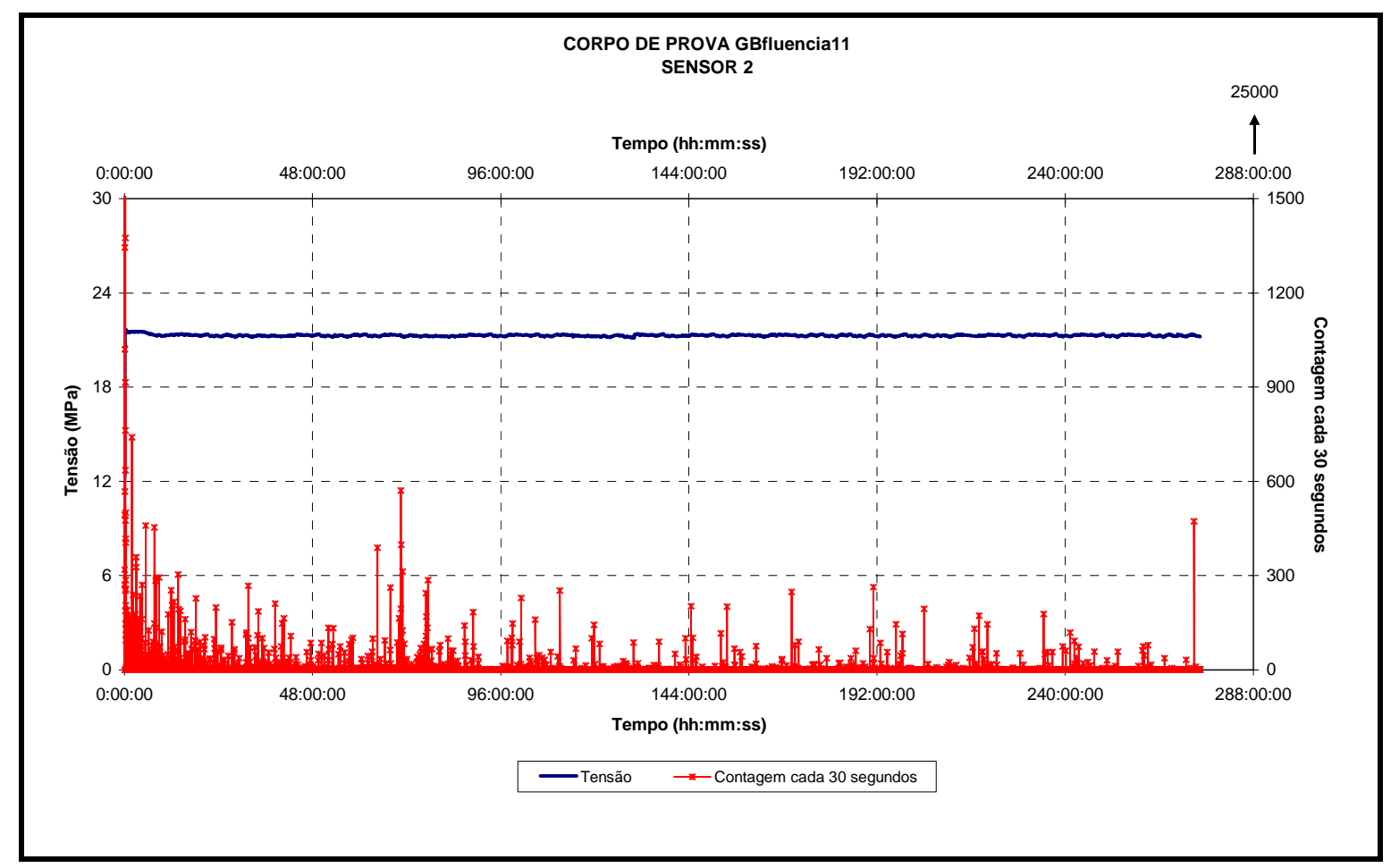

(a)

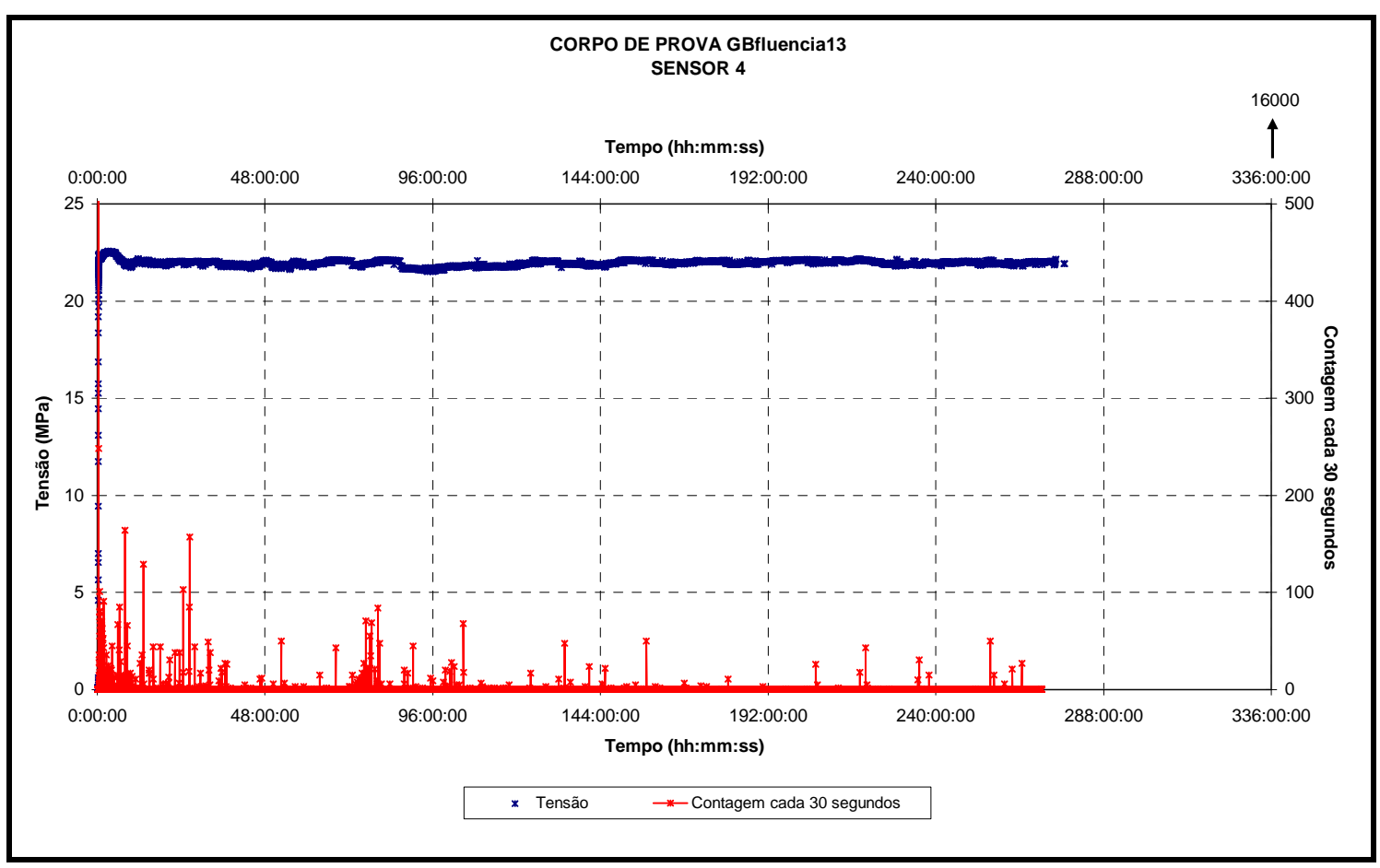

(b)

Figura 4.20 Tensão e contagem cada 30 segundos versus tempo dos eventos de emissão acústica no sensor 2 (freqüências intermediárias de 100 a $400 \mathrm{kHz}$ ) do ensaio de fluência de longa duração (274 horas) (a) No corpo de prova GBfluencia11 e (b) No corpo de prova GBfluencia13 


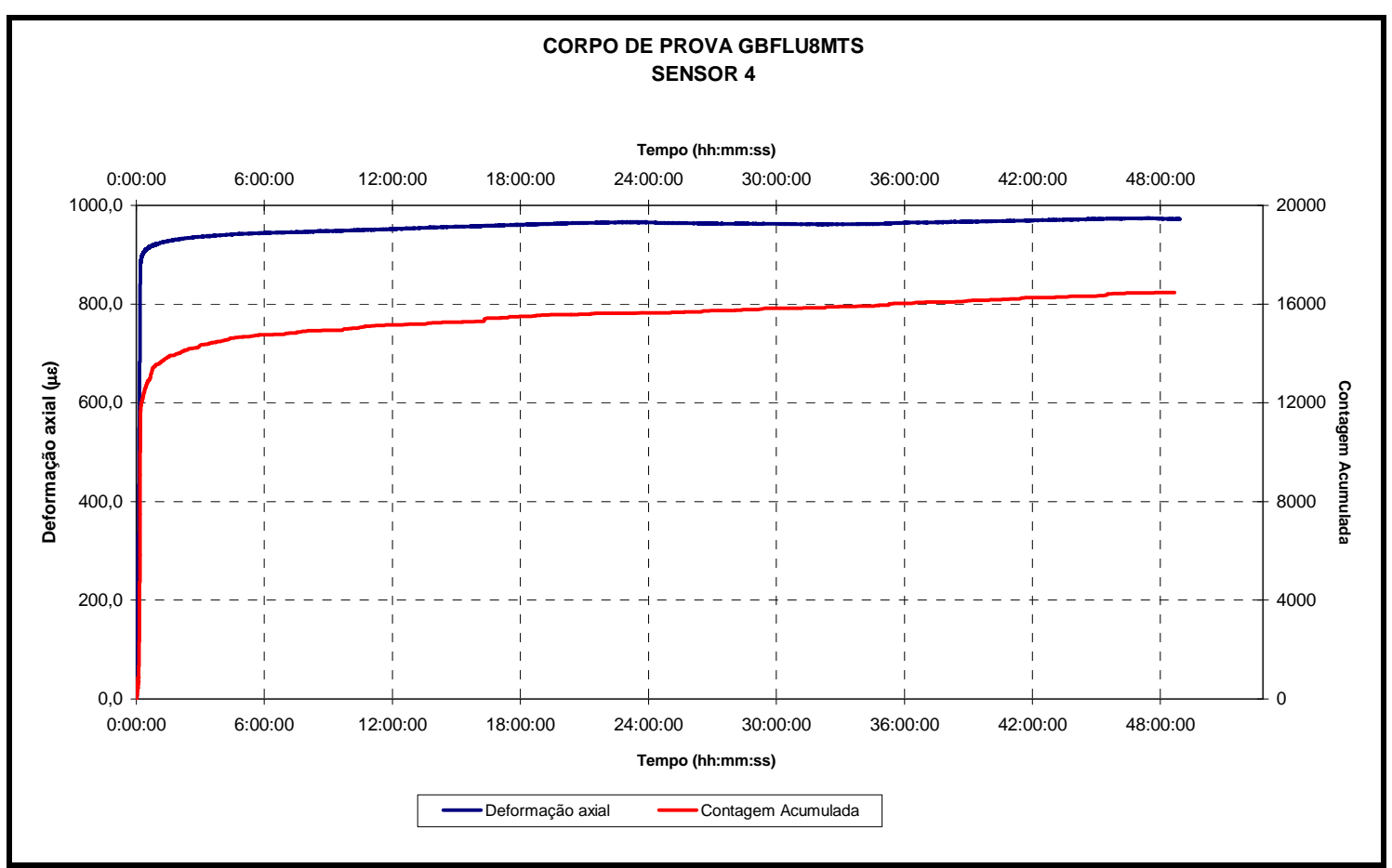

(a)

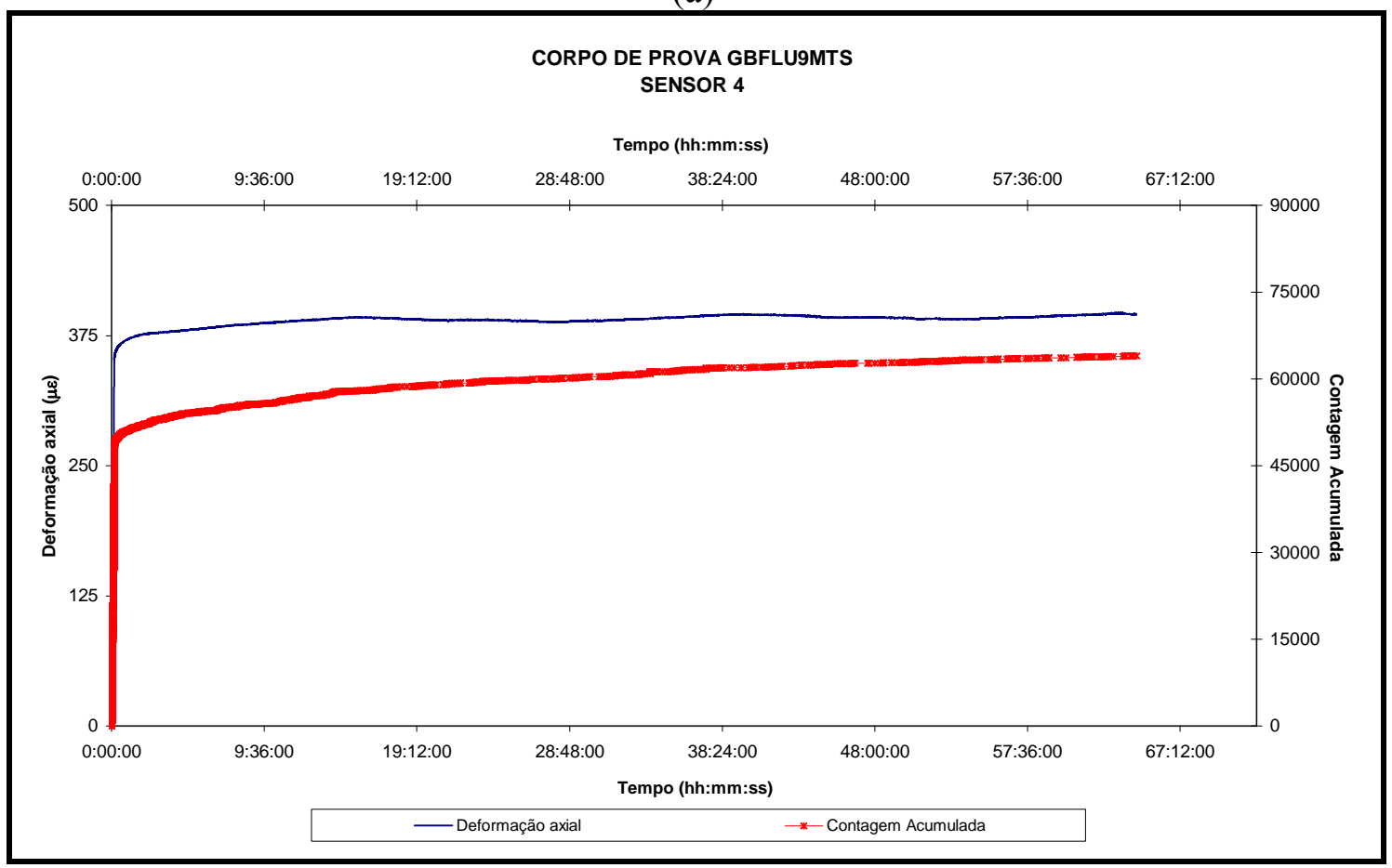

(b)

Figura 4.21 Deformação axial e contagem acumulada versus tempo dos eventos de emissão acústica no sensor 4 (freqüências intermediárias de 100 a $400 \mathrm{kHz}$ ) do ensaio de fluência de curta duração. (a) No corpo de prova GBflu8MTS (49 horas) e (b) No corpo de prova GBflu9MTS (64 horas) 


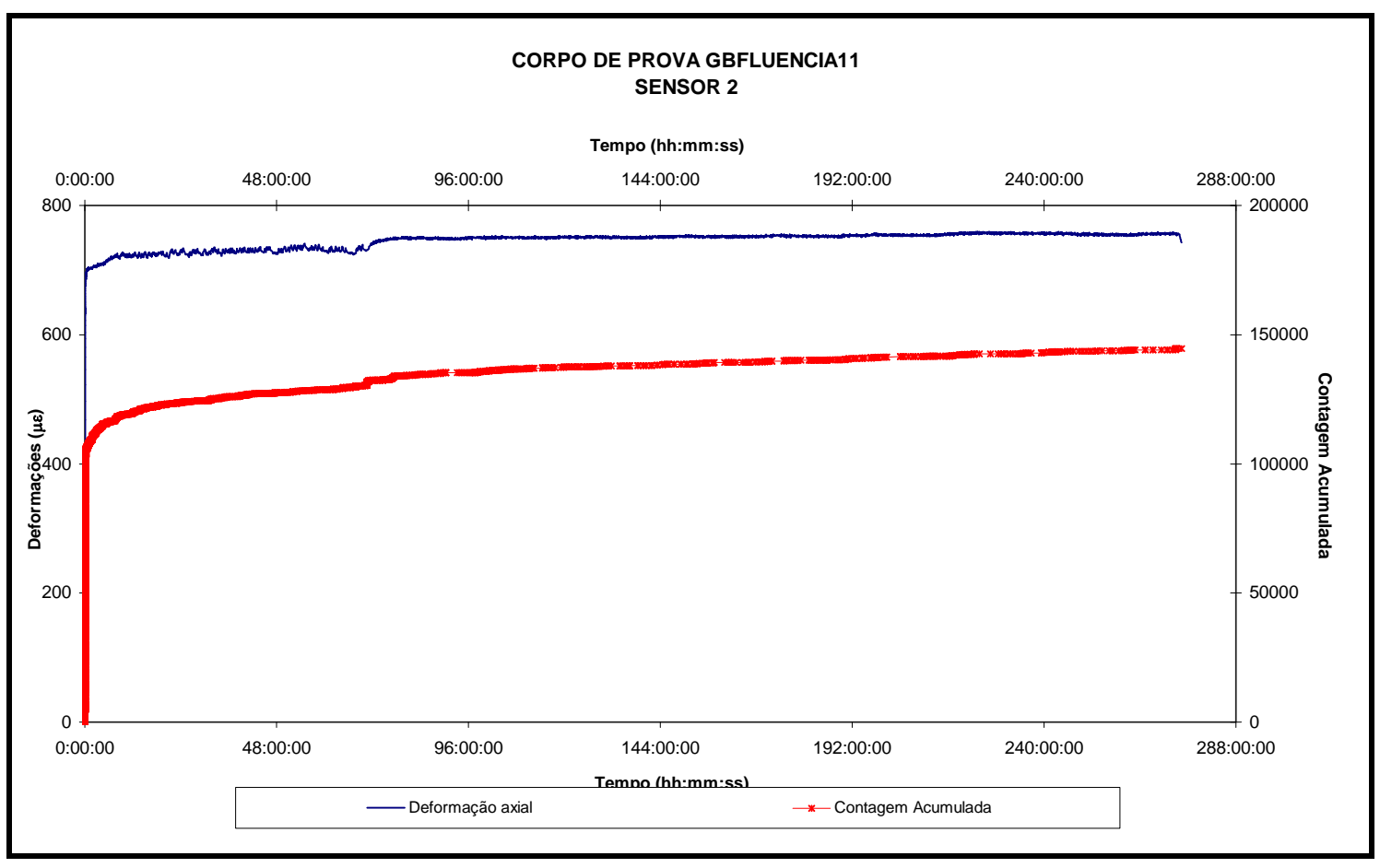

(a)

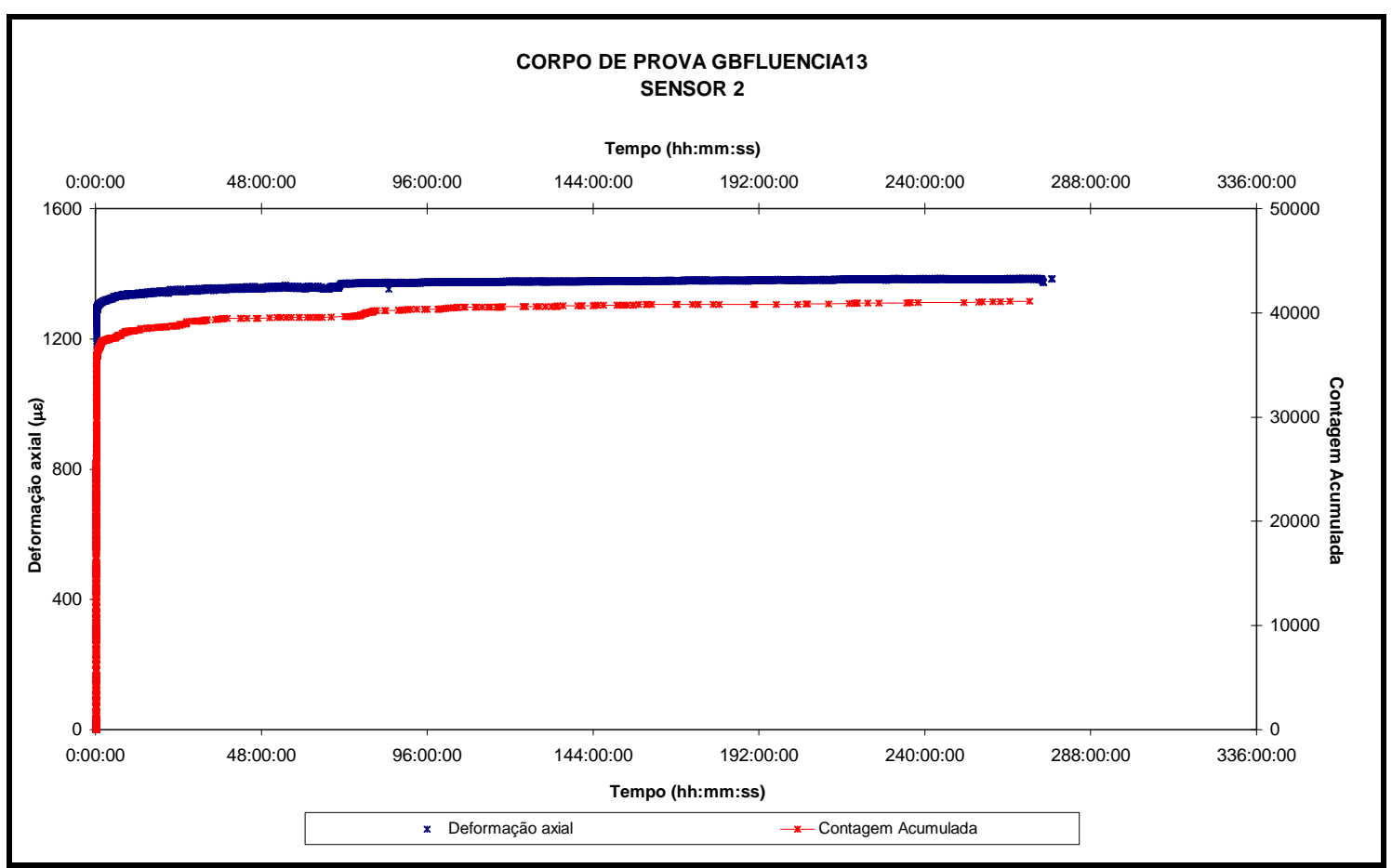

(b)

Figura 4.22 Deformação axial e contagem acumulada versus tempo dos eventos de emissão acústica no sensor 2 (freqüências intermediárias de 100 a $400 \mathrm{kHz}$ ) do ensaio de fluência de longa duração (274 horas). (a) No corpo de prova GBfluencia11 e (b) No corpo de prova GBfluencia13 


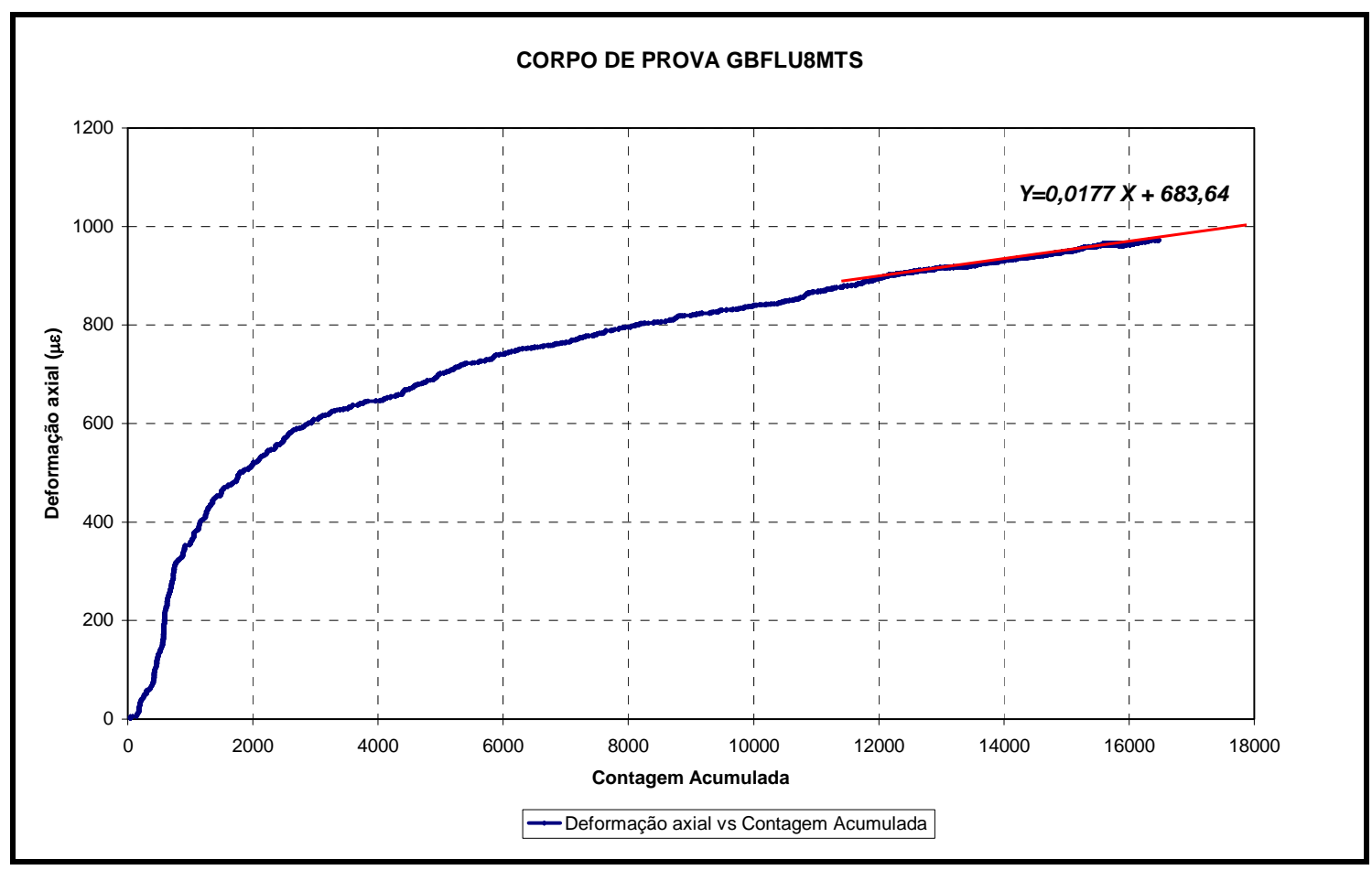

(a)

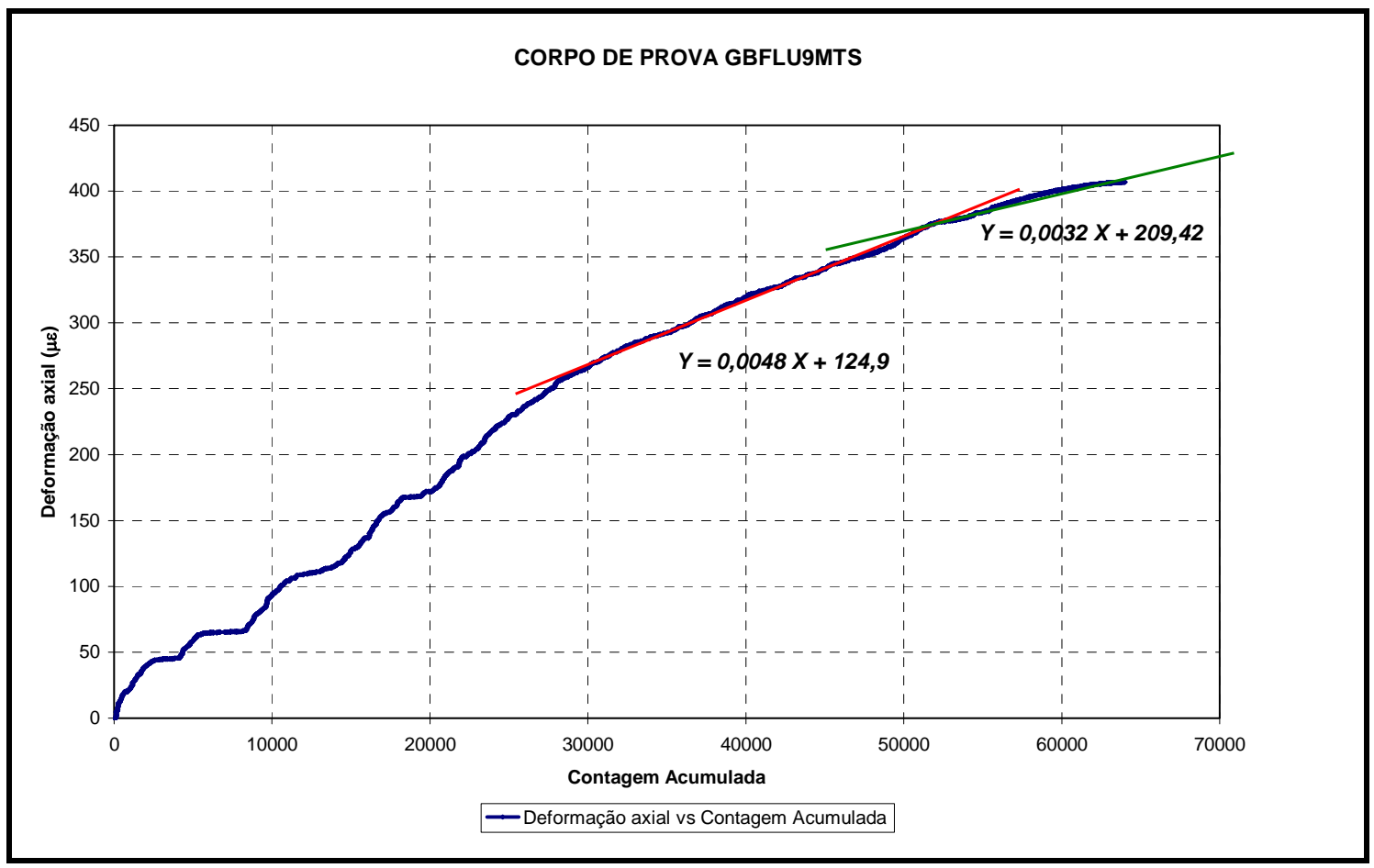

(b)

Figura 4.23 Deformação axial versus contagem acumulada dos eventos de emissão acústica no sensor 4 (freqüências intermediárias de 100 a $400 \mathrm{kHz}$ ) do ensaio de fluência de curta duração. (a) No corpo de prova GBflu8MTS (49 horas) e (b) No corpo de prova GBflu9MTS (64 horas). Observe-se a relação linear que existe entre a deformação axial e a contagem acumulada 


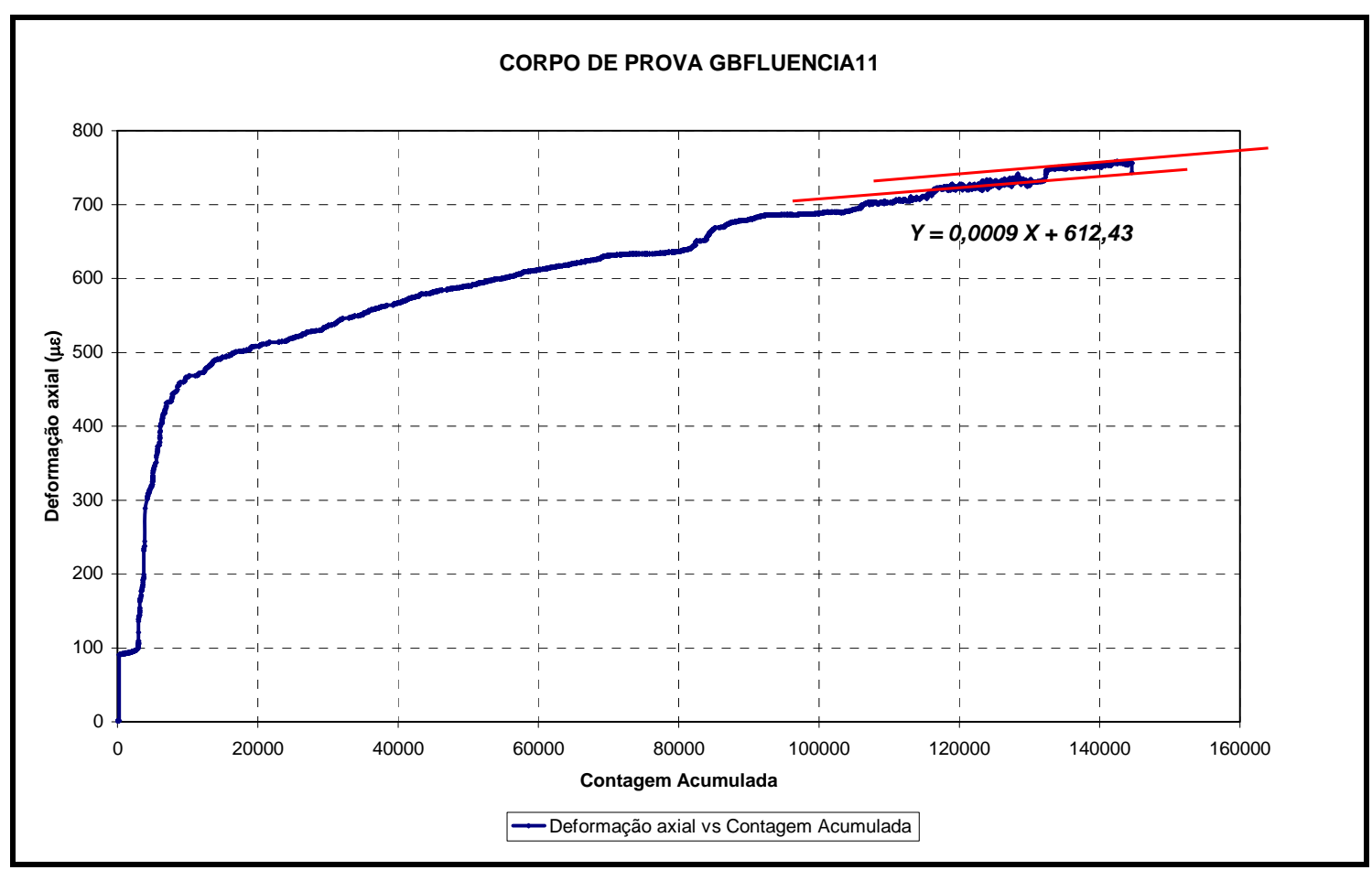

(a)

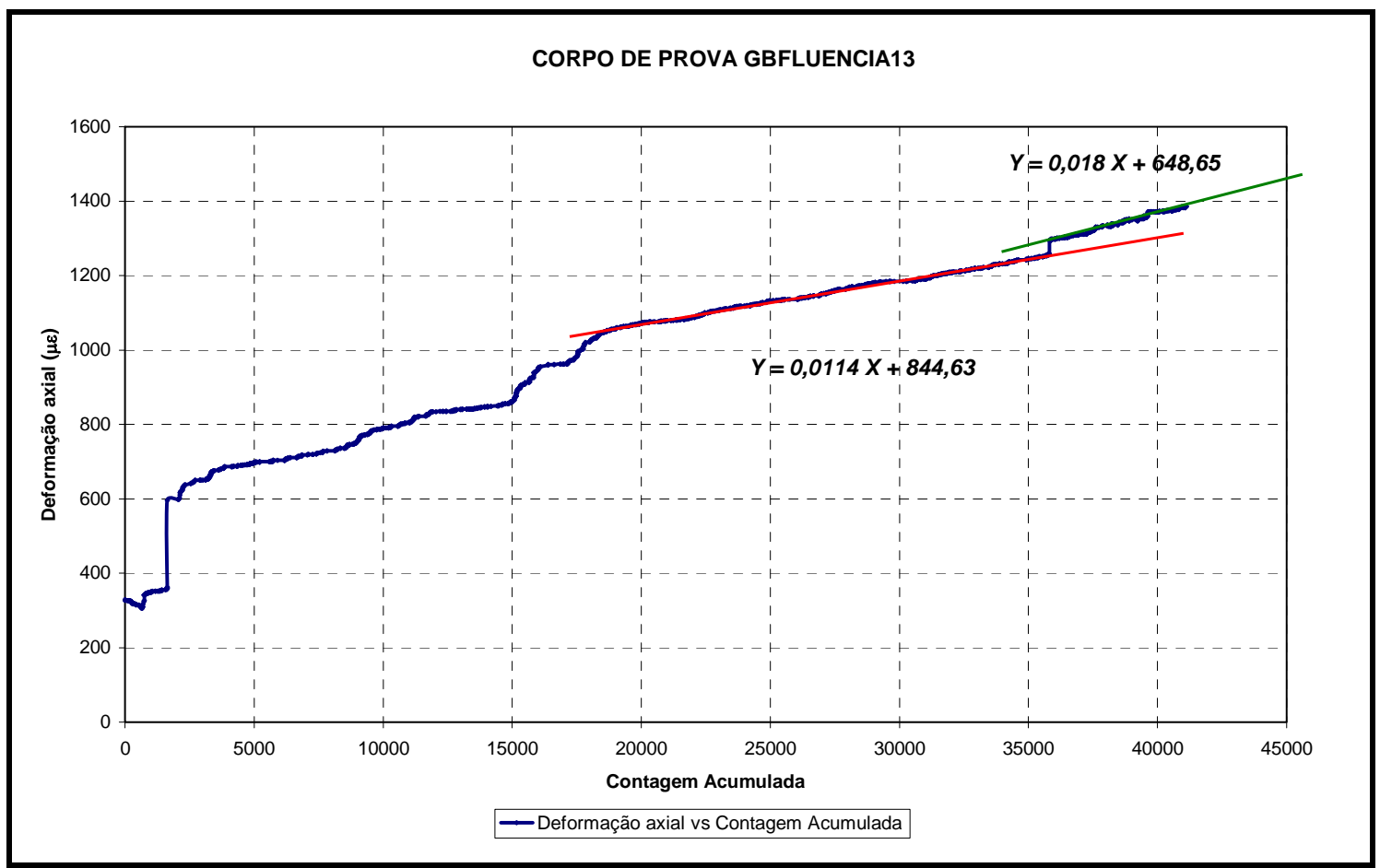

(b)

Figura 4.24 Deformação axial versus contagem acumulada dos eventos de emissão acústica no sensor 4 (freqüências intermediárias de $100 \mathrm{a} 400 \mathrm{kHz}$ ) do ensaio de fluência de longa duração (274 horas). (a) No corpo de prova GBfluencia11 e (b) No corpo de prova GBfluencia13. Observe-se a relação linear que existe entre a deformação axial e a contagem acumulada 
Nos ensaios de fluência de curta e longa duração do gipsito bandado os gráficos deformação axial vs contagem acumulada obedecem a uma correlação linear na fluência secundária como mostrado a continuação:

$$
\varepsilon_{a x}=A N_{a c u m}+B
$$

onde:

$N_{a c u m}:$ Número de contagens acumulada

$\varepsilon_{a x}:$ Deformação axial

$A, B$ : Constantes da correlação na fluência secundária

$A$ e $B$ são constantes que dependem do nível de tensão aplicado, da orientação das camadas e do tempo de aplicação do carregamento.

As curvas estão bem ajustadas à curva de deformação axial. A correlação é muito boa à exceção de quando existe uma variação na tensão aplicada ou quando coincide com transições de fluência primária para secundária.

Estas correlações são válidas para freqüências intermediárias (de 100 a 400 kHz). Para freqüência baixa (de 20 a $100 \mathrm{kHz}$ ) não existe a correlação. Eventos de emissão acústica neste intervalo são indicativos de abertura e fechamento de fissuras, que no entanto não provocam progresso de microfissuramento.

A respeito das freqüências predominantes nos eventos de emissão acústica, as Figuras 4.25 e 4.26 mostram a relação do parâmetro I1/(I1+H1) (\%) e da deformação axial com o tempo em janelas de 30 segundos, onde: $\mathrm{I} 1=$ número de contagens no sensor 3 (freqüências baixas de 20 a $100 \mathrm{kHz}$ ) e $\mathrm{H1} 1=$ número de contagens no sensor 4 (freqüências médias de 100 a $400 \mathrm{kHz}$ ). Os resultados obtidos nestas figuras reforçam a constatação experimental de que a deformação de fluência é predominantemente devida 
ao microfissuramento da rocha e não ao fechamento ou abertura das fissuras preexistentes. O microfissuramento libera energia detectada em forma de eventos de emissão acústica predominantemente no intervalo de freqüências de 100 a $400 \mathrm{kHz}$.

Ohnaka (1983) utiliza o parâmetro I1/(I1+H1) (\%) para investigar as freqüências predominantes em cada trecho dos ensaios. Isto permite afirmar que a ocorrência conspícua de tais eventos de emissão de freqüência baixa durante o carregamento ou descarregamento estaria relacionada ao fechamento ou abertura das fissuras preexistentes.

Nos apêndices 3 e 4 são apresentados gráficos típicos de histórico de carregamentos, deformações, contagem, contagem acumulada, energia absoluta e energia absoluta acumulada dos corpos de prova submetidos a ensaios de fluência de curta e longa duração nas duas orientações do carregamento com relação às camadas (paralelo e perpendicular) e com os dois tipos de controle (deslocamento do prato ou força). 


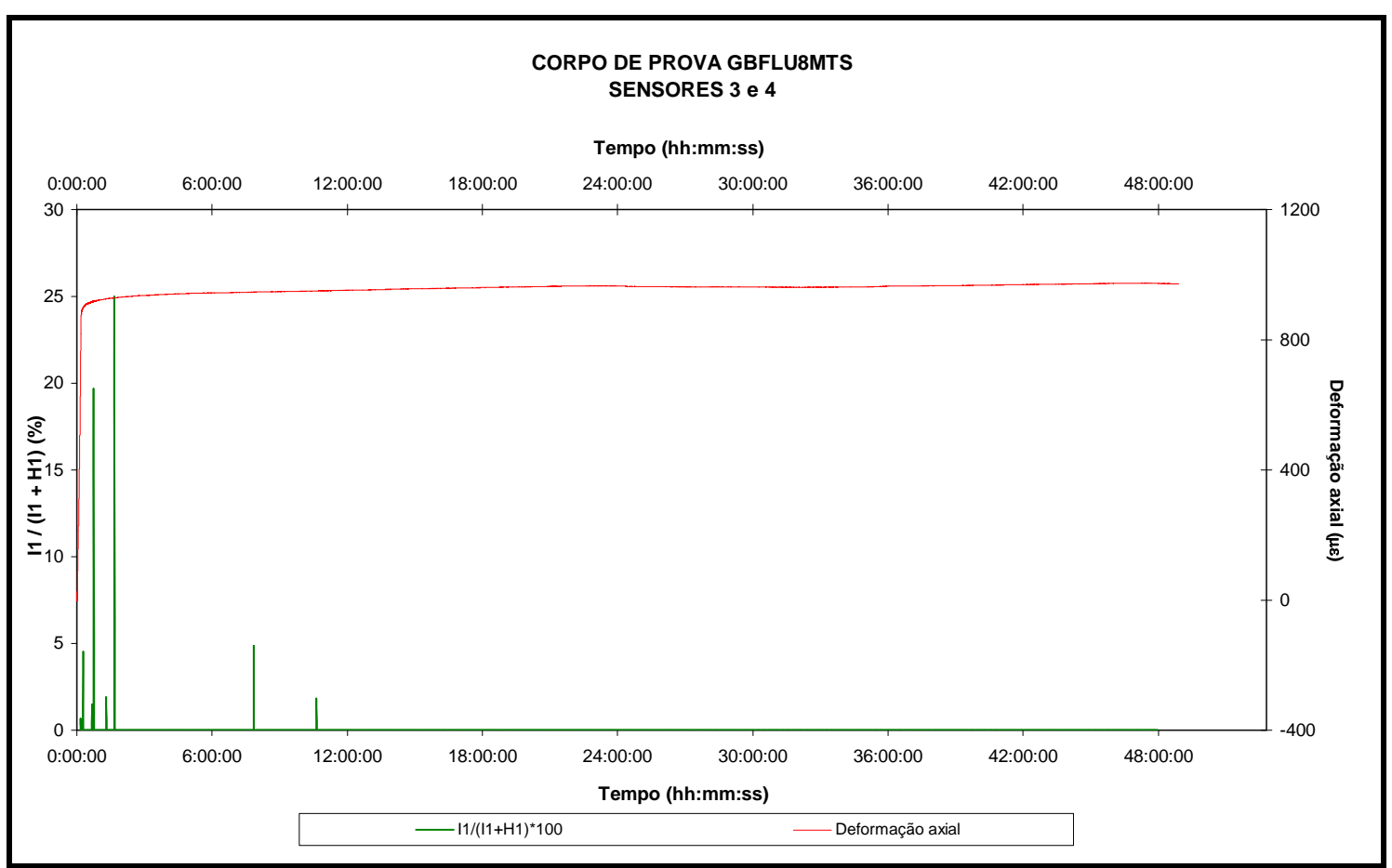

(a)

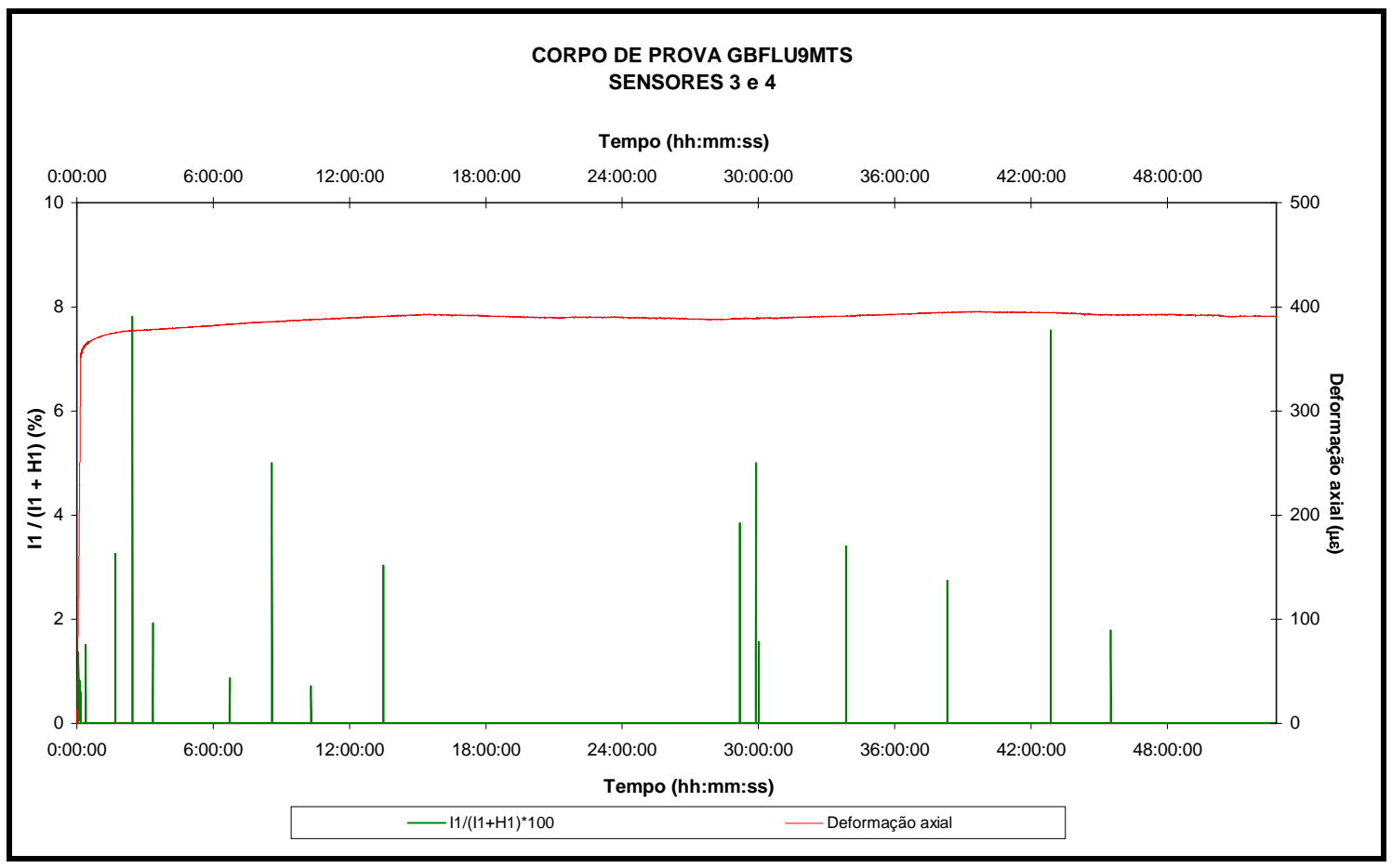

(b)

Figura 4.25 Relação I1/(I1+H1) e deformação axial vs tempo em janelas de 30 segundos, onde: I1 numero de contagens no sensor 3 (freqüências baixas de 20 a $100 \mathrm{kHz}$ ) e $\mathrm{H1}$ numero de contagens no sensor 4 (freqüências intermediárias de 100 a $400 \mathrm{kHz}$ ) do ensaio de fluência de curta duração. (a) No corpo de prova GBflu8MTS (49 horas) (b) No corpo de prova GBflu9MTS (64 horas) 


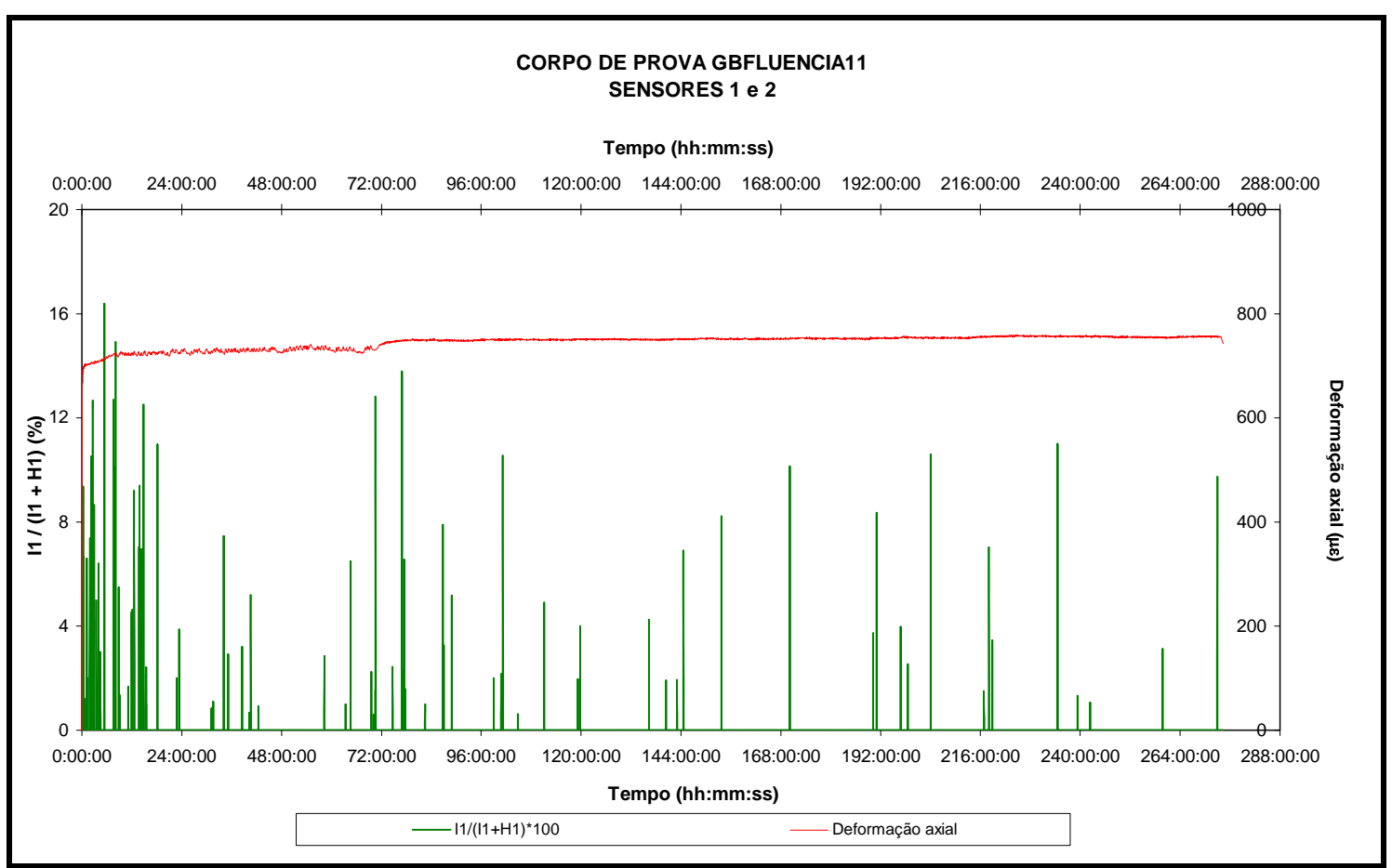

(a)

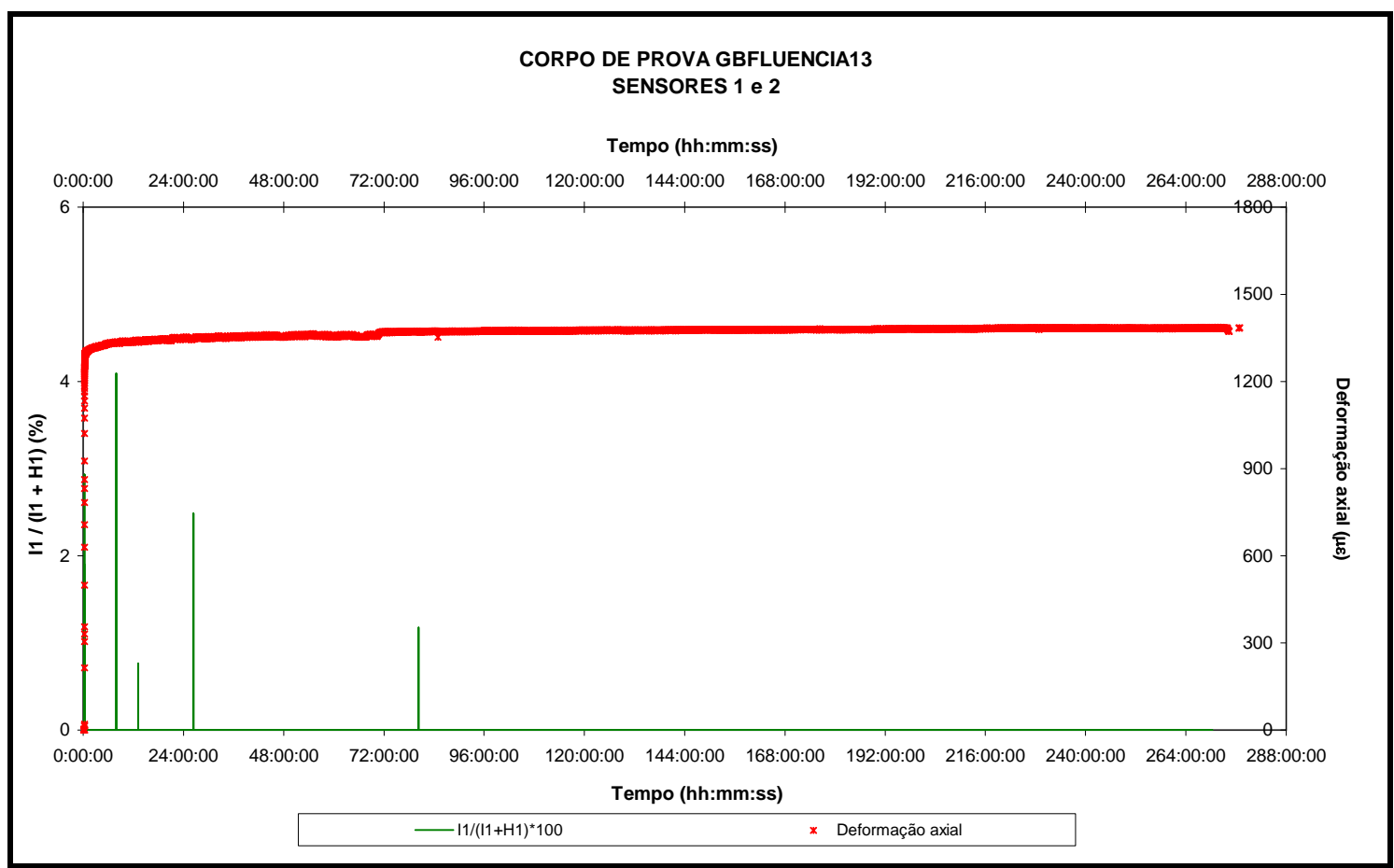

(b)

Figura 4.26 Relação I1/(I1+H1) e deformação axial versus tempo em janelas de 30 segundos, onde: I1 numero de contagens no sensor 1 (freqüências baixas de 20 a $100 \mathrm{kHz}$ ) e H1 numero de contagens no sensor 2 (freqüências intermediárias de $100 \mathrm{a} 400 \mathrm{kHz}$ ) do ensaio de fluência de longa duração (274 horas). (a) No corpo de prova GBfluencia11 e (b) No corpo de prova GBfluencia13 


\subsection{Comportamento Acústico do Gipsito Bandado após os Ensaios de Fluência}

Já ficou demonstrado anteriormente que o fenômeno de microfissuramento é detectado pelo sensor de emissão acústica de freqüências intermediárias (de 100 a 400 kHz). A análise do comportamento acústico dos corpos de prova durante ensaios de fluência também demonstra que o processo de microfissuramento é intenso no início da fluência secundária, e se atenua com o tempo. Isto pode ser observado pela contagem acumulada de eventos de emissão acústica como mostrado nas Figuras 4.27 e 4.28 e nas Figuras 4.19 e 4.20 mostradas anteriormente.

Por outro lado, como se verifica que ocorre o efeito Kaiser nos ensaios de carregamento, descarregamento e recarregamento de curta duração, seria de esperar que o mesmo efeito ocorresse também após os ensaios de fluência de longa duração. Ou seja, o corpo de prova não deveria emitir sinais acústicos detectáveis no sensor de freqüências intermediárias (de 100 a $400 \mathrm{kHz}$ ) ao ser recarregado até o mesmo nível de carregamento a que já tivesse sido submetido anteriormente em ensaio de fluência. Entretanto, não é o que se verifica. Os corpos de prova que foram submetidos a ensaios de fluência de longa duração, ao serem recarregados em compressão simples, apresentaram, desde o início do recarregamento, o mesmo padrão de emissão acústica que corpos de prova virgens. Isto pode ser observado, por exemplo, nas Figuras 4.29 e 4.30, que apresentam o histórico de carregamento e contagem acumulada de eventos medidos no sensor de freqüências intermediárias (de 100 a $400 \mathrm{kHz}$ ) nos corpos de prova GBfluencia6, GBfluencia8, GBfluencia9 e GBfluencia10. 


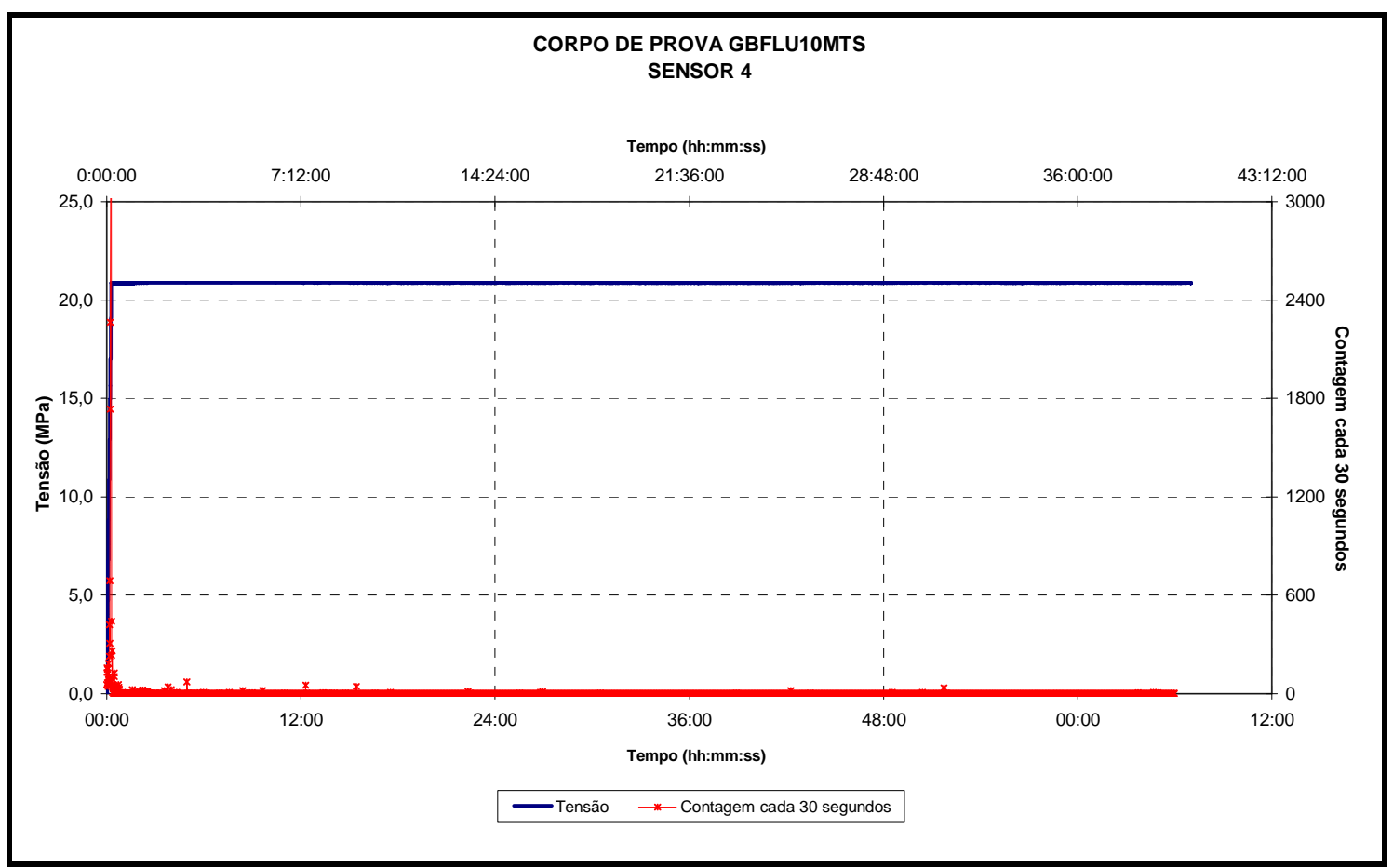

(a)

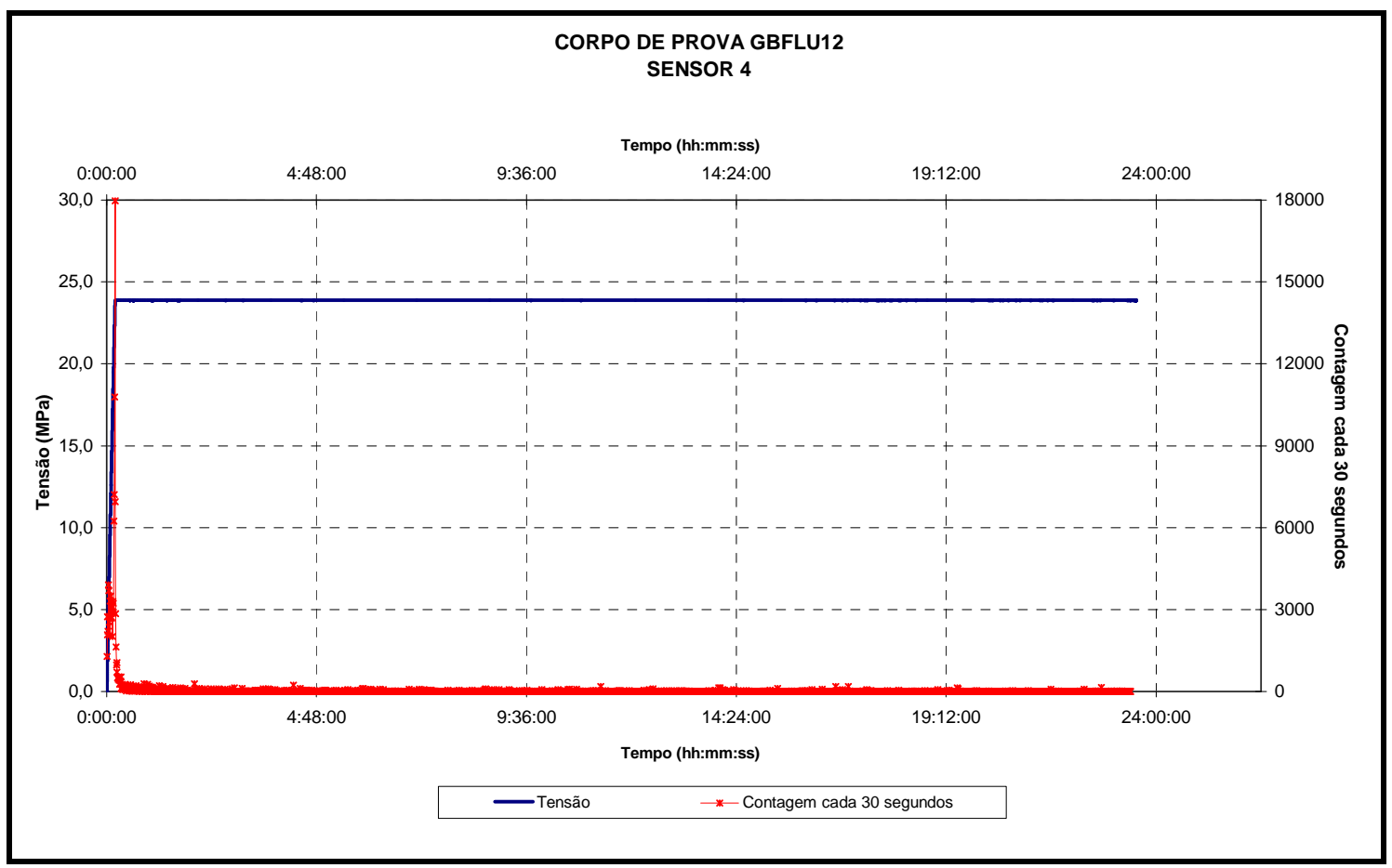

(b)

Figura 4.27 Emissão acústica indicativa de microfissuramento no sensor 4 (freqüências intermediárias de 100 a $400 \mathrm{kHz}$ ) em ensaios de fluência de curta duração. (a) No corpo de prova GBflu10MTS (40 horas). (b) No corpo de prova GBflu12MTS (23 horas) 


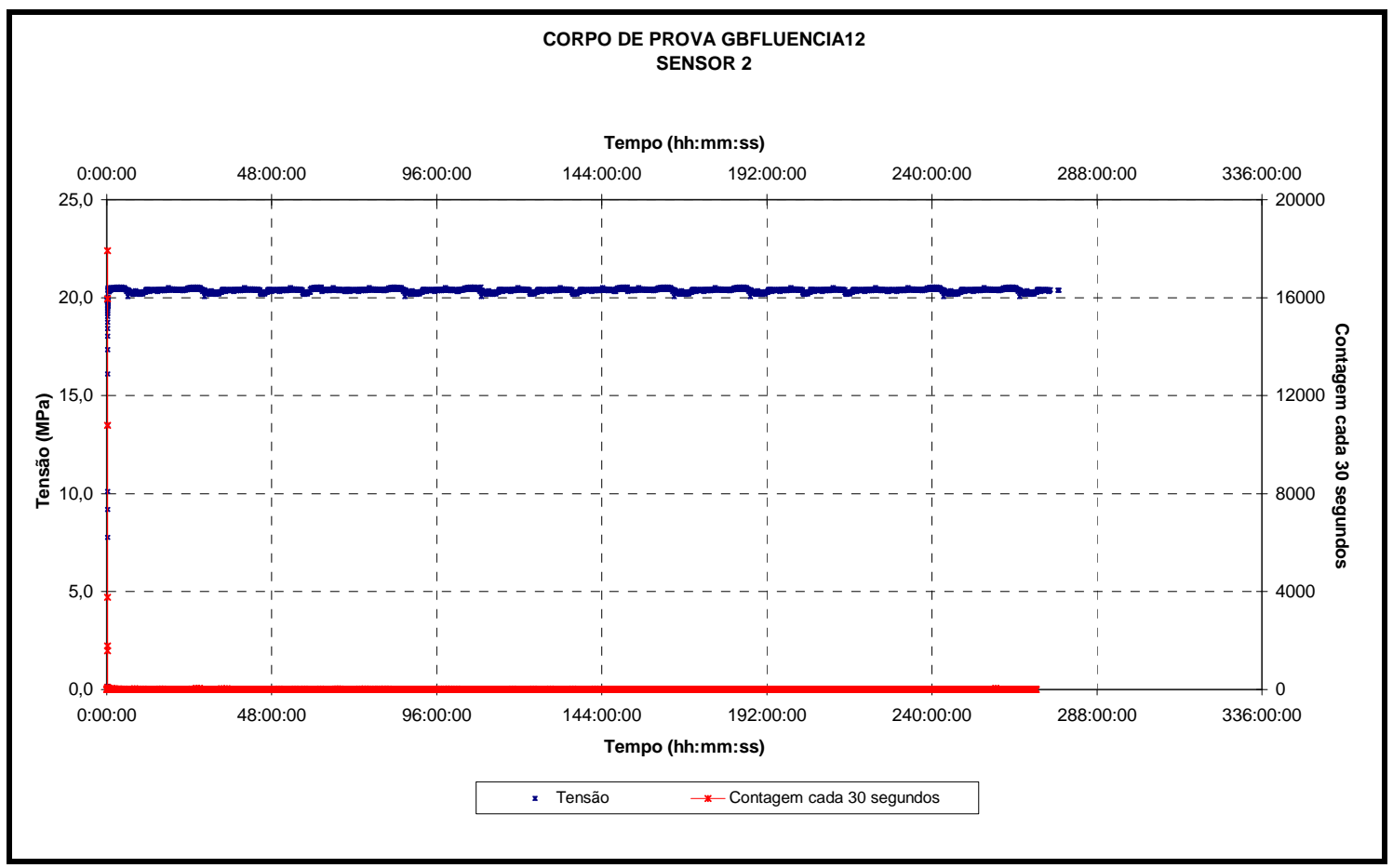

(a)

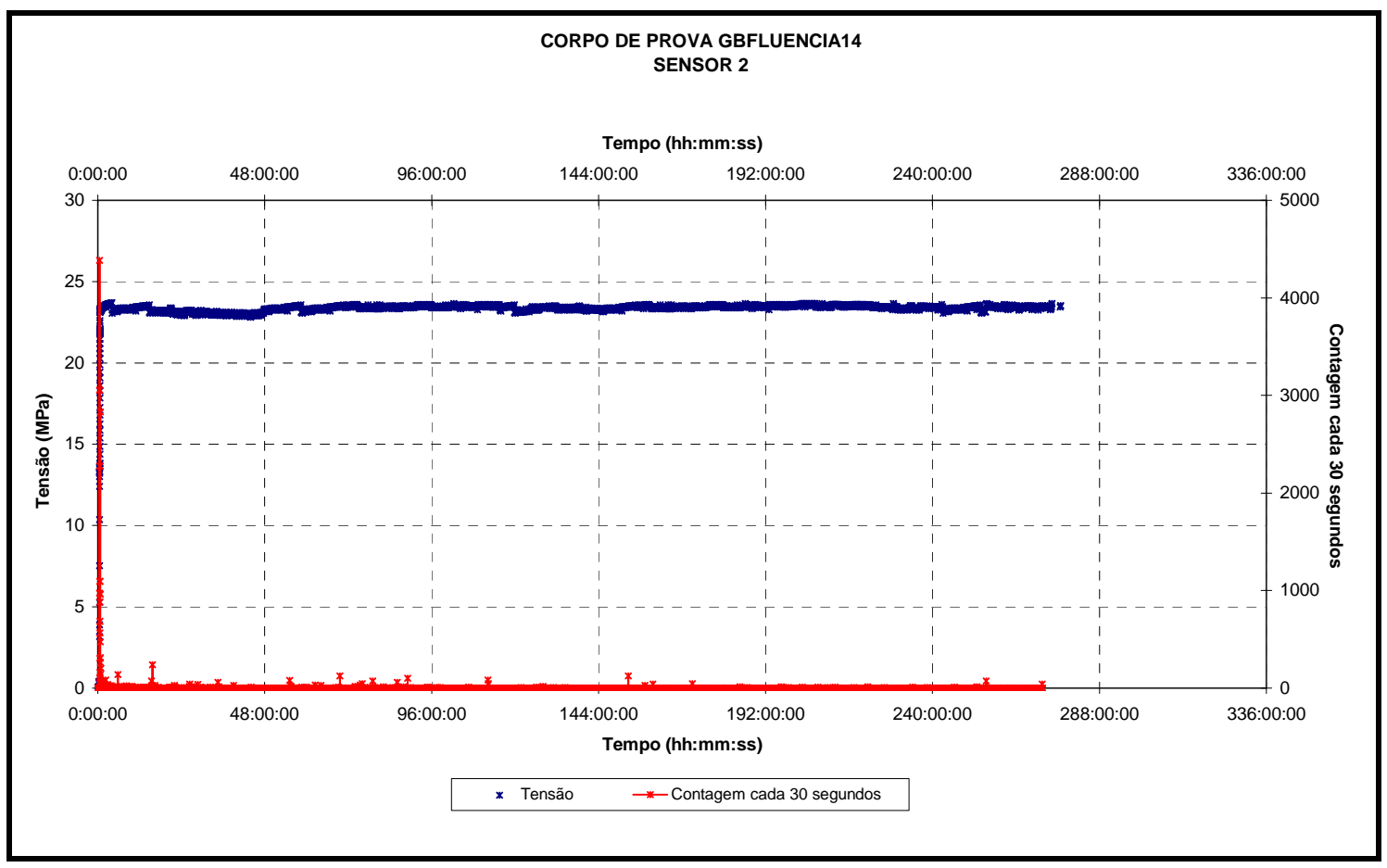

(b)

Figura 4.28 Emissão acústica indicativa de microfissuramento no sensor 2 (freqüências intermediárias de 100 a $400 \mathrm{kHz}$ ) em ensaios de fluência de longa duração (274 horas). (a) No corpo de prova GBfluencia12. (b) No corpo de prova GBfluencia14 


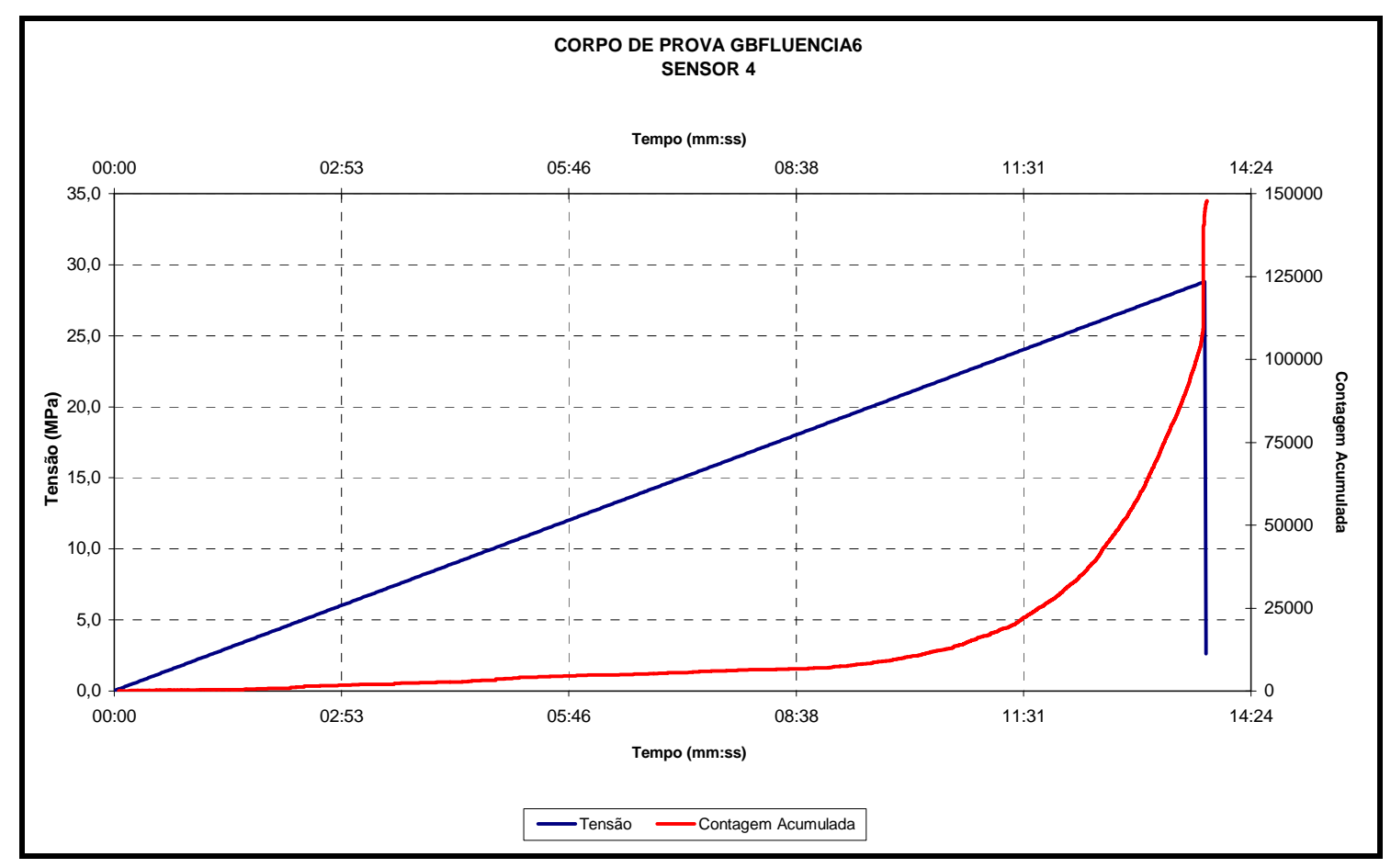

(a)

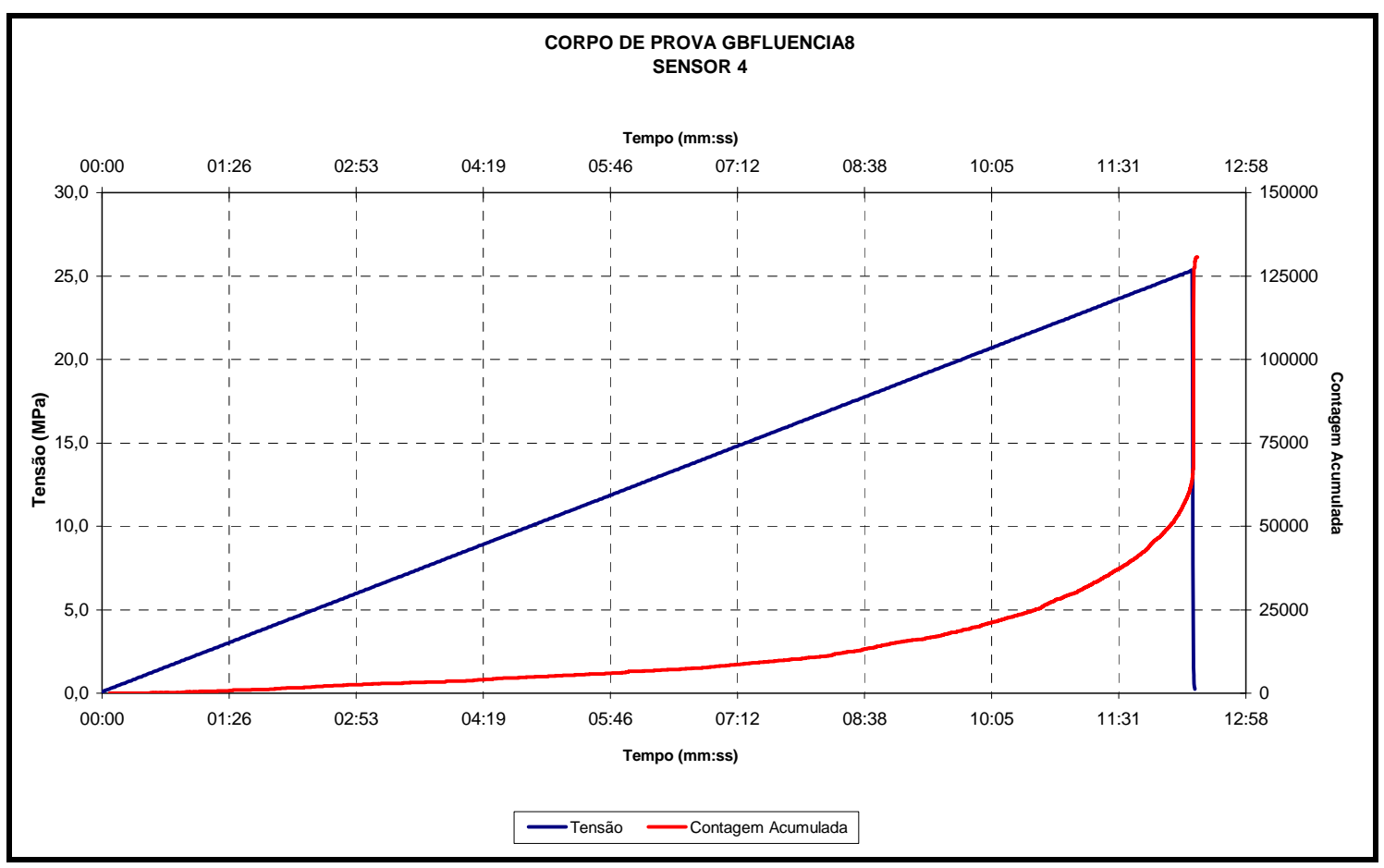

(b)

Figura 4.29 Tensão e contagem acumulada versus tempo para recarregamento no sensor 4 (freqüências intermediárias de 100 a $400 \mathrm{kHz}$ ) - (a) Ensaio GBfluencia6. (b) Ensaio GBfluencia8 (corpos de prova submetidos anteriormente à fluência de longa duração de 55 dias) 


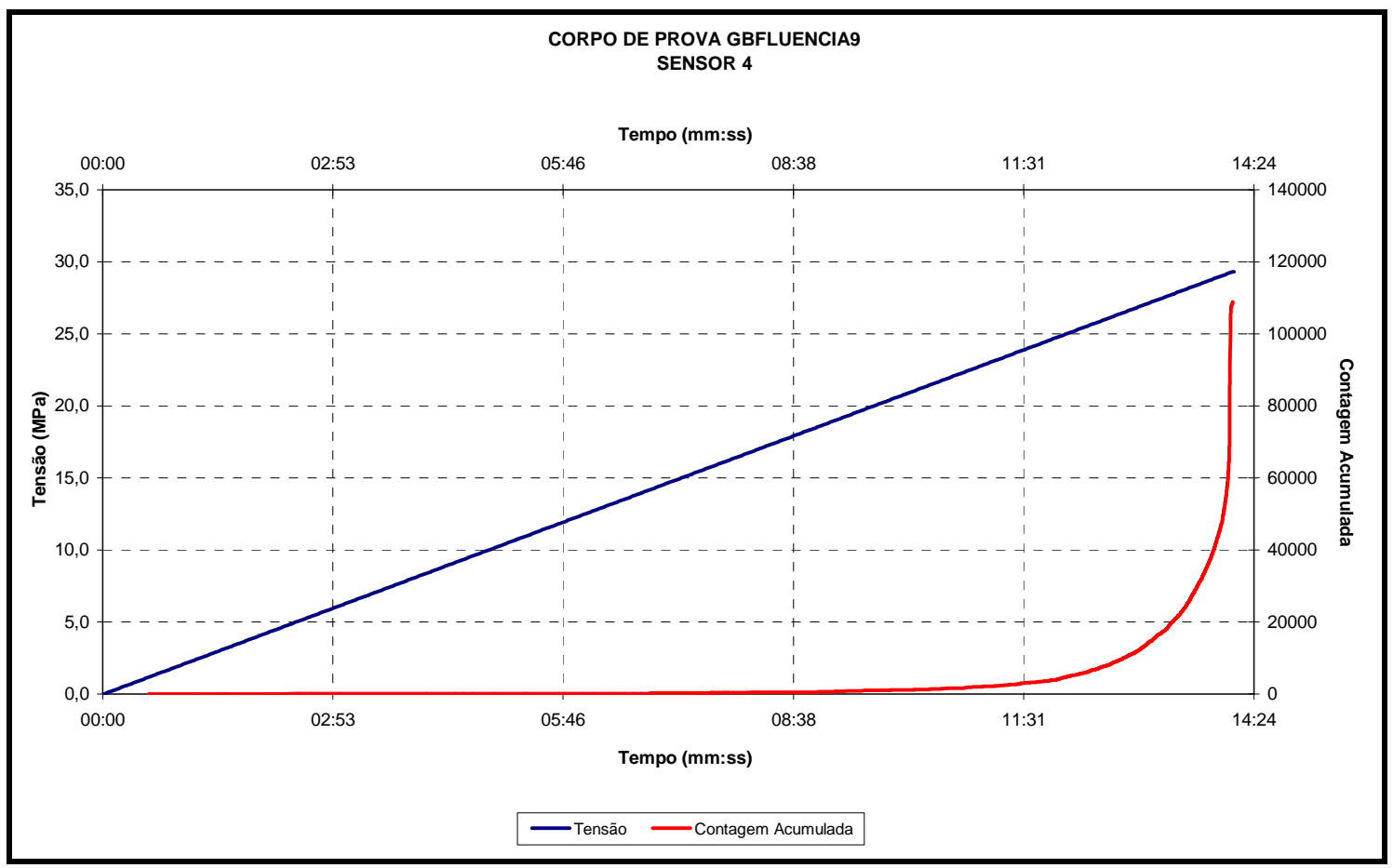

(a)

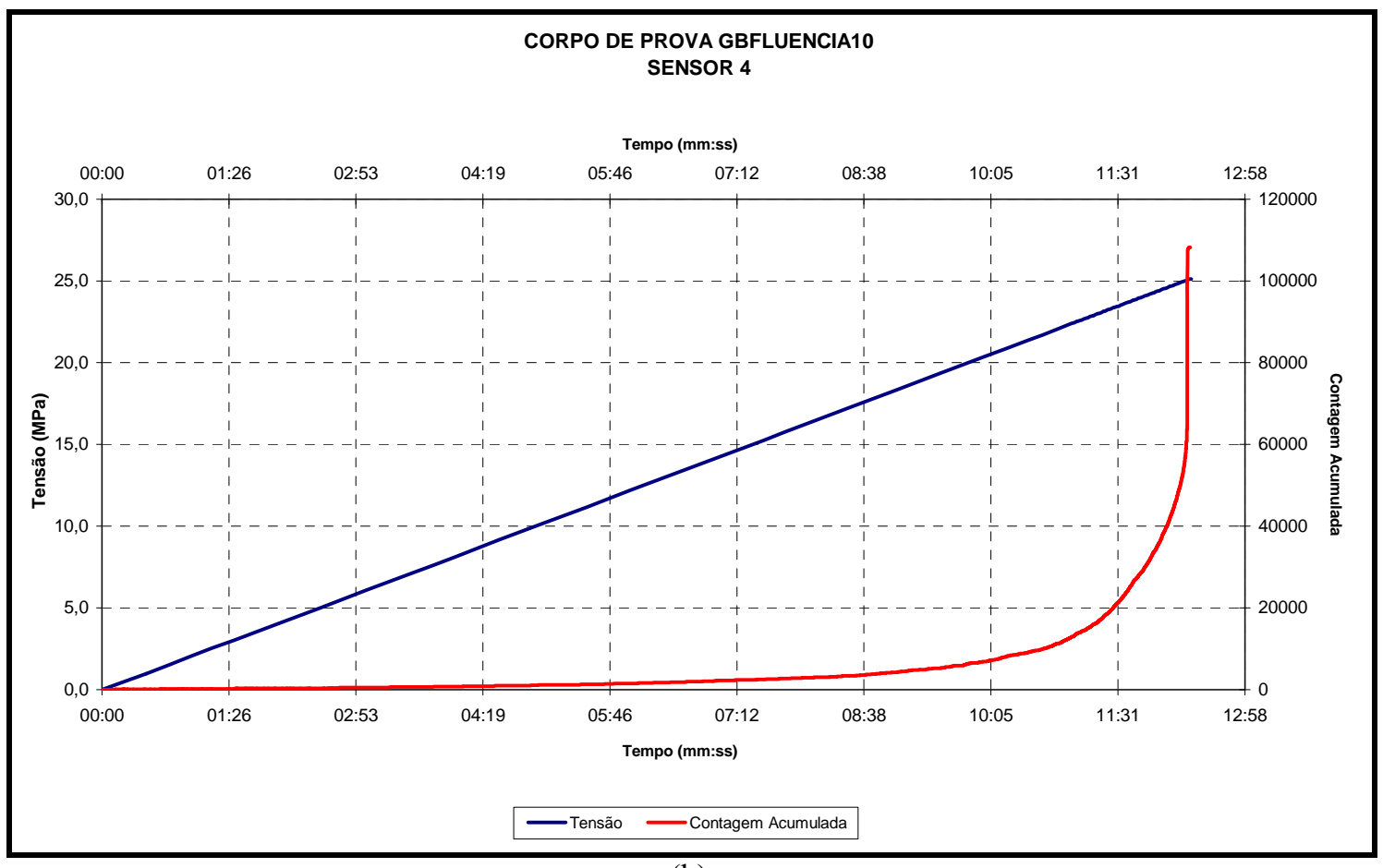

(b)

Figura 4.30 Tensão e contagem acumulada versus tempo para recarregamento no sensor 4 (freqüências intermediárias de 100 a $400 \mathrm{kHz}$ ) - (a) Ensaio GBfluencia9. (b) Ensaio GBfluencia10 (corpos de prova submetidos anteriormente à fluência de longa duração de 45 dias) 
Os corpos de prova GBfluencia6 e GBfluencia8 foram submetidos antes a ensaios de fluência de longa duração (55 dias), sob níveis de tensões de 86 e 95\% respectivamente, da resistência à compressão simples. De forma análoga, os corpos de prova GBfluencia9 e GBfluencia10 foram submetidos a ensaios de 45 dias e tensões de 77 e $85 \%$, respectivamente.

Observa-se que o padrão de emissão acústica, tanto em termos de freqüência como de progresso da contagem acumulada de eventos, é muito semelhante, por exemplo, ao ensaio sobre o corpo de prova virgem GBEA17 (Figura 4.9a), submetido a ensaio de compressão simples convencional. Isto só pode ser explicado se as microfissuras provocadas pelo carregamento durante o ensaio de fluência de longa duração tiverem passado por um processo de cicatrização. De fato, há várias evidências que apontam nesta direção.

Em primeiro lugar, Giambastiani (2005) observou, submetendo o mesmo gipsito bandado da Formação Santana a ensaios de fluência de 25 dias (portanto mais curtos que os do presente programa), que as velocidades sônicas dos corpos de prova após o ensaio não demonstravam qualquer sinal de diminuição. Em outras palavras, não parecia haver qualquer degradação mecânica após a fluência. Isto não é usual em outras rochas. Giambastiani encontrou diminuição de até $45 \%$ na velocidade sônica da anidrita Auquilco e de até $18 \%$ nas anidrita Muribeca, quando submetidas ao mesmo tipo de ensaio de fluência. A água molecular do gipsito (ausente nos anidritos) propicia mecanismos de difusão que podem ser responsáveis pela cicatrização das microfissuras, no período de duração dos ensaios de fluência.

Em termos termodinâmicos, alguns autores (SENSENY et al., 1992; BAUMANN, 1984) correlacionaram o parâmetro $n$ (derivada da curva de taxa de 
deformação em fluência secundária versus tensão aplicada) com o regime de deformação.

Giambastiani (2005), observou que em níveis de tensões mais baixos nos ensaios de fluência em corpos de prova dos gipsitos da Formação Santana $n$ corresponde a mecanismos de difusão e dissolução por pressão. Sob níveis de tensões intermediárias, os deslocamentos intra e intercristalinos são os mecanismos principais, enquanto que as microfissuras dominam a níveis de tensões altas.

$\mathrm{Na}$ realidade, os três mecanismos devem ocorrer simultaneamente. É amplamente conhecido que para muitos tipos de rochas, a atividade do microfissuramento começa assim que a carga excede um limiar. Se a carga é mantida constante, a atividade do microfissuramento decai com o tempo. Entretanto, as condições para dissolução por pressão e recristalização permanecem ativas, e este se torna o fenômeno mais importante durante o ensaio de fluência de longa duração.

Giambastini (2005), também observou, quando ensaiou anidritas, que o valor resultante de $n$ nunca correspondia à dissolução por pressão.

Em ensaios de fluência com vários ciclos de carregamento e descarregamento, Giambastiani (2005), observou que o módulo de elasticidade do gipsito não diminuía ao longo dos diferentes ciclos, enquanto o decréscimo era apreciável para as anidritas. Esta é outra evidência de que microfissuras não afetaram a rigidez do gipsito em ensaios de longa duração.

Nesta tese, foram também encontrados acréscimos substanciais de módulos de elasticidade em corpos de prova após serem submetidos a ensaios de fluência com 45 e 55 dias de duração, como mostra a Tabela 4.13. Acréscimos de mais de 50\% foram encontrados, um indício muito forte de aumento de rigidez por cicatrização de 
microfissuras. Os acréscimos de módulo de elasticidade observados variaram de 48 a $83 \%$ e o coeficiente de Poisson aumentou entre 5 e $20 \%$.

Tabela 4.13 Resultados dos ensaios de fluência de longa duração e que foram carregados depois até a ruptura

\begin{tabular}{ccccccc}
\hline Corpo de prova & $\mathbf{E}$ & $\mathbf{v}$ & $\begin{array}{c}\mathbf{E}_{\text {cl }}^{\prime} \\
(\mathbf{G P a})\end{array}$ & $\begin{array}{c}\mathbf{v}_{\mathbf{c l}}^{\prime} \\
\text { GPa) }\end{array}$ & $\frac{\mathbf{E}_{\mathbf{c l}}{ }^{\prime}}{\mathbf{E}}$ & $\frac{\mathbf{v}_{\mathbf{c l}}^{\prime}}{\mathbf{v}}$ \\
\hline GBfluencia6 & 26,62 & 0,20 & 48,69 & 0,24 & 1,83 & 1,20 \\
GBfluencia8 & 30,74 & 0,35 & 45,43 & 0,38 & 1,48 & 1,09 \\
GBfluencia9 & 36,75 & 0,38 & 65,43 & 0,40 & 1,78 & 1,05 \\
GBfluencia10 & 23,38 & 0,24 & 39,01 & 0,27 & 1,67 & 1,13 \\
\hline
\end{tabular}

Onde:

E, $v=$ Módulo de elasticidade e coeficiente de Poisson no início do carregamento no ensaio de fluência de longa duração.

$\mathrm{E}_{\mathrm{cl}}^{\prime}, v^{\prime}{ }_{\mathrm{cl}}=$ Módulo de elasticidade e coeficiente de Poisson no ensaio de compressão simples dos corpos de prova depois do ensaio de fluência de longa duração.

Também nesta tese foi constatado um acréscimo da resistência à compressão simples dos corpos de prova submetidos a ensaios de fluência de curta e longa duração. Após os ensaios de fluência, os corpos de prova foram submetidos a ensaios de compressão simples, e as resistências apresentadas foram em todos os casos superiores às médias dos ensaios em corpos de prova virgens sob as mesmas combinações de condições de carregamento (controle de força ou de deslocamento, e carregamento paralelo ou perpendicular à estratificação), como mostra a Tabela 4.14. Estes acréscimos variam de 11 a $20 \%$. 
Tabela 4.14 Resultados das médias da resistência à compressão uniaxial $\left(\bar{\sigma}_{c}\right)$, resistência pico depois do ensaio de fluência de curta duração $\left(\bar{\sigma}_{c S}\right)$ e resistência pico depois do ensaio de fluência

\begin{tabular}{cccccc}
\multicolumn{7}{c}{ de longa duração $\left(\bar{\sigma}_{c l}\right)$} \\
\hline $\begin{array}{c}\text { Orientação } \\
\text { das camadas }\end{array}$ & $\overline{\boldsymbol{\sigma}}_{\mathbf{c}}$ & $\overline{\boldsymbol{\sigma}}_{\mathbf{c s}}$ & $\overline{\boldsymbol{\sigma}}_{\mathbf{c l}}$ & $\overline{\boldsymbol{\sigma}}_{\mathbf{c s}}$ & $\overline{\boldsymbol{\sigma}}_{\mathbf{c l}}$ \\
\hline Perpendicular & 23,00 & 25,43 & 25,89 & 1,11 & $\overline{\boldsymbol{\sigma}}_{\mathbf{c}}$ \\
Paralela & 24,00 & 28,29 & 28,85 & 1,18 & 1,13 \\
\hline
\end{tabular}

Onde:

$\bar{\sigma}_{c}=$ Média da resistência à compressão uniaxial com taxa de carregamento com acréscimo de força constante $(4,5 \mathrm{kN} / \mathrm{min})$.

$\bar{\sigma}_{c s}=$ Média da resistência pico depois do ensaio de fluência de curta duração.

$\bar{\sigma}_{c l}=$ Média da resistência pico depois do ensaio de fluência de longa duração.

Pelo exposto, pode-se concluir que o carregamento dos ensaios de fluência inicialmente provoca microfissuramento do gipsito. Por outro lado, como a duração dos ensaios permite, começam a ocorrer fenômenos de difusão e dissolução por pressão que inibem não apenas o microfissuramento gerado no carregamento do ensaio, mas até o microfissuramento natural ou decorrente da preparação do corpo de prova, anterior, portanto, ao carregamento.

\subsection{Ensaios de fluência de longa duração com dois ciclos de carregamento e descarregamento sucessivos e posterior ciclo crescente de carga}

As características dos ensaios de fluência de longa duração (150 dias) nas direções perpendicular e paralela às camadas são apresentados nas Tabelas 4.15 e 4.16. Nestes ensaios cada ciclo dura aproximadamente 32 dias em média, exceto no corpo de 
prova GBEAF3 que teve um ciclo de carregamento e descarregamento adicional e as durações dos ciclos diferentes, conforme item 3.12.4.1 (Ensaios tipo FLI).

A variação do módulo de elasticidade nos carregamentos ou descarregamentos são mostradas nas Figuras 4.31, 4.32 e 4.33.

Tabela 4.15 Características dos ensaios de fluência de longa duração com carregamento na direção paralela às camadas e medições de emissão acústica com um sensor

\begin{tabular}{|c|c|c|c|c|c|}
\hline $\begin{array}{c}\text { Corpo de } \\
\text { prova }\end{array}$ & Condição & $\begin{array}{l}\text { Tensão média } \\
\text { aplicada (MPa) }\end{array}$ & $\begin{array}{l}\text { Duração } \\
\text { (dias) }\end{array}$ & $\begin{array}{l}\text { Módulo de } \\
\text { Elasticidade } \\
\text { (GPa) }\end{array}$ & $\begin{array}{l}\text { Coeficiente } \\
\text { de Poisson }\end{array}$ \\
\hline \multirow[t]{7}{*}{ GBEAF1 } & Primeiro carregamento & 9,00 & 32 & 26,10 & 0,38 \\
\hline & Descarregamento instantâneo & - & 3 & 30,02 & 0,38 \\
\hline & Segundo carregamento & 11,00 & 30 & 29,73 & 0,38 \\
\hline & Descarregamento instantâneo & - & 16 & 29,36 & 0,41 \\
\hline & Terceiro carregamento & 14,20 & 34 & 31,47 & 0,38 \\
\hline & Quarto carregamento & 18,10 & 33 & - & - \\
\hline & Descarregamento instantâneo & - & - & 31,34 & 0,38 \\
\hline \multirow[t]{7}{*}{ GBEAF2 } & Primeiro carregamento & 10,10 & 32 & 33,52 & 0,30 \\
\hline & Descarregamento instantâneo & - & 3 & 35,31 & 0,31 \\
\hline & Segundo carregamento & 12,10 & 30 & 35,34 & 0,31 \\
\hline & Descarregamento instantâneo & - & 16 & 35,41 & 0,31 \\
\hline & Terceiro carregamento & 15,00 & 34 & 35,38 & 0,31 \\
\hline & Quarto carregamento & 18,20 & 33 & - & - \\
\hline & Descarregamento instantâneo & - & - & 38,38 & 0,32 \\
\hline \multirow[t]{10}{*}{ GBEAF3 } & Primeiro carregamento & 8,60 & 17 & 30,25 & 0,35 \\
\hline & Descarregamento instantâneo & - & 0 & 34,75 & 0,35 \\
\hline & Segundo carregamento & 11,60 & 15 & 32,90 & 0,43 \\
\hline & Descarregamento instantâneo & - & 7 & 33,18 & 0,35 \\
\hline & Terceiro carregamento & 11,70 & 27 & 32,89 & 0,37 \\
\hline & Descarregamento instantâneo & - & 16 & 34,11 & 0,35 \\
\hline & Quarto carregamento & 13,10 & 5 & 35,30 & 0,38 \\
\hline & Quinto carregamento & 18,10 & 30 & - & - \\
\hline & Sexto carregamento & 19,50 & 33 & - & - \\
\hline & Descarregamento instantâneo & - & - & 33,79 & 0,41 \\
\hline
\end{tabular}


Tabela 4.16 Características dos ensaios de fluência de longa duração com carregamento na direção perpendicular às camadas e medições de emissão acústica com um sensor

\begin{tabular}{cccccc}
\hline $\begin{array}{c}\text { Corpo de } \\
\text { prova }\end{array}$ & Condição & $\begin{array}{c}\text { Tensão média } \\
\text { aplicada }(\text { MPa) }\end{array}$ & $\begin{array}{c}\text { Duração } \\
\text { do ensaio } \\
\text { (dias) }\end{array}$ & $\begin{array}{c}\text { Módulo de } \\
\text { Elasticidade } \\
\text { (GPa) }\end{array}$ & $\begin{array}{c}\text { Coeficiente } \\
\text { de Poisson }\end{array}$ \\
\hline GBEAF4 & Primeiro carregamento & 9,70 & 32 & 36,12 & 0,31 \\
& Descarregamento instantâneo & - & 3 & 42,49 & 0,33 \\
& Segundo carregamento & 11,40 & 30 & 38,25 & 0,32 \\
& Descarregamento instantâneo & - & 16 & 42,21 & 0,36 \\
& Terceiro carregamento & 15,30 & 34 & 40,21 & 0,33 \\
\hline GBEAF5 & Quarto carregamento & 18,30 & 33 & - & 0,35 \\
\hline & Descarregamento instantâneo & - & - & 41,01 & 0,42 \\
& Primeiro carregamento & Muito variável & 32 & 36,23 & 0,38 \\
& Descarregamento instantâneo & - & 3 & 42,66 & 0,38 \\
& Segundo carregamento & 11,80 & 30 & 39,76 & 0,37 \\
& Descarregamento instantâneo & - & 16 & 42,48 & 0,32
\end{tabular}

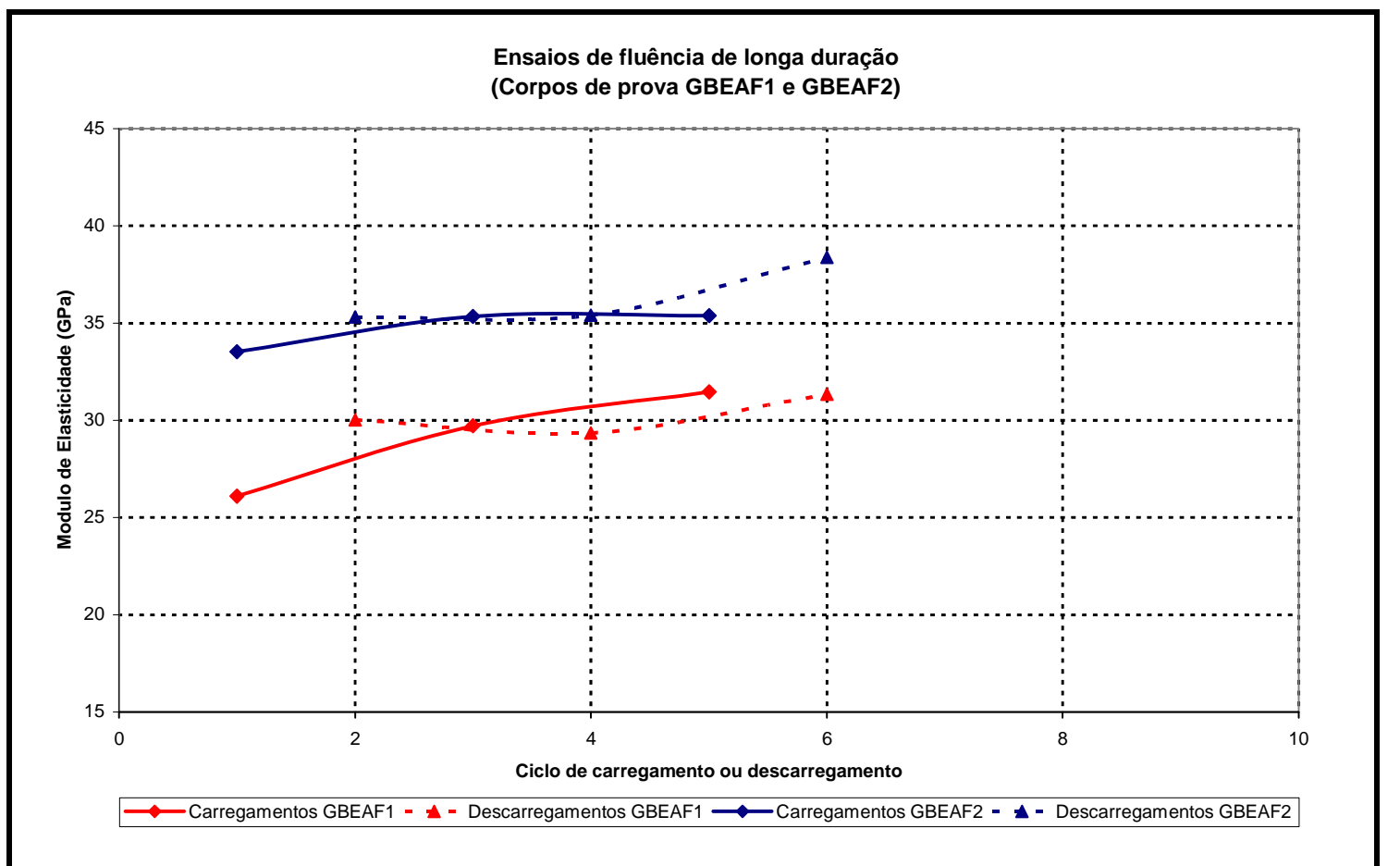

Figura 4.31 Módulo de elasticidade versus número de ciclo de carregamento ou descarregamento dos corpos de prova GBEAF1 e GBEAF2 (carregamento paralelo às camadas) nos ensaios de fluência de longa duração (150 dias) 


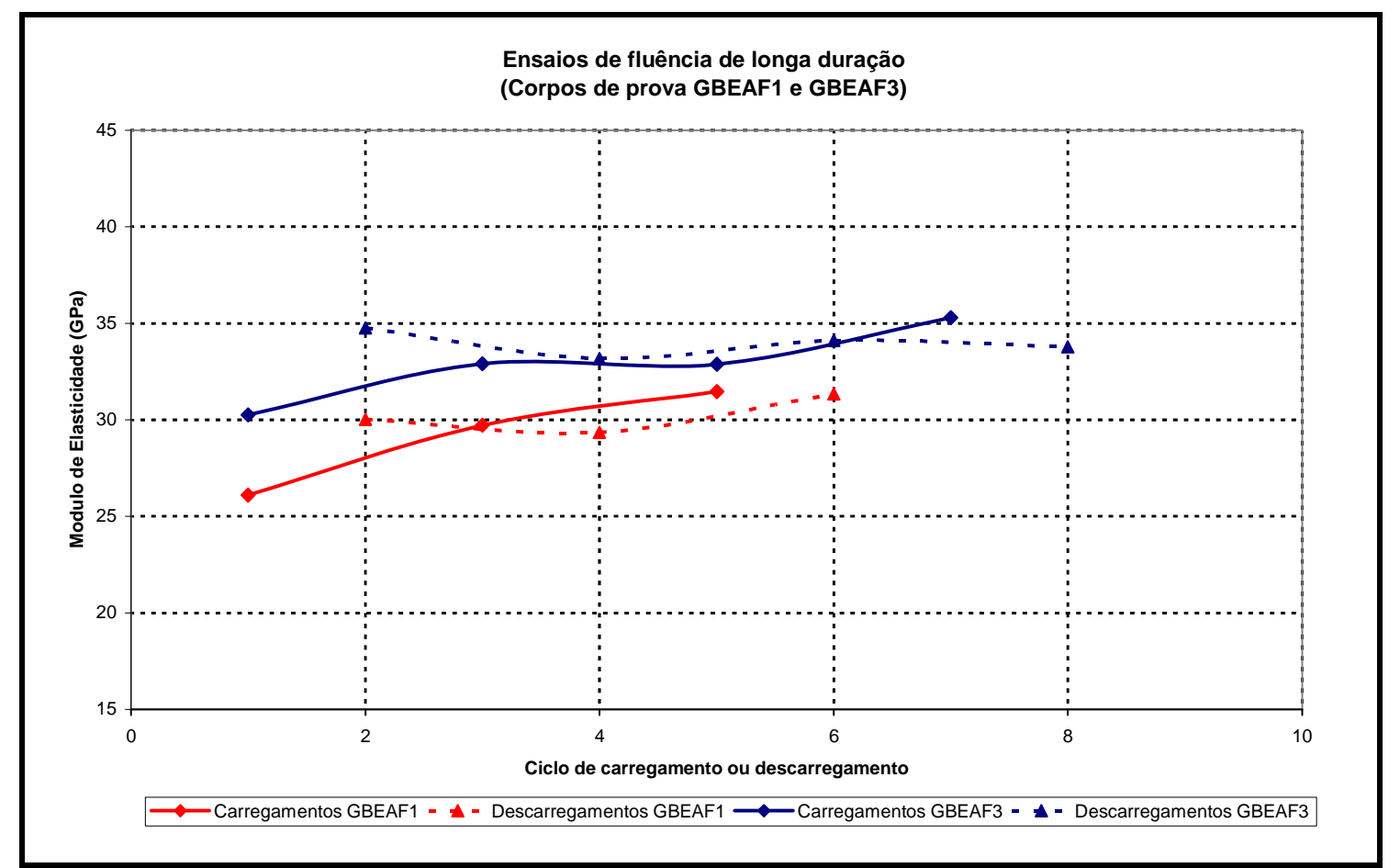

Figura 4.32 Módulo de elasticidade versus número de ciclo de carregamento ou descarregamento dos corpos de prova GBEAF1 e GBEAF3 (carregamento paralelo às camadas) nos ensaios de fluência de longa duração (150 dias)

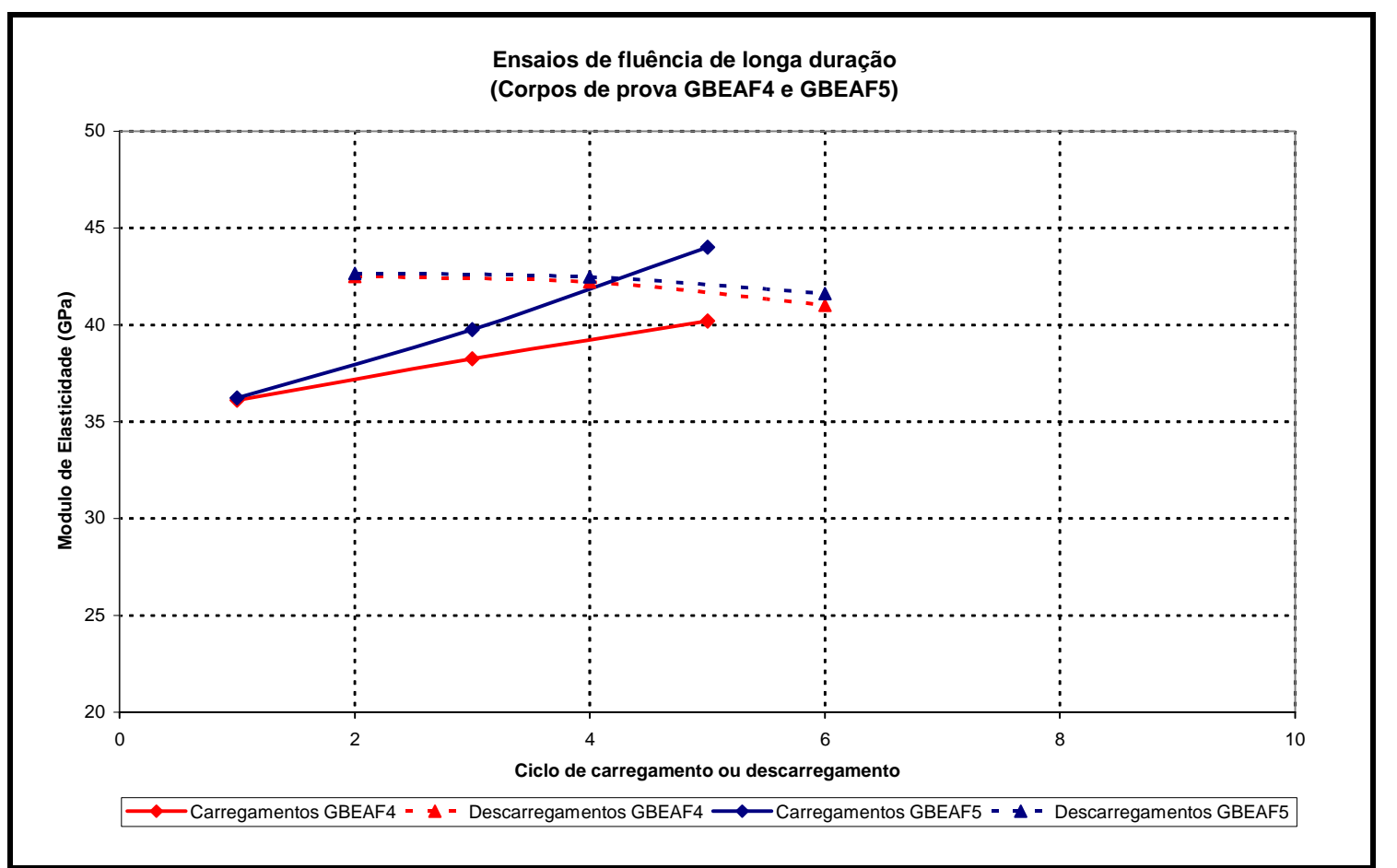

Figura 4.33 Módulo de elasticidade versus número de ciclo de carregamento ou descarregamento dos corpos de prova GBEAF4 e GBEAF5 (carregamento perpendicular às camadas) nos ensaios de fluência de longa duração (150 dias) 
A Figura 4.34 mostra a evolução dos módulos de elasticidade no carregamento em função da tensão aplicada nos ensaios de fluência de longa duração para o gipsito bandado da Formação Santana.

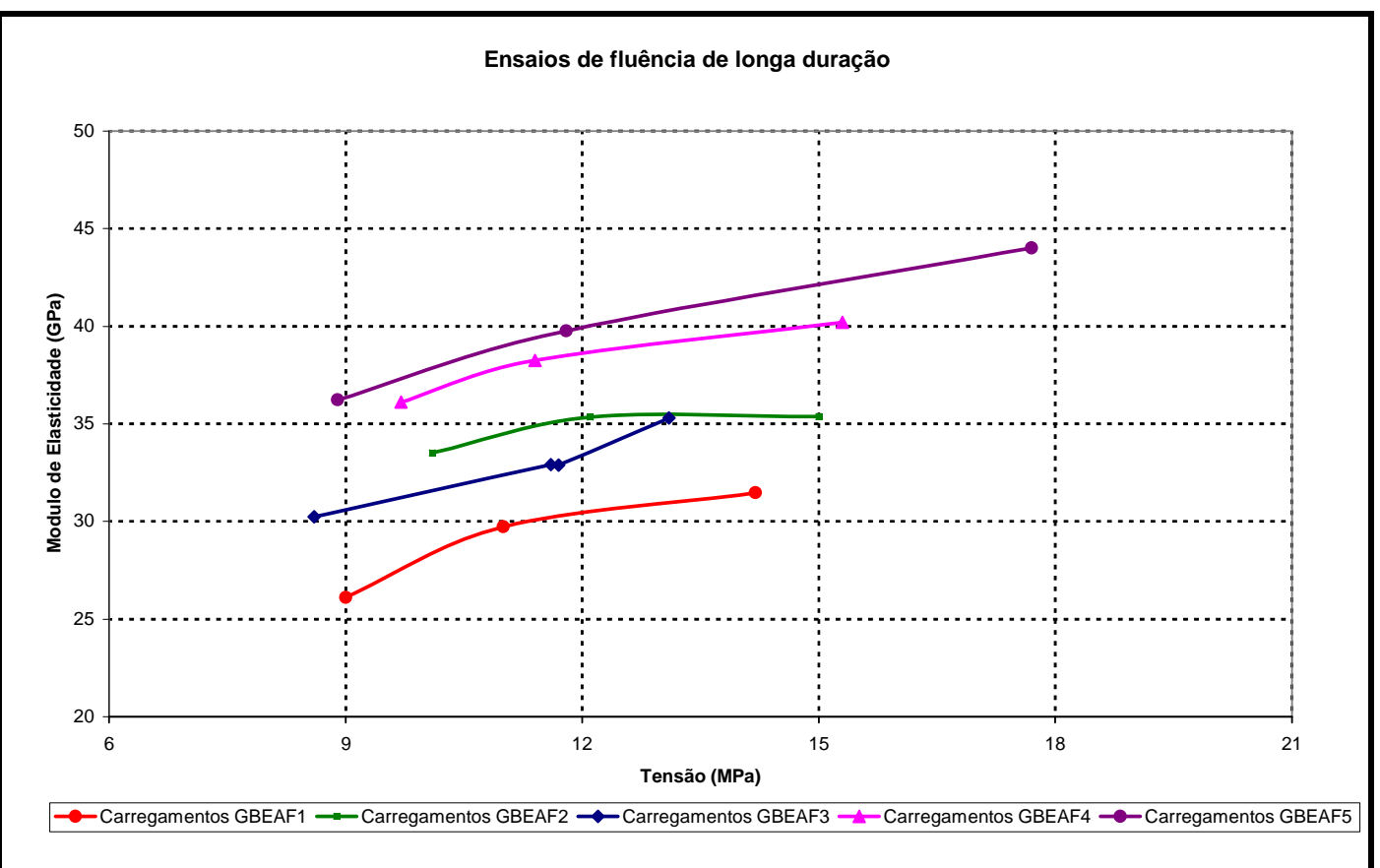

Figura 4.34 Evolução dos módulos de elasticidade nos carregamentos dos corpos de prova versus tensão aplicada nos ensaios de fluência de longa duração (150 dias)

Analisando as Tabelas 4.15 e 4.16 e as Figuras 4.31, 4.32, 4.33 e 4.34, pode ser verificado que o Módulo de elasticidade do gipsito bandeado não diminui ao longo dos diferentes ciclos de carregamento e é independente da direção do carregamento (paralelo ou perpendicular às camadas).

Giambastiani (2005) já tinha observado este comportamento ao longo dos diferentes ciclos com corpos de prova carregados na direção perpendicular às camadas. O comportamento é o mesmo nas duas direções, mas a cicatrização que produz esse certo "encruamento" é mais evidente quando o carregamento é perpendicular às camadas (Figura 4.33).

A Figura 4.35 mostra que independentemente do nível de tensão aplicado, uma vez que a tensão é mantida constante, a taxa de eventos de emissão acústica cai com o tempo. 


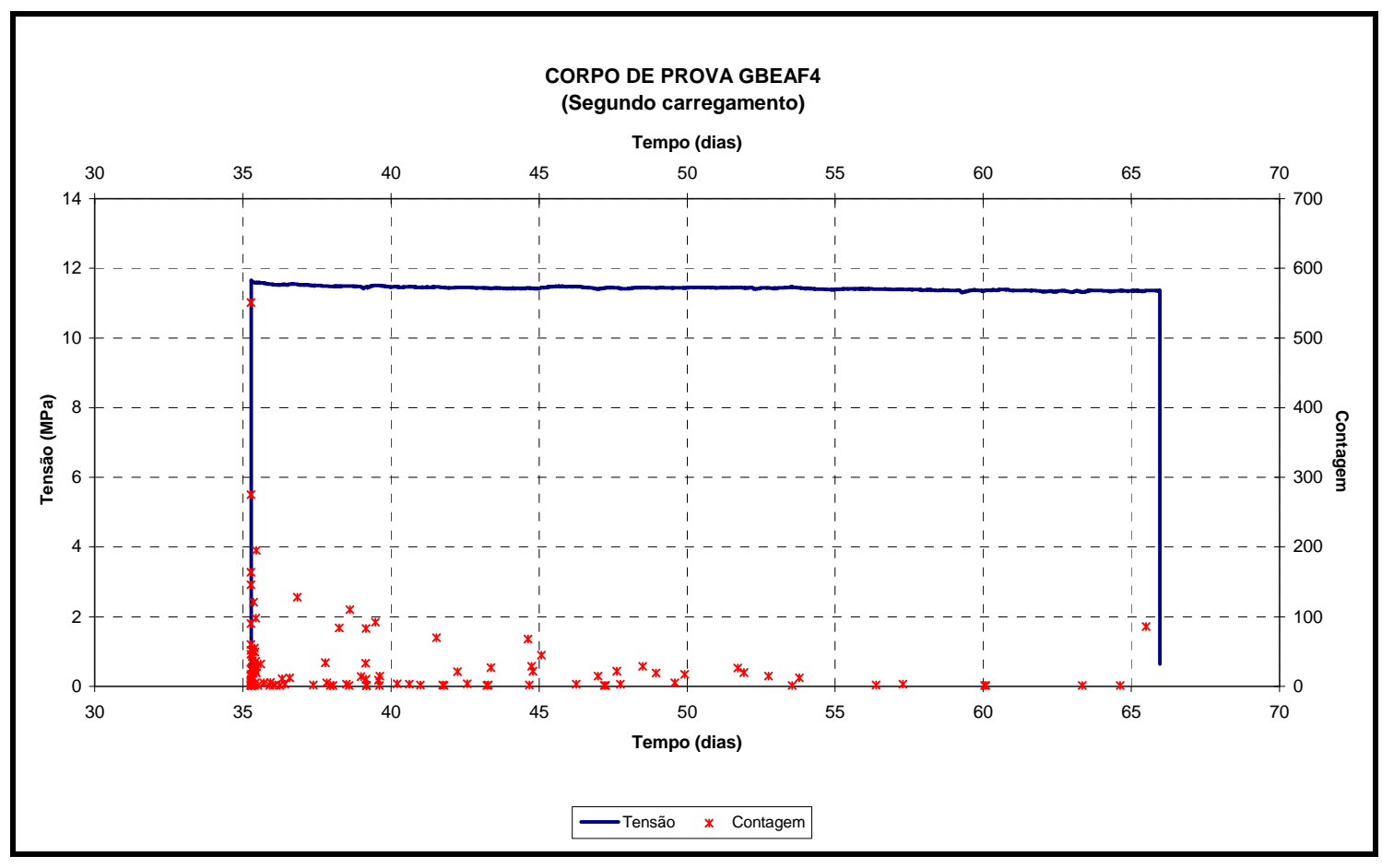

(a)

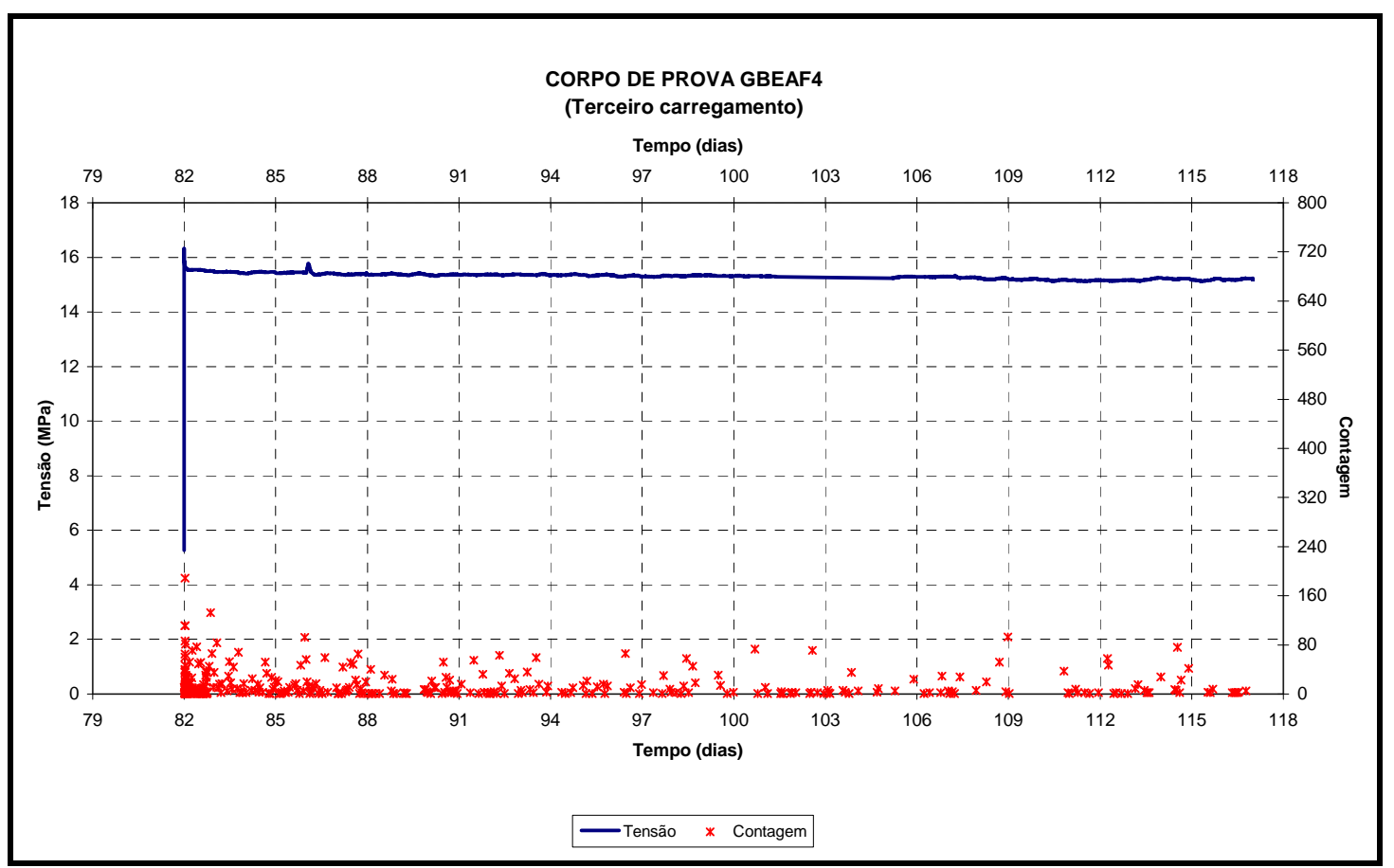

(b)

Figura 4.35 Tensão e contagem versus tempo dos eventos de emissão acústica do ensaio de fluência de longa duração no corpo de prova GBEAF4. (a) Segundo carregamento e (b) Terceiro carregamento 
Na Figura 4.36, o número acumulado de contagens dos eventos de emissão acústica e a deformação axial são traçados ao longo do tempo, sugerindo uma correlação entre estas duas variáveis.

Pode-se observar uma relação linear entre a deformação axial e a contagem acumulada no trecho predominantemente de fluência secundaria na Figura 4.37.

Salienta-se que resultados similares foram obtidos nos ensaios de fluência de curta e longa duração com níveis de tensões superiores aos $75 \%$ da tensão de ruptura e com carregamentos paralelos ou perpendiculares às camadas. Pelo exposto, pode-se concluir que o carregamento dos ensaios de fluência inicialmente provoca microfissuramento do gipsito independentemente do nível de tensão aplicado que atenua ao longo do tempo pelos fenômenos de difusão e dissolução por pressão explicados no item anterior.

No Apêndice 5, são apresentadas gráficos típicos de histórico de carregamentos, deformações, contagem, contagem acumulada, energia absoluta e energia absoluta acumulada de corpos de prova submetidos a ensaios de fluência com dois ciclos de carregamento e descarregamento sucessivos e posterior ciclo crescente de carga nas duas orientações do carregamento com relação às camadas (paralelo e perpendicular) e com os dois tipos de controle (deslocamento do prato ou força). 


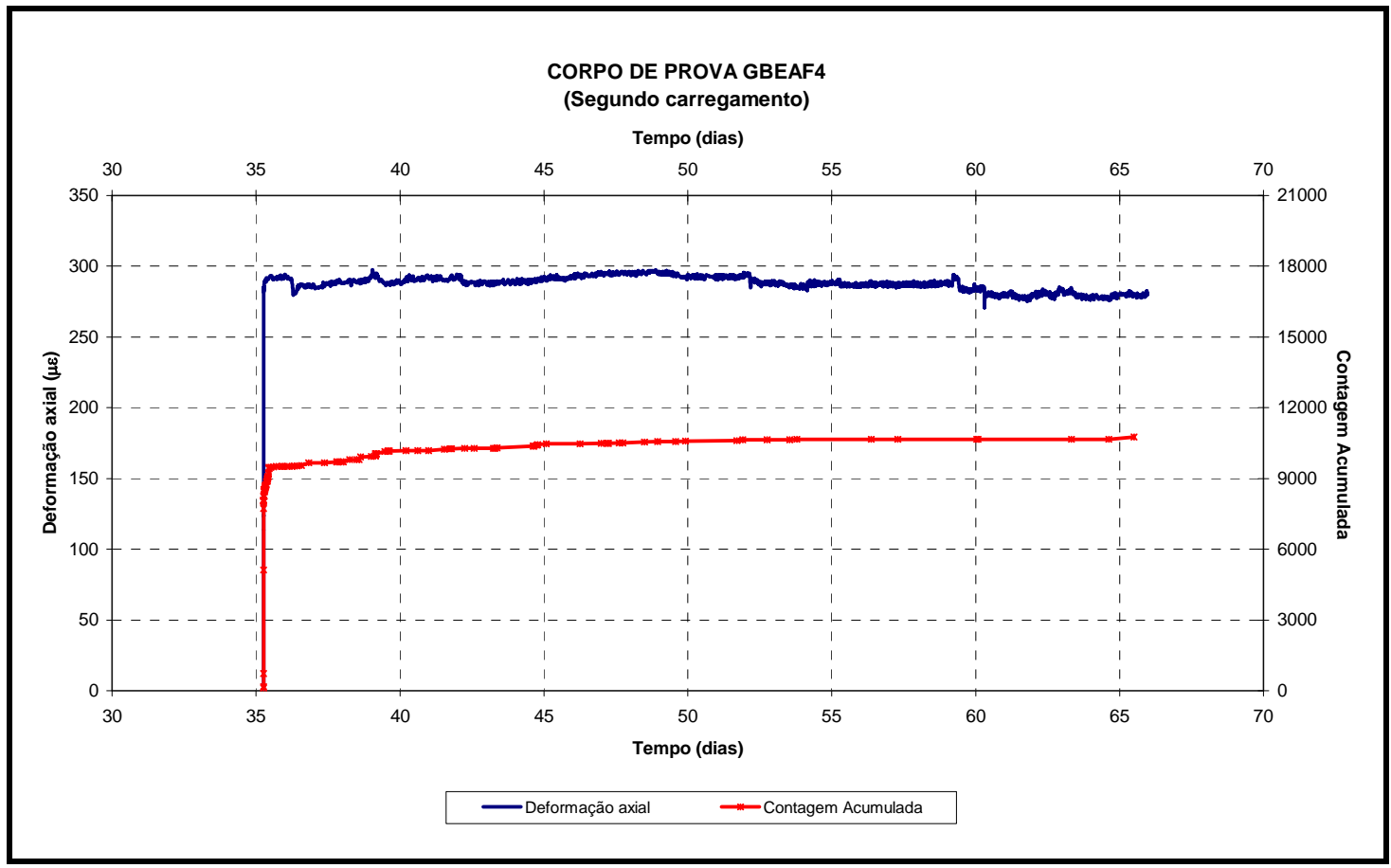

(a)

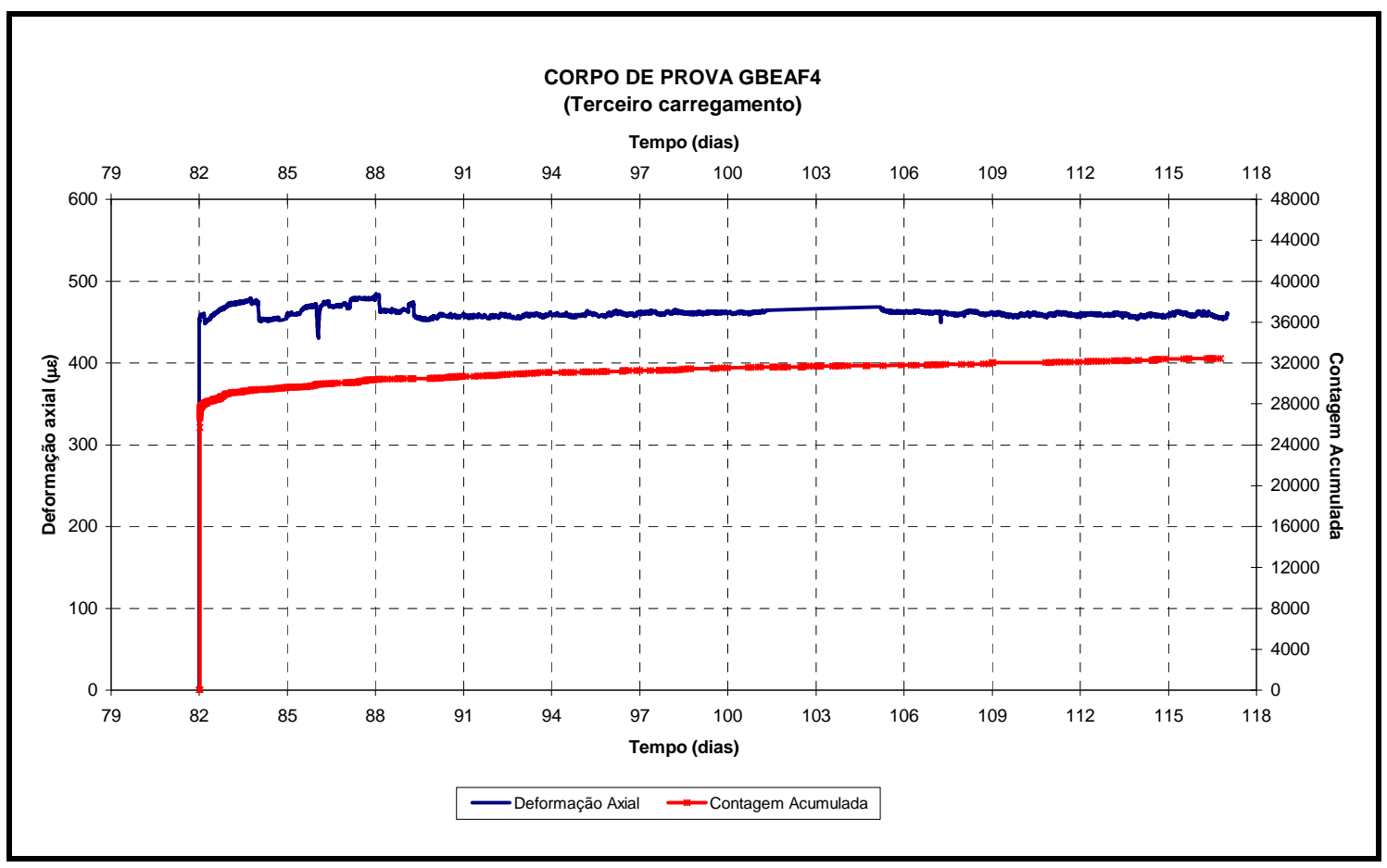

(b)

Figura 4.36 Deformação axial e contagem acumulada versus tempo dos eventos de emissão acústica do ensaio de fluência de longa duração no corpo de prova GBEAF4. (a) Segundo carregamento e (b) Terceiro carregamento 


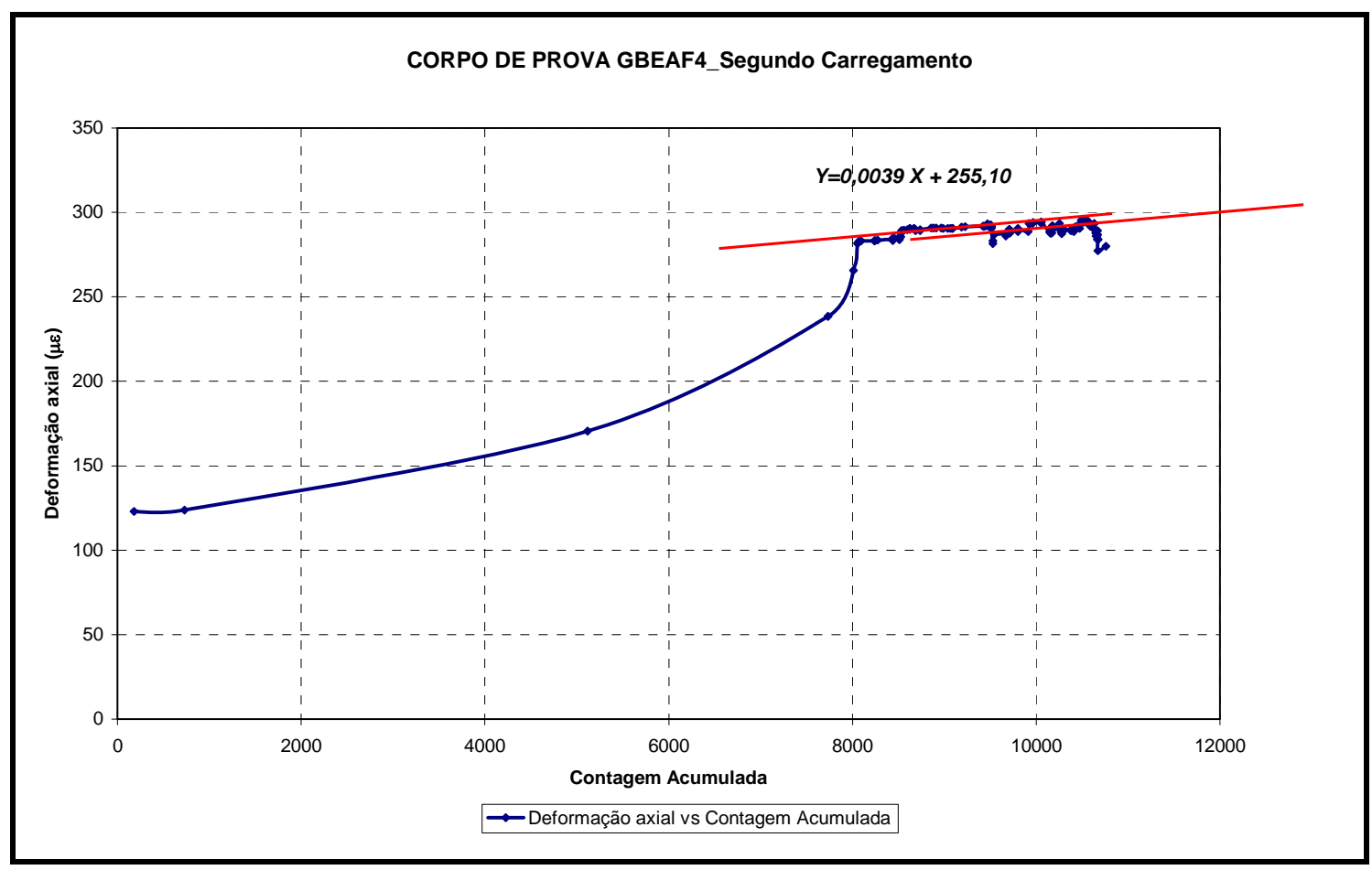

(a)

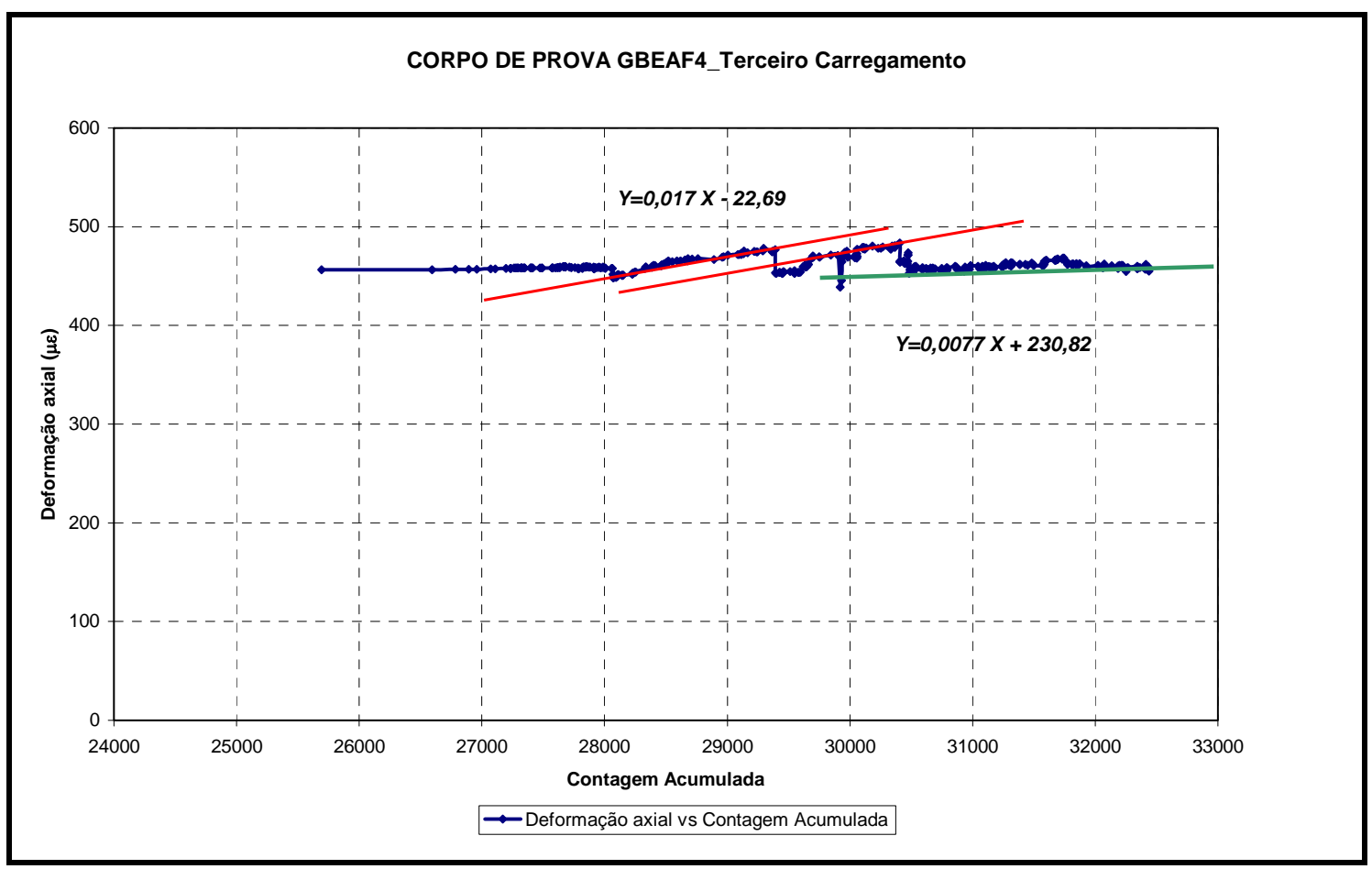

(b)

Figura 4.37 Deformação axial versus contagem acumulada dos eventos de emissão acústica do ensaio de fluência de longa duração no corpo de prova GBEAF4. (a) Segundo carregamento e (b) Terceiro carregamento 


\subsection{Ensaios especiais de fluência de curta duração com ciclos de acréscimos de carregamento anteriores e posteriores ao descarregamento}

Os corpos de prova foram submetidos a um ensaio de fluência de curta duração (de 3 a 6 horas), aplicando os níveis de tensão de fluência indicados na Tabela 3.12. Em seguida, procedeu-se à aplicação dos ciclos de acréscimos de carregamentos, como mostrado na Figura 3.71. Prosseguindo descarregou-se e recarregou-se completamente o corpo de prova, aplicando-se um novo carregamento cíclico como também foi mostrado na Figura 3.71. Seguiu-se novo descarregamento completo e recarregamento até a ruptura. Salienta-se que as freqüências dos ciclos anteriores e posteriores ao descarregamento foram as mesmas. O objetivo foi verificar se o descarregamento provoca progresso no microfissuramento. Esta verificação foi feita por comparação dos valores de módulo de elasticidade medidos nos ciclos de carregamento anteriores e posteriores ao descarregamento.

Analisando a variação dos módulos de elasticidade estáticos e dinâmicos, nos carregamentos destes ensaios especiais ao longo do tempo (Figuras 4.38, 4.39 e 4.40), observa-se que nos três casos existe um ligeiro aumento do módulo de elasticidade estático (Eest), sendo mais notorio no corpo de prova GBEA14 (Figura 4.38) com carregamento perpendicular às camadas e ciclos de acréscimos de carregamento anteriores e posteriores ao descarregamento de freqüência $0,25 \mathrm{~Hz}(1,14 \mathrm{MPa} / \mathrm{s})$. Este acréscimo do módulo de elasticidade estático, ocorrido durante o período de fluência, pode ser atribuído ao processo de cicatrização.

As Tabelas 4.17, 4.18 e 4.19 apresentam os resultados dos módulos de elasticidade na fase cíclica (Ecicl) nos ciclos de carregamento anteriores e posteriores ao descarregamento completo. Excluindo-se o primeiro valor, consistentemente 
bastante discrepante dos demais, obtêm-se médias e desvios padrões também mostrados nas tabelas.

Os resultados dos corpos de prova GBEA14 (carregamento perpendicular às camadas, Tabela 4.17) e GBEA25 (carregamento paralelo às camadas, Tabela 4.18) mostram decréscimos consistentes do módulo de elasticidade na fase cíclica, independentemente do sentido do carregamento com respeito às camadas, denotando portanto progresso das microfissuras e aumento do dano durante o descarregamento. Isto ocorre tanto para carregamento perpendicular quanto paralelo às camadas. Em ambos casos, as microfissuras se desenvolvem na direção paralela ao carregamento, e o dano foi demonstrado pela diminuição do módulo de elasticidade na fase cíclica.

No corpo de prova GBEA24 (carregamento $45^{\circ}$ com camadas, Tabela 4.19) observa-se um acréscimo do módulo de elasticidade na fase cíclica. O progresso do dano é mais complexo para ser analisado.

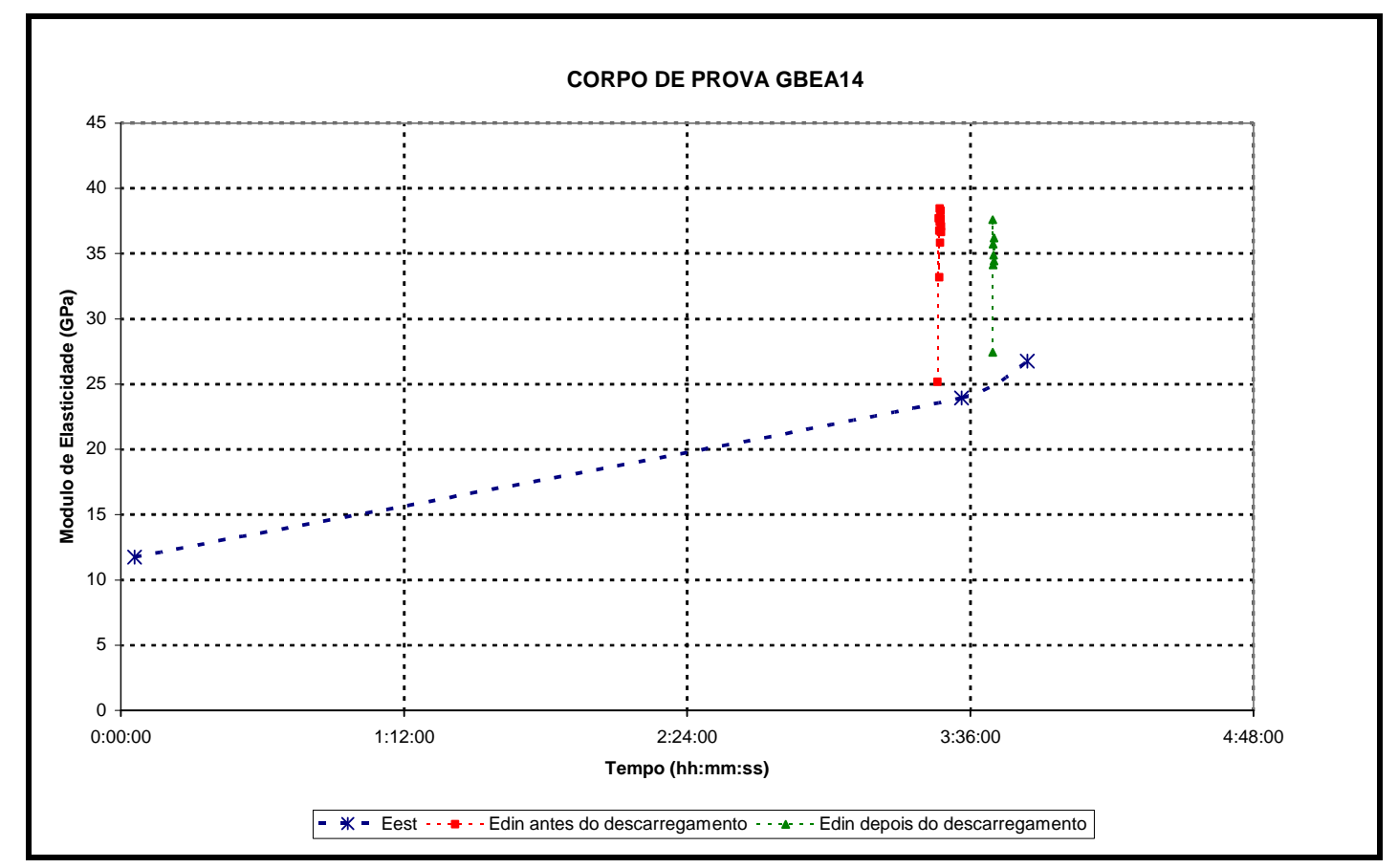

Figura 4.38 Módulos de elasticidade (estático e na fase cíclica) versus tempo no corpo de prova GBEA14 (carregamento perpendicular às camadas), com ciclos de acréscimos de carregamento anteriores e posteriores ao descarregamento de freqüência $0,25 \mathrm{~Hz}(1,14 \mathrm{MPa} / \mathrm{s})$ 


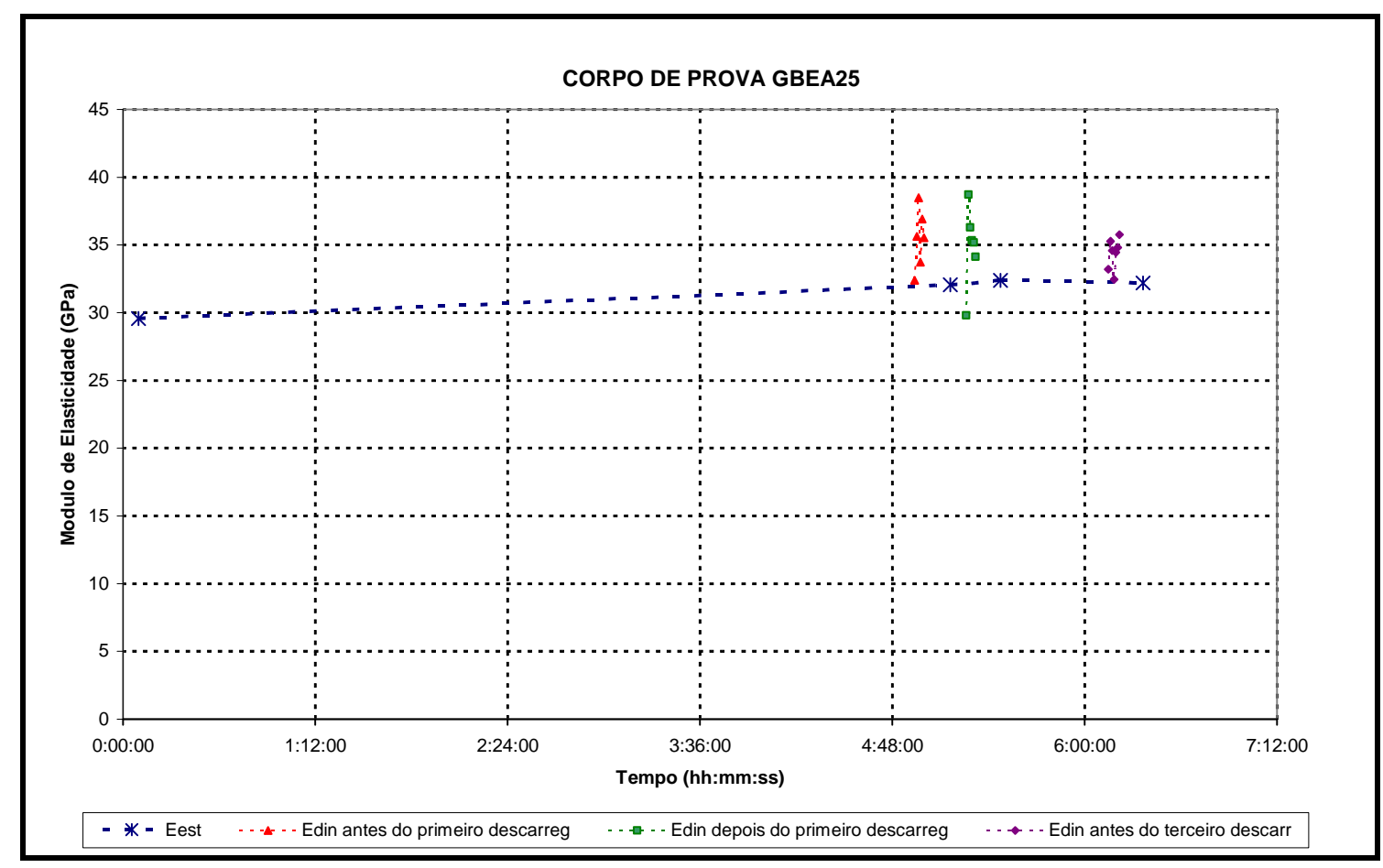

Figura 4.39 Módulos de elasticidade (estático e na fase cíclica) versus tempo no corpo de prova GBEA25 (carregamento paralelo às camadas), com ciclos de acréscimos de carregamento anteriores e posteriores ao descarregamento de freqüência $0,025 \mathrm{~Hz}(6,82 \mathrm{MPa} / \mathrm{min})$

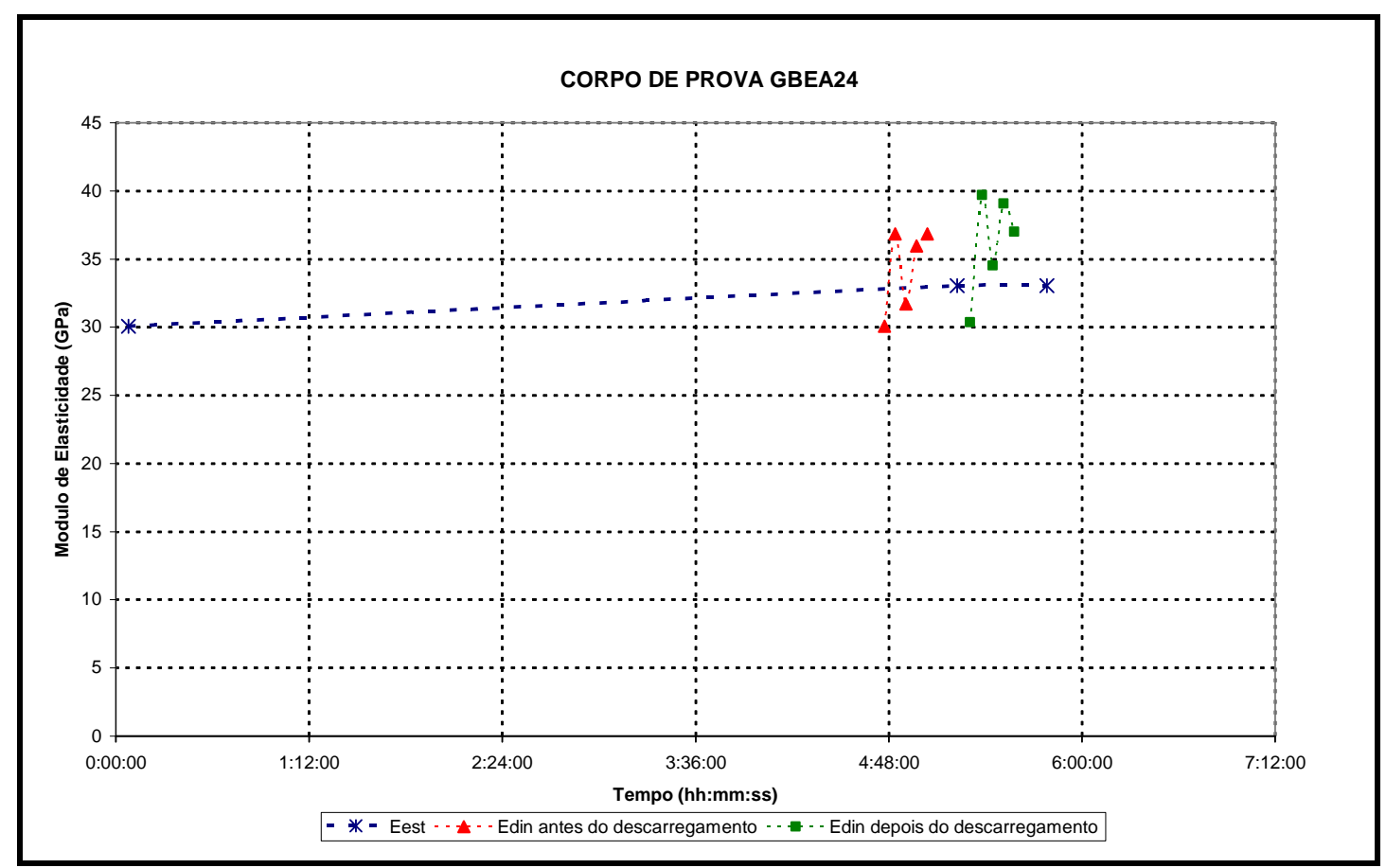

Figura 4.40 Módulos de elasticidade (estático e na fase cíclica) versus tempo no corpo de prova GBEA24 (carregamento $45^{\circ} \mathrm{com}$ camadas), com ciclos de acréscimos de carregamento anteriores e posteriores ao descarregamento de freqüência $0,004 \mathrm{~Hz}(1,14 \mathrm{MPa} / \mathrm{min})$ 
Tabela 4.17 Resultados de módulos de elasticidade na fase cíclica nos ciclos de carregamento anteriores e posteriores ao descarregamento completo no corpo de prova GBEA14 (perpendicular às camadas)

\begin{tabular}{ccc|ccc}
\hline \multicolumn{2}{c|}{ Anterior ao descarregamento completo } & \multicolumn{3}{c}{ Posterior ao descarregamento completo } \\
\hline Carregamento & $\begin{array}{c}\text { Ecicl } \\
\text { (GPa) }\end{array}$ & $\begin{array}{c}\text { Coeficiente } \\
\text { de Poisson }\end{array}$ & Carregamento & $\begin{array}{c}\text { Ecicl } \\
\text { (GPa) }\end{array}$ & $\begin{array}{c}\text { Coeficiente } \\
\text { de Poisson }\end{array}$ \\
\hline 1 & 25,17 & 0,35 & 1 & 27,43 & 0,31 \\
2 & 37,70 & 0,40 & 2 & 37,58 & 0,32 \\
3 & 33,18 & 0,31 & 3 & 34,12 & 0,27 \\
4 & 36,74 & 0,29 & 4 & 35,73 & 0,33 \\
5 & 38,44 & 0,35 & 5 & 34,88 & 0,34 \\
6 & 37,41 & 0,33 & 6 & 34,45 & 0,26 \\
7 & 35,84 & 0,29 & 7 & 36,20 & 0,32 \\
8 & 37,67 & 0,28 & & & \\
9 & 38,29 & 0,39 & & & \\
10 & 37,09 & 0,30 & & & \\
11 & 36,65 & 0,32 & & & \\
Média & 36,90 & 0,33 & Média & 35,49 & 0,31 \\
Desvio Padrão & 1,52 & 0,04 & Desvio Padrão & 1,28 & 0,03 \\
\hline
\end{tabular}

Tabela 4.18 Resultados de módulos de elasticidade na fase cíclica nos ciclos de carregamento anteriores e posteriores ao descarregamento completo no corpo de prova GBEA25 (paralelo às camadas)

\begin{tabular}{ccc|ccc|cccc}
\hline \multicolumn{2}{c}{$\begin{array}{c}\text { Anterior ao descarregamento } \\
\text { completo }\end{array}$} & \multicolumn{3}{c}{$\begin{array}{c}\text { Posterior ao primeiro } \\
\text { descarregamento completo }\end{array}$} & \multicolumn{3}{c}{$\begin{array}{c}\text { Posterior ao segundo } \\
\text { descarregamento completo }\end{array}$} \\
\hline Carregamento & $\begin{array}{c}\text { Ecicl } \\
\text { (GPa) }\end{array}$ & $\begin{array}{c}\text { Relação } \\
\text { Poisson }\end{array}$ & Carregamento & $\begin{array}{c}\text { Ecicl } \\
\text { (GPa) }\end{array}$ & $\begin{array}{c}\text { Relação } \\
\text { Poisson }\end{array}$ & Carregamento & $\begin{array}{c}\text { Ecicl } \\
\text { (GPa) }\end{array}$ & $\begin{array}{c}\text { Relação } \\
\text { Poisson }\end{array}$ \\
\hline 1 & 32,39 & 0,31 & 1 & 29,79 & 0,25 & 1 & 33,20 & 0,21 \\
2 & 35,65 & 0,21 & 2 & 38,72 & 0,20 & 2 & 35,28 & 0,16 \\
3 & 38,49 & 0,21 & 3 & 36,28 & 0,18 & 3 & 34,59 & 0,18 \\
4 & 33,72 & 0,21 & 4 & 35,34 & 0,14 & 4 & 32,45 & 0,20 \\
5 & 36,90 & 0,18 & 5 & 35,17 & 0,26 & 5 & 34,47 & 0,20 \\
6 & 35,55 & 0,25 & 6 & 34,13 & 0,25 & 6 & 34,81 & 0,29 \\
& & & & & & 7 & 35,78 & 0,25 \\
\hline Média & 36,06 & 0,21 & Média & 35,93 & 0,21 & Média & 34,56 & 0,21 \\
Desvio Padrão & 1,77 & 0,02 & Desvio Padrão & 1,74 & 0,05 & Desvio Padrão & 1,14 & 0,05 \\
\hline
\end{tabular}


Tabela 4.19 Resultados de módulos de elasticidade na fase cíclica nos ciclos de carregamento anteriores e posteriores ao descarregamento completo no corpo de prova GBEA24 $\left(45^{\circ} \mathrm{com}\right.$ camadas)

\begin{tabular}{ccc|ccc}
\hline \multicolumn{2}{c|}{ Anterior ao descarregamento completo } & \multicolumn{3}{c}{ Posterior ao descarregamento completo } \\
\hline Carregamento & $\begin{array}{c}\text { Ecicl } \\
\text { (GPa) }\end{array}$ & $\begin{array}{c}\text { Coeficiente } \\
\text { de Poisson }\end{array}$ & Carregamento & $\begin{array}{c}\text { Ecicl } \\
\text { (GPa) }\end{array}$ & $\begin{array}{c}\text { Coeficiente } \\
\text { de Poisson }\end{array}$ \\
\hline 1 & 30,09 & 0,35 & 1 & 30,37 & 0,29 \\
2 & 36,84 & 0,33 & 2 & 39,71 & 0,42 \\
3 & 31,70 & 0,27 & 3 & 34,54 & 0,31 \\
4 & 35,96 & 0,42 & 4 & 39,06 & 0,35 \\
5 & 36,87 & 0,34 & 5 & 37,02 & 0,35 \\
\hline Média & 35,33 & 0,34 & Média & 37,58 & 0,36 \\
Desvio Padrão & 2,46 & 0,06 & Desvio Padrão & 2,33 & 0,04 \\
\hline
\end{tabular}

A Figura 4.41 apresenta o histórico de carregamento no corpo de prova GBEA25 (carregamento paralelo às camadas) juntamente com as contagens de eventos. As Figuras 4.42, 4.43 e 4.44 apresentam detalhes da contagens de eventos no primeiro, segundo e terceiro descarregamentos, respectivamente.

No corpo de prova GBEA25 há evidências que o descarregamento provoca microfissuramento tanto porque se intensifica a quantidade dos eventos de emissão acústica no descarregamento (Figuras 4.42, 4.43 e 4.44), quanto pelo decréscimo dos módulos de elasticidade dinâmicos nos ciclos de acréscimos de carregamento anteriores e posteriores ao descarregamento (Tabela 4.18). 


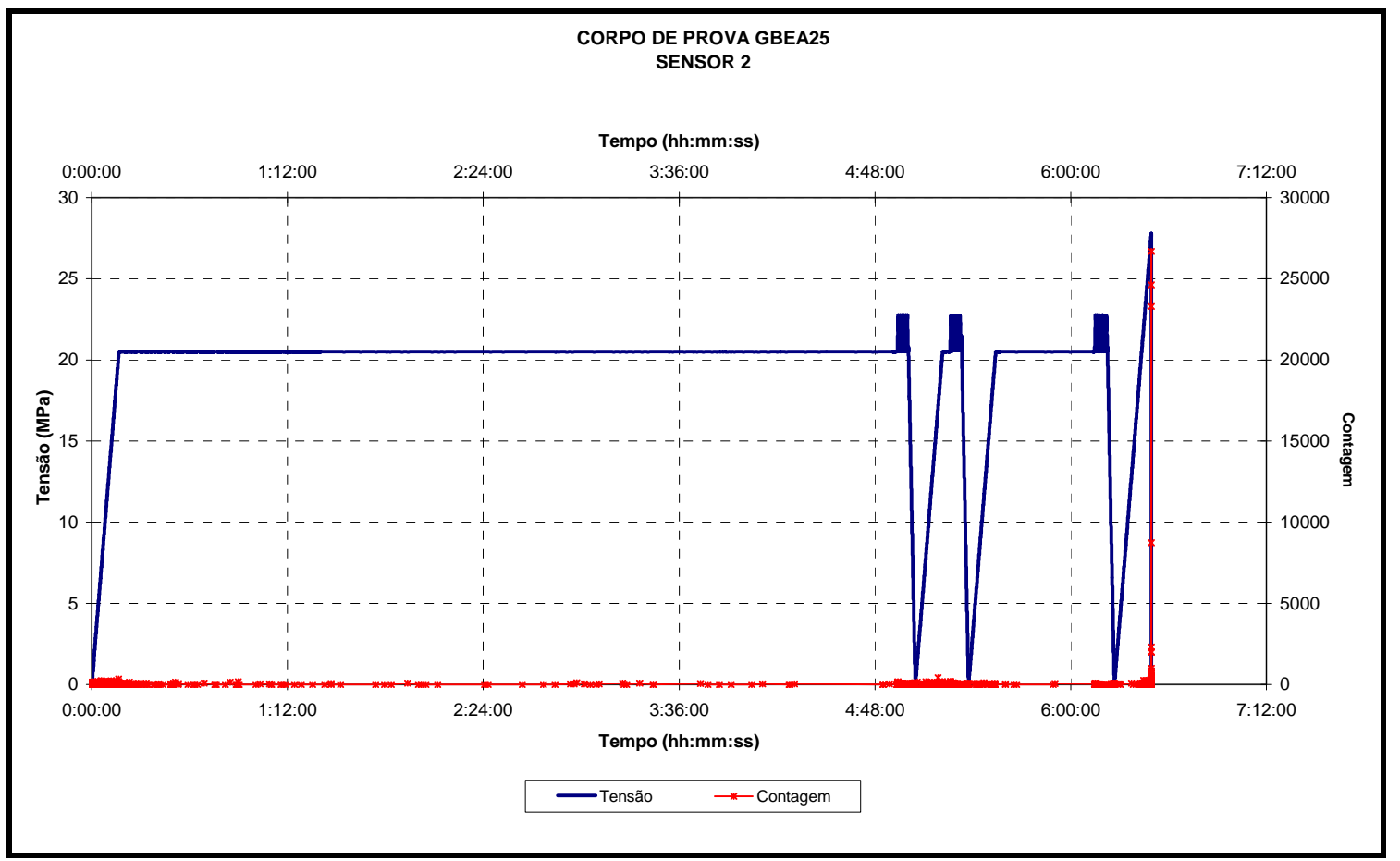

Figura 4.41 Tensão e contagem versus tempo dos eventos de emissão acústica no sensor 2 (freqüências intermediárias de 100 a $400 \mathrm{kHz}$ ) do corpo de prova GBEA25 (carregamento paralelo às camadas)

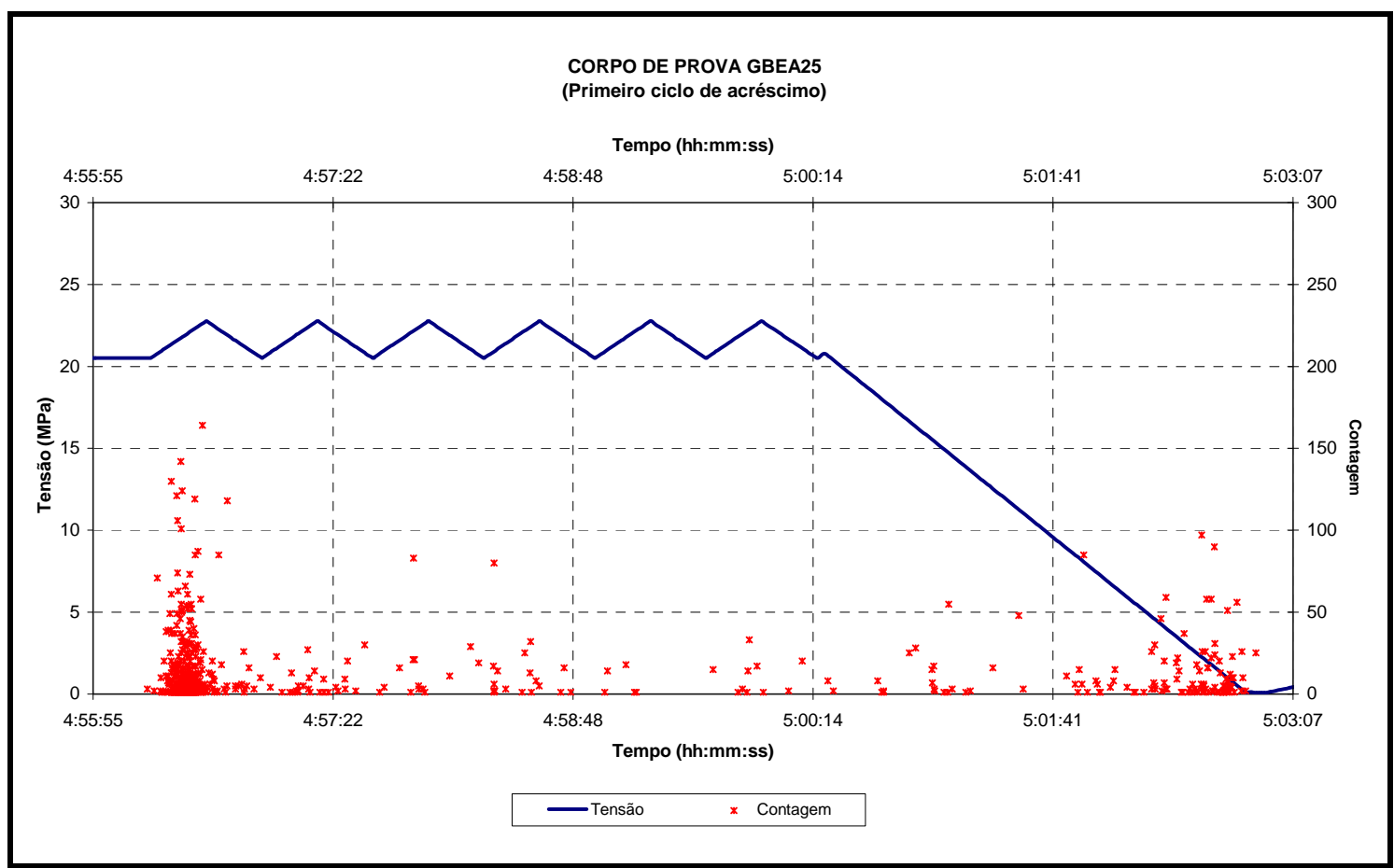

Figura 4.42 Tensão e contagem versus tempo dos eventos acústicos no primeiro ciclo de acréscimo de carregamento anterior ao descarregamento correspondente ao corpo de prova GBEA25 com freqüência de $0,025 \mathrm{~Hz}(6,82 \mathrm{MPa} / \mathrm{min})$ 


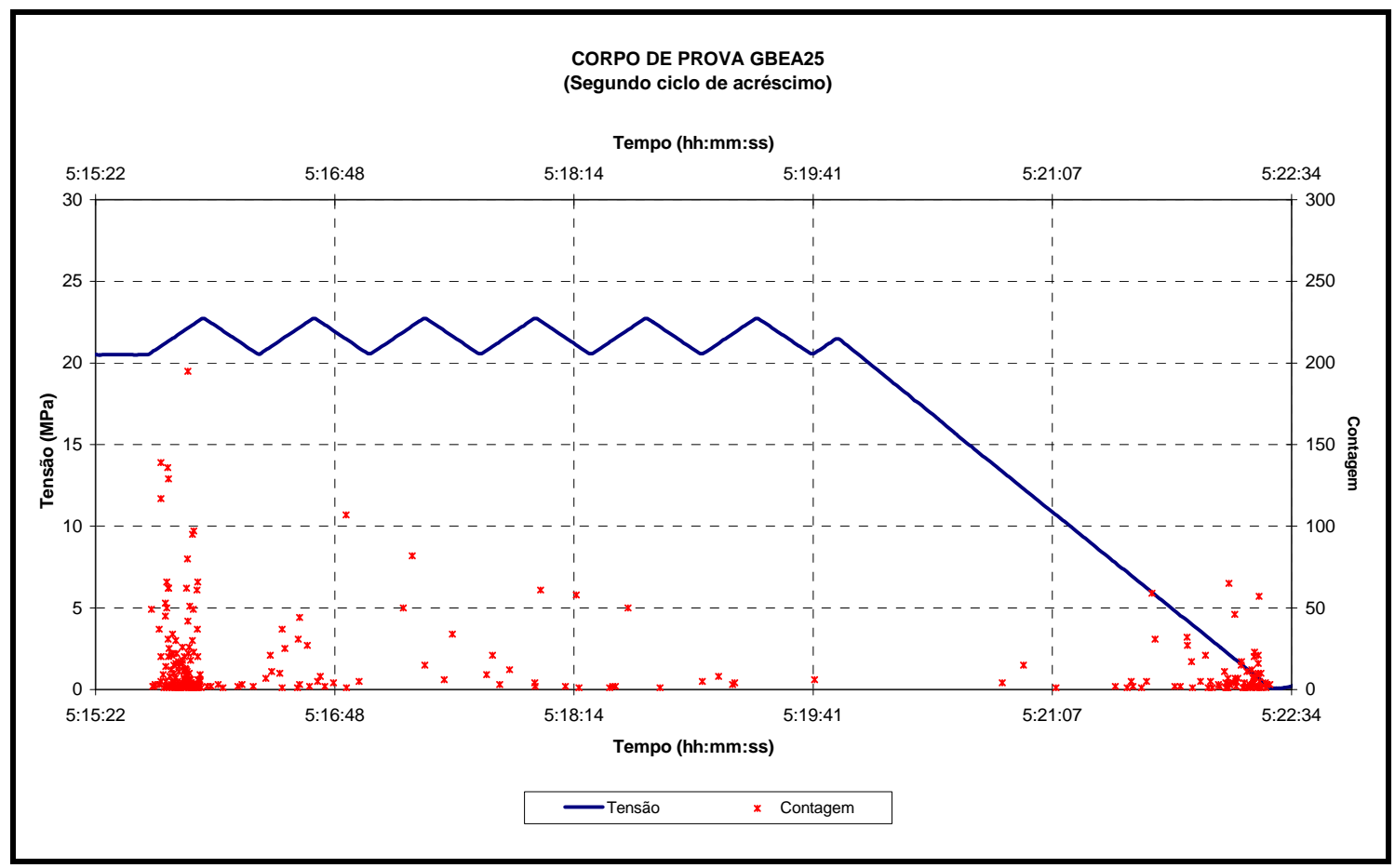

Figura 4.43 Tensão e contagem versus tempo dos eventos acústicos no segundo ciclo de acréscimo de carregamento anterior ao descarregamento correspondente ao corpo de prova GBEA25 com freqüência de $0,025 \mathrm{~Hz}(6,82 \mathrm{MPa} / \mathrm{min})$

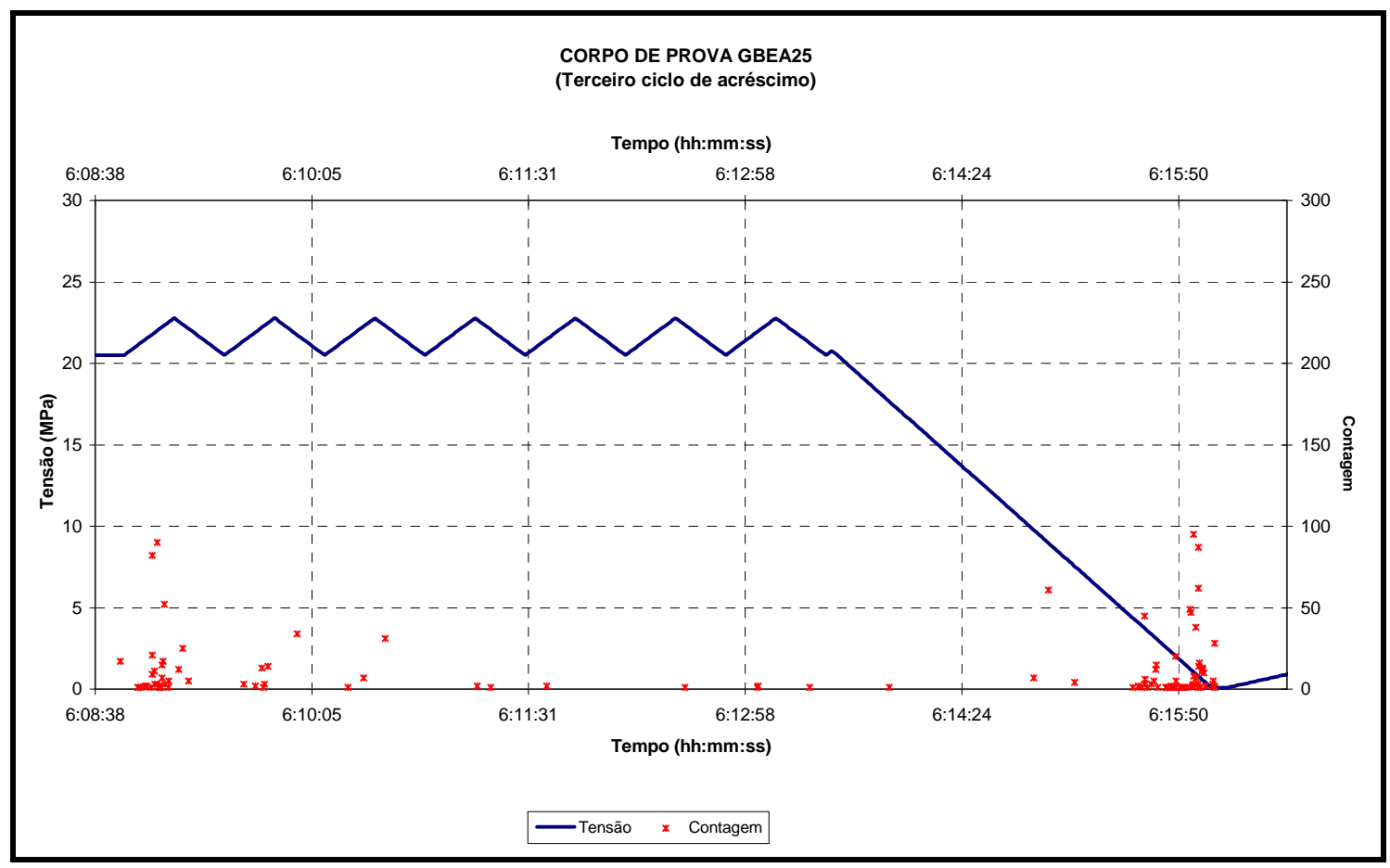

Figura 4.44 Tensão e contagem versus tempo dos eventos acústicos no terceiro ciclo de acréscimo de carregamento anterior ao descarregamento correspondente ao corpo de prova GBEA25 com freqüência de $0,025 \mathrm{~Hz}(6,82 \mathrm{MPa} / \mathrm{min})$ 
A Figura 4.45 apresenta o histórico de carregamento no corpo de prova GBEA24 (carregamento $45^{\circ}$ com camadas) juntamente com as contagens de eventos. As Figuras 4.46 e 4.47 apresentam detalhes da contagem de eventos no primeiro e segundo descarregamentos, respectivamente.

No corpo de prova GBEA24 há evidências que o descarregamento provoca microfissuramento porque se intensifica a quantidade dos eventos de emissão acústica no descarregamento (Figuras 4.46 e 4.47). O acréscimo de módulo de elasticidade na fase cíclica como comentado antes, é um fenômeno complexo, com camadas oblíquas ao carregamento.

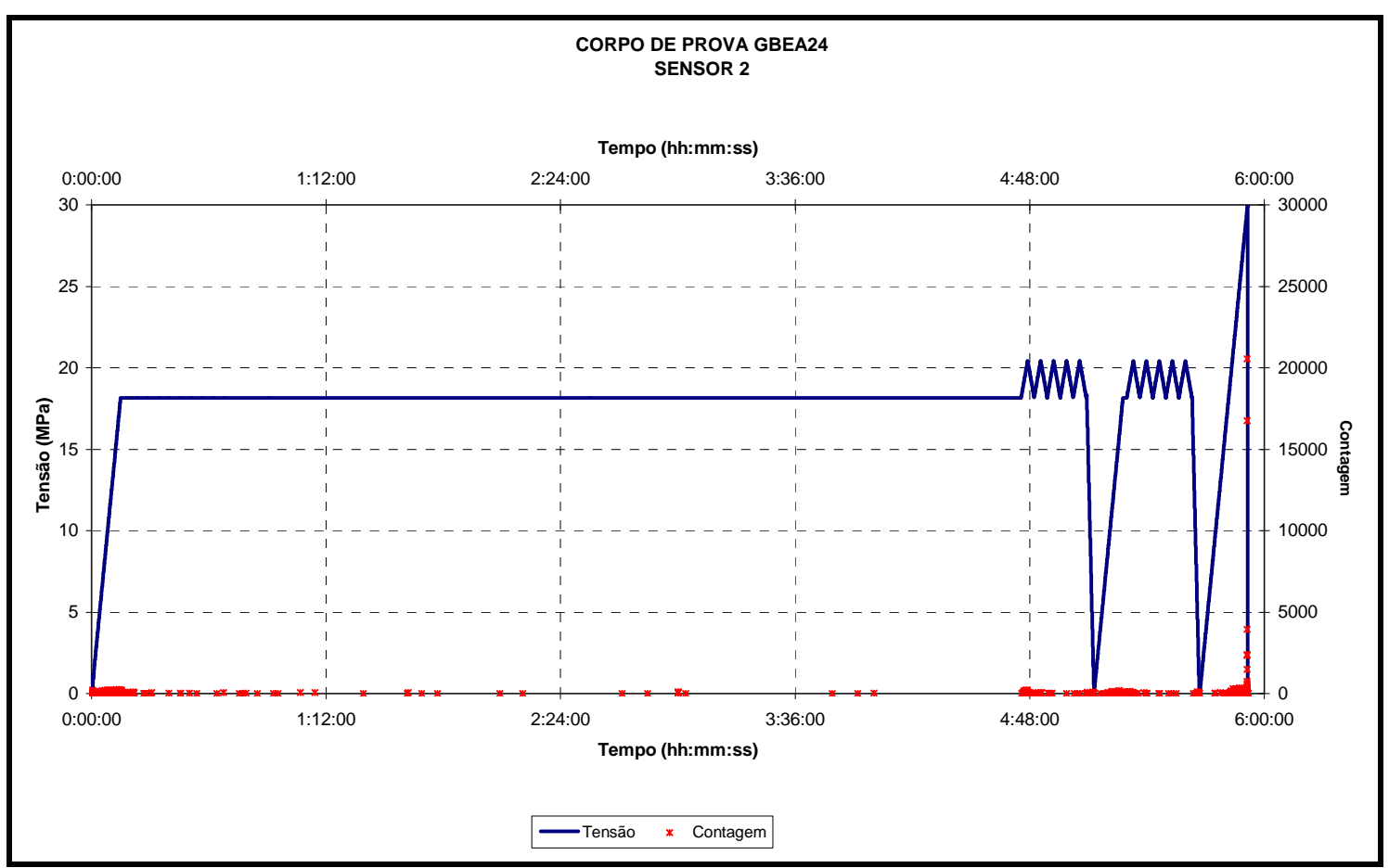

Figura 4.45 Tensão e contagem versus tempo dos eventos de emissão acústica no sensor 2 (freqüências intermediárias de 100 a $400 \mathrm{kHz}$ ) do corpo de prova GBEA24 (carregamento $45^{\circ} \mathrm{com}$ camadas) 


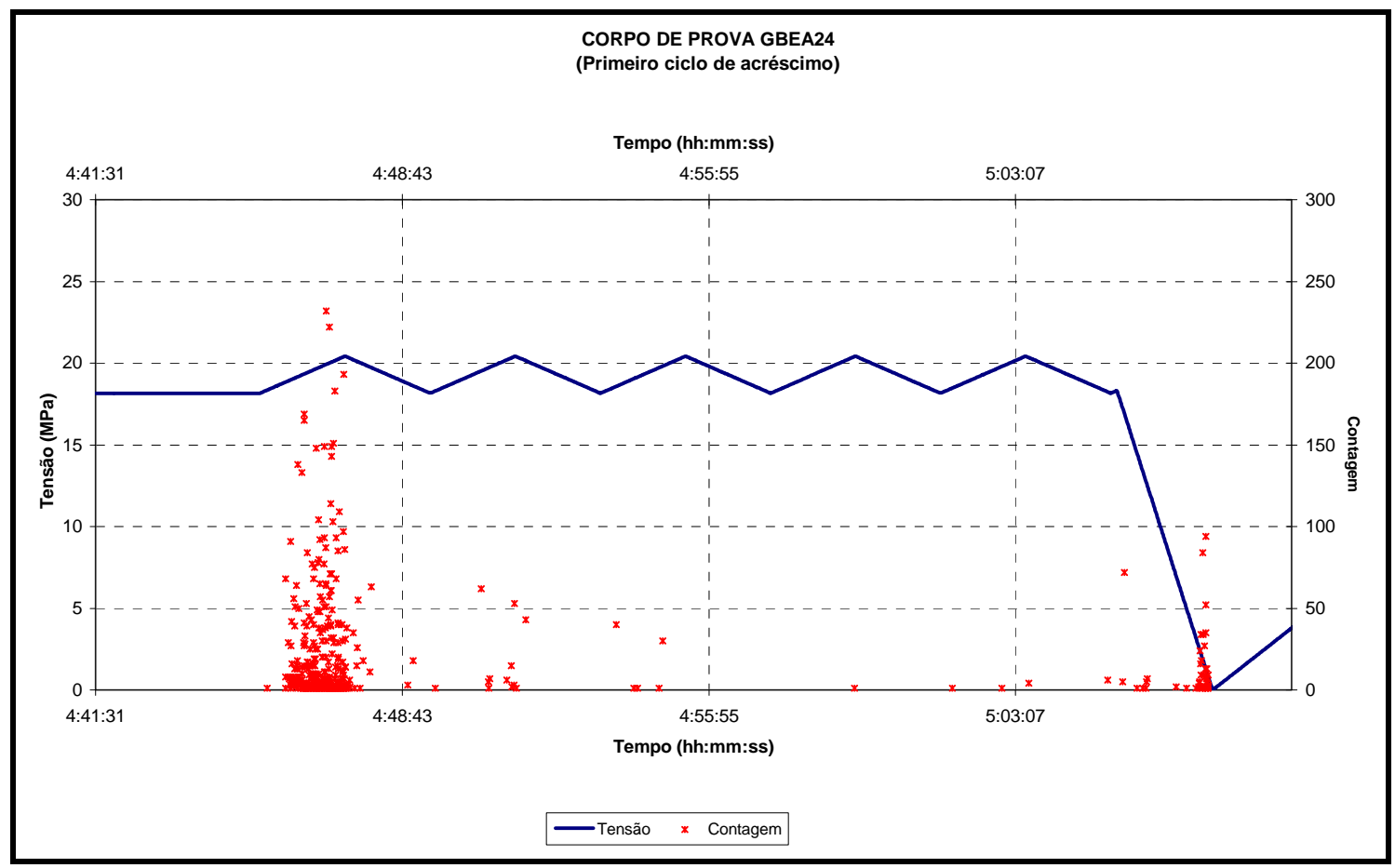

Figura 4.46 Tensão e contagem versus tempo dos eventos acústicos no primeiro ciclo de acréscimo de carregamento anterior ao descarregamento correspondente ao corpo de prova GBEA24 com freqüência de $0,004 \mathrm{~Hz}(1,14 \mathrm{MPa} / \mathrm{min})$

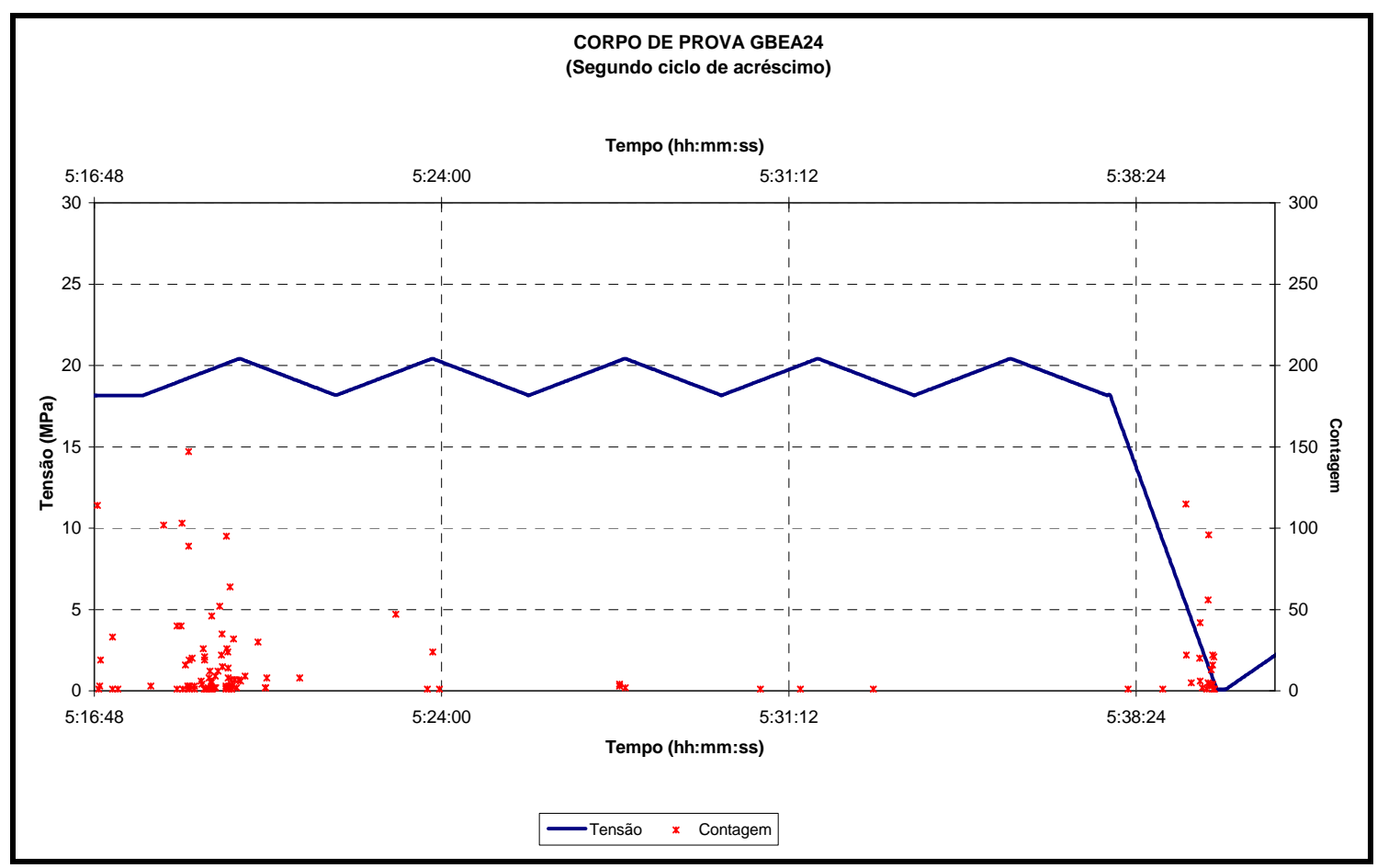

Figura 4.47 Tensão e contagem versus tempo dos eventos acústicos no segundo ciclo de acréscimo de carregamento anterior ao descarregamento correspondente ao corpo de prova GBEA24 com freqüência de $0,004 \mathrm{~Hz}(1,14 \mathrm{MPa} / \mathrm{min})$ 
A Figura 4.48 apresenta o histórico de carregamento no corpo de prova GBEA14 (carregamento perpendicular às camadas) juntamente com as contagens de eventos. As Figuras 4.49 e 4.50 apresentam detalhes da contagem de eventos no primeiro e segundo descarregamentos, respectivamente.

No corpo de prova GBEA14, a atividade acústica no descarregamento é pequena, porém existe (Figuras 4.49 e 4.50). Pode parecer uma contradição, mas tem-se uma explicação na orientação preferencial dos cristais, a qual ocorre na direção perpendicular às camadas, conforme itens 3.6 e 3.7. Este mesmo motivo levou a resistência à compressão uniaxial nesta direção a ser menor que aquela correspondente ao carregamento na direção paralela às camadas, conforme item 4.1.

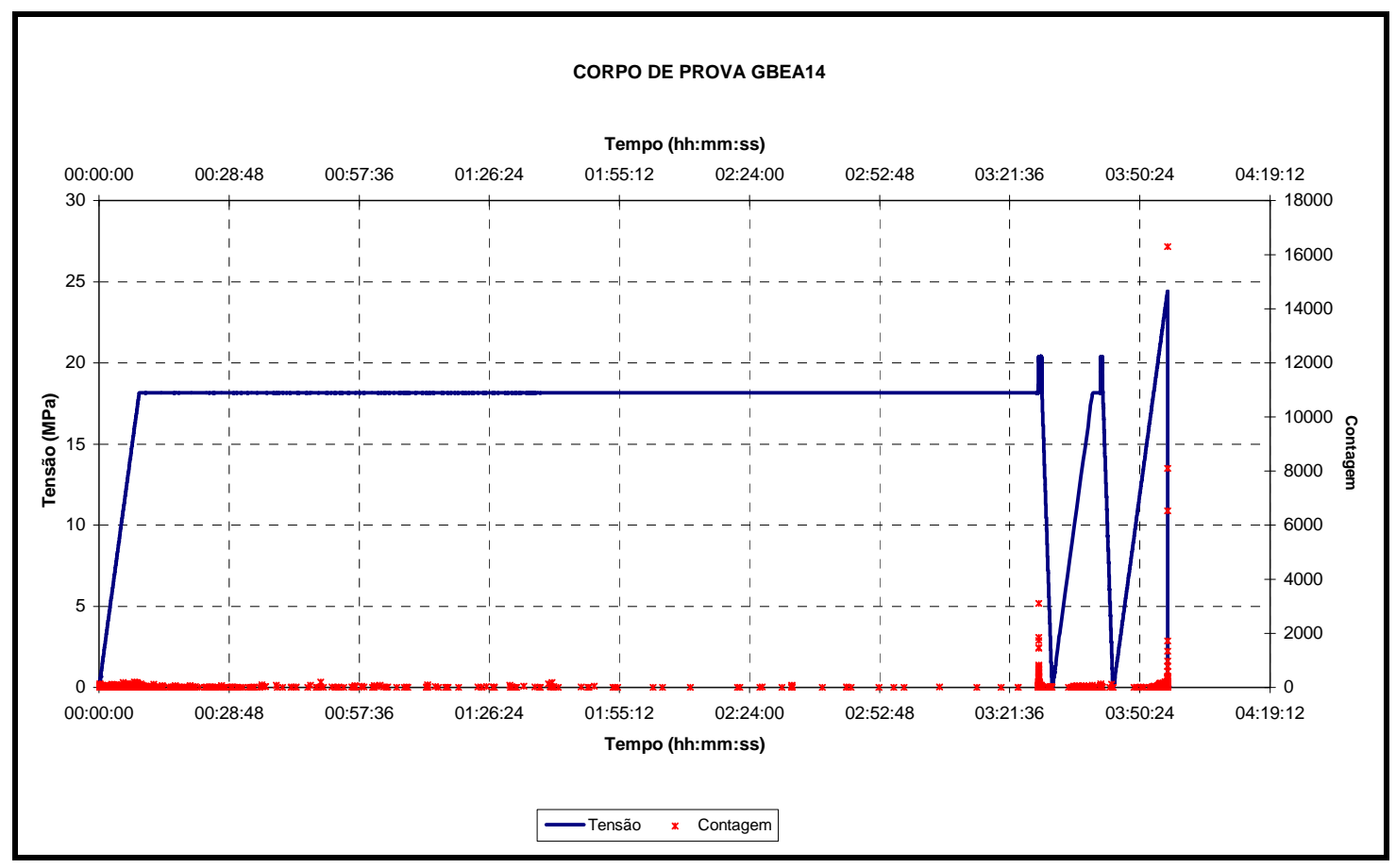

Figura 4.48 Tensão e contagem versus tempo dos eventos de emissão acústica no sensor 2 (freqüências intermediárias de 100 a $400 \mathrm{kHz}$ ) do corpo de prova GBEA14 (perpendicular às camadas) 


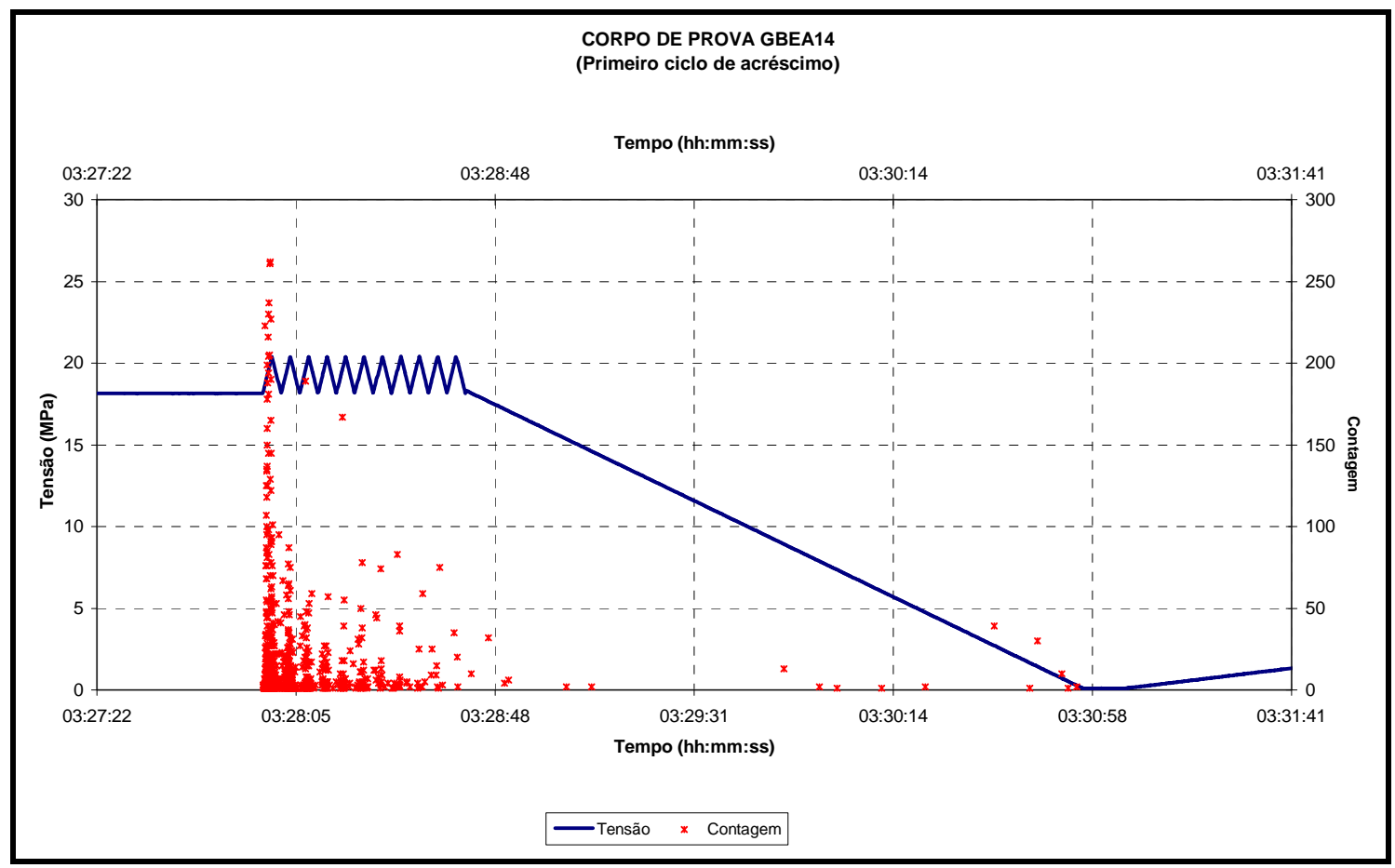

Figura 4.49 Tensão e contagem versus tempo dos eventos acústicos no primeiro ciclo de acréscimo de carregamento anterior ao descarregamento correspondente ao corpo de prova GBEA14 com freqüência de $0,25 \mathrm{~Hz}(1,14 \mathrm{MPa} / \mathrm{s})$

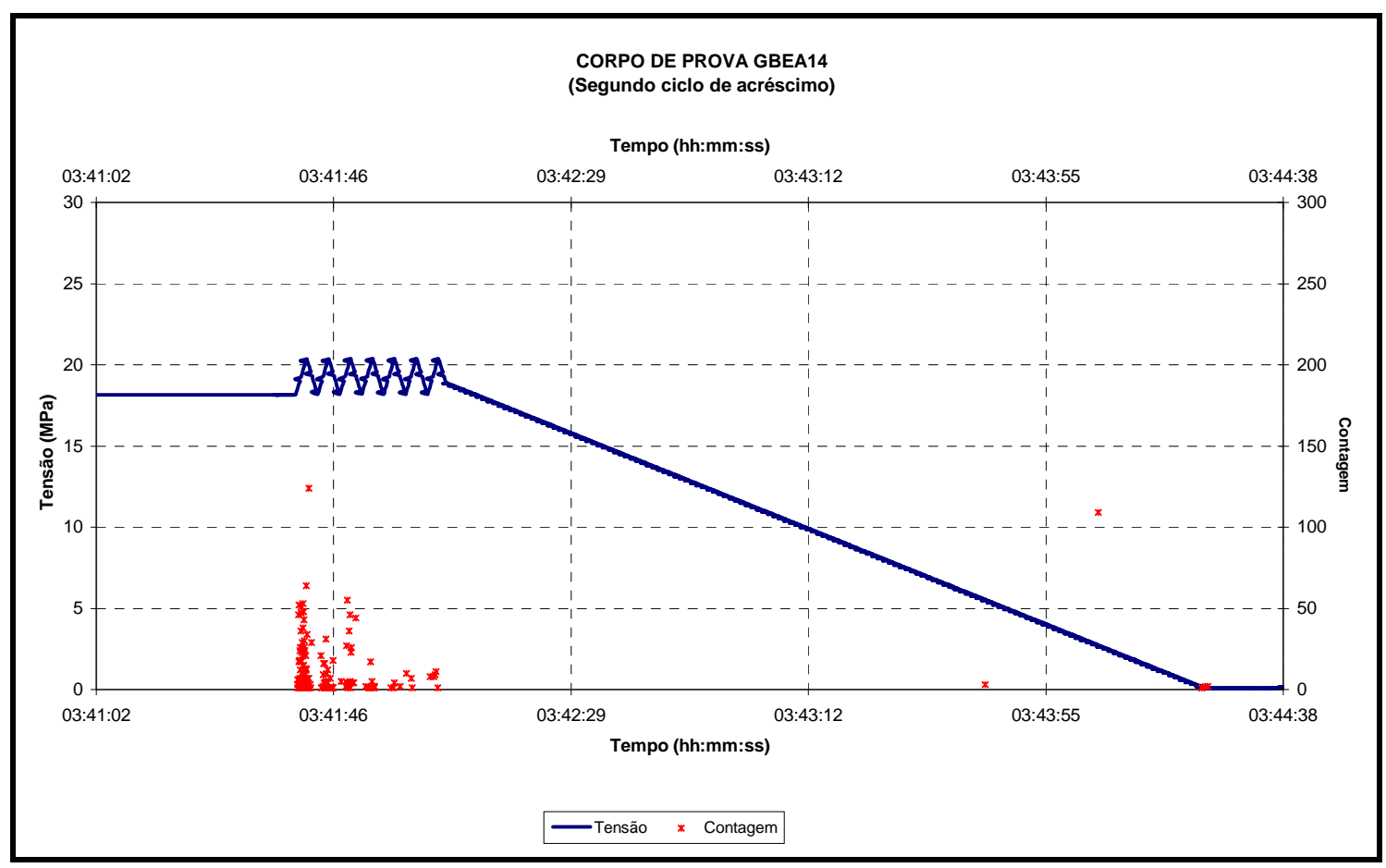

Figura 4.50 Tensão e contagem versus tempo dos eventos acústicos no segundo ciclo de acréscimo de carregamento anterior ao descarregamento correspondente ao corpo de prova GBEA14 com freqüência de $0,25 \mathrm{~Hz}(1,14 \mathrm{MPa} / \mathrm{s})$ 


\subsection{Ensaio especial de compressão uniaxial com ciclos variáveis de carregamento antes e após o pico de resistência (Complementação do tipo CVIII)}

Estes ensaios seguiram os procedimentos indicados no item 3.12.6. Nas Figuras 4.51 e 4.52, apresenta-se a evolução do módulo de elasticidade e da relação entre a deformação radial e a deformação axial do corpo de prova GBpec4da ao longo dos ensaios a que foi submetido.

Observa-se claramente:

a) Diminuição do módulo de elasticidade com o aumento da carga aplicada. A perda de rigidez é atribuída à danificação da rocha por criação e propagação de microfissuras e pode estar ligada à não linearidade intrínseca do comportamento tensãodeformação.

b) Aumento da relação entre a deformação radial e a deformação axial devido às aberturas das fissuras ao longo do ensaio, produzindo dilatância no corpo de prova;

c) Relação entre a deformação radial e a deformação axial maior que 0,5 , portanto muito além do limite elástico, quando o pico de resistência é ultrapassado. 


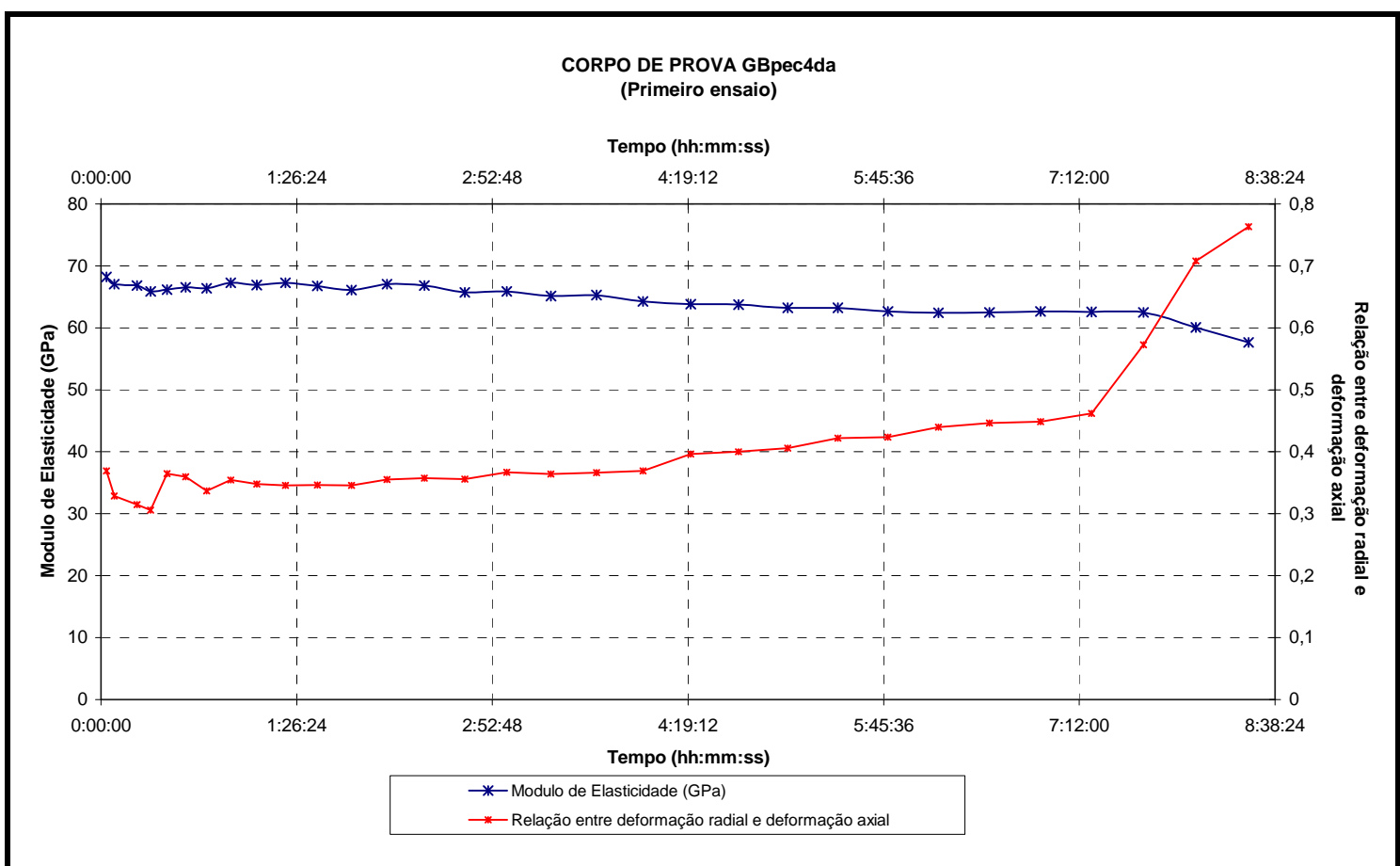

Figura 4.51 Módulo de elasticidade e relação entre a deformação radial e deformação axial versus tempo do ensaio de carregamento e descarregamento antes e após o pico de resistência no corpo de prova GBpec4da (Primeiro ensaio)

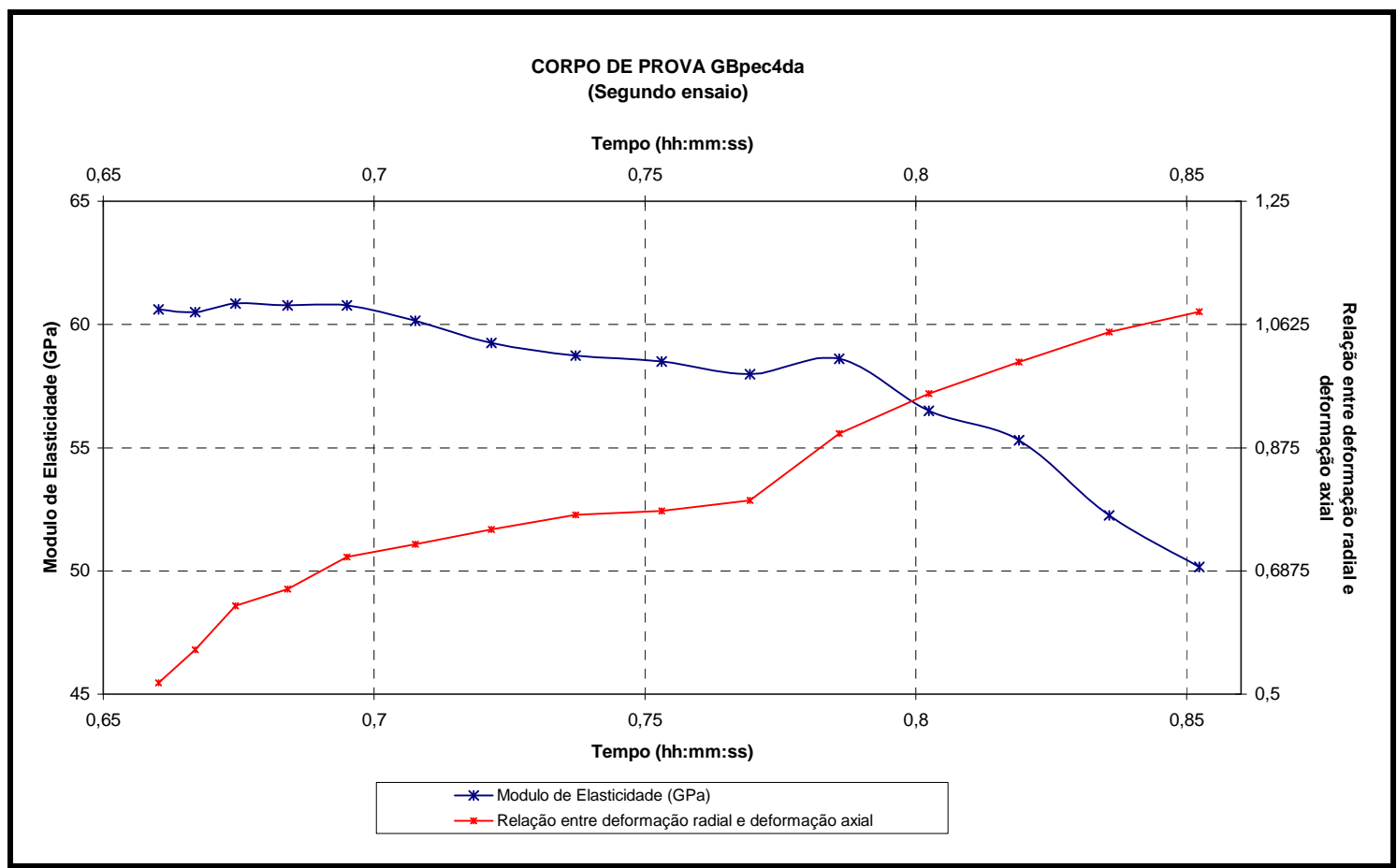

Figura 4.52 Módulo de elasticidade e relação entre a deformação radial e a deformação axial versus tempo do ensaio de carregamento e descarregamento antes e após o pico de resistência no corpo de prova GBpec4da (Segundo ensaio) 
Nas Figuras 4.53 e 4.54, verifica-se o seguinte:

a) Ocorre o efeito Kaiser nos ensaios de carregamento, descarregamento e recarregamento de curta duração;

b) O segundo ensaio de carregamento e descarregamento antes e após o pico de resistência foi realizado depois de 3 horas de finalizado o ensaio anterior; ocorre o efeito Kaiser típico até carregamento pós-pico, mas como o corpo de prova se encontra danificado, existe propagação das microfissuras no descarregamento, registrando eventos de emissão acústica depois do sétimo ciclo de carregamento e descarregamento (Figura 4.54).

O corpo de prova GBpec4da foi submetido finalmente a um ensaio de compressão simples 15 dias depois do descarregamento; este corpo de prova apresenta, desde o início do carregamento, registros de eventos de emissão acústica (Figura 4.55). Verifica-se, portanto, que o fenômeno de microfissuramento é detectado pelo sensor de emissão acústica de freqüências intermediárias (de 100 a $400 \mathrm{kHz}$ ). Isto só pode ser explicado pela ocorrência de cicatrização. 


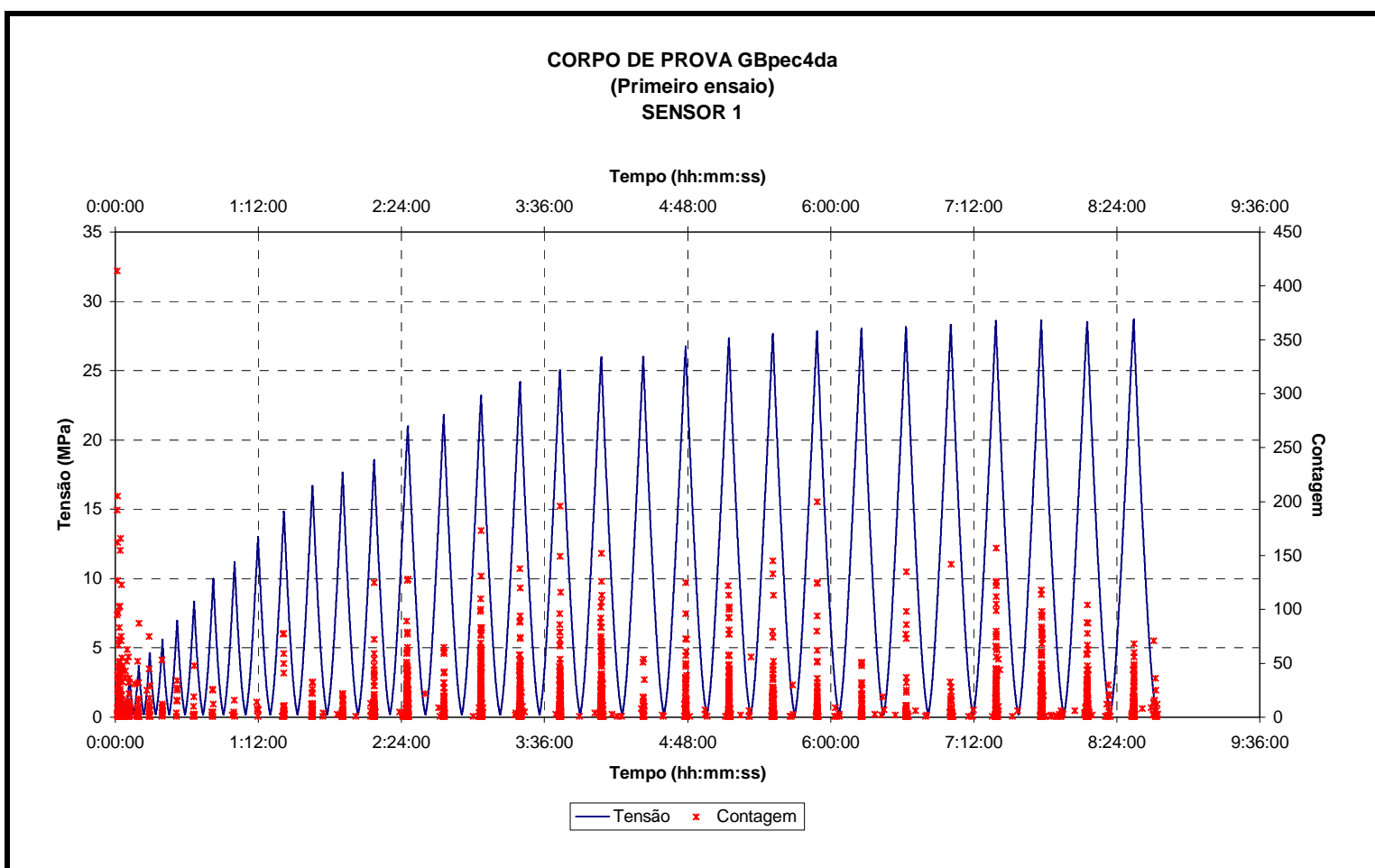

Figura 4.53 Tensão e contagem versus tempo dos eventos de emissão acústica no sensor 1 (freqüências intermediárias de 100 a $400 \mathrm{kHz}$ ) do ensaio de carregamento e descarregamento antes e após o pico de resistência no corpo de prova GBpec4da (Primeiro ensaio)

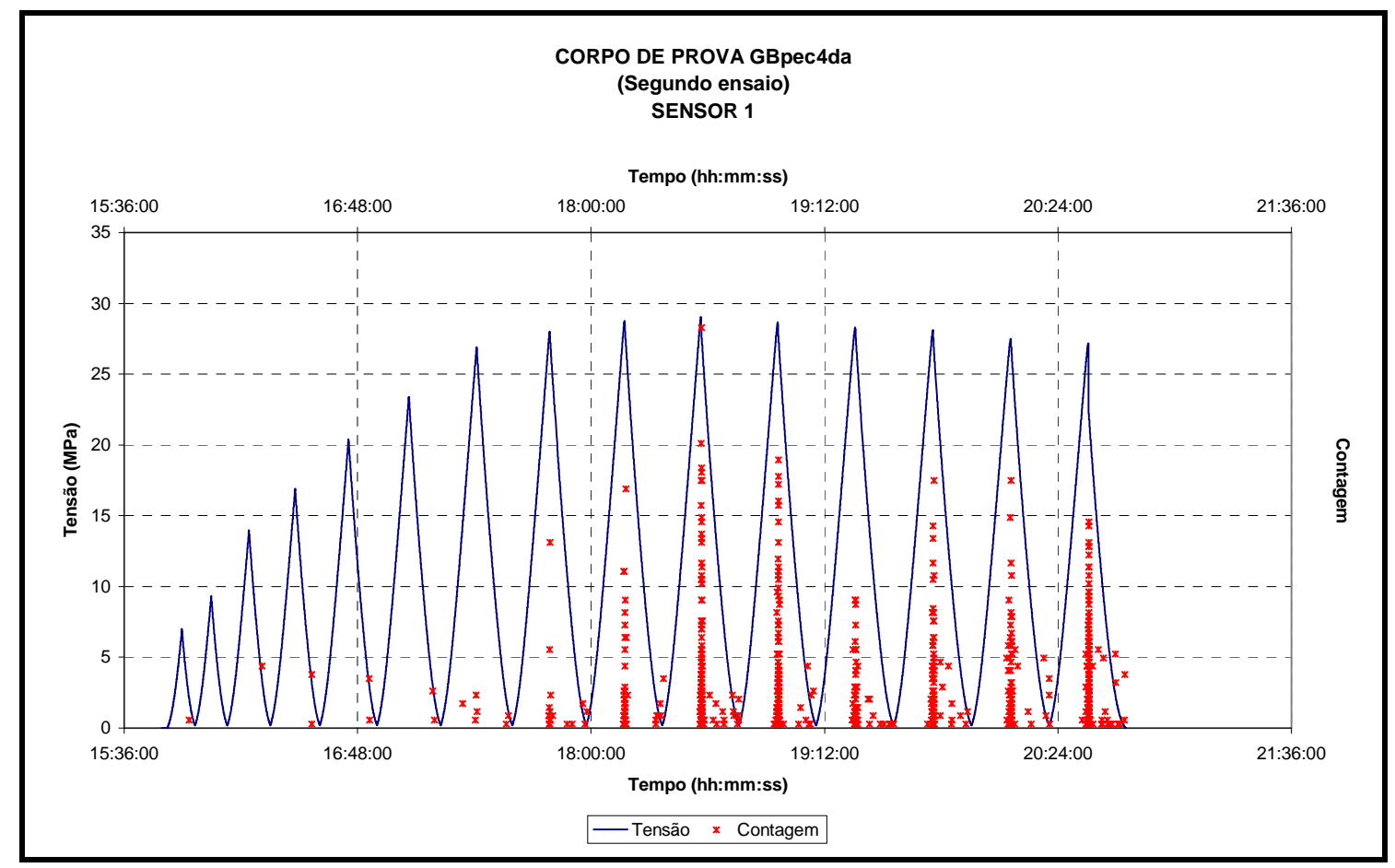

Figura 4.54 Tensão e contagem versus tempo dos eventos de emissão acústica no sensor 1 (freqüências intermediárias de 100 a $400 \mathrm{kHz}$ ) do ensaio de carregamento e descarregamento antes e após o pico de resistência no corpo de prova GBpec4da (Segundo ensaio) 


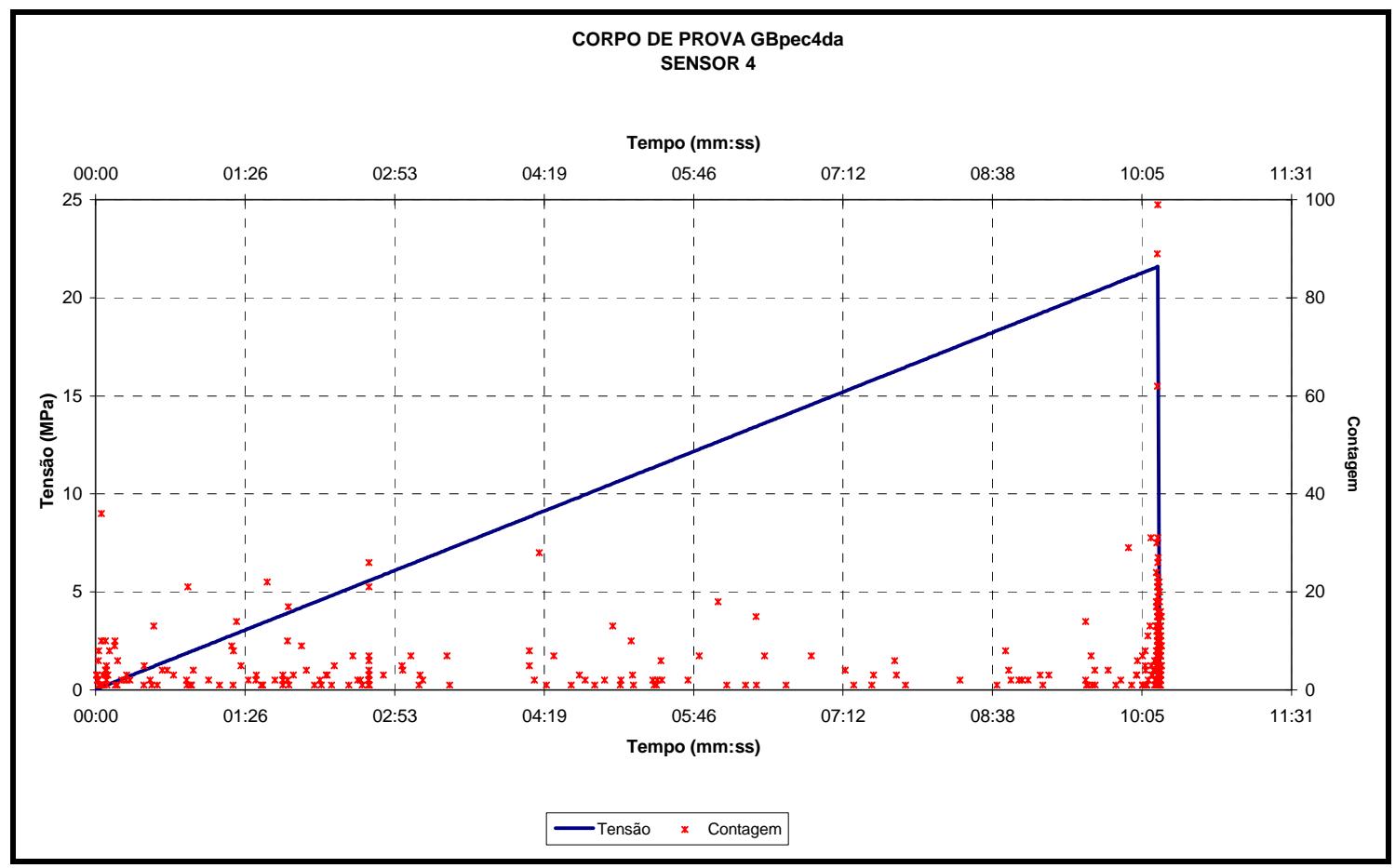

Figura 4.55 Detalhe do gráfico Tensão e contagem versus tempo para recarregamento no ensaio do corpo de prova GBpec4da (corpo de prova submetido anteriormente a dois ensaios de carregamento e descarregamento antes e após o pico de resistência) 
4. RESULTADOS E DISCUSSÃO

4.1. Ensaios de compressão uniaxial com uso da técnica de emissão acústica..... 117

4.2. Ensaios de compressão uniaxial com ciclos variáveis de carregamento antes do pico de resistência com técnica de emissão acústica.

4.3. Ensaios de compressão uniaxial com ciclos variáveis de carregamento antes e após o pico de resistência

4.4. Ensaios de fluência de curta e longa duração

4.5. Comportamento Acústico do Gipsito Bandado após os Ensaios de Fluência ......

4.6. Ensaios de fluência de longa duração com dois ciclos de carregamento e descarregamento sucessivos e posterior ciclo crescente de carga

4.7. Ensaios especiais de fluência de curta duração com ciclos de acréscimos de carregamento anteriores e posteriores ao descarregamento.

4.8. Ensaio especial de compressão uniaxial com ciclos variáveis de carregamento antes e após o pico de resistência (Complementação do tipo CVIII) .... 188

Figura 4.1 Tensão e contagem versus tempo dos eventos de emissão acústica do ensaio de compressão uniaxial no corpo de prova GBEA2 (controle de deslocamento do prato e carregamento perpendicular às camadas)

Figura 4.2 Tensão e energia absoluta versus tempo dos eventos de emissão acústica do ensaio de compressão uniaxial no corpo de prova GBEA2 (controle de deslocamento do prato e carregamento perpendicular às camadas)

Figura 4.3 Tensão e contagem versus tempo dos eventos de emissão acústica no sensor 4 (freqüências intermediárias de 100 a $400 \mathrm{kHz}$ ) do ensaio de compressão uniaxial no corpo de prova GBEA18 (controle de força e carregamento perpendicular às camadas).

Figura 4.4 Tensão e energia absoluta versus tempo dos eventos de emissão acústica no sensor 4 (freqüências intermediárias de 100 a $400 \mathrm{kHz}$ ) do ensaio de compressão uniaxial no corpo de prova GBEA18 (controle de força e carregamento perpendicular às camadas) 
Figura 4.5 Tensão e energia absoluta acumulada versus tempo dos eventos de emissão acústica do ensaio de compressão uniaxial no corpo de prova GBEA2 (controle de deslocamento do prato e carregamento perpendicular às camadas)

Figura 4.6 Tensão e energia absoluta acumulada versus tempo dos eventos de emissão acústica no sensor 4 (freqüências intermediárias de 100 a $400 \mathrm{kHz}$ ) do ensaio de compressão uniaxial no corpo de prova GBEA18 (controle de força e carregamento perpendicular às camadas)

Figura 4.7 Energia absoluta acumulada dos eventos de emissão acústica como função da tensão aplicada durante o carregamento do corpo de prova GBEA2 (carregamento perpendicular às camadas).

Figura 4.8 Geometria do corpo de prova utilizado por Ganne, Vervoort e Wevers..... 128

Figura 4.9 Ensaio de compressão simples no corpo de prova GBEA17 - (a): escala normal; (b): ampliação do eixo de contagem acumulada. O sensor 3 detecta freqüências baixas (de 20 a $100 \mathrm{kHz}$ ) e o sensor 4 detecta freqüências intermediárias (de 100 a $400 \mathrm{kHz}$ )

Figura 4.10 Ensaio de compressão simples no corpo de prova GBEA18 - (a): escala normal; (b): ampliação do eixo de contagem acumulada. O sensor 3 detecta freqüências baixas (de 20 a $100 \mathrm{kHz}$ ) e o sensor 4 detecta freqüências intermediárias (de 100 a 400 kHz)

Figura 4.11 Ensaio de compressão simples no corpo de prova GBEA19 - (a): escala normal; (b): ampliação do eixo de contagem acumulada. O sensor 3 detecta freqüências baixas (de 20 a $100 \mathrm{kHz}$ ) e o sensor 4 detecta freqüências intermediárias (de 100 a $400 \mathrm{kHz}$ )

Figura 4.12 Ensaio de compressão simples no corpo de prova GBEA20 - (a): escala normal; (b): ampliação do eixo de contagem acumulada. O sensor 3 detecta freqüências baixas (de 20 a $100 \mathrm{kHz}$ ) e o sensor 4 detecta freqüências intermediárias (de 100 a $400 \mathrm{kHz}$ )

Figura 4.13 Curva tensão versus deformações axial, radial e volumétrica do corpo de prova GBEA10 submetido a 5 ciclos de carregamento e descarregamento (carregamento perpendicular às camadas). 
Figura 4.14 Energia absoluta acumulada dos eventos de emissão acústica como função da tensão aplicada durante o carregamento e descarregamento do corpo de prova GBEA5 antes do pico de resistência (carregamento paralelo às camadas)

Figura 4.15 Tensão e energia absoluta versus tempo do corpo de prova GBEA5 submetido a ciclos variáveis de carregamento antes do pico de resistência (carregamento paralelo às camadas)

Figura 4.16 Tensão e energia absoluta acumulada versus tempo do corpo de prova GBEA5 submetido a ciclos variáveis de carregamento antes do pico de resistência (carregamento paralelo às camadas)

Figura 4.17 Tensão e energia absoluta acumulada versus tempo dos sensores 1, 2 e 3 no corpo de prova GBEA12 submetido a ciclos variáveis de carregamento antes e após o pico de resistência (carregamento perpendicular às camadas)

Figura 4.18 Tensão e energia absoluta acumulada versus tempo dos sensores 4, 5 e 6 no corpo de prova GBEA12 submetido a ciclos variáveis de carregamento antes e após o pico de resistência (carregamento perpendicular às camadas).

Figura 4.19 Tensão e contagem cada 30 segundos versus tempo dos eventos de emissão acústica no sensor 4 (freqüências intermediárias de 100 a $400 \mathrm{kHz}$ ) do ensaio de fluência de curta duração (a) No corpo de prova GBflu8MTS (49 horas) e (b) No corpo de prova GBflu9MTS (64 horas)

Figura 4.20 Tensão e contagem cada 30 segundos versus tempo dos eventos de emissão acústica no sensor 2 (freqüências intermediárias de 100 a $400 \mathrm{kHz}$ ) do ensaio de fluência de longa duração (274 horas) (a) No corpo de prova GBfluencia11 e (b) No corpo de prova GBfluencia13

Figura 4.21 Deformação axial e contagem acumulada versus tempo dos eventos de emissão acústica no sensor 4 (freqüências intermediárias de 100 a 400 kHz) do ensaio de fluência de curta duração. (a) No corpo de prova GBflu8MTS (49 horas) e (b) No corpo de prova GBflu9MTS (64 horas)

Figura 4.22 Deformação axial e contagem acumulada versus tempo dos eventos de emissão acústica no sensor 2 (freqüências intermediárias de 100 a 400 kHz) do ensaio de fluência de longa duração (274 horas). (a) No corpo de prova GBfluencia11 e (b) No corpo de prova GBfluencia13 
Figura 4.23 Deformação axial versus contagem acumulada dos eventos de emissão acústica no sensor 4 (freqüências intermediárias de 100 a $400 \mathrm{kHz}$ ) do ensaio de fluência de curta duração. (a) No corpo de prova GBflu8MTS (49 horas) e (b) No corpo de prova GBflu9MTS (64 horas). Observe-se a relação linear que existe entre a deformação axial e a contagem acumulada .....

Figura 4.24 Deformação axial versus contagem acumulada dos eventos de emissão acústica no sensor 4 (freqüências intermediárias de 100 a $400 \mathrm{kHz}$ ) do ensaio de fluência de longa duração (274 horas). (a) No corpo de prova GBfluencia11 e (b) No corpo de prova GBfluencia13. Observe-se a relação linear que existe entre a deformação axial e a contagem acumulada

Figura 4.25 Relação I1/(I1+H1) e deformação axial vs tempo em janelas de 30 segundos, onde: I1 numero de contagens no sensor 3 (freqüências baixas de 20 a $100 \mathrm{kHz}$ ) e $\mathrm{H} 1$ numero de contagens no sensor 4 (freqüências intermediárias de 100 a $400 \mathrm{kHz}$ ) do ensaio de fluência de curta duração. (a) No corpo de prova GBflu8MTS (49 horas) (b) No corpo de prova GBflu9MTS (64 horas).....

Figura 4.26 Relação I1/(I1+H1) e deformação axial versus tempo em janelas de 30 segundos, onde: I1 numero de contagens no sensor 1 (freqüências baixas de 20 a $100 \mathrm{kHz}$ ) e $\mathrm{H} 1$ numero de contagens no sensor 2 (freqüências intermediárias de 100 a $400 \mathrm{kHz}$ ) do ensaio de fluência de longa duração (274 horas). (a) No corpo de prova GBfluencia11 e (b) No corpo de prova GBfluencia13

Figura 4.27 Emissão acústica indicativa de microfissuramento no sensor 4 (freqüências intermediárias de 100 a $400 \mathrm{kHz}$ ) em ensaios de fluência de curta duração. (a) No corpo de prova GBflu10MTS (40 horas). (b) No corpo de prova GBflu12MTS (23 horas).

Figura 4.28 Emissão acústica indicativa de microfissuramento no sensor 2 (freqüências intermediárias de 100 a $400 \mathrm{kHz}$ ) em ensaios de fluência de longa duração (274 horas). (a) No corpo de prova GBfluencia12. (b) No corpo de prova GBfluencia14

Figura 4.29 Tensão e contagem acumulada versus tempo para recarregamento no sensor 4 (freqüências intermediárias de 100 a $400 \mathrm{kHz}$ ) - (a) Ensaio GBfluencia6. (b) Ensaio GBfluencia8 (corpos de prova submetidos anteriormente à fluência de longa duração de 55 dias) 
Figura 4.30 Tensão e contagem acumulada versus tempo para recarregamento no sensor 4 (freqüências intermediárias de 100 a $400 \mathrm{kHz}$ ) - (a) Ensaio GBfluencia9. (b) Ensaio GBfluencia10 (corpos de prova submetidos anteriormente à fluência de longa duração de 45 dias)

Figura 4.31 Módulo de elasticidade versus número de ciclo de carregamento ou descarregamento dos corpos de prova GBEAF1 e GBEAF2 (carregamento paralelo às camadas) nos ensaios de fluência de longa duração (150 dias)

Figura 4.32 Módulo de elasticidade versus número de ciclo de carregamento ou descarregamento dos corpos de prova GBEAF1 e GBEAF3 (carregamento paralelo às camadas) nos ensaios de fluência de longa duração (150 dias)

Figura 4.33 Módulo de elasticidade versus número de ciclo de carregamento ou descarregamento dos corpos de prova GBEAF4 e GBEAF5 (carregamento perpendicular às camadas) nos ensaios de fluência de longa duração (150 dias).

Figura 4.34 Evolução dos módulos de elasticidade nos carregamentos dos corpos de prova versus tensão aplicada nos ensaios de fluência de longa duração (150 dias)

Figura 4.35 Tensão e contagem versus tempo dos eventos de emissão acústica do ensaio de fluência de longa duração no corpo de prova GBEAF4. (a) Segundo carregamento e (b) Terceiro carregamento

Figura 4.36 Deformação axial e contagem acumulada versus tempo dos eventos de emissão acústica do ensaio de fluência de longa duração no corpo de prova GBEAF4. (a) Segundo carregamento e (b) Terceiro carregamento

Figura 4.37 Deformação axial versus contagem acumulada dos eventos de emissão acústica do ensaio de fluência de longa duração no corpo de prova GBEAF4. (a) Segundo carregamento e (b) Terceiro carregamento

Figura 4.38 Módulos de elasticidade (estático e na fase cíclica) versus tempo no corpo de prova GBEA14 (carregamento perpendicular às camadas), com ciclos de acréscimos de carregamento anteriores e posteriores ao descarregamento de freqüência $0,25 \mathrm{~Hz}(1,14 \mathrm{MPa} / \mathrm{s})$

Figura 4.39 Módulos de elasticidade (estático e na fase cíclica) versus tempo no corpo de prova GBEA25 (carregamento paralelo às camadas), com ciclos de 
acréscimos de carregamento anteriores e posteriores ao descarregamento de freqüência $0,025 \mathrm{~Hz}(6,82 \mathrm{MPa} / \mathrm{min})$

Figura 4.40 Módulos de elasticidade (estático e na fase cíclica) versus tempo no corpo de prova GBEA24 (carregamento $45^{\circ}$ com camadas), com ciclos de acréscimos de carregamento anteriores e posteriores ao descarregamento de freqüência $0,004 \mathrm{~Hz}(1,14 \mathrm{MPa} / \mathrm{min})$

Figura 4.41 Tensão e contagem versus tempo dos eventos de emissão acústica no sensor 2 (freqüências intermediárias de 100 a $400 \mathrm{kHz}$ ) do corpo de prova GBEA25 (carregamento paralelo às camadas).

Figura 4.42 Tensão e contagem versus tempo dos eventos acústicos no primeiro ciclo de acréscimo de carregamento anterior ao descarregamento correspondente ao corpo de prova GBEA25 com freqüência de $0,025 \mathrm{~Hz}(6,82 \mathrm{MPa} / \mathrm{min})$.

Figura 4.43 Tensão e contagem versus tempo dos eventos acústicos no segundo ciclo de acréscimo de carregamento anterior ao descarregamento correspondente ao corpo de prova GBEA25 com freqüência de $0,025 \mathrm{~Hz}(6,82 \mathrm{MPa} / \mathrm{min})$.

Figura 4.44 Tensão e contagem versus tempo dos eventos acústicos no terceiro ciclo de acréscimo de carregamento anterior ao descarregamento correspondente ao corpo de prova GBEA25 com freqüência de $0,025 \mathrm{~Hz}(6,82 \mathrm{MPa} / \mathrm{min})$.

Figura 4.45 Tensão e contagem versus tempo dos eventos de emissão acústica no sensor 2 (freqüências intermediárias de 100 a $400 \mathrm{kHz}$ ) do corpo de prova GBEA24 (carregamento $45^{\circ}$ com camadas)

Figura 4.46 Tensão e contagem versus tempo dos eventos acústicos no primeiro ciclo de acréscimo de carregamento anterior ao descarregamento correspondente ao corpo de prova GBEA24 com freqüência de $0,004 \mathrm{~Hz}(1,14 \mathrm{MPa} / \mathrm{min})$.

Figura 4.47 Tensão e contagem versus tempo dos eventos acústicos no segundo ciclo de acréscimo de carregamento anterior ao descarregamento correspondente ao corpo de prova GBEA24 com freqüência de $0,004 \mathrm{~Hz}(1,14 \mathrm{MPa} / \mathrm{min})$.

Figura 4.48 Tensão e contagem versus tempo dos eventos de emissão acústica no sensor 2 (freqüências intermediárias de 100 a $400 \mathrm{kHz}$ ) do corpo de prova GBEA14 (perpendicular às camadas). 
Figura 4.49 Tensão e contagem versus tempo dos eventos acústicos no primeiro ciclo de acréscimo de carregamento anterior ao descarregamento correspondente ao corpo de prova GBEA14 com freqüência de $0,25 \mathrm{~Hz}(1,14 \mathrm{MPa} / \mathrm{s})$

Figura 4.50 Tensão e contagem versus tempo dos eventos acústicos no segundo ciclo de acréscimo de carregamento anterior ao descarregamento correspondente ao corpo de prova GBEA14 com freqüência de $0,25 \mathrm{~Hz}(1,14 \mathrm{MPa} / \mathrm{s})$

Figura 4.51 Módulo de elasticidade e relação entre a deformação radial e deformação axial versus tempo do ensaio de carregamento e descarregamento antes e após o pico de resistência no corpo de prova GBpec4da (Primeiro ensaio)..... 189

Figura 4.52 Módulo de elasticidade e relação entre a deformação radial e a deformação axial versus tempo do ensaio de carregamento e descarregamento antes e após o pico de resistência no corpo de prova GBpec4da (Segundo ensaio)..... 189

Figura 4.53 Tensão e contagem versus tempo dos eventos de emissão acústica no sensor 1 (freqüências intermediárias de 100 a $400 \mathrm{kHz}$ ) do ensaio de carregamento e descarregamento antes e após o pico de resistência no corpo de prova GBpec4da (Primeiro ensaio)

Figura 4.54 Tensão e contagem versus tempo dos eventos de emissão acústica no sensor 1 (freqüências intermediárias de 100 a $400 \mathrm{kHz}$ ) do ensaio de carregamento e descarregamento antes e após o pico de resistência no corpo de prova GBpec4da (Segundo ensaio)

Figura 4.55 Detalhe do gráfico Tensão e contagem versus tempo para recarregamento no ensaio do corpo de prova GBpec4da (corpo de prova submetido anteriormente a dois ensaios de carregamento e descarregamento antes e após o pico de resistência) 
Tabela 4.1 Resultados do ensaio de compressão uniaxial com controle de deslocamento do prato de $0,03 \mathrm{~mm} / \mathrm{min}$

Tabela 4.2 Resultados do ensaio de compressão uniaxial com controle de força de $4,50 \mathrm{kN} / \mathrm{min}$

Tabela 4.3 Níveis de tensão no início do registro de eventos de emissão acústica (fae), na ocorrência e no crescimento das fissuras intergranulares (ie) e resistência pico $\left(\sigma_{\mathrm{c}}\right)$ dos corpos de prova com controle de deslocamento do prato. Entre parêntesis, a percentagem em relação à resistência pico $\left(\sigma_{c}\right)$

Tabela 4.4 Nível de tensão no início do fissuramento $\left(\sigma_{\mathrm{ci}}\right)$, tensão de dano por fissuramento $\left(\sigma_{\mathrm{cd}}\right)$ e a resistência pico $\left(\sigma_{\mathrm{c}}\right)$ dos corpos de prova com controle do deslocamento do prato.

Tabela 4.5 Níveis de tensão no início do registro de eventos de emissão acústica (fae), na ocorrência e no crescimento das fissuras intergranulares (ie) e resistência pico $\left(\sigma_{\mathrm{c}}\right)$ dos corpos de prova com controle de força. Entre parêntesis, a percentagem em relação à resistência pico $\left(\sigma_{\mathrm{c}}\right)$.

Tabela 4.6 Nível de tensão no início do fissuramento $\left(\sigma_{\mathrm{ci}}\right)$, tensão de dano por fissuramento $\left(\sigma_{\mathrm{cd}}\right)$ e a resistência pico $\left(\sigma_{\mathrm{c}}\right)$ dos corpos de prova com controle de força

Tabela 4.7 Níveis de tensão alcançados nos ciclos de carregamento e descarregamento para os corpos de prova GBEA5 e GBEA10.

Tabela 4.8 Níveis de tensão no inicio do registro de emissão acústica (fae), na ocorrência e no crescimento das fissuras intergranulares (ie) e resistência pico dos corpos de prova GBEA5 e GBEA10

Tabela 4.9 Níveis de tensão alcançados nos ciclos de carregamento e descarregamento para os corpos de prova estudados, indicando a condição de carregamento e se foi realizado antes ou após o pico de resistência

Tabela 4.10 Níveis de tensão no inicio do registro de eventos de emissão acústica (fae), na ocorrência e no crescimento das fissuras intergranulares (ie) e resistência pico dos corpos de prova 
Tabela 4.12 Resultados dos ensaios de fluência de longa duração

Tabela 4.13 Resultados dos ensaios de fluência de longa duração e que foram carregados depois até a ruptura

Tabela 4.14 Resultados das médias da resistência à compressão uniaxial $\left(\bar{\sigma}_{c}\right)$, resistência pico depois do ensaio de fluência de curta duração $\left(\bar{\sigma}_{c s}\right)$ e resistência pico depois do ensaio de fluência de longa duração $\left(\bar{\sigma}_{c l}\right)$

Tabela 4.15 Características dos ensaios de fluência de longa duração com carregamento na direção paralela às camadas e medições de emissão acústica com um sensor.....

Tabela 4.16 Características dos ensaios de fluência de longa duração com carregamento na direção perpendicular às camadas e medições de emissão acústica com um sensor

Tabela 4.17 Resultados de módulos de elasticidade na fase cíclica nos ciclos de carregamento anteriores e posteriores ao descarregamento completo no corpo de prova GBEA14 (perpendicular às camadas)

Tabela 4.18 Resultados de módulos de elasticidade na fase cíclica nos ciclos de carregamento anteriores e posteriores ao descarregamento completo no corpo de prova GBEA25 (paralelo às camadas).

Tabela 4.19 Resultados de módulos de elasticidade na fase cíclica nos ciclos de carregamento anteriores e posteriores ao descarregamento completo no corpo de prova GBEA24 (45 com camadas) 


\section{CONCLUSÕES E SUGESTÕES PARA PESQUISAS \\ FUTURAS}

Nesta tese, foram exploradas as potencialidades da técnica de emissão acústica para identificar os mecanismos físicos de deformação durante a fluência, correlacionando os níveis de tensões associados ao desenvolvimento das microfissuras com a liberação de energia associada a estes mecanismos.

Importantes resultados experimentais foram obtidos e apresentados com a finalidade de sustentar a conclusão de que é o microfissuramento o mecanismo físico fundamental da fluência nos gipsitos bandados da Formação Santana (Brasil) independentemente da direção de carregamento em relação às camadas.

Encontrou-se que o material, tendo sofrido microfissuramento, passa por um processo de cicatrização durante a fluência de longo prazo devido a fenômenos de difusão e dissolução por pressão. 


\subsection{Conclusões}

$\underline{\text { Quanto à rocha estudada }}$

As análises petrográficas mostraram uma orientação preferencial do crescimento dos cristais na direção perpendicular às camadas do gipsito bandado ensaiado. Esta orientação preferencial é devida, provavelmente, a esforços deformacionais tectônicos horizontais que causaram uma compressão da rocha na direção paralela às camadas.

A resistência à compressão uniaxial é maior nos corpos de prova submetidos a carregamento na direção paralela às camadas que nos corpos de prova submetido a carregamento na direção perpendicular às camadas (contrariamente ao esperado) devido à orientação preferencial do crescimento dos cristais.

O fenômeno de microfissuramento no gipsito bandado foi detectado por eventos de emissão acústica de freqüência entre 100 e 400 kHz (freqüências intermediárias), conforme os ensaios de compressão uniaxial, onde se conhece o padrão de microfissuramento. Freqüências semelhantes já foram determinadas para outras rochas, mas não podiam ser tomadas “a priori” como válidas para o gipsito bandado da Formação Santana.

Quanto aos registros dos eventos de emissão acústica nos ensaios de compressão $\underline{\text { uniaxial }}$

A máxima contagem e a máxima energia absoluta dos eventos de emissão acústica não coincidem nos ensaios com controle do deslocamento. A máxima 
contagem ocorre após o pico de resistência, enquanto a máxima energia absoluta ocorre antes do pico de resistência.

Nos ensaios com controle de força, a máxima contagem e a máxima energia absoluta dos eventos de emissão acústica coincidem com o pico de resistência dos corpos de prova.

\section{Quanto ao efeito Kaiser}

O efeito Kaiser é bem pronunciado antes e após o início da dilatância e na região após o pico na parte descendente da curva tensão-deformação.

O efeito Kaiser se manifesta de modo inequívoco para solicitações rápidas.

Após ensaios de fluência de longa duração, o efeito Kaiser não mais se manifesta. Ou seja, corpos de prova submetidos mais uma vez a compressão uniaxial após o descarregamento, voltam a apresentar eventos de emissão acústica e, portanto, geração de novas microfissuras. Isto só pode ser explicado por um processo de cicatrização das microfissuras durante a fluência de longo prazo.

\section{Quanto aos ensaios de fluência}

A deformação axial obedece a uma relação linear com o número acumulado de contagens de eventos da freqüência que denota microfissuramento na fluência secundária. Isto prova ser o microfissuramento o mecanismo predominante da fluência.

Os resultados obtidos nos gráficos Relação I1/(I1+H1) (onde: I1 número de contagens no sensor de freqüências baixas e H1 número de contagens no sensor de freqüências intermediárias do ensaio de fluência de longa duração) versus tempo e 
deformação axial versus tempo em janelas de 30 segundos indicam que a deformação de fluência é devida ao microfissuramento dentro da rocha, e não ao fechamento ou abertura das fissuras preexistentes.

Estas conclusões foram obtidas a partir dos ensaios de fluência de curta, longa duração com níveis de tensões superiores aos 75\% da tensão de ruptura e longa duração com ciclos de carregamento e descarregamento sucessivos.

Pode-se afirmar com estas conclusões que o microfissuramento é o mecanismo físico fundamental da fluência nos gipsitos bandados da Formação Santana, independentemente da direção de carregamento em relação às camadas. Dissolução por pressão, responsável pela recicatrização também ocorre. Como o microfissuramento decai com o tempo, a dissolução por pressão passa a prevalecer, prevalecendo a recristalização.

Quando a duração dos ensaios permite, começam a ocorrer fenômenos de difusão e dissolução por pressão que inibem e cicatrizam não apenas o microfissuramento gerado no carregamento do ensaio, mas até o microfissuramento natural ou decorrente da preparação do corpo de prova, anterior, portanto, ao carregamento.

A cicatrização por recristalização decorrente de fenômenos físico-químicos apresentou outras manifestações: não diminuição do módulo de elasticidade e da velocidade de propagação de ondas, medidos após ensaios de fluência, em comparação aos valores anteriores ao ensaio; e até um acréscimo da resistência à compressão simples, também após a fluência. O comportamento é o mesmo nas duas direções, mas a cicatrização que produz esse certo "endurecimento" é mais evidente quando o carregamento é perpendicular às camadas, pelo aumento do módulo de elasticidade nessa direção. 
O descarregamento provoca progresso do microfissuramento. Isto foi constatado tanto pela emissão acústica quanto pela comparação de módulos de elasticidade medidos após fluência em ciclos de carregamento antes e depois do descarregamento completo. Observou-se decréscimo do módulo após o descarregamento, indicativo de dano e de progresso de microfissuramento. Isto foi observado tanto com carregamento paralelo quanto perpendicular às camadas.

\subsection{Sugestões para pesquisas futuras}

O estudo dos processos envolvidos na fluência em rochas evaporíticas sulfáticas (gipsito, no presente caso) é, como se pode verificar, muito recente e incipiente. Existem estudos mais avançados e de maior quantidade em rochas de comportamento frágil. A definitiva elucidação dos mecanismos que efetivamente atuam nos gipsitos vai requer um volume muito grande de pesquisa experimental.

Alguns problemas a resolver surgiram com esta pesquisa. Assim, algumas sugestões para pesquisas futuras são apresentadas na seqüência:

a. Estudo dos espectros de freqüências nos eventos de emissão acústica mediante técnicas atuais, tais como inteligência artificial, redes neurais, transformadas de wavelet.

b. Realizar ensaios de compressão triaxiais em diferentes níveis de tensão.

c. Estudar a influência da temperatura no comportamento dependente do tempo dos gipsitos.

d. Analisar as condições termodinâmicas que favorecem a ocorrência da cicatrização observada nesta tese. 
5. CONCLUSÕES E SUGESTÕES PARA PESQUISAS FUTURAS................ 203

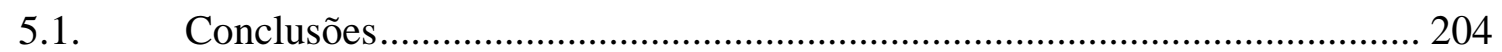

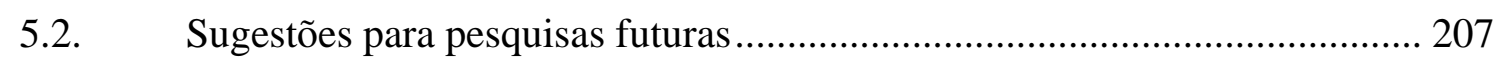




\section{REFERÊNCIAS}

ADAMS, A.E.; MACKENZIE, W.S.; GUILFORD, C. (1984). Atlas of sedimentary rocks under the microscope. Harlow: Longman.

AMERICAN SOCIETY FOR TESTING AND MATERIALS (1995). D 2938-95 (Reapproved 2002) - Standard test method for unconfined compressive strength of intact rock core specimens. In: ANNUAL book at ASTM standards. Philadelphia: ASTM. v.04.08, Section 4.

. (1999). D 4405-93 (Reapproved 1998) - Standard test method for creep of cylindrical soft rock core specimens in uniaxial compression. In: ANNUAL book at ASTM standards. Philadelphia: ASTM. v.04.08, Section 4.

(2002). D 4543-01 - Standard practices for preparing rock core specimens and determining dimensional and shape tolerances. In: ANNUAL book at ASTM standards. Philadelphia: ASTM. v.04.08, Section 4.

AMITRANO, D. (1999). Emission acoustique dês roches et endommagement. Approches expérimentale et numérique: application à la sismicité minière. 1256p. PhD.Thèse de Docteur. San Martin D’Hères: L’Universite de Grenoble, 1999.

ASSINE, M.L. (1992). Análise estratigráfica da Bacia do Araripe, Nordeste do Brasil. Revista Brasileira de Geociências, São Paulo, v.22, n.3, p.289-300.

ASSOCIAÇÃO BRASILEIRA DE NORMAS TÉCNICAS (2004). NBR 15181 Ensaios não destrutivos - emissão acústica - terminologia. Rio de Janeiro.

AUBERTIN, M.; GILL, D. (1993). Elastoplastic modeling for the ductile behavior of polycrystalline sodium chloride with SUIVIC. International Journal of Plasticity, Oxford, v.9, n.4, p.479-505.

AUVRAY, C.H.; HOMAND, F.; HOXHA, D. (2008). The Influence of relative humidity on the rate of convergence in an underground gypsum mine. International Journal of Rock Mechanics and Mining Sciences, Oxford, v.45, n.8, p.1454-1468, Dec.

BADENS, E. et al. (1999). Relation between young's modulus of set plaster and complete wetting of grain boundaries by water. Colloids and Surfaces A: physiochemical and engineering aspects, Amsterdam, v.156, n.1/3, p.373-379.

BARR, S.P.; HUNT, D.P. (1999). Anelastic strain recovery and the Kaiser effect retention span in the Carnmenellis Granite, U.K. Rock Mechanics and Rock Engineering, Wien, v.32, n.3, p.169-193, July.

BAUMANN, W. (1984). Rheologische untersuchungen and gips. Eclogae Geological Helvetiae, Basel, v.77, p.301-325. 
BIENIAWSKI, Z.T. (1967). Mechanism of brittle fracture of rock: part I - theory of the fracture process. International Journal of Rock Mechanics and Mining Sciences \& Geomechanics Abstracts, Oxford, v.4, n.4, p.395-404, Oct.

BLUM, W. (2001). Creep of crystalline materials: experimental basis, mechanisms and models. Materials Science and Engineering: A, Lausanne, v.319/321, p.8-15, Dec.

CARLSON, S.R. et al. (1998). Pore pressure transients, strain and acoustic emission activity during creep in India granite. International Journal of Rock Mechanics and Mining Sciences, Oxford, v.35, n.2, p.135-146, Mar.

CAROZZI, A. (1993). Sedimentary petrography. Englewood Cliffs: PTR Prentice Hall.

CARVALHO, F.C.S.; LABUZ, J.F. (2002). Moment tensors of acoustic emissions in shear faulting under plane-strain compression. Tectonophysics, Amsterdam, v.356, n.1/3, p.199-211, Oct.

CELESTINO, T.B.; BORTOLUCCI, A.A.; NOBREGA, C.A. (1995). Determination of rock fracture toughness under creep and fatigue. In: SYMPOSIUM ON ROCK MECHANICS, 35., 1995, Reno. Proceedings... Rotterdam: A.A.Balkema. v.1, p.147152.

CELESTINO, T. et al. (2001). Fracture mechanics of marble using a splitting tension test. Journal of Materials in Civil Engineering, New York, v.13, n.6, p.407-411, Nov./Dec.

CHANG, S.H.; LEE, C.I. (2004). Estimation of cracking and damage mechanisms in rock under triaxial compression by moment tensor analysis of acoustic emission. International Journal of Rock Mechanics and Mining Sciences, Oxford, v.41, n.7, p.1069-1086, Oct.

CHENGYONG, W. et al. (1990). Study of the fracture process zone in rock by laser speckle interferometry. International Journal of Rock Mechanics and Mining Sciences \& Geomechanics Abstracts, Oxford, v.27, n.1, p.65-69, Feb.

COQUARD, P.; BOISTELLE, R. (1994). Water and solvent effects on the strength of set plaster. International Journal of Rock Mechanics and Mining Sciences \& Geomechanics Abstracts, Oxford, v.31, n.5, p.517-524, Oct.

COX, S.J.D.; MEREDITH, P.G. (1993). Microcrack formation and material softening in rock measured by monitoring by acoustic emission. International Journal of Rock Mechanics and Mining Sciences \& Geomechanics Abstracts, Oxford, v.30, n.1, p.11-24, Feb.

COX, S.J.D.; MEREDITH, P.G.; STUART, C.E. (1991). Microfracturing during brittle rock failure: a model for the Kaiser effect including sub-critical crack growth. In: INTERNATIONAL CONGRESS ON ROCK MECHANICS, 7., 1991, Aachen. Proceedings... Rotterdam: A.A.Balkema. v.1, p.703-707. 
CRACKER, W.E.; SCHILLER, K.K. (1962). Plastic deformation of gypsum. Nature, London, v.193, n.4816, p.672-673, Feb.

CRUDEN, D.M. (1970). A Theory of brittle creep in rock under uniaxial compression. Journal Geophysical Research, Washington, v.75, n.17, p.3431-3442.

DANA, J.D. (1971). Manual of mineralogy. $18^{\text {th }}$ ed. New York: Wiley.

DE MEER, S.; SPIERS, C.J. (1993). Influence of pore fluid salinity on pressure solution creep in gypsum. Tectonophysics, Amsterdam, v.308, n.3, p.311-330, July.

(1995). Creep of wet gypsum aggregates under hydrostatic loading conditions. Tectonophysics, Amsterdam, v.245, n.3/4, p.171-183, May.

DE MEER, S.; SPIERS, C.J.; PEACH, C. (1997). Pressure solution creep in gypsum: evidence for precipitation reaction control. Physics and Chemistry of the Earth, Oxford, v.22, n.1/2, p.33-37.

DIEDERICHS, M.; KAISER, P.; EBERHARDT, E. (2004). Damage initiation and propagation in hard rock during tunneling and the influence of near-face stress rotation. International Journal of Rock Mechanics and Mining Sciences, Oxford, v.41, n.5, p.785-812, July.

EBERHARDT, E. et al. (1997). Changes in acoustic event properties with progressive fracture damage. International Journal of Rock Mechanics and Mining Sciences, Oxford, v.34, n.3/4, p.71e1-71e16, Apr./June.

(1998). Identifying crack initiation and propagation thresholds in brittle rock. Canadian Geotechnical Journal, Ottawa, v.35, n.2, p.222-233, Apr.

EBERHARDT, E.; STEAD, D.; STIMPSON, B. (1999). Quantitying progressive prepeak brittle fracture damage in rock during uniaxial compression. International Journal of Rock Mechanics and Mining Sciences, Oxford, v.36, n.3, p.361-380, Apr.

ESTREIN, Y. (1998). Dislocation theory based constitutive modeling: foundations and applications. Journal of Materials Processing Technology, Amsterdam, v.80/81, p.3339, Aug.

FILIMONOV, Y. et al. (2002). Observation of post-failure Kaiser effect in a plastic rock. Pure Applied Geophysics, Milano, v.159, n.6, p.1321-1331, May.

FINOT, E. et al. (1997). Reactivity of gypsum faces according to the relativity humidity by scanning force microscopy. Surface Science, Amsterdam, v.384, n.1/3, p.201-217, July.

(2000). Investigations of surface forces between gypsum microcrystals in air using atomic force microscopic. Langmuir: the ACS journal of surfaces and colloids, Washington, v.16, n.9, p.4237-4244, May. 
(2001). Correlating surface forces with surface reactivity of gypsum crystals by atomic force microscopy. Comparison with rheological properties of plaster. Solid State Ionics, Amsterdam, v.141/142, p.39-46, May.

GANNE, P.; VERVOORT, A.; WEVERS, M. (2007). Quantification of pre-peak brittle damage: correlation between acoustic emission and observed micro-fraturing. International Journal of Rock Mechanics and Mining Sciences, Oxford, v.44, n.5, p.720-729, July.

GIAMBASTIANI, M. (2005). Comportamento dependente do tempo de rochas sulfáticas de anidrita e gipso. 431p. Tese (Doutorado) - Escola de engenharia de São Carlos, universidade de São Paulo, São Carlos, 2005.

GLASER, S.D.; NELSON, P.P. (1992). Acoustics emissions produced by discrete fracture in rock. Part 2 - kinematics of crack growth during controlled mode I and mode II loading of rock. International Journal of Rock Mechanics and Mining Sciences \& Geomechanics Abstracts, Oxford, v.29, n.3, p.253-265, May.

GRATIER, J.P. (1993). Pressure solution-deposition creep of rocks in the upper crust. Bulletin de la Societe Geologique de France, Paris, v.164, n.2, p.267-287, Mar.

HARDY, H.R. (1981). Applications of acoustic emission techniques to rock and rock structures: a state-of-the-art review. In: SYMPOSIUM ON ACOUSTIC IN GEOTECHNICAL ENGINEERING PRACTICE, 1981, Detroit. Acoustic emissions in geotechnical engineering practice... Philadelphia: ASTM. p.4-92. (ASTM-STP-750).

HARDY, H.R.; TAIOLI, F. (1988). Mechanical waveguides for use in Ae/Ms geotechnical applications. In: YAMAGUCHI, K.; KIMPARA, I.; HIGO, Y. Progress in acoustic emission IV, Kobe: JSNDI. p.292-302.

HEIJNEN, W.M.M.; HARTMAN, P. (1991). Structural morphology of gypsum $\left(\mathrm{CaSO}_{4} \cdot 2 \mathrm{H}_{2} \mathrm{O}\right)$, brushite $\left(\mathrm{CaHPO}_{4} \cdot 2 \mathrm{H}_{2} \mathrm{O}\right)$ and pharmacolite $\left(\mathrm{CaHAsO}_{4} \cdot 2 \mathrm{H}_{2} \mathrm{O}\right)$. Journal of Crystal Growth, Amsterdam, v.108, n.1/2, p.290-300, Jan.

HOEK, E.; BIENIAWSKI, Z.T. (1965). Brittle fracture propagation in rock under compression. International Journal of Fracture Mechanics, Groningen, v.1, n.3, p.137155.

HOLCOMB, D.J. (1978). A Theoretical and experimental investigation of dilatancy; an aspect of nonlinear behavior in rock. PhD. Thesis - University of Colorado, Boulder, 1978.

HOLCOMB, D.J.; MARTIN, R.J. (1985). Determining peak stress history using acoustic emissions. In: SYMPOSIUM ON ROCK MECHANICS, 26., 1985, Rapid city. Proceedings... Rotterdam: A.A.Balkema. v.1, p.715-722.

HOXHA, D.; GIRAUD, A.; HOMAND, F. (2005). Modelling long-term behavior of a natural gypsum rock. Mechanics of Materials, Amsterdam, v.37, n.12, p.1223-1241, Dec. 
HOXHA, D.; HOMAND, F.; AUVRAY, C. (2006). Deformation on natural gypsum rock: mechanism and questions. Engineering Geology, Amsterdam, v.86, n.1, p.1-17, July.

HUNSCHE, U.; HAMPEL, A. (1999). Rock salt - the mechanical properties of the host rock material for a radioactive waste repository. Engineering Geology, Amsterdam, v.52, n.3/4, p.271-291, Apr.

INTERNATIONAL SOCIETY OF ROCK MECHANICS (1978a). Suggested methods for determining tensile strength of rock materials. International Journal of Rock Mechanics and Mining Sciences \& Geomechanics Abstracts, Oxford, v.15. n.3. p.99103, June.

(1978b). Suggested methods for determining sound velocity. International Journal of Rock Mechanics and Mining Sciences \& Geomechanics Abstracts, Oxford, v.15, n.2, p.53-58, Apr.

(1979a). Suggested methods for determining water content, porosity, density, absorption and related properties and swelling and slake durability index properties. International Journal of Rock Mechanics and Mining Sciences \& Geomechanics Abstracts, Oxford, v.16, n.2, p.141-156, Apr.

(1979b). Suggested methods for determining the uniaxial compressive strength and deformability of rock materials. International Journal of Rock Mechanics and Mining Sciences \& Geomechanics Abstracts, Oxford, v.16, n.2, p.135-140, Apr.

. (1999). Draft ISRM suggested method for the complete stress-strain curve for intact rock in uniaxial compression. International Journal of Rock Mechanics and Mining Sciences, Oxford, v.36, n.3, p.279-289, Apr.

JESCHKE, A.A.; VOSBECK, K.; DREYBRODT, W. (2001). Surface controlled dissolution rates of gypsum in aqueous solutions exhibit nonlinear dissolution kinetics. Geochimica et Cosmochimica Acta, New York, v.65, n.1, p.27-34, Jan.

KEMENY, J.; COOK, N.G.W. (1986). Effective moduli, Non-linear deformation and strength of a cracked elastic solid. International Journal of Rock Mechanics and Mining Sciences \& Geomechanic Abstracts, Oxofrd, v.23, n.2, p.107-118, Apr.

KERR, P.F. (1959). Optical mineralogy. New York: Mc Graw-Hill.

KRANZ, R.L.; SCHOLZ, C.H. (1977). Critical dilatant volume of rocks at the onset of terciary creep. Journal of Geophysical Research, Washington, v.82, n.30, p.4893-4898.

LABUZ, J.F.; SHAH, S.; DOWDING, C. (1987). The Fracture process zone in granite: evidence and effect. International Journal of Rock Mechanics and Mining Sciences \& Geomechanic Abstracts, Oxford, v.24, n.4, p.235-246, Aug.

LAVROV, A. (2000). Modeling of non-linear behavior and the Kaiser effect in ductile rocks. EUROCONFERENCE ON ROCK PHYSICS AND ROCK MECHANICS 
(Thermo-Hydro-Mechanical Coupling in Fractured Rocks), 3., 2000, Germany. Proceedings... Germany: University of Bonn. Paper n.12.

. (2001). Kaiser effect observation in brittle rock cyclically loaded with different $\overline{\text { loading }}$ rates. Mechanics of Material, Amsterdam, v.33, n.11, p.669-677, Nov.

(2003). The Kaiser effect in rocks: principles and stress estimation techniques. International Journal of Rock Mechanics and Mining Sciences, Oxford, v.40, n.2, p.151-171, Feb.

LAVROV, A. et al. (2002a). Experimental and numerical study of the Kaiser effect in cyclic Brazilian tests with disk rotation. International Journal of Rock Mechanics and Mining Sciences, Oxford, v.39, n.3, p.287-302, Apr.

. (2002b). Acoustic emission in host-rock material for radioactive waste disposal: comparison between clay and rock salt. Bulletin Engineering Geology and the Environmental, Berlin, v.61, n.4, p.379-387, Nov.

LI, C.; NORDLUND, E. (1993). Assessment of damage in rock using the Kaiser effect of acoustic emission. International Journal of Rock Mechanics and Mining Sciences \& Geomechanic Abstracts, Oxford, v.30, n.7, p.943-946, Dec.

LOCKNER, D.A. et al. (1992). Observations of quasi-static fault growth from acoustic emissions. In: EVANS, B.; WONG, T.F. (Ed.). Fault mechanics and transport properties of rocks: a festschrift in honor of W.F.Brace. New York: Academic. p.1-20.

MANDAL, P.K.; MANDAL, T.K. (2002). Anion water in gypsum $\left(\mathrm{CaSO}_{4} \cdot 2 \mathrm{H}_{2} \mathrm{O}\right)$ and hemihydrate $\left(\mathrm{CaSO}_{4} .1 / 2 \mathrm{H}_{2} \mathrm{O}\right)$. Cement and Concrete Research, Elmsford, v.32, n.2, p.313-316, Feb.

MANSUROV, V.A. (1994). Acoustic emission from failing rock behaviour. Rock Mechanics and Rock Engineering, Wien, v.27, n.3, p.631-646, July.

MANTHEI, G. (2005). Characterization of acoustic emission sources in a rock slat specimen under triaxial compression. Bulletin Seismological Society America, Palo Alto, v.95, n.5, p.1674-1700, Oct.

MARTIN, C.D. (1993). Strength of massive lac du bonnet granite around underground openings. PhD.Thesis - Department of Civil and Geological Engineering, University of Manitoba, Winnipeg, 1993.

(1997). Seventeeth canadian geotechnical colloquium: the effect of cohesion loss and stress path on brittle rock strength. Canadian Geotechnical Journal, Ottawa, v.34, n.5, p.698-725, Oct.

MARTIN, C.D.; CHANDLER, N.A. (1994). The Progressive fracture of lac du bonnet granite. International Journal of Rock Mechanics and Mining Sciences \& Geomechanic Abstracts, Oxford, v.31, n.6, p.643-659, Dec. 
MURRAY, G.E. (1964). Origin and diagenesis of gypsum and anhydrite. Journal of Sedimentary Petrology, Tulsa, v.34, n.3, p.512-523, Sept.

NÓBREGA, C.A. (1994). Comportamento mecânico de um calcário dolomítico e de argamassa submetidos a carregamento cíclico em compressão uniaxial. 224p. Tese (Doutorado) - Escola de Engenharia de São Carlos, Universidade de São Paulo, São Carlos, 1994.

NÓBREGA, C.A.; CELESTINO, T.B. (1995). Discussion: comments on the paper of G.Li; K.H.R. Moelle and J.A.Lewis "Fatigue crack growth in brittle sandstones". International Journal of Rock Mechanics and Mining Sciences \& Geomechanic Abstracts, Oxford, v.32, n.2, p.185, Feb.

OHNAKA, M. (1983). Acoustic emission during creep of brittle rock. International Journal of Rock Mechanics and Mining Sciences \& Geomechanic Abstracts, Oxford, v.20, n.3, p.121-134, June.

OHNAKA, M.; MOGI, K. (1981). Frequency dependence of acoustic emission activity in rocks under incremental, uniaxial compression. Bulletin of the Earthquake Research Institute, Tokyo, v.56, p.67-89.

(1982). Frequency characteristics of acoustic emission in rocks under uniaxial compression and their relation to the fracturing process of fracture. Journal of Geophysical Research, Washington, v.87, n.B5, p.3873-3884.

ORTI CABO, F.; ROSELL ORTIZ, L. (1981). Fábricas cristalinas de la anhidrita nodular y laminada. Acta Geológica Hispánica, Barcelona, v.16, n.4, p.235-255.

PESTMAN, B.J.; VAN MUNSTER, J.G. (1996). An Acoustic emisión study of damage development and stress-memory effects in sandstone. International Journal of Rock Mechanics and Mining Sciences \& Geomechanic Abstracts, Oxford, v.33, n.6, p.585-593, Sept.

PETTIJOHN, F.J. (1980). Rocas sedimentarias. 4.ed. Buenos Aires: E.Universitaria.

PRICE, N.J. (1964). A Study of the time-strain behaviour of coal-measure rocks. International Journal of Rock Mechanics and Mining Sciences \& Geomechanics Abstracts, Oxford, v.1, n.2, p.277-303, Mar.

RE, F.; SCAVIA, C. (1998). Study of scale effects on the deformability modulus of rock by means of a discontinuous model. INTERNATIONAL CONFERENCE ON MECHANICS OF JOINTED AND FAULTED ROCH, 3., 1998, Vienna.

Proceedings... Rotterdam: A.A.Balkema. p.349-353.

RUDAJEV, V.; VILHELM, J.; LOKAJIČEV, T. (2000). Laboratory studies of acoustic emission prior to uniaxial compressive rock failure. International Journal of Rock Mechanics and Mining Sciences, Oxford, v.37, n.4, p.699-704, June.

RUTTER, E.H. (1983). Pressure solution in nature, theory and experiment. Journal of the Geological Society, London, v.140, n.5, p.725-740, Oct. 
SANTOS, J.B.; VARGAS JR., E.A.; BARROSO, E.B. (2004). Ensaios de compressão simples com acompanhamento em tempo real por tomografia computarizada de raios X. In: SIMPÓSIO BRASILEIRO DE JOVENS GEOTÉCNICOS, 2004, São Carlos. Anais... São Carlos: EESC/USP. CD-ROM.

SCAVIA, C. (1995). A Method for the study of crack propagation in rock structures. Geotechnique, London, v.45, n.3, p.447-463.

SCHOLZ, C.H. (1968). Experimental study of the fracturing process in brittle rocks. Journal of Geophysical Research, Washington, v.73, n.4, p.1447-1453.

SENSENY, P.E. et al. (1992). Mechanical behaviour of rock salt: phenomenology and micromechanisms. International Journal of Rock Mechanics and Mining Sciences \& Geomechanic Abstracts, Oxford, v.29, n.4, p.363-378, July.

SIPPLE, E.M. et al. (2001). Microstructural modifications resulting from the dehydration of gysum. Solid State Ionics, Amsterdam, v.141/142, p.447-454, May.

THILL, R.E. (1972). Acoustic method for monitoring failure in rock. In: SYMPOSIUM ON ROCK MECHANICS, 14., 1972, Pennsylvania. Proceedings... Pennsylvania: University Park. p.649-687.

VAN DE STEEN, B.; VERVOOT, A.; SAHIN, K. (2002). Influence of internal structure of crinoidal limestone on fracture paths. Engineering Geology, Amsterdam, v.67, n.1/2, p.109-125, Dec.

VAN DE STEEN, B. et al. (1998). Evaluation of mineral building materials: problems related to resistivity methods. Material and Structure= Matériaux et Construction, Paris, v.31, n.206, p.126-132, Mar.

VEVERKA, J.; RUDAJEV, V.; LOKAJIČEK, T. (2004). Correlation analysis of ultrasound emission foci in loaded granites and migmatities. In: EUROPEAN CONFERENCE ON ACOUSTIC TESTING, 26., 2004, Berlin. Proceedings... Berlin: Deutsche Gesellschaff fur Zerstorungsfreie. CD-ROM.

WALSH, J.B. (1965). The Effect of cracks on the compressibility of rocks. Journal of Geophysical Research, Washington, v.70, n.2, p.381-389.

WAWERSIK, W.R.; FAIRHURST, C.A. (1970). A Study of brittle rock fracture in laboratory compression experiments. International Journal of Rock Mechanics and Mining Sciences \& Geomechanic Abstracts, Oxford, v.7, n.5, p.561-575, Sept.

WILLIAMS, S.C. (1988). The Shear strength of gypsum single crystal on three cleavage planes. Tectonophysics, Amsterdam, v.148, n.1/2, p.163-173, Apr.

YAHYA, O.M.L.; AUBERTIN, M.; JULIEN, M.R. (2000). A Unified representation of the plasticity, creep and relaxation behaviour of rock salt. International Journal of Rock Mechanics and Mining Sciences, Oxford, v.37, n.5, p.787-800, July. 
ZHANG, J. et al. (1990). Pressure-induced microcracking and grain crushing in Berea and Boise sandstones: acoustic emission and quantitative microscopy measurements. Mechanics of Materials, Amsterdam, v.9, n.1, p.1-15, May.

ZIETLOW, W.K.; LABUZ, J.F. (1998). Measurement of the intrinsic process zone in rock using acoustic emission. International Journal of Rock Mechanics and Mining Sciences, Oxford, v.35, n.3, p.291-299, Apr. 


\section{A pêndice 1}

ENSAIOS DE COMPRESSÃO UNIAXIAL COM USO DA TÉCNICA DE EMISSÃO ACÚSTICA 


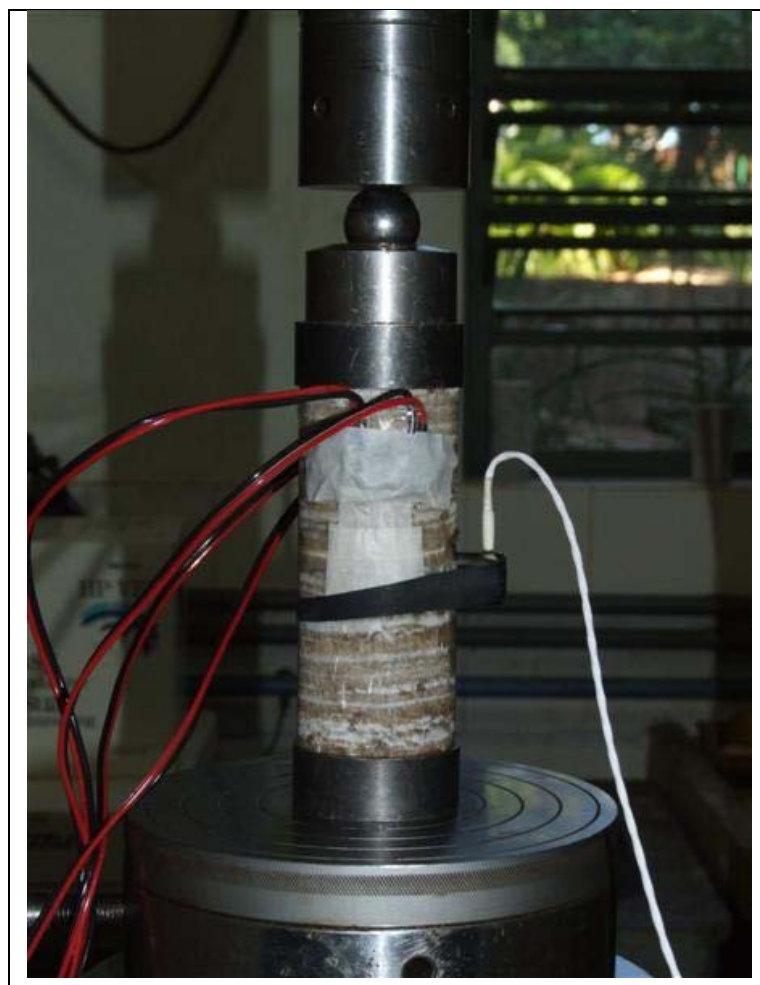

Compressão uniaxial - Corpo de prova GBEA1

Controle: Deslocamento do prato

Condição: Perpendicular às camadas

Taxa: $0,03 \mathrm{~mm} / \mathrm{min}$

Massa específica: $2,30 \mathrm{~g} / \mathrm{cm} 3$

$\sigma_{\mathrm{c}}=25,18 \mathrm{MPa}$

$\mathrm{E}=25,98 \mathrm{GPa}$

$v=0,24$

Foto do corpo de prova GBEA1 antes do ensaio, condição, controle e taxa de carregamento e resultados do ensaio

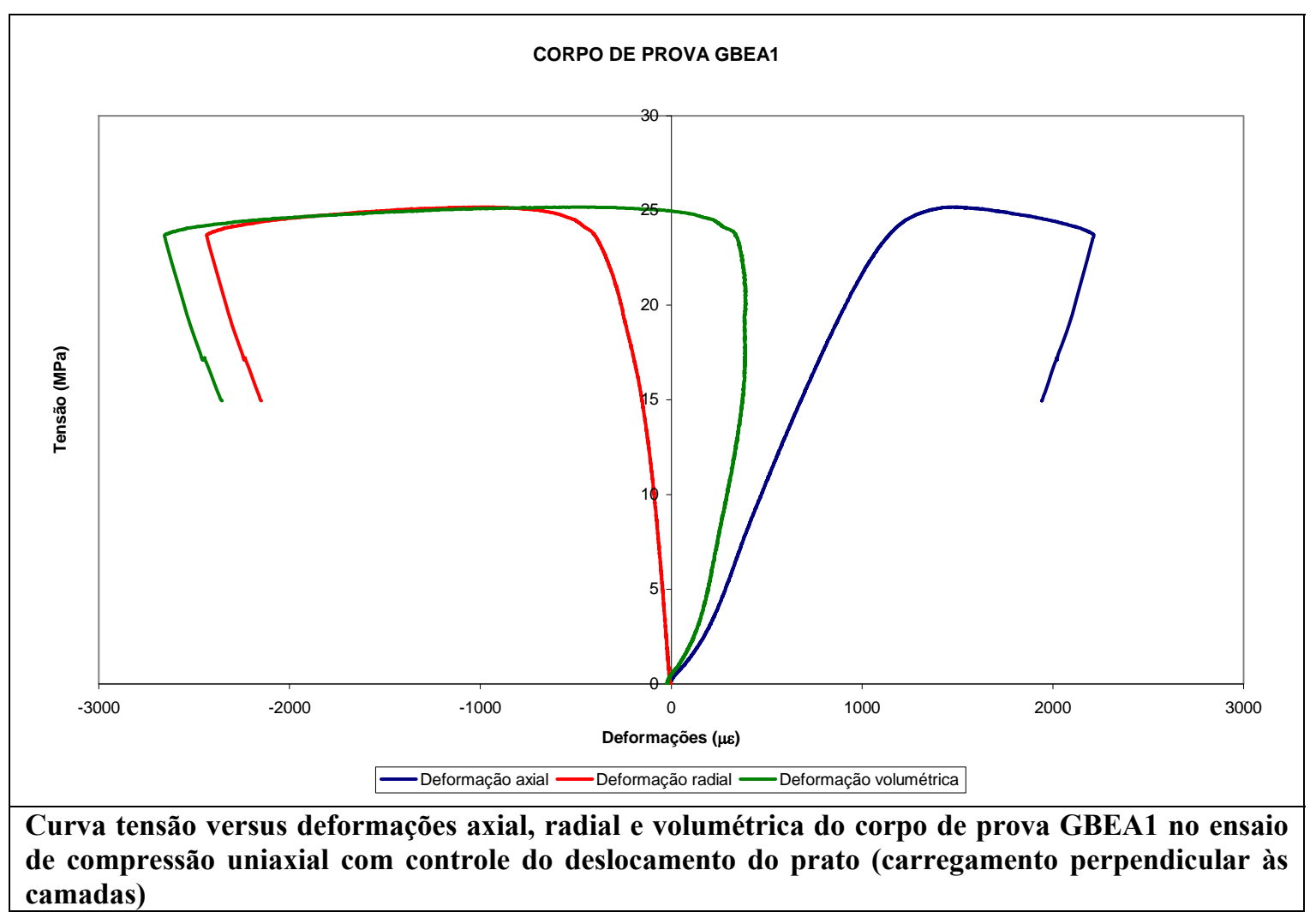



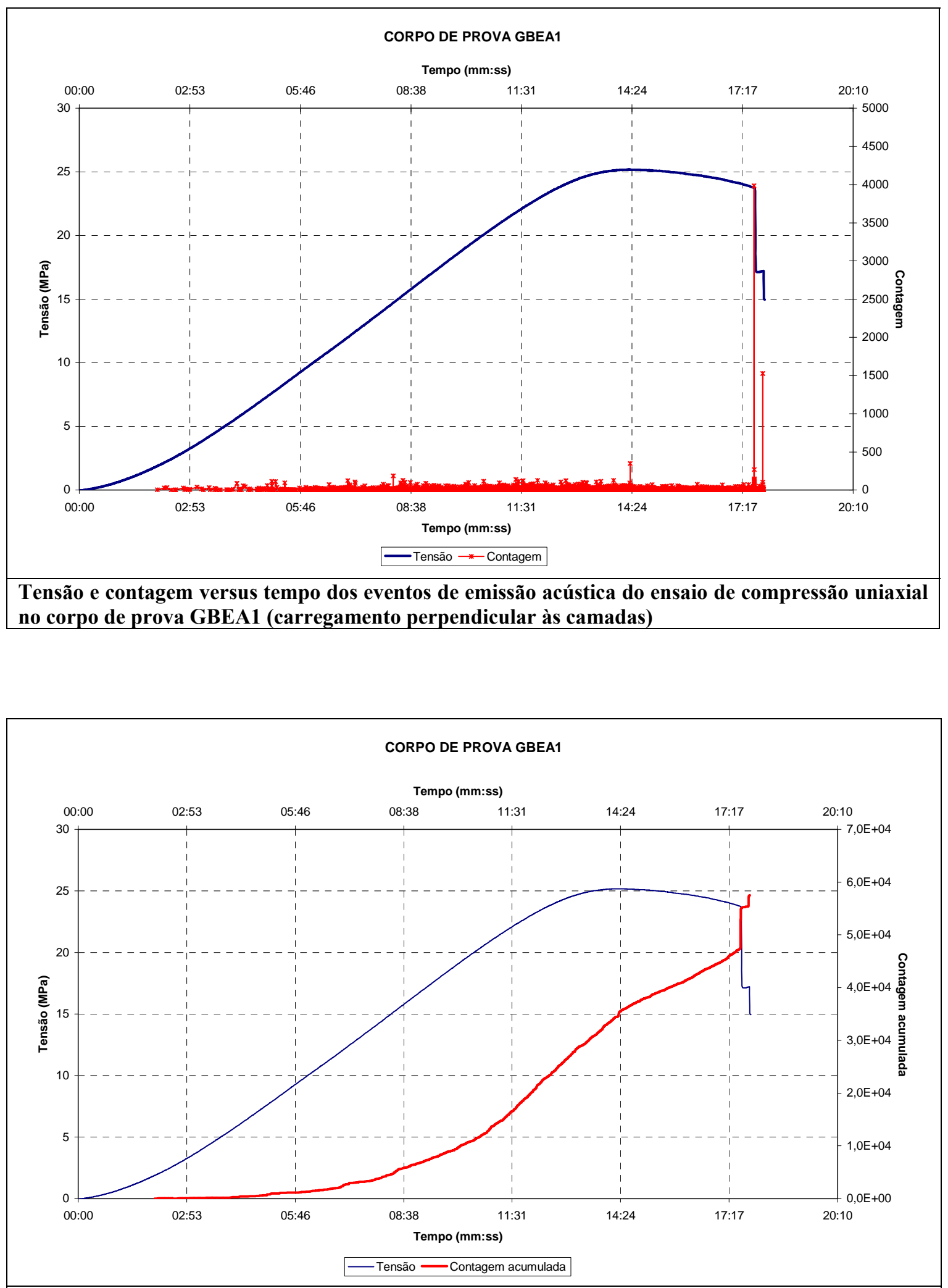

Tensão e contagem acumulada versus tempo dos eventos de emissão acústica do ensaio de compressão uniaxial no corpo de prova GBEA1 (carregamento perpendicular às camadas) 

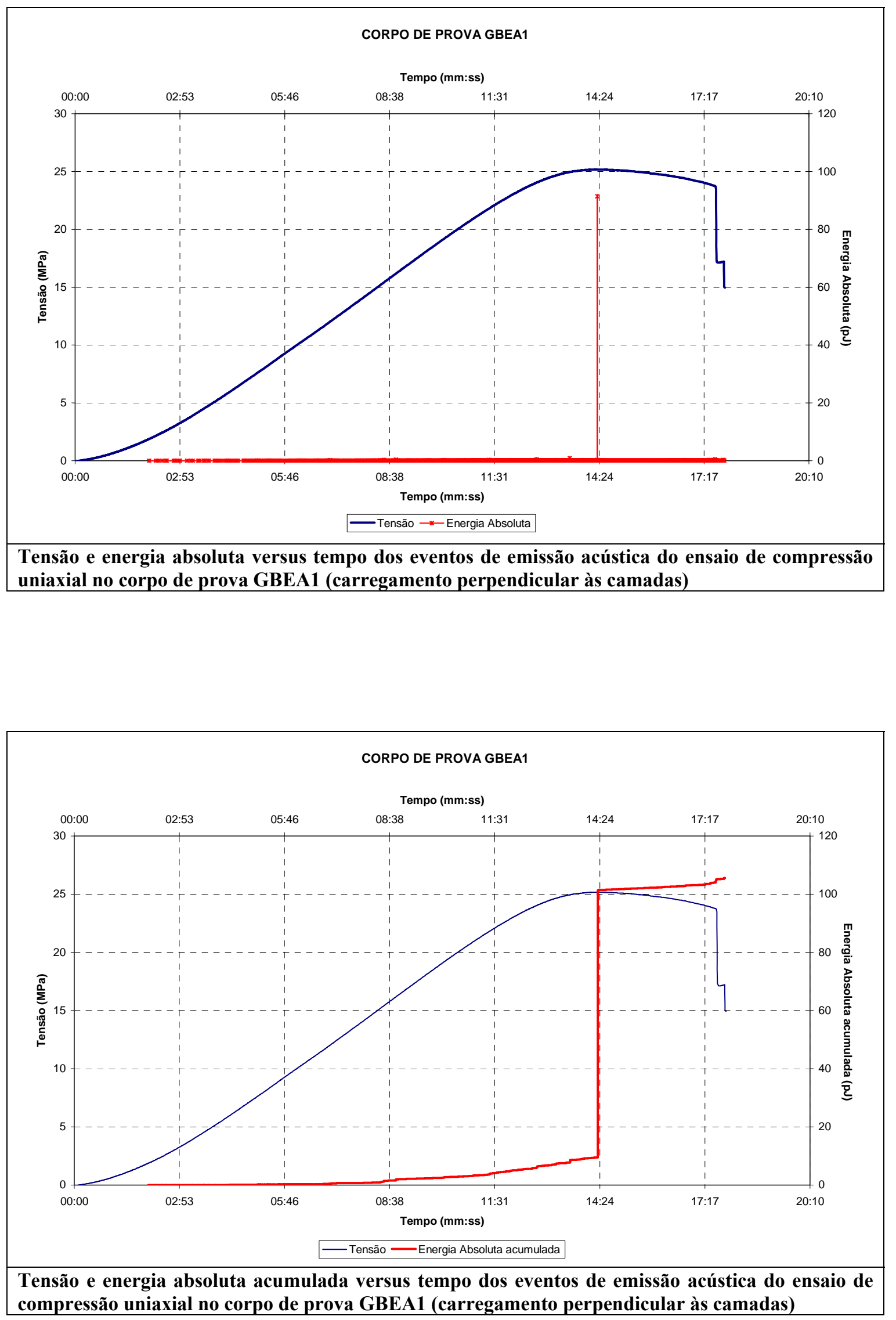

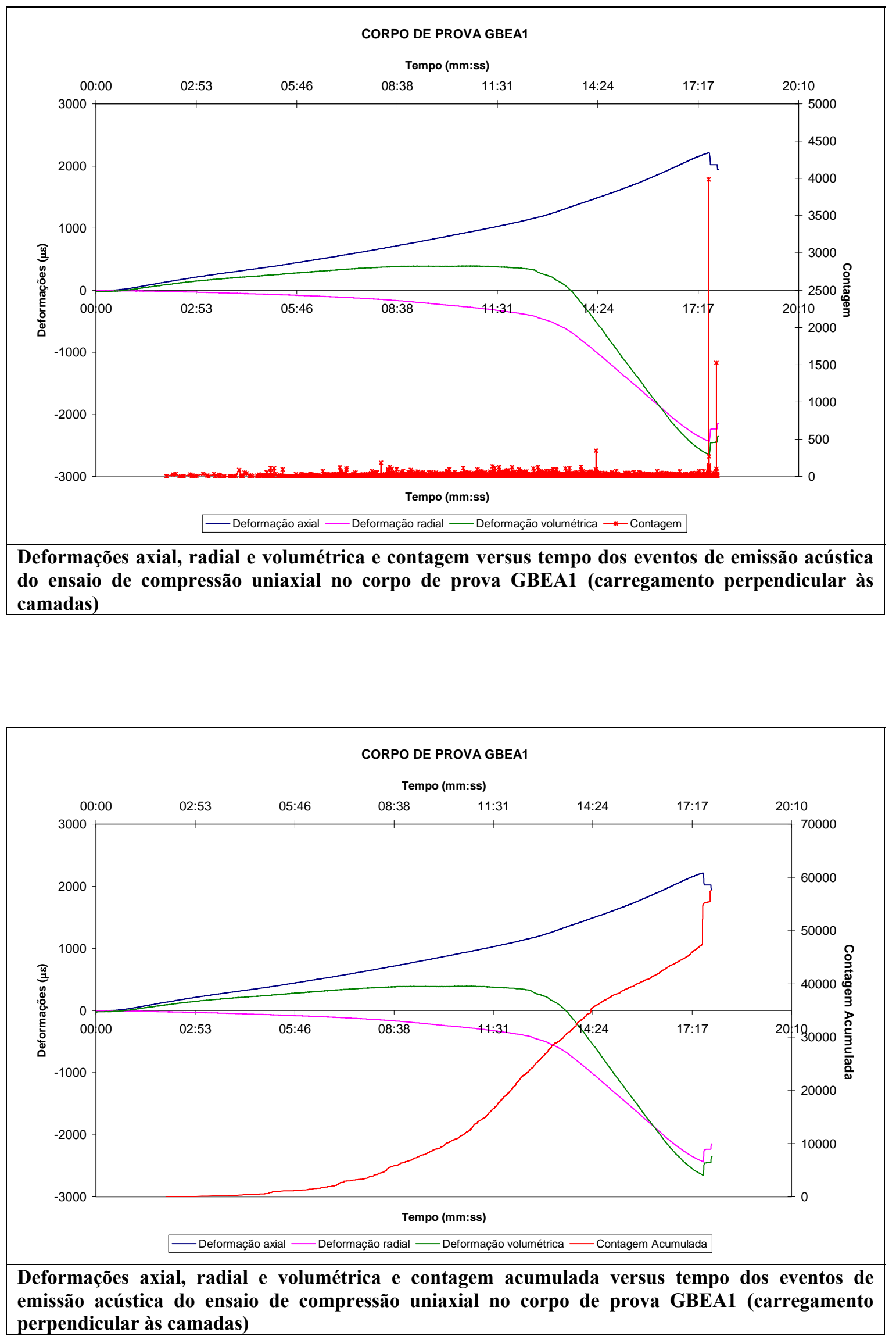

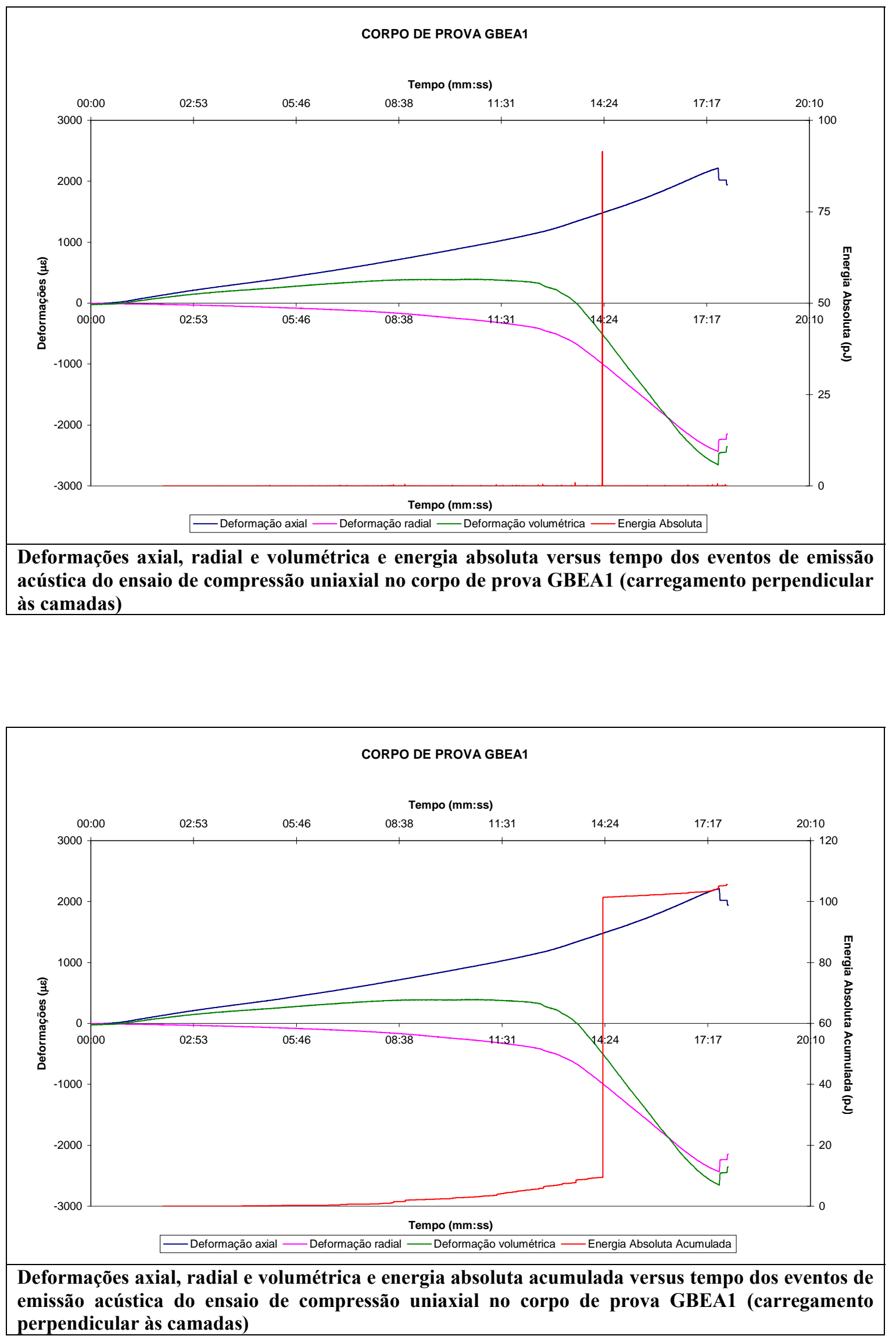


\begin{tabular}{|c|c|}
\hline & Compressão uniaxial - Corpo de prova GBEA3 \\
Controle: Deslocamento do prato \\
\hdashline \\
$\because$
\end{tabular}

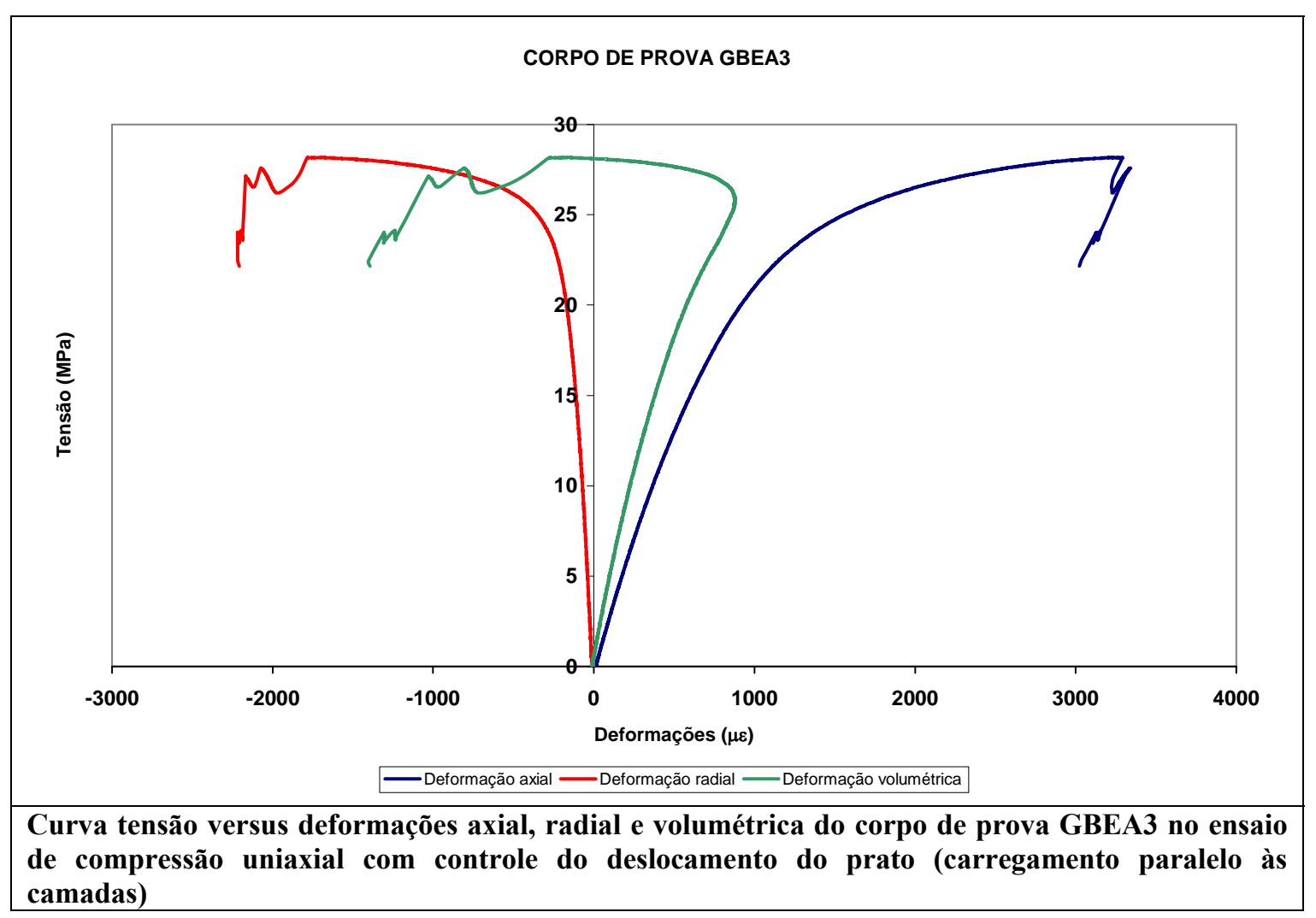



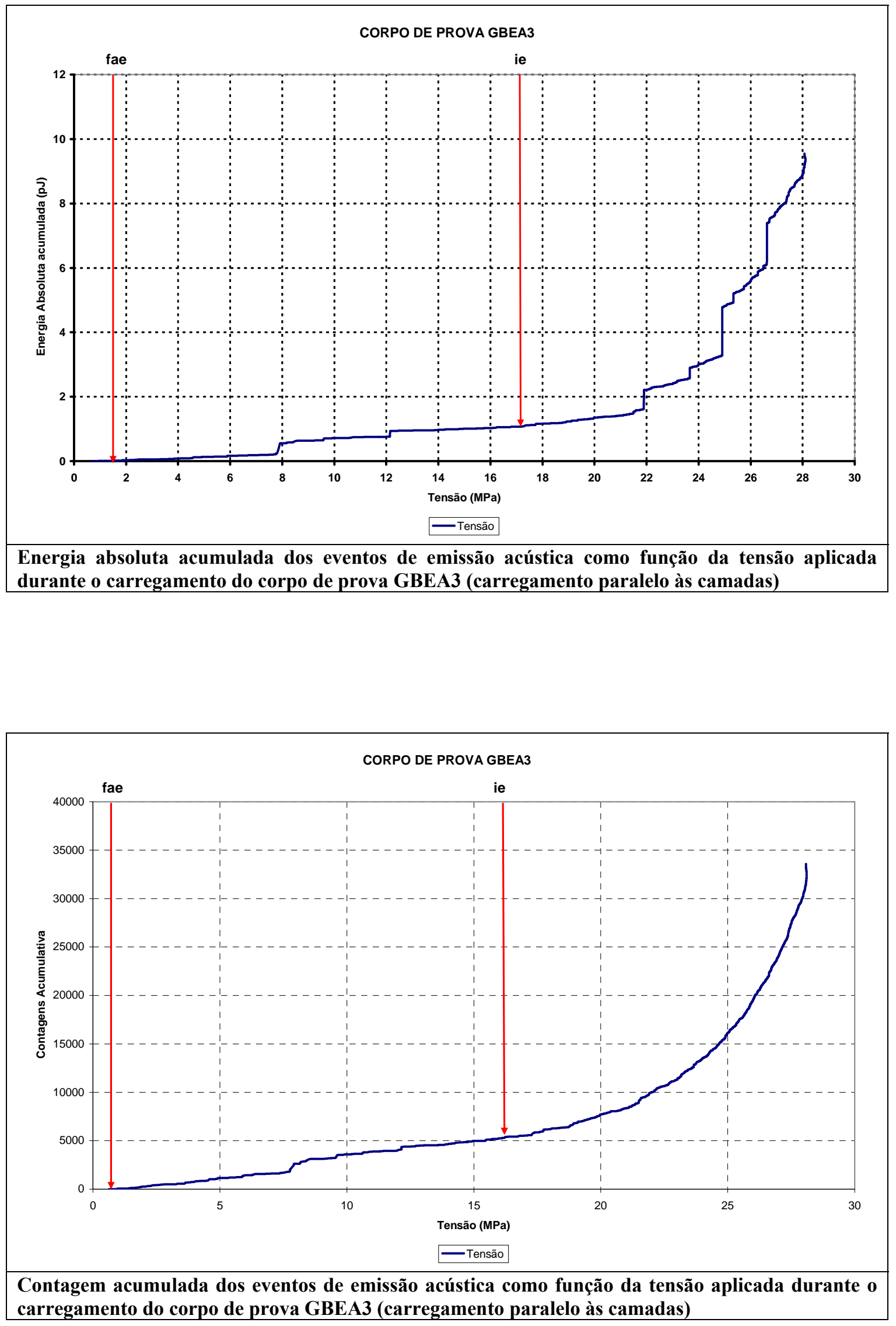

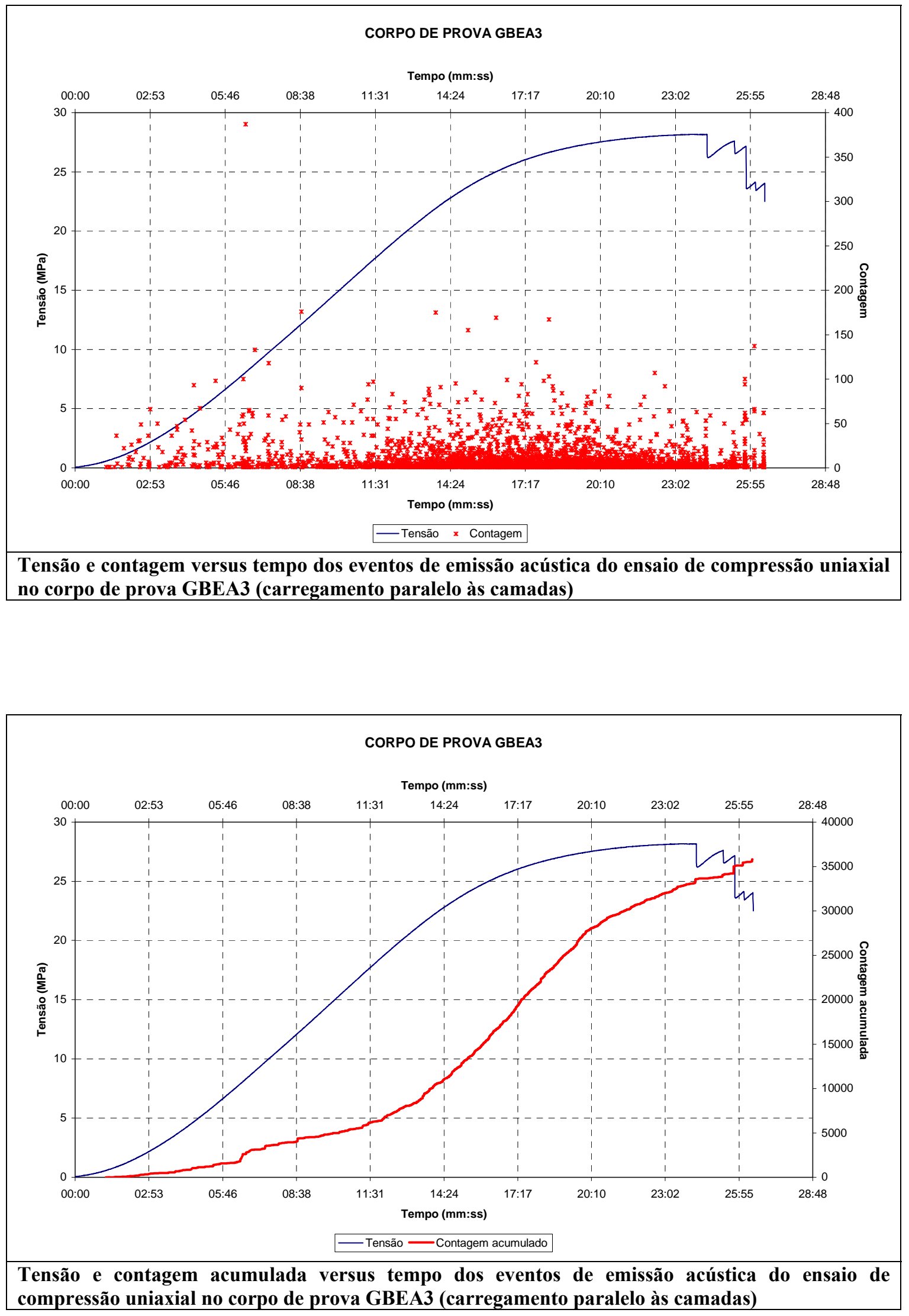

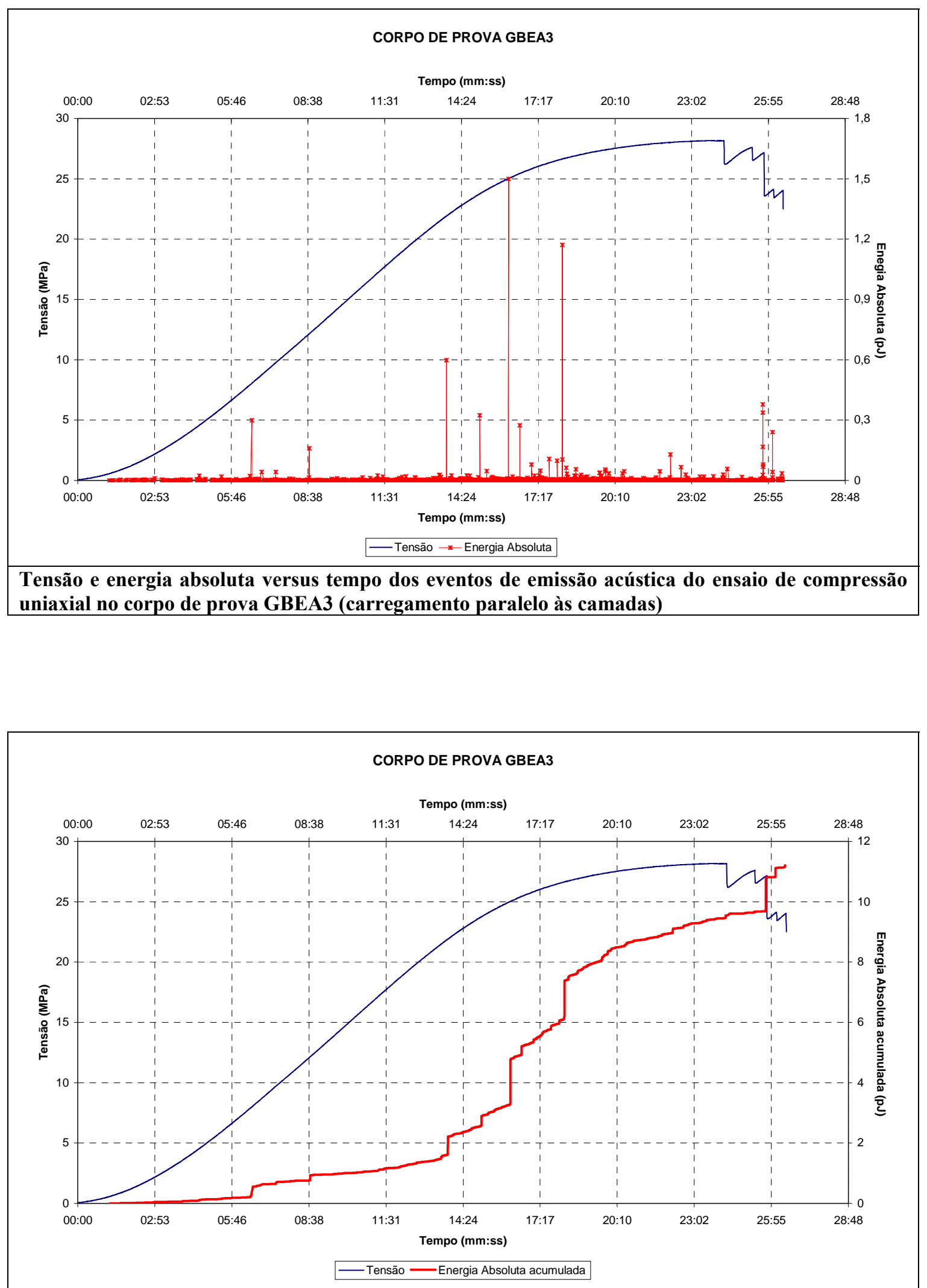

Tensão e energia absoluta acumulada versus tempo dos eventos de emissão acústica do ensaio de compressão uniaxial no corpo de prova GBEA3 (carregamento paralelo às camadas) 

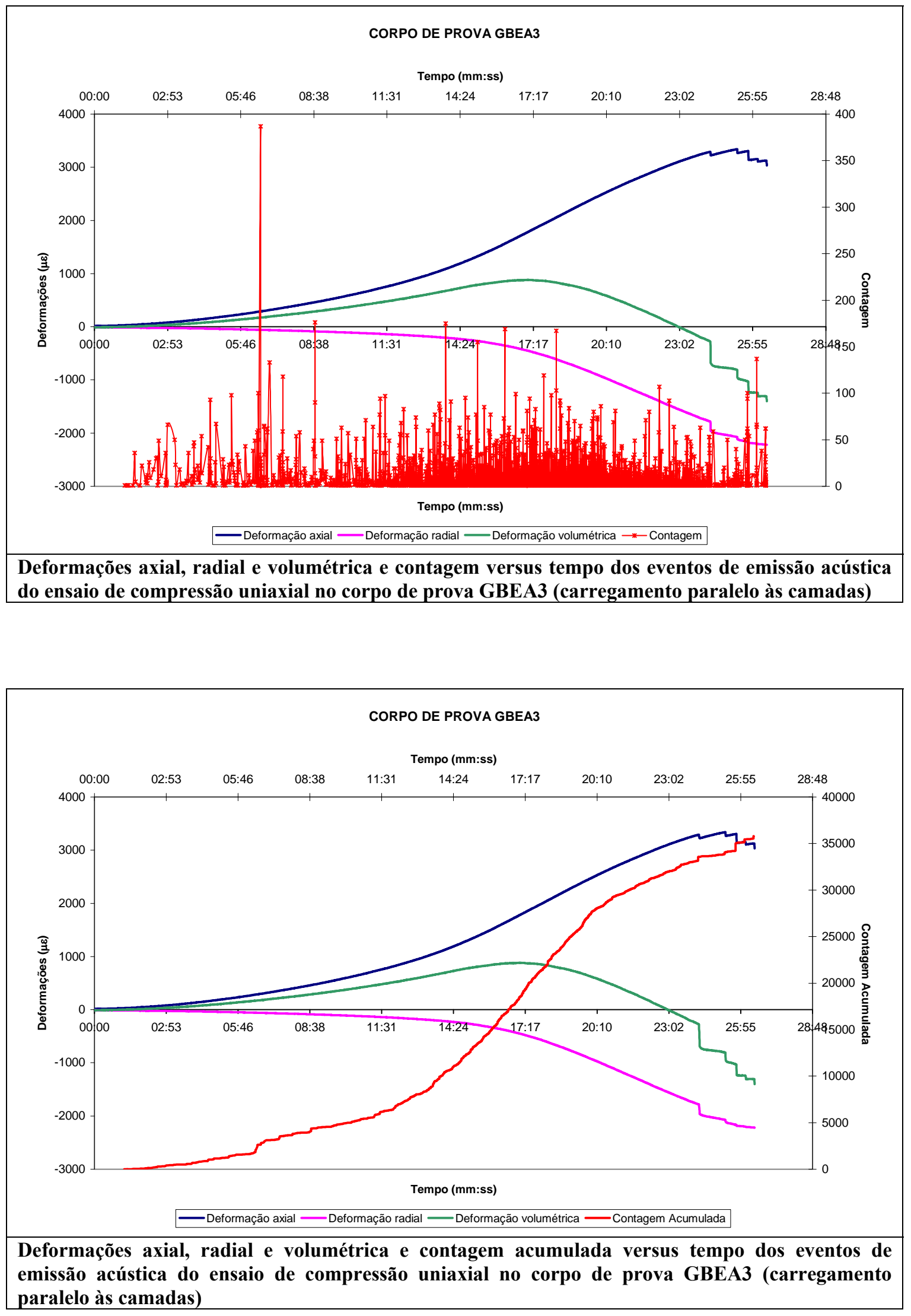

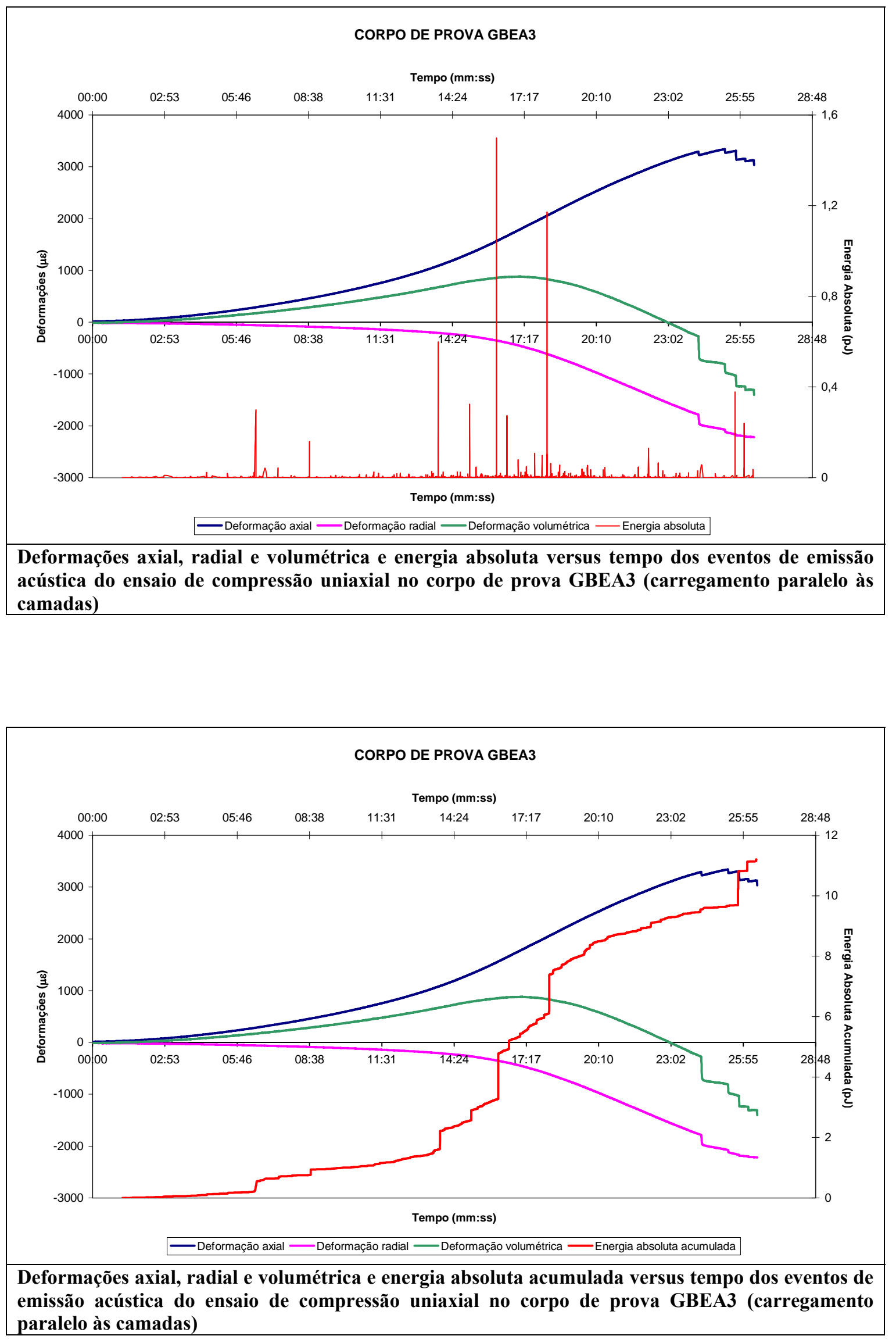


\begin{tabular}{|l|c|}
\hline & $\begin{array}{c}\text { Compressão uniaxial - Corpo de prova } \\
\text { GBEA19 }\end{array}$ \\
Controle: Força \\
\hline \\
\hline
\end{tabular}

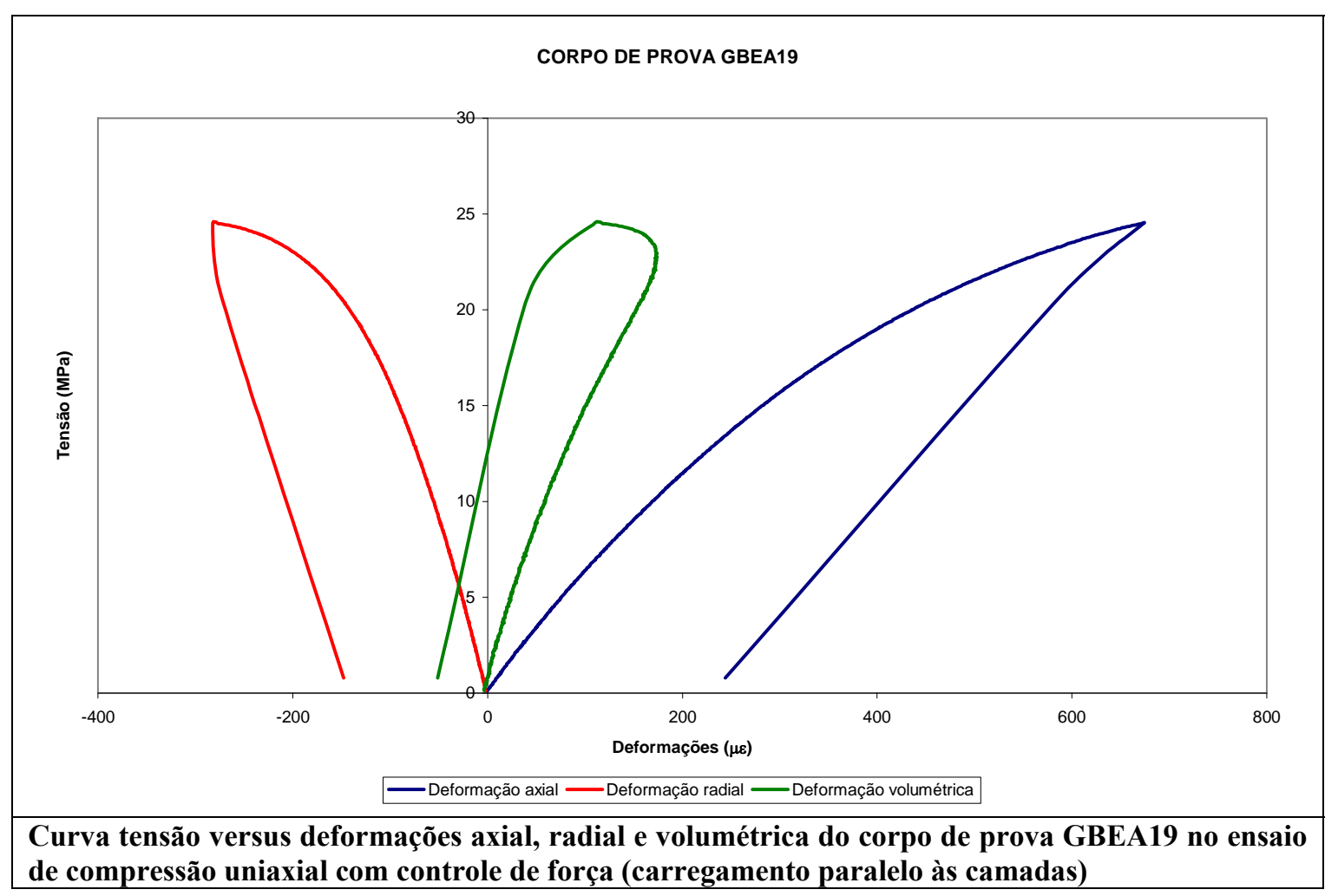



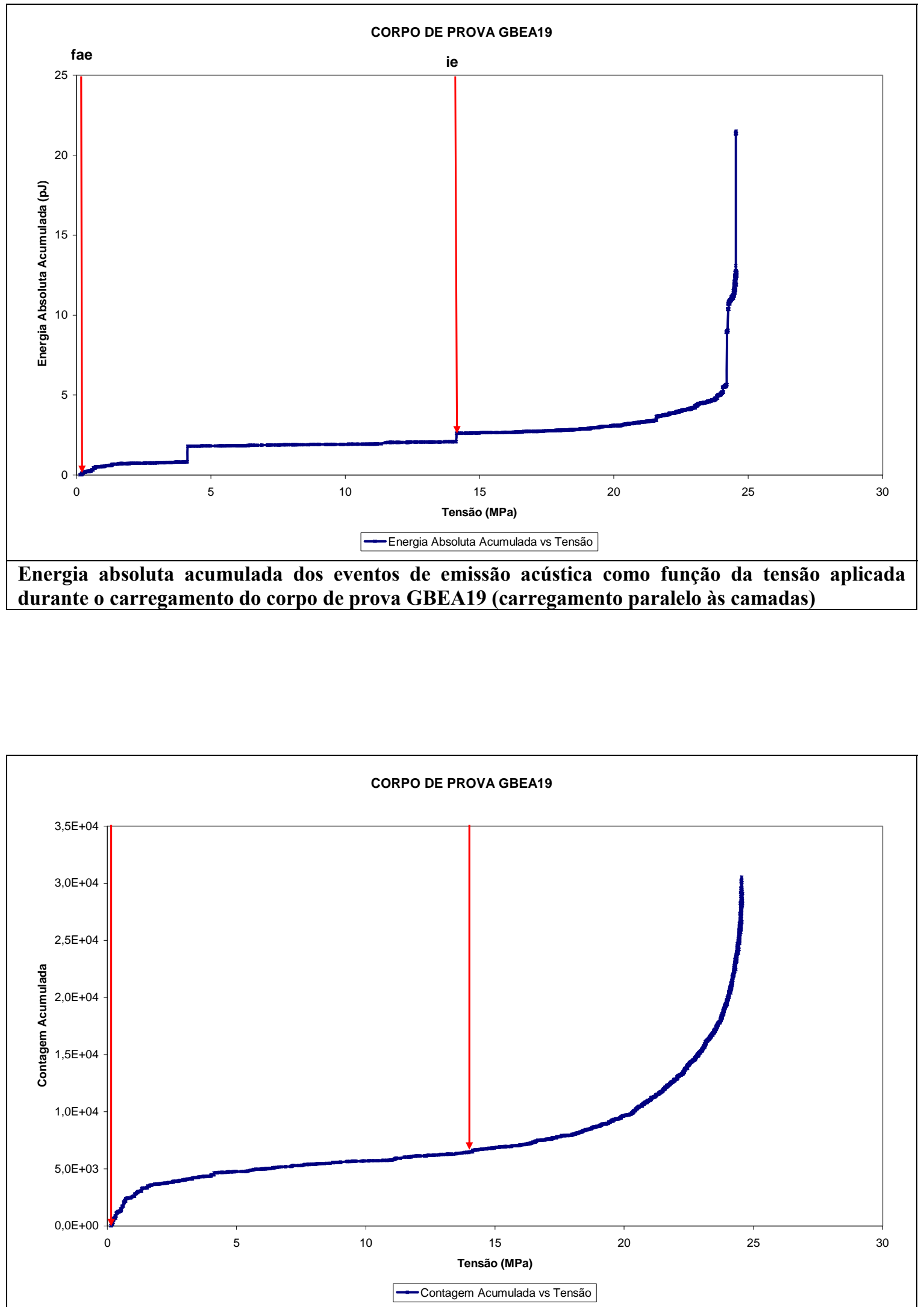

Contagem acumulada dos eventos de emissão acústica como função da tensão aplicada durante o carregamento do corpo de prova GBEA19 (carregamento paralelo às camadas) 

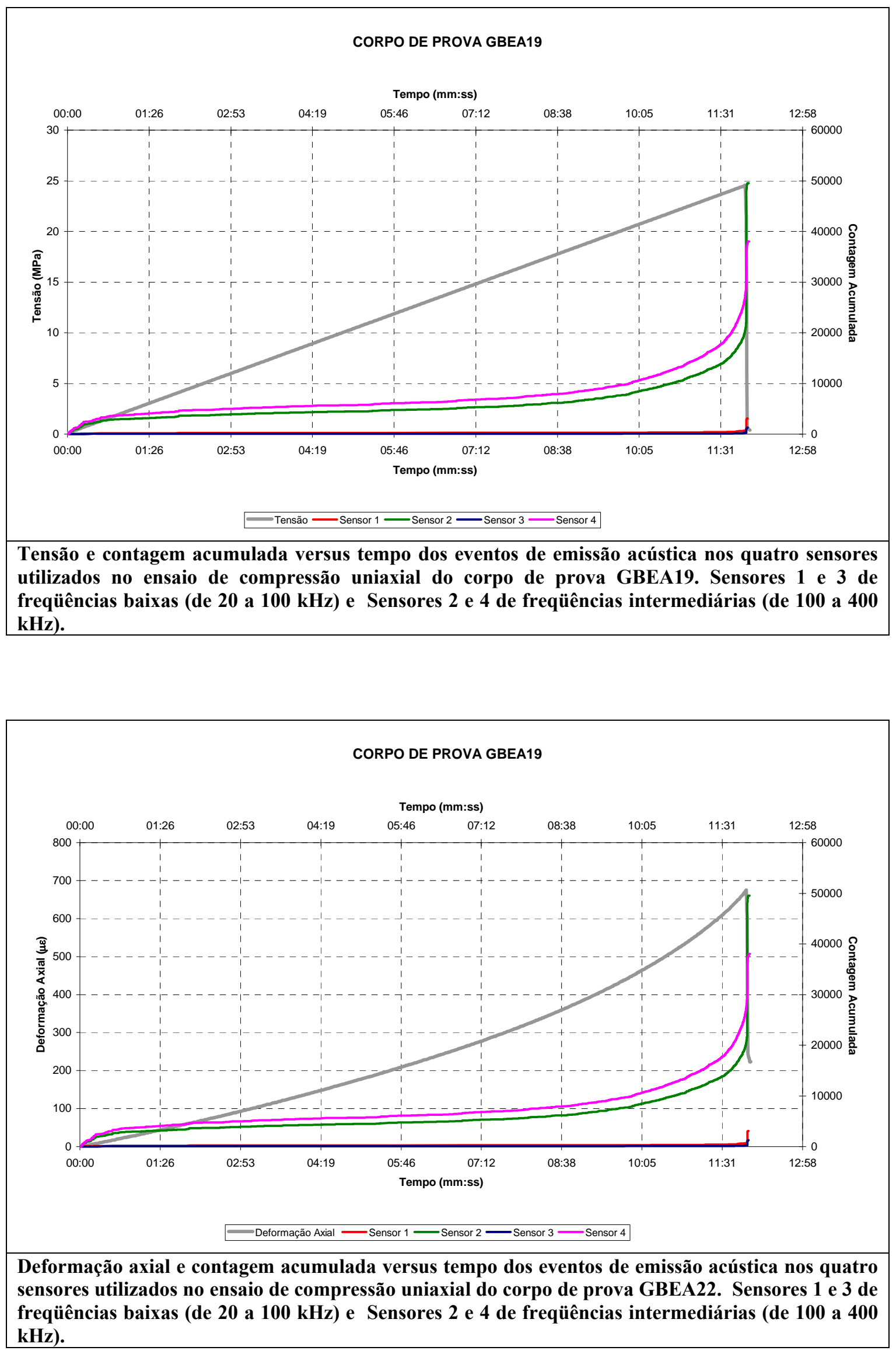

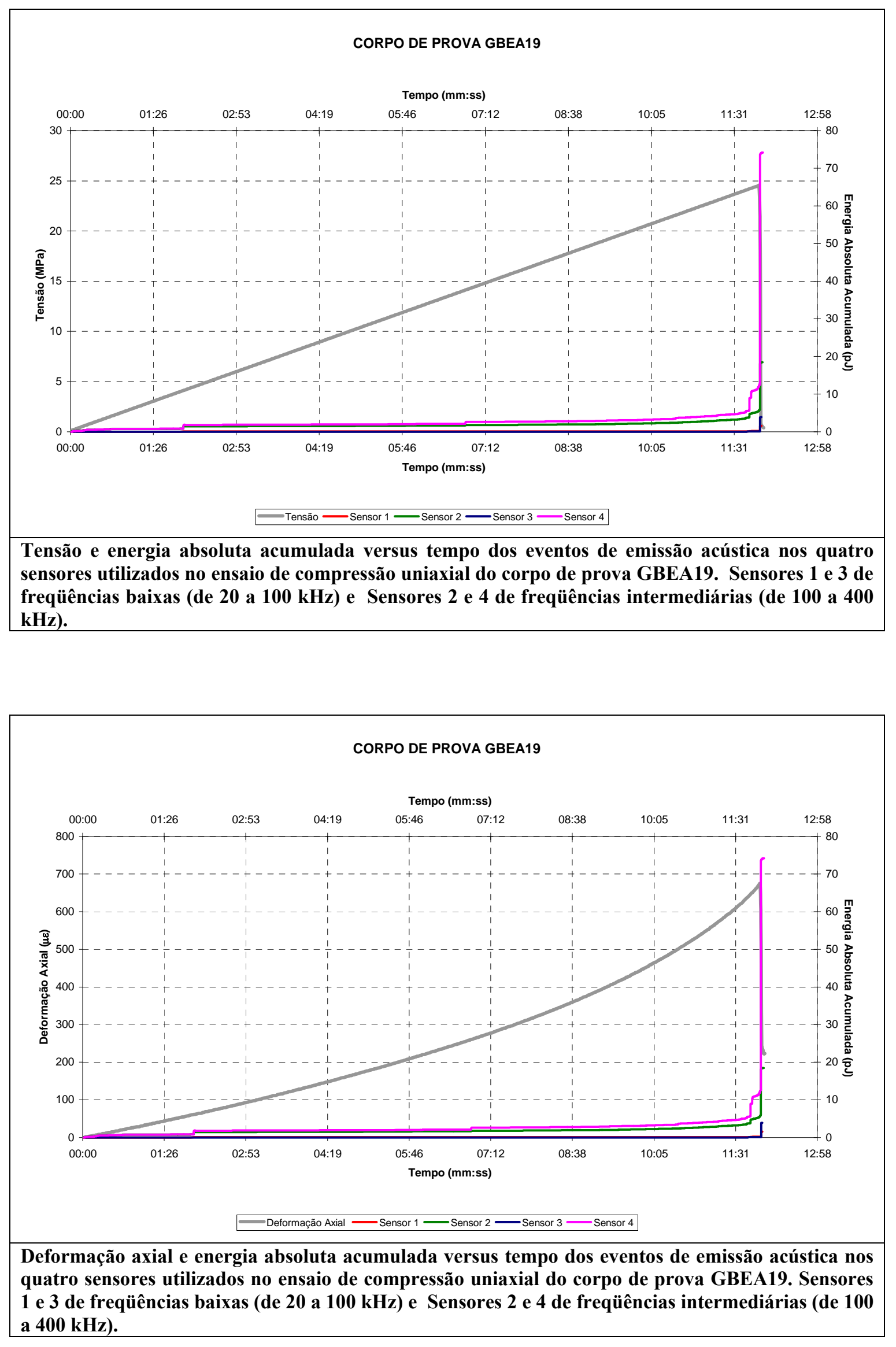

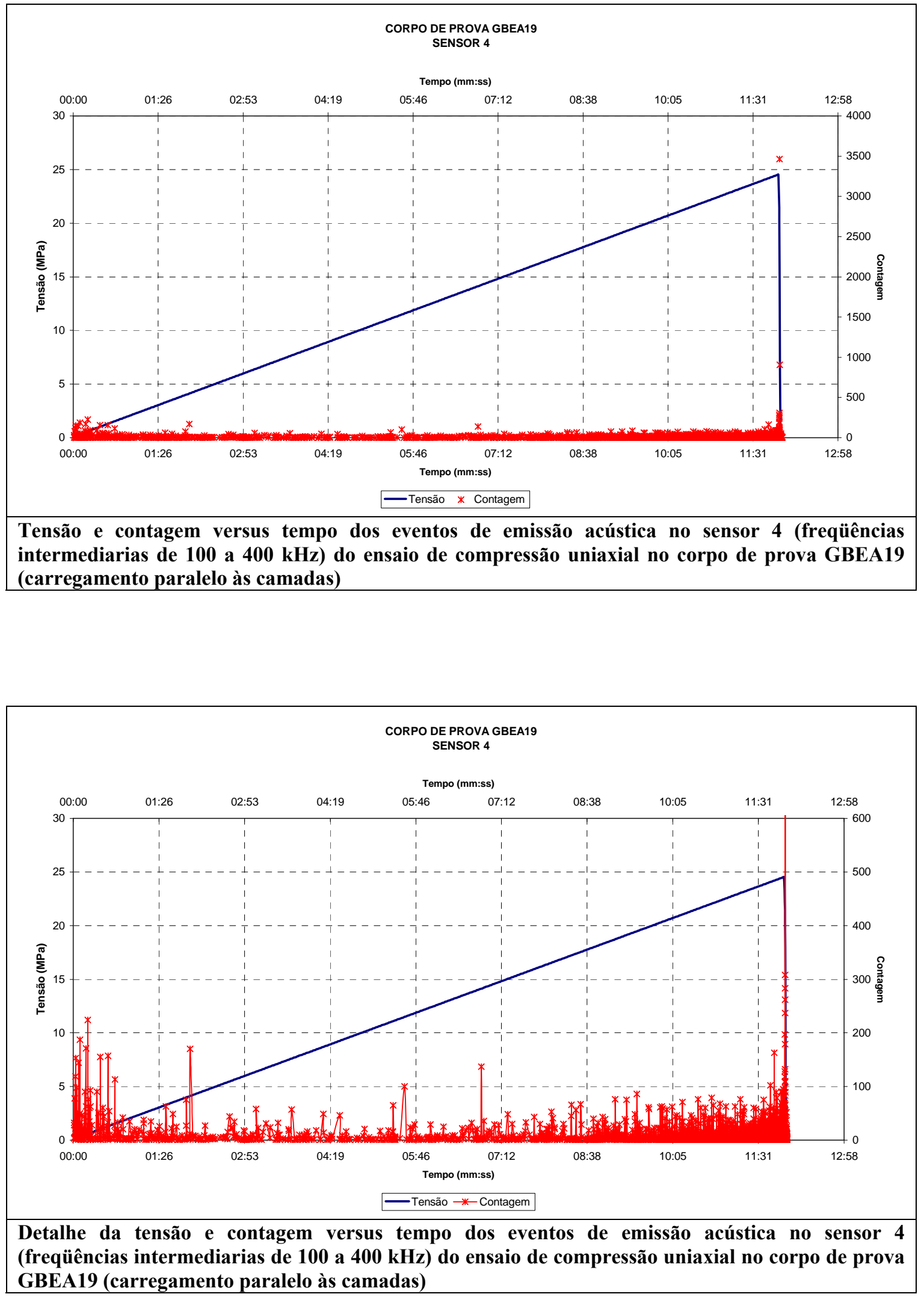

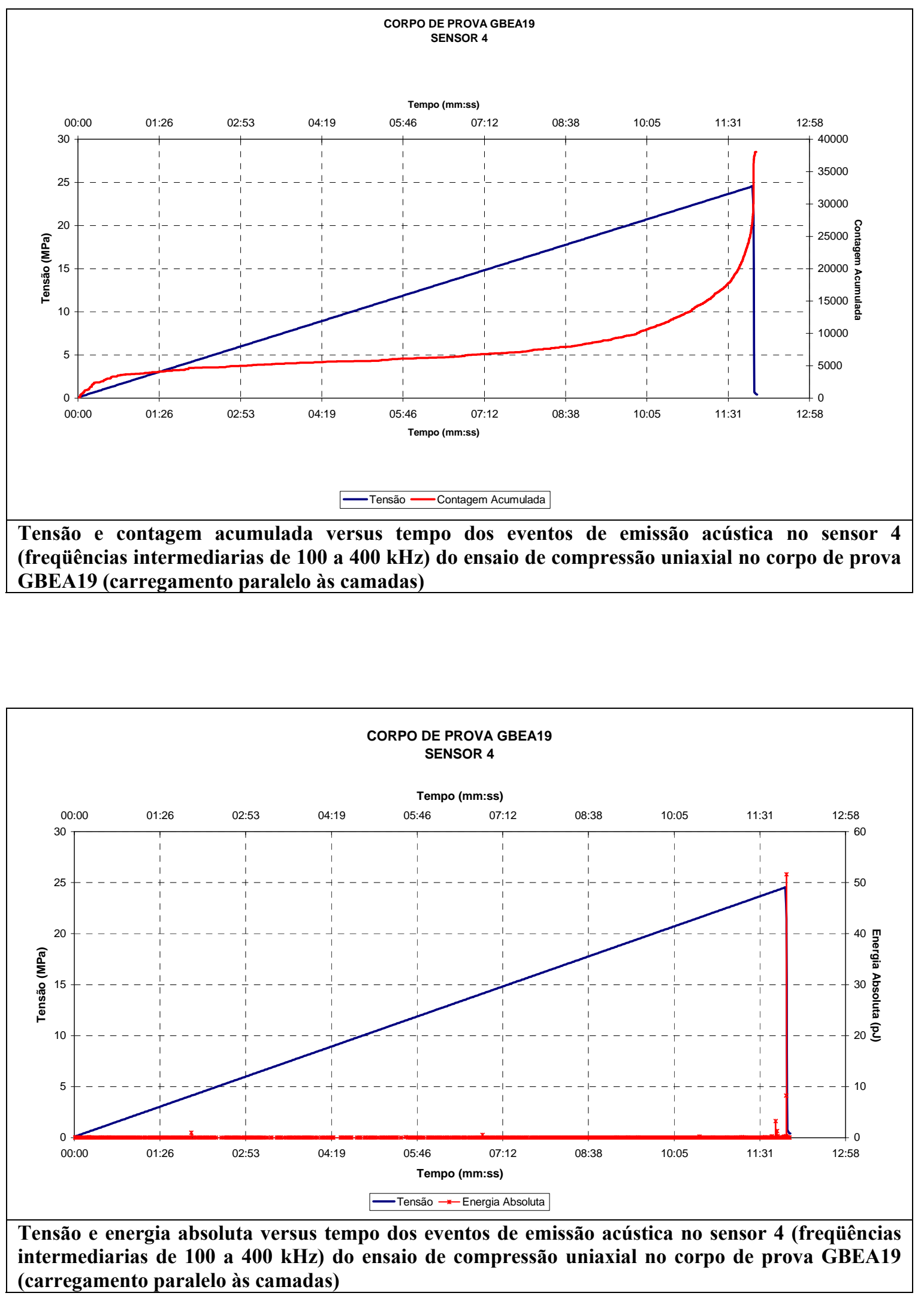

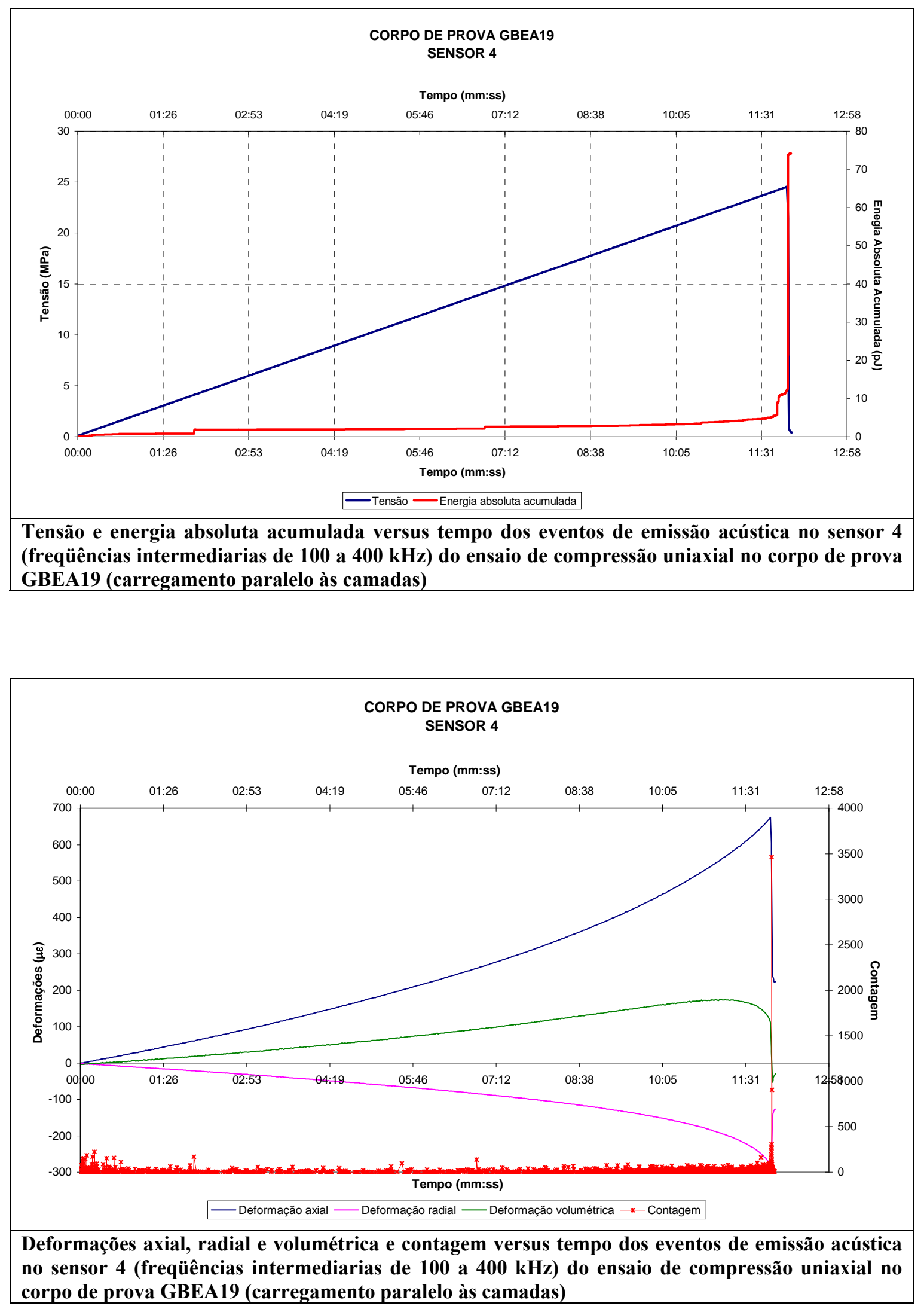


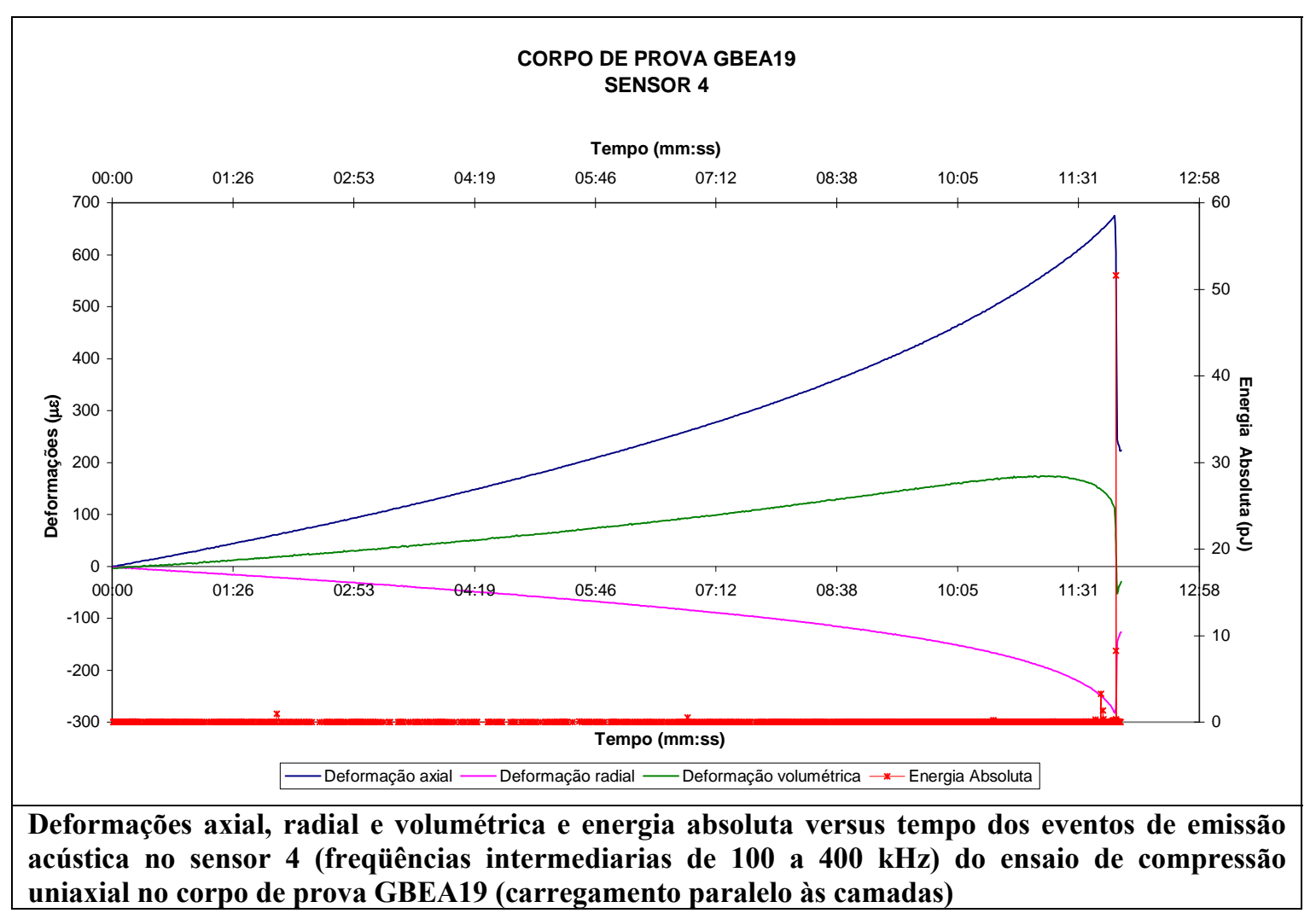




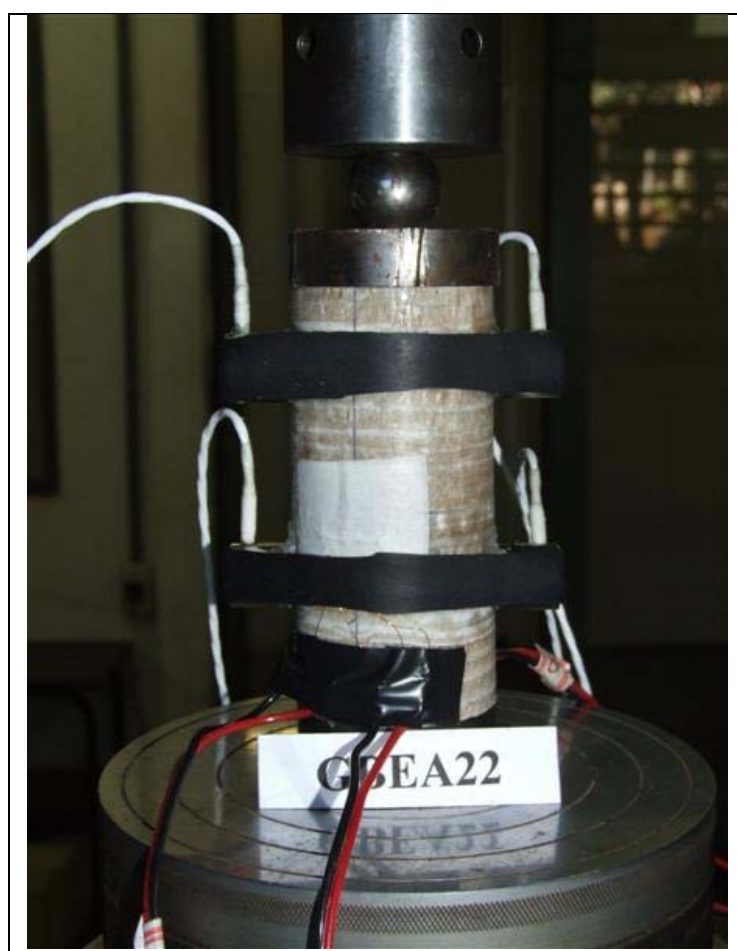

\begin{tabular}{|c|}
$\begin{array}{c}\text { Compressão uniaxial - Corpo de prova } \\
\text { GBEA22 }\end{array}$ \\
\hline Controle: Força \\
\hline Condição: Perpendicular às camadas \\
\hline Taxa: $4,50 \mathrm{kN} / \mathrm{min}$ \\
\hline Massa específica: $2,30 \mathrm{~g} / \mathrm{cm} 3$ \\
\hline$\sigma_{\mathrm{c}}=\mathbf{2 7 , 4 9} \mathrm{MPa}$ \\
\hline $\mathrm{E}=\mathbf{5 1 , 6 8} \mathrm{GPa}$ \\
$\mathbf{v}=\mathbf{0 , 2 9}$ \\
\hline
\end{tabular}

Foto do corpo de prova GBEA22 antes do ensaio, condição, controle e taxa de carregamento e resultados do ensaio

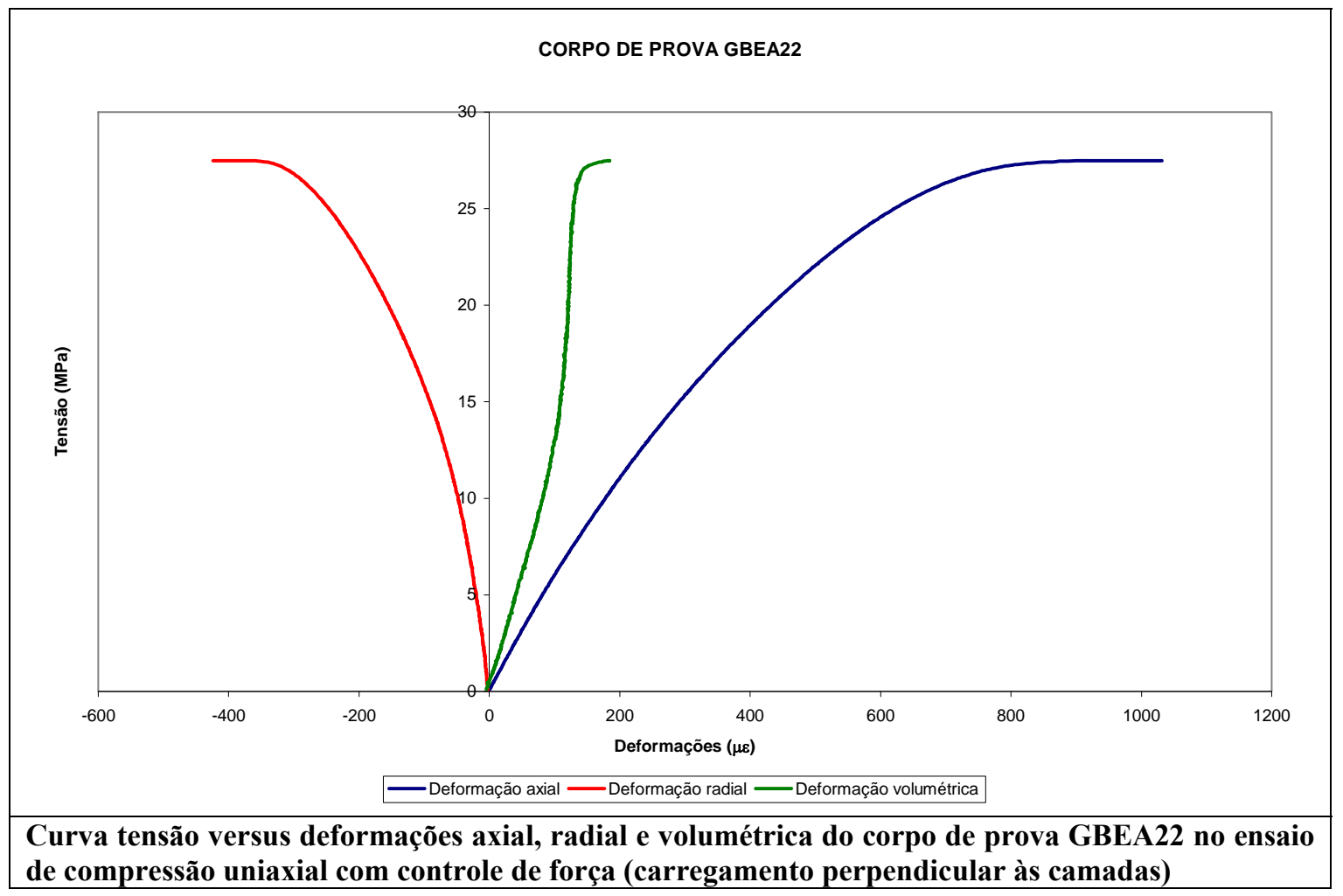




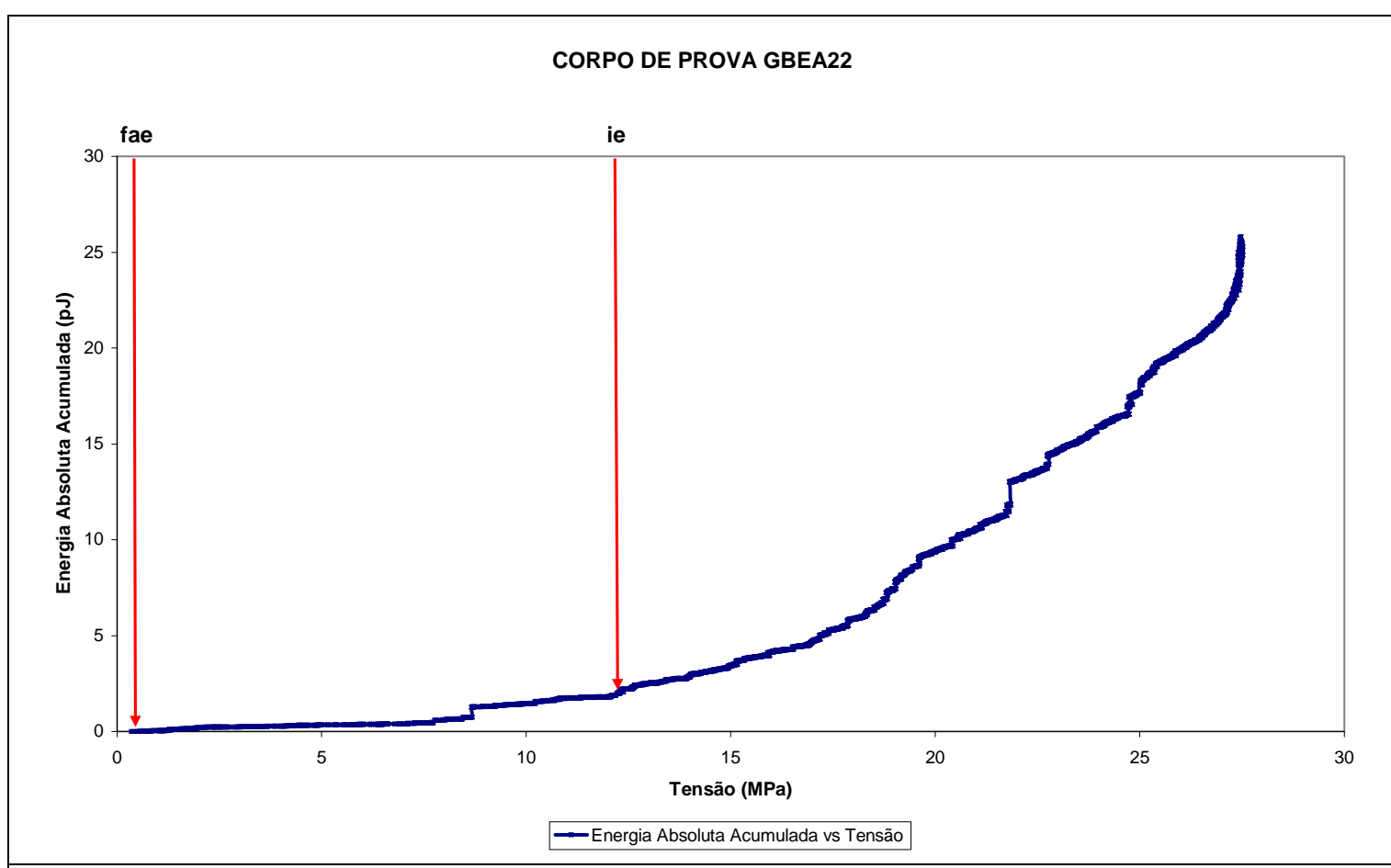

Energia absoluta acumulada dos eventos de emissão acústica como função da tensão aplicada durante o carregamento do corpo de prova GBEA22 (carregamento perpendicular às camadas)

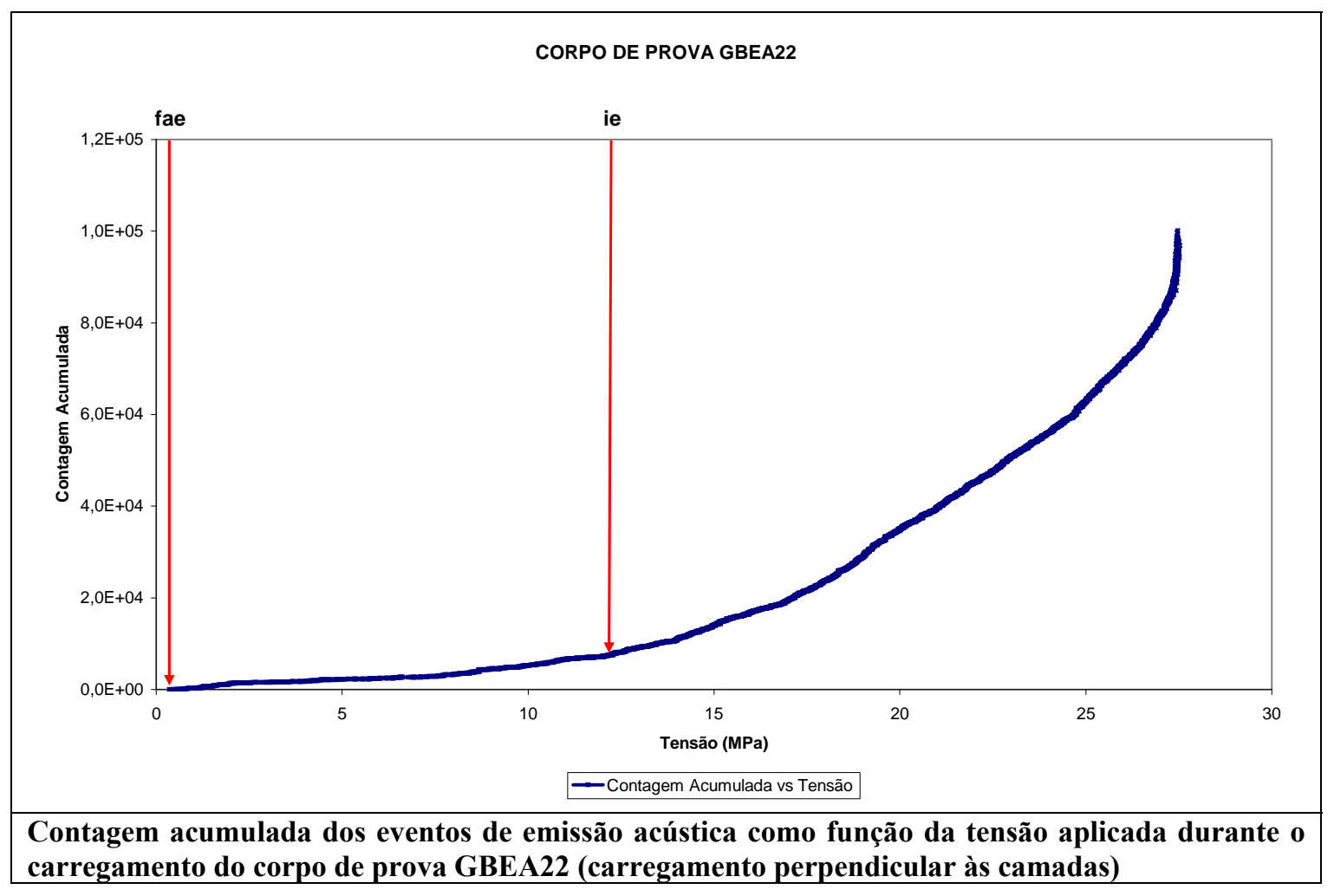



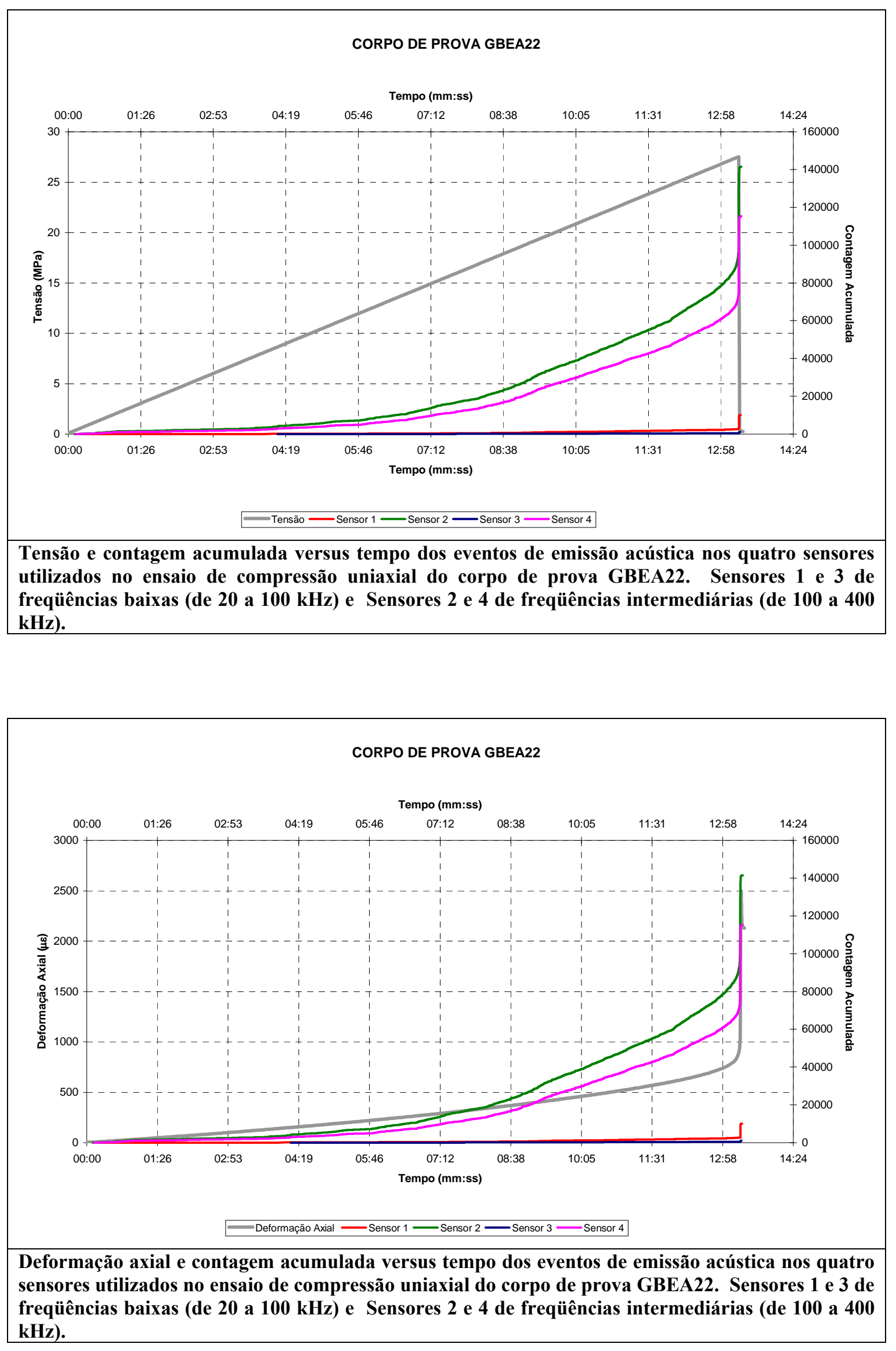

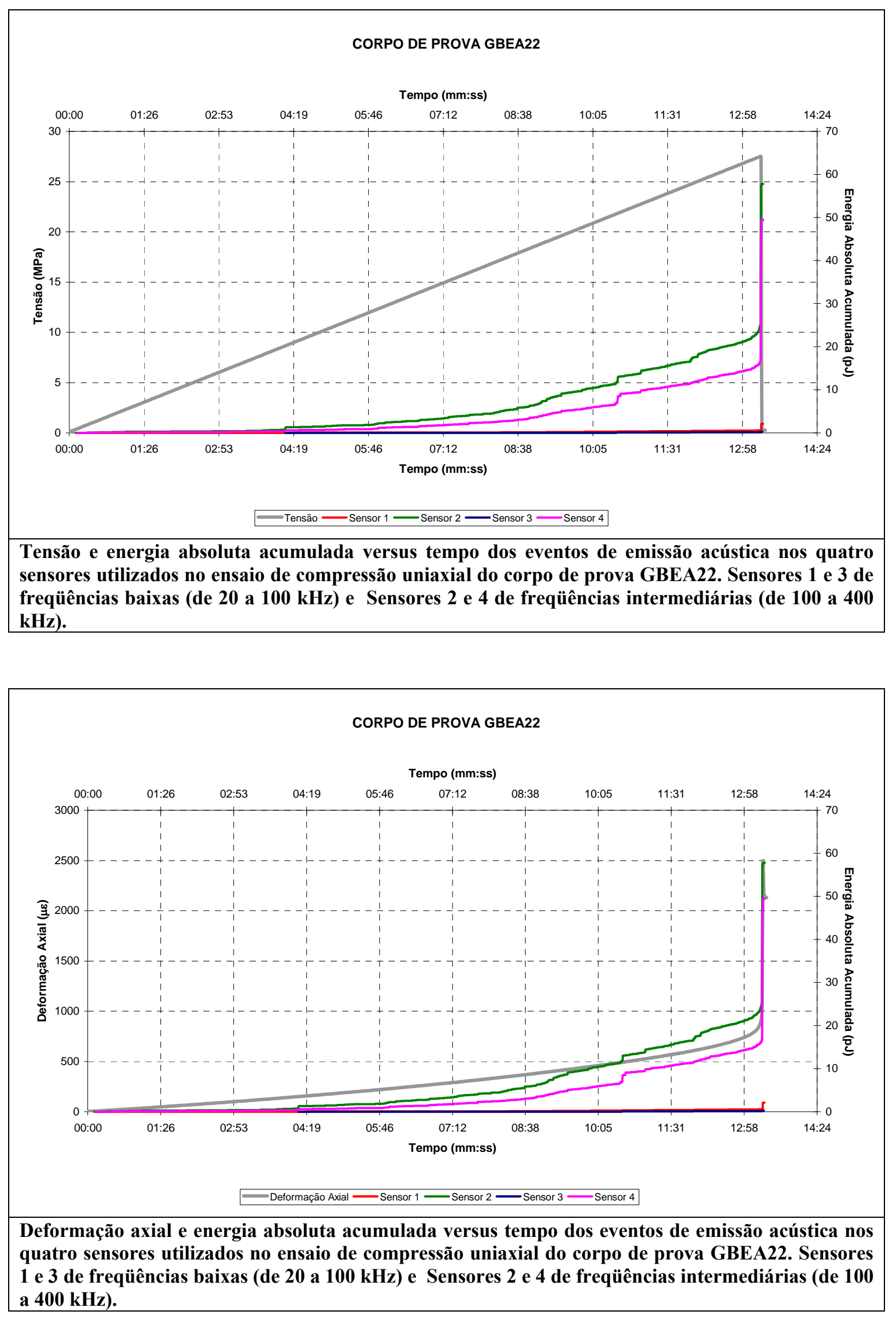

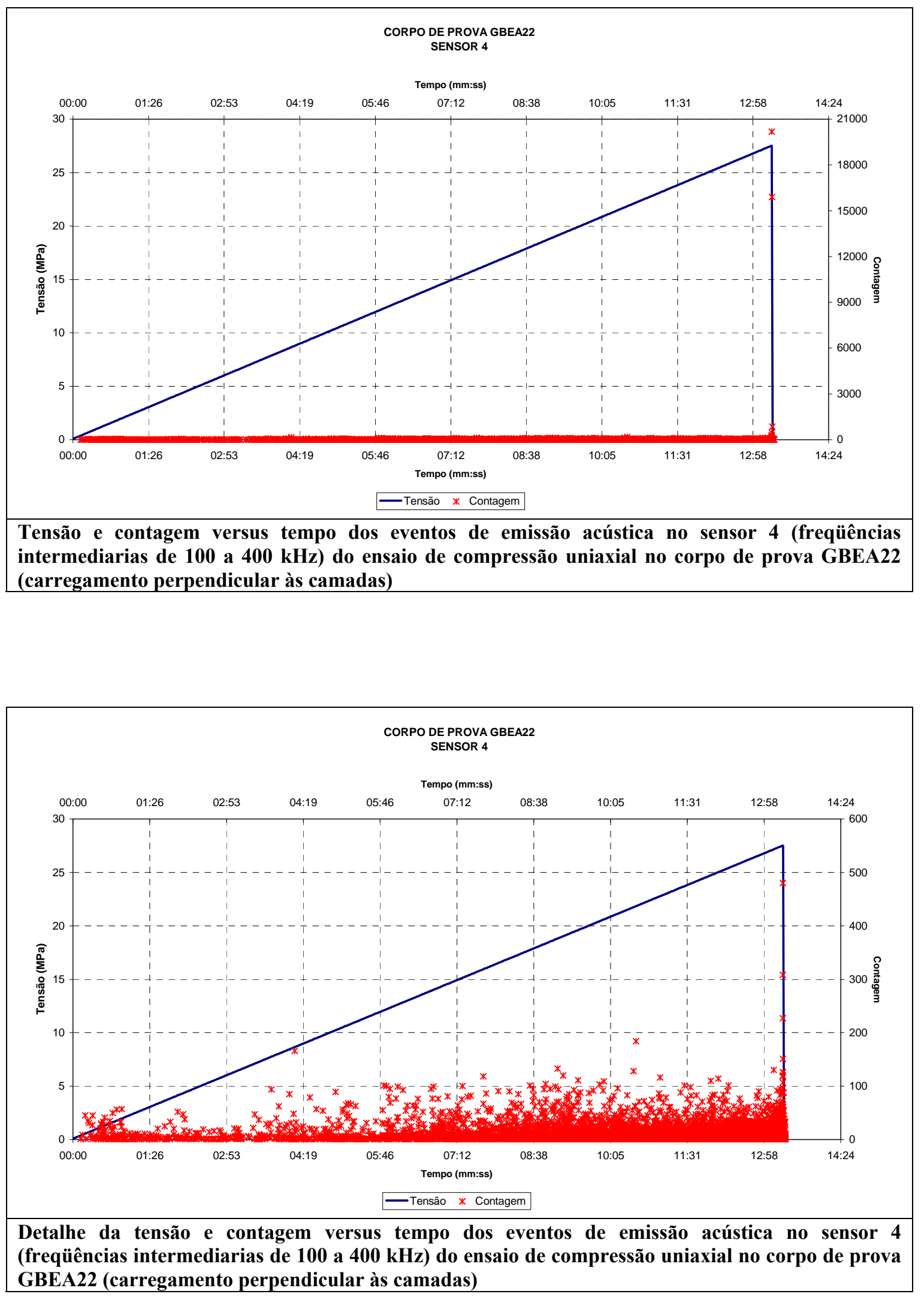

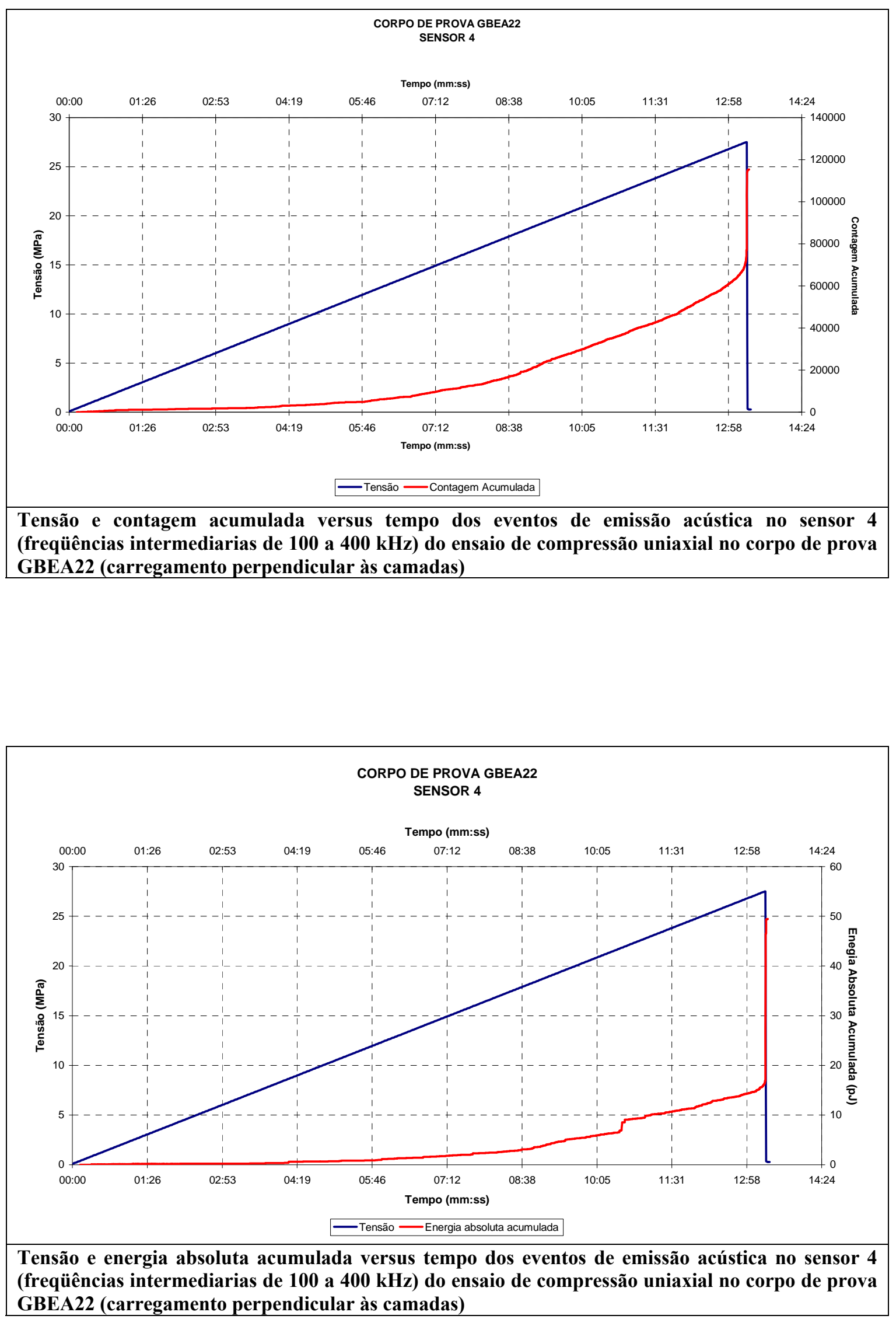

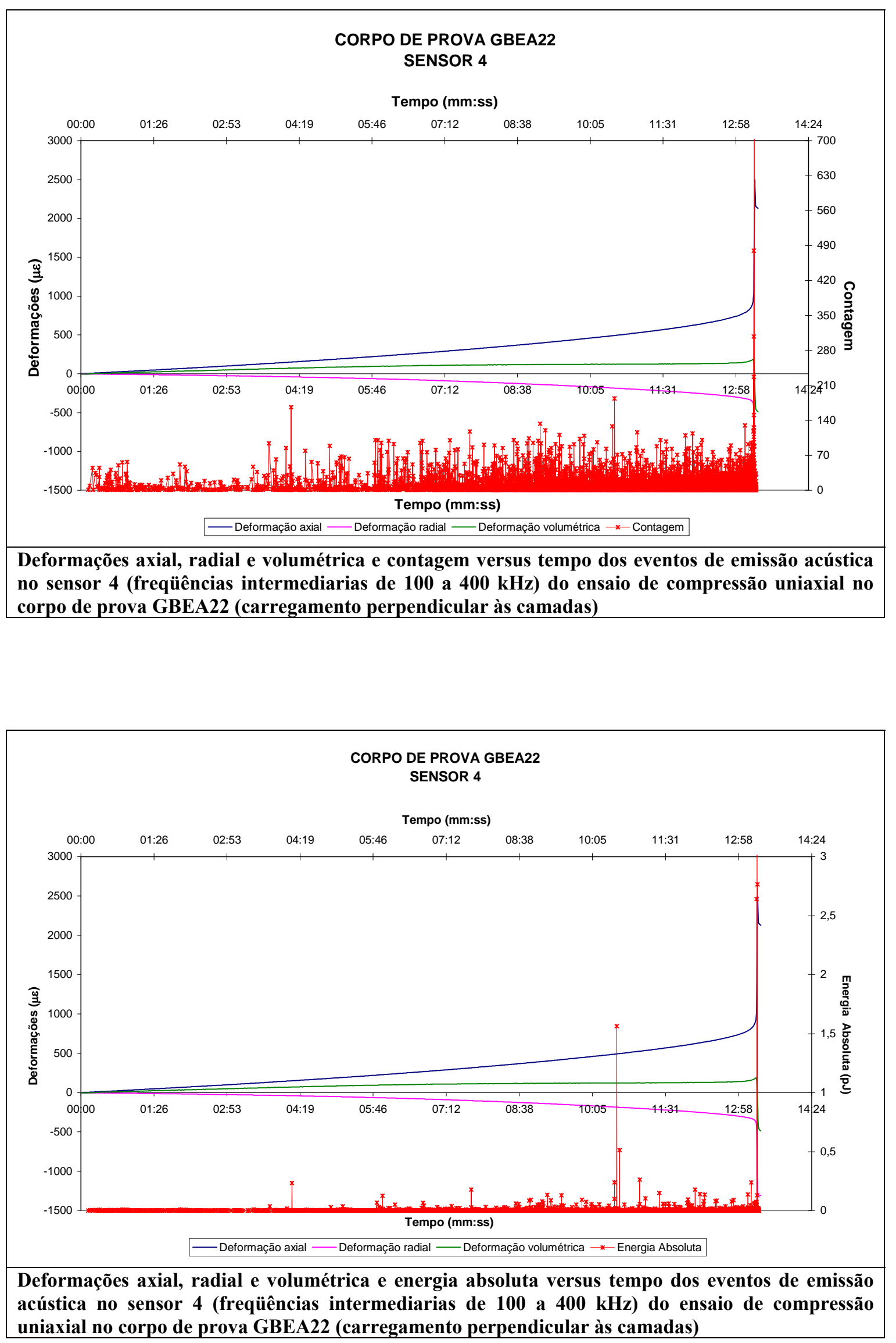


\section{Apêndice 2}

ENSAIOS DE COMPRESSÃO UNIAXIAL COM CICLOS VARIÁVEIS DE CARREGAMENTO ANTES E APÓS O PICO DE RESISTÊNCIA 


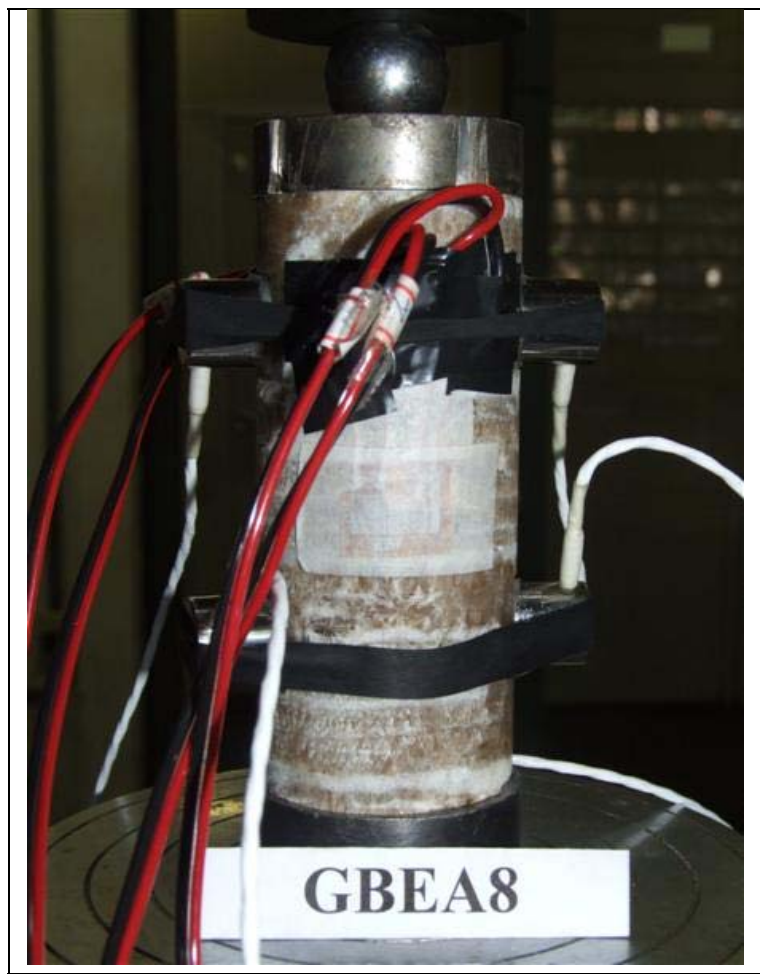

Compressão uniaxial com ciclos variáveis de carregamento antes e após o pico de resistência Corpo de prova GBEA8

Controle: Deslocamento do prato

Condição: Perpendicular às camadas

Taxa: $0,03 \mathrm{~mm} / \mathrm{min}$ tanto no carregamento como no descarregamento

Resistência pico: 23,84 MPa

fae $=0,60 \mathrm{MPa}$

ie $=13,70 \mathrm{MPa}$

Foto do corpo de prova GBEA8 antes do ensaio, condição, controle, taxa de carregamento e descarregamento, resistência pico, fae e ie

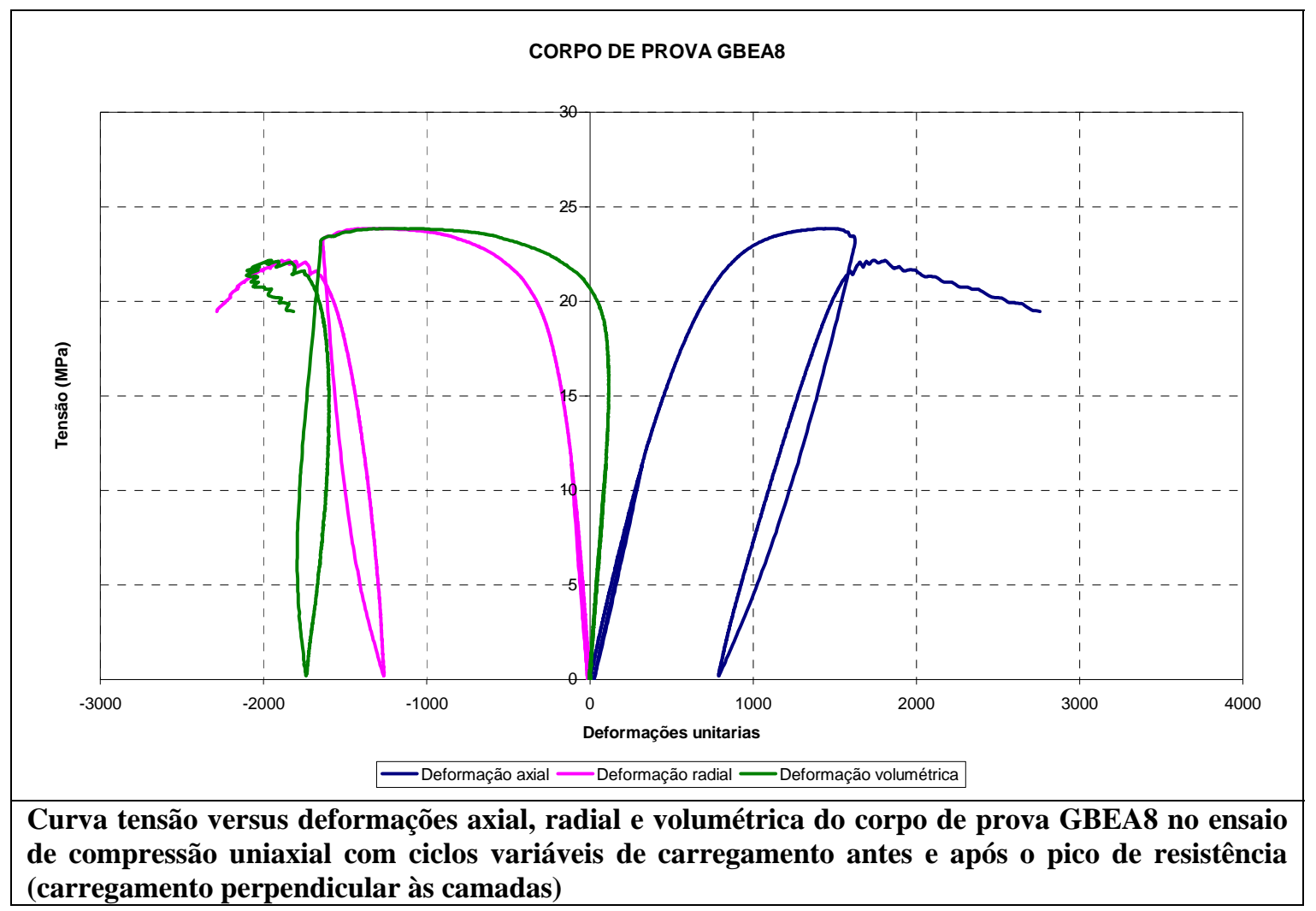



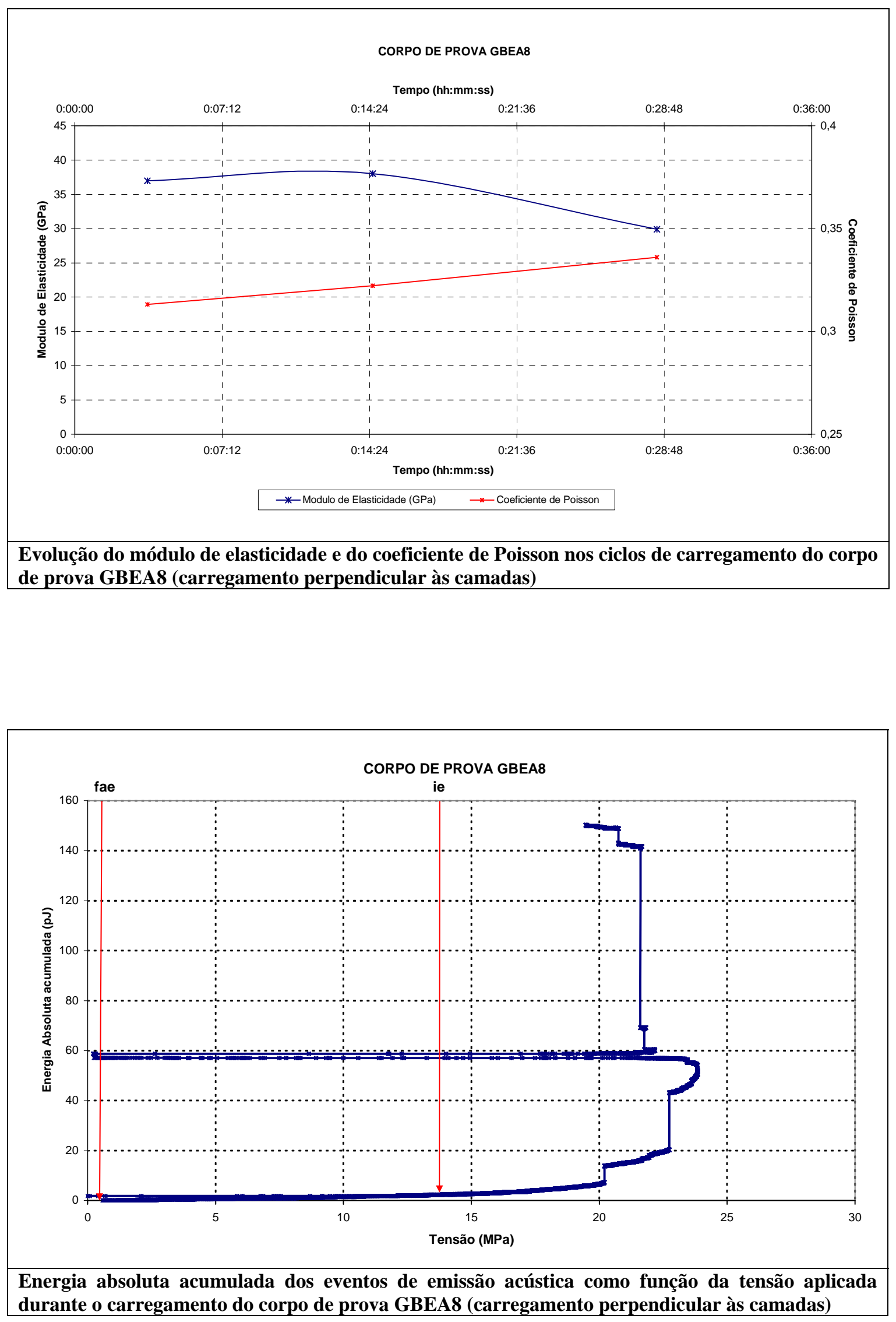

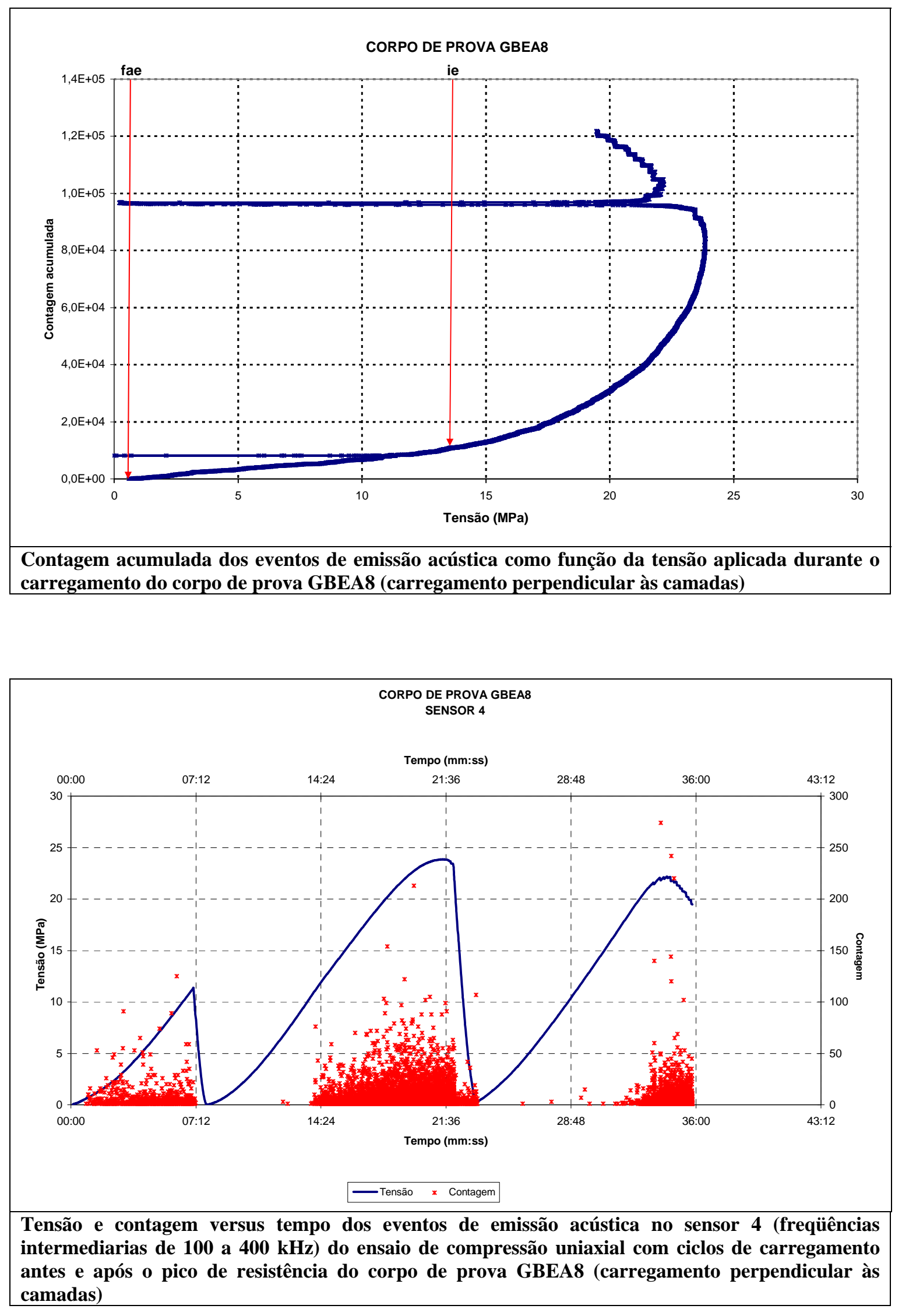

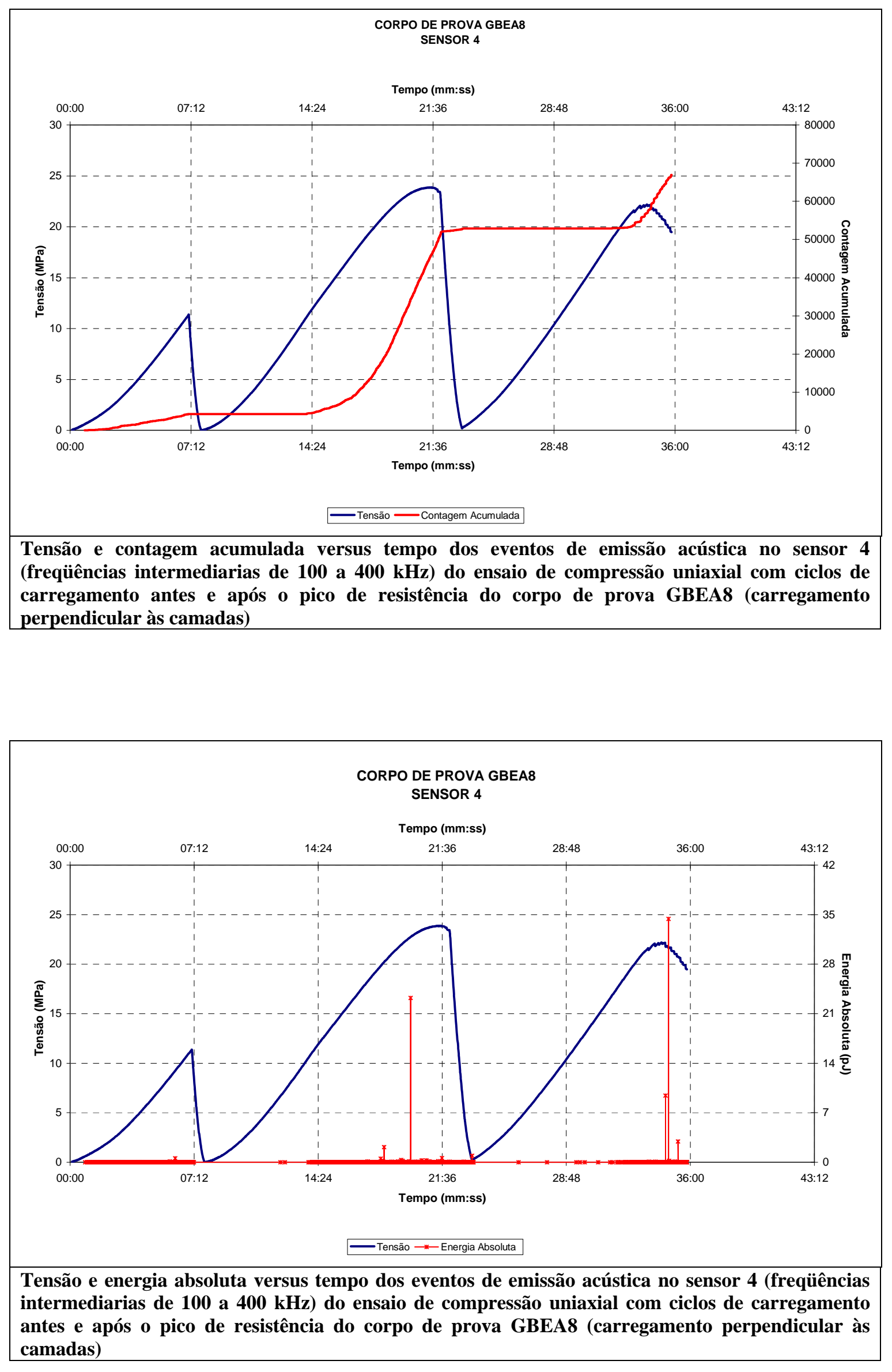

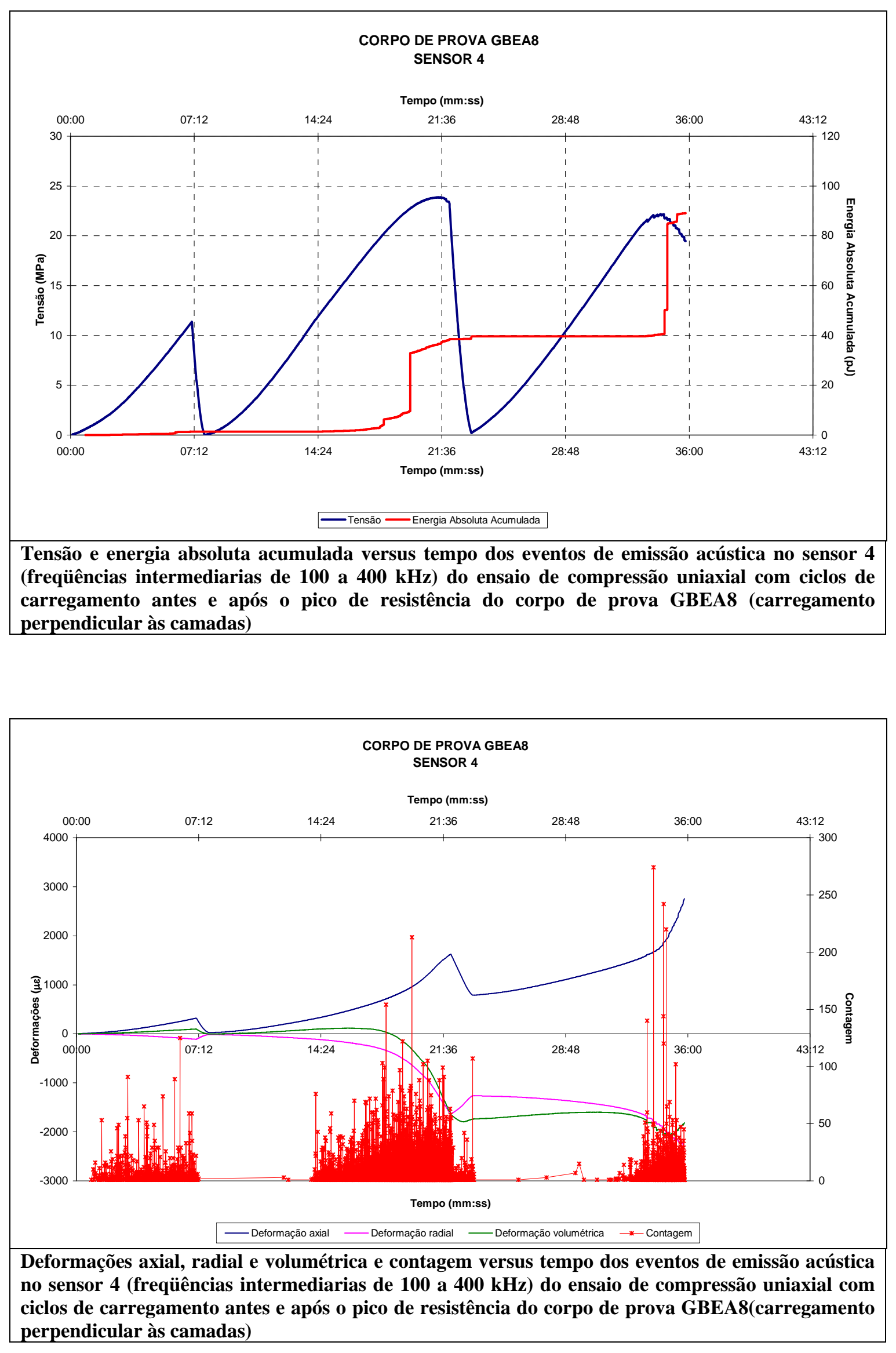


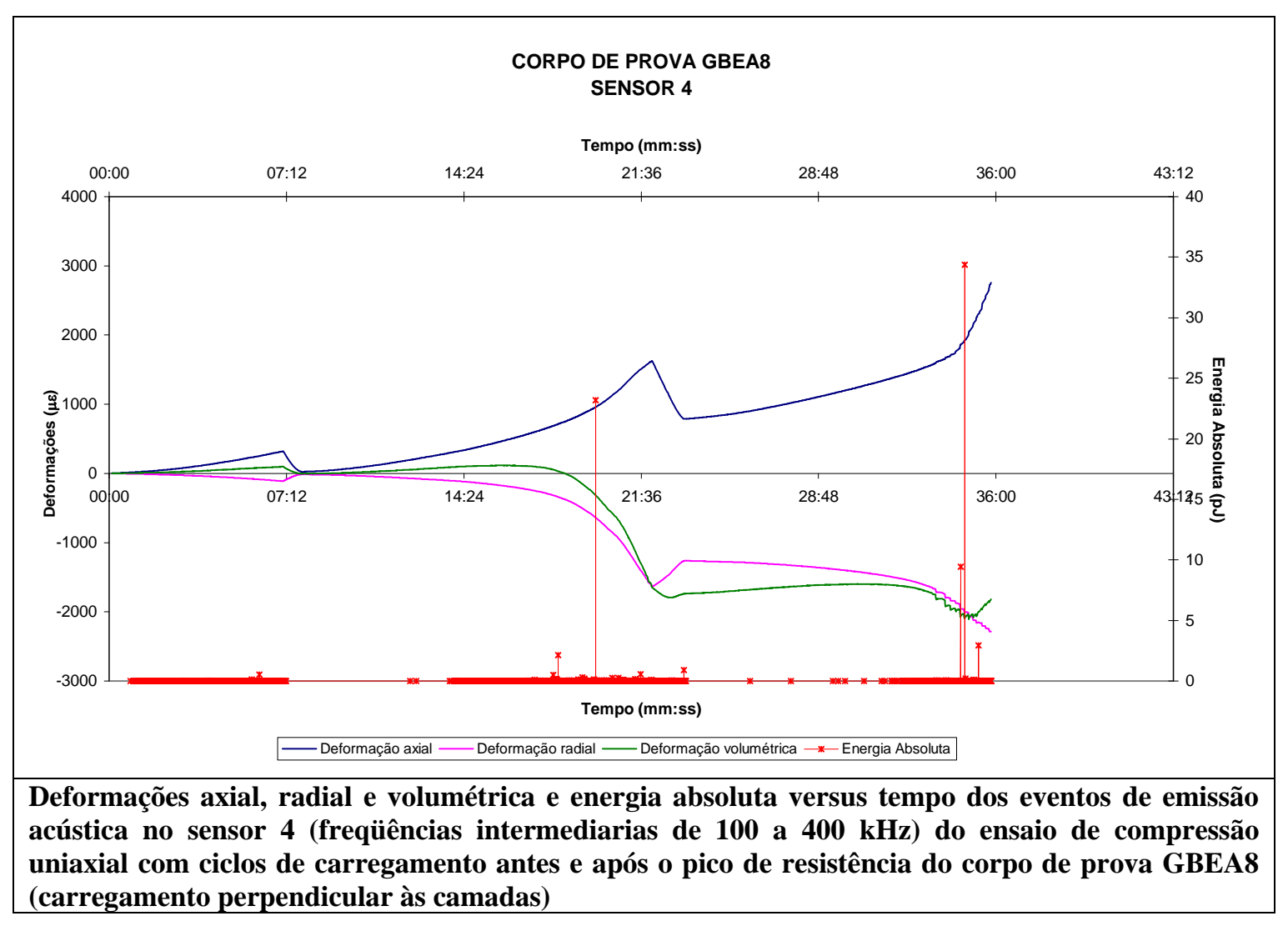



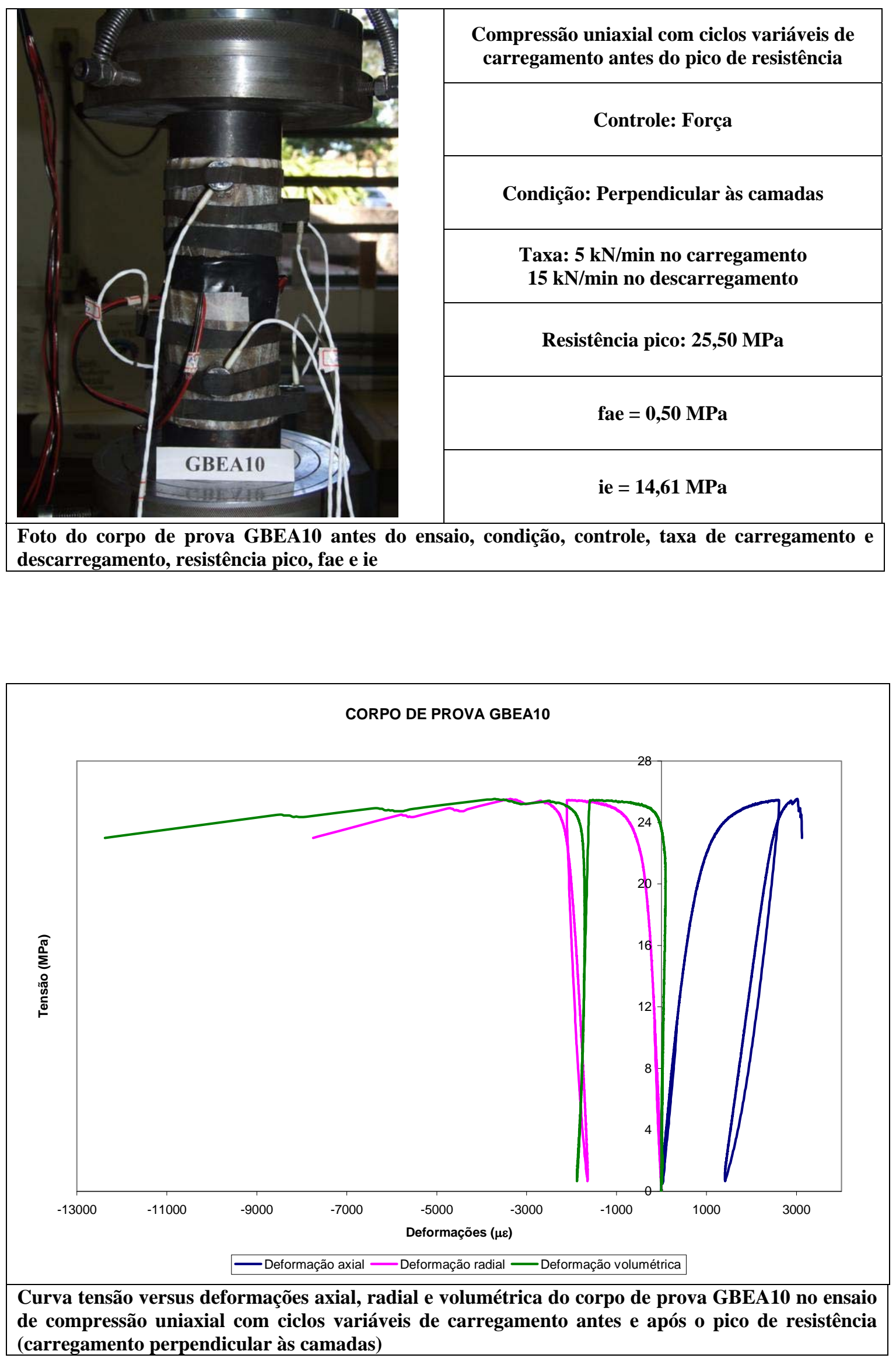

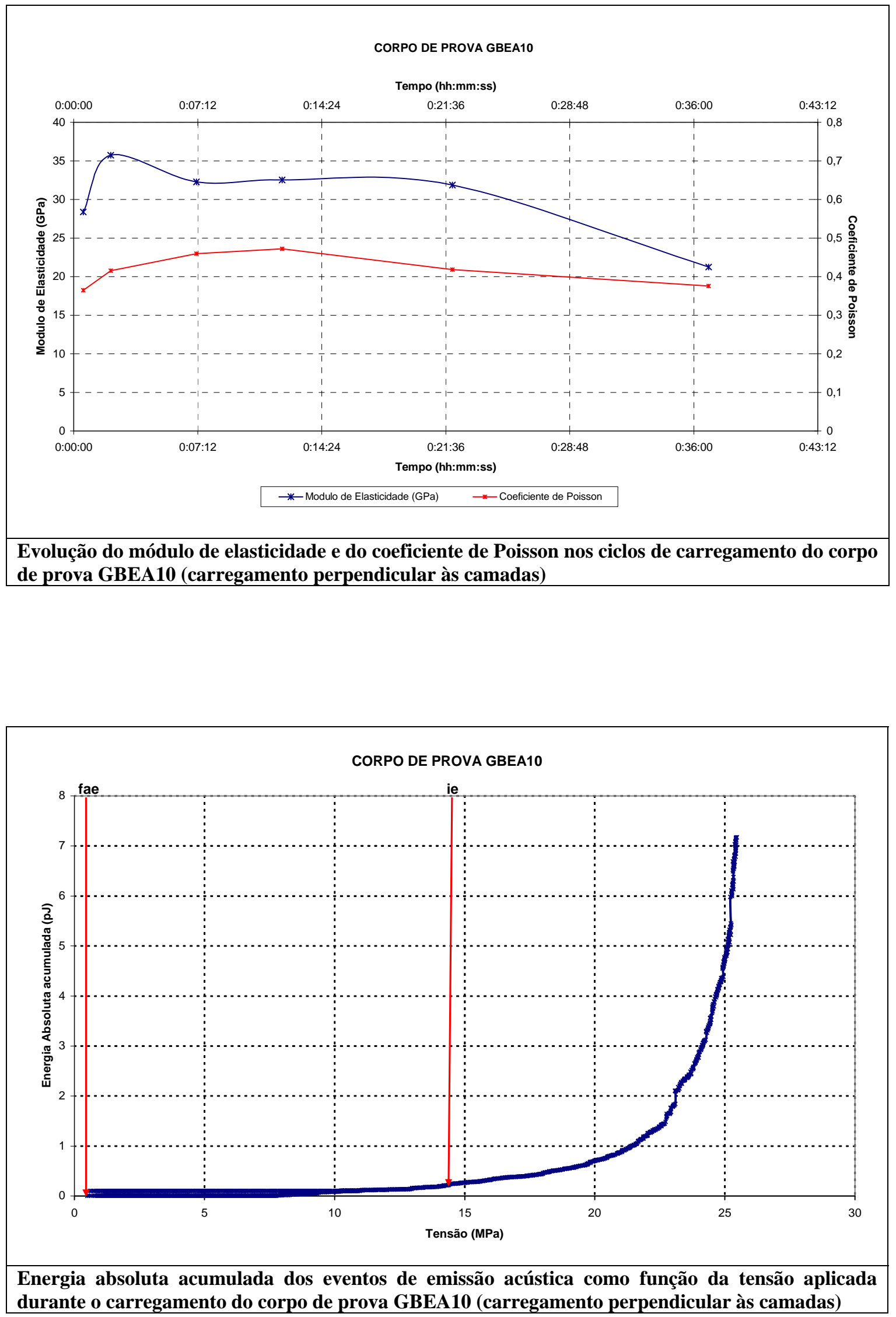

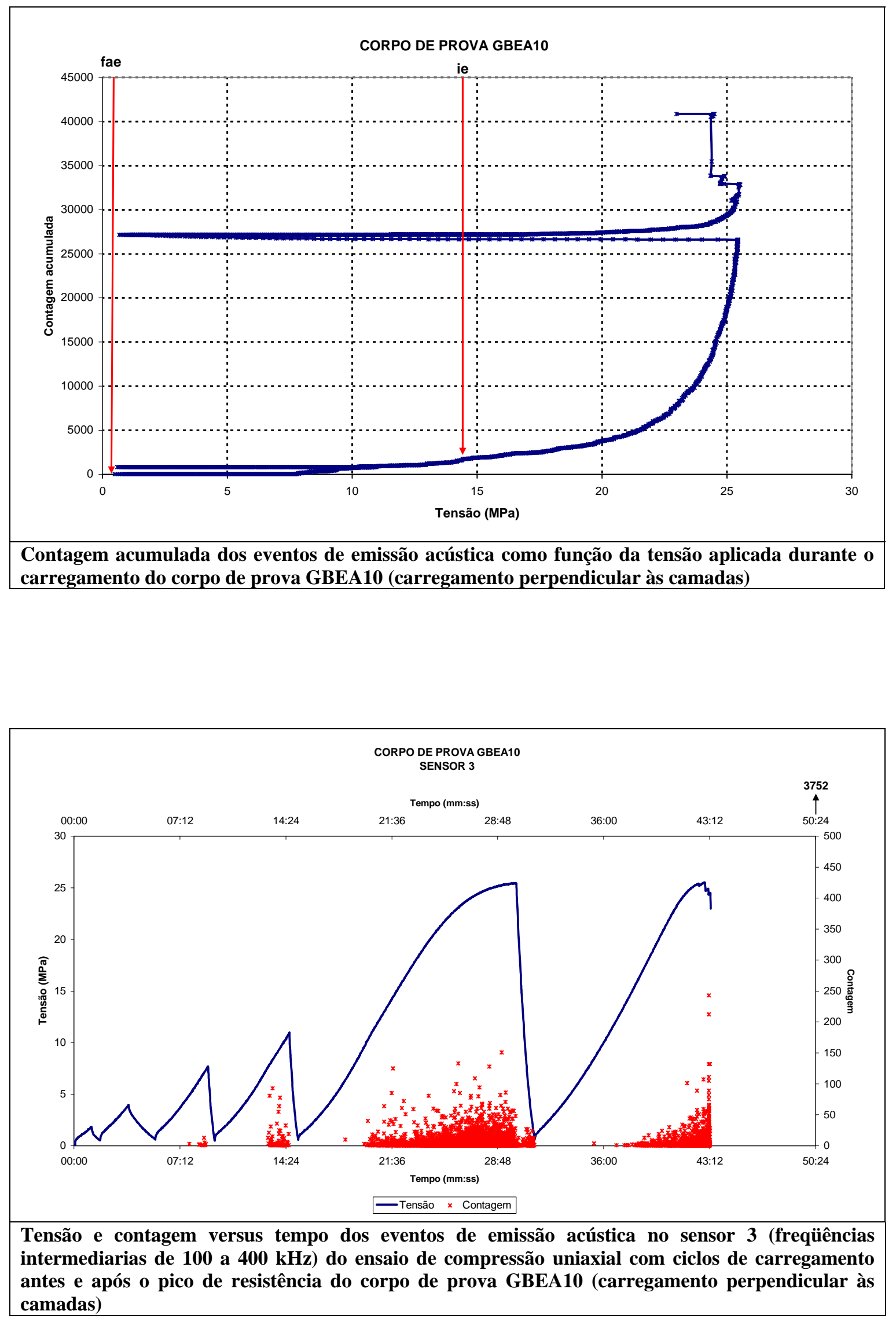

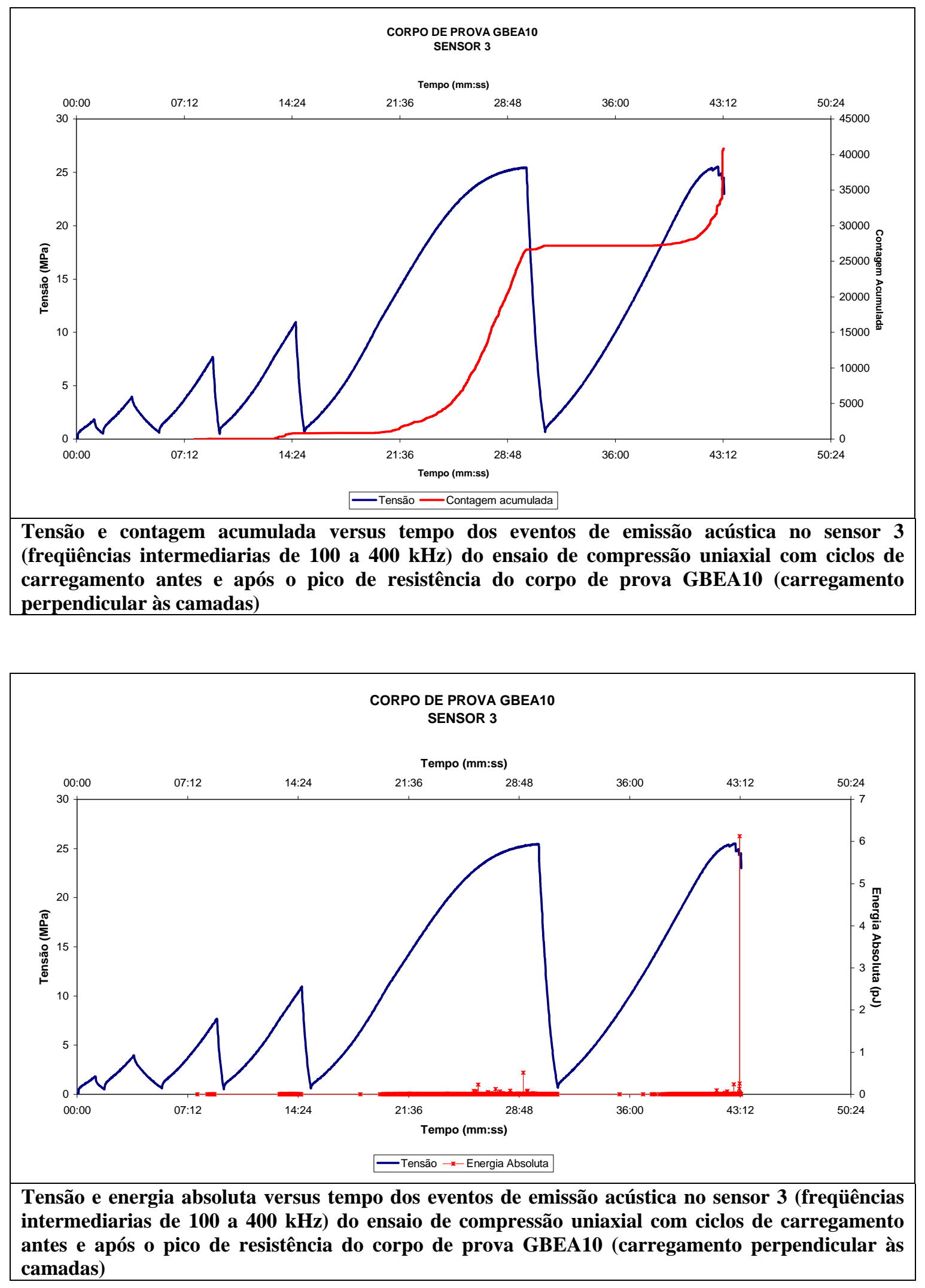

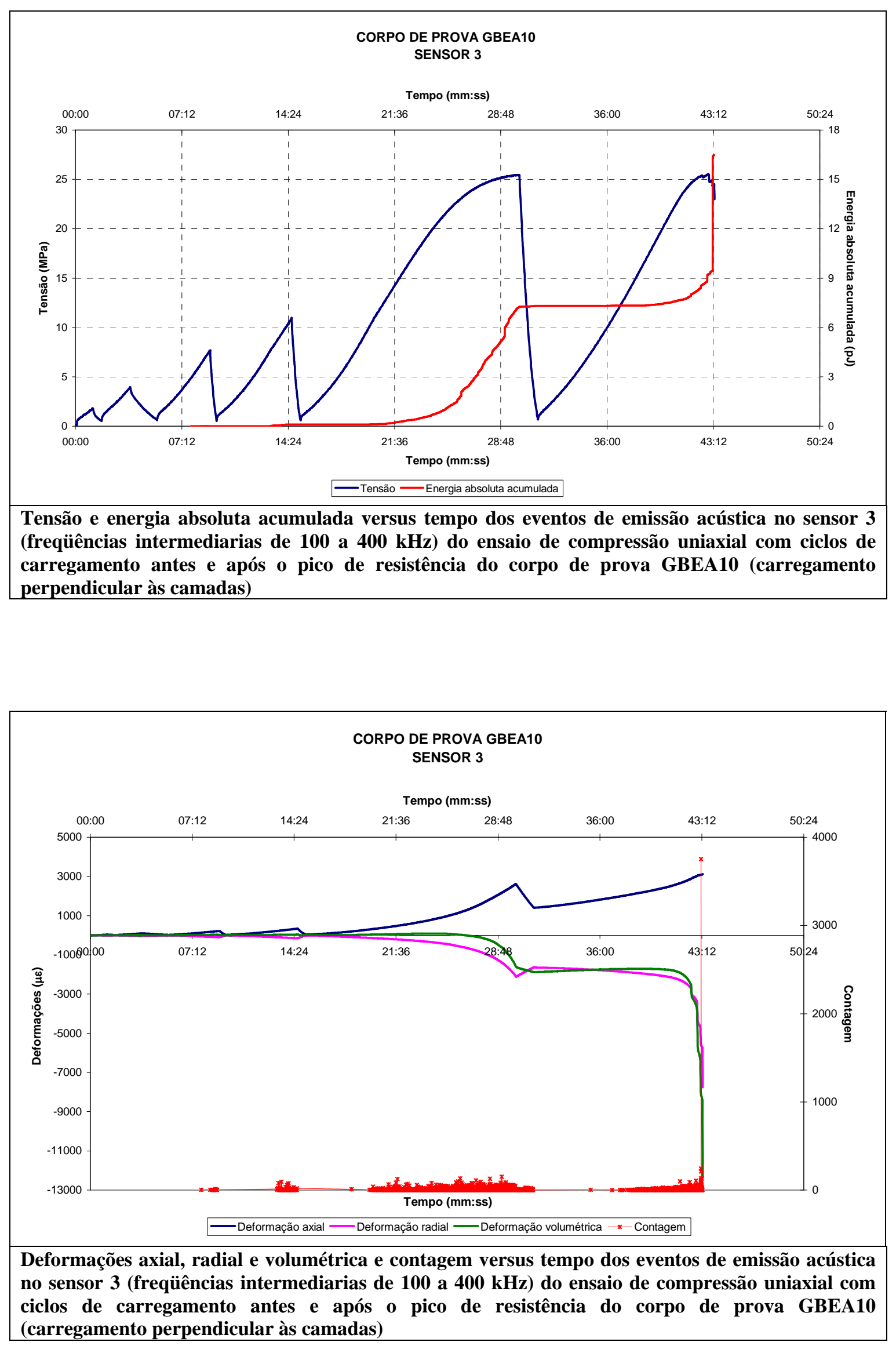


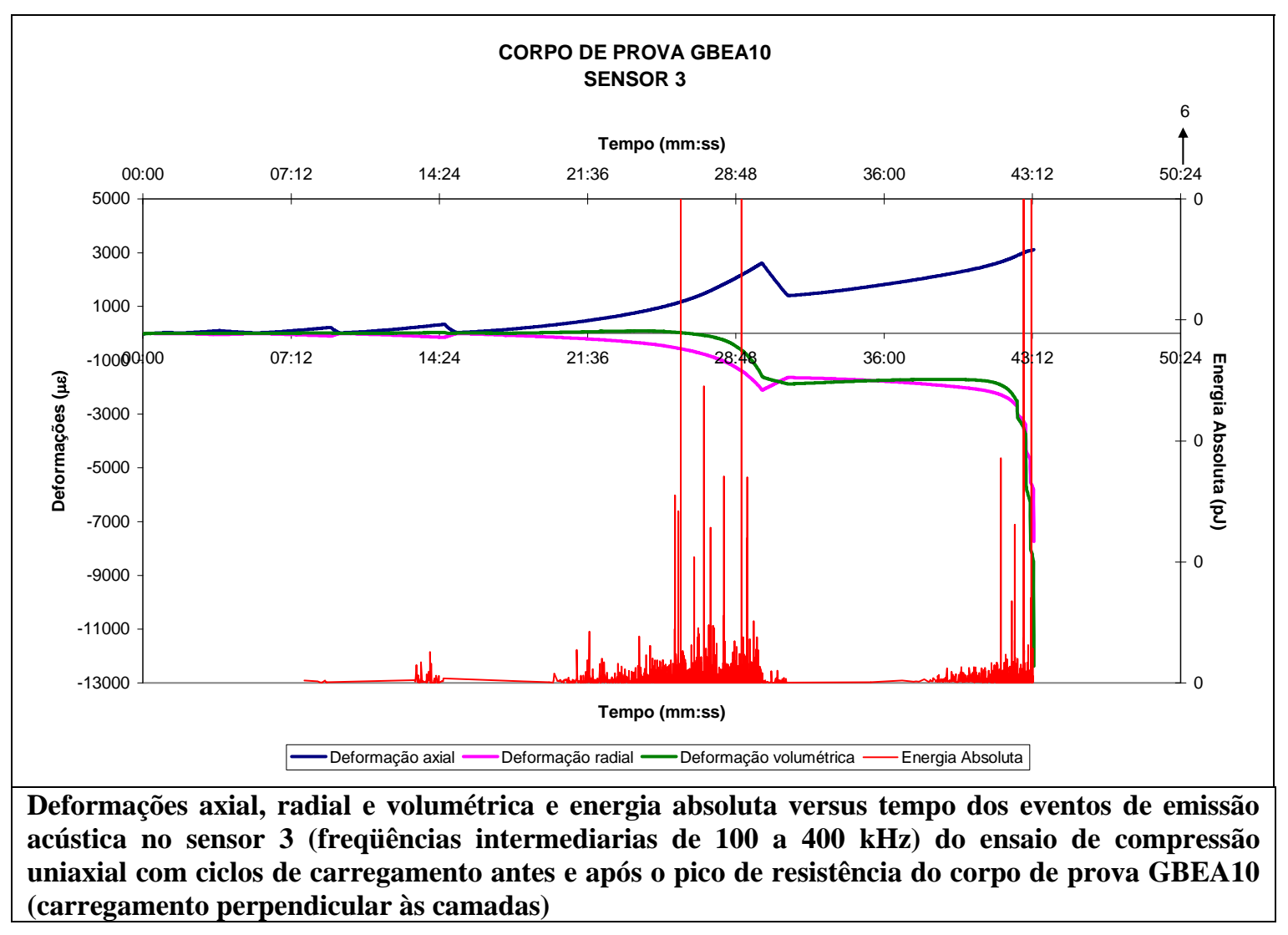




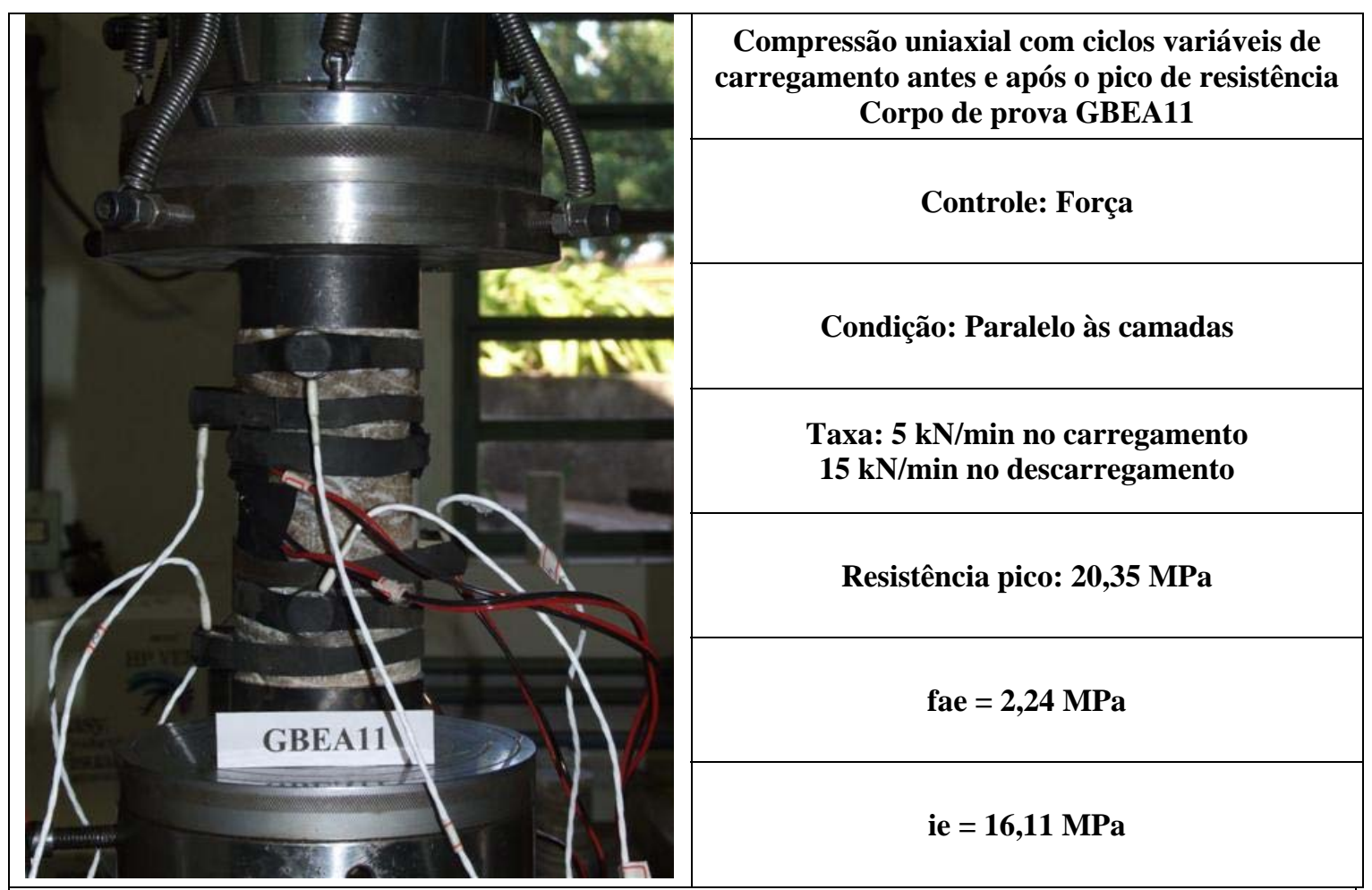

Foto do corpo de prova GBEA11 antes do ensaio, condição, controle, taxa de carregamento e descarregamento, resistência pico, fae e ie

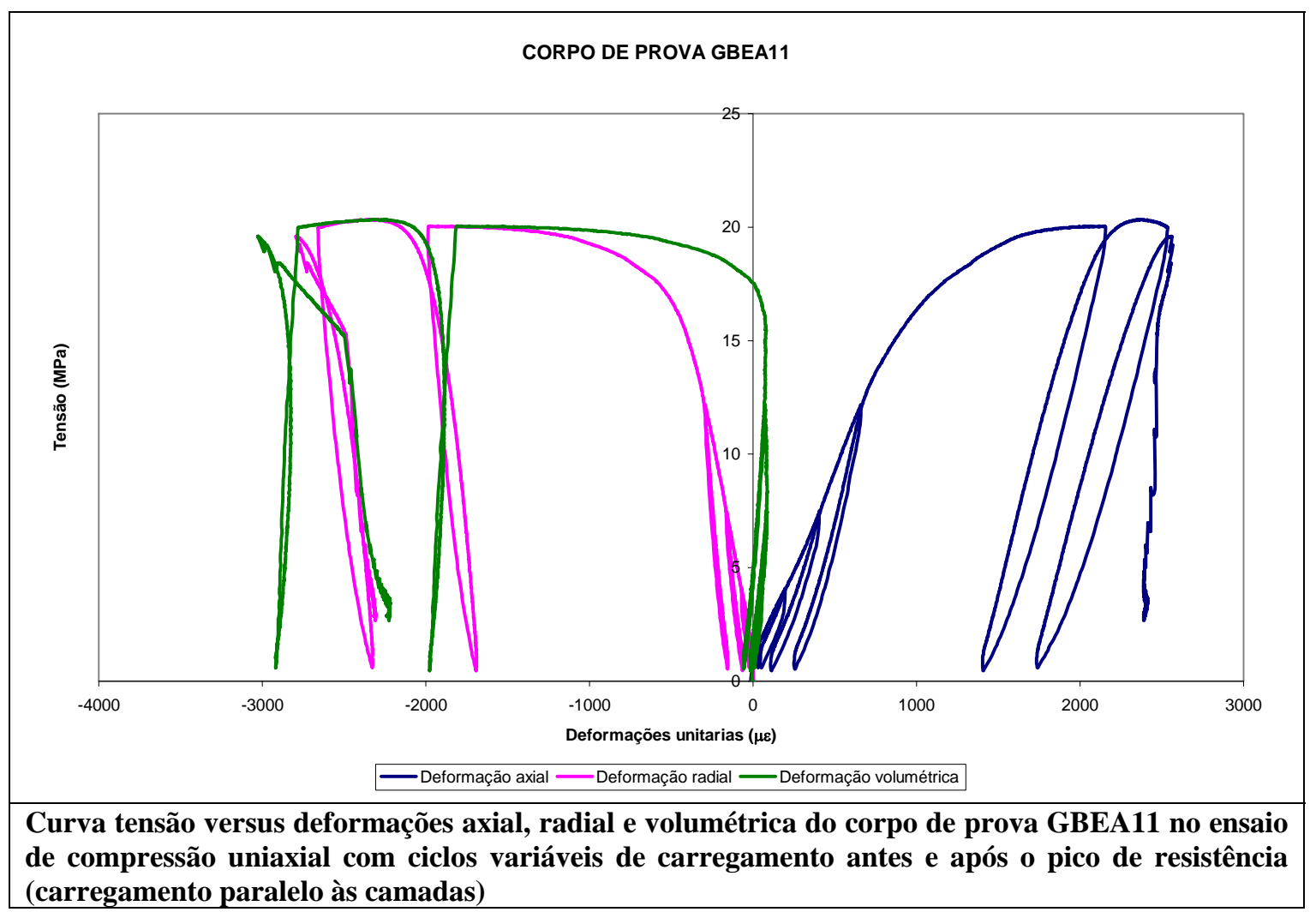



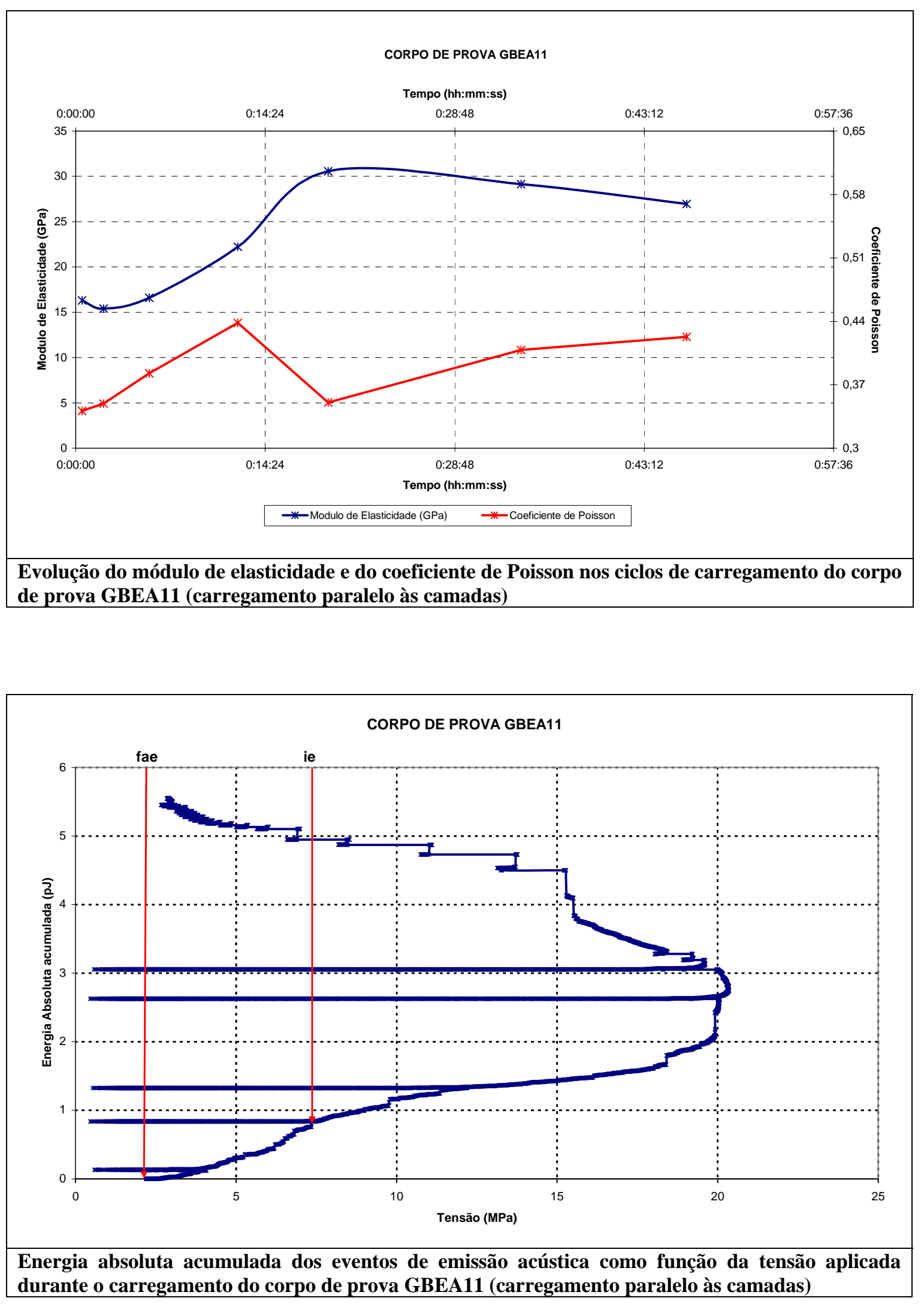

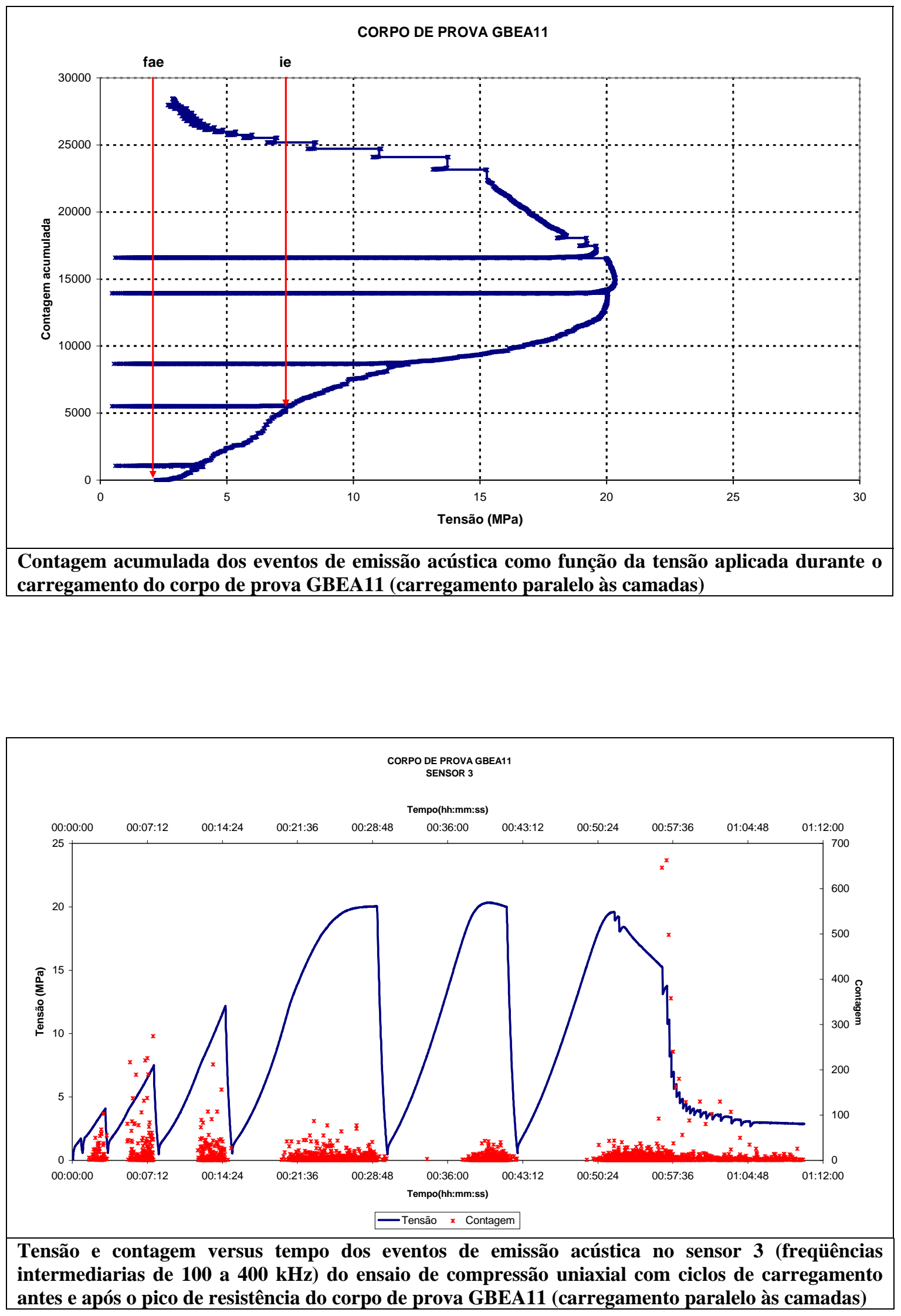

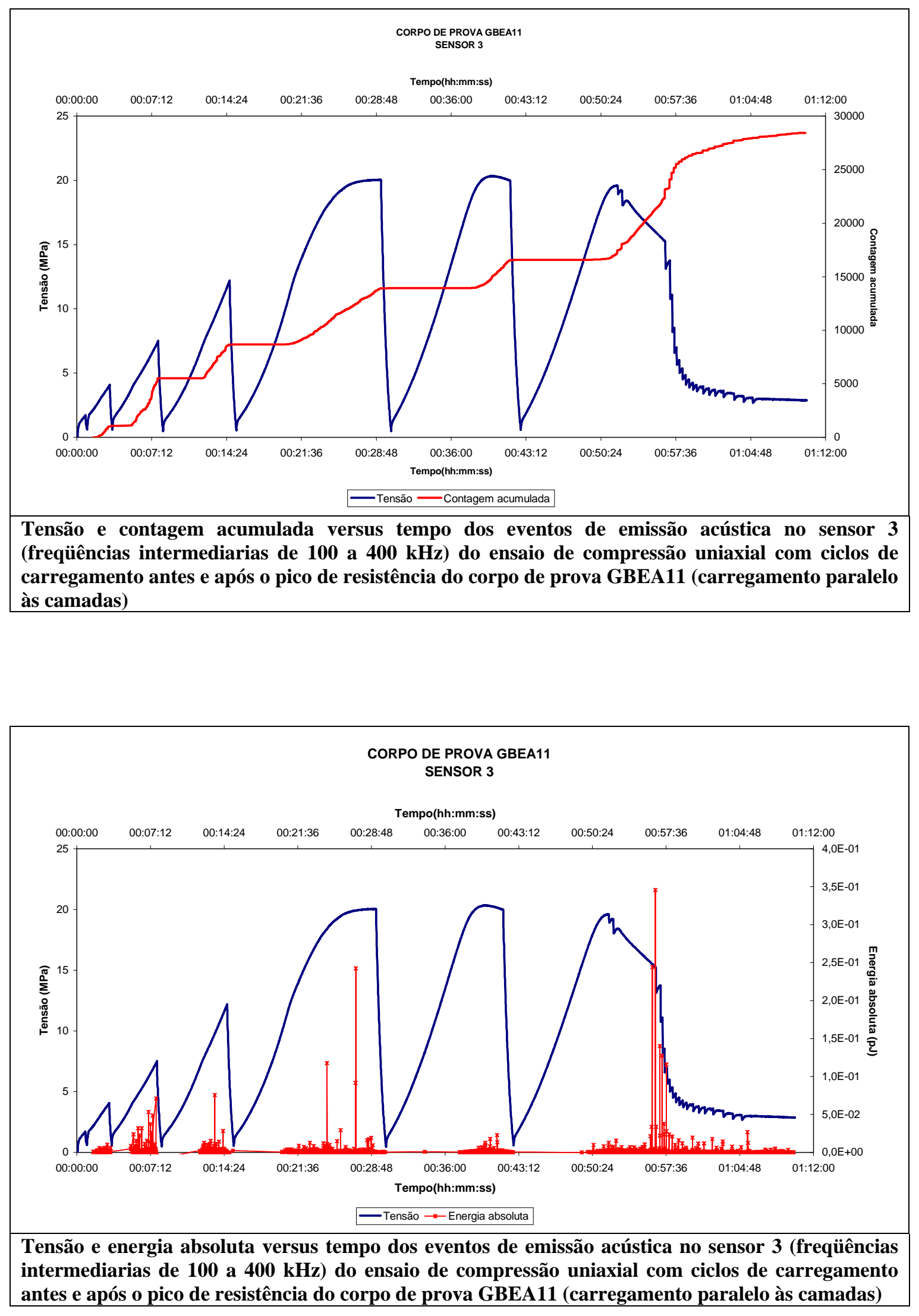

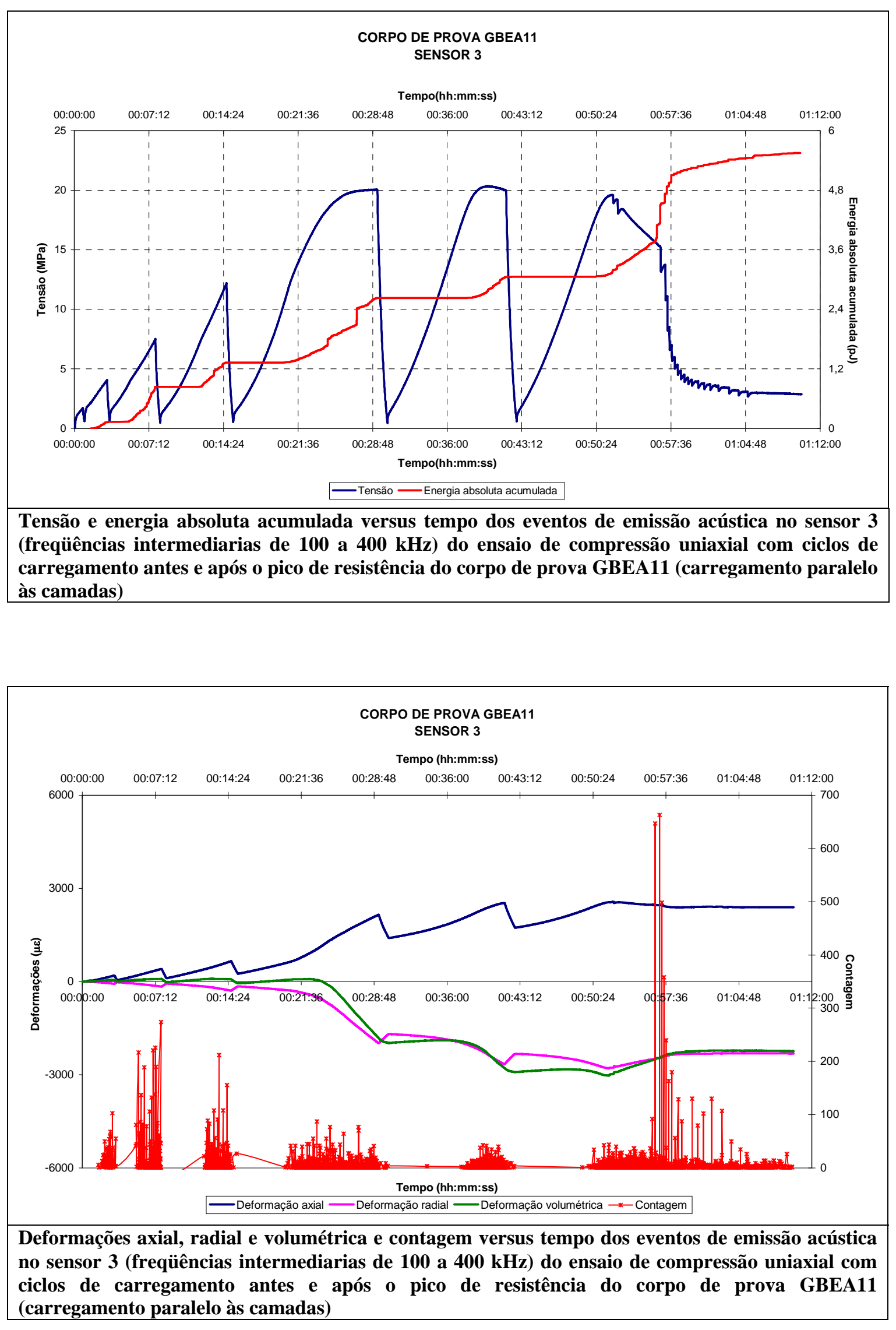


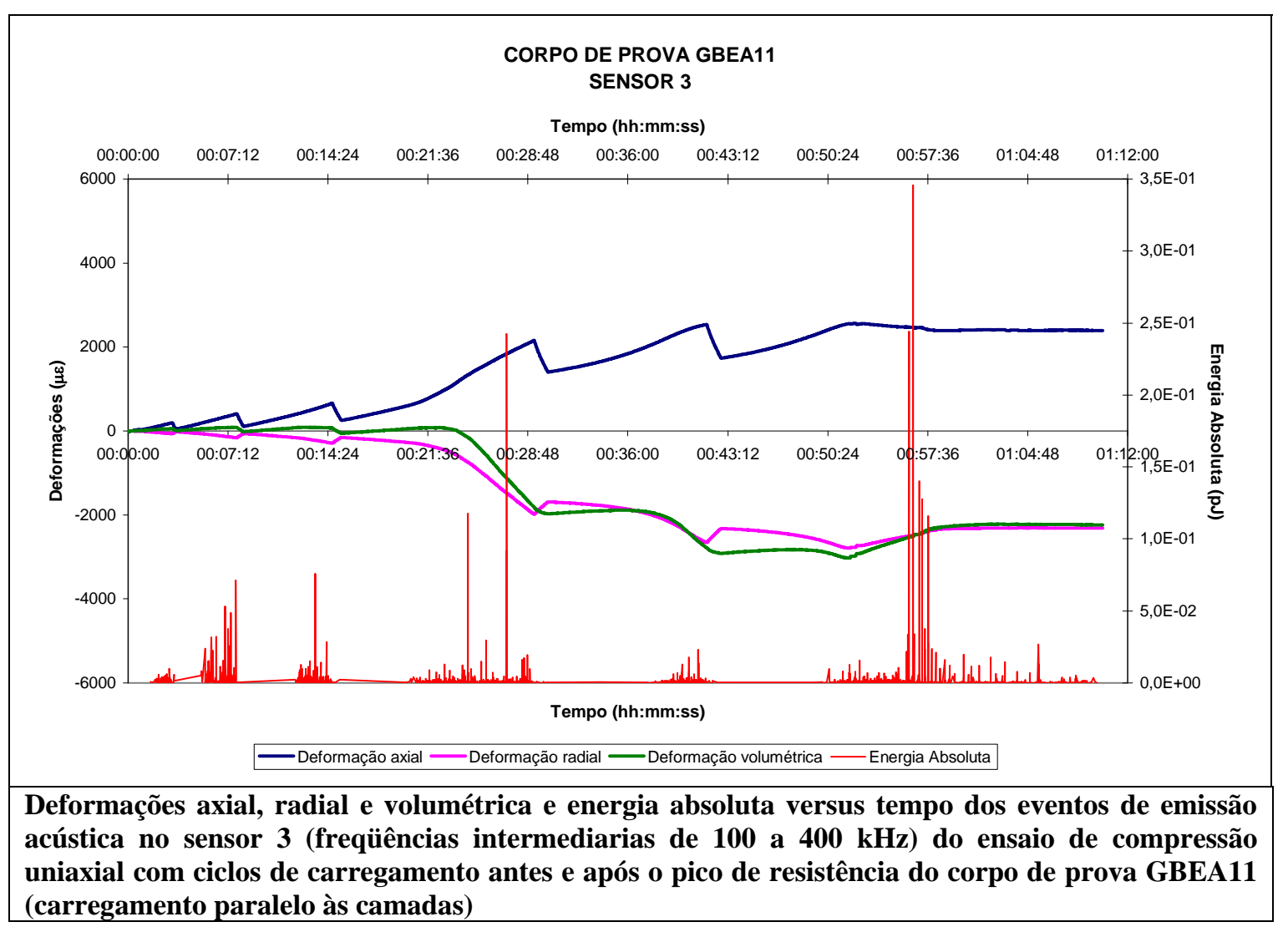




\section{Apêndice 3}

ENSAIOS DE FLUÊNCIA DE CURTA DURAÇÃO 


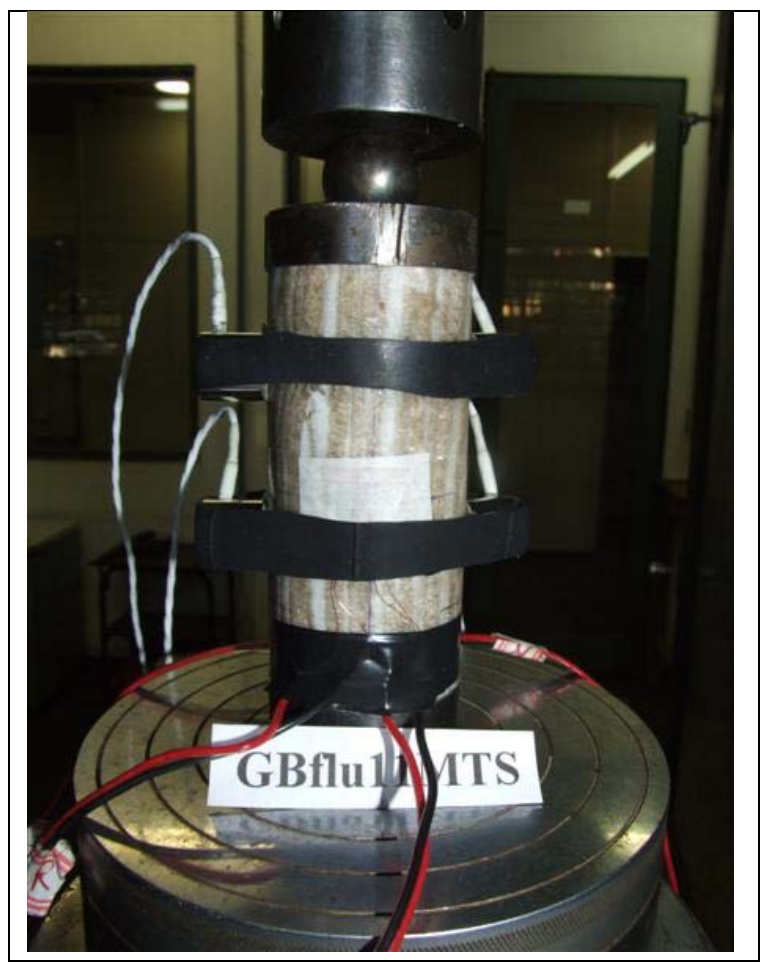

\begin{tabular}{|c|}
\hline $\begin{array}{c}\text { Ensaio de fluência de curta duração } \\
\text { Corpo de prova GBflu11MTS }\end{array}$ \\
\hline Condição: Paralela às camadas \\
Duração do ensaio: 22 horas \\
\hline Tensão aplicada: 22,78 MPa \\
\hline \% em relação à tensão de ruptura: 79,82 \\
\hline Tensão de ruptura: 28,54 MPa \\
\hline
\end{tabular}

aplicada, percentagem em relação à tensão de ruptura e tensão de ruptura

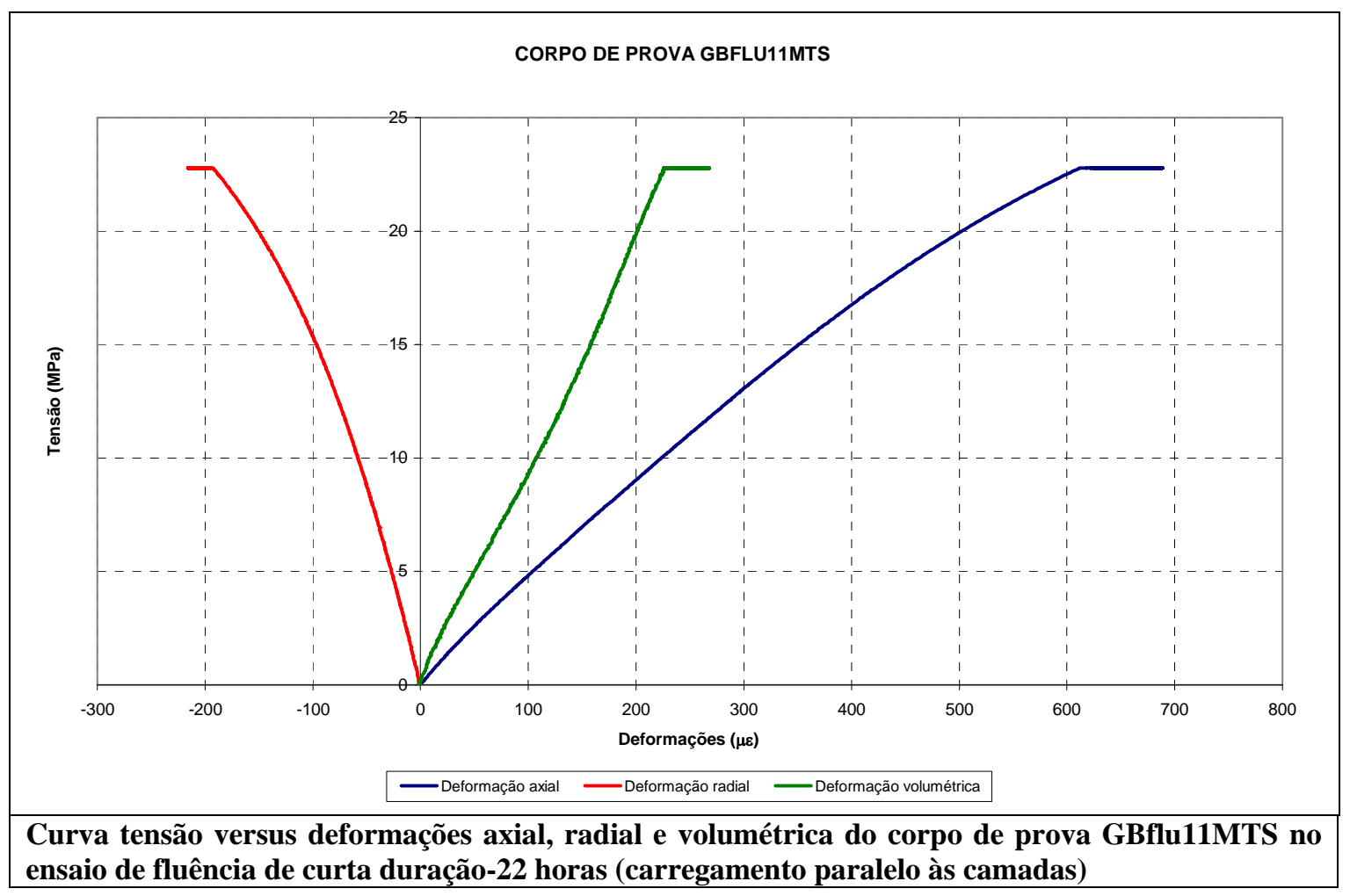



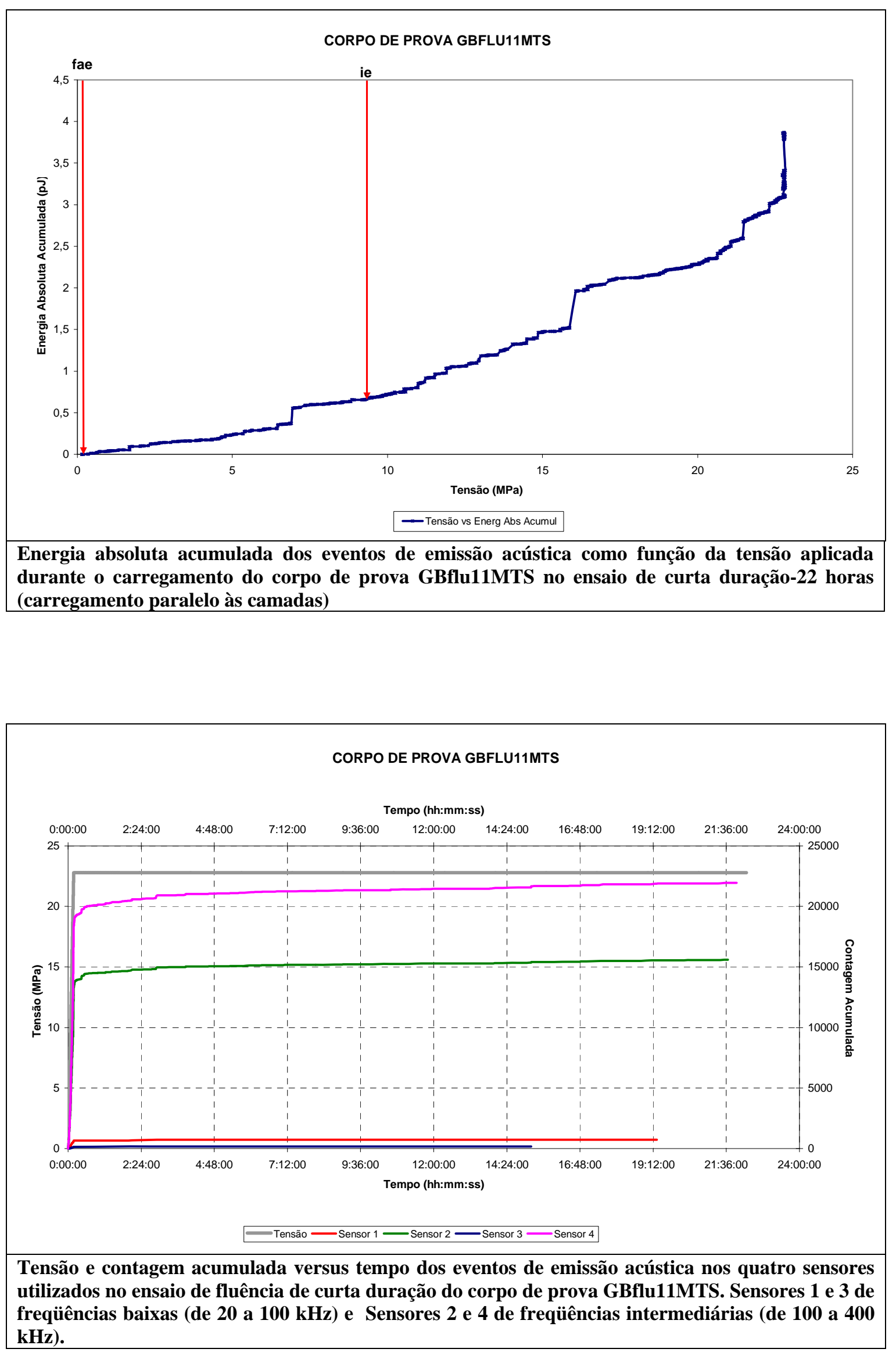

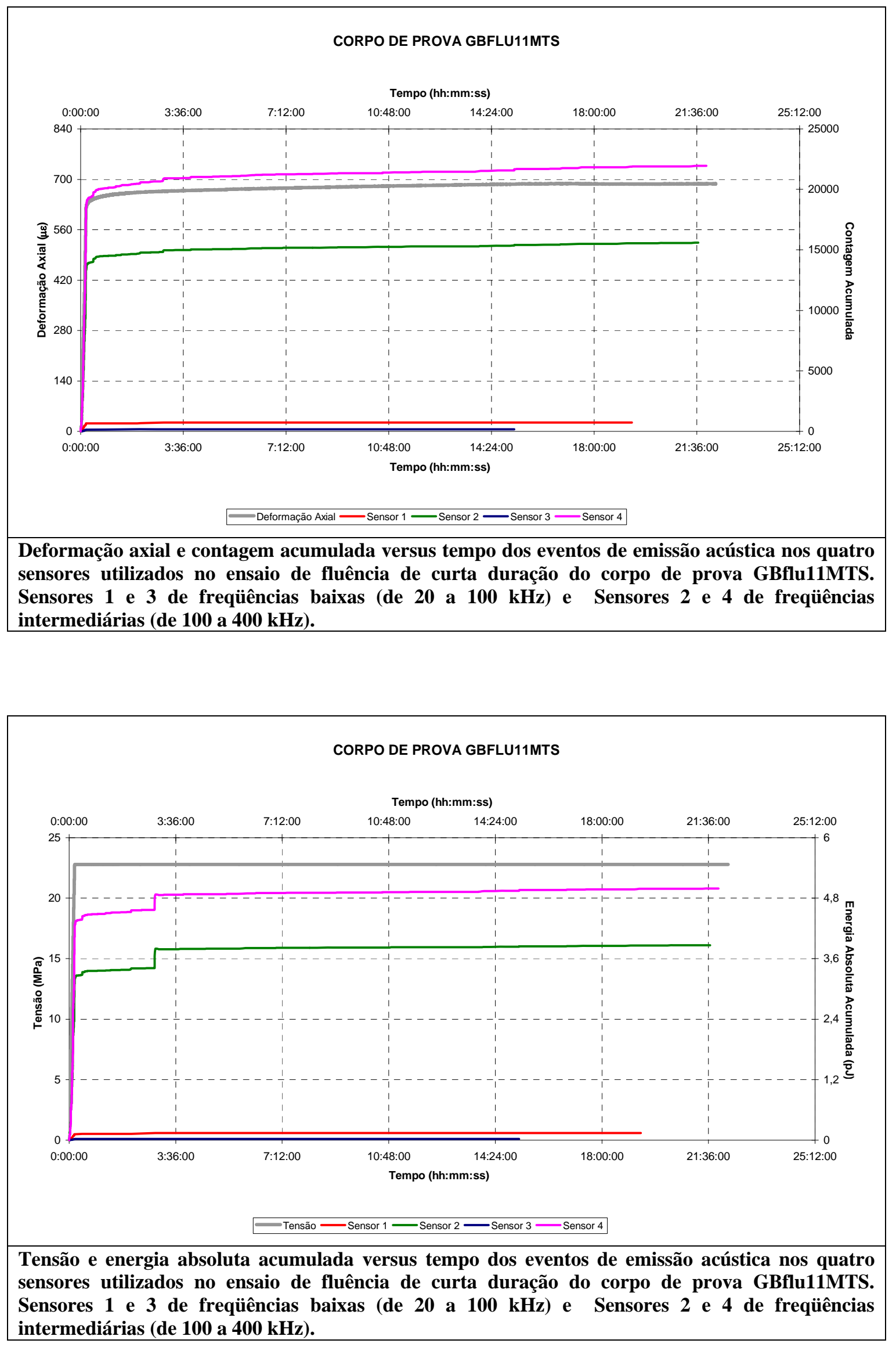

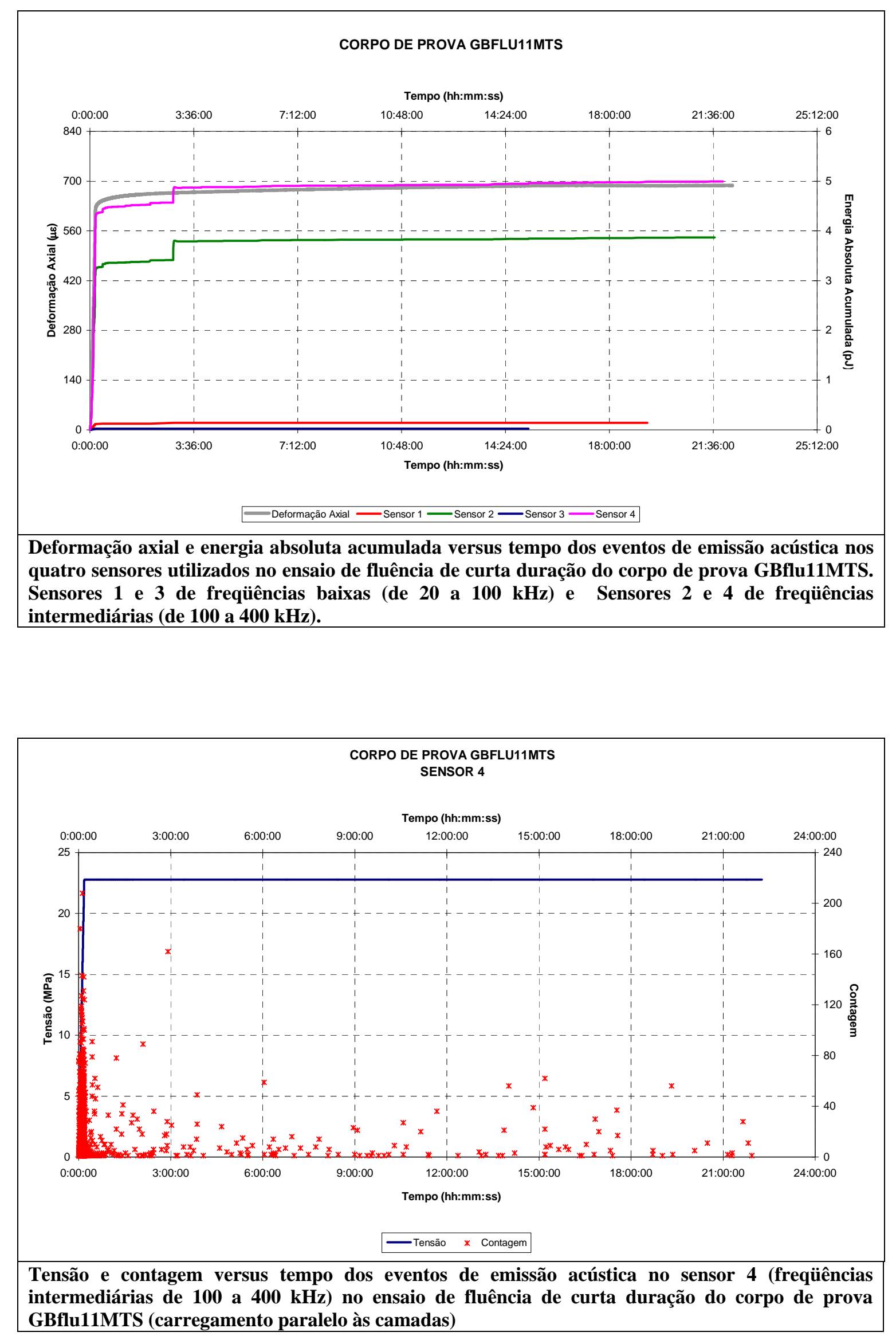

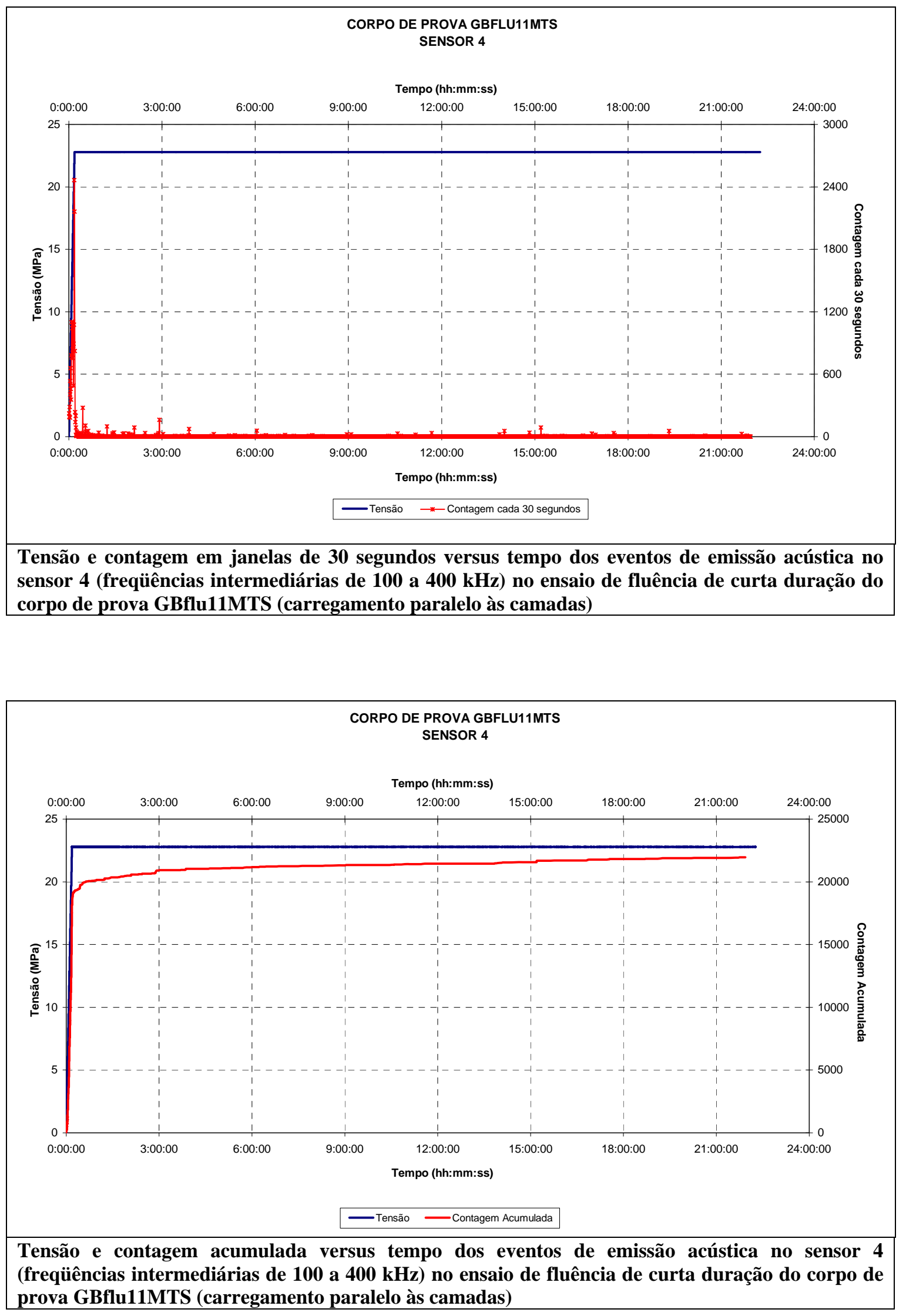

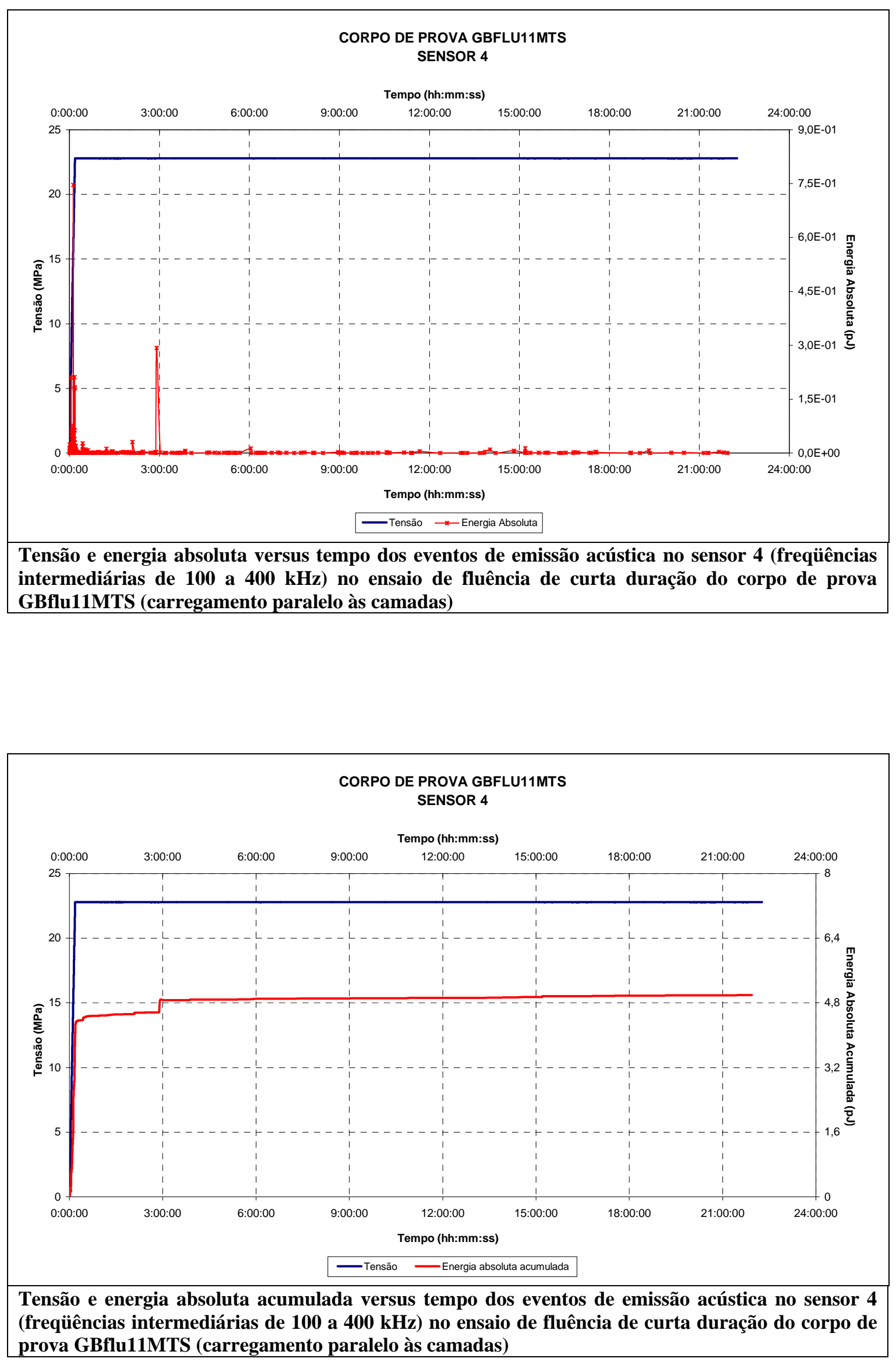


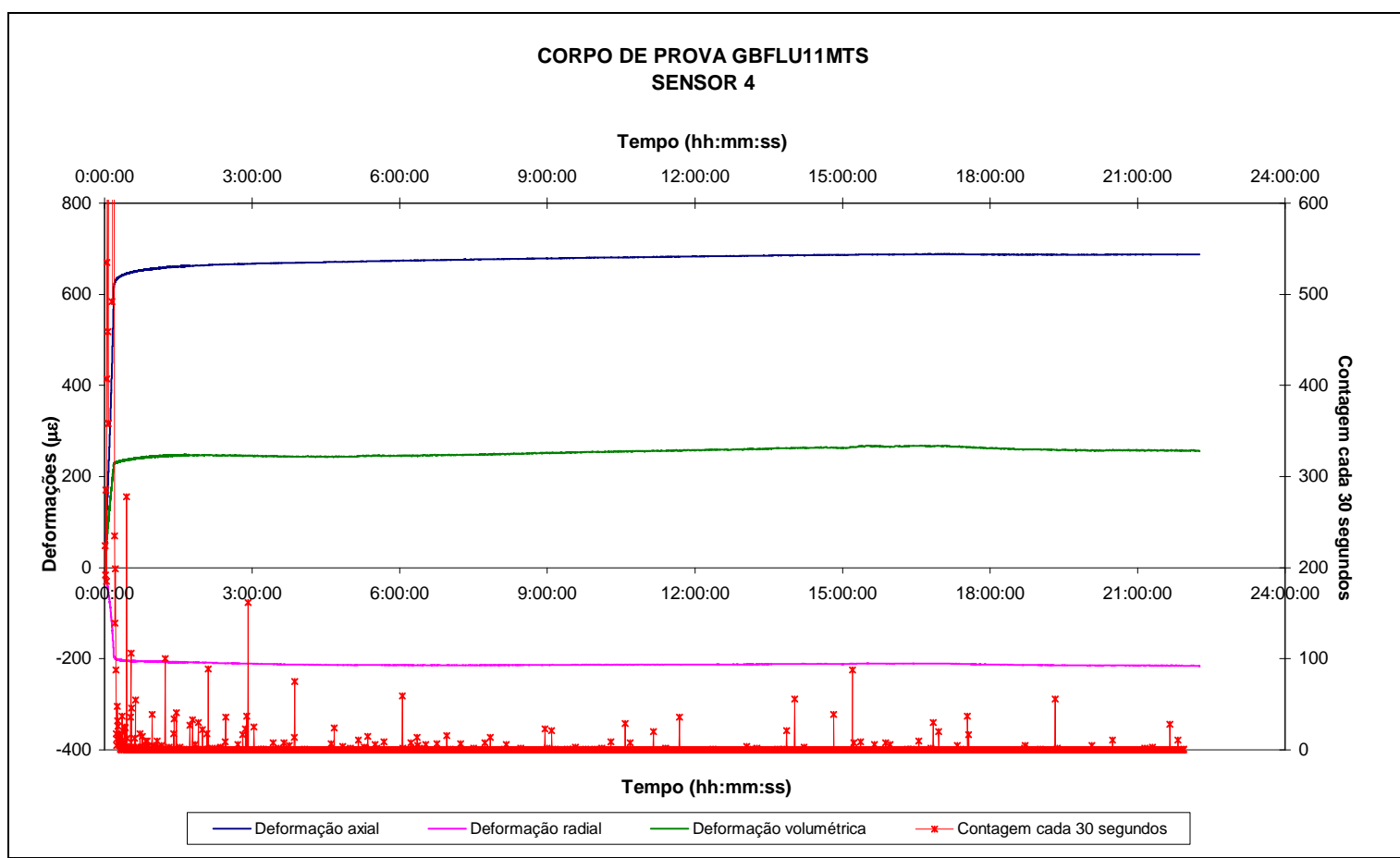

Deformações axial, radial e volumétrica e contagem em janelas de 30 segundos versus tempo dos eventos de emissão acústica no sensor 4 (freqüências intermediárias de 100 a $400 \mathrm{kHz}$ ) no ensaio de fluência de curta duração do corpo de prova GBflu11MTS (carregamento paralelo às camadas)

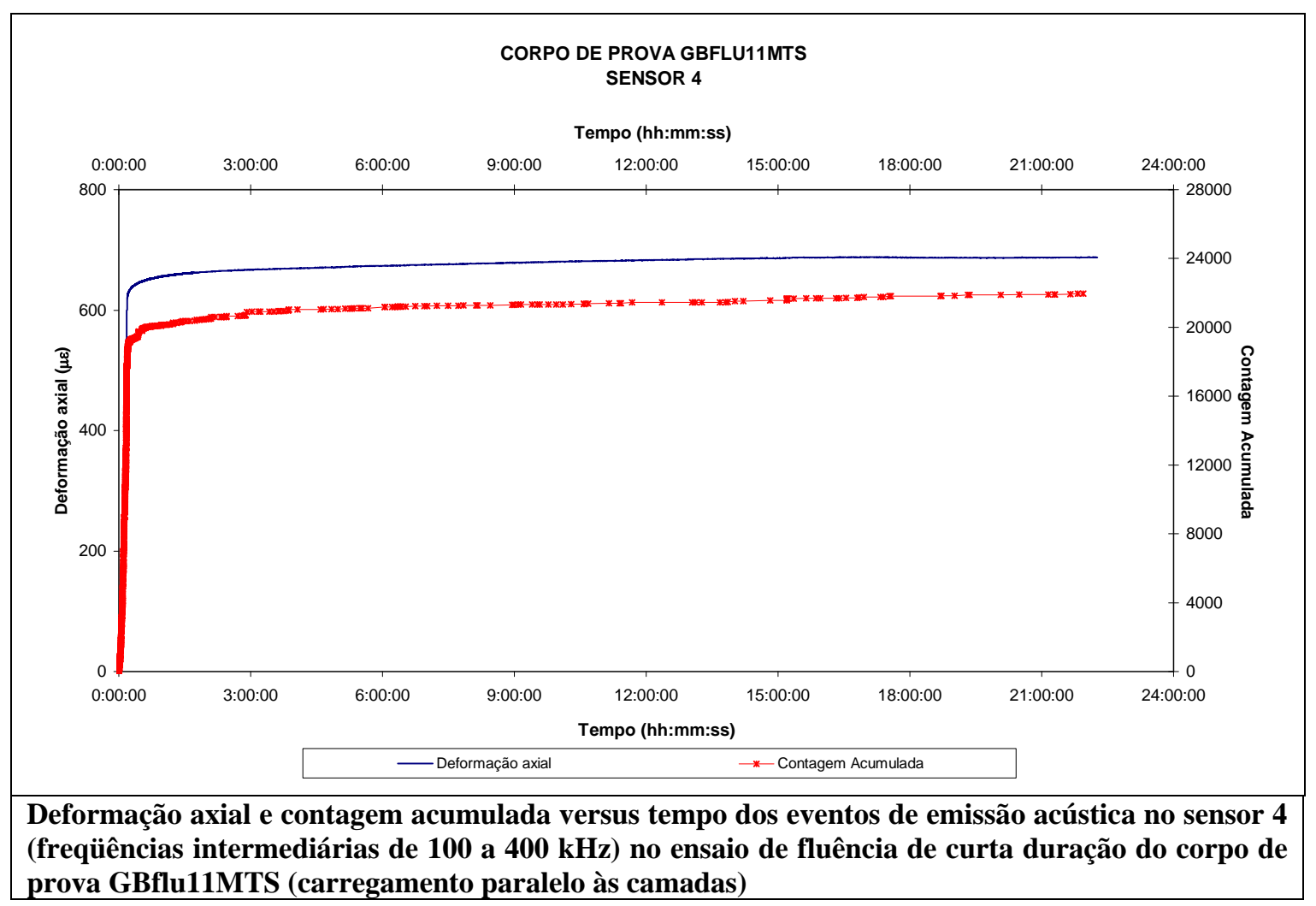



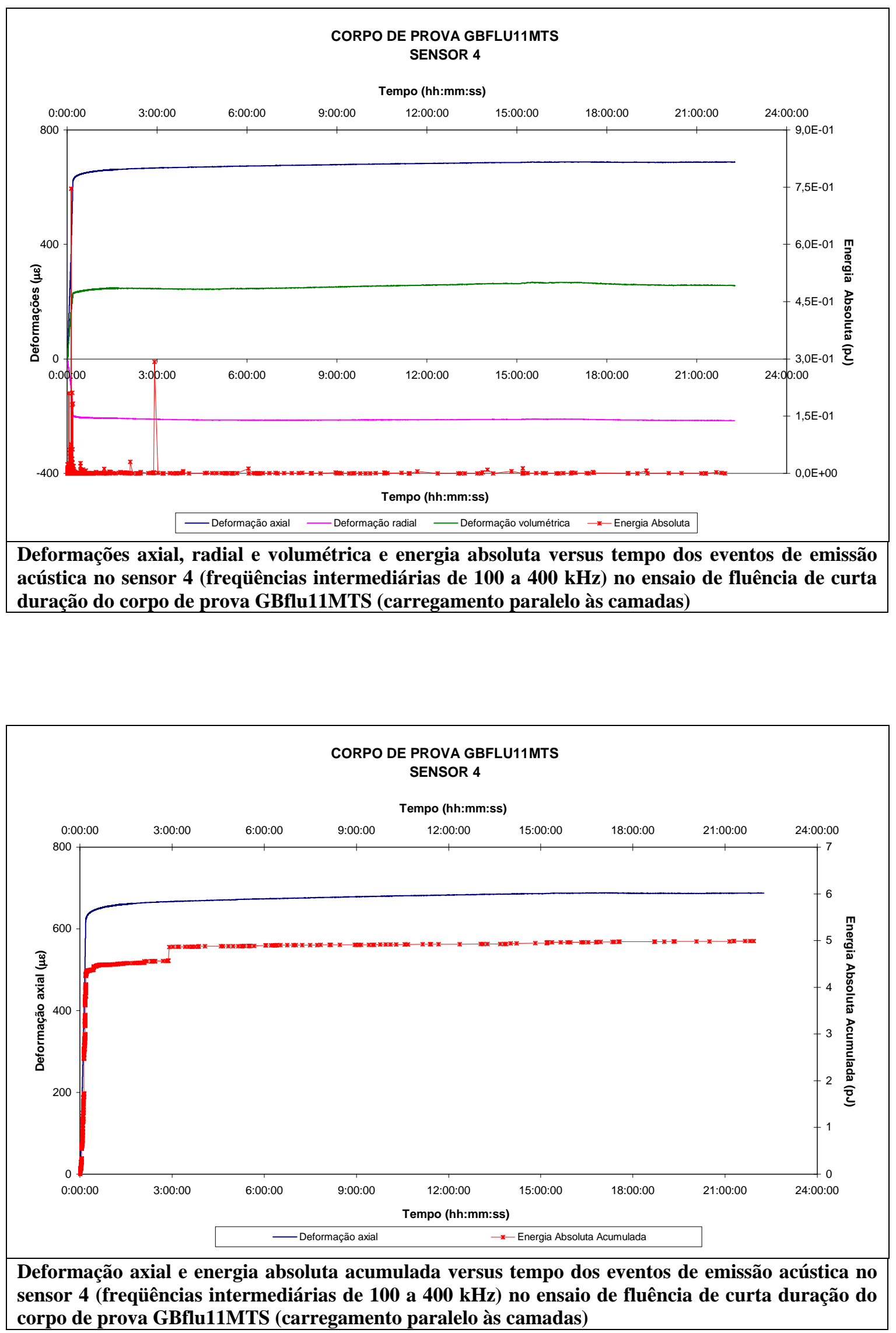

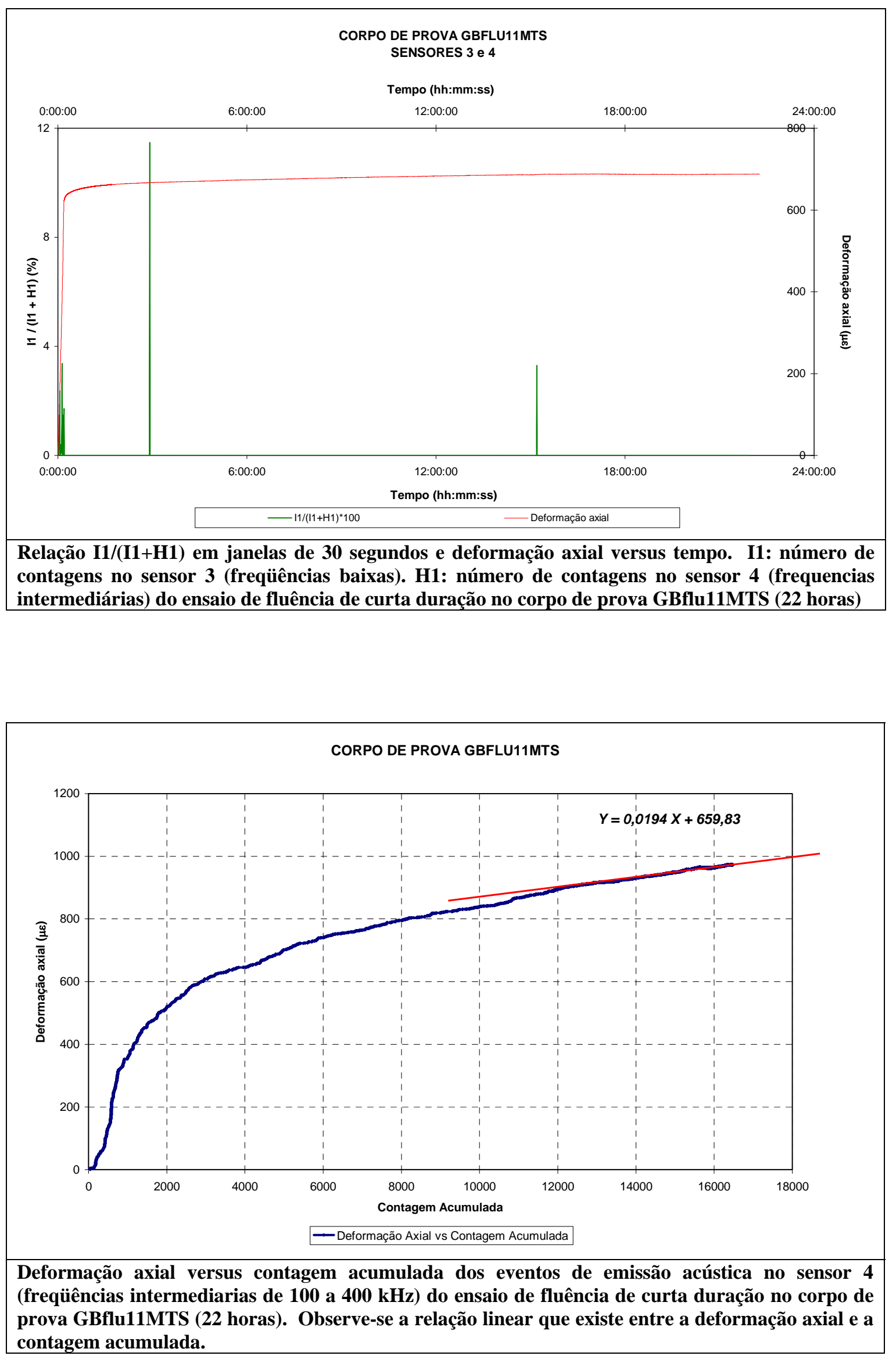

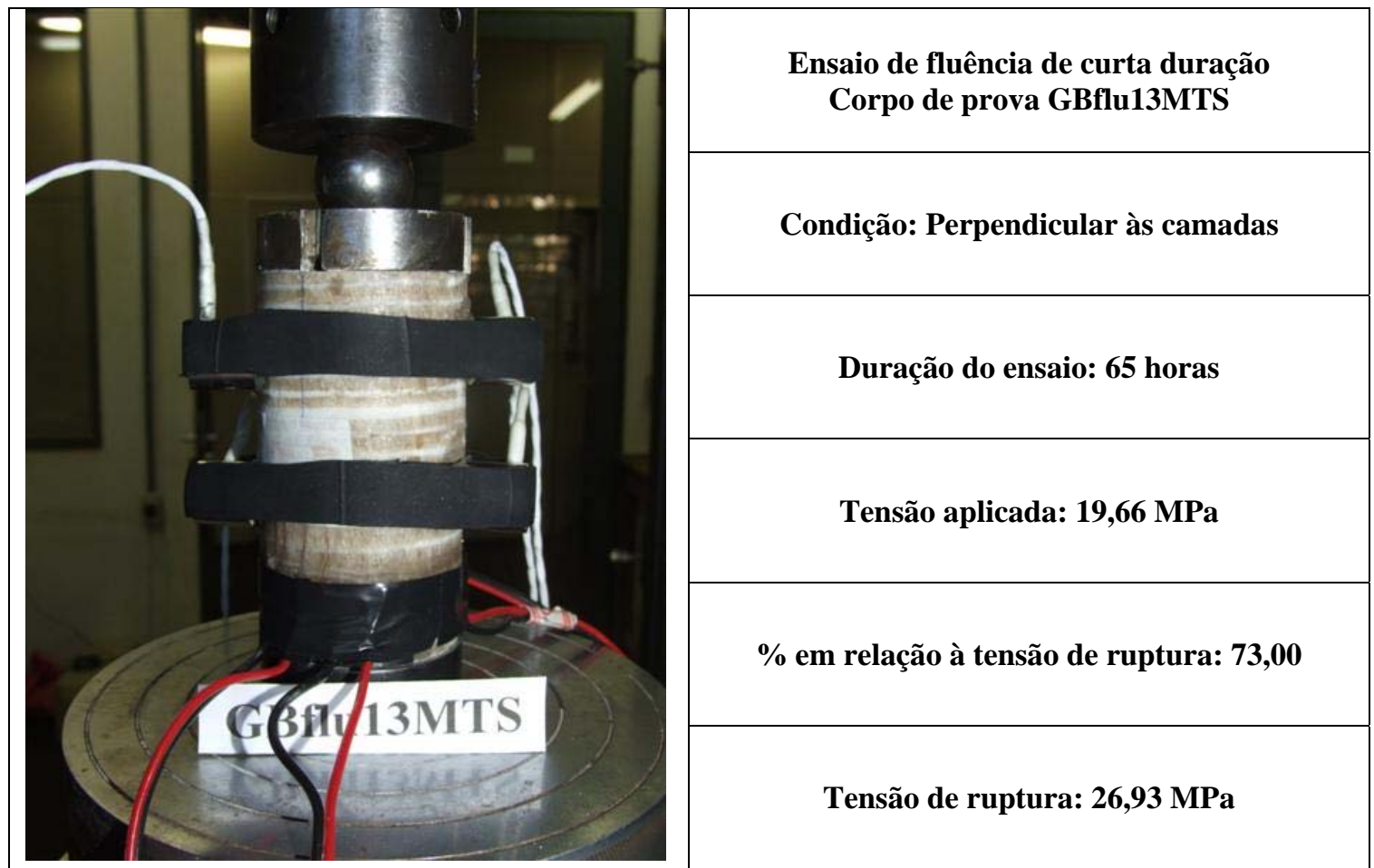

Foto do corpo de prova GBflu13MTS antes do ensaio, condição, duração do ensaio, tensão aplicada, percentagem em relação à tensão de ruptura e tensão de ruptura

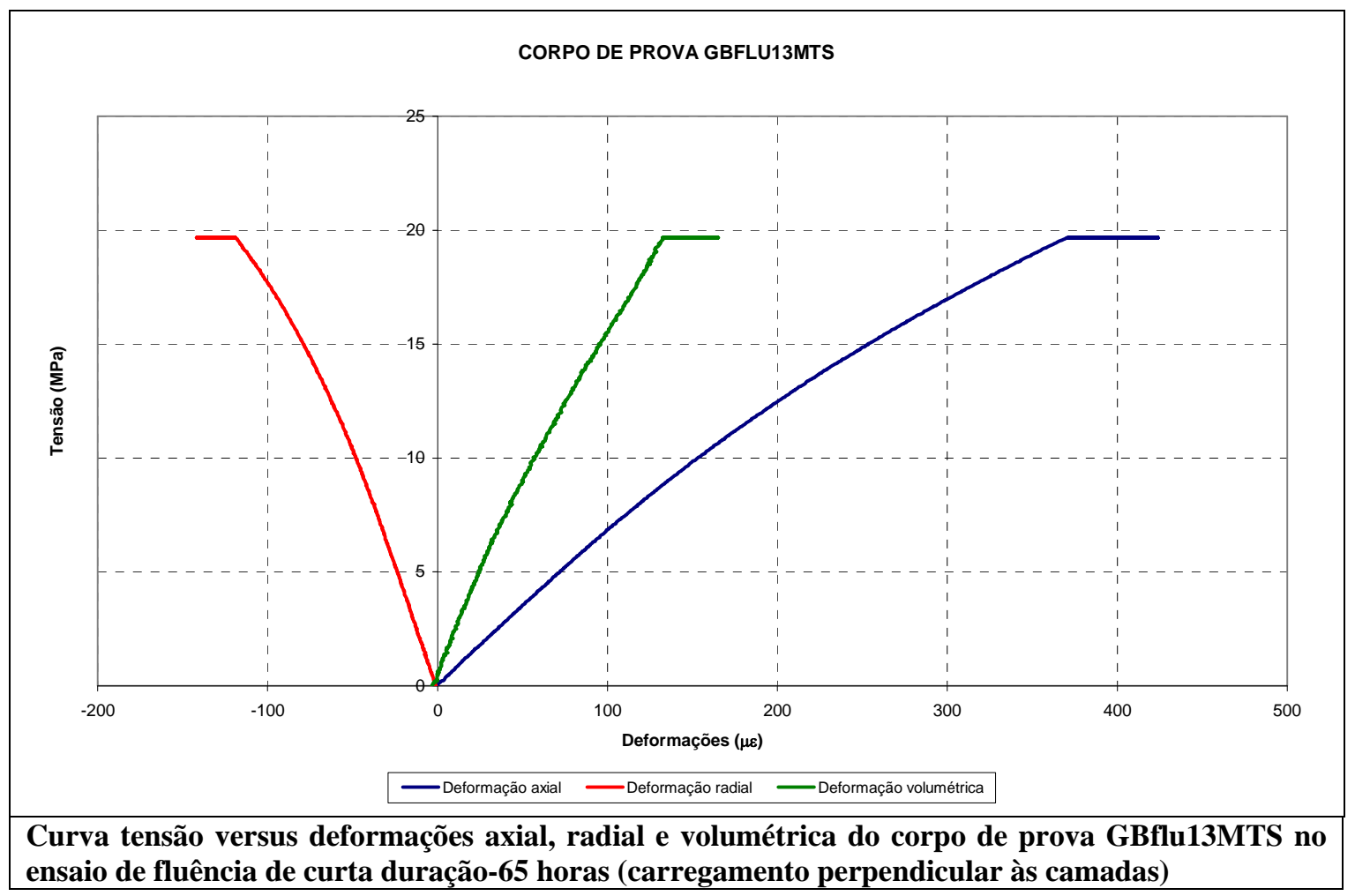



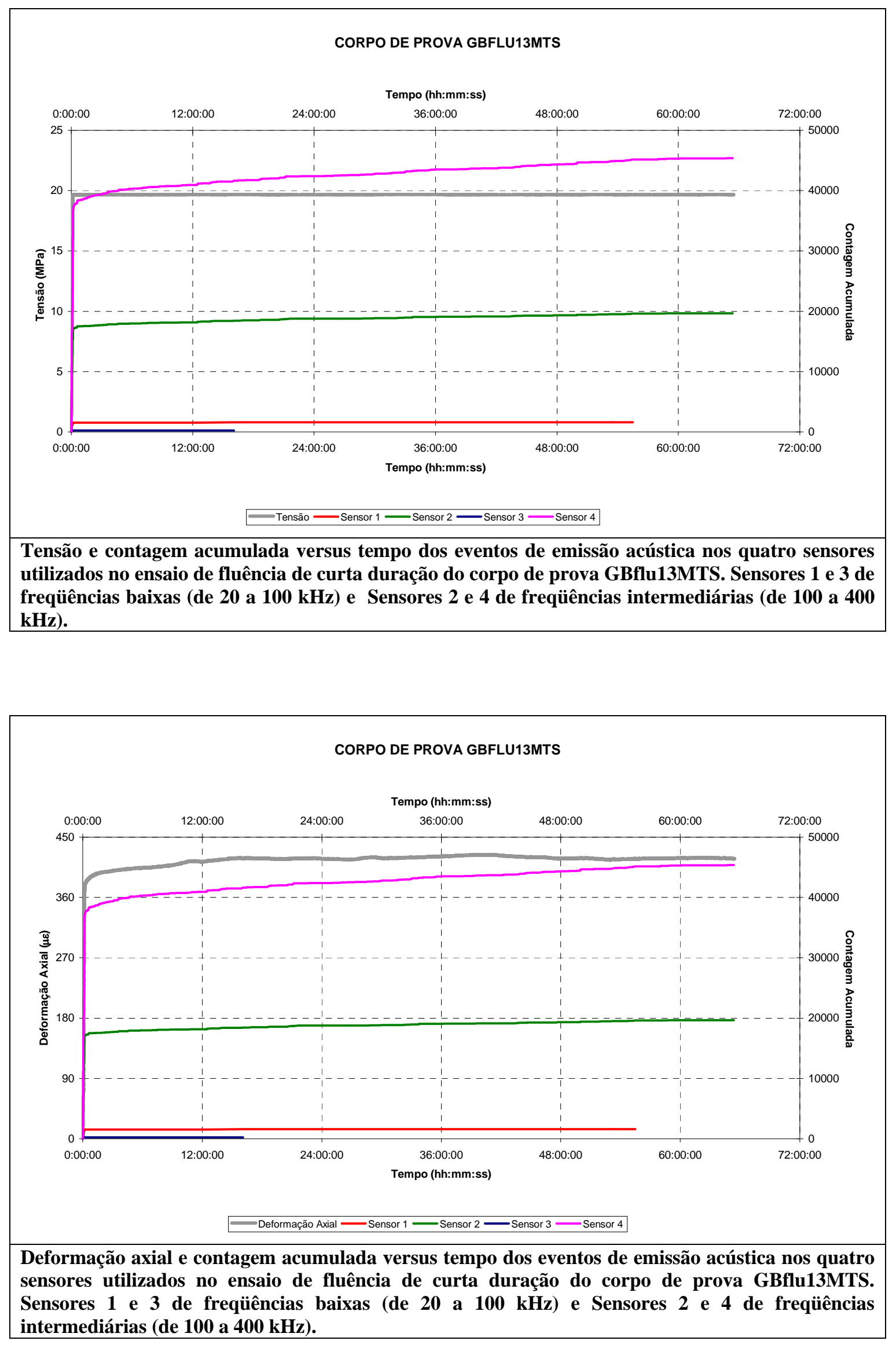

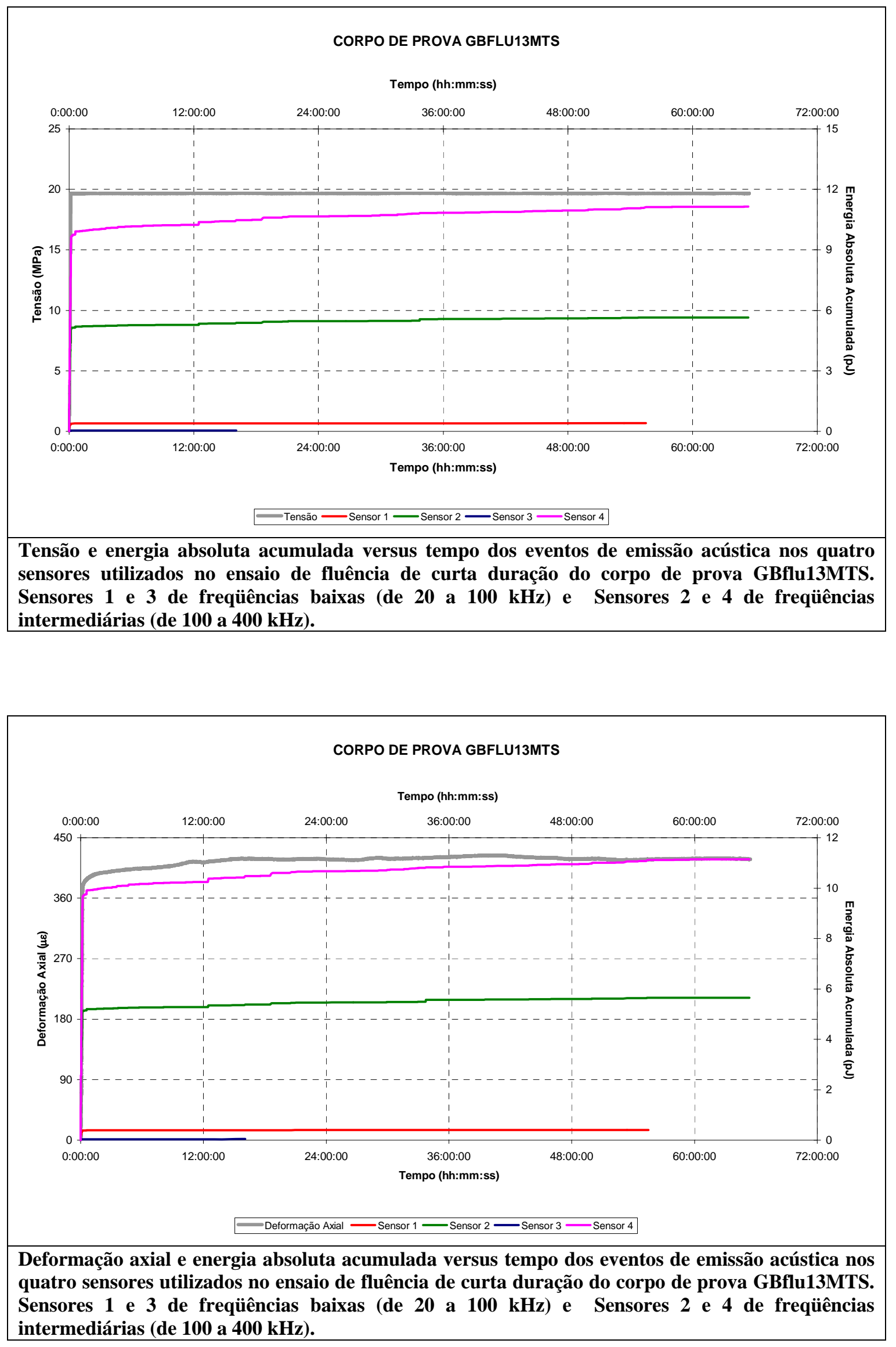

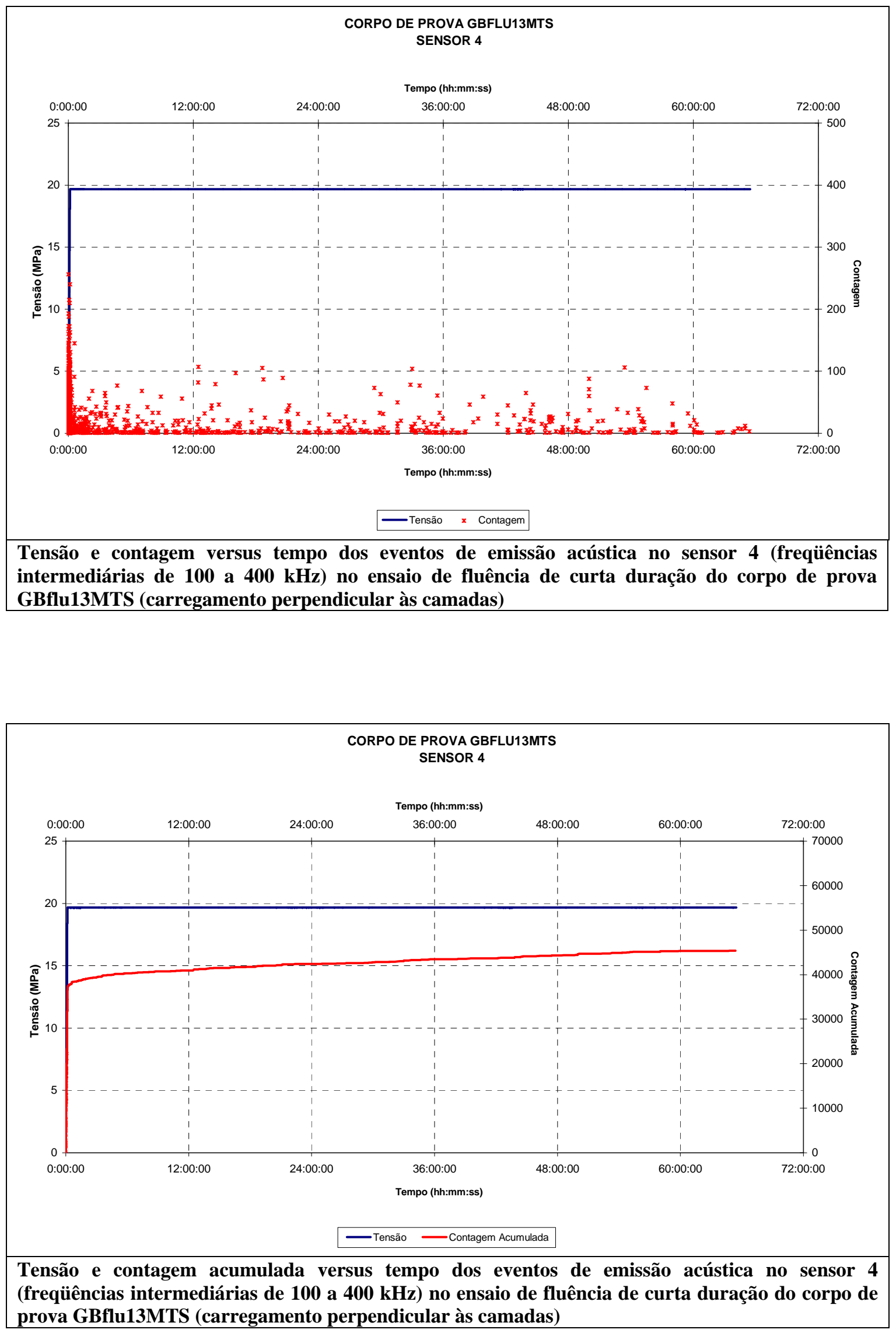

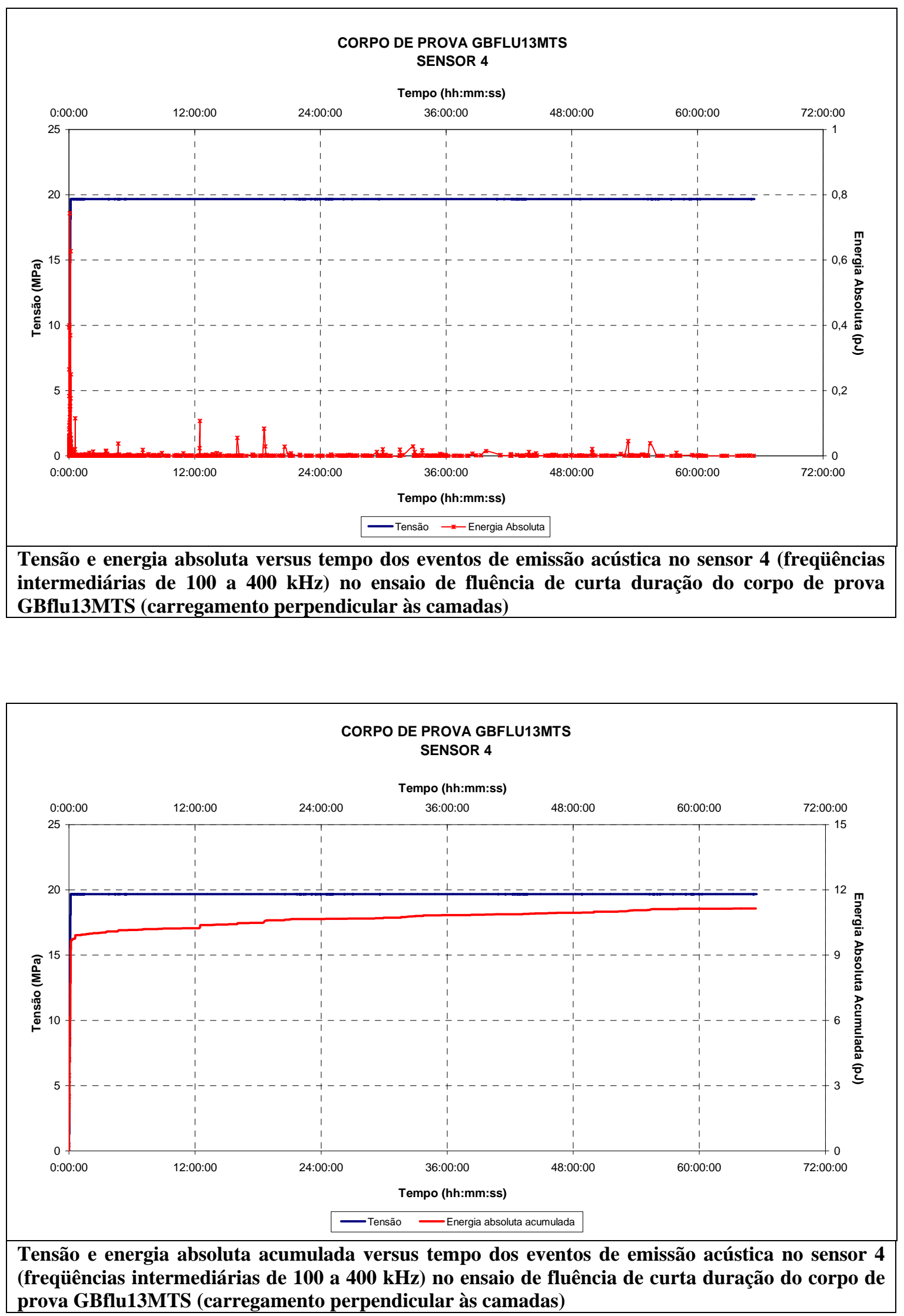

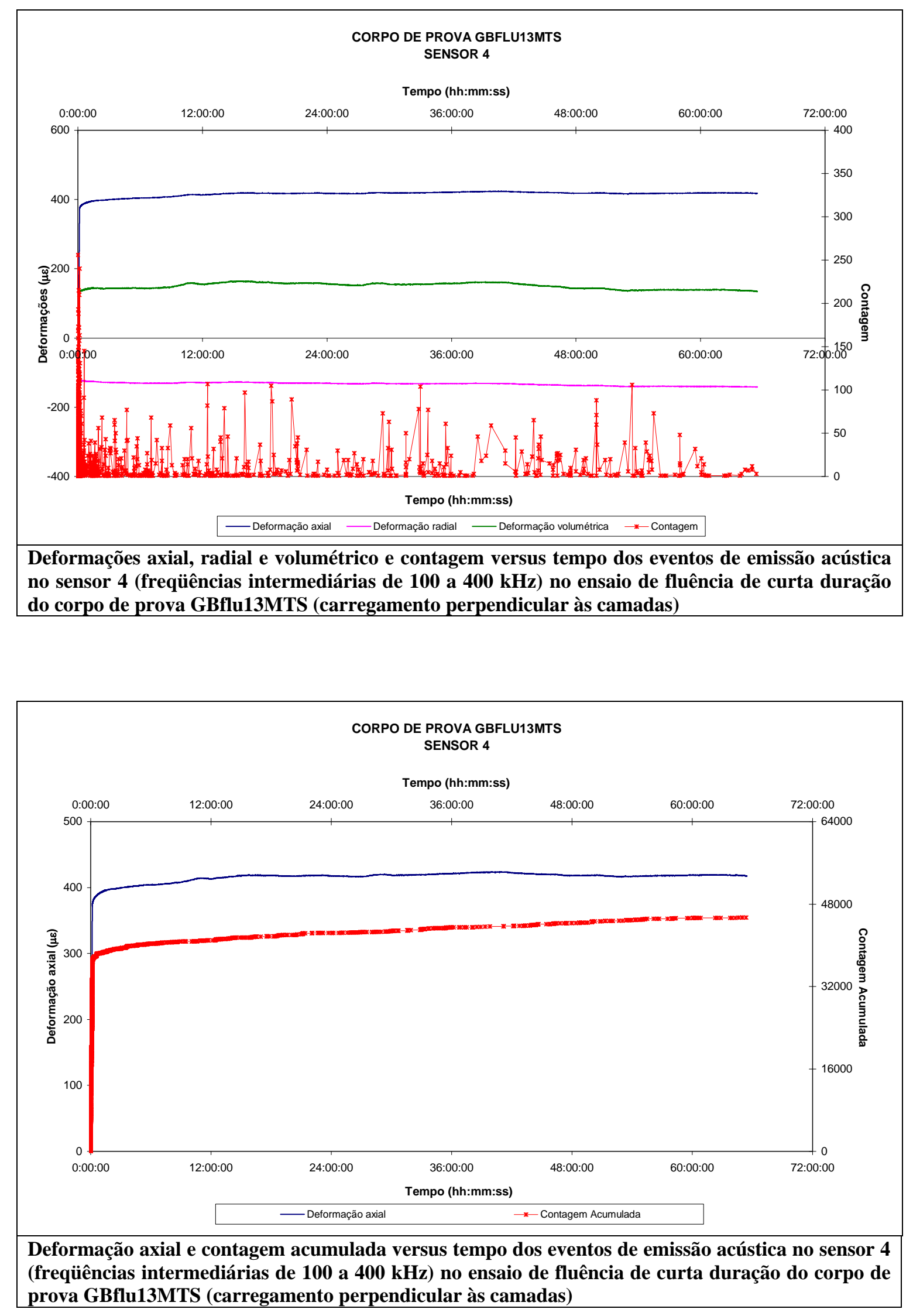

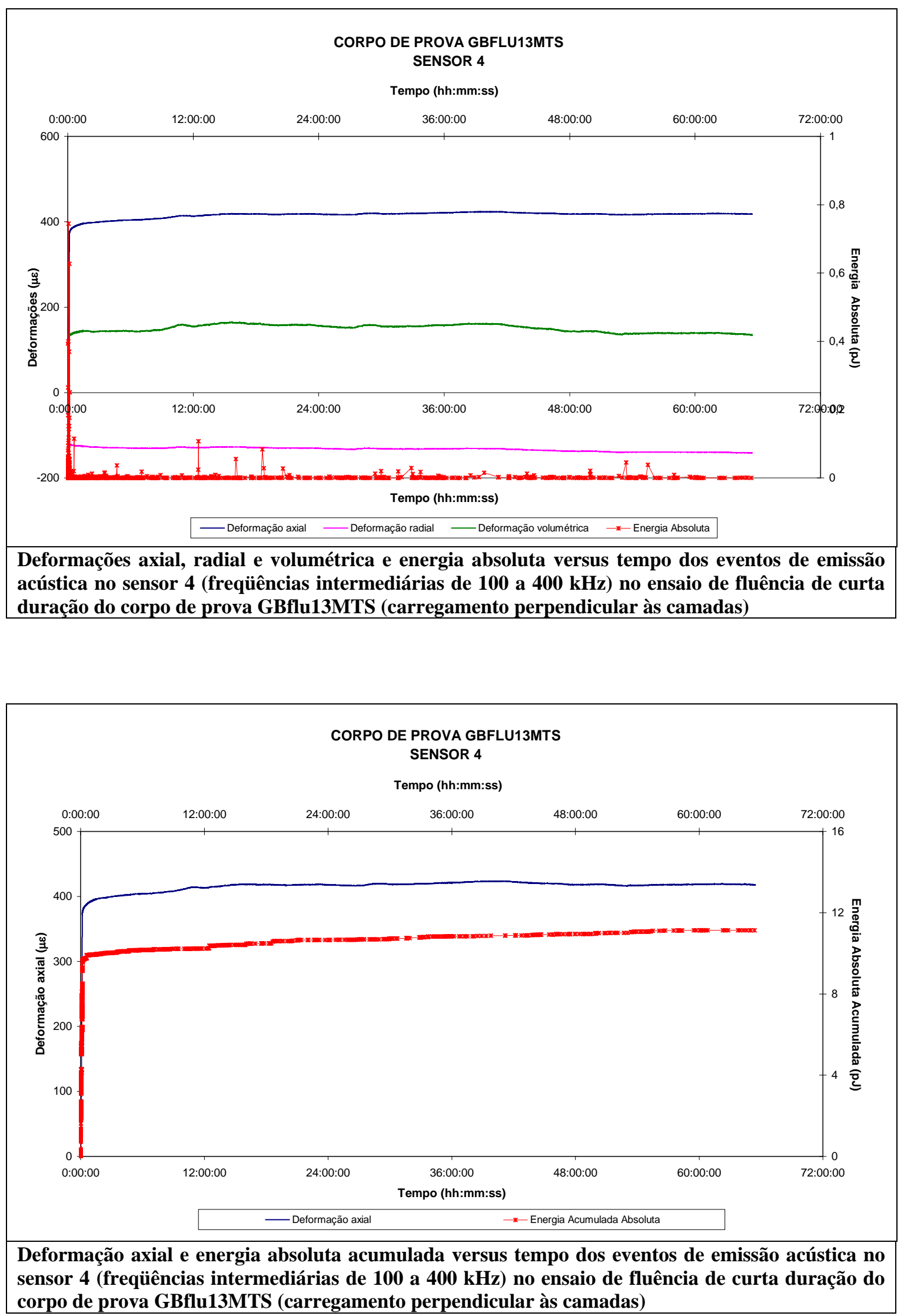


\section{A pêndice 4}

ENSAIOS DE FLUÊNCIA DE LONGA DURAÇÃO 

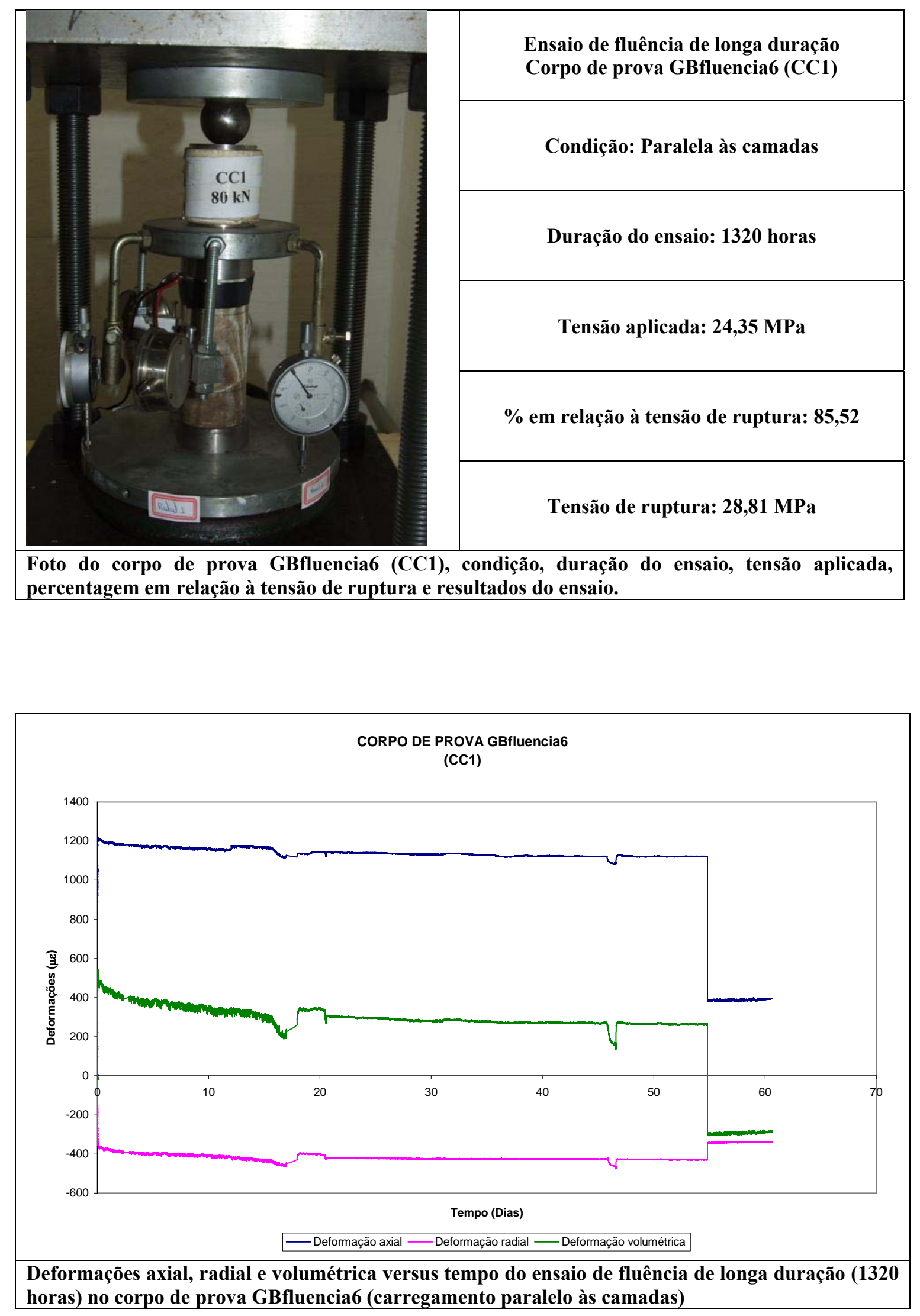

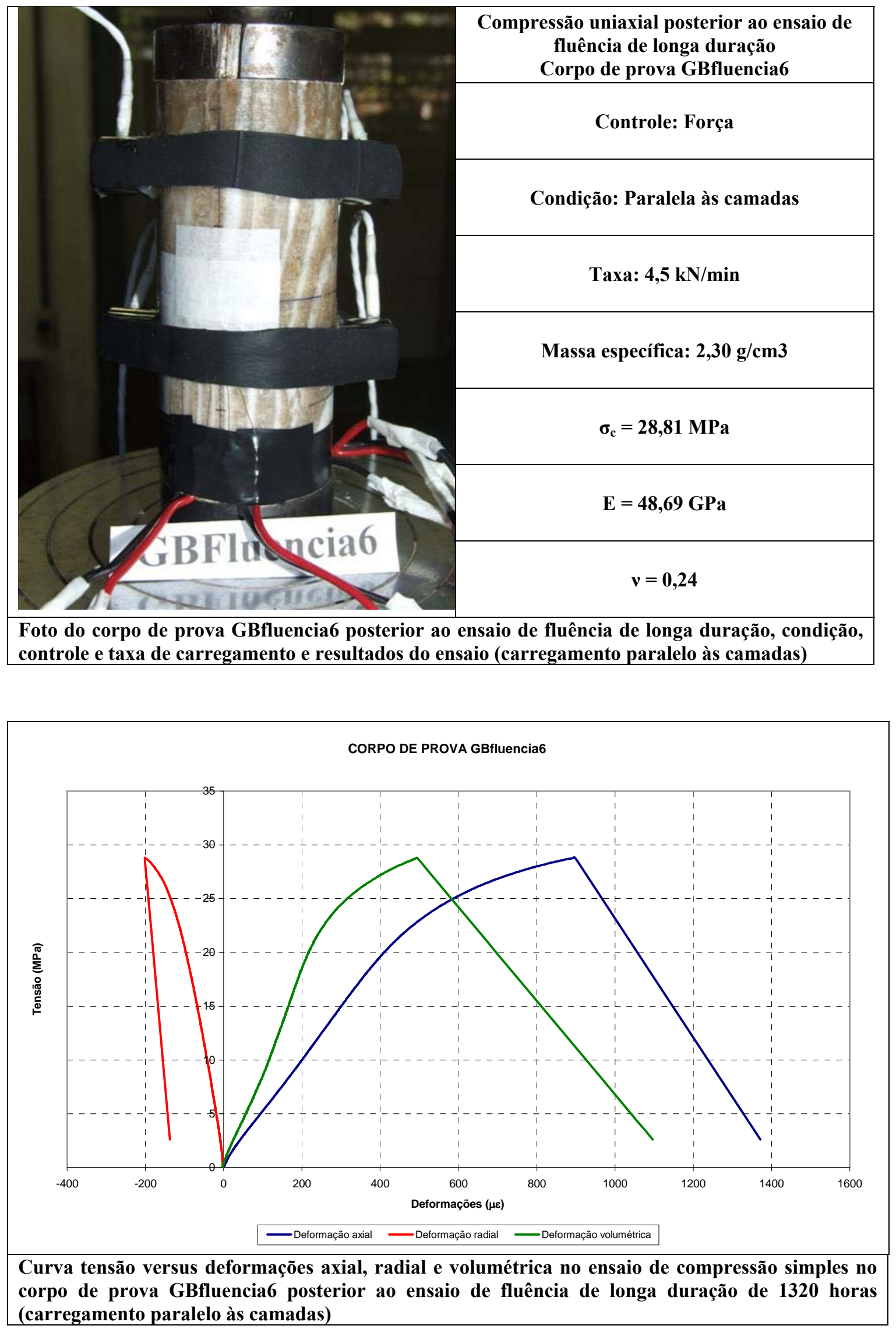

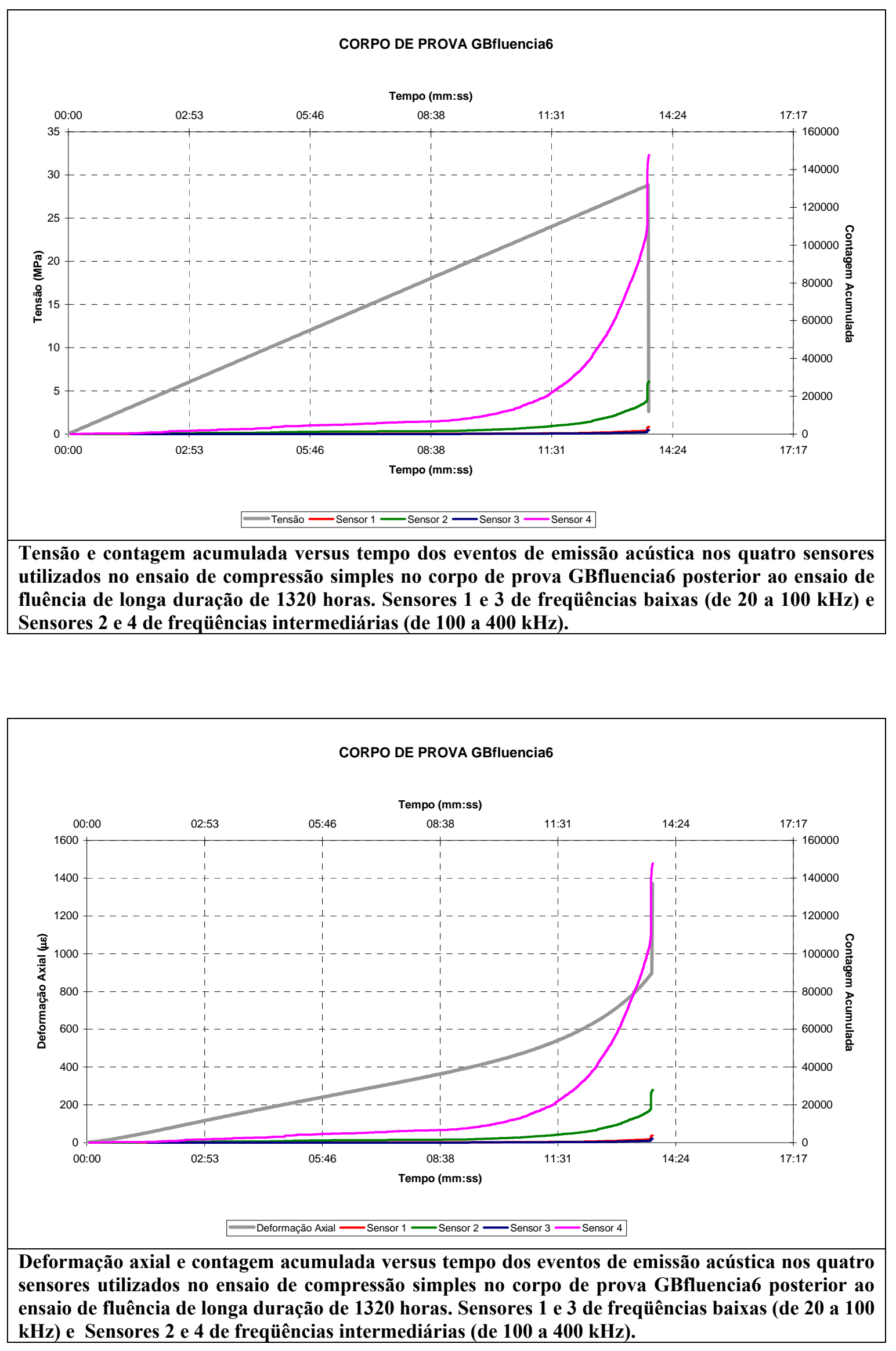

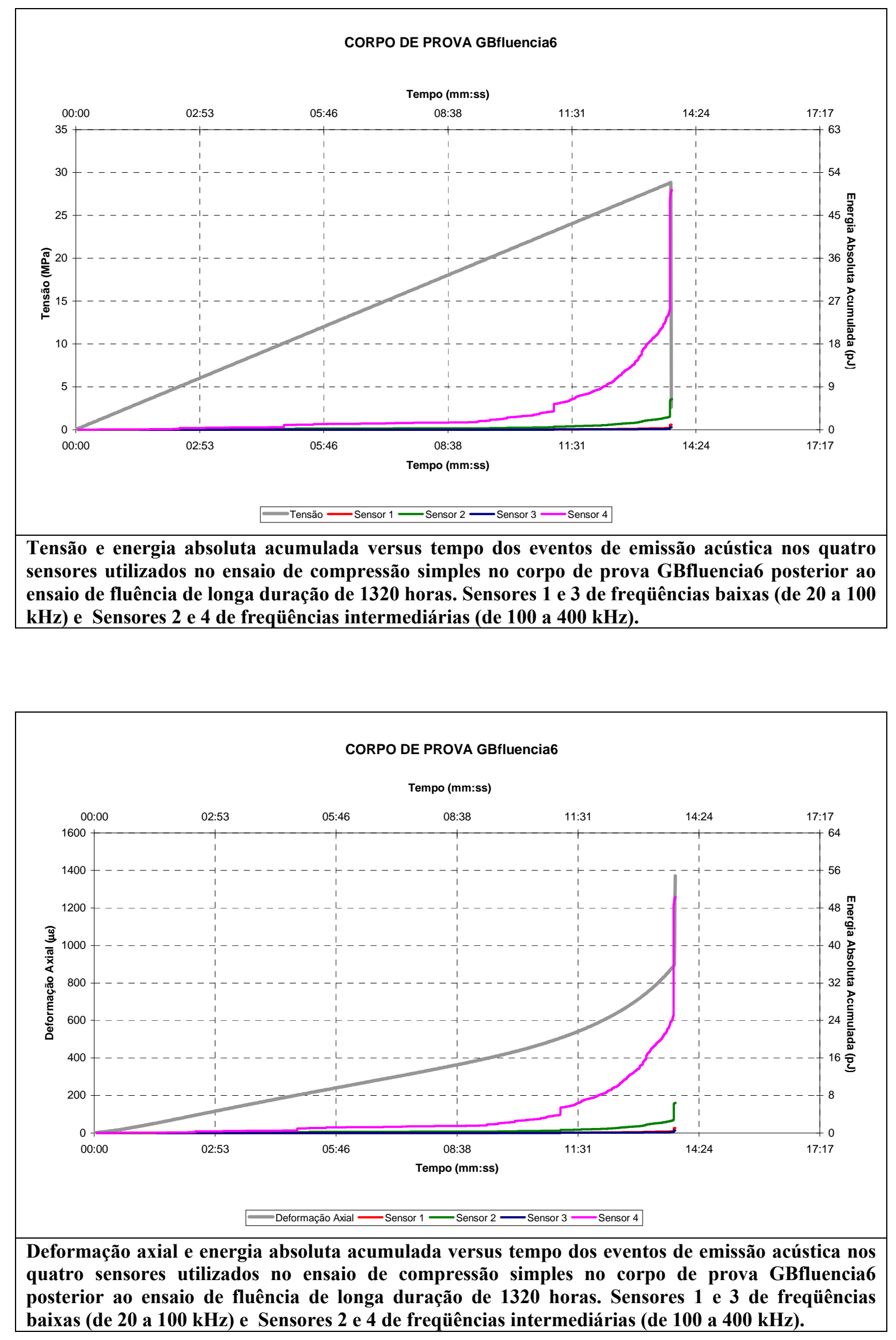

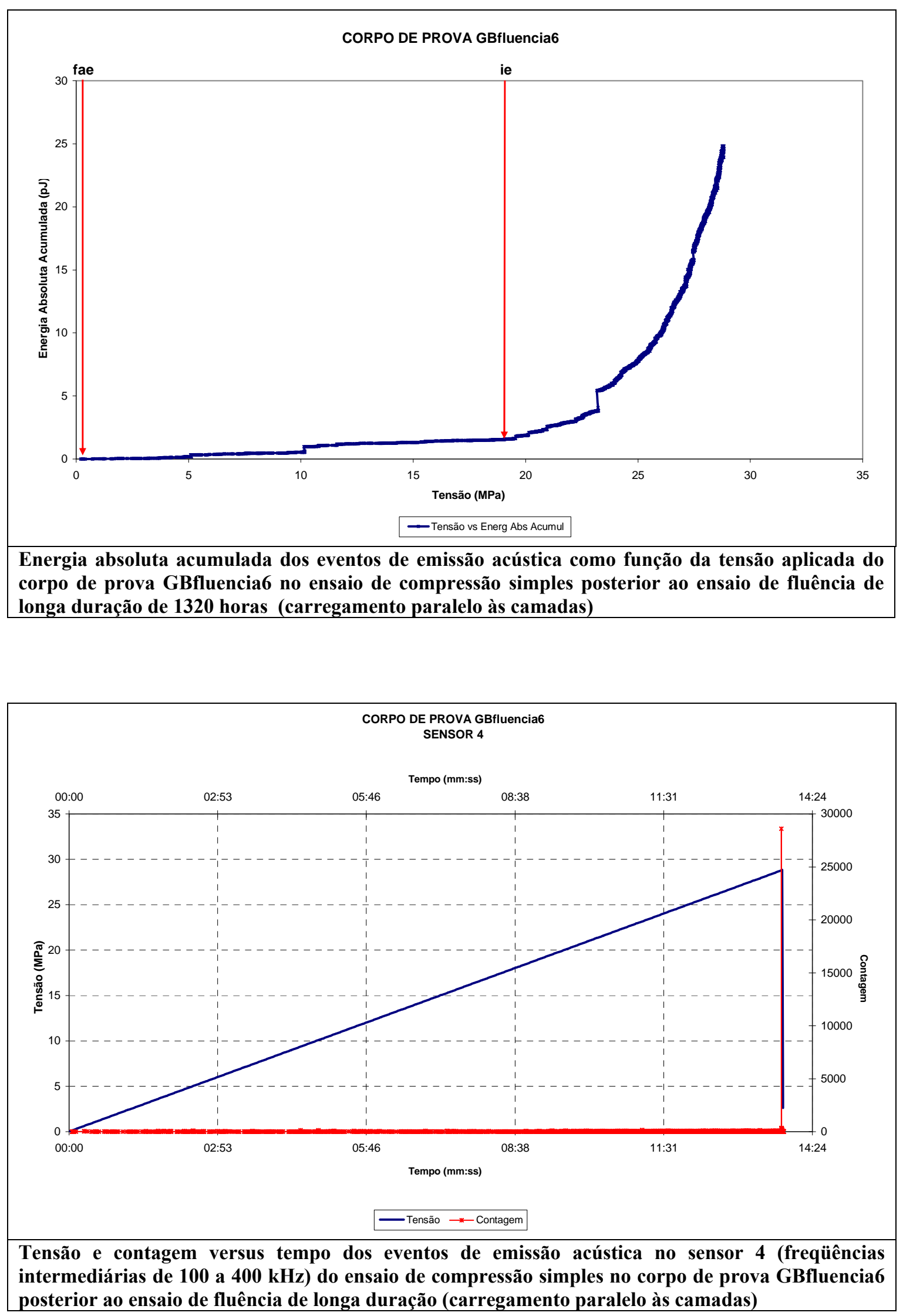

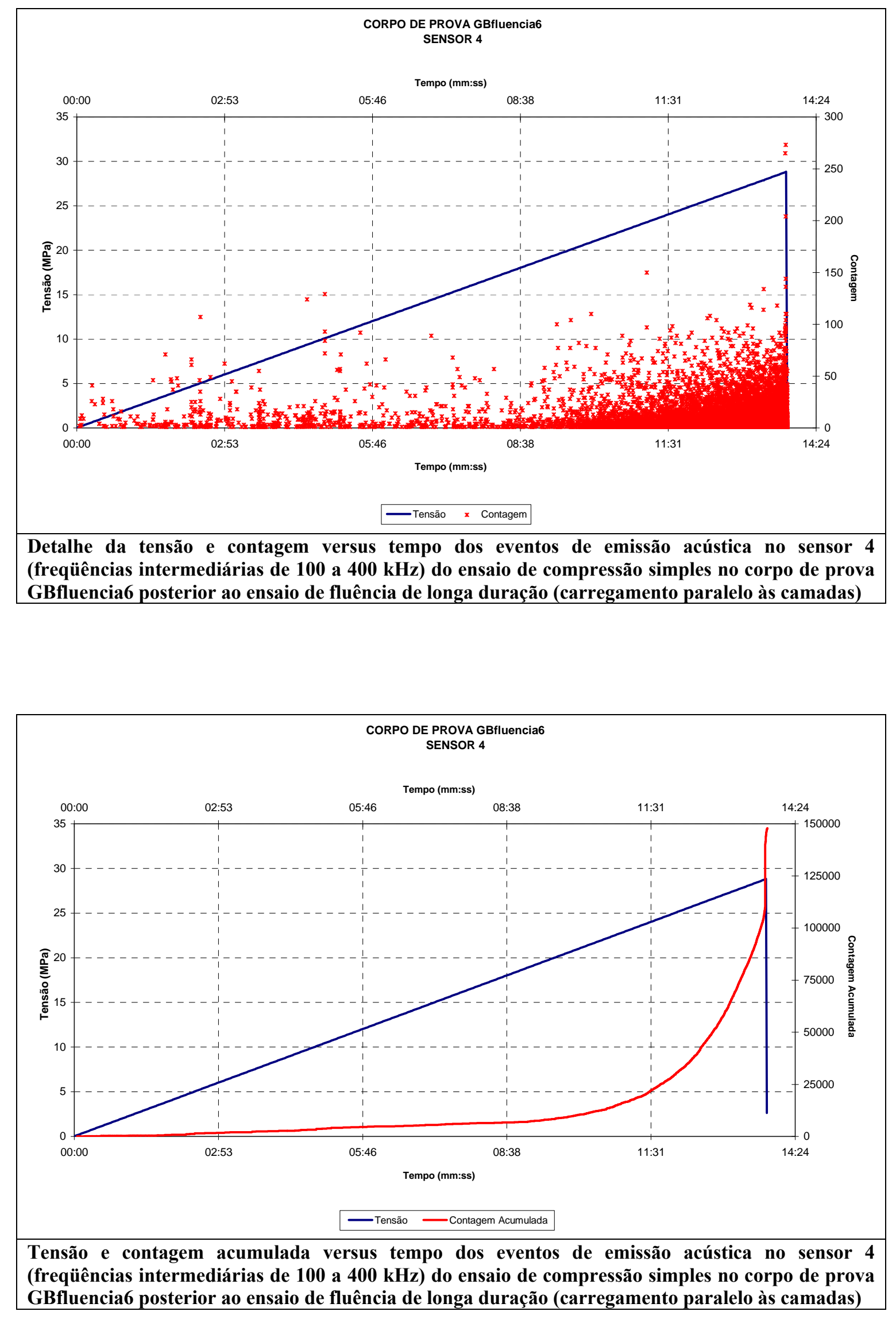

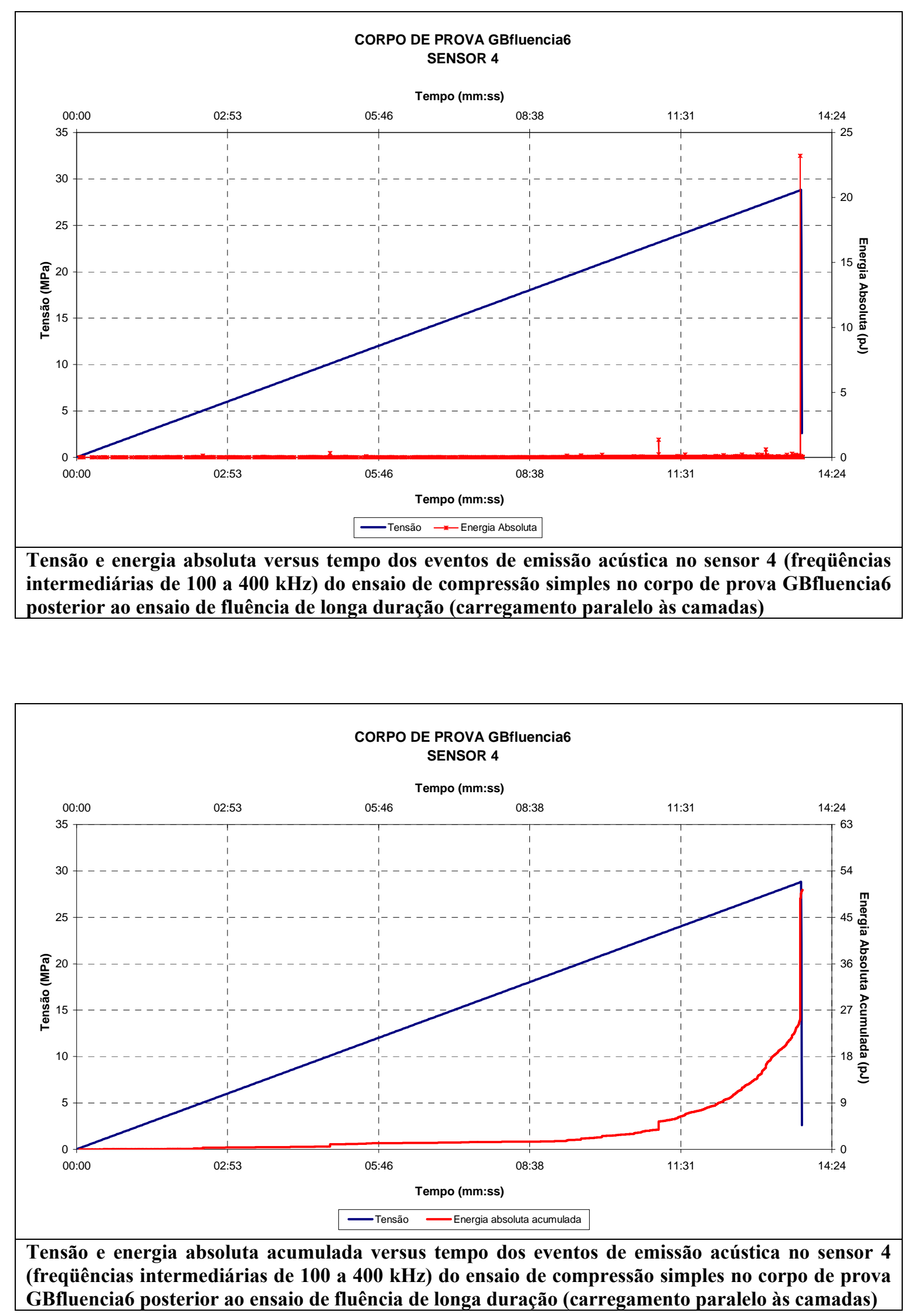

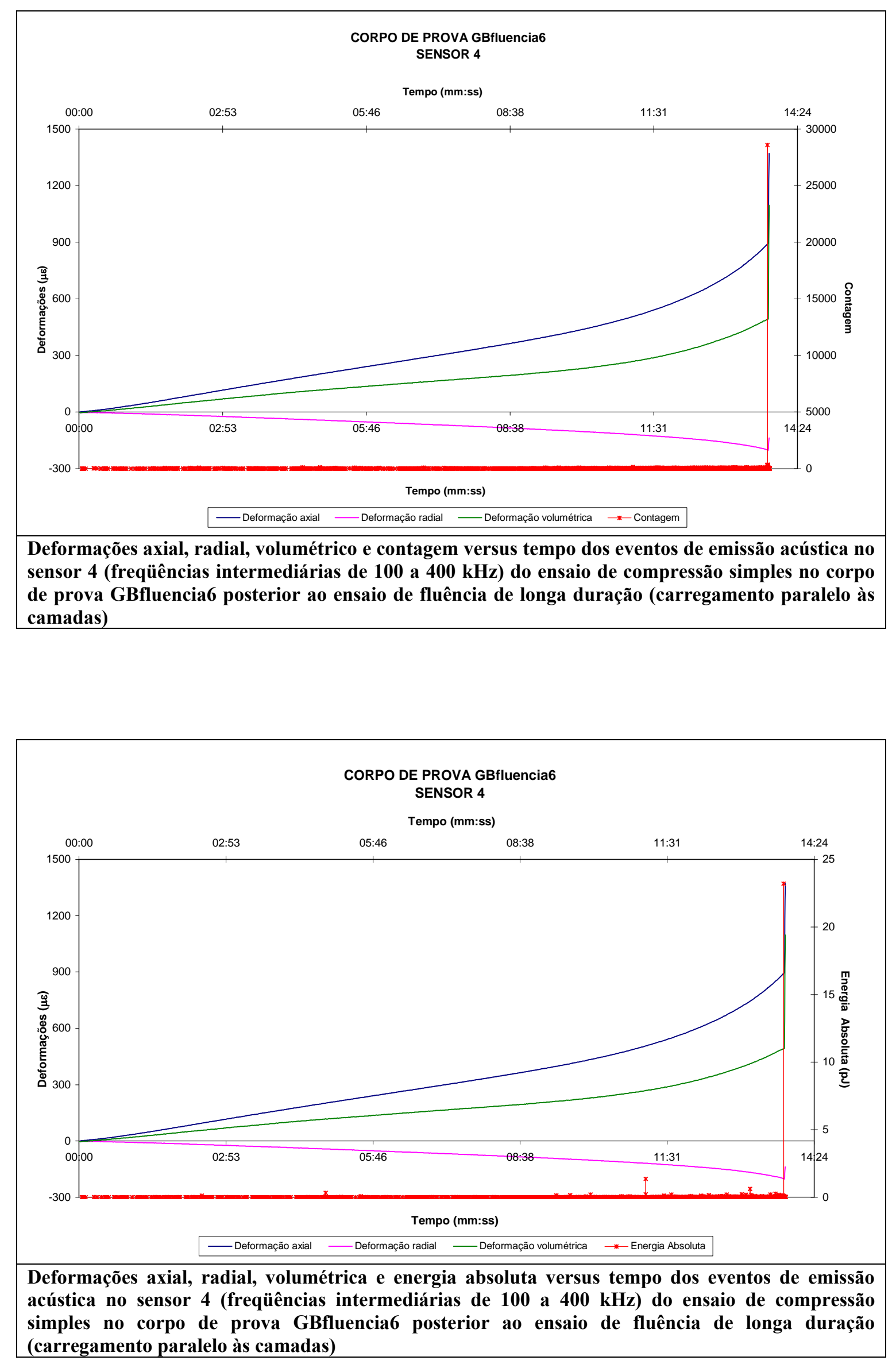


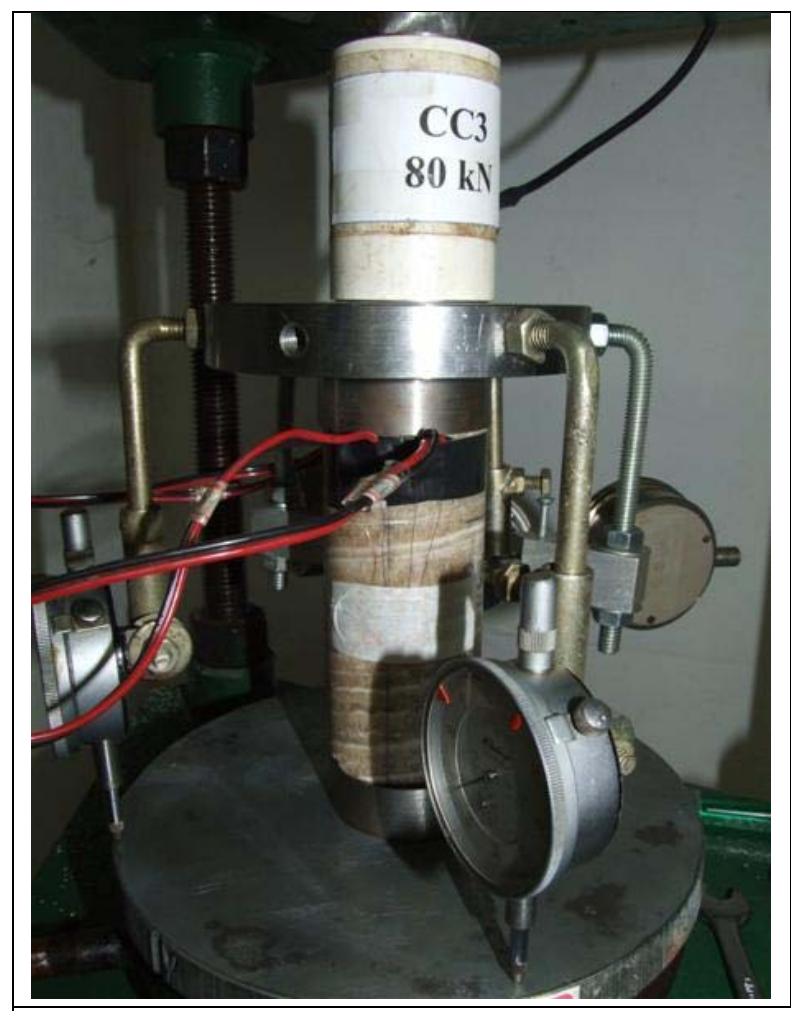

Ensaio de fluência de longa duração

Corpo de prova GBfluencia8 (CC3)

Condição: Perpendicular às camadas

Duração do ensaio: 1320 horas

Tensão aplicada: $24,16 \mathrm{MPa}$

\% em relação à tensão de ruptura: 95,38

Tensão de ruptura: 25,33 MPa

Foto do corpo de prova GBfluencia8 (CC3), condição, duração do ensaio, tensão aplicada, percentagem em relação à tensão de ruptura e resultados do ensaio.

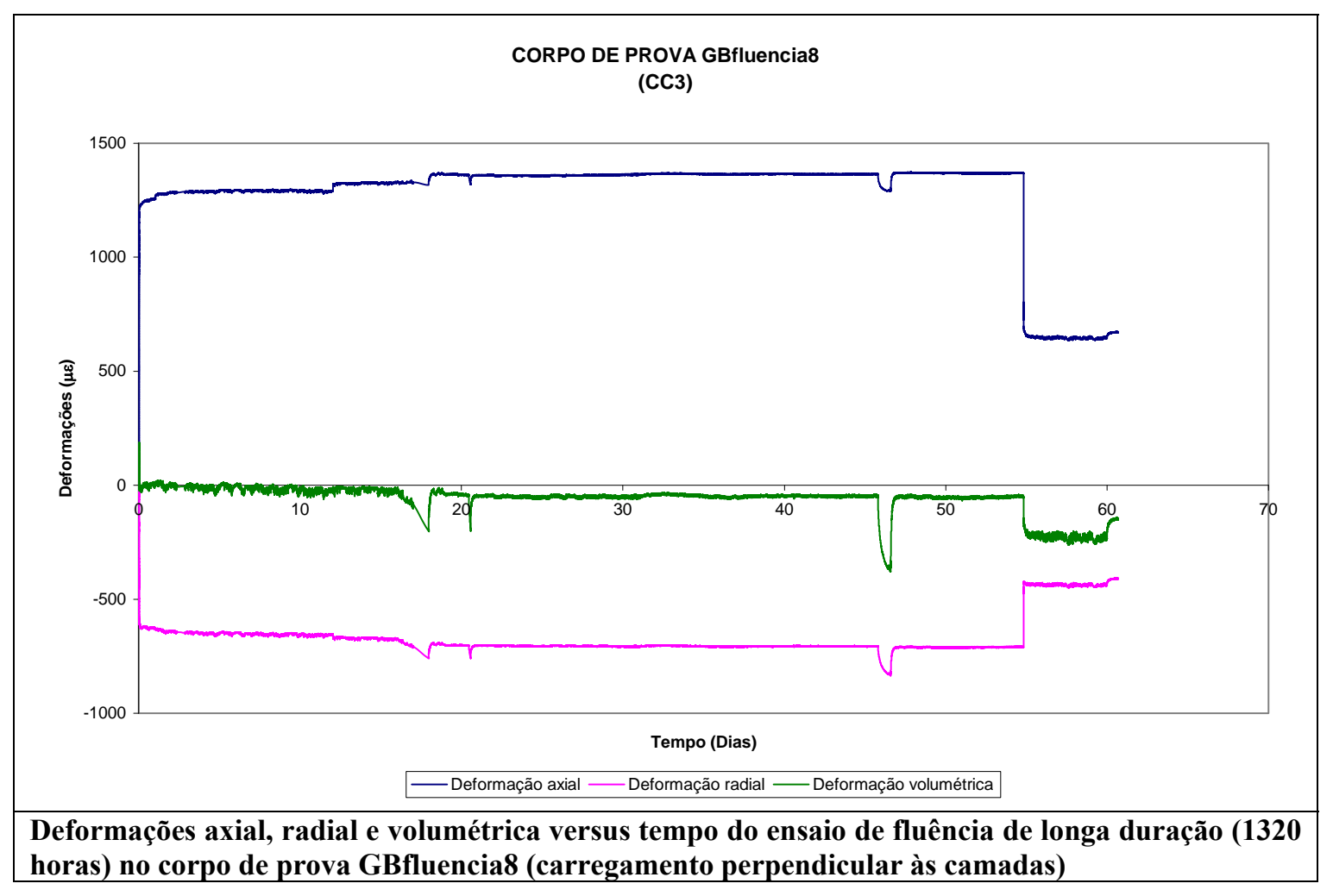




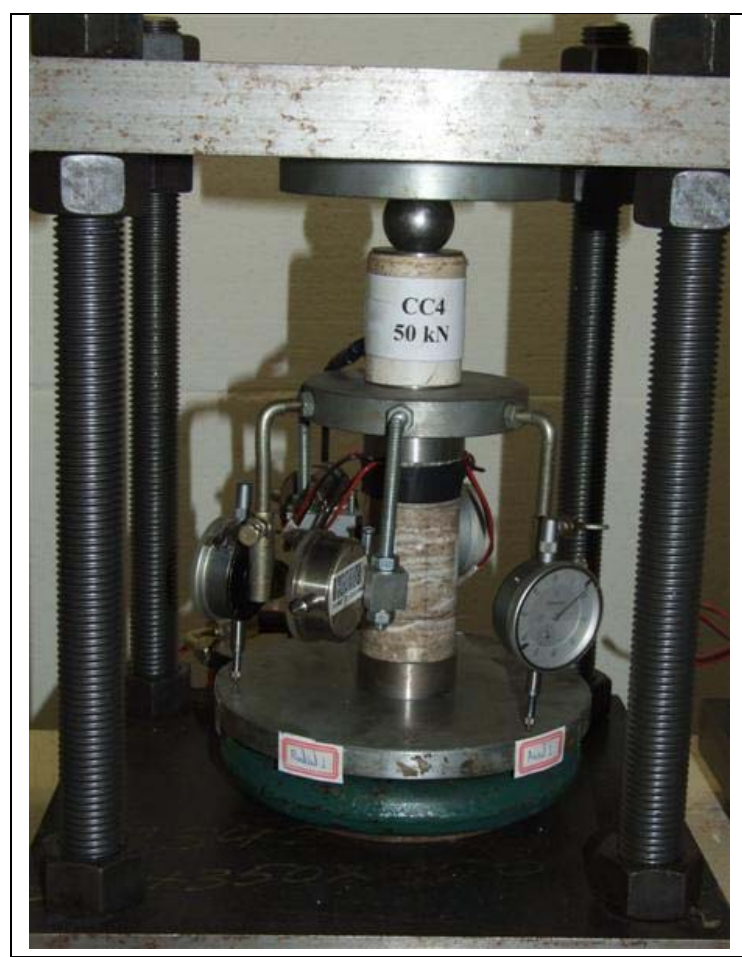

Ensaio de fluência de longa duração

Corpo de prova GBfluencia9 (CC4)

Condição: Perpendicular às camadas

Duração do ensaio: 1080 horas

Tensão aplicada: 22,43 MPa

\% em relação à tensão de ruptura: 76,53

Tensão de ruptura: 29,31 MPa

Foto do corpo de prova GBfluencia9 (CC4), condição, duração do ensaio, tensão aplicada, percentagem em relação à tensão de ruptura e resultados do ensaio.

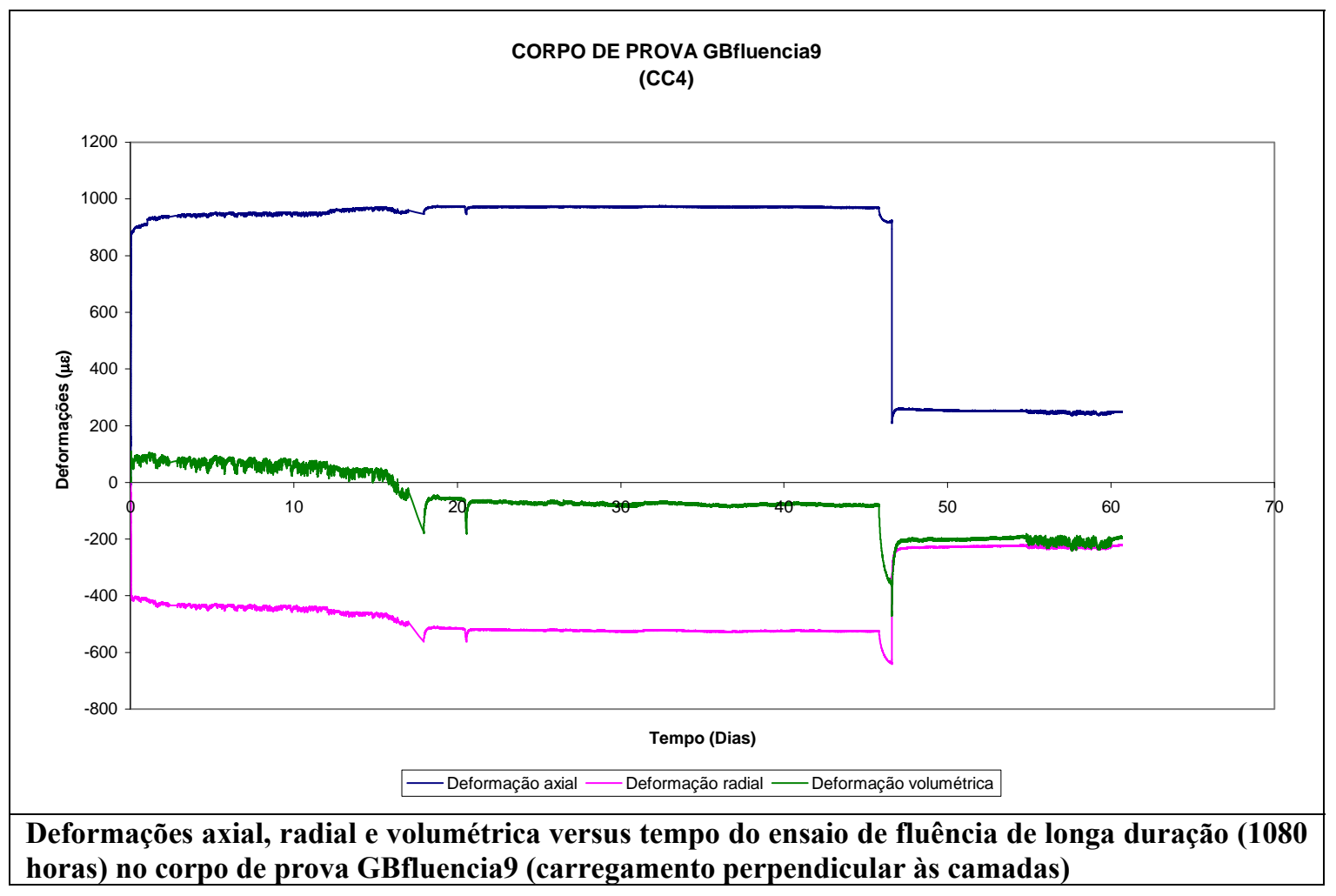



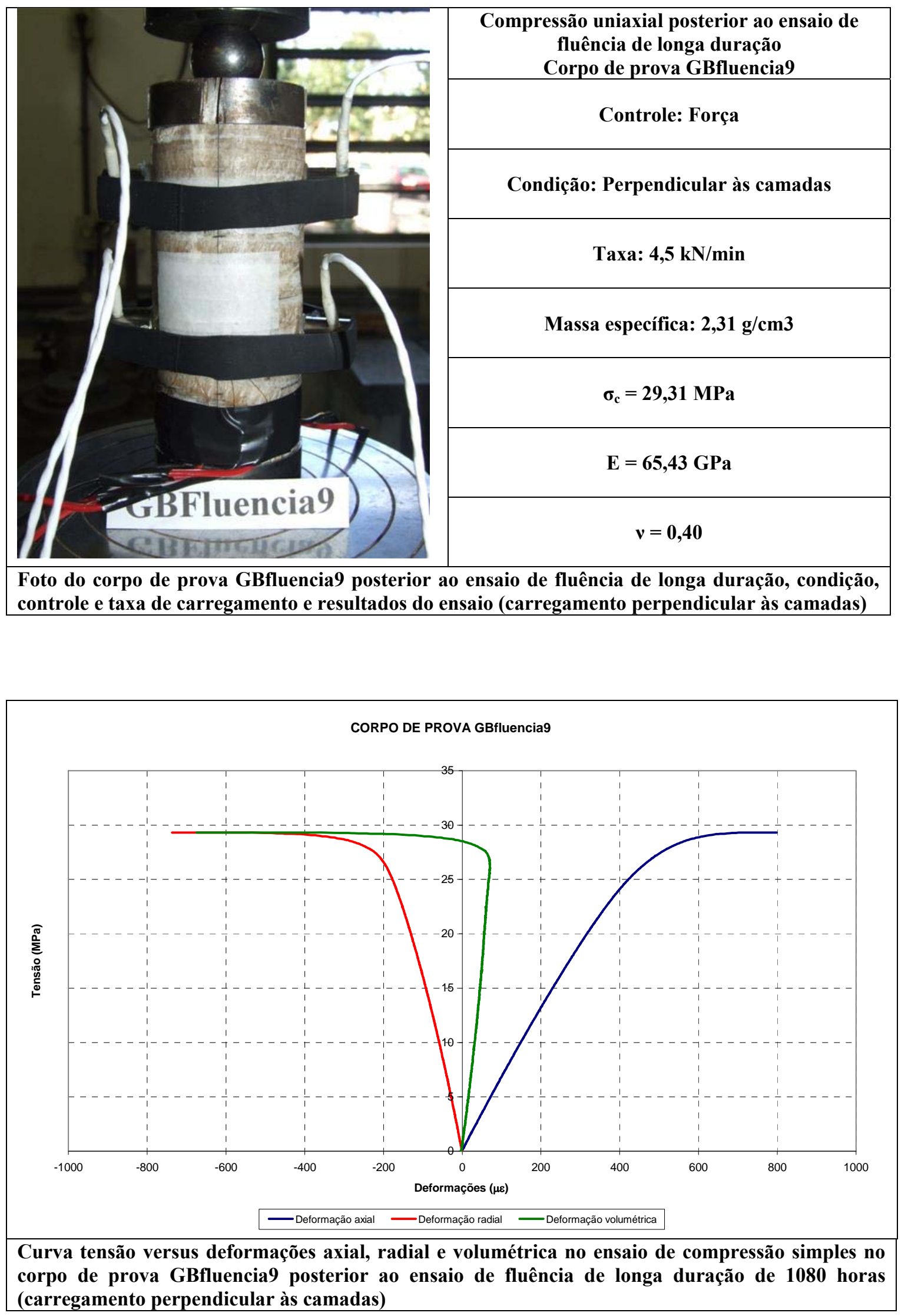

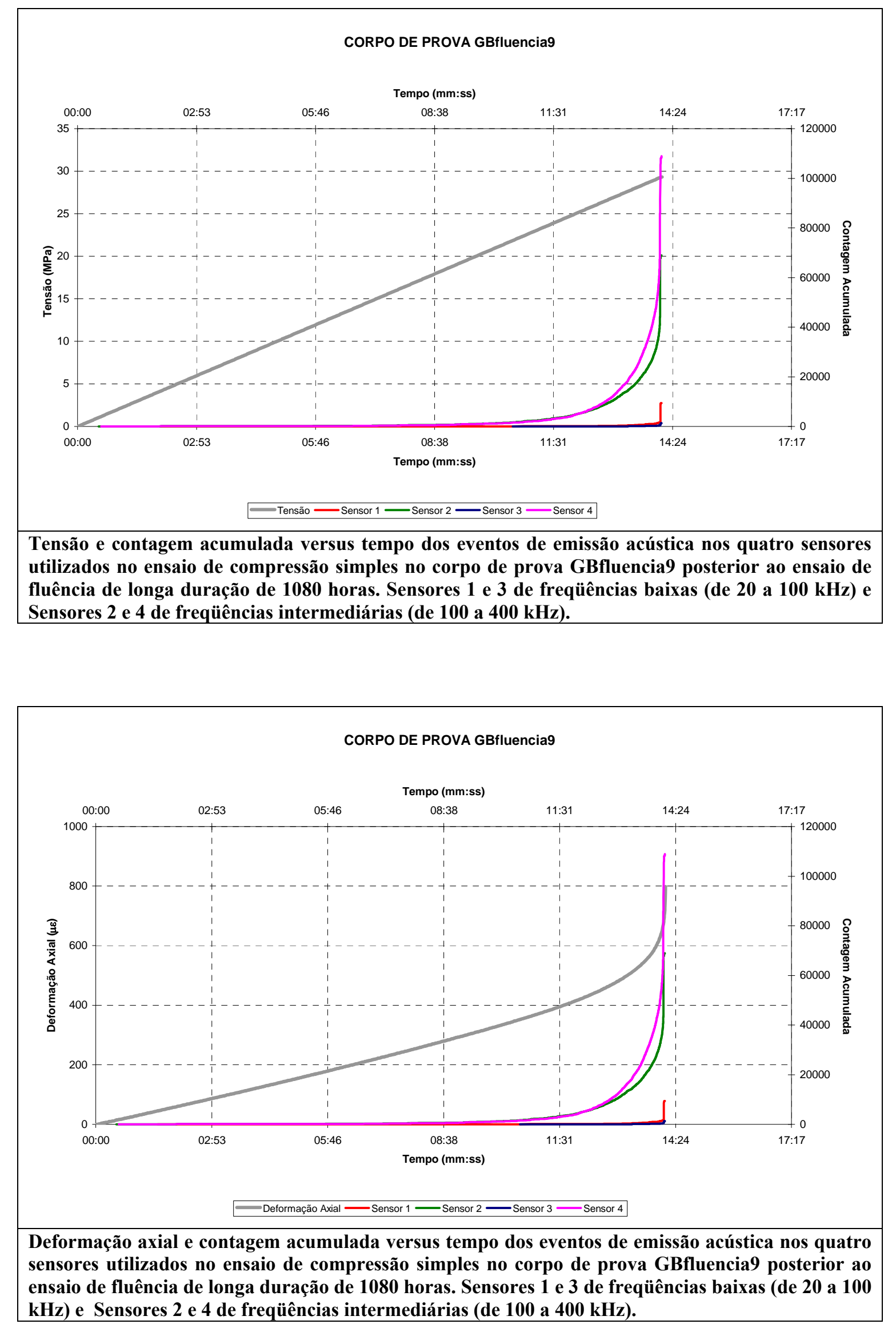

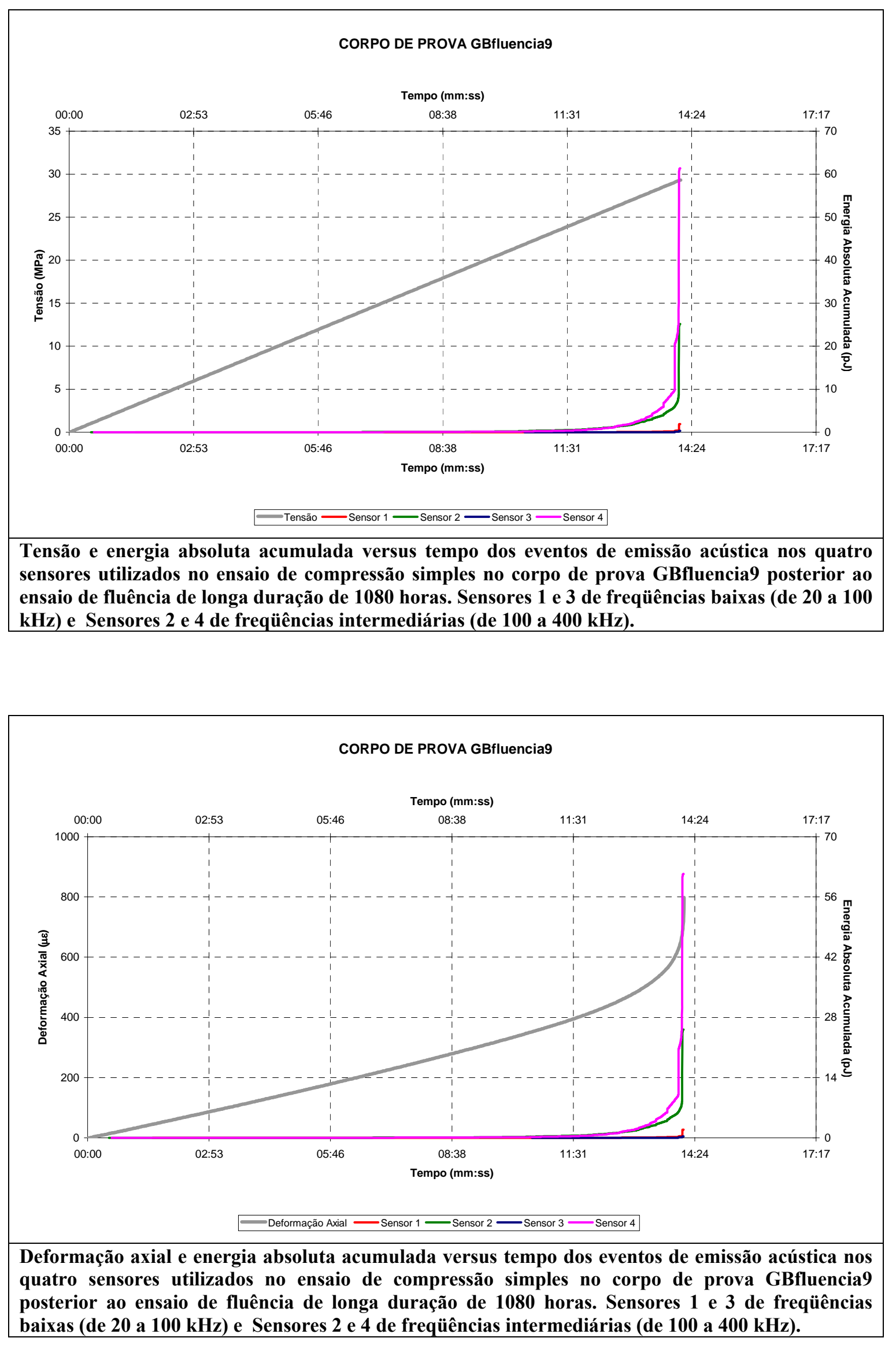

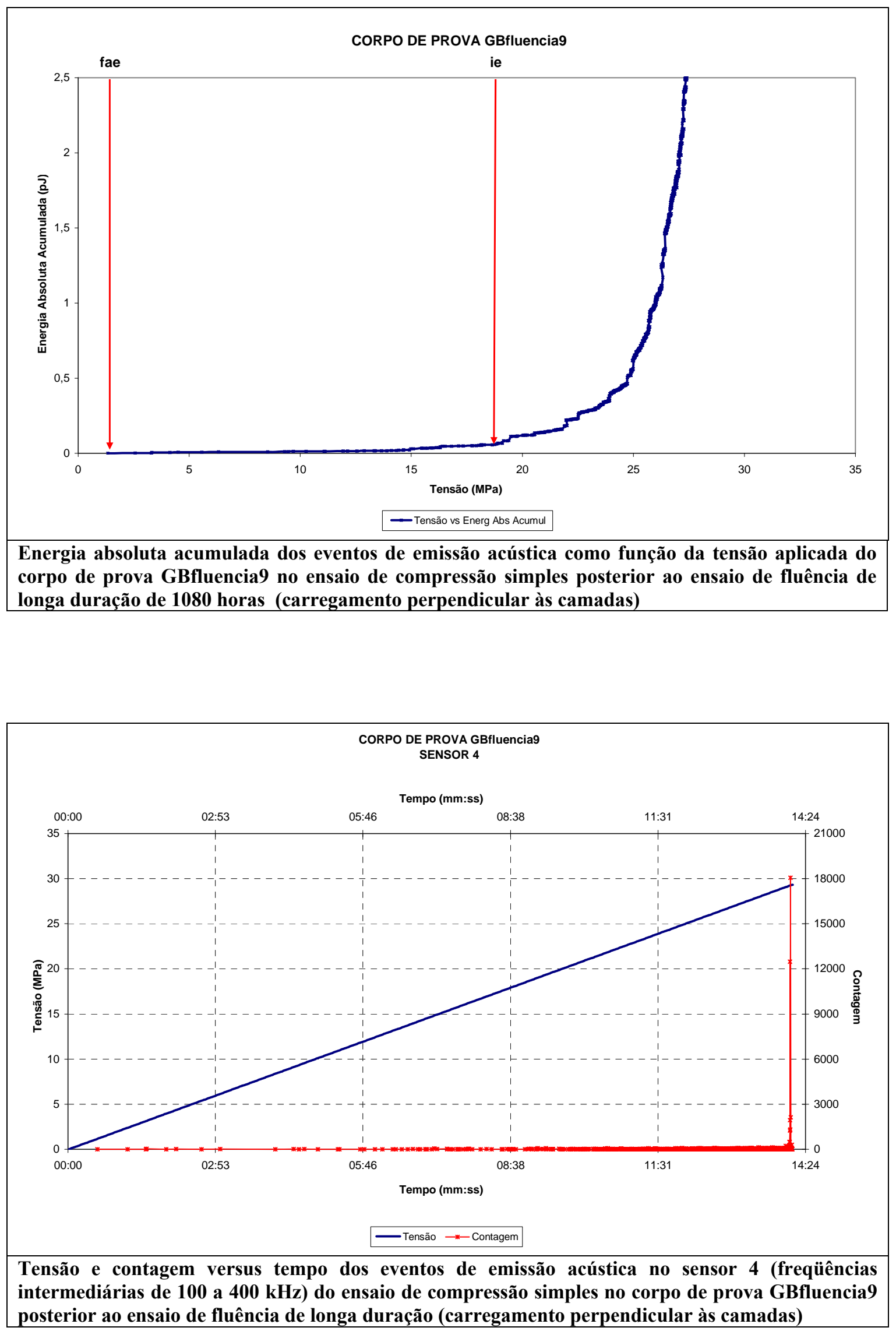

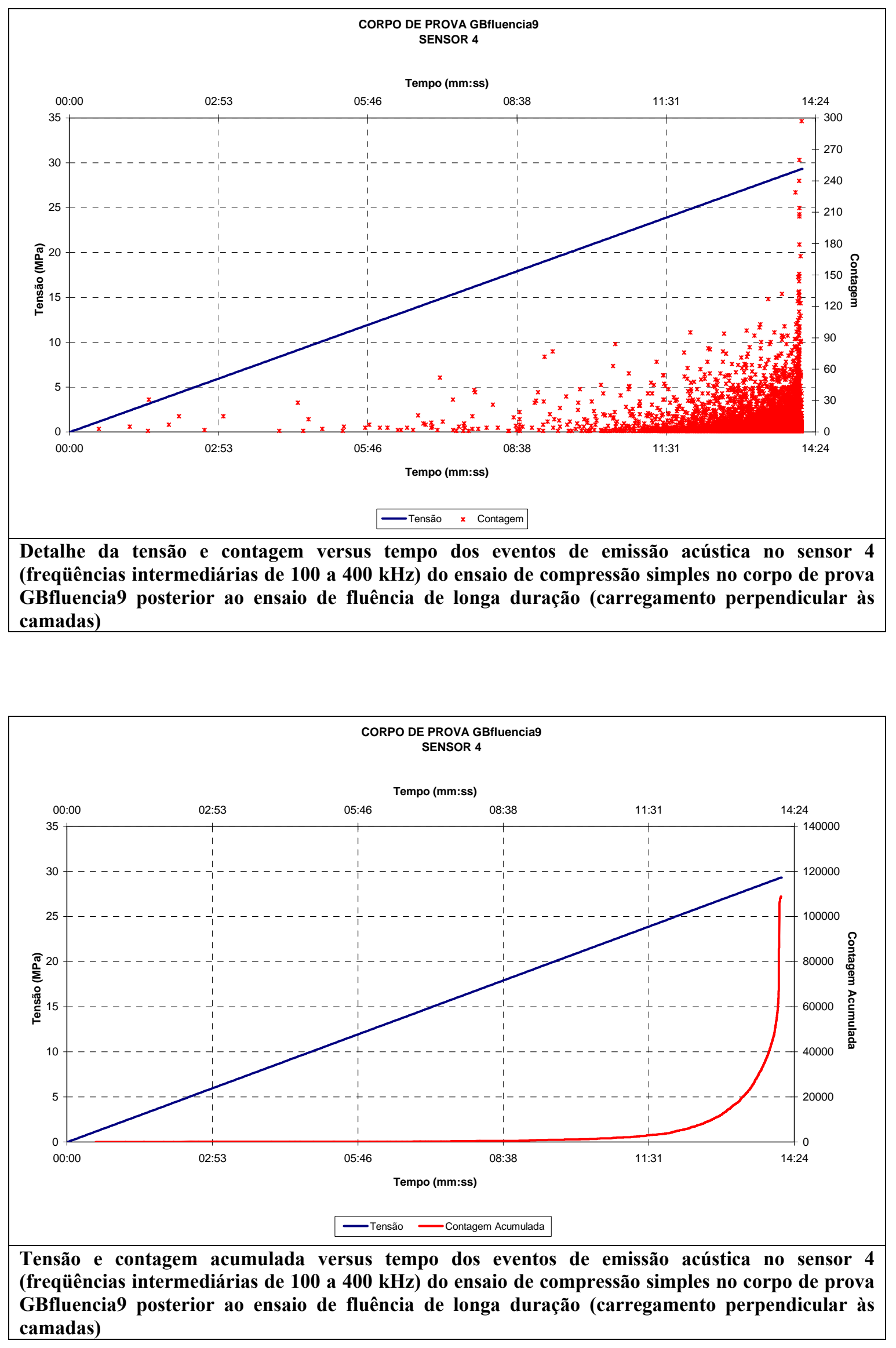

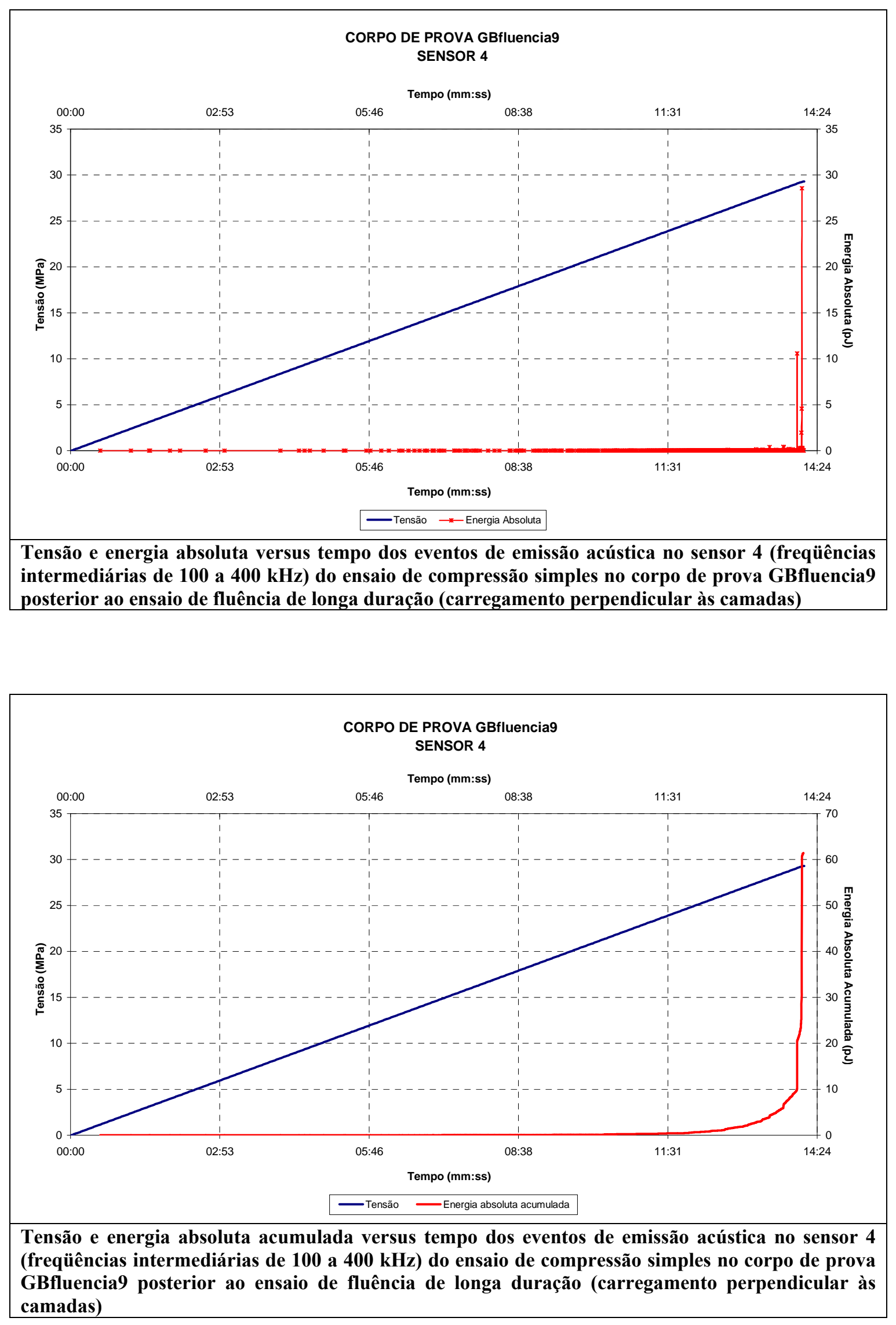

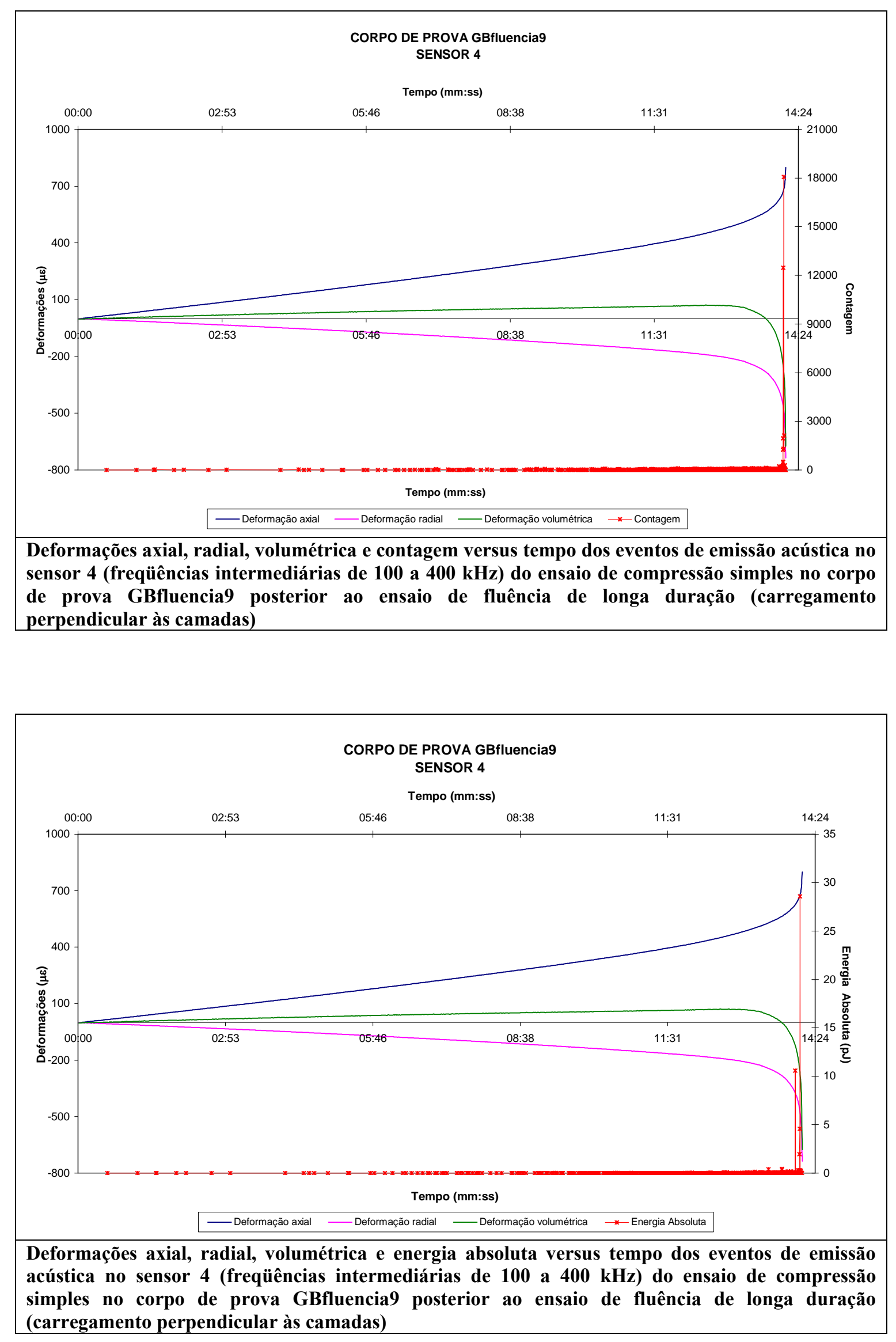

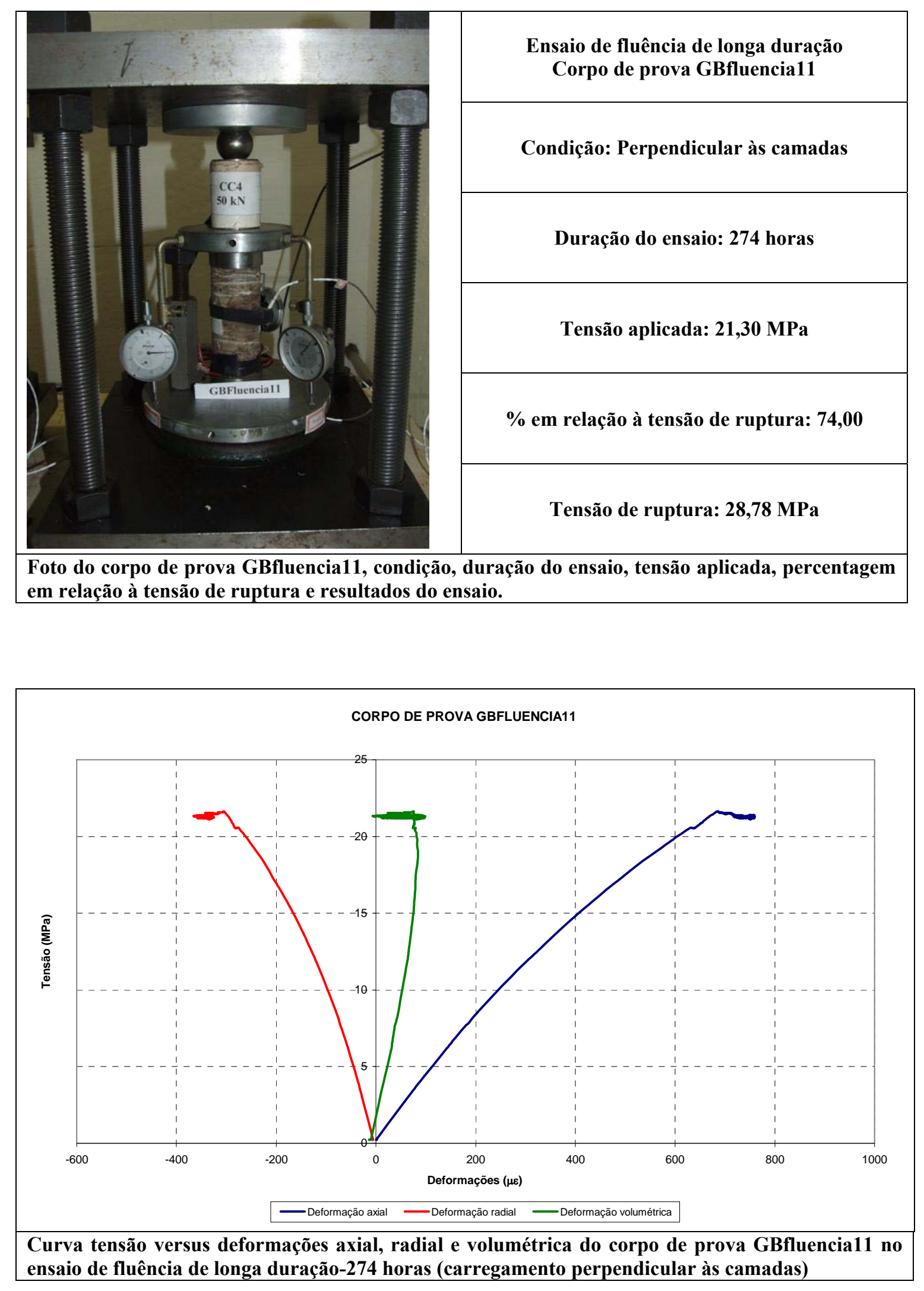

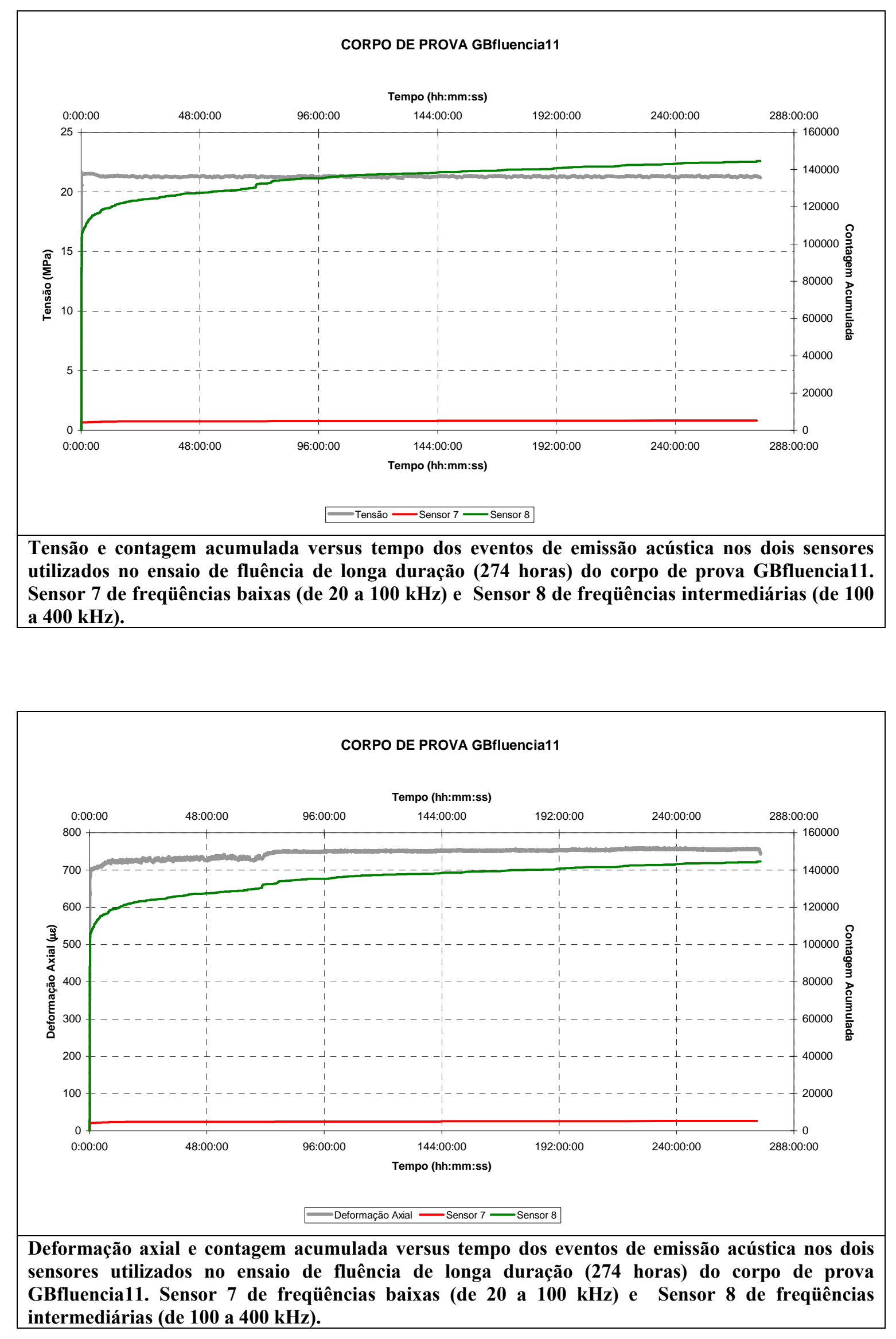

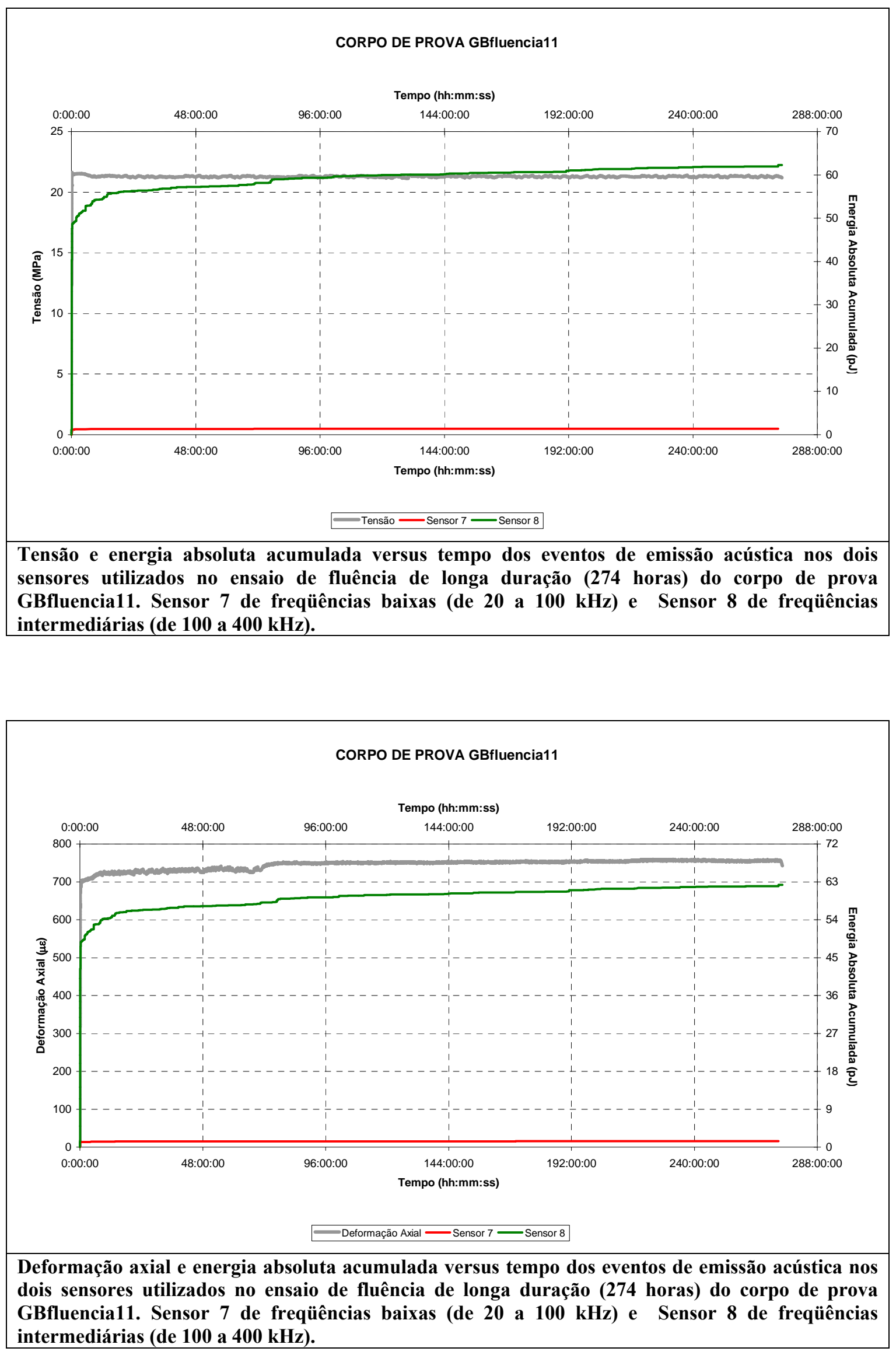

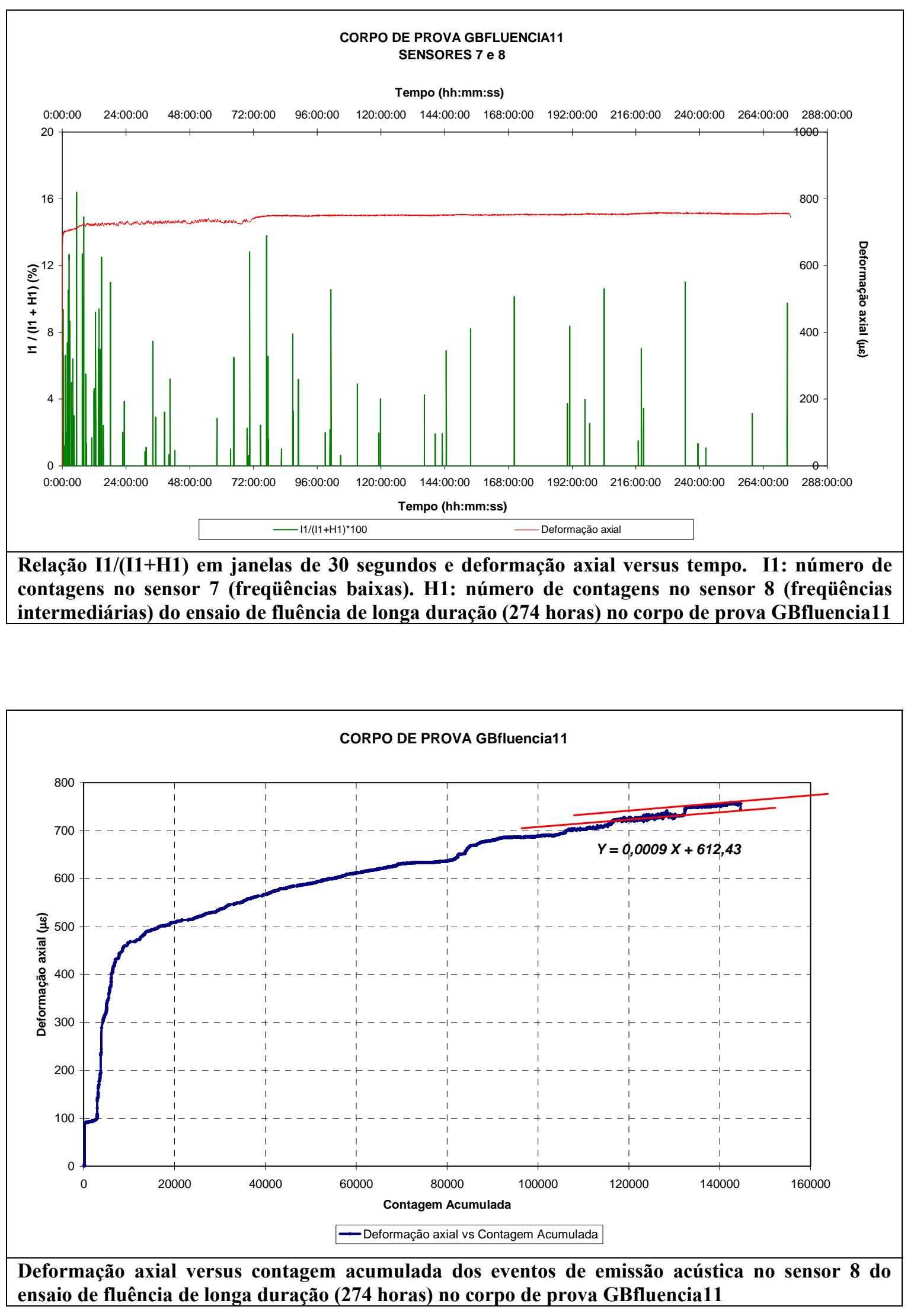

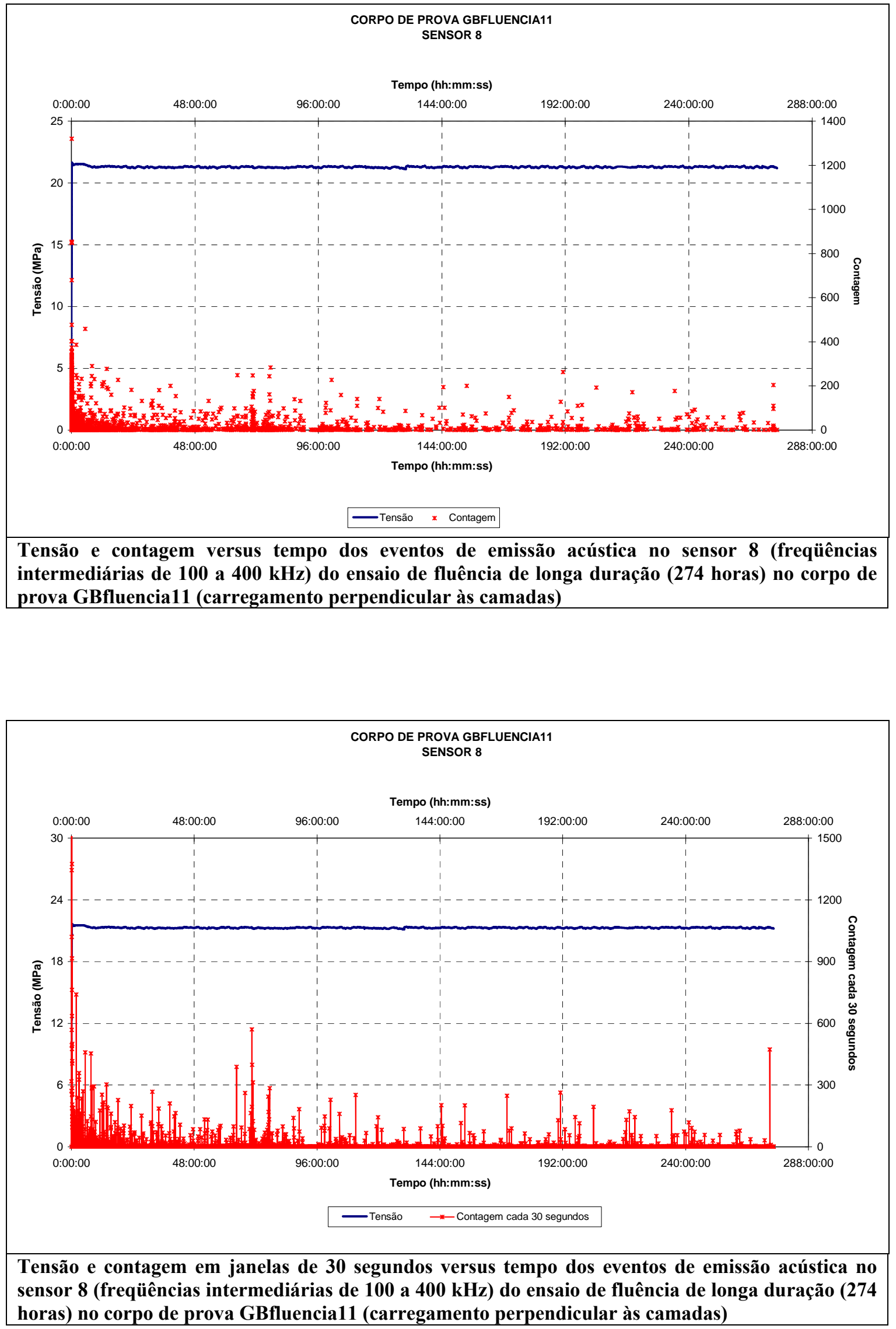

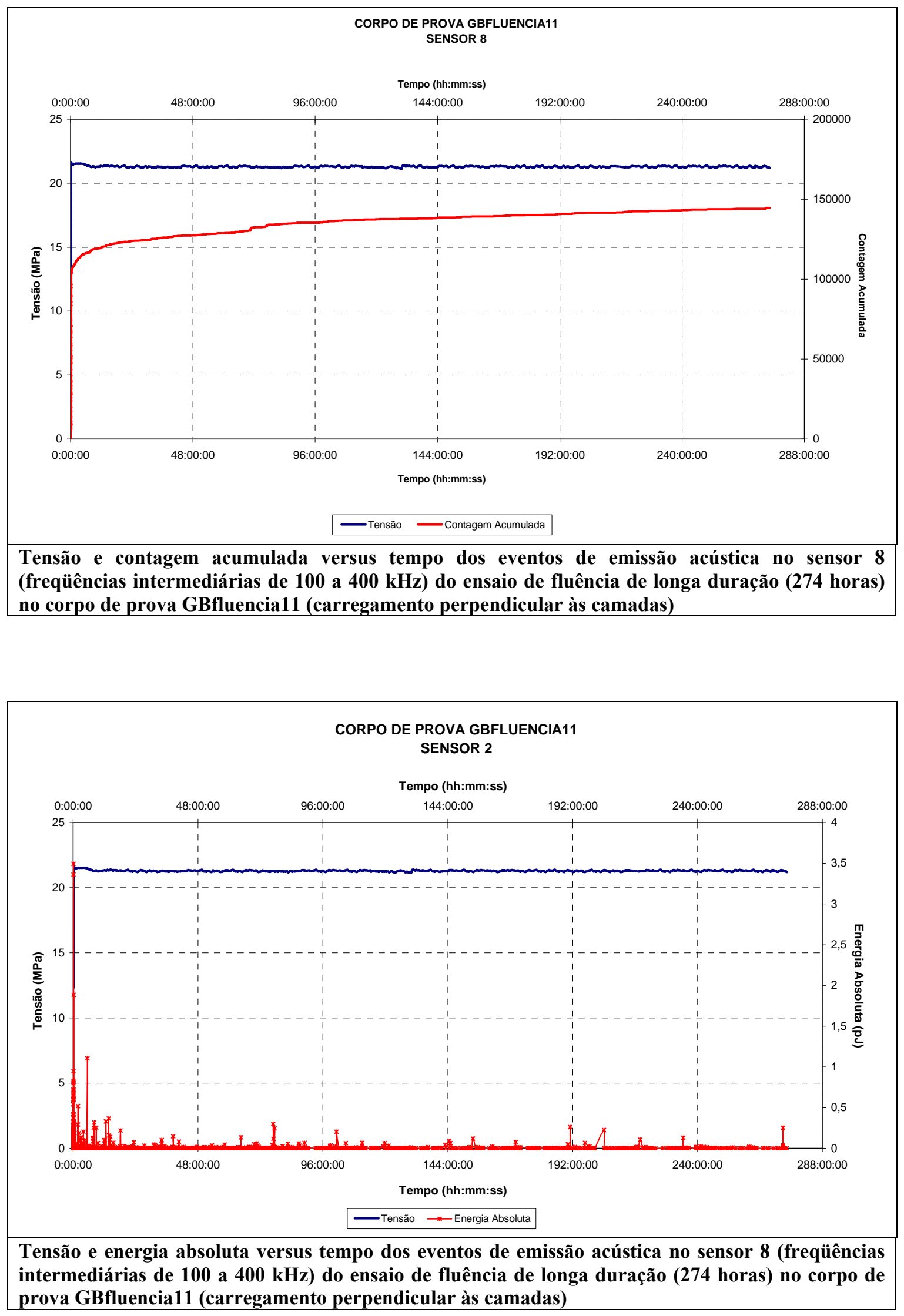

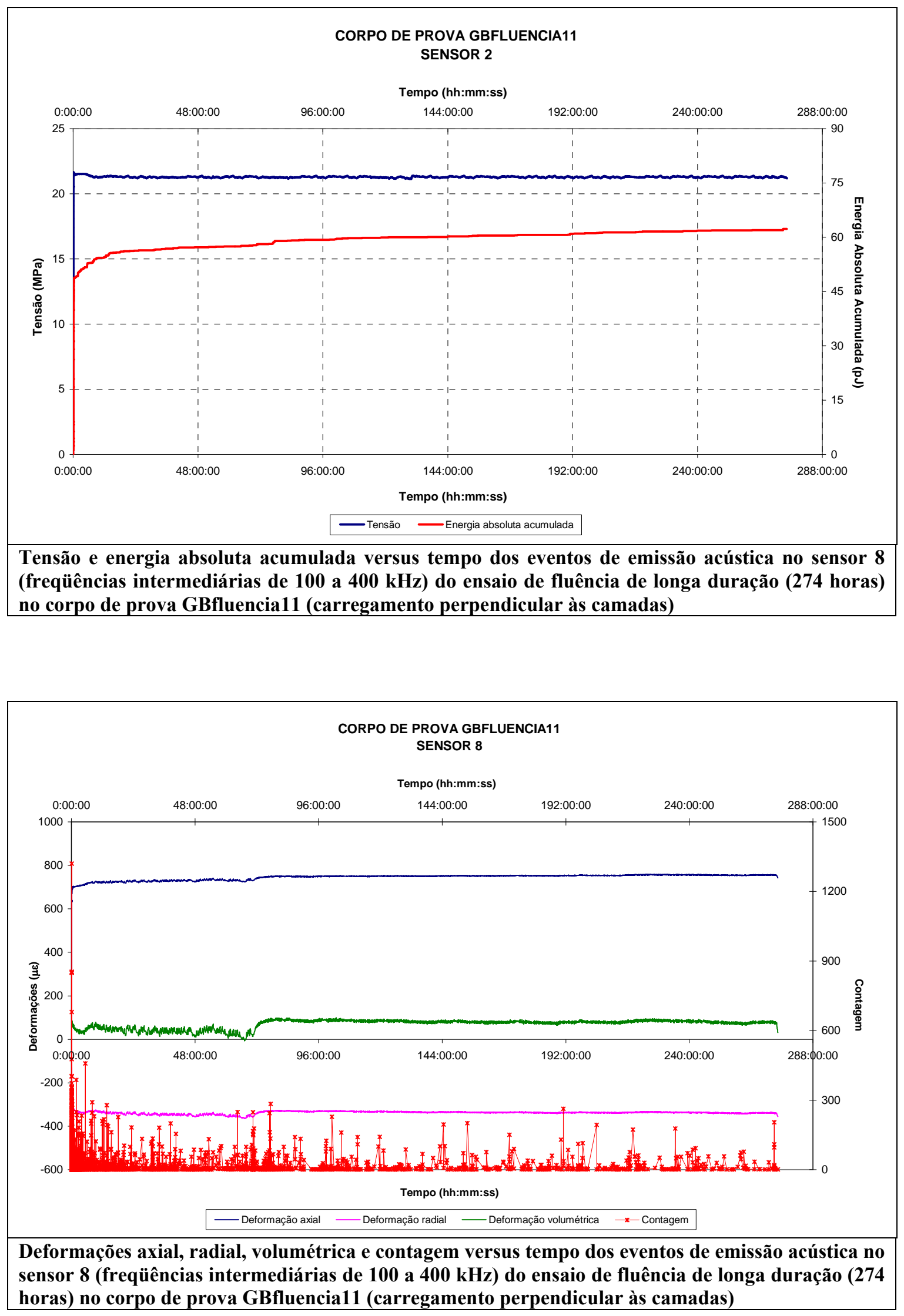

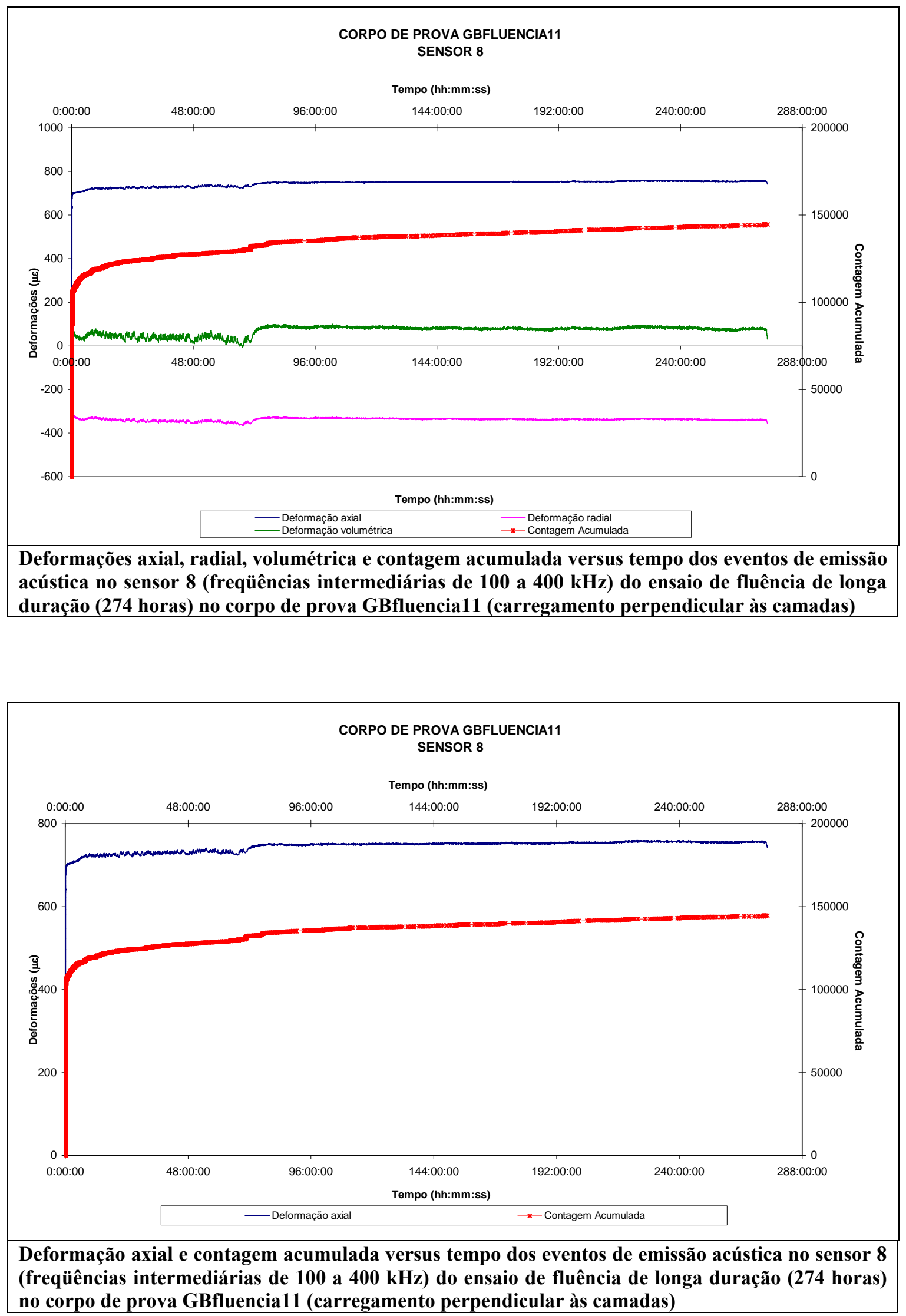

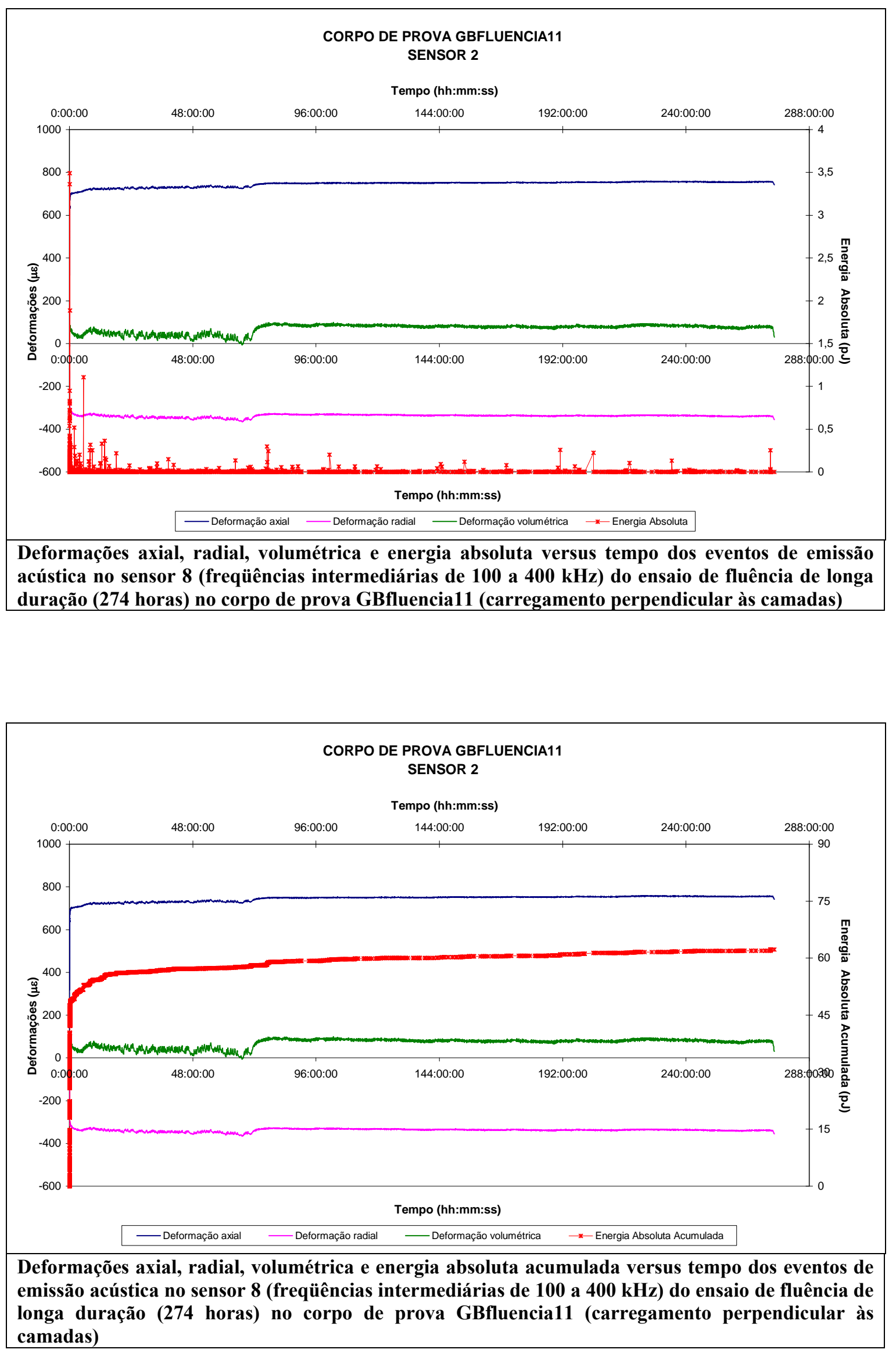

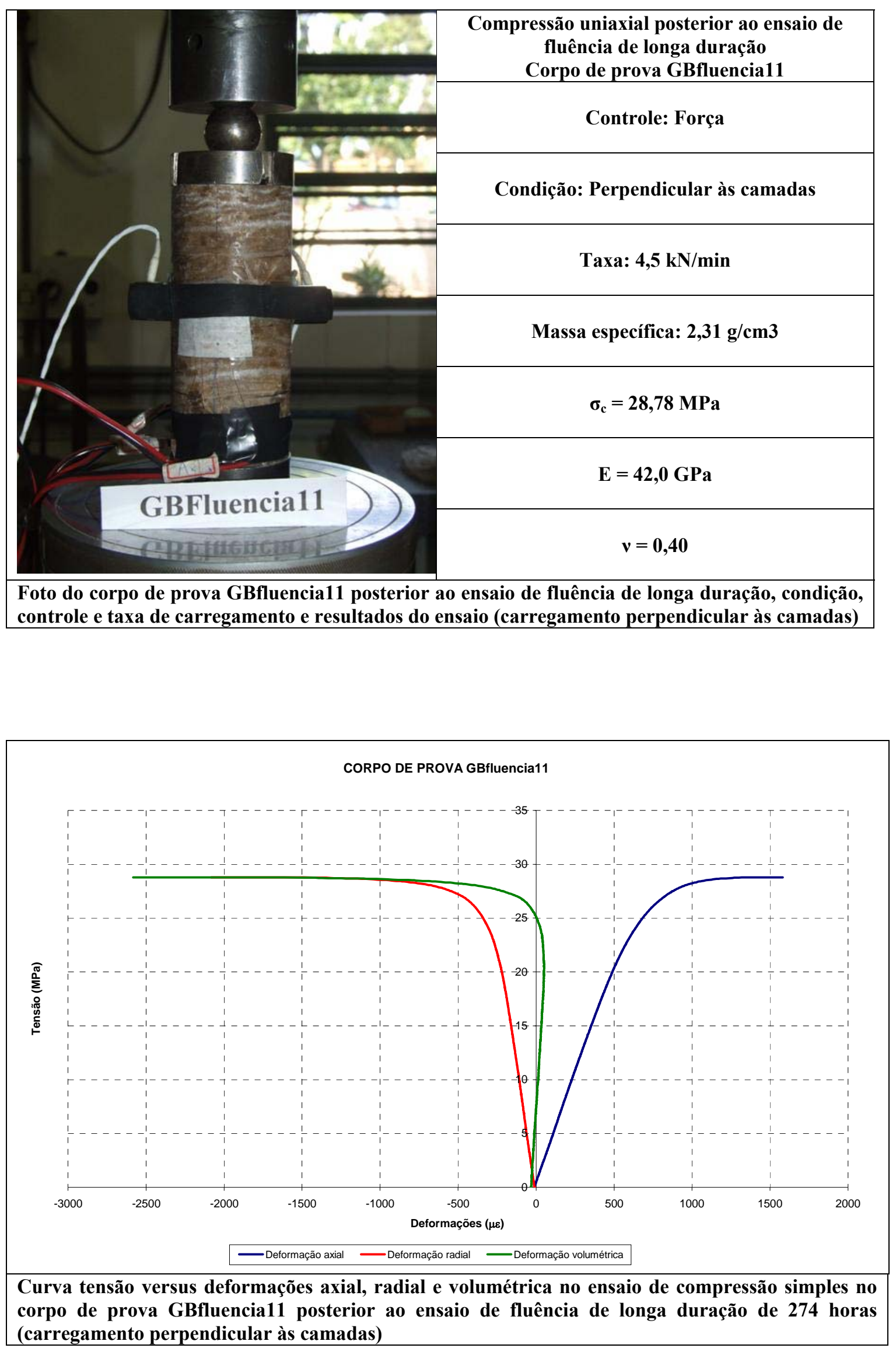

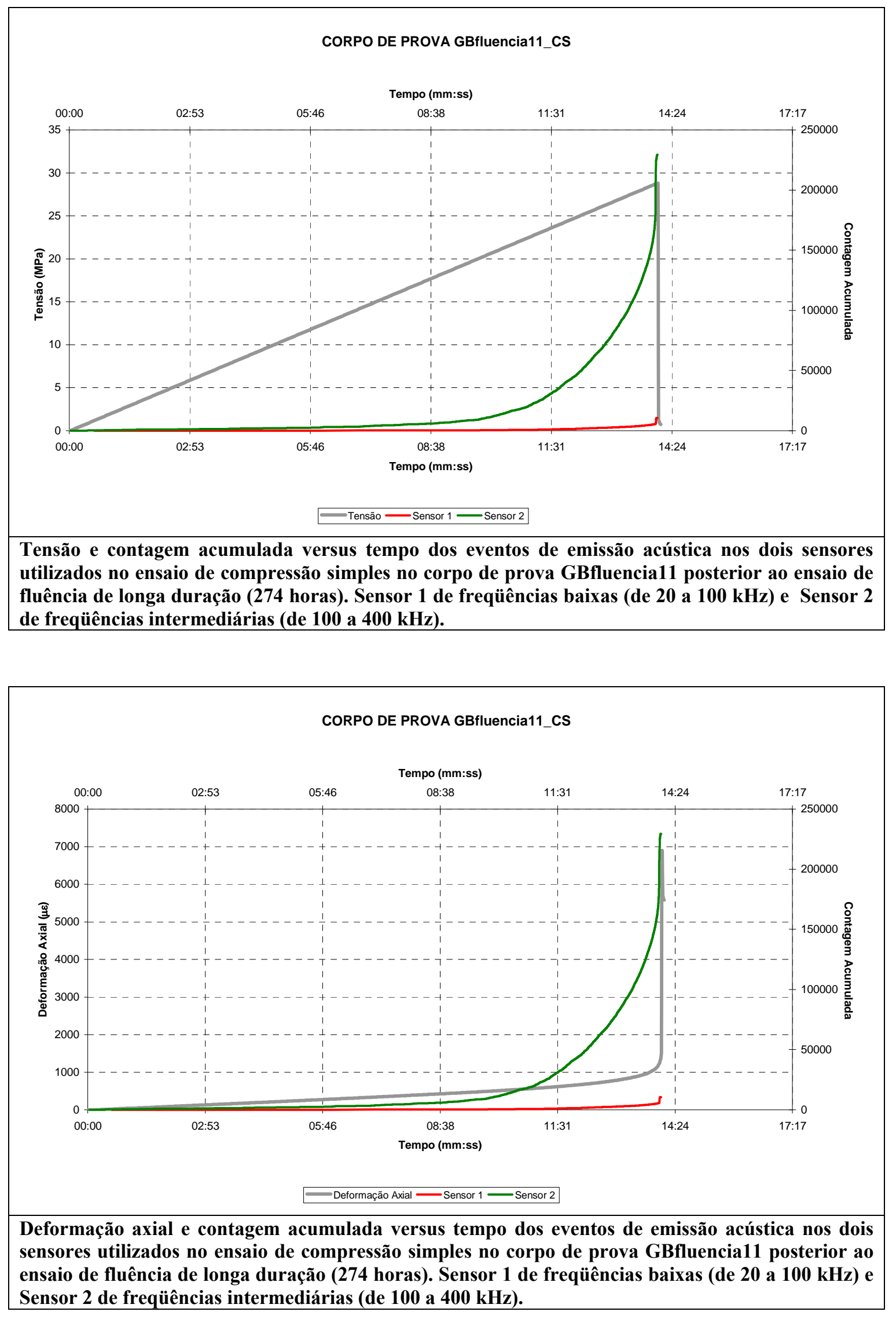

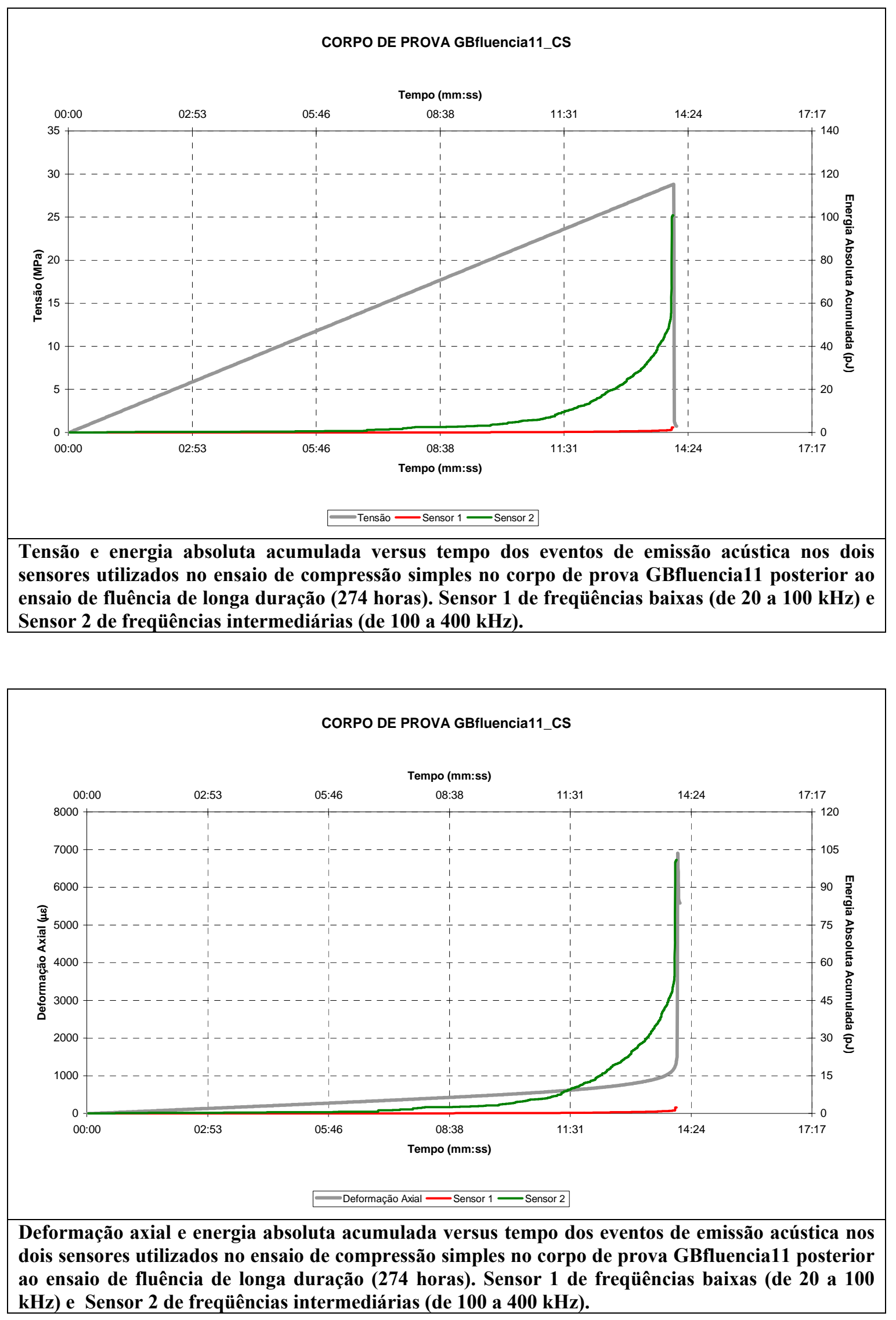

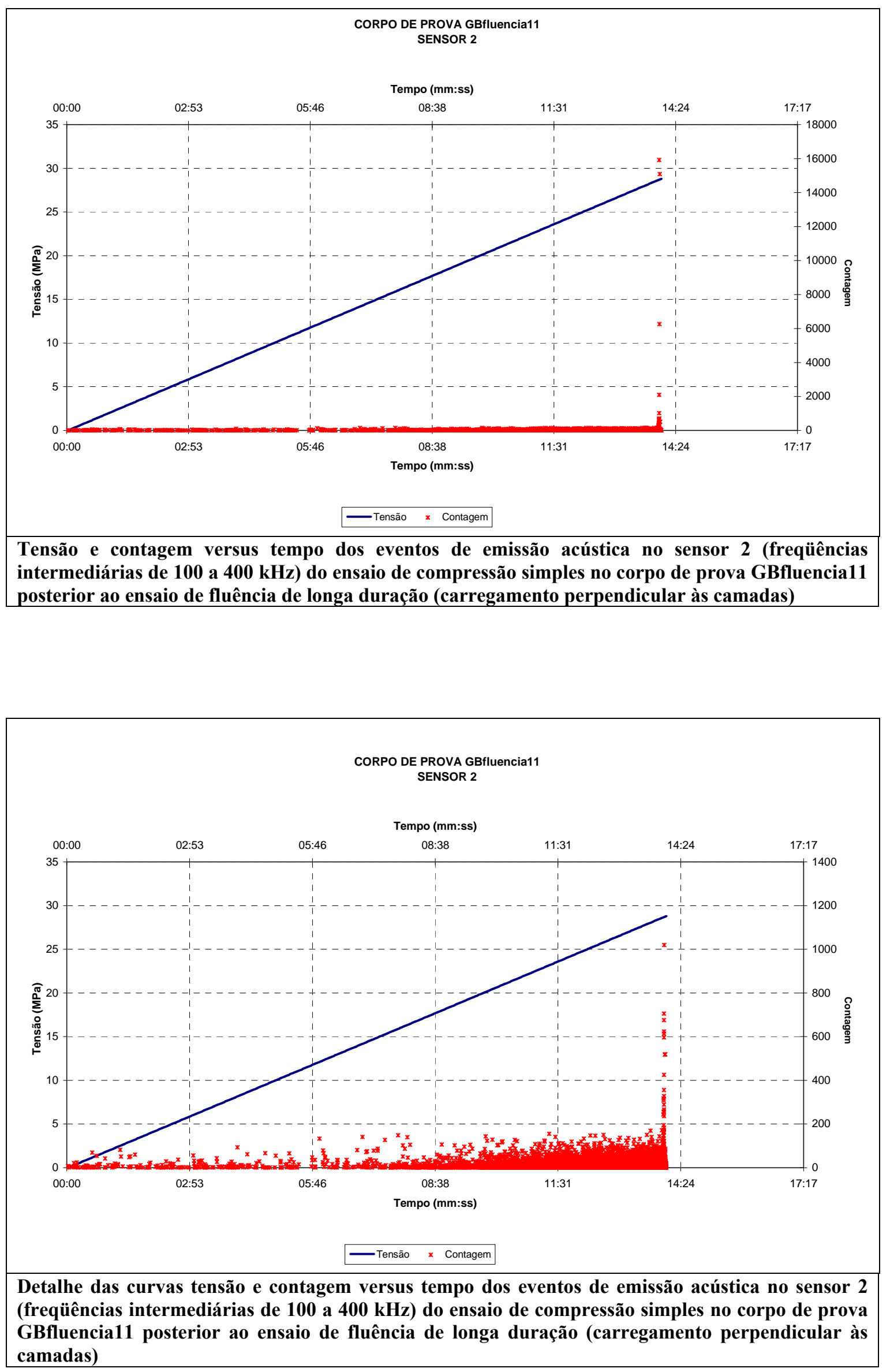

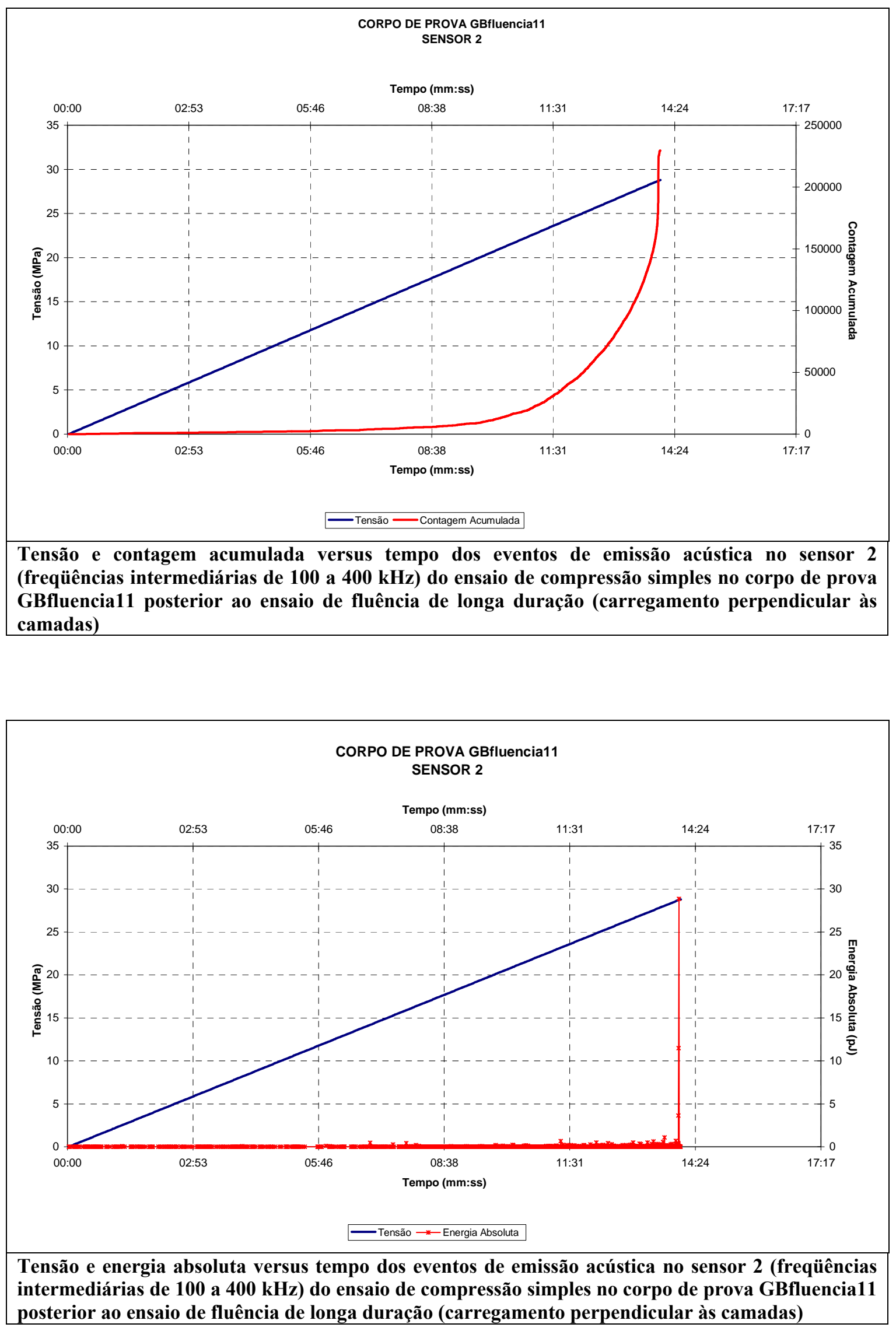

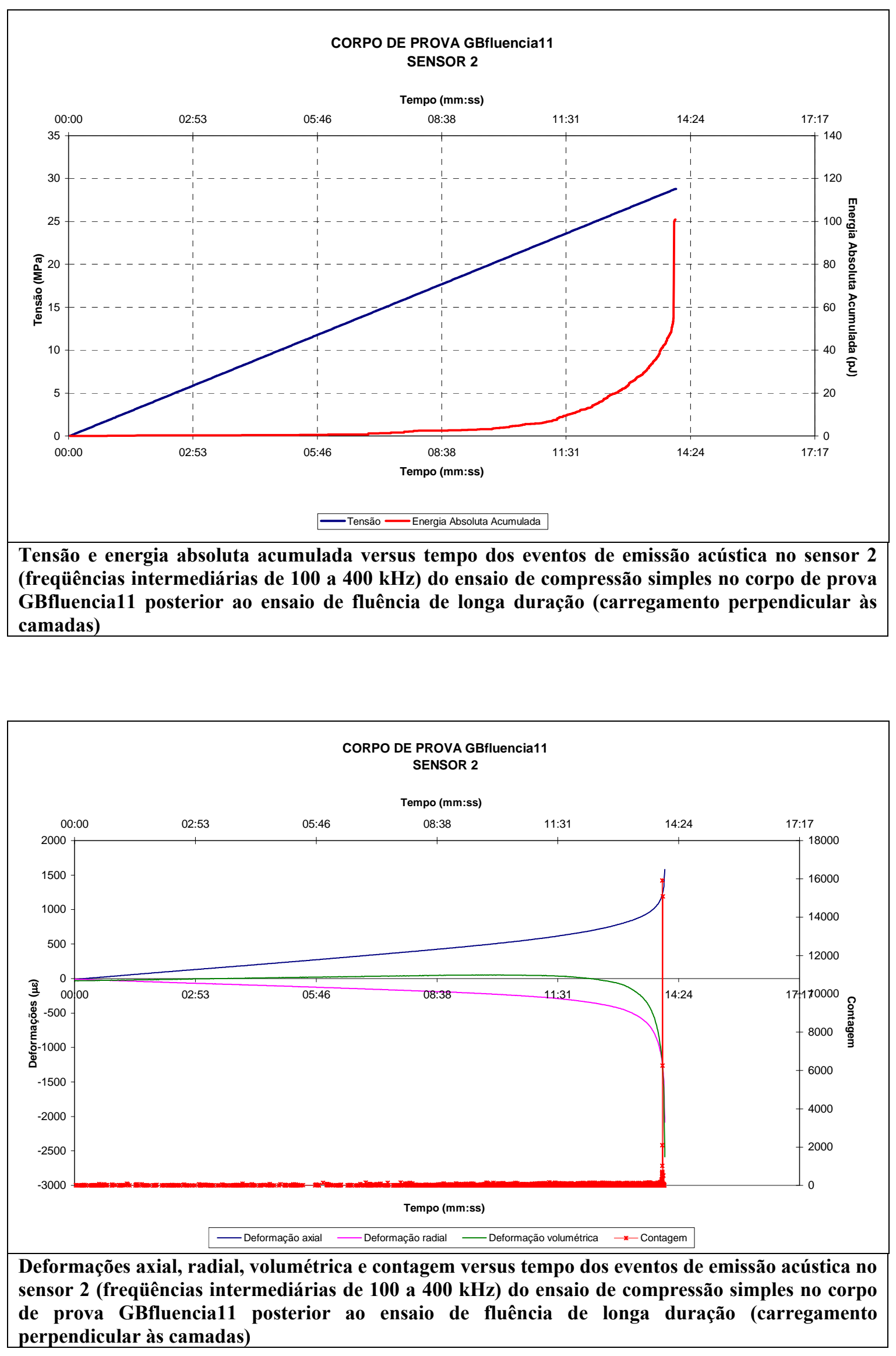


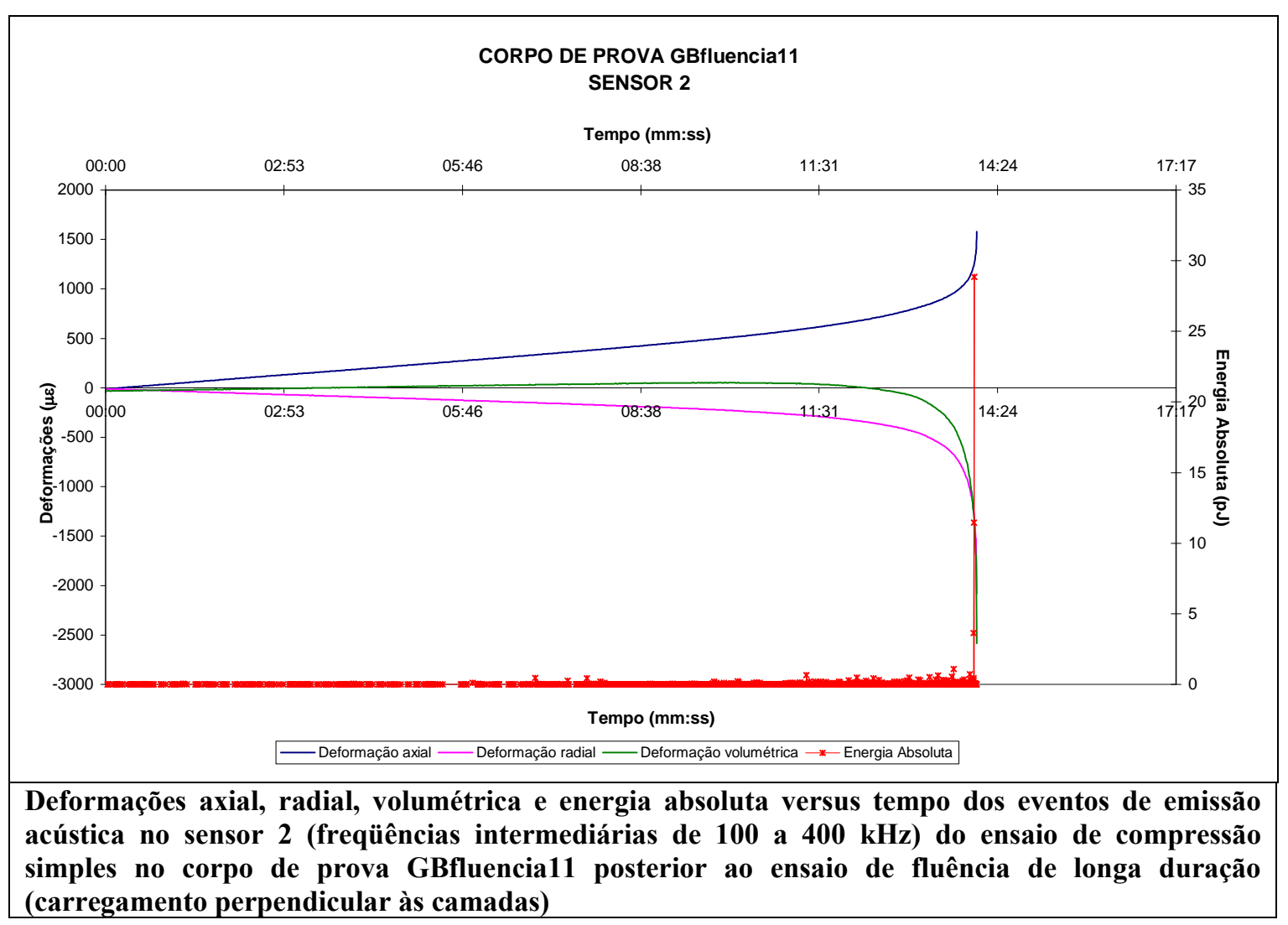




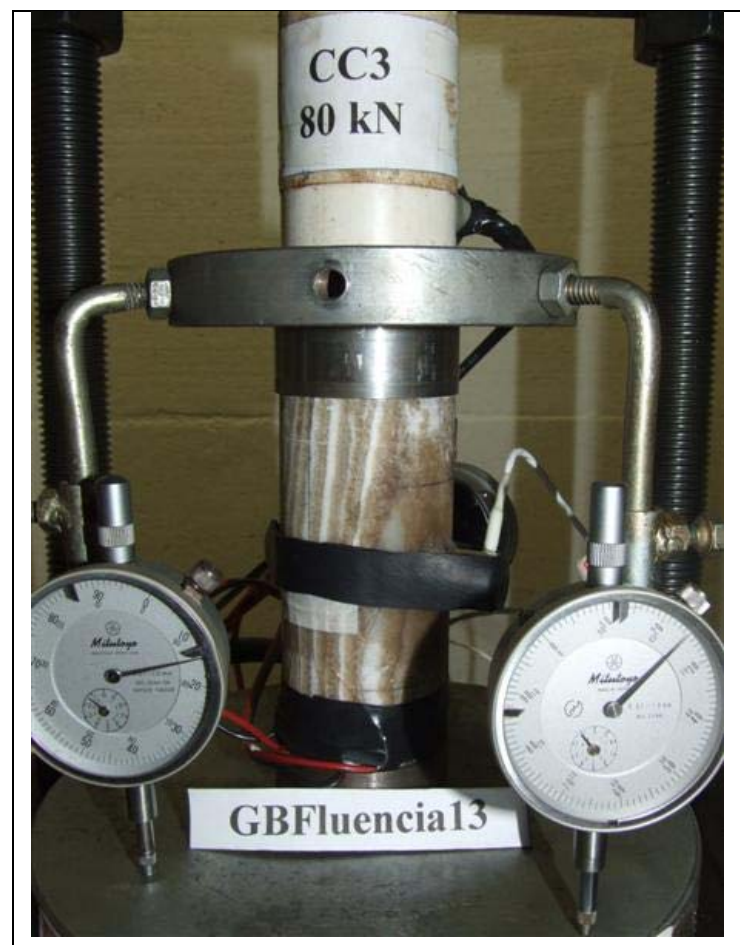

\begin{tabular}{|c|}
\hline $\begin{array}{c}\text { Ensaio de fluência de longa duração } \\
\text { Corpo de prova GBfluencia13 }\end{array}$ \\
\hline Condição: Paralela às camadas \\
\hline Duração do ensaio: 274 horas \\
\hline Tensão aplicada: 21,97 MPa \\
\hline em relação à tensão de ruptura: 70,94 \\
\hline Tensão de ruptura: 30,97 MPa \\
\hline
\end{tabular}

Foto do corpo de prova GBfluencia13, condição, duração do ensaio, tensão aplicada, percentagem em relação à tensão de ruptura e resultados do ensaio.

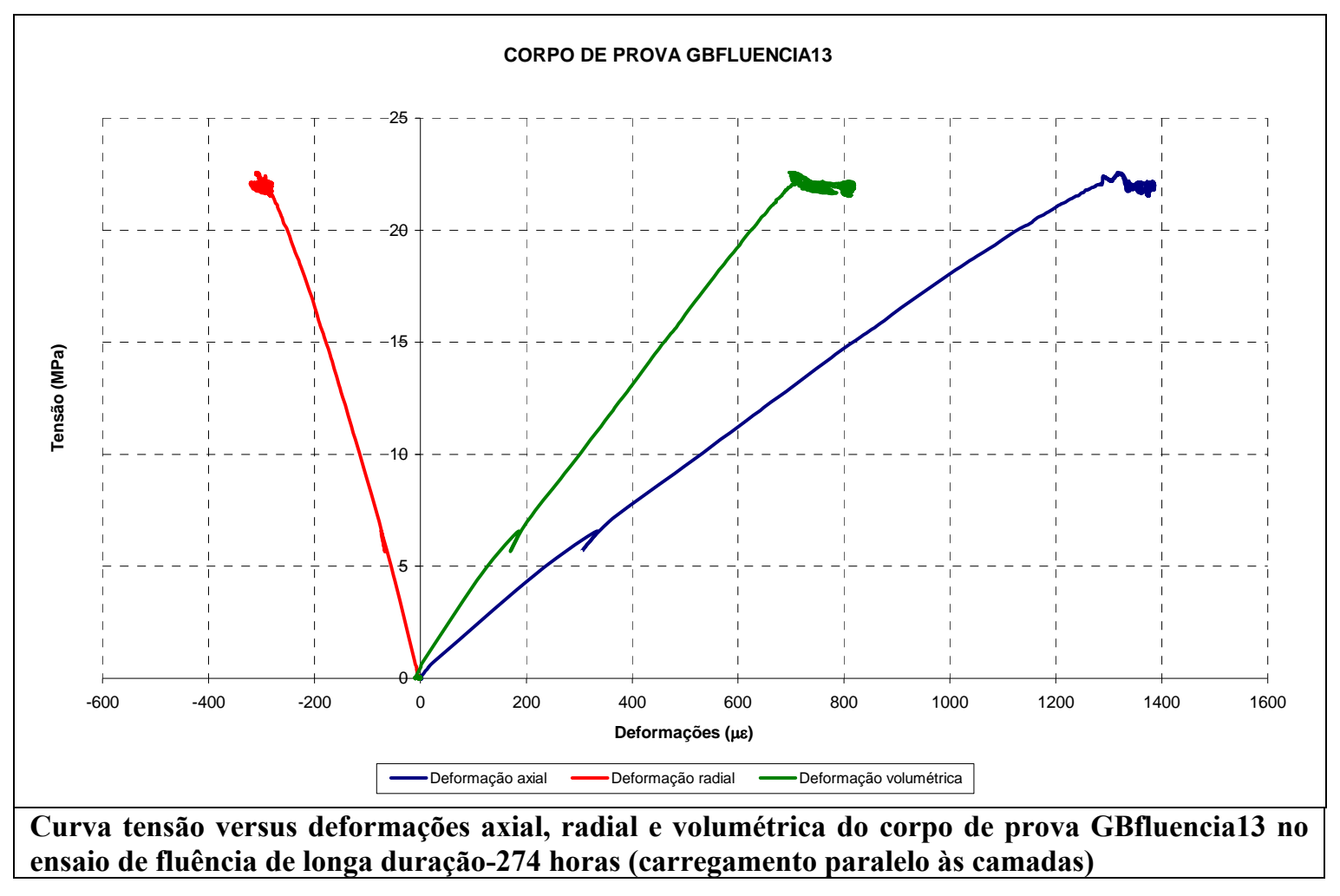



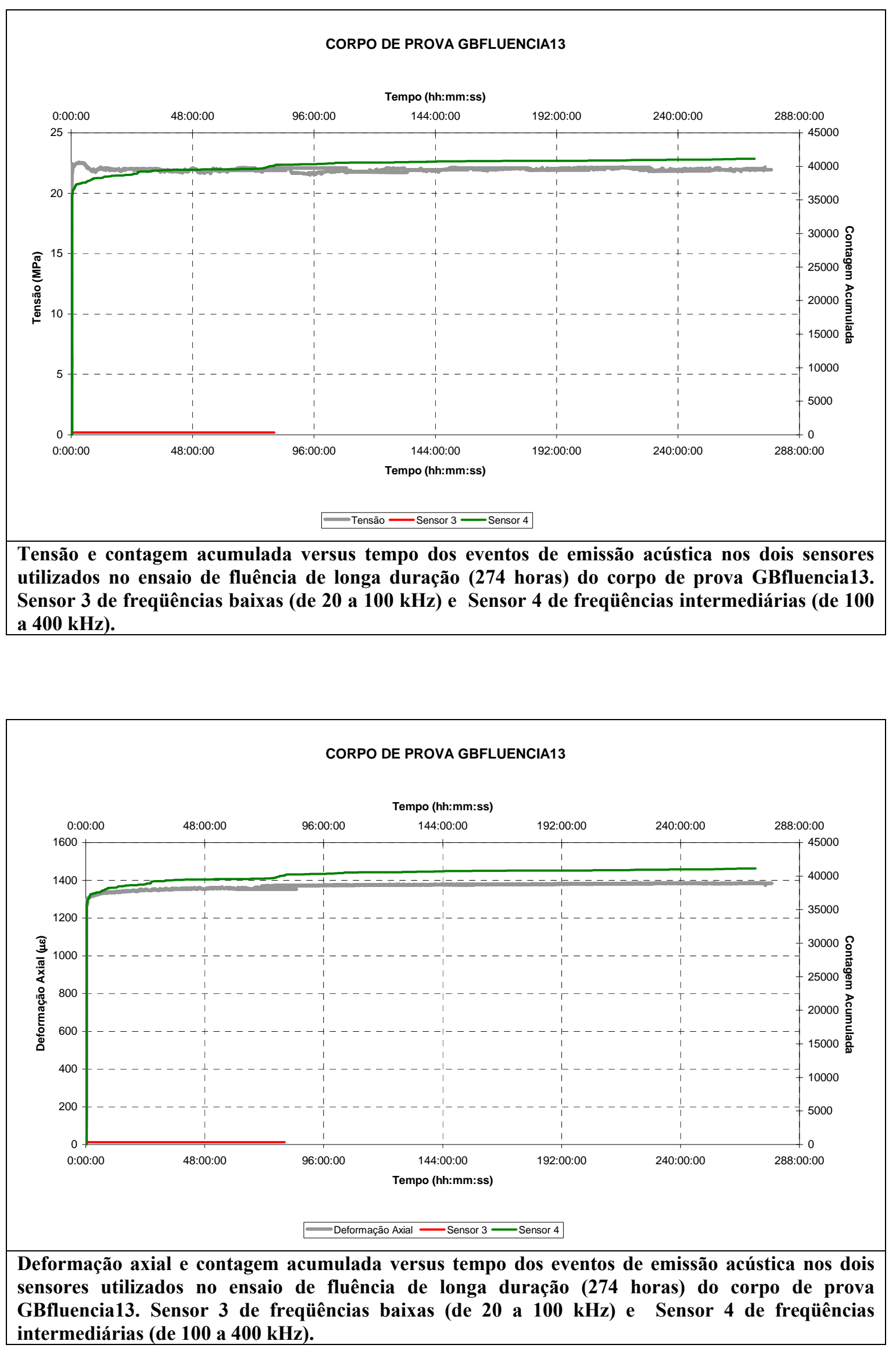

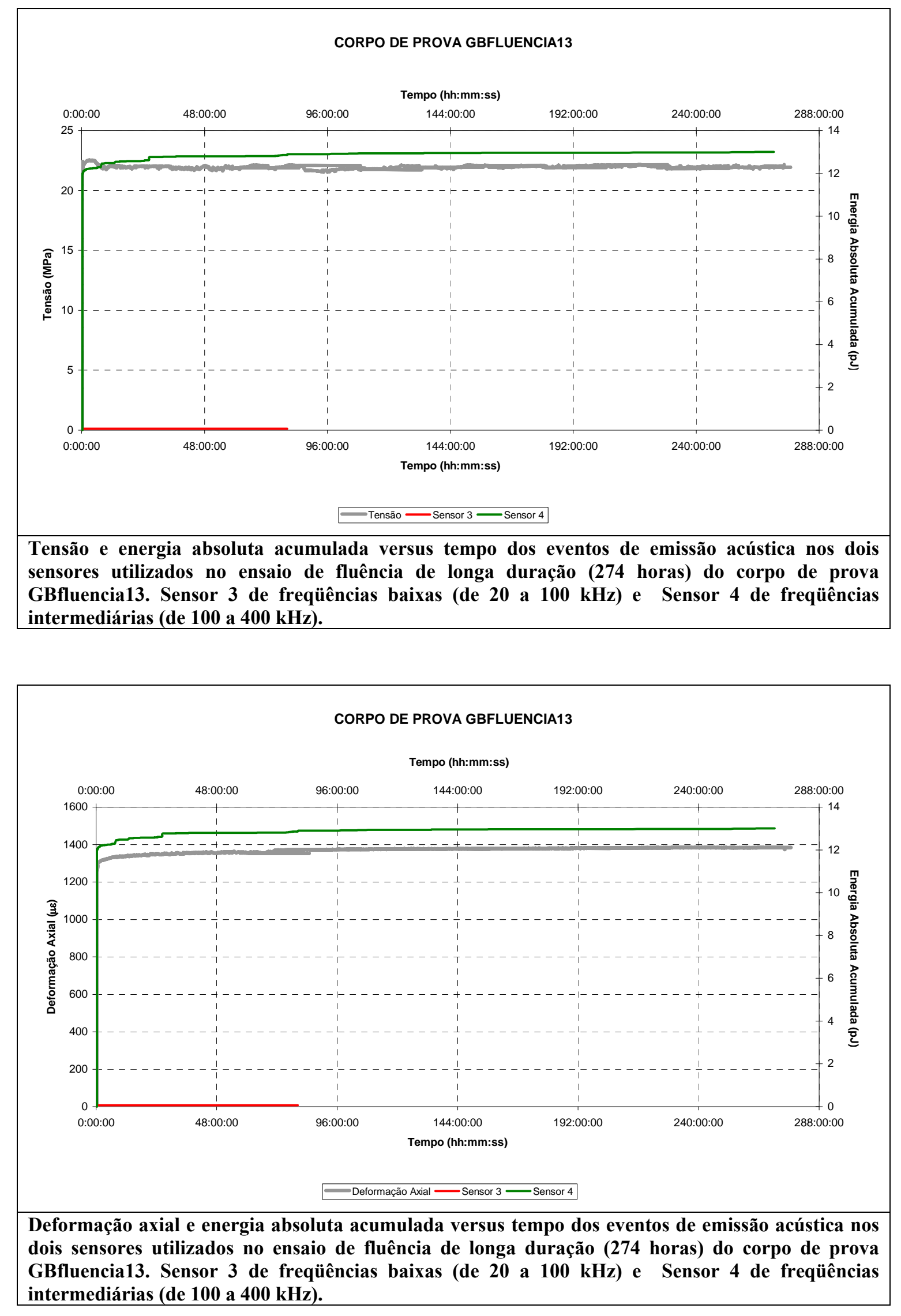

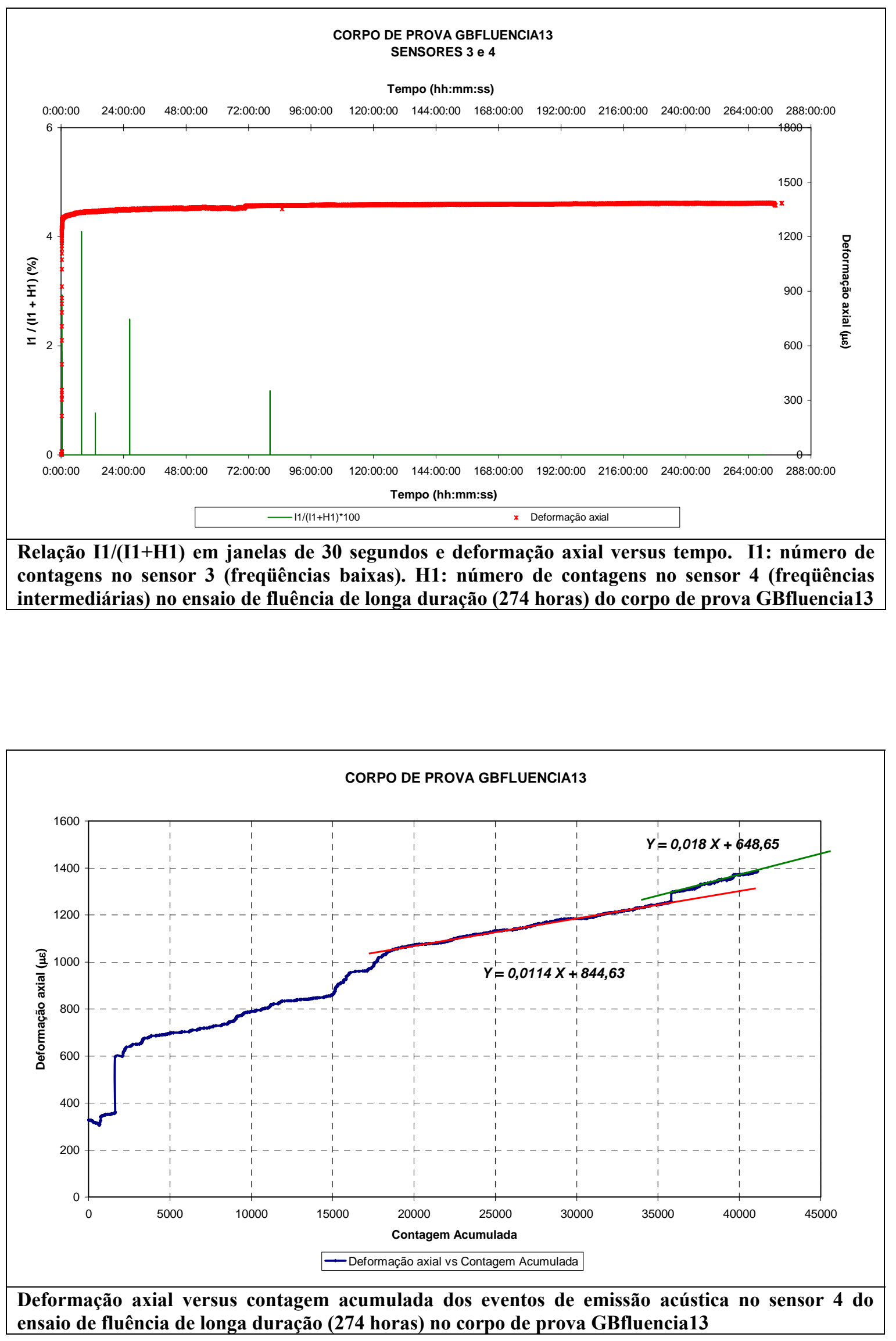

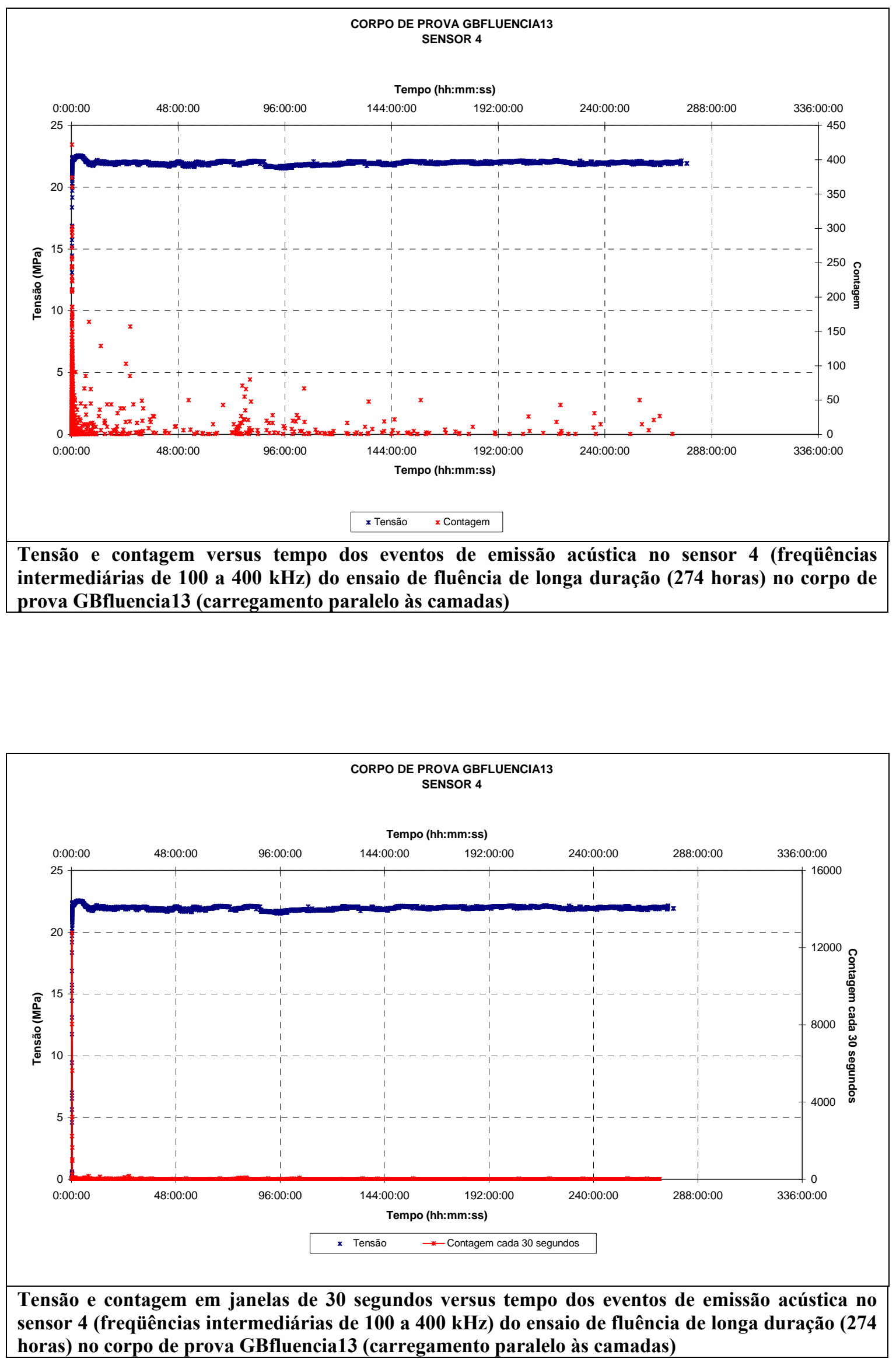

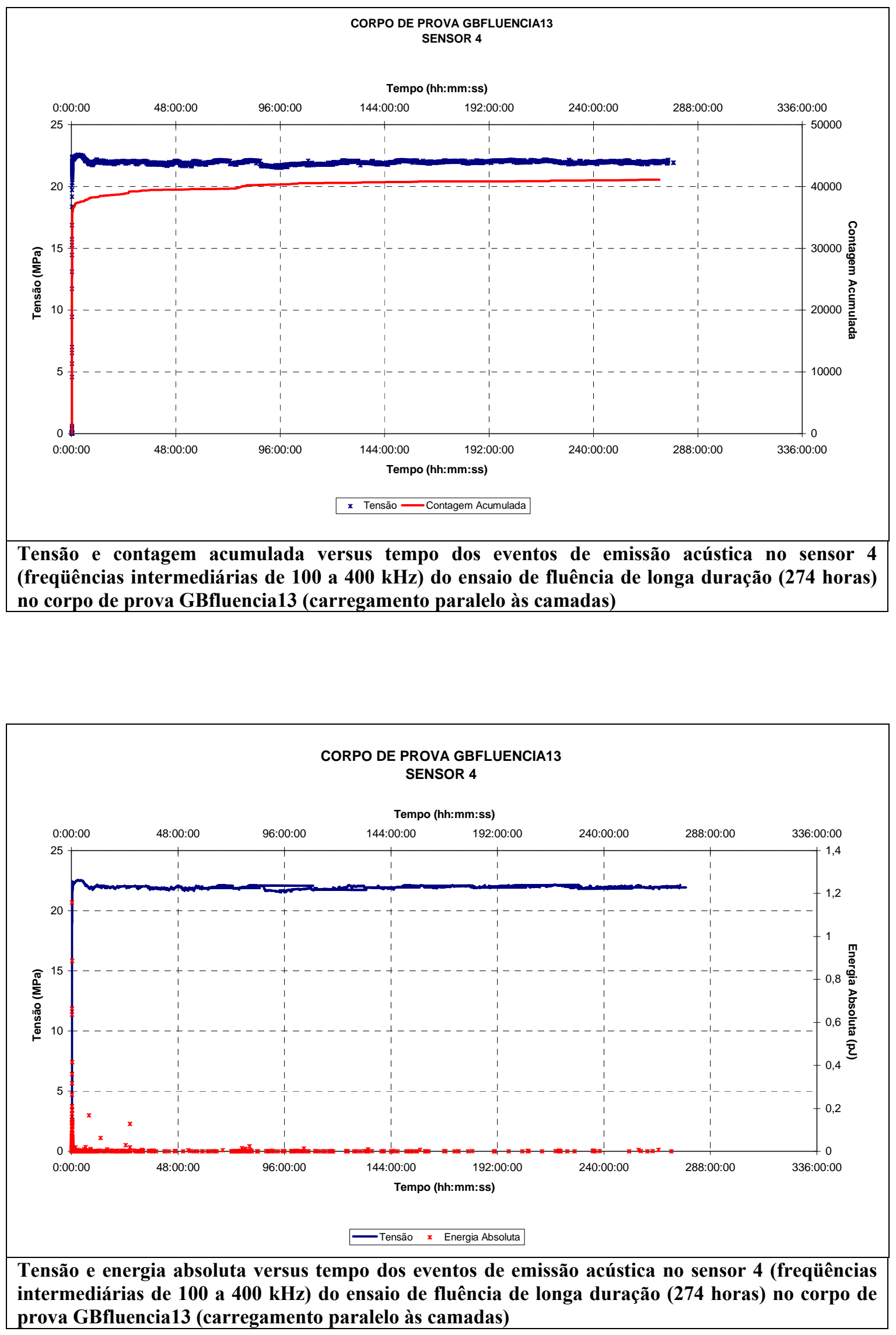

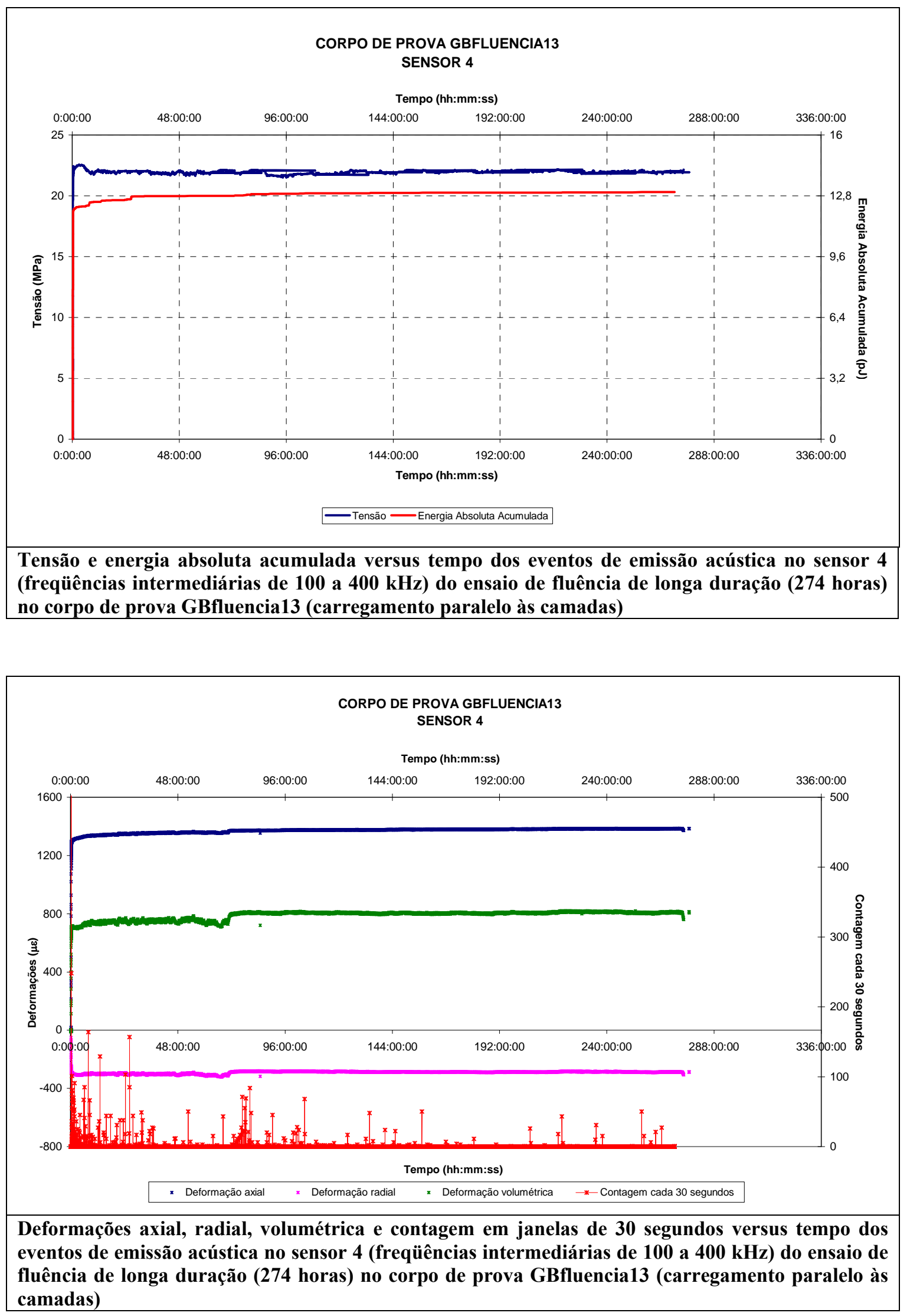

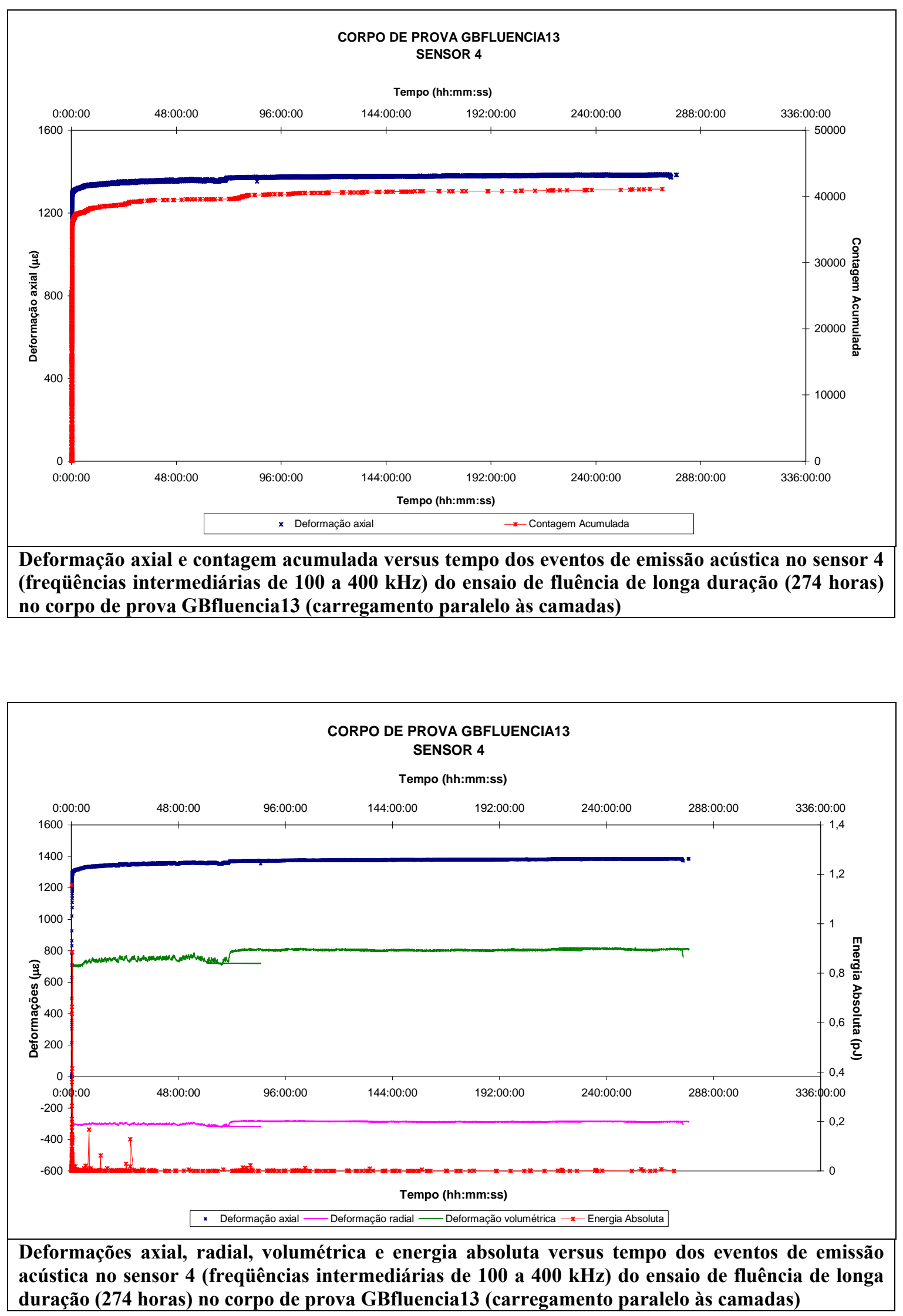


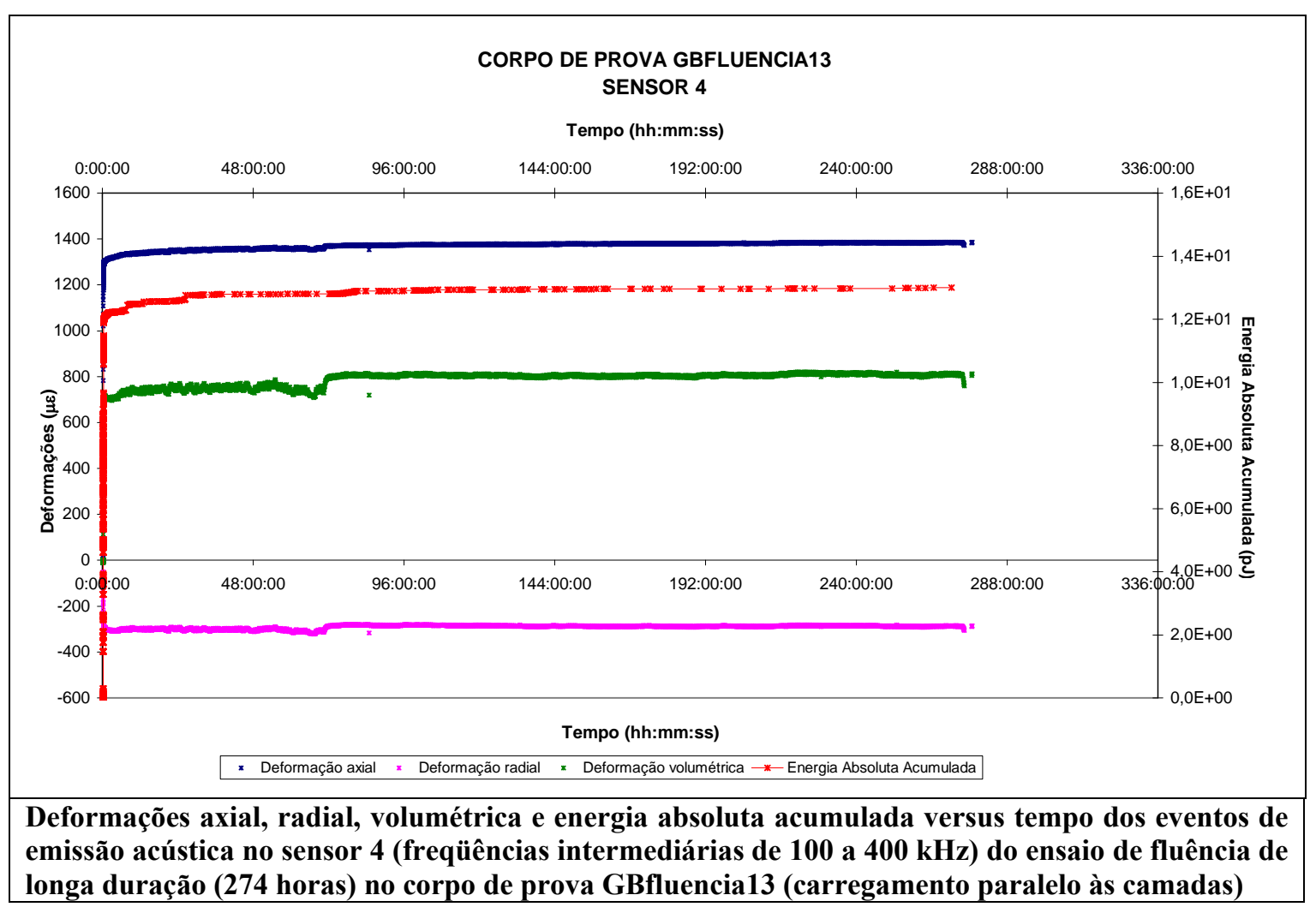




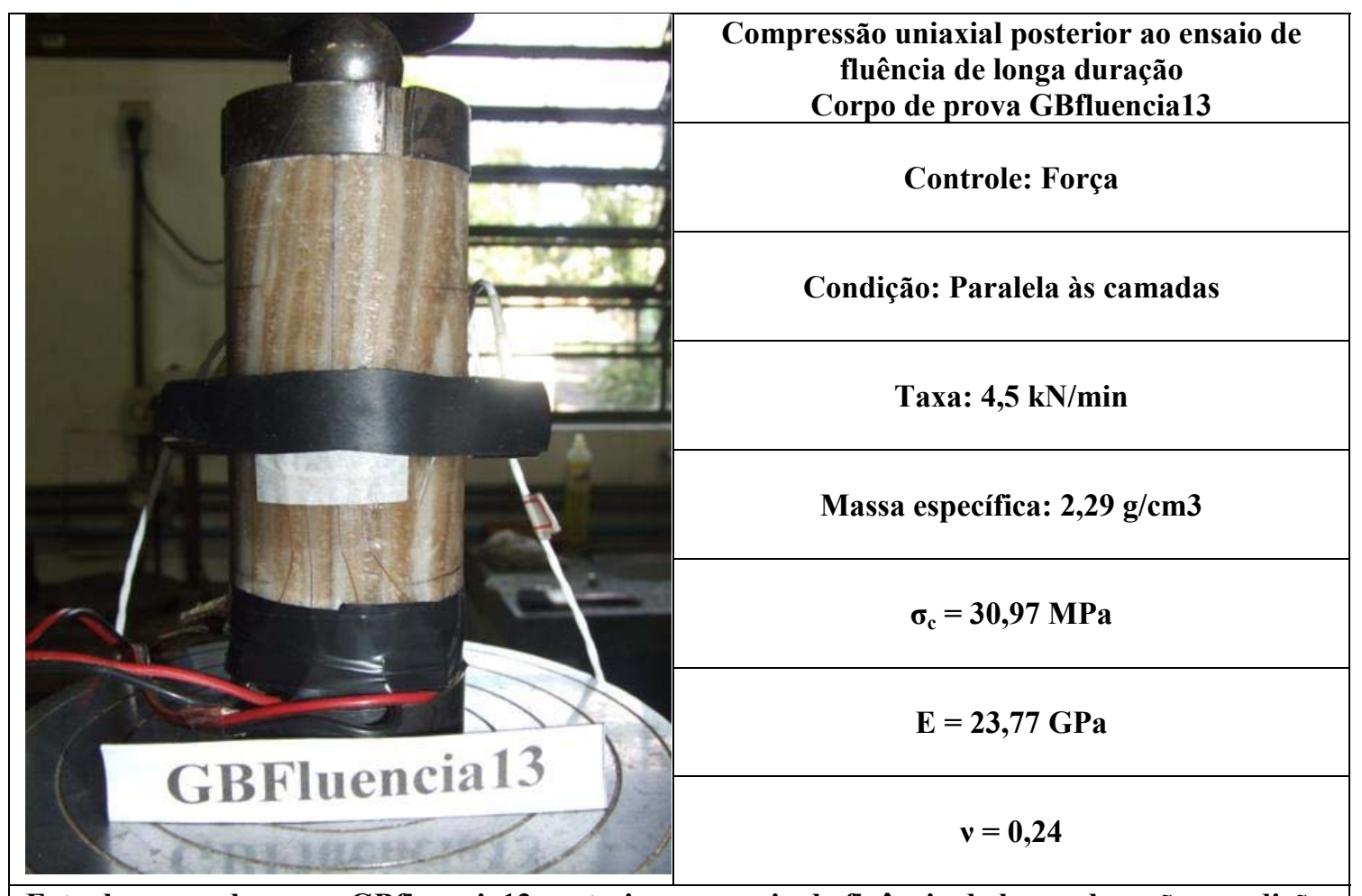

Foto do corpo de prova GBfluencia13 posterior ao ensaio de fluência de longa duração, condição, controle e taxa de carregamento e resultados do ensaio (carregamento perpendicular às camadas)

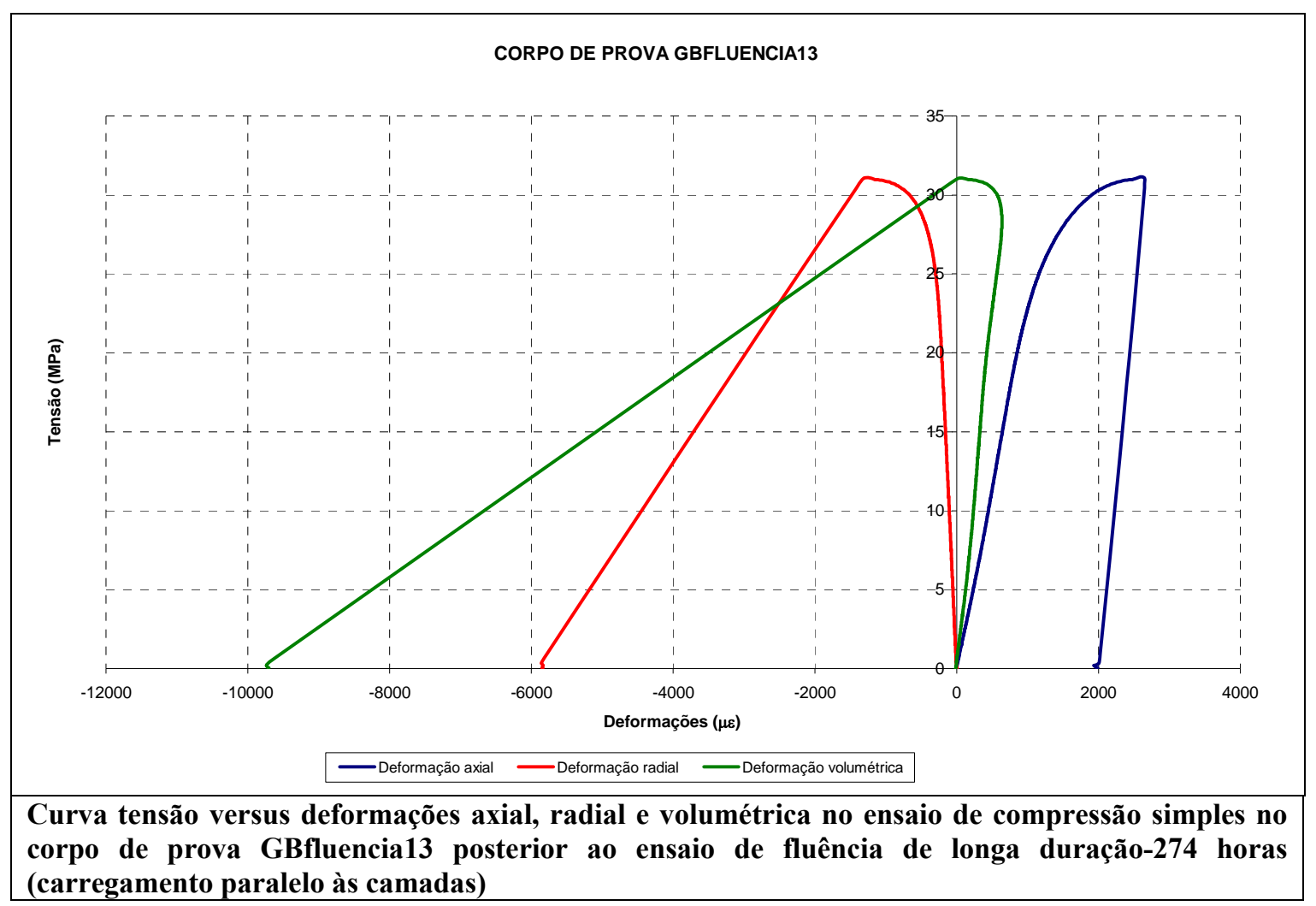



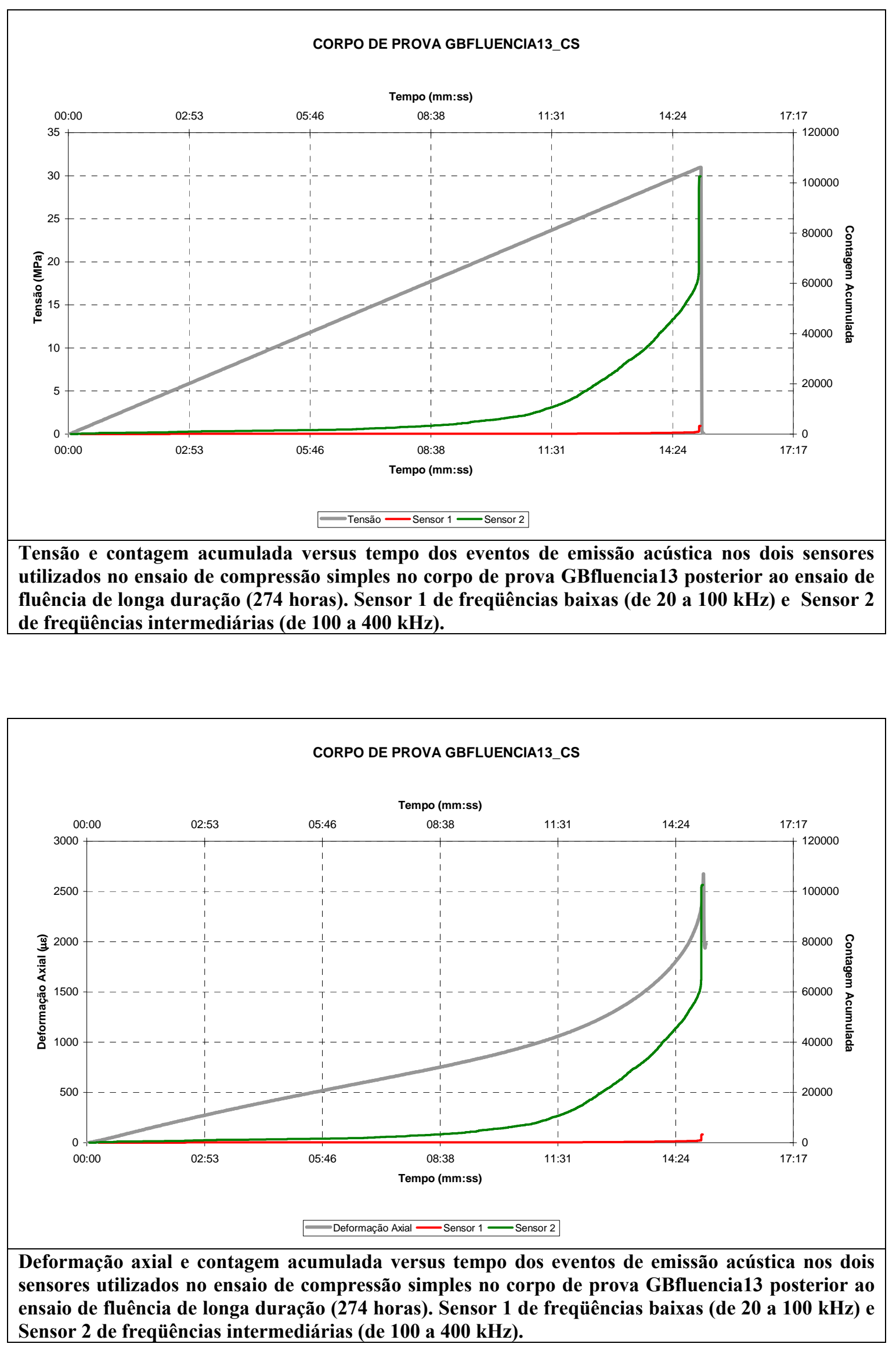

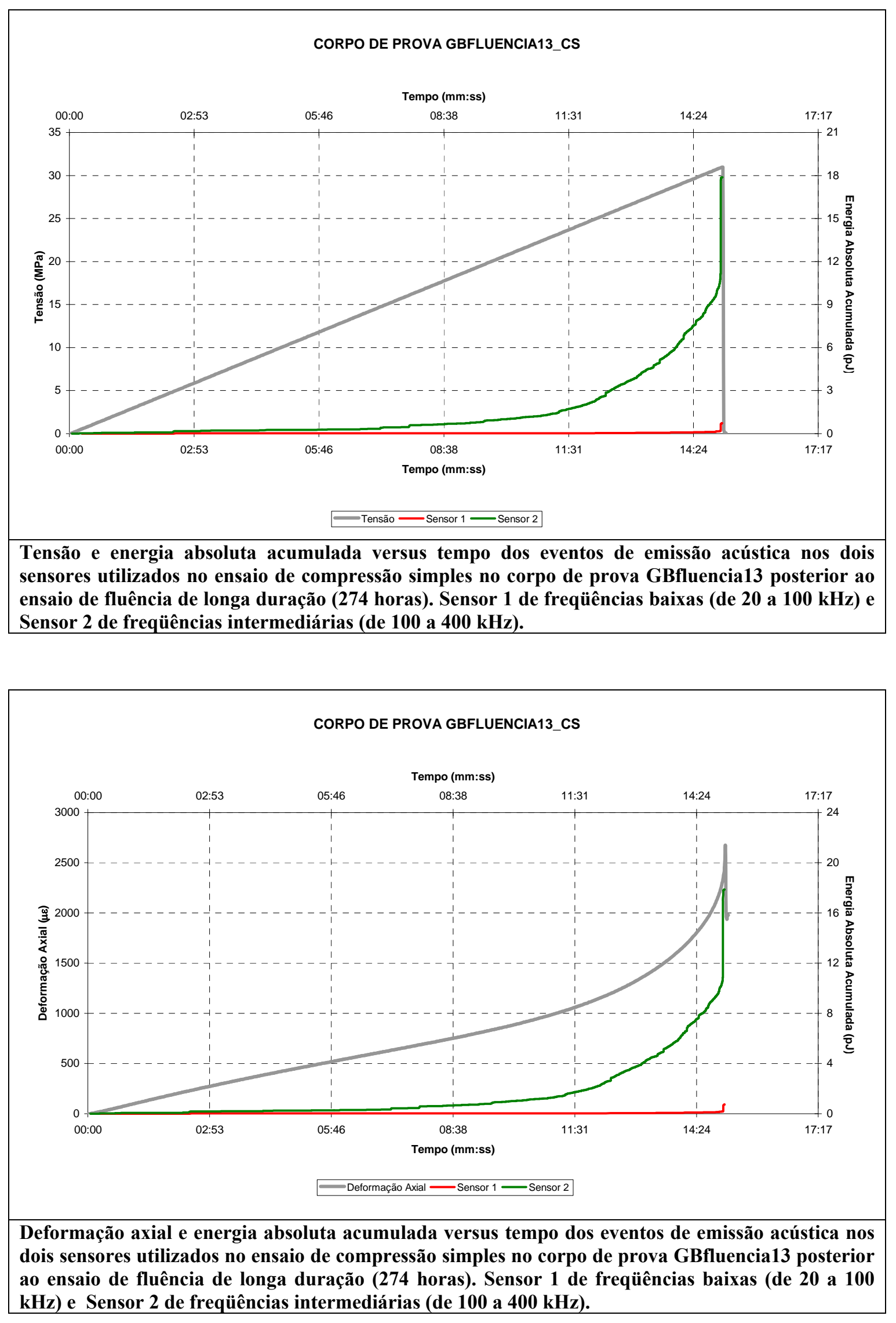

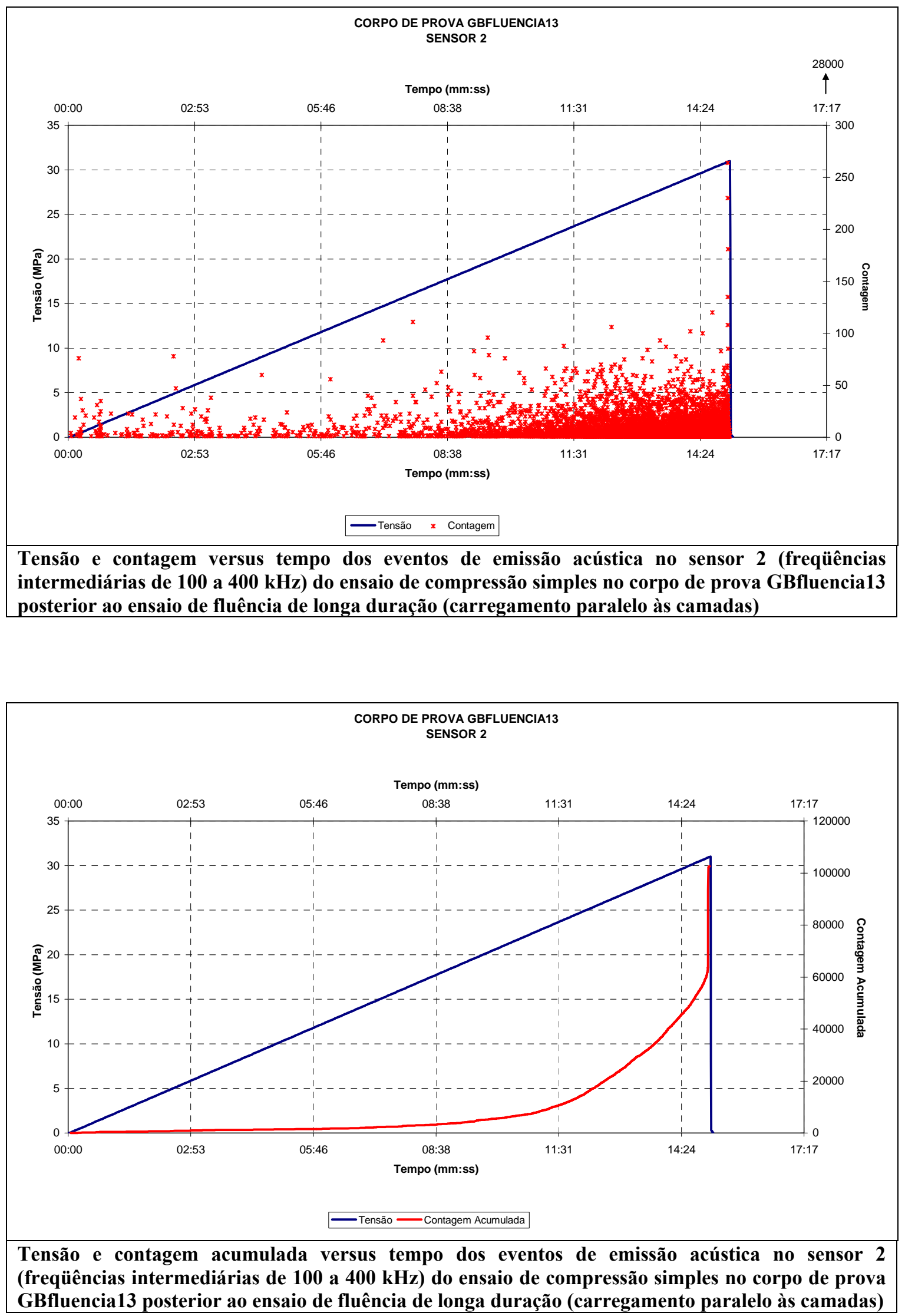

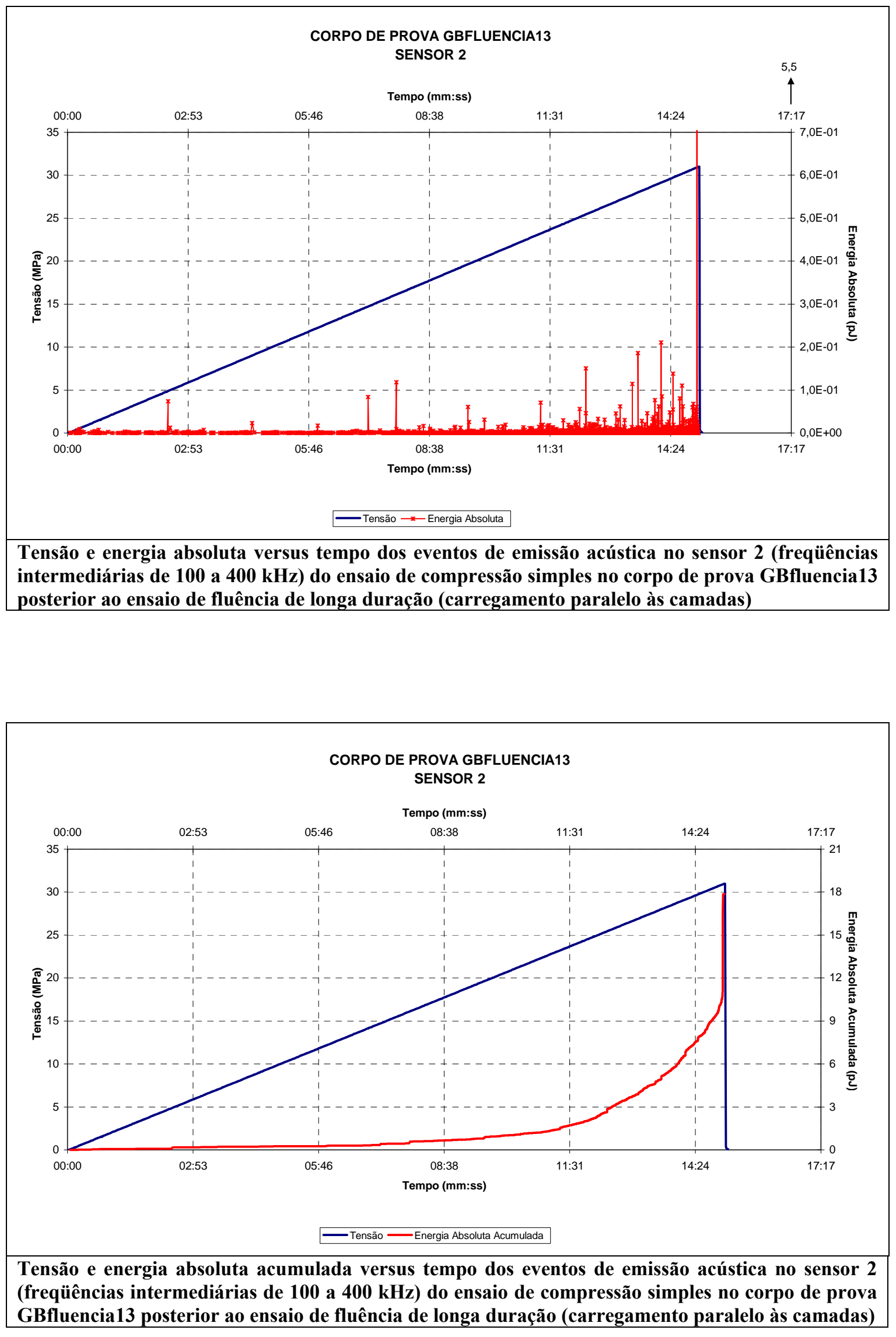

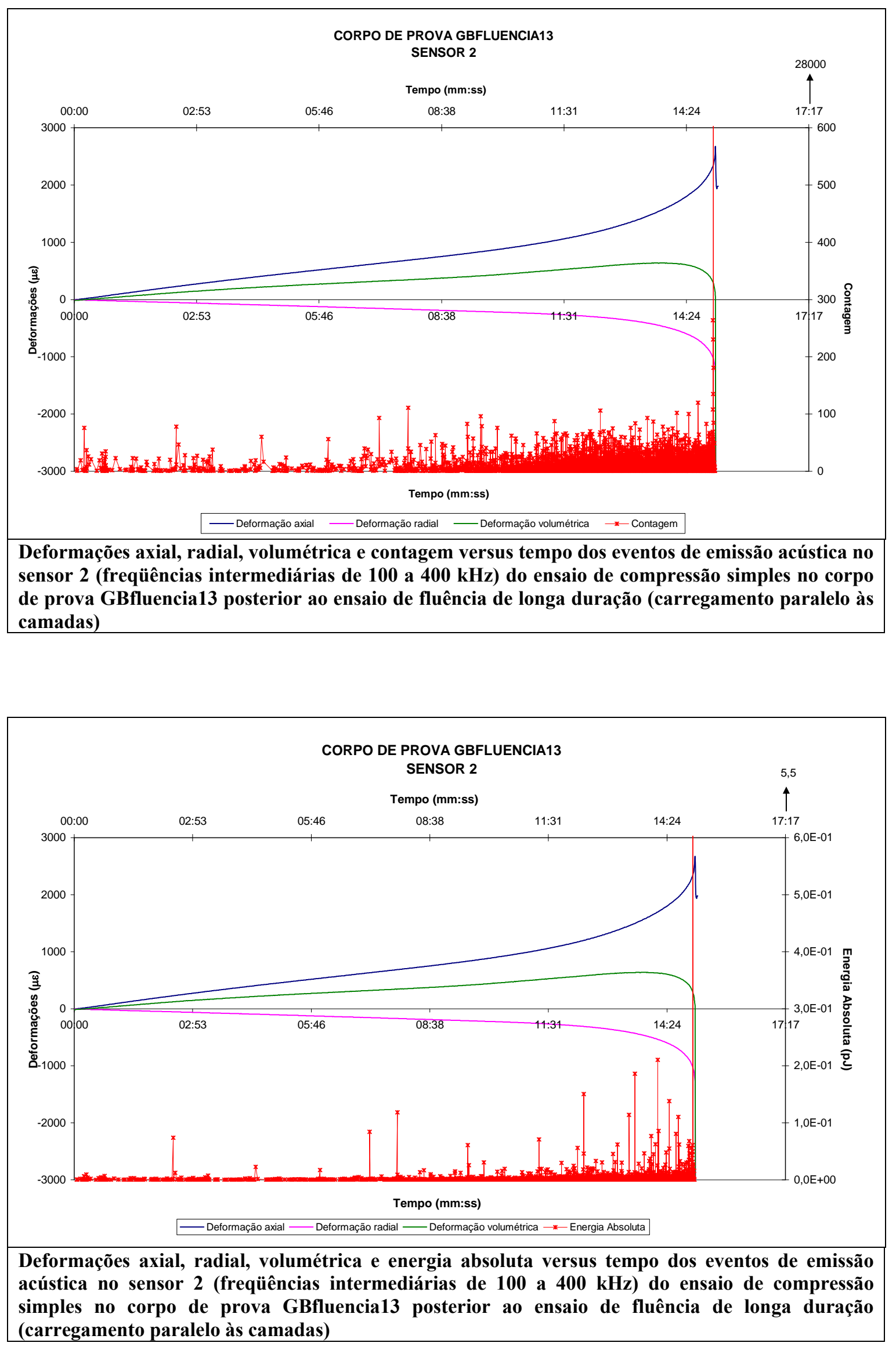


\section{A pêndice 5}

ENSAIOS DE FLUÊNCIA DE LONGA DURAÇÃO COM DOIS CICLOS DE CARREGAMENTO E DESCARREGAMENTO SUCESSIVOS E POSTERIOR CICLO CRESCENTE DE CARGA 


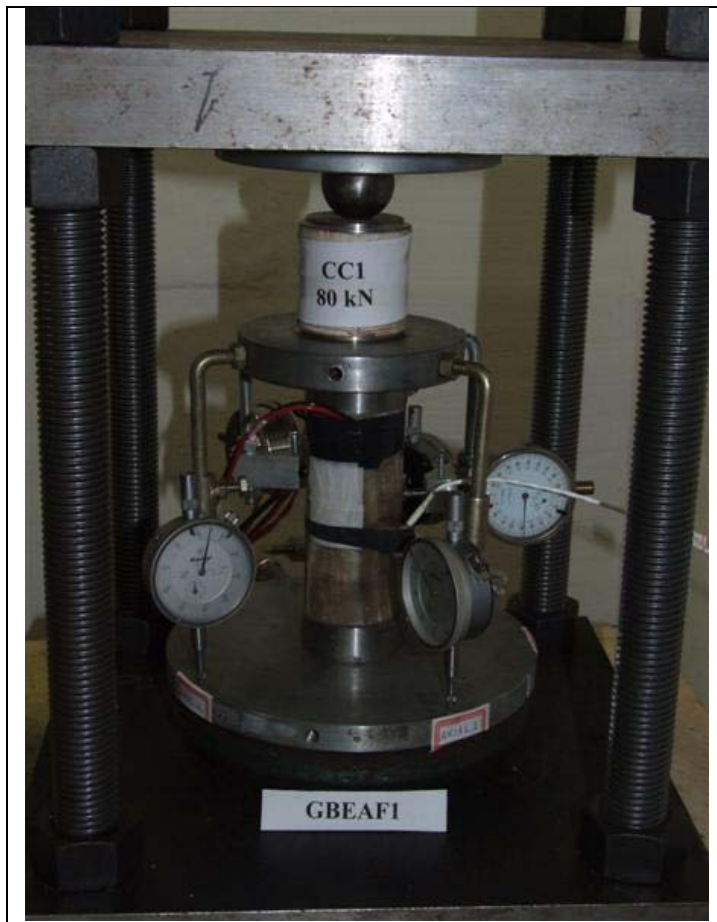

Ensaio de fluência de longa duração com dois ciclos de carregamento e descarregamento sucessivos e posterior ciclo crescente de carga Corpo de prova GBEAF1

Foto do corpo de prova GBEAF1, condição do carregamento, ciclos de carregamento, tensão média aplicada e resultados do ensaio.

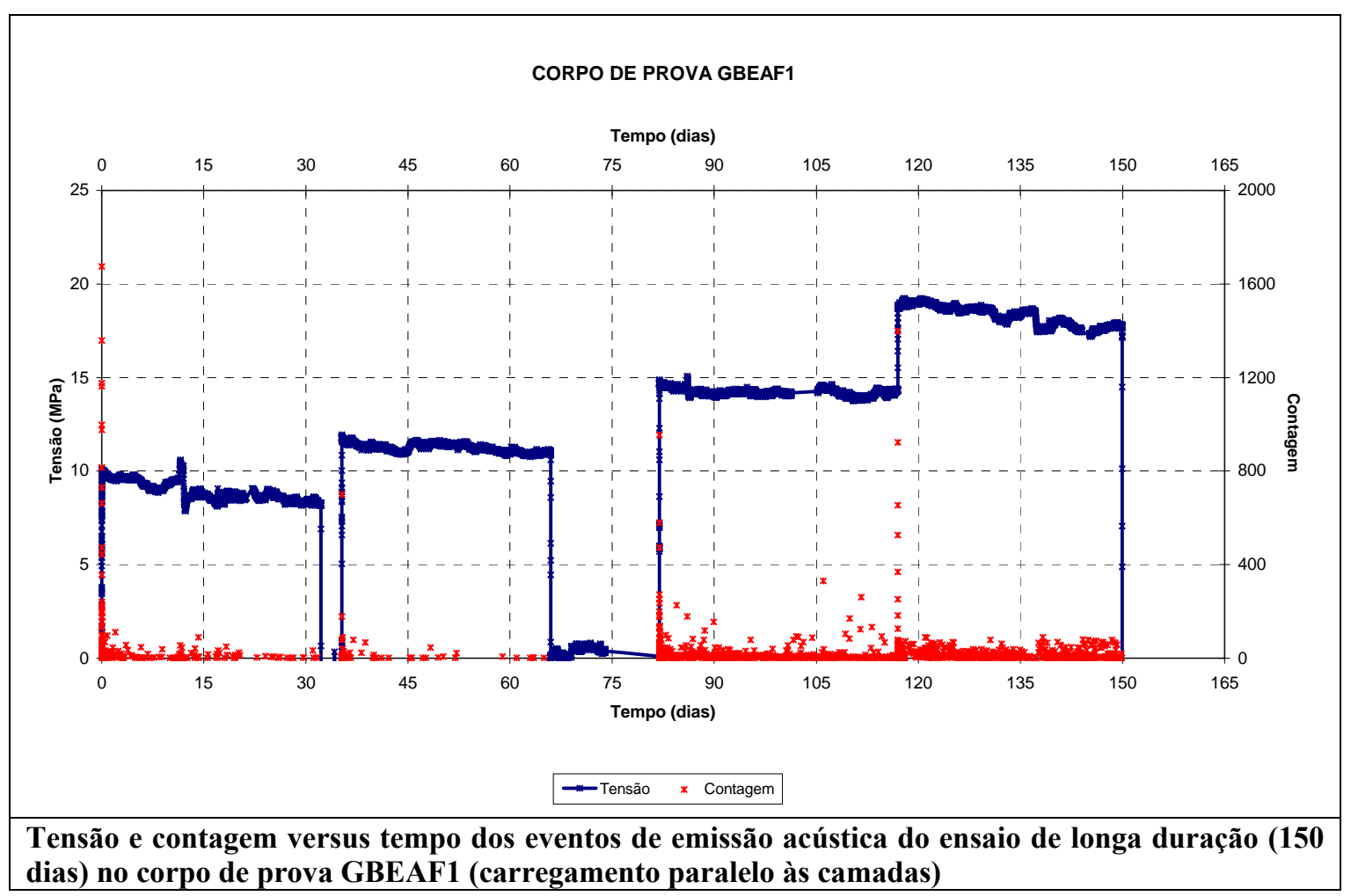

\begin{tabular}{|c|c|c|c|c|}
\hline Carregamento & 10 & 20 & 30 & 40 \\
\hline $\begin{array}{l}\text { Tensão média } \\
\text { aplicada } \\
\text { (MPa) }\end{array}$ & 9,0 & 11,0 & 14,2 & 18,1 \\
\hline E (GPa) & 26,1 & 29,73 & 31,47 & \\
\hline $\mathbf{v}$ & $\mathbf{0 , 3 8}$ & $\mathbf{0 , 3 8}$ & 0,38 & \\
\hline
\end{tabular}

\section{Condição: Paralela às camadas}

dias) no corpo de prova GBEAF1 (carregamento paralelo às camadas) 

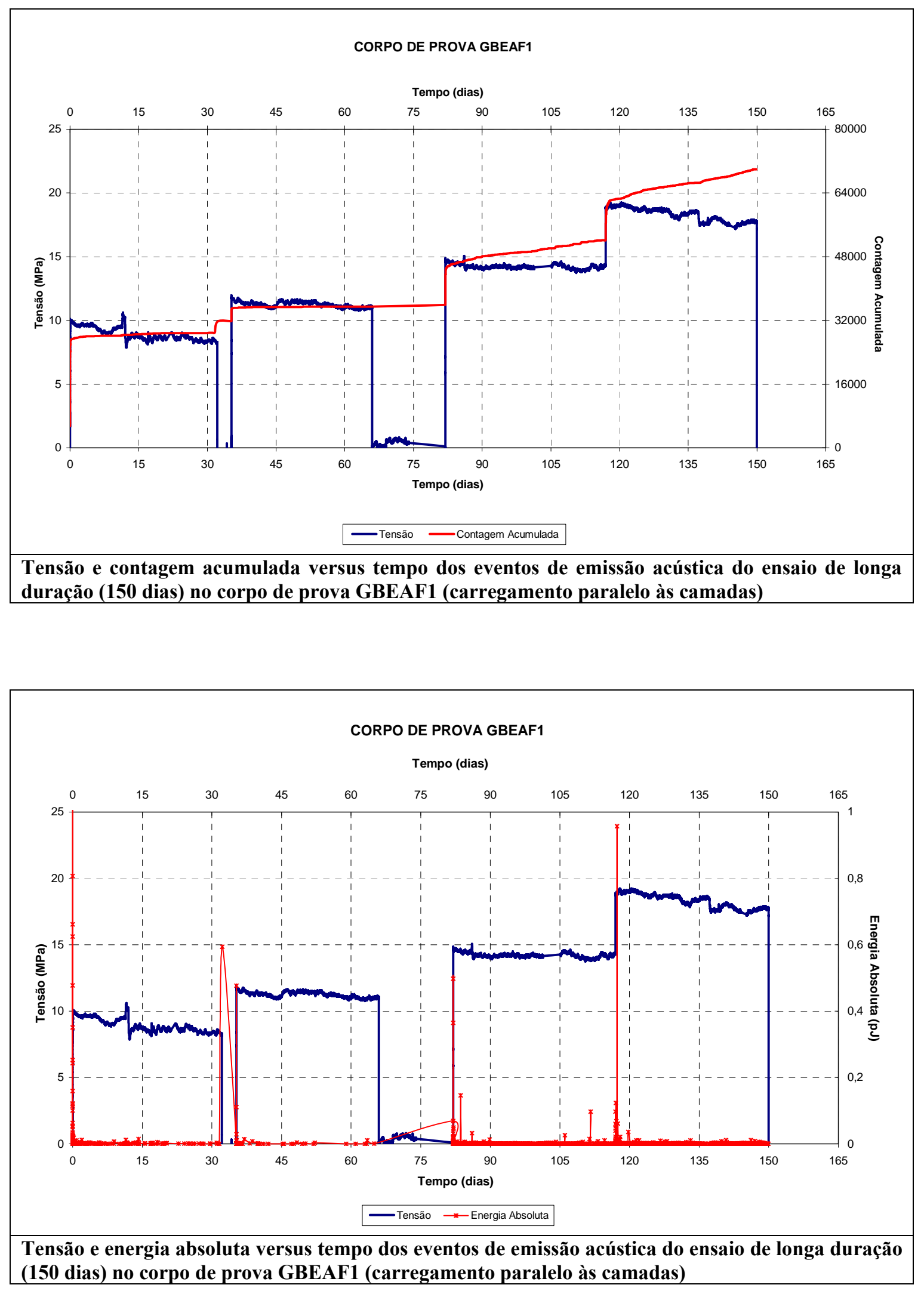

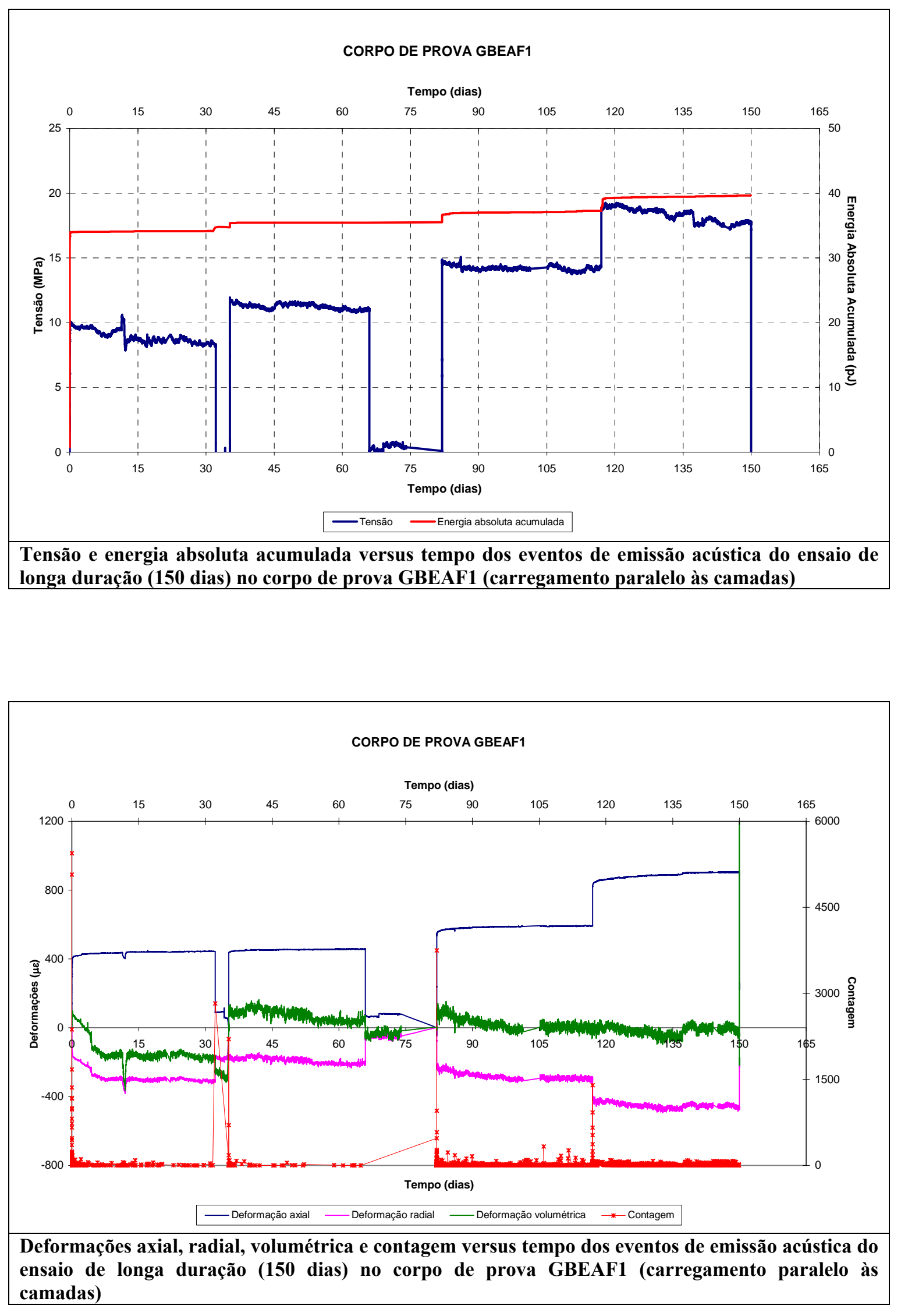

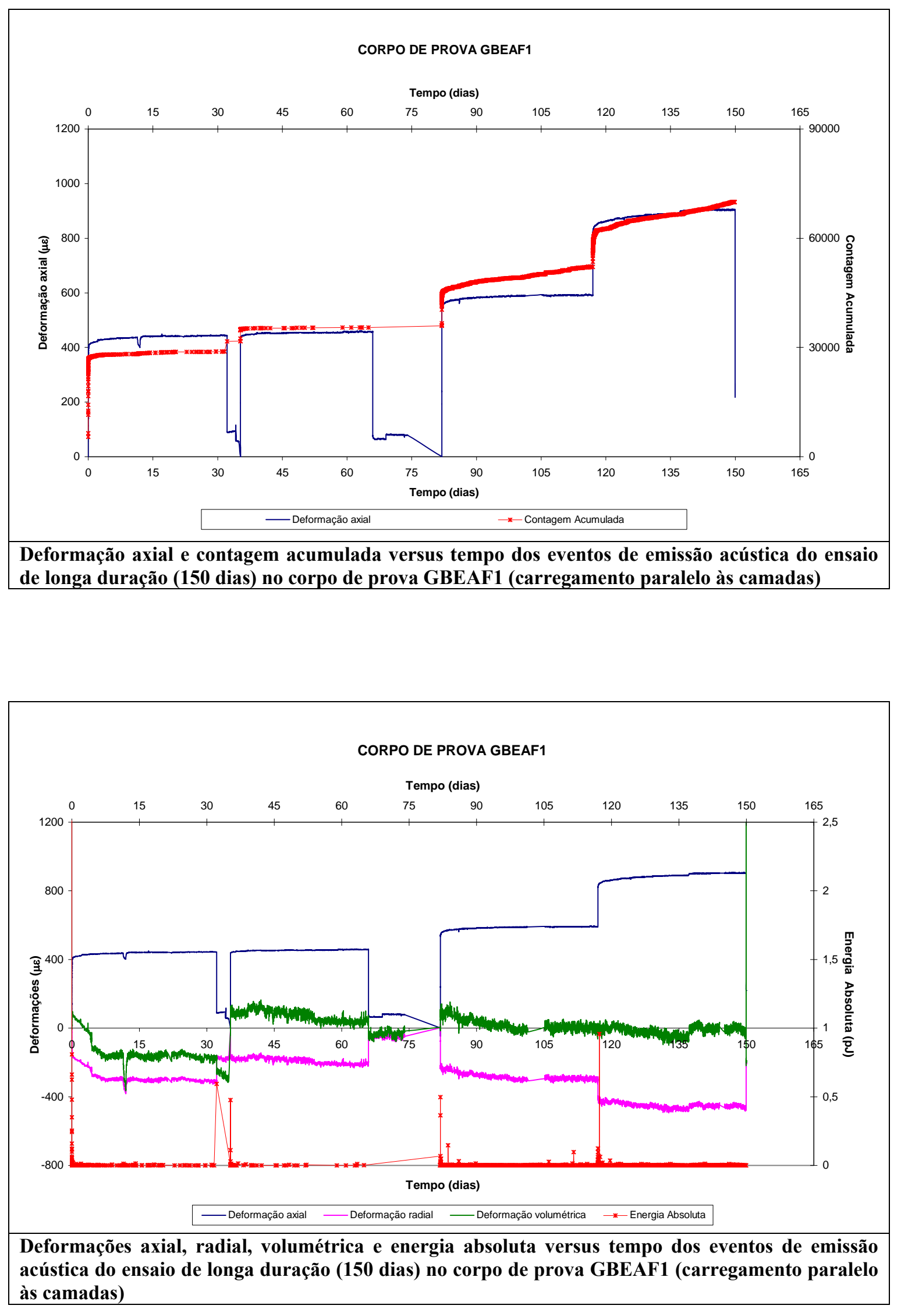

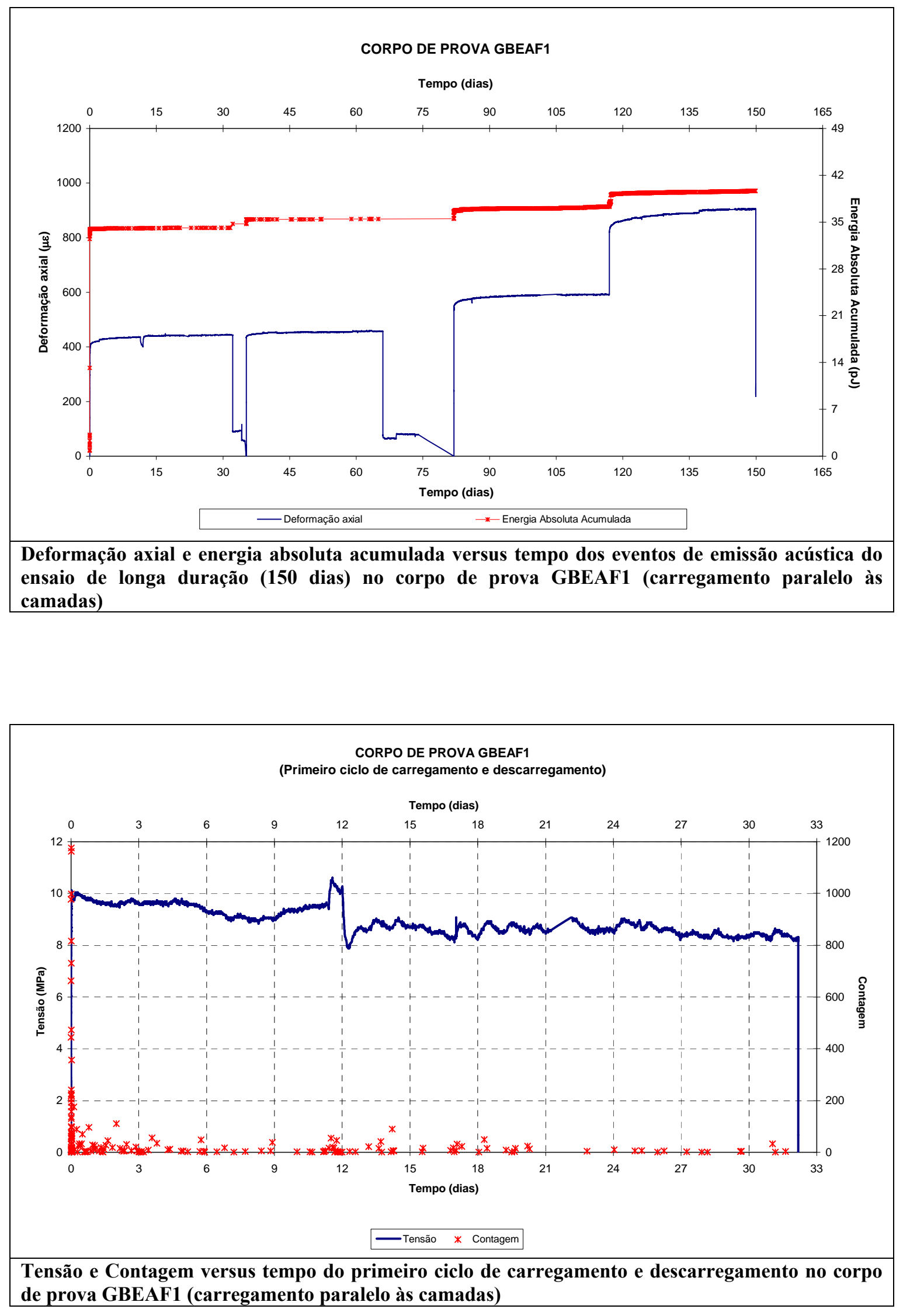

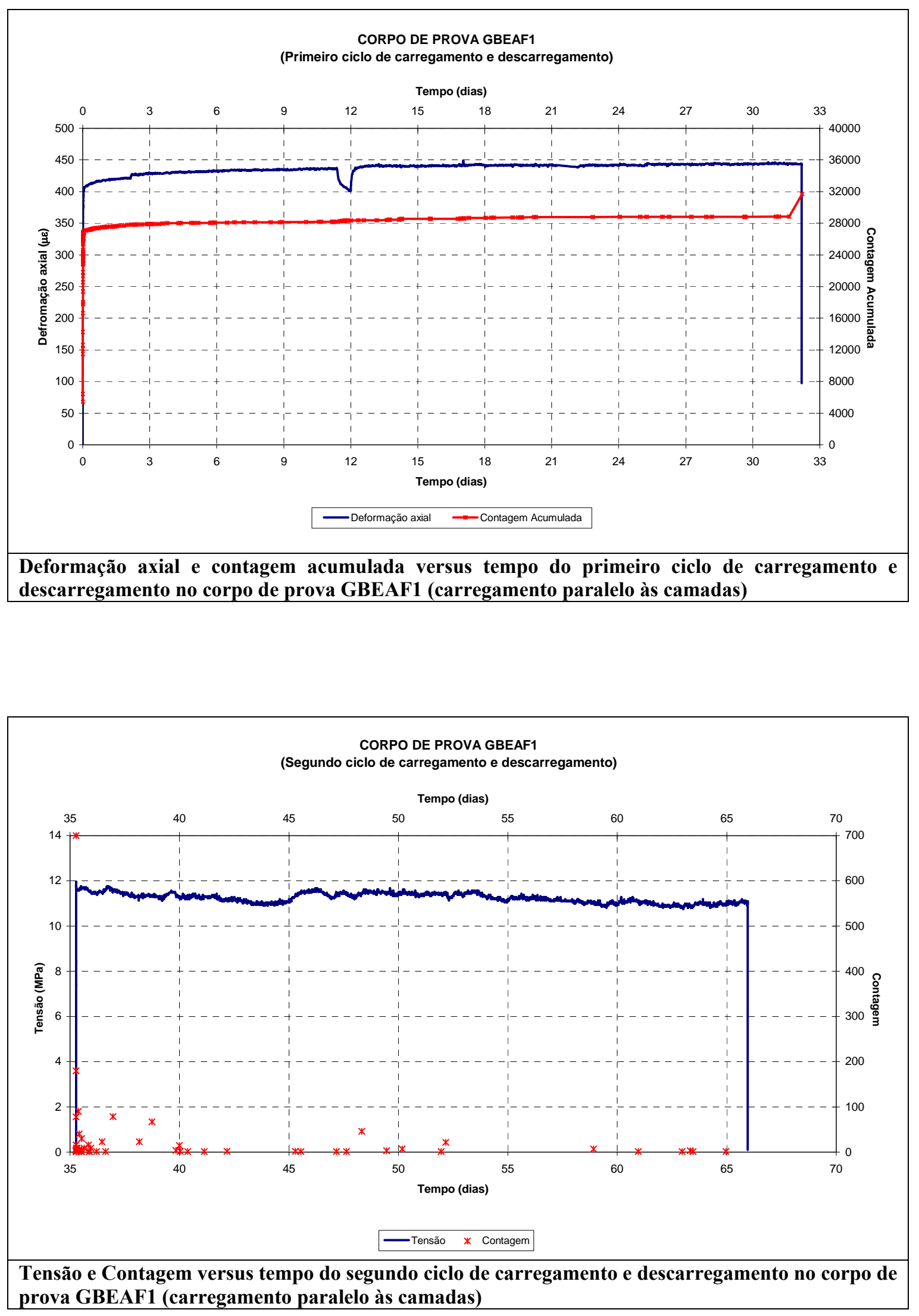

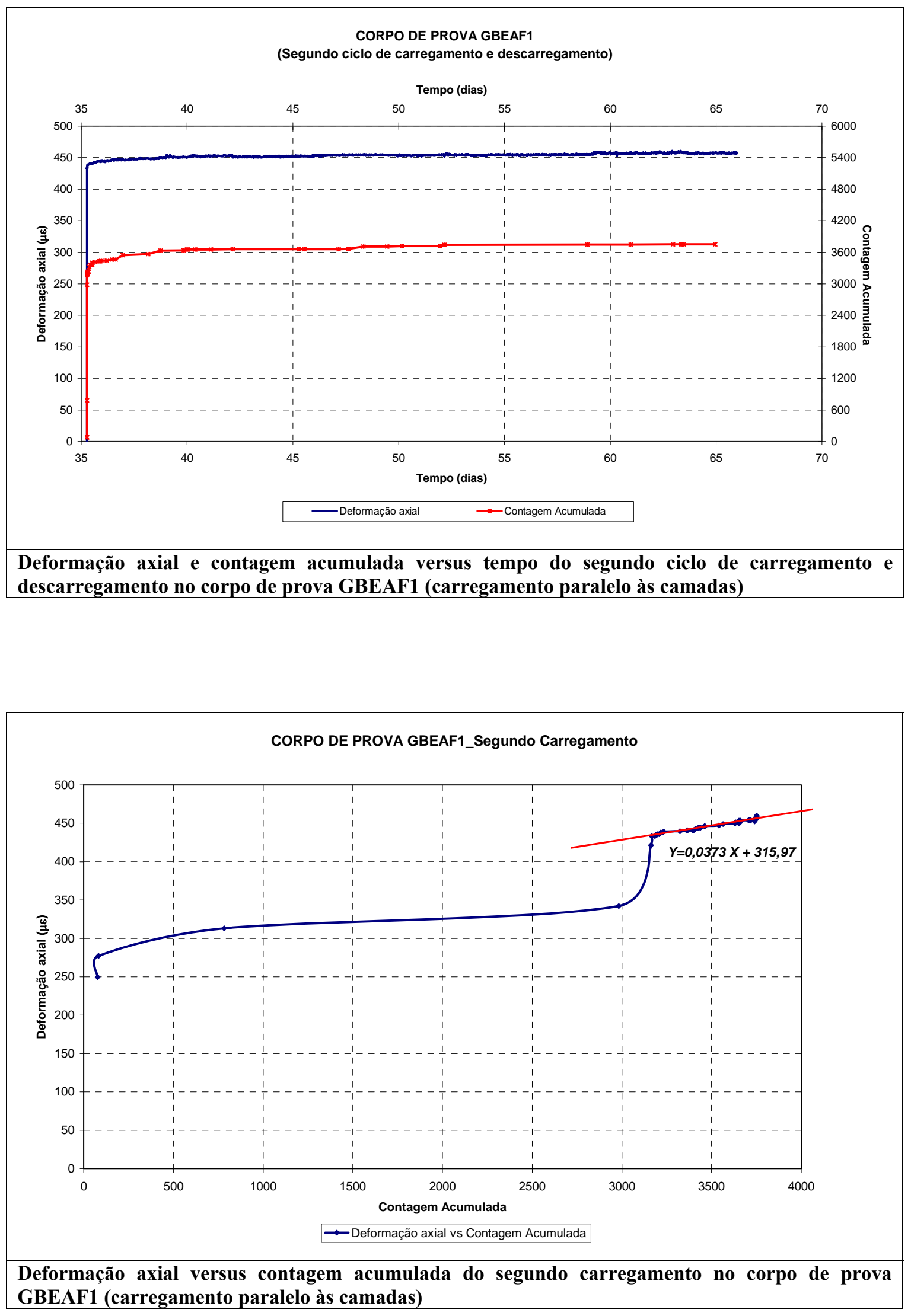

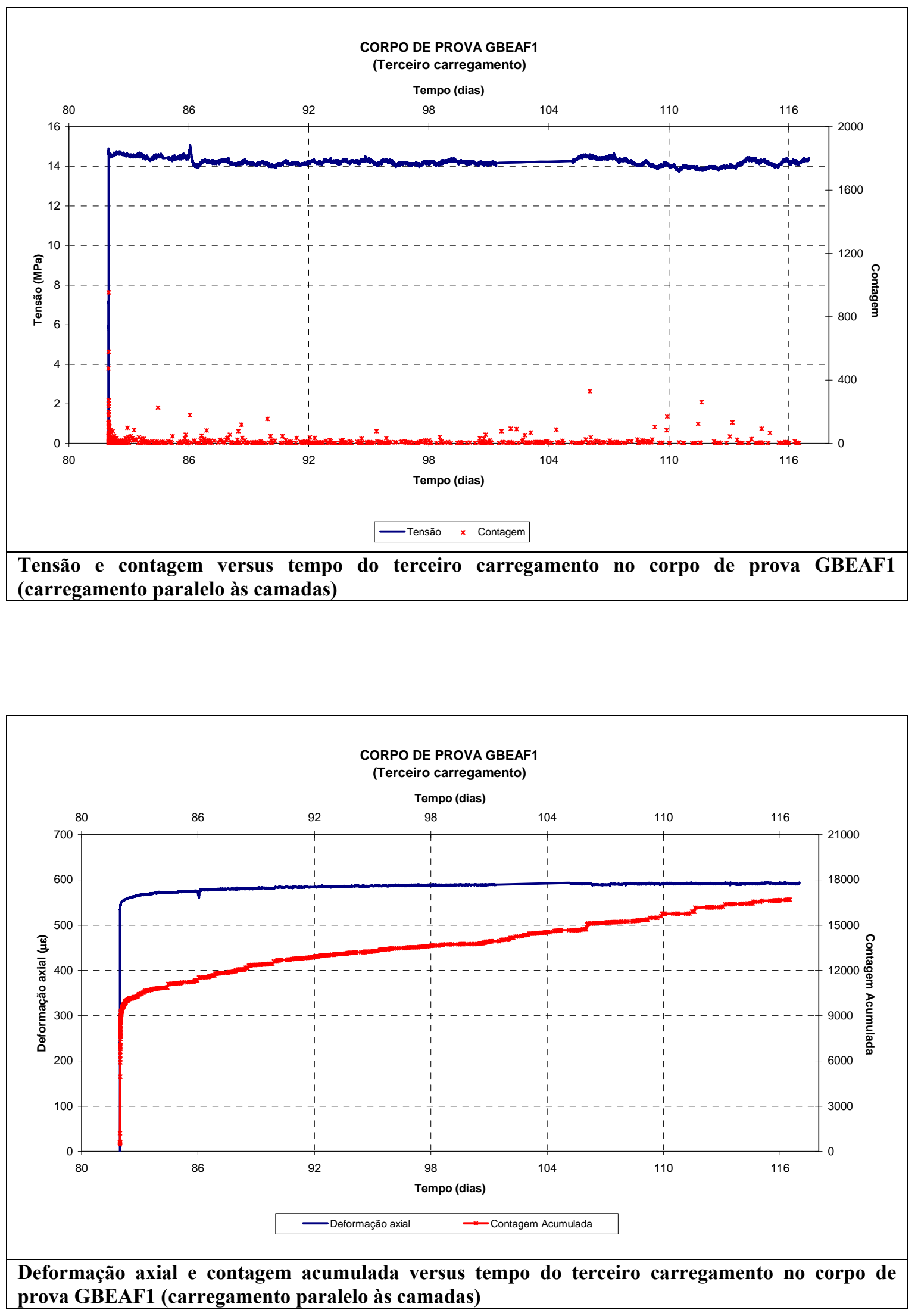

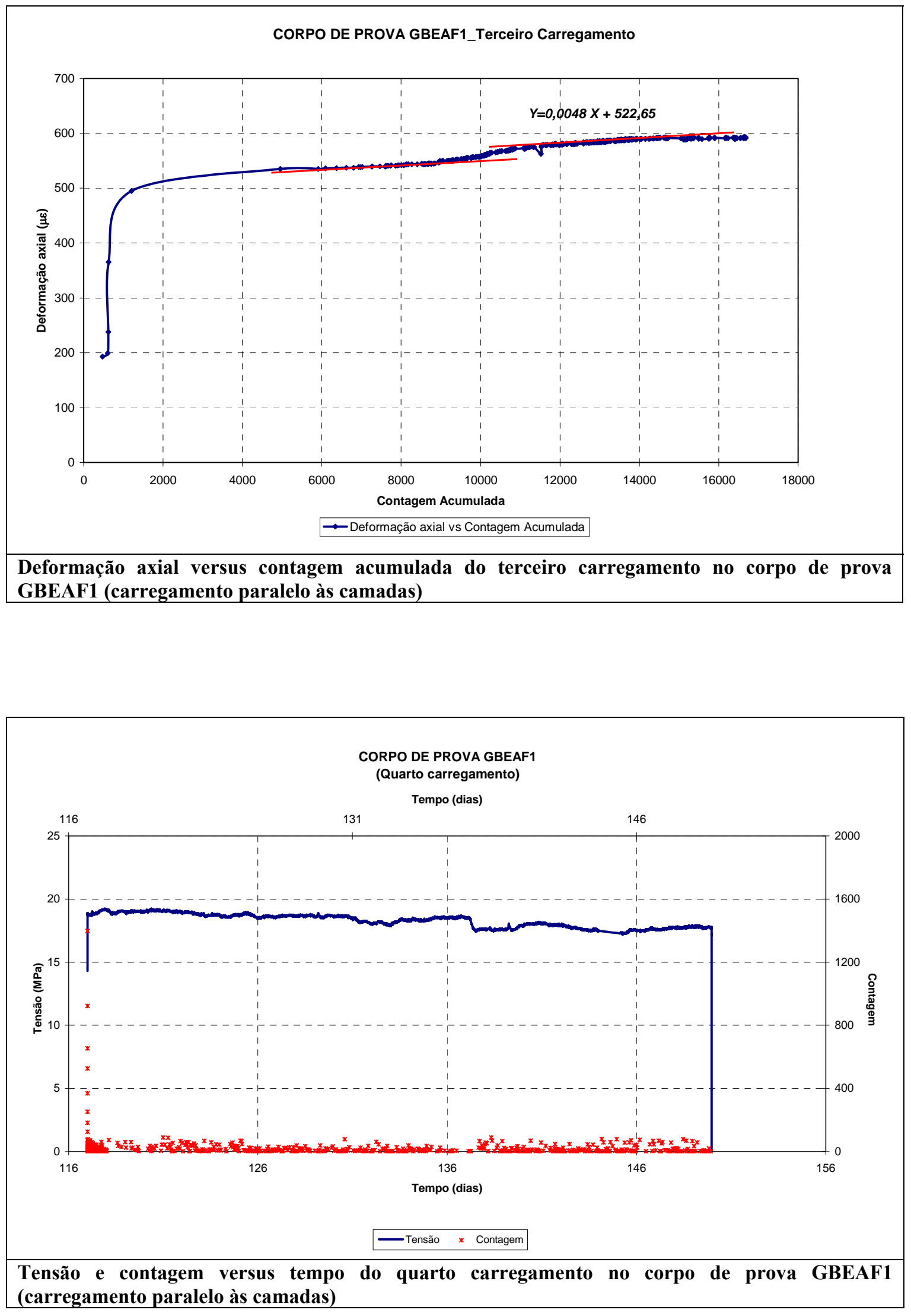

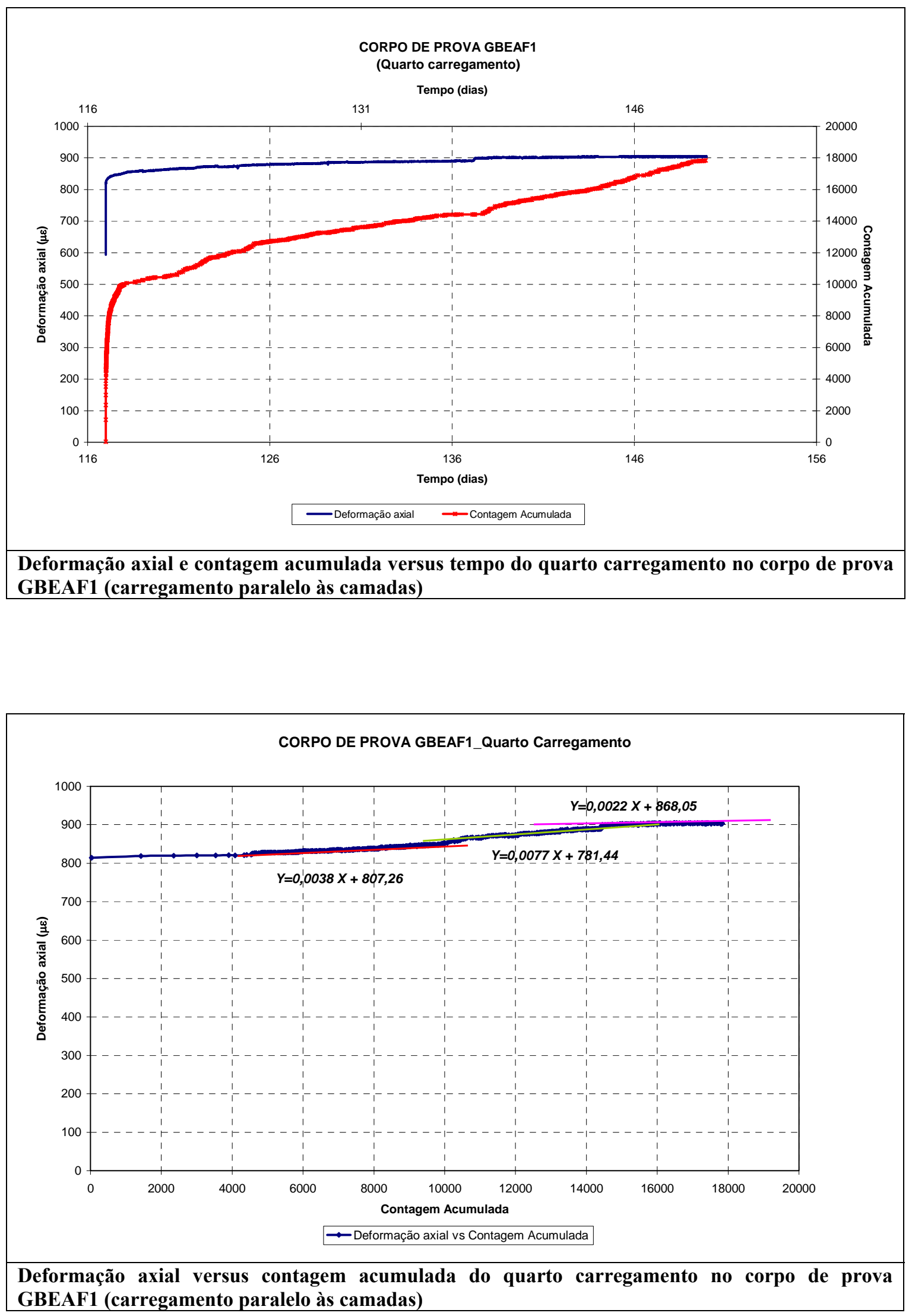


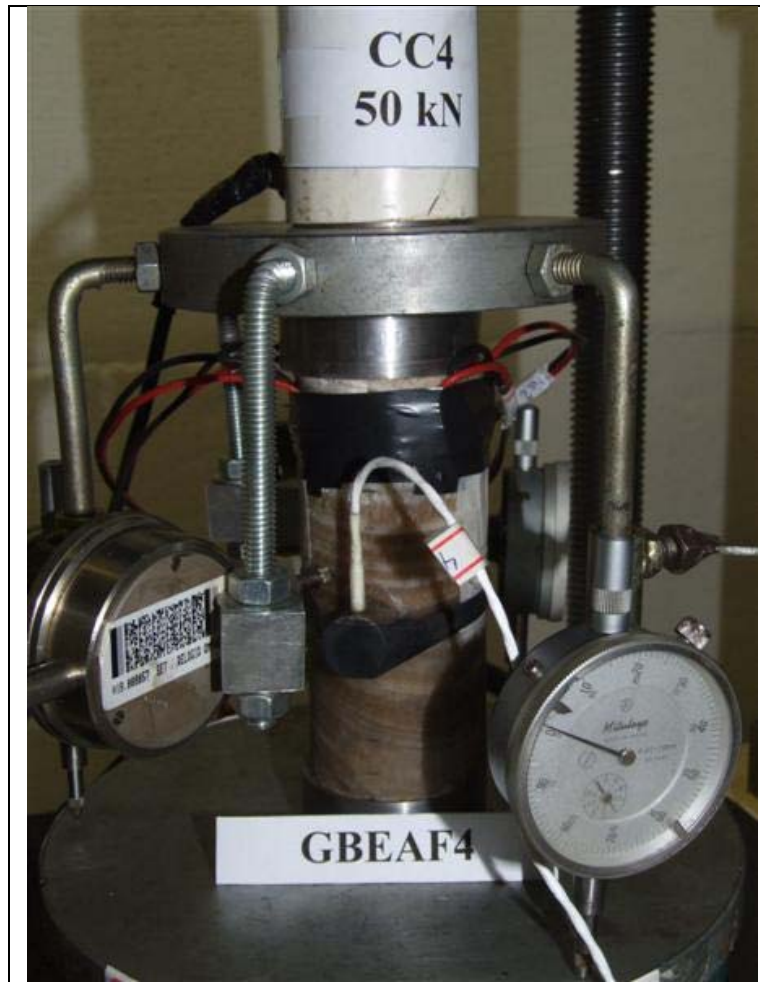

Ensaio de fluência de longa duração com dois ciclos de carregamento e descarregamento sucessivos e posterior ciclo crescente de carga Corpo de prova GBEAF4

Condição: Perpendicular às camadas

\begin{tabular}{|c|c|c|c|c|}
\hline Carregamento & 10 & 20 & 30 & 40 \\
\hline $\begin{array}{c}\text { Tensão média } \\
\text { aplicada } \\
\text { (MPa) }\end{array}$ & 9,7 & 11,4 & 15,3 & 18,3 \\
\hline E (GPa) & $\mathbf{3 6 , 1 2}$ & $\mathbf{3 8 , 2 5}$ & $\mathbf{4 0 , 2 1}$ & \\
\hline $\mathbf{v}$ & $\mathbf{0 , 3 1}$ & $\mathbf{0 , 3 2}$ & $\mathbf{0 , 3 3}$ & \\
\hline
\end{tabular}

Foto do corpo de prova GBEAF4, condição do carregamento, ciclos de carregamento, tensão média aplicada e resultados do ensaio.

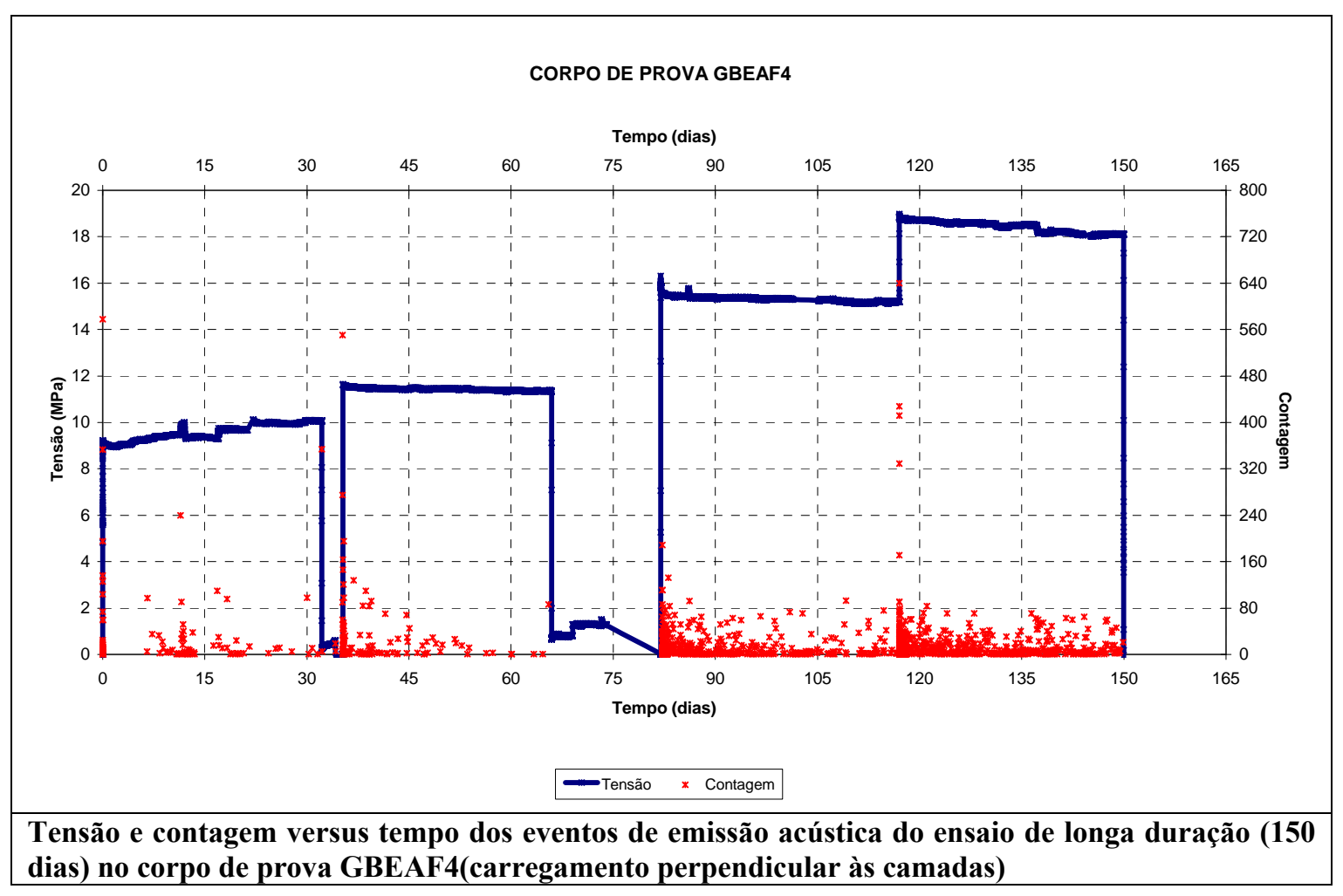




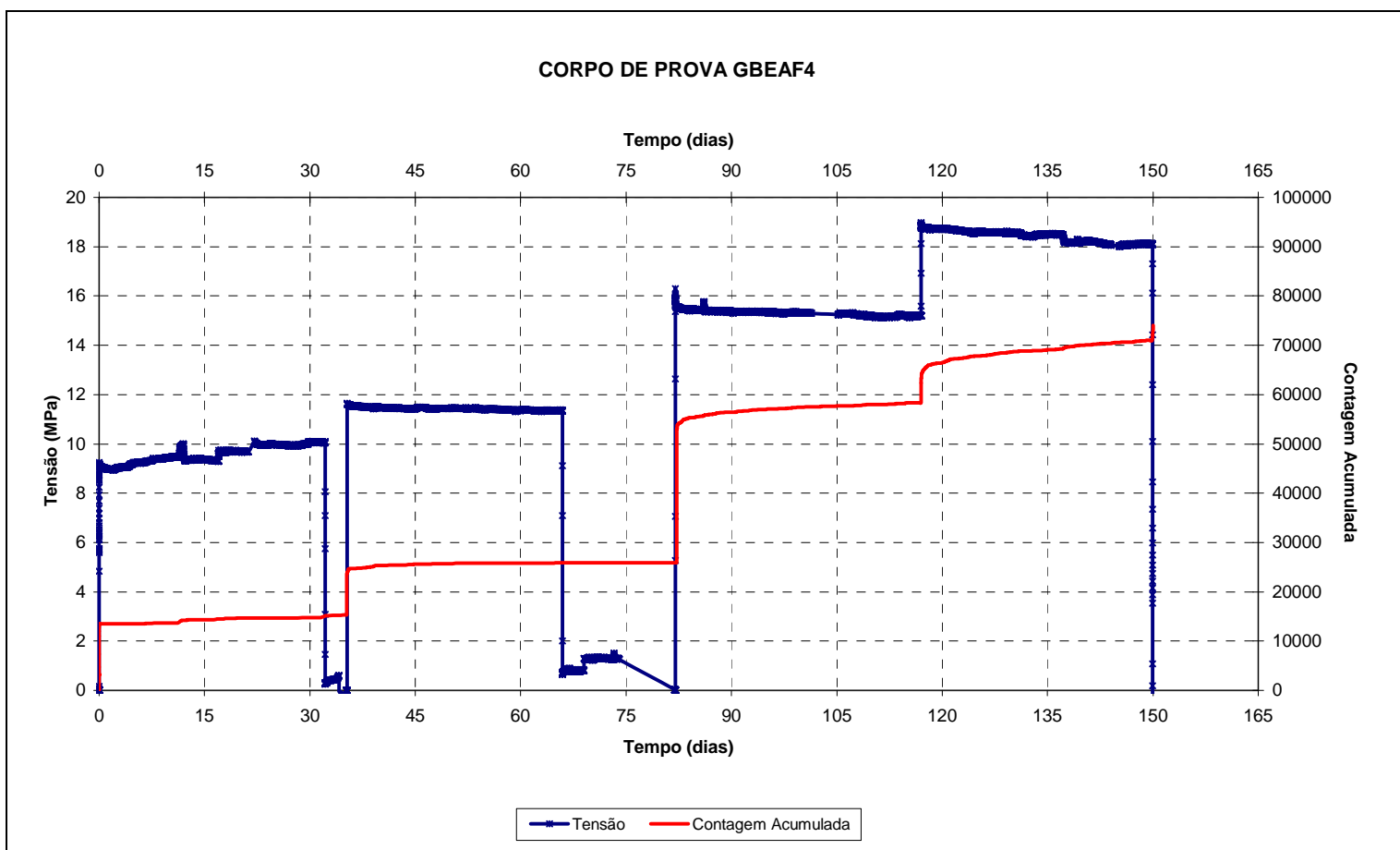

Tensão e contagem acumulada versus tempo dos eventos de emissão acústica do ensaio de longa duração (150 dias) no corpo de prova GBEAF4 (carregamento perpendicular às camadas)

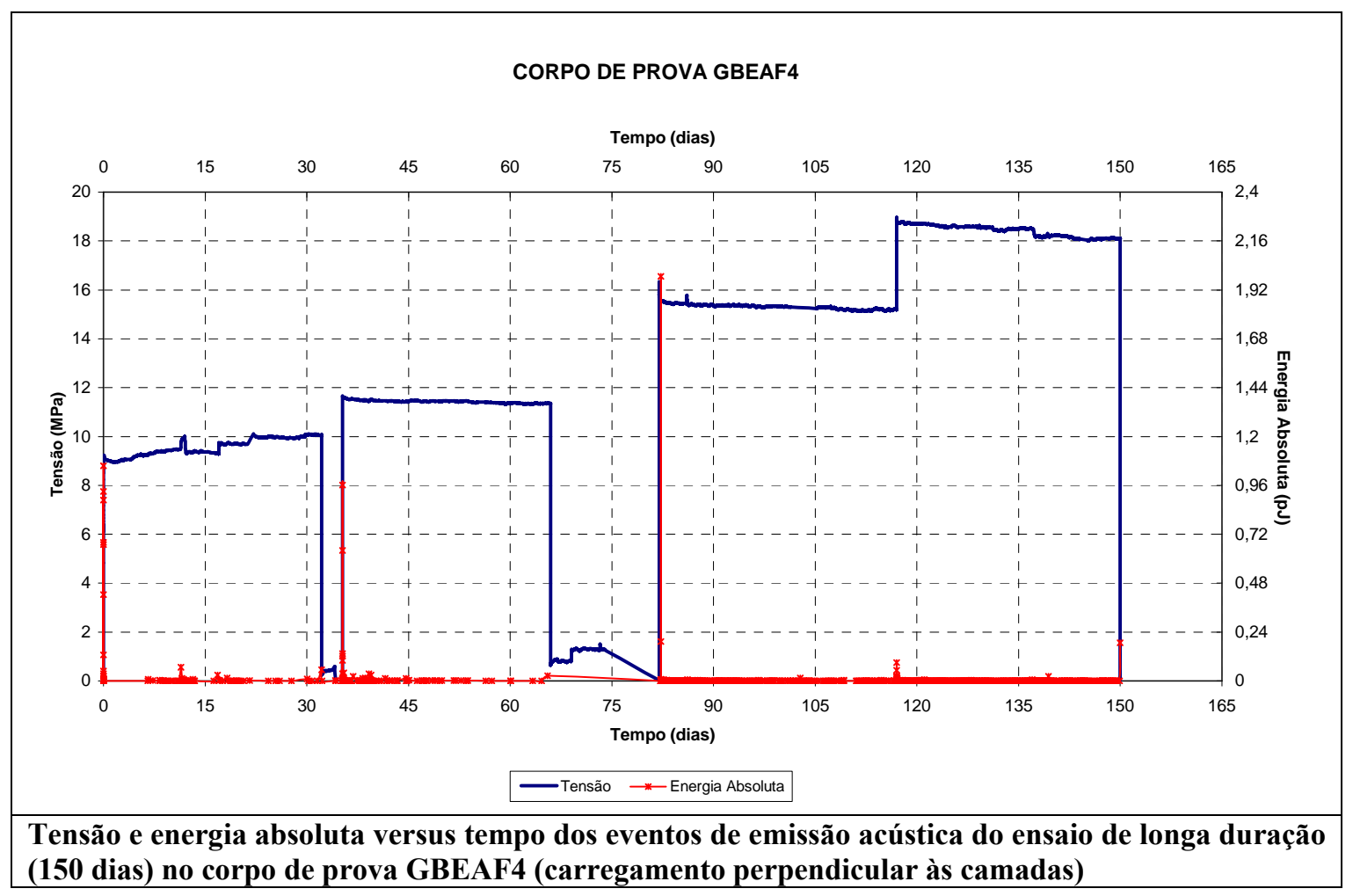



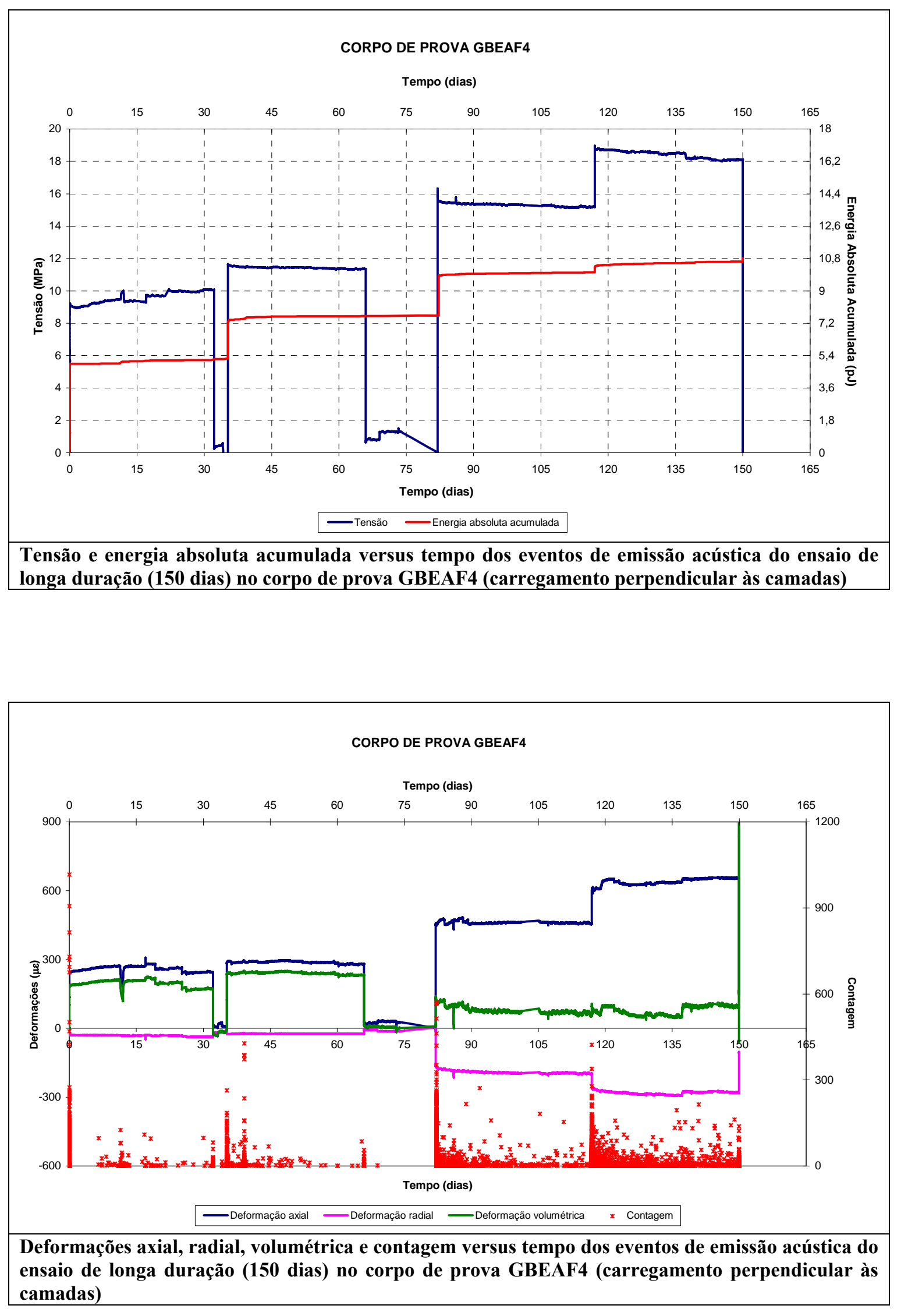

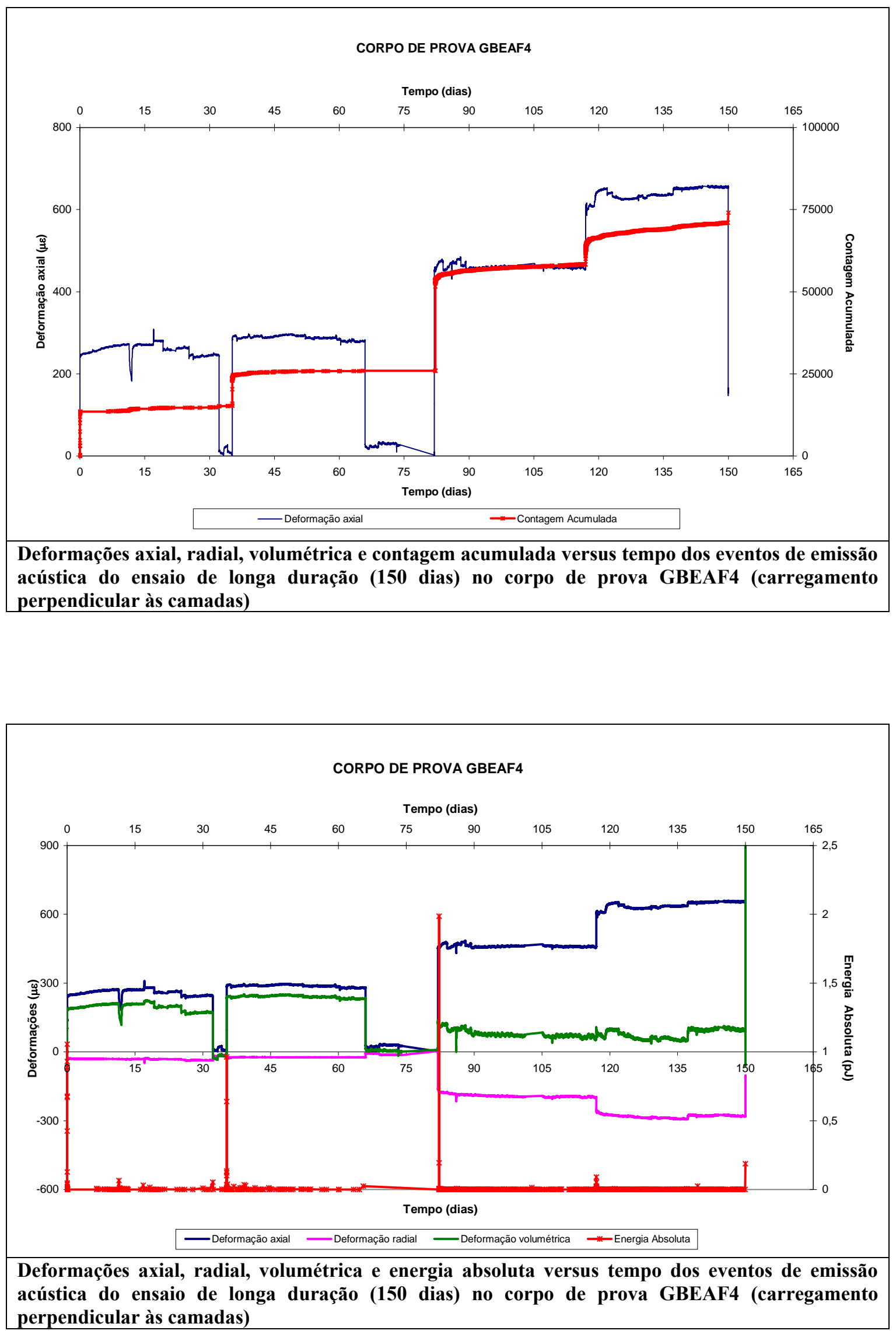

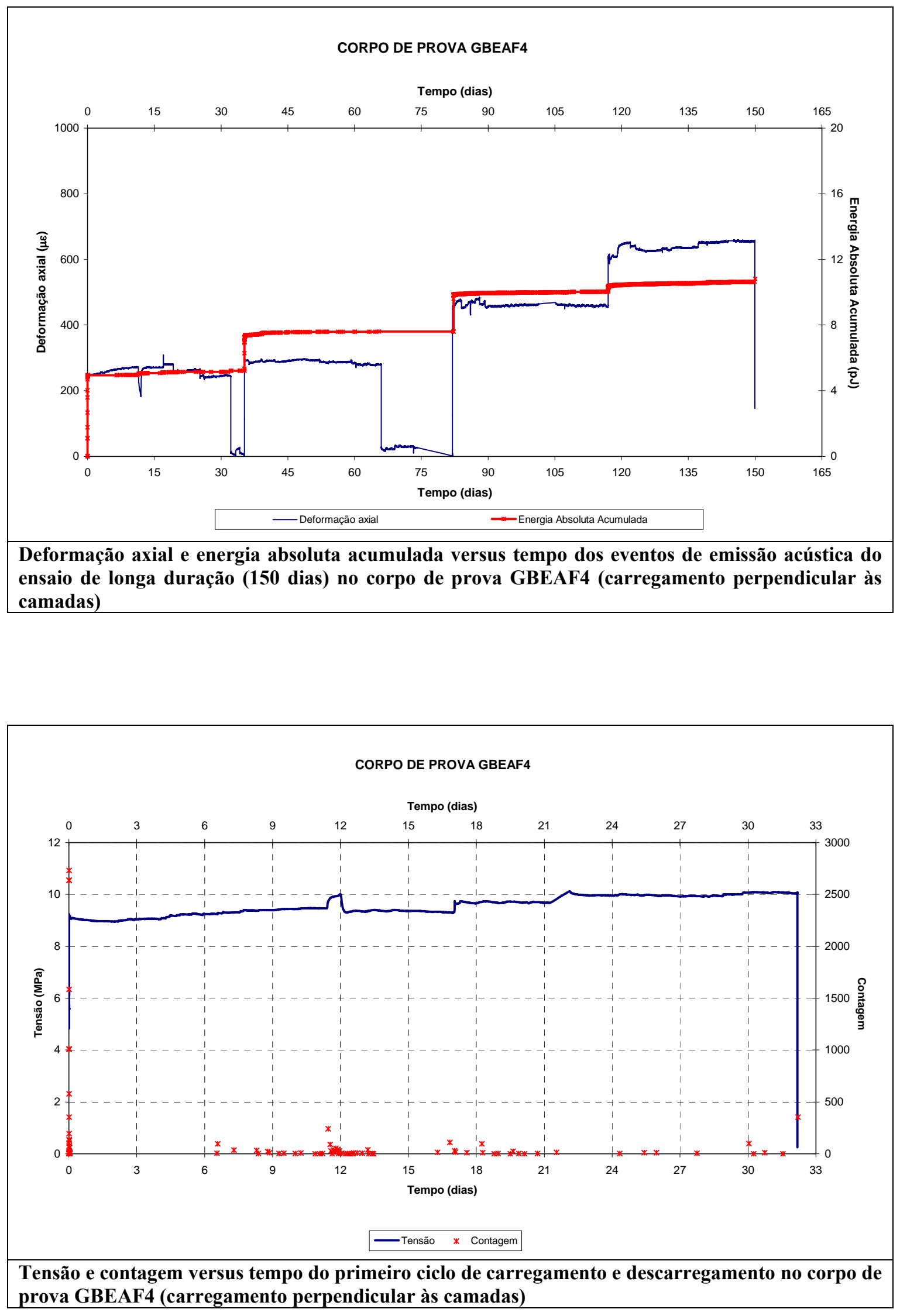

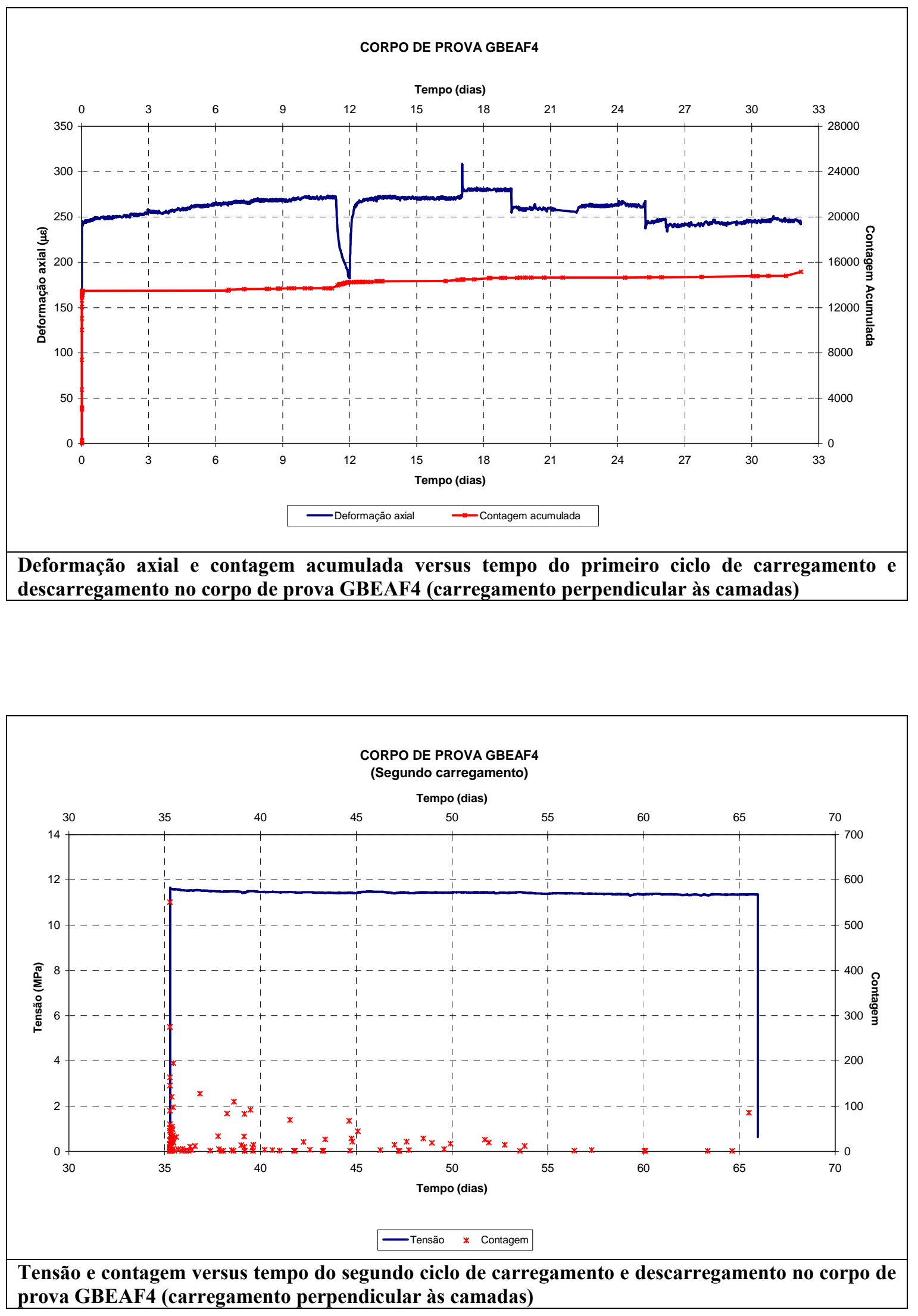

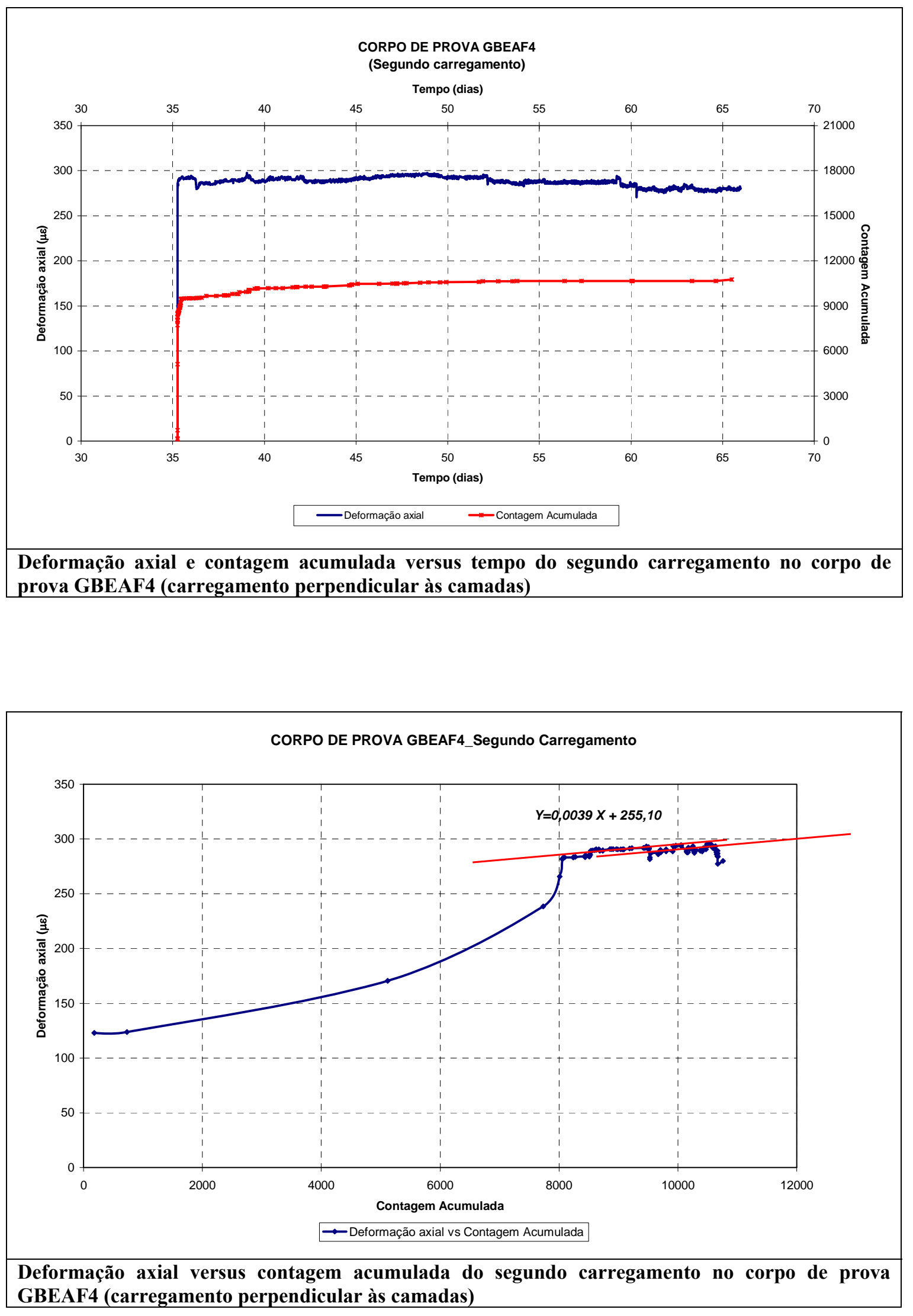

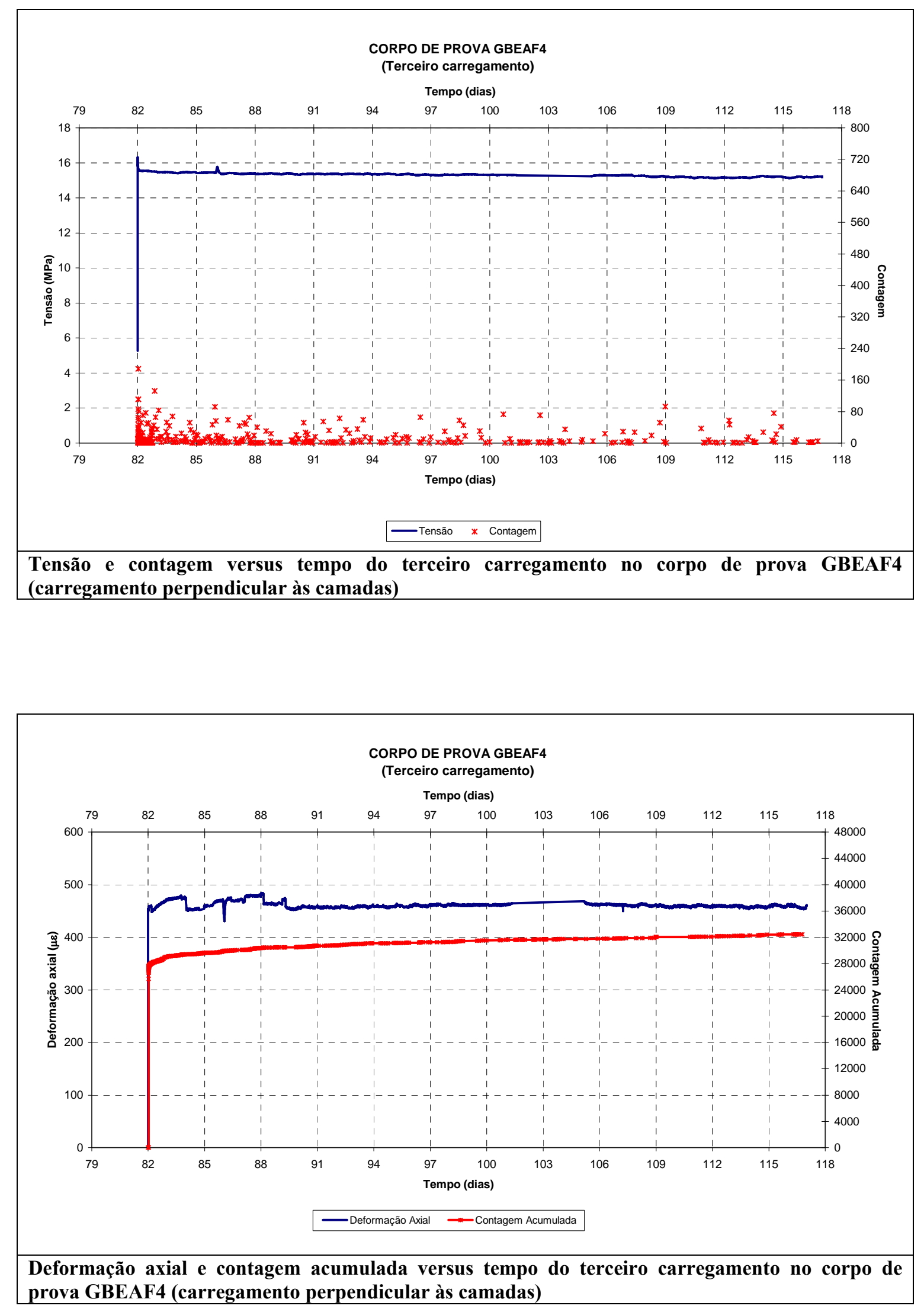

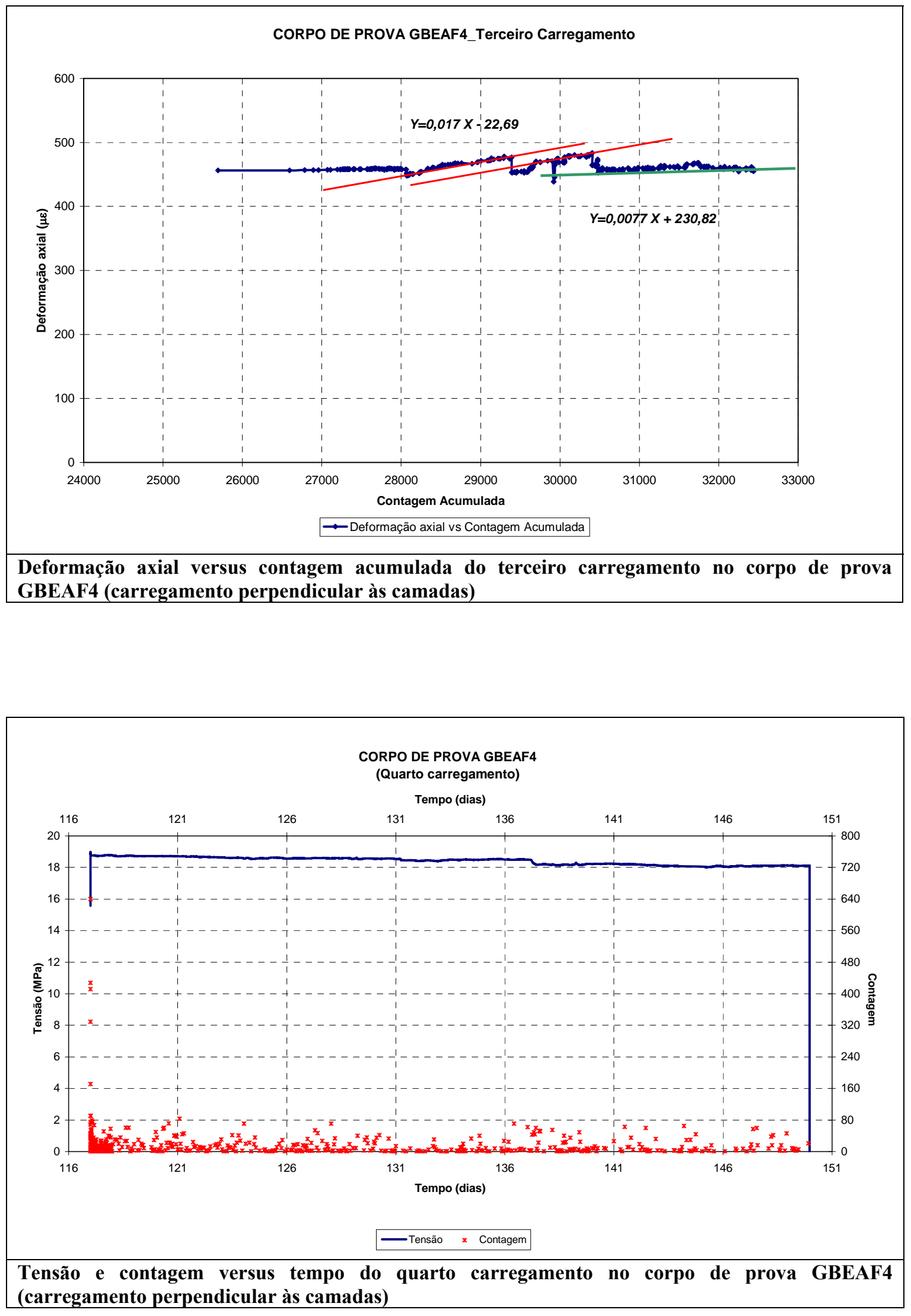

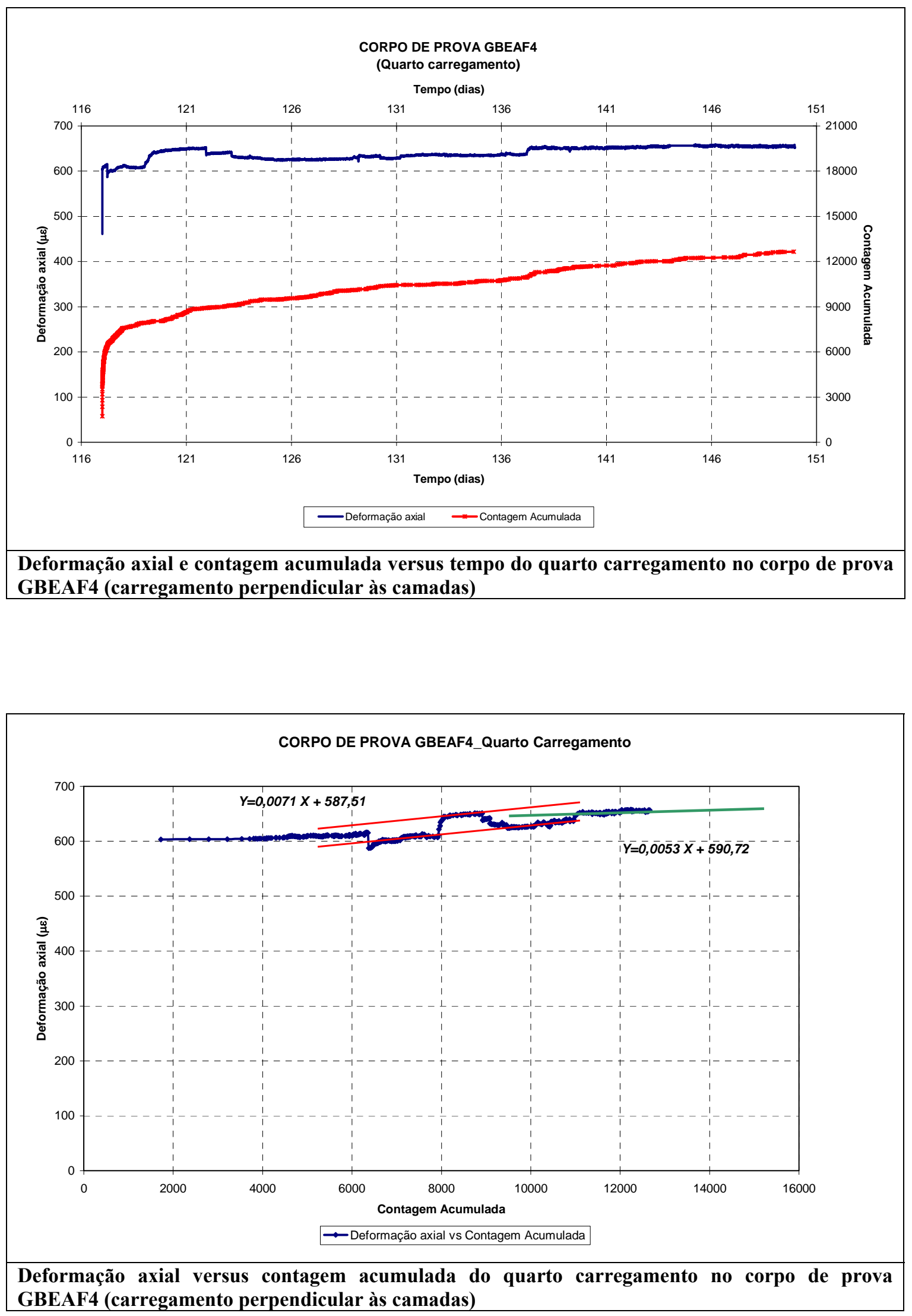